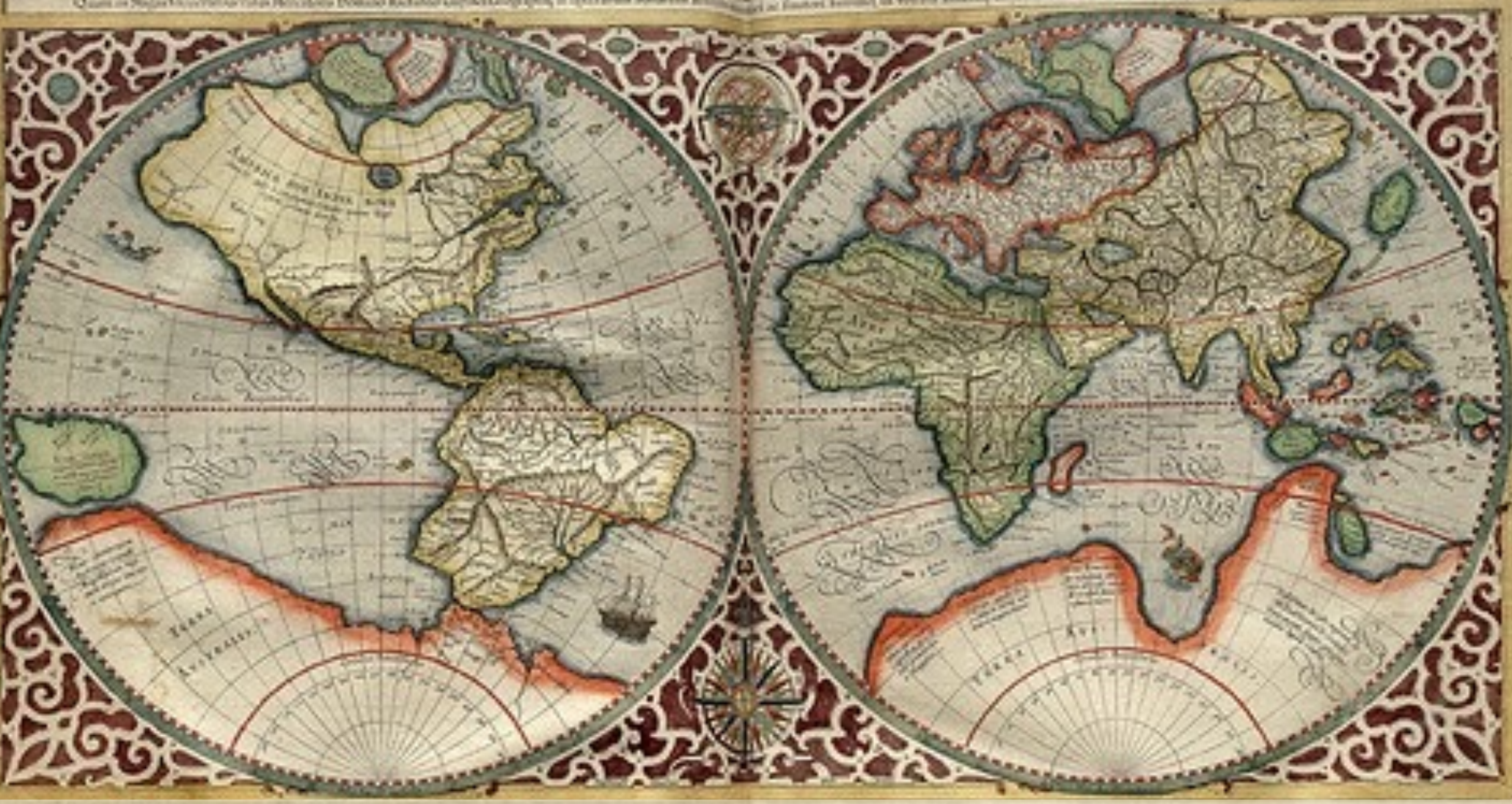

Memorias transatlánticas: pan-hispanismos, latinismos, americanismos

Coordinado por Ileana Rodríguez y Josebe Martínez

Kamchatka. Revista de análisis cultural 9 (julio 2017)

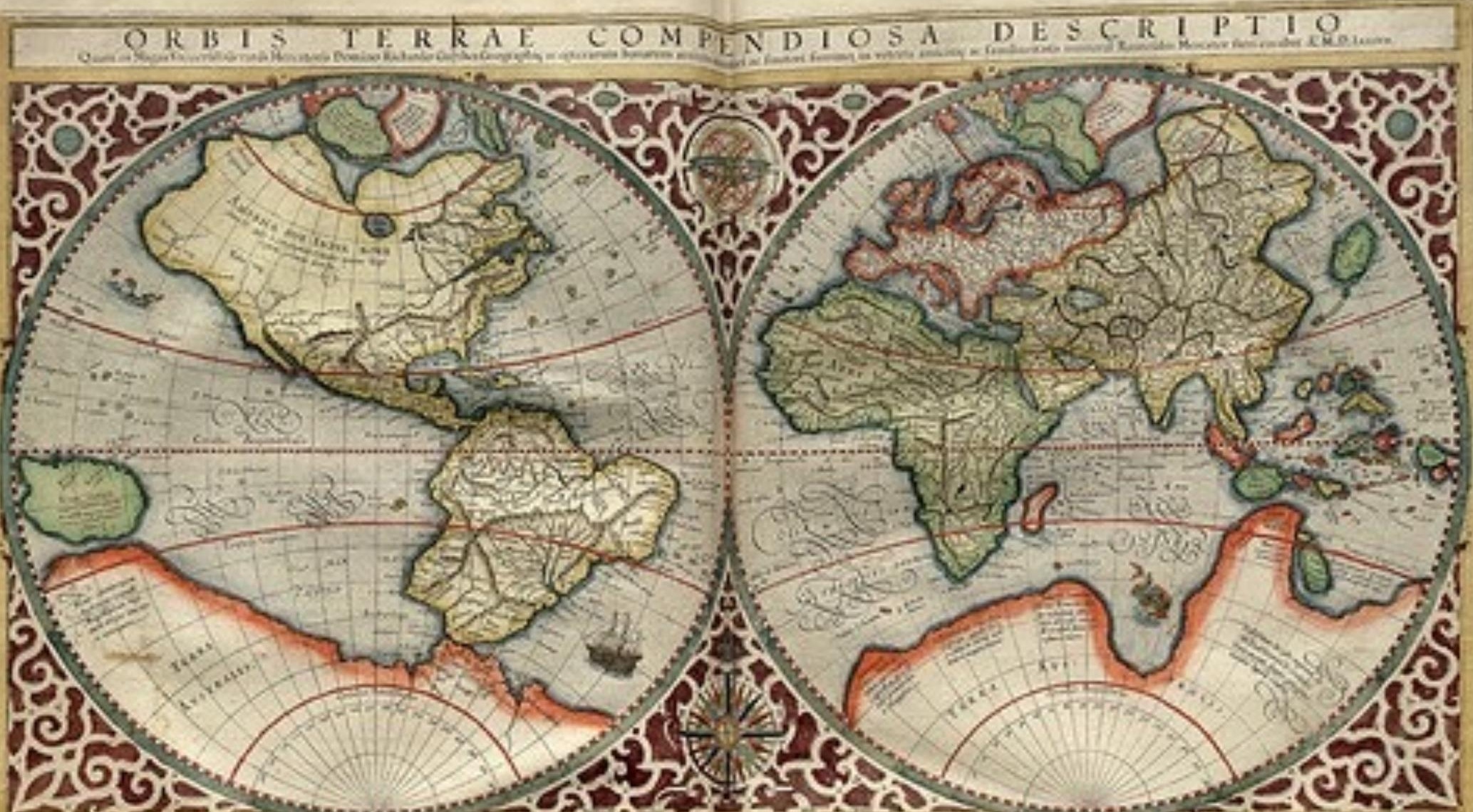


Presentación

Ileana Rodríguez y Josebe Martínez

$5-12$

1. Poéticas de la ambigüedad

En el rincón de un quicio oscuro

Sergio Ramírez

$15-23$

Ambigüedades de la fraternidad entre España e Hispanoamérica Eva M르 Valero Juan.

Geopolítica, (De)colonialidalidad e Identidad: La conciencia dividida de Rubén Darío.

Jared List

$47-64$

Escritores Latinoamericanos en la España del siglo xx

Carmen Alemany Bay

$65-82$

¿Moros en la costa? Centroamericana leída desde España

Arturo Arias

83-101

Literaturas nacionales y literaturas nacionalizadas: Consideraciones en torno a la recepción del boom hispanoamericano en España.

Mario Santana

$103-120$

Al hilo de la literatura Latinoamericana: estudios literarios/ estudios culturales

María Caballero Wangüemert

$121-151$

2. Articulación de la colonialidad del poder/saber

Memoria transatlántica, ensayos "fundacionales" y espectros de la historia

Javier Sanjinés C.

$155-172$

La rapsodia postcolonial como activismo global: el Movimiento Zapatista y la guerra de la palabra

Héctor Dominguez Ruvalcaba

$173-187$ 
Colonialismos, poscolonialismos y poderes hegemónicos en la frontera norte de México: arte, literatura y resistencia cultural Nuria Vilanova

Una revisión histórico-política de la producción literaria puertorriqueña. Entrevista con Fernando Feliú Matilla Endika Santibáñez.

207-222

\section{Migraciones y Exilios}

Las migraciones coloniales del Caribe a Estados Unidos y Europa Occidental: colonialidades diferenciadas en cuatro centros del sistema-mundo

Ramon Grosfoguel

225-250

El Mashreq en México: Patronazgo, propiedad, y la lectura de los cuerpos en la Poscolonia

Camila Pastor de Maria y Campos

$251-283$

'Prender de Gajo': sujetos transplantados e imaginarios globales en Luisa Futoransky

Marta Sierra

285-296

Transatlantismo: Reflexiones sobre la Identidad Nacional. El caso de Argentina

María Claudia André

$297-311$

Gaitas, panderos y tambores. La nueva música gallega y una identidad glocalizada

Eugenia R. Romero

313-331 
MONOGRÁFICO

\section{MEMORIAS TRANSATLÁNTICAS: \\ PAN-HISPANISMOS, LATINISMOS, AMERICANISMOS}

Transatlantic Memories: Pan-hispanisms, Latinisms, Americanisms

Coordinado por:

ILEANA RODRÍGUEZ

OHIO STATE UnIVERSITY, EEUU rodriguez.89@osu.edu

JOSEBE MARTÍNEZ

UNIVERSIDAD DEL PAís VASCO, ESPAÑA josebe.martinezg@ehu.eus

Este monográfico, Memorias transatlánticas, conforma el cuarto volumen de Estudios Transatlánticos Postcoloniales, que hemos decidido publicar en abierto, de manera digital, en Kamchatka. Revista de análisis cultural. La colección incluye un buen número de trabajos cuyo punto de articulación es la dinámica entre literatura española y literatura en lengua española. Dicha literatura se inicia desde la colonia pero alcanza un hito sobresaliente a finales del siglo XIX y principios del XX con la producción poética de Rubén Darío y la relación que él establece con los poetas y narradores de la generación del 98, y del 27, en España, en la cual, la guerra contra Cuba, ya perdida, juega un papel cardinal. Sergio Ramírez lo expresa de la siguiente manera:

Una tarde de diciembre de 1896 (...) Juan Ramón Jiménez leía (...) unos poemas de Rubén Darío que habían aparecido en La Nueva Ilustración de Barcelona. Un reventar de cohetes, un repicar de campanas, gritos, y las notas de la marcha de Cádiz que tocaba una banda lo hicieron salir al balcón, y vio que las calles estaban llenas de gente porque pueblo y autoridades celebraban la muerte de José Antonio Maceo al grito entusiasta de ¡mueran los mambises! (....) Y, triste, como si el muerto fuera Darío y la celebración contra Darío, pensó en América, y en Cuba de los cromos de las cajas de tabaco con sus paisajes románticos de palmas airosas, y superpuso en su mente el rostro de Maceo, que adornaba las cajas de chocolate, al de Darío que lo miraba desde la portada de la revista.

Los dos rostros que miran a España de frente son, uno negro (Maceo) y el otro mestizo (Darío), remanentes de un exotismo continental de cuño imperial del que solo quedaban Cuba y Puerto Rico. La caída de Maceo no iba a interrumpir la voluntad cubana de emancipación en la cual ya había perdido la vida su más grande poeta, José Martí. Esta era la última guerra colonial y la primera imperial. 
Esta nueva relación transatlántica cuyo hito político marcaba Maceo iba a empezar también con el hito poético de Darío, su vanguardia:

Juan Ramón Jiménez, el poeta adolescente que lo leía en un balcón en Huelva mientras abajo celebraban la muerte de Maceo, iría en su busca luego a Madrid, y formaría parte de la pléyade de los modernistas que nacería con Darío, y con el fin del imperio colonial: Valle Inclán, Azorín, Benavente, Baroja, Pérez de Ayala, Villaespesa, los Machado. "Esparcí entre la juventud los principios de libertad individual y personalismo estético que habían sido la base de nuestra vida nueva en el pensamiento y el arte de escribir. Y la juventud vibrante me siguió”, diría él mismo.

Este volumen abre con esta relación y llega hasta la producción y colaboración fílmica entre España y la América Latina, pero también vuelve, con afán reiterativo y aleccionador, a tocar temas álgidos como son las diversas idas y vueltas, los exilios, exotismos, colonialidades e incluye ensayos que comprenden dentro del término transatlántico la relación entre Europa y regiones del África.

El volumen está dividido en tres secciones, a saber: 1/ Poética de la ambigüedad; 2/ Articulación de la colonialidad del poder/saber; y 3/ Migraciones/Exilios. La primera es una vuelta a la literatura que nos permite discutir en qué consisten las relaciones transatlánticas a nivel de una poética caracterizada por la ambivalencia. La segunda vuelve al asunto de lo indígena. La tercera se desarrolla en torno a las migraciones.

\section{POÉTICA DE LA ESCUCHA}

Abrimos la primera sección con un trabajo de Sergio Ramírez que ilustra la relación de Rubén Darío con los poetas españoles y el sentimiento que animaba a ambos en su relación respecto a la independencia de Cuba, al atraso peninsular, y al comienzo de la hegemonía norteamericana. Este ensayo poético inaugura el tipo de ambigüedad en las relaciones Península Ibérica/América Latina y destaca el desplazamiento de la relación este/oeste a la norte/sur.

Estamos a fines del XIX, al borde del poderío peninsular gestado a través de siglos de colonialidad y cuyo impulso había llegado prácticamente a cero. Ramírez apunta cómo Darío, además de su estética innovadora, traía como parangón de desarrollo que España debería seguir, a la Argentina, una civilización triunfante contra la barbarie, tal como lo había propuesto Sarmiento en su Facundo. Argentina era el sol de la aurora,

que atasca sus graneros, exporta barco tras barco de carne congelada, levanta enjambres de fábricas, y hace crecer una masa obrera pujante, un espejo que multiplica a Bilbao y Barcelona, nada más, pero que deja fuera de sus reflejos a la España feudal y rural de los caciques. Y Darío... recomienda que España debería... modernizarse... abrirse al comercio internacional, desarrollar la industria. Ser, en fin de cuentas, como Argentina... tierra de promisión y granero del orbe, sus montañas de simientes, sus hecatombes bovinas, y llama a los pueblos extraños a que vengan a comer el pan de su harina, un país abierto, tolerante, y en paz... Ensalza puntualmente las corrientes migratorias... -rusos, judíos, italianos, suizos, franceses, españoles- que han encontrado allá su tierra prometida, y propone crear la otra España, la moderna, en suelo de Argentina, con todos los inmigrantes andaluces, asturianos, vascos, castellanos, catalanes, levantinos que siguen llegando en los barcos (Ramírez, en este monográfico). 
Con este pensamiento, la línea transatlántica se hace transoceánica y la hegemonía de la migración española se abre a todo el continente europeo, al este y al sur principalmente.

Siguiendo esta misma dirección de Ramírez, el trabajo de Eva María Valero Juan se sitúa también en el momento de la derrota del imperio español a manos de los mambises cubanos el año de 1898. Pero esta derrota, argumenta Valero, dio lugar a un imaginario en el que América era concebida desde España, como una prolongación de la propia identidad nacional que subyace al nacionalismo de los regeneracionistas. El análisis de los 'males patrios' demandaba propuestas para redefinir las identidades nacionales en las que América persistía como el horizonte utópico, paliativo, que servía la postración española y el imperativo de su modernización a fin de re-establecer su prestigio internacional. Ya había perdido la guerra en Cuba que era una guerra contra el tiempo. Por eso mismo, España hablaba de los lazos transatlánticos, constituidos a partir de lo cultural y lingüístico que era sentimental en la medida que mediaba la recreación de una 'patria grande' e incluso de una raza ibérica que iba a revitalizar a España. Pero eran un negro, Maceo, y un mestizo, Darío, los que la interpelaban ahora desde lo híbrido, desde las medias tintas, desde el medio-pelo, uno político; poético el otro.

La idea primero de hermandad o más, de familia hispanoamericana, sostenía un mito irónicamente compartido por varios intelectuales a quienes estas mismas ideas servían para combatir la fuerza del nuevo imperio del norte que amenazaba absorberlas. Estas circunstancias coyunturales, daban forma a ese tipo de "España esencial" o de hispanismo iberoamericano que inaugura el 98, que este volumen desmiente. Este discurso ignoraba las realidades americanas, indígenas, mestizas y heterogéneas y atribuía a España los logros alcanzados por las tierras americanas, sobre todo, la idea de traer la civilización a gentes bárbaras y degeneradas que el artículo de Ramírez critica en la representación de una Argentina pujante en vías a una modernidad exaltada y generosa. España se resistía a aceptar que lo latinoamericano era una configuración propia, un mundo que había dejado de lado el tutelaje y que aquello que lo español había legado al continente era sólo parte de ello.

En esta línea, Jared List se pregunta si Rubén Darío es un pensador eurocéntrico y da cuenta de su ambigüedad. Darío oscila entre una posición eurocéntrica (colonial) y una no-eurocéntrica (decolonial). Darío es un pensador de conciencia fracturada: por un lado, reproduce el pensamiento Europeo y, por el otro, lo cuestiona. Esta conciencia dividida y conflictuada refleja la inestabilidad geopolítica de su época, aún cuando la producción literaria, el modernismo latinoamericano, dice romper las anteriores relaciones coloniales del conocimiento que aún perduraban en las políticamente libres naciones latinoamericanas. La popularidad de Darío como autor y poeta en Europa fortalecía un flujo bidireccional de conocimiento a través del Atlántico. Sin embargo, Darío enfrentó la colonialidad de saberes y poderes. El genio de Darío consistió en proyectar y observar la subjetividad moderna como auto-conciencia siempre perseguida por la otredad. Sin duda, Darío se preocupaba profundamente por la geopolítica. Su prosa refleja esta relación. Una clasificación de sus ensayos, crónicas y artículos periodísticos muestran su angustia sobre la relación entre América Latina a la que contrapone lo que él llama la "Unión Latina”, en alianza con Europa en particular, con España, Francia e Italia como contrapeso. 
Para Carmen Alemany Bay, la presencia de Rubén Darío es España es la del primer renovador de las letras españolas. A partir de él, otros escritores de América Latina como Vicente Huidobro, Pablo Neruda, César Vallejo y otros intelectuales durante la Guerra Civil española establecerán estancias más o menos fluidos en España. Esto traerá la polémica del "meridiano intelectual” entre españoles y latinoamericanos. De la entrada de Darío en el campo de las letras en castellano, se establecen relaciones literarias entre las generaciones, por ejemplo, la relación entre los poetas españoles de la llamada “Generación del 50” y los de la llamada poética coloquial, para ya no hablar de la llegada del boom, que intensificará las relaciones que finalmente desembocarán en el llamado boomerang.

Los trabajos de Arturo Arias, Mario Santana, y María Caballero en este volumen discuten estos malentendidos, distancias y desencuentros en las relaciones transatlánticas. El trabajo de Arturo Arias, por ejemplo, regresa al momento peninsular de Rubén Darío, simplemente para señalar la relación errática entre las dos orillas atlánticas y subrayar el tipo de recepción de otros trabajos de centroamericanos como Rigoberta Menchú, Gioconda Belli, o Sergio Ramírez a principios del veintiuno. El énfasis de Arias recae en lo local, en poner de relieve la especificidad de la producción cultural centroamericana. Se trata de señalar que la recepción peninsular de la producción latinoamericana es siempre reconocida en abstracto y genéricamente como cosmopolititismo continental. El trabajo propone iluminar la presencia centroamericana en los espacios transatlánticos postnacionales y localizar su especificidad real, simbólica o fantasmática de estos espacios regionales, nacionales, locales, concretos. Lo que el artículo puntualiza es precisamente la falta de conocimiento o escasa conciencia de los rasgos diferenciales regionales de la América Hispánica. Todos somos latinoamericanos. Vital a este señalamiento es poner en escena la problemática indígena que diferencia al istmo del resto del continente y que explora la diferencia colonial más sentida-relación que será trabajada con pujanza en el artículo de Héctor Domínguez sobre los Zapatistas.

El trabajo de Mario Santana plantea la disyuntiva entre literatura nacional (que en España, tendrían que ser escrita en varias lenguas-catalán, euskera, gallego) y literatura en lengua castellana (que tendría que incluir todas la literaturas en lenguas castellanas no nacionales). La crítica cultural de España, se ve así presionada desde un frente interno, con su agenda pluricultural del Estado español que contradice el monolingüismo hegemónico; y un frente externo, el de la exitosa entrada en escena de la literatura latinoamericana en los años sesenta del siglo pasado. Ambos frentes cuestionan el concepto de literatura española construido por la historiografía cultural del siglo XIX. La literatura española se escribía también y con más éxito de mercado, en los ámbitos de ultramar. Era imperativo prestar atención al estudio de la dimensión transatlántica de las letras en lengua castellana. El éxito de escritores latinoamericanos fue percibido en España como una competencia, una intrusión. Los escritores españoles ya no gozaban del monopolio cultural de únicos herederos de la lengua. Había que examinar, una vez más, como el caso de Darío qué se significaba por literatura española. Santana propone formular un concepto de literatura nacional no limitado a la producción de los propios ciudadanos sino inclusiva de aquellos productores, tanto autóctonos como importados, disponibles en el mercado internacional; propone fomentar la experimentación de imaginarios culturales diversos 
en una nación globalizada. Las literaturas nacionales son espacios ambiguos, circunscritos y abiertos, permeables y sujetos a todas las presiones mercantiles. En este caso, el trans-atlantismo significa la ruptura de lo nacional, la puesta en cuestión de la hegemonía de la lengua, y la hegemonía mercantil sobre el producto cultural.

María Caballero Wangüemert hace un recorrido por la discusión entre estudios literarios y estudios culturales y se pregunta por cómo inciden los últimos en el canon literario latinoamericano. Su interés transatlántico radica en traer a colación la discusión entre estudios culturales, estudios postcoloniales, y estudios subalternos y los cánones y preguntas que genera. Al hilo de estas preguntas, el trabajo realiza una cala en la crítica y teoría en y sobre Latinoamérica a partir de los noventa, tomando como guía los congresos y números monográficos de revistas literarias. El trabajo es descriptivo, da cuenta del proceso y lo deja abierto, no sin apuntar algunas de sus consecuencias: fin de la búsqueda identitaria de las naciones decimonónicas con sus parnasos locales; abandono de los esencialismos y binarismos sustituidos por identidades híbridas, multilingüísticas y transterritoriales; diseño de nuevas cartografías; desencuentros entre la Academia norteamericana y Latinoamérica, tras el desplazamiento del canon (blanco, culto, escrito) generado desde Europa. En definitiva, la transformación de la experiencia de lo literario por los estudios culturales que, a su vez, generan malestar en algunos sectores de la crítica.

\section{ARTICULACIÓN DE LA COLONIALIDAD DEL PODER/SABER}

Esta sección reúne tres artículos y una entrevista, dos de los cuales están dedicados a discutir la presencia indígena en los textos culturales, criollo-mestizos, peninsulares y de campo, uno a la problematización del concepto de frontera, tal y como se ve en la relación entre México y los Estados Unidos y uno a la producción cinematográfica transatlántica.Todos ellos analizan en distintos contextos la articulación de la colonialidad del poder/saber

El primer trabajo, el de Javier Sanjinés, argumenta que las concepciones de la historia de los intelectuales criollos y mestizos de los Andes son claras instancias de eurocentrismos y occidentalismos. Estos ignoran temporalidades alternas, como son las circulares de las civilizaciones indígenas y son, por ende, instancias de la colonialidad del poder/saber. Si la historia es estatal, positivista, lineal, la pregunta es: ¿qué lugar ocupan los relatos pre-colombinos?, ¿acaso se reducen a meras supersticiones o relatos tendientes a desaparecer bajo el peso de memorias reguladas por una historia de marco Europeo? El estudio propone la reflexión sobre las diferentes temporalidades, el análisis crítico de los intelectuales mestizos y criollos quienes, desde Pueblo enfermo de Alcides Arguedas, de la primera década del siglo pasado, hasta Nacionalismo y coloniaje de Carlos Montenegro, quien introduce la idea de la modernidad revolucionaria en 1940, muestran esta centralidad acrítica. El ensayo de Sanjinés examina este fenómeno y plantea, como núcleo de su argumento, que solamente el peruano José Carlos Mariátegui pudo, en esa primera mitad del siglo XX, revelarnos el hecho de que si el "horizonte de expectativas" del futuro no puede ser conocido con antelación, la memoria local, anclada en el mito, lo conflictúa y contrarresta. Esta pone en duda el 
sentido lineal y progresivo de la memoria universal impuesta por el historicismo europeo.

En esta misma línea de trabajo, Héctor Domínguez-Ruvalcaba considera que todo discurso anti-colonial debe su existencia a la bipolaridad centro/periferia labrada por el occidente. Las comunidades zapatistas se posicionan como autonómicas, doblemente articuladas local/globalmente. Dentro de este marco, Domínguez-Ruvalcaba habla de las declaraciones del Ejército Zapatista de Liberación Nacional en la Selva Lacandona. Su argumento es que las prácticas zapatistas son una síntesis de la teología de la liberación y la ideología guerrillera marxista que aglutina los discursos de las cultural de resistencia- ambas ideologías anticoloniales y pro-liberacionistas. Importa señalar cómo la pluralidad de discursos es una forma postcolonial de hacer política. Propone tener en cuenta que la interlocución zapatista es de redes virtuales (quizá el inventario más extenso jamás visto) que se establecen a partir de la periferia chiapaneca. La Selva Lacandona es un punto de quiasmo de diversas agendas políticas altermundistas. La pregunta clave es si este quiasmo, que articula una multiplicidad de agendas reivindicativas, es una extensión del binomio colonialidad-liberación y si el proyecto autonomista en el que el zapatismo ha desembocado constituye una puerta de salida de la colonialidad endémica.

Nuria Vilanova, por su parte, se mueve hacia la frontera norte para hablar de resistencias culturales, colonialismos y postcolonialismos. Su artículo explora el impacto de dicho pensamiento en la frontera y la relación entre dos mundo dominantes, el que habla español y el que habla inglés. El trabajo interroga el lugar de ese centralismo hegemónico mexicano que privilegia la capital. La frontera no es tierra de nadie sino más bien espacio cruzado por varias dominancias y que se irá configurando como propio a partir de la dinámica de entre mundos que la caracteriza, a veces en forma desafiante. El trabajo contextualiza en la historia y el desarrollo económico y demográfico la relación de los colonialismos con la creación y producción artística de la frontera, especialmente en Tijuana y Ciudad Juárez. El objetivo final es argumentar que la proliferante creatividad y espíritu innovador que se ha desarrollado en la frontera norte mexicana en los últimos veinte años es, junto a otros factores, una reacción a la permanente subordinación y a la vez al abandono a los que el espacio fronterizo ha estado históricamente sometido.

Una historia literaria que también ha estado sometida tanto a la hegemonía anglosajona como a la invisibilidad hispánica ha sido la de la producción literaria boricua. Tal y como muestra la entrevista de Endika Basañez al catedrático en literatura puertorriqueña en la Universidad de Puerto Rico, Fernando Feliú Matilla. En ella tenemos una visión histórica de la génesis artística llevada a cabo en la Isla a través de los diferentes contextos socio-políticos que han tenido lugar en su suelo, desde la aparición de una literatura puertorriqueña propia y distintiva hasta la anexión de Puerto Rico a los Estados Unidos de América como Estado Libre Asociado en 1952 y su impronta en la génesis isleña. Si bien la entrevista tiene como objeto principal la literatura boricua, también se debaten en la misma el falocentrismo cultural presente en la cultura puertorriqueña, las relaciones políticas entre San Juan y Washington D.C., la influencia de los textos diaspóricos en la producción isleña o la situación del panorama artístico actual en Puerto Rico. 


\section{MIGRACIONES Y EXILIOS}

La tercera parte, "Migraciones y Exilios," discute el rico tema de las diásporas en sus distintas manifestaciones, desde la migración de personas hasta la de artefactos culturales. Lo relevante de la sección es subrayar como la migración no es viaje solamente, desplazamiento geográfico. A la vez que produce conflictos sociales e interraciales, también es productora de cultura y pensamiento utópico.

La sección se abre con el ensayo de Ramón Grosfoguel que, al discutir cuatro circuitos de migraciones transatlánticas caribeñas, problematiza los efectos culturales y paradigmáticos que tiene el desplazamiento geográfico hacia centros metropolitanos diversos: Francia, Holanda, Inglaterra y los Estados Unidos. El énfasis del artículo es establecer un estudio comparativo que desentrañe la puesta en discurso de los migrantes caribeños al lugar donde migran partiendo de los mitos fundacionales de la nación. El ensayo pone de relieve los discursos racistas y colonialistas de las cuatro metrópolis e indica sus diferencias. La historia colonial de los territorios fundados por diferentes imperios (holandés, francés, británico y estadounidense) es discutida en relación a las migraciones caribeñas de los territorios todavía dependientes de sus metrópolis.

En la misma línea pero en sentido inverso, Camila Pastor de María y Campos, pone en escena las migraciones del este del mediterráneo hacia las Américas. De esta manera amplía también el marco de referencia y coloca, como foco hegemónico de las relaciones transatlánticas, las prácticas imperiales francesas. De esta manera muestra dos movimientos importantes, primero, los procesos de subalternización de sujetos mashrequíes, a quienes la administración francesa subalterniza; y, segundo, pone a la vista el proceso en reversa al enseñar como estos sujetos subalternizados se tornan elites en México. Al igual que Grosfoguel, Pastor de María incluye poblaciones, países, sociedades antes no pensadas dentro de estas relaciones transmarítimas. Lo mismo hace Marta Sierra, al examinar la obra de la escritora argentina Luisa Futoransky. Aquí empieza el viraje estético pues el punto de partida es la estética fragmentaria y profundamente escéptica de Futoransky, que genera la impresión de postmodernidad. Utilizando el concepto de "hegemonías dispersas" de Inderpal Grewal y Caren Kaplan, el trabajo refiere a la subjetividad de esta autora como múltiple, sujeto que se contrasta o sustituye al unitarismo del sujeto europeo. Esto produce una crítica a los modelos ontológicos hegemónicos de la modernidad que han regido el imaginario global desde el siglo XVI. La lectura de Futoransky se sitúa desde una doble óptica, feminista y postcolonial. A la manera de la 'literatura menor' de Deleuze y Guattari, esta autora instala una estética de lo subalterno en los imaginarios globales: socava las tradiciones estéticas de las denominadas "grandes" literaturas e invita a gozar el fragmento y el collage, textualidad ensamblada a partir de territorialidades dispersas y tradiciones heterogéneas.

En el trabajo de María Claudia André, el migrante se muestra como una fuerza social viva. El ensayo releva la compleja red de referentes y discursos que conforman la identidad de una región, de un país o una nación y evidencia cómo la inmigración europea a la Argentina moldeó y transformó la cultura fundacional del país; redefinió no sólo su política y economía, sino también gran parte de su formación intelectual, social y cultural. La música, el baile (tango), y el habla del ciudadano porteño 
(lunfardo), modificaron los procesos de representación y formación cultural. El tango es una expresión cultural cuya cartografía sirve para ilustrar la injerencia del discurso poscolonial y la construcción de la Otredad en cuanto a la articulación y la definición de la identidad argentina.

Finalmente, y siguiendo este mismo ritmo de lo cultural como migrancia, Eugenia R. Romero estudia la relación en el ámbito popular, entre la música y el lugar junto a la migración y formación de identidades. Romero muestra como la muñeira, que incorpora melodías populares y danzas de corte campesino o marinero, es uno de los ritmos más conocidos pero las gaitas y la pandereitas han influenciado otra vertiente de la música popular en Galicia. El resurgimiento de la música gallega en los 70, le dio un papel preponderante a la gaita como símbolo de galleguidad. De hecho, este simbolismo llegó hasta Sur América gracias a la emigración. En un principio, los representantes del folklore gallego estaban contenidos en los grupos de descendientes gallegos; con el tiempo, dieron como resultado una síntesis de influencias gallegas y latinoamericanas. Mas los ritmos viajan en círculo y las influencias musicales de otras partes del mundo han llegado también a Galicia. El trabajo muestra la incorporación de estilos, ritmos e instrumentos que no son propiamente gallegos en sus producciones y explora la manera en que esta nueva música gallega contribuye a la creación de una identidad nacional globalizada que estos mismos artistas promueven. La vena más popular de lo transatlántico. 
1. Poéticas de la ambigüedad 


\title{
EN EL RINCÓN DE UN QUICIO OSCURO ${ }^{1}$
}

\author{
SERGIO RAMÍrEZ
}

Actor central de la literatura y la política nicaragüense reciente. En el terreno literario ha publicado numerosas novelas, como La fugitiva, Margarita, está linda la mar o Mil y una muertes y ha participado de múltiples iniciativas culturales y editoriales, algunas de ellas fundamentales para entender la cultura centroamericana de las últimas cuatro décadas. En política, Ramírez formó parte del Grupo de los Doce formado por intelectuales, empresarios, sacerdotes y dirigentes civiles que apoyaban al Frente Sandinista de Liberación Nacional y posteriormente fue vicepresidente del gobierno junto a Daniel Ortega.

Ha sido profesor visitante o invitado de varias universidades, como la de Maryland, Libre de Berlín o Harvard. Colabora habitualmente en varios periódicos tanto en Estados Unidos, como en Centro y Sudamérica y España.

Una tarde de diciembre de 1896, en la casa de su hermana Ignacia, calle de las Vendederas en Huelva, Juan Ramón Jiménez leía, embargado por la novedad, unos poemas de Rubén Darío que habían aparecido en La Nueva Ilustración de Barcelona. Un reventar de cohetes, un repicar de campanas, gritos, y las notas de la marcha de Cádiz que tocaba una banda lo hicieron salir al balcón, y vio que las calles estaban llenas de gente porque pueblo y autoridades celebraban la muerte de José Antonio Maceo al grito entusiasta de ¡mueran los mambises!

Se quedó acongojado contemplando aquella celebración que presidían los curas y los militares, en la mano el número de la revista. Y, triste, como si el muerto fuera Darío y la celebración contra Darío, pensó en América, y en Cuba de los cromos de las cajas de tabaco con sus paisajes románticos de palmas airosas, y superpuso en su mente el rostro de Maceo, que adornaba las cajas de chocolate, al de Darío que lo miraba desde la portada de la revista.

Por las calles y plazas en toda España se festejaba en grandes algaradas la caída de Maceo, que se tomaba como anuncio del triunfo inminente de la guerra en Cuba. El General Weyler, que había inventado desde entonces la reconcentración de campesinos en aldeas estratégicas, lo había cazado con su ardid de partir la isla en cuatro con fosos rellenos de dinamita y alambre de púas que los focos eléctricos iluminaban en las noches.

La guerra de Cuba era una guerra perdida desde muchos años atrás, y España no lo sabía, o pretendía ignorarlo, y todavía ignoraba mucho más a manos de quién iba a perderla. Los dos rostros, Maceo y Darío, el uno negro, el otro mestizo, representaban la imaginería exótica de un continente del

\footnotetext{
${ }^{1}$ Este texto se publicó originalmente en Cuadernos Hispanoamericanos 743 (mayo 2012): 79-92. Se integra en este monográfico con el permiso de su autor a las coordinadoras del volumen.
}

Ramírez, Sergio. "En el rincón de un quicio oscuro".

Kamchatka. Revista de análisis cultural 9 (Julio 2017): 15-23.

DOI: 10.7203/KAM. 9.9556 ISSN: 2340-1869 
que sólo Cuba y Puerto Rico quedaban ya como parte del viejo imperio; un rezago. Desde Céspedes, Cuba peleaba otra vez su guerra de independencia, la seguía peleando tras la caída de Martí en Dos Ríos, en mayo del año anterior, y no iba a dejar de pelearla tras la muerte de Maceo. Para España, era la última de sus guerras coloniales. Para Estados Unidos, sería la primera de la construcción de su imperio.

Ramiro de Maetzu, uno de los intelectuales de la generación del 98, sabía ya que la guerra en Cuba era una guerra en contra de los tiempos, como lo sabía Darío. Maetzu se había ganado la vida en Cuba una colonia más rica que la propia península- recitando a Ibsen, a Marx y Schopenhauer a los cigarreros de una fábrica de tabaco, un oficio exótico, como aquellos rostros de cromos y portadas. También ya para entonces eran exóticos los indianos que regresaban ricos a España, y se segregaban en barrios nuevos, como recuerda Clarín en La Regenta. La idea de América misma, lejana a los ardides hispanistas de la restauración, era exótica.

Aquel sentimiento triunfal, que llegó a convertirse en delirio, ya no cesaría ni cuando Estados Unidos entró en la guerra menos de dos años después, y los acontecimientos fueron demasiado vertiginosos para que el público de los cafés y las corridas entendiera que se trataba, desde el principio, de una guerra perdida. Por diez céntimos los niños podían volar el Maine en una postal untada con una pequeña dotación de fósforo, y el ardor patriótico alcanzaba para atizar campañas en contra del consumo de la Emulsión de Scott, por ser producto yanki.

Un enemigo lejano y más bien risible, zaherido en las zarzuelas. “¿Cómo va a tener miedo de los marranos el país de las corridas de toros?" se decía en las crónicas taurinas. Y la imagen del yanki fue la del cerdo, rudo, vulgar y mantecoso. Una lucha ya inadvertidamente desigual entre el león rampante y el cerdo productor de montañas de tocino al que Darío, desde Buenos Aires, aborrecía como enemigo de la sangre latina. En mayo de 1898, cuando tras la batalla de Cavite, que significó la pérdida de Filipinas, era inminente la derrota en Cuba, escribía desde Buenos Aires:

Y los he visto a esos yankees, en sus abrumadoras ciudades de hierro y piedra...parecíame sentir la opresión de una montaña, sentía respirar en un país de cíclopes, comedores de carne cruda, herreros bestiales, habitadores de casas mastodontes. Colorados, pesados, groseros, van por sus calles empujándose y rozándose animadamente a la caza del dollar. El ideal de esos calibanes está circunscrito a la bolsa y la fábrica...

Esta era una visión del bárbaro que también se alentaba en España en esos días, en los periódicos, los sermones y los discursos, pero una visión que no trasladaba a la opinión pública la advertencia de que eran bárbaros ya poderosos, preparándose para iniciar su expansión en el mundo, dueños de los nuevos avances tecnológicos. Y la imagen contrapuesta del viejo y noble poderío español, arraigado en la propaganda de los regímenes de la restauración, iba a servir de muy poco. Darío, desde el otro lado del Atlántico, muy partidario de España, bien sentía, a la par que una fuga de americanos potros, el estertor postrero de un caduco león.

En las tres décadas finales del siglo XIX los Estados Unidos habían multiplicado sus índices de producción en hierro, carbón y acero, ya mayor que la de Inglaterra y Francia a la vez; tenían, además, las fuentes del petróleo en su propio territorio, y dos veces más kilómetros construidos de ferrocarril que toda Europa en su conjunto. Su producción de cereales era diez veces mayor que las de Alemania y 
Francia. No eran todavía la primera potencia naval, pero comenzarían a serlo después de destrozar a la flota española en Filipinas y Santiago de Cuba. La era de las cañoneras, bajo McKinley, estaba por abrirse. Y pronto empezarían los sufrimientos del caribe exótico, de donde Darío venía, que se verían ocupados militarmente a partir de entonces por la infantería de Marina, Haití, México, Honduras, Nicaragua. Y así como McKinley había ocupado Cuba y Puerto Rico bajo un nuevo régimen colonial, Roosevelt segregaría Panamá del territorio de Colombia para construir el canal interoceánico.

Darío siempre había tomado partido del lado de Cuba en su guerra de independencia, aunque hubiera lamentado como un sacrificio inútil la muerte de Martí: “¡Oh, maestro! ¿Qué has hecho?” le preguntaba en un artículo recogido en Los Raros. Martí, a quien había conocido en New York en 1893, invitado por él a un mitin patriótico en Hardman Hall, lo llamó entonces, hijo. Y desde entonces, Darío sabía lo que aquellos "búfalos de dientes de plata” representaban para América: "Behemot es gigantesco pero no he de sacrificarme por mi propia voluntad bajo sus patas".

Derrotada España, y sacrificada Cuba, Darío volvía por España, y volvía a España, donde sólo había estado una vez, con motivo de las fiestas del cuarto centenario del descubrimiento en 1892, como parte de la delegación de Nicaragua que sólo constaba de dos personas. Tenía veintidós años entonces, pero ya había publicado $A z u l$, al que Valera dedicó una de sus Cartas Americanas; y en el salón de doña Emilia Pardo Bazán, y en otros cenáculos, pudo conocer entonces a toda la ancianidad intelectual de España, al propio Valera, a Núñez de Arce, a Zorrilla, a Campoamor, y a Menéndez y Pelayo que vivía en el Hotel de las Cuatro Naciones donde Darío se hospedaba; como preámbulo, ausente el anciano en Santander, un mozo le había abierto en secreto la puerta del apartamento para dejarlo husmear entre sus libros y papeles, y advirtió las sábanas manchadas de tinta. Nunca escapó a su percepción que aquella vieja generación intelectual moría ya, cada uno de sus próceres coronados por turnos en fiestas parnasianas, con lauros de utilería. La nueva generación estaba por venir, y vendría en la circunstancia de la derrota.

Un día de finales de noviembre de 1898 se apareció en la redacción de La Nación en Buenos Aires, para averiguar si no había en ciernes la muerte de algún personaje célebre. Las notas fúnebres se las encargaban por adelantado -un croquetmort, como se llama él mismo- pero sólo se las pagaban cuando el deceso se consumaba, y ya algunos, como Mark Twain, le habían jugado la mala pasada de no morirse. Ese año, fructífero en necrologías, le había tocado escribir las de Mallarmé y Puvis de Chavanne.

Se encontró, en cambio, con que necesitaban de urgencia a alguien que fuera a España para informar sobre las consecuencias de la débacle, y él se ofreció voluntario. Iba a cumplir treintidós años. Después de Azul ya había publicado Los Raros en 1896, y Prosas Profanas en 1897, y Juan Ramón Jiménez, el poeta adolescente que lo leía en un balcón en Huelva mientras abajo celebraban la muerte de Maceo, iría en su busca luego a Madrid, y formaría parte de la pléyade de los modernistas que nacería con Darío, y con el fin del imperio colonial: Valle Inclán, Azorín, Benavente, Baroja, Pérez de Ayala, Villaespesa, los Machado. "Esparcí entre la juventud los principios de libertad individual y personalismo estético que había sido la base de nuestra vida nueva en el pensamiento y el arte de escribir. Y la juventud vibrante me siguió”, diría él mismo. 
De aquel viaje - y ya no volvería más a Buenos Aires, sino de paso- resultó España Contemporánea, que contiene los despachos de más de un año para La Nación, y que vistos en su conjunto resultan una crónica lúcida -verdaderamente contemporánea hoy día- de la vida española del fin del siglo XIX, en momentos de pesimismo e incertidumbre. Una España "amputada, doliente, vencida", abatida de decadencia, los ancianos poetas y oradores esperando turno de ser embalsamados, las exposiciones pictóricas aturdidas de color local, el teatro sin lustre que sólo saca chispas en los corrales, los periódicos de servidumbre política, las editoriales de catálogos pobres y las librerías lejos de las novedades europeas, y más lejos aún de las americanas.

Y pudo ver a realce los colores de la España honda, la vieja España negra tan de Goya y tan socorrida -ya había en su memoria otra Juana la Loca, la viuda de Cánovas del Castillo, que se había encerrado en vida después del asesinato de su marido - la España de los supliciados de semana santa y la reina regenta, con fama de avara, lavando los pies de los mendigos en una ceremonia palaciega y los nobles sirviéndoles la comida, como en una toma negra de Buñuel; la España popular de los toreros, el Guerra, Algabeño y Machaquito, y el entierro de la sardina en la cuaresma de carnavales, ya la gente olvidándose de la derrota mientras Madrid iba llenándose de más mendigos inválidos de guerra, los repatriados de Cuba y Filipinas recibidos con charanga y alboroto mientras estallaban los motines reprimidos a tiros, toda la España siempre negra de los esperpentos de Valle Inclán que en Luces de Bohemia agregaría a otros dos -él mismo, y Darío- de paseo, bastón en mano, entre las tumbas de un cementerio.

Lo que conmovía más a España, desbastada por la derrota, tal como lo percibió Darío desde su arribo a Barcelona a finales de 1898, era el sentimiento, en el fin de siglo, del fin de todo un poderío gestado cuatro siglos atrás con el descubrimiento y que venía perdiendo impulso desde siempre, una piedra que había empezado a rodar ya desmoronándose, las semillas de su propia destrucción en su cauda incandescente desde la derrota de la Armada Invencible cuando Cervantes manco requisaba vituallas en las provincias, hasta el reinado de esperpentos de Carlos IV cuando Goya pintaba a Godoy cebado en los establos reales, un imperio que había terminado, realmente, con las guerras de independencia del primer cuarto de siglo en América, tras la invasión napoleónica. Cuba, Puerto Rico y las Filipinas, no eran sino las últimas pertenencias del reino venido a menos. Una cauda ya macilenta que no se apagaba con la debacle de 1898, y que arrastraría todavía, por años, más allá del fin de siglo, el peso muerto de la restauración.

Darío regresaba a España con el encargo de ver a España como periodista, bajo la influencia de ideas que siendo contradictorias, son recurrentes, no sólo en España Contemporánea, sino en otros escritos suyos, y aún en sus mejores poemas de esa época, y que la debacle contribuyó a aguzar. Recurrentes, pero no homogéneas. Darío no tenía ideas ni homogéneas ni invariables, más que las obsesivas de la vida y la muerte; y advertía que si en sus cantos había política, es porque la política era universal.

Y viendo ya de cerca a España en España, sentado entre los jóvenes que le rodeaban, se encontraba con visiones diversas, y también contradictorias; desde los desparpajos anarquistas de Valle Inclán, a las tesis regeneracionistas de Maetzu, a Baroja que creía en las viejas hidalguías castellanas, y a Unamuno 
que quería enterrarlas. Y en su visión de la España contemporánea Darío es precisamente atractivo por contradictorio, y porque, además, la realidad lo contradice, a su vez, muchas veces. En su selva plena de armonía los ruidos del mundo no siempre entraban tal como eran.

Traía a vender una Argentina donde al fin se había realizado el ideal expuesto por Sarmiento en Facundo, civilización triunfante contra barbarie. Tras seis años de vivir en Buenos Aires, primero como cónsul de Colombia, y después como redactor de La Nación, Darío habla como argentino, y su idea americana es argentina. Buenos Aires es la metrópoli universal, cosmopolita, el crisol de razas, contrapunto de New York. Madrid, siempre provinciano, no.

Argentina es el país de la aurora, abierto a las nutridas migraciones europeas - uno de los grandes ideales del positivismo copiado en América-, que atasca sus graneros, exporta barco tras barco de carne congelada, levanta enjambres de fábricas, y hace crecer una masa obrera pujante, un espejo que multiplica a Bilbao y Barcelona, nada más, pero que deja fuera de sus reflejos a la España feudal y rural de los caciques. Y Darío, con cifras en la mano, recomienda que España debería hacer otro tanto, modernizarse, transformar el régimen del campo, introducir la ganadería en Andalucía, abrirse al comercio internacional, desarrollar la industria. Ser, en fin de cuentas, como Argentina.

En el Canto a la Argentina, un largo poema escrito en 1910 con motivo de las fiestas del centenario de Buenos Aires, Darío canta las glorias de esa tierra de promisión y granero del orbe, sus montañas de simientes, sus hecatombes bovinas, y llama los pueblos extraños a que vengan a comer el pan de su harina, un país abierto, tolerante, y en paz, según el guión de Sarmiento en Facundo. Ensalza puntualmente las corrientes migratorias, una estrofa para cada una -rusos, judíos, italianos, suizos, franceses, españoles - que han encontrado allá su tierra prometida, y propone crear la otra España, la moderna, en suelo de Argentina, con todos los inmigrantes andaluces, asturianos, vascos, castellanos, catalanes, levantinos que siguen llegando en los barcos:

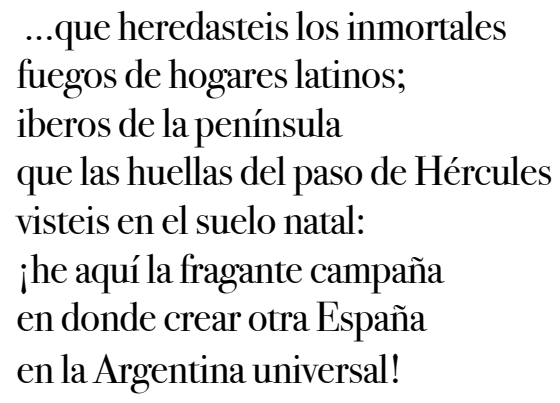

No dejaba de ser un espejismo el desarrollo interno y la prosperidad argentina, como lo fue bajo Perón, y como aún lo sigue siendo un siglo después. Argentina exportaba -en barcos británicos- carne congelada y cereales, pero el régimen de propiedad seguía siendo atrozmente feudal, de explotación inicua de los trabajadores campesinos; $y$, para colmo, la expansión del comercio exterior estaba en manos de Inglaterra, para entonces la mayor potencia colonial del mundo. Inglaterra, que además de los barcos, era dueña de los ferrocarriles, los frigoríficos, las fábricas de conservas, el gas, los tranvías, la banca y los seguros, y le vendía a Argentina las manufacturas. 
El ingreso de Argentina en los mercados internacionales no significaba industrialización real, ni desarrollo hacia adentro, como el que impulsaban en Estados Unidos "los estupendos gorilas colorados", lanzándose hacia el oeste con los ferrocarriles y abriendo a la agricultura mecanizada nuevos campos, sino una alianza entre el capital oligárquico y los capitales ingleses.

Argentina no era, realmente, el otro polo de desarrollo en el continente americano, como contaba, y cantaba, Darío, aunque lo parecía, y aunque tenía más pujanza que España empobrecida. Buenos Aires era, de verdad, una gran urbe. Precisamente, la política de los gobiernos liberales posteriores a la dictadura de Rosas -el de Bartolomé Mitre, propietario de La Nación el primero- había consistido en convertir a Buenos Aires en eje de atracción e impulso, y era ya la metrópoli macrocéfala, típica de la posterior configuración urbana de América Latina, tan engañosa para medir el desarrollo. La Nación, uno de los diarios más grandes del mundo, tenía lectores suficientes para enviar a Europa un corresponsal como Darío con tarjeta de presentación en cartulina de lino, un verdadero embajador. Ningún diario de Madrid, con tiradas mucho más modestas, podía pagarse entonces ese lujo.

Mitre puso desde el principio a su periódico del lado de España en la guerra contra los Estados Unidos. Electo en 1862, tras la caída de Rosas, había gobernado con el apoyo de la burguesía porteña más moderna. Para él, partidario de una Argentina unitaria y de cabeza fuerte como debía serlo Buenos Aires, seguía válido el ideal de civilización y progreso que Sarmiento - presidente en el período siguiente al suyo- había planteado en Facundo.

Facundo no era un mito. Juan Facundo Quiroga, caudillo sanguinario de La Rioja, había mandado a Sarmiento al exilio. La Argentina bárbara de los años posteriores a la independencia se encarnaba en su figura, con todo lo que representaba de brutalidad y atraso; ayudó a poner a Rosas en el poder, y Rosas había sido eficaz en su política de tierra arrasada entre los indios para asegurar el dominio de los latifundistas en las pampas. Rosas centralizó el poder en sí mismo, y unificó a la Argentina, bajo su puño, desarrollando el agro sin que la tierra se quitara de manos de los terratenientes, y amplió el comercio exterior. Era la modernidad arcaica del caudillo.

Pero el ideal civilizador propuesto en Facundo también era un mito americano, de inspiración europea. Sarmiento admiraba a John Fenimor Cooper en su visión de El Ultimo Mohicano, donde, a fuerza, del choque de dos razas una debía resultar triunfante. Civilización, otra vez, contra barbarie. El progreso pasaba necesariamente por esta dilucidación; y la raza vencedora del salvaje era europea, ni siquiera mestiza. Lo que resultó fue que en Argentina, como en toda la América Latina bajo los gobiernos liberales, nuevos terratenientes - muchos de ellos mestizos disfrazados de europeos- pasaron a señorear la economía agraria, y la forma de dominio fue siempre feudal.

Darío comparte muchas veces este ideal de civilización americana, que llega a emparentarse con el darwinismo social, extremo del positivismo europeo, tan de moda en la época pero ya al fin de siglo sujeto a revisión, como estaba ocurriendo dentro de España entre los jóvenes de la generación del 98. El progreso ya no sería inevitable, ni sólo sobrevivirían los más fuertes. La razón se había vuelto diabólica. Es Unamuno el que señala la pérdida absoluta de fe en la razón humana, base del iluminismo, y la necesaria vuelta a la fe en el hombre, que es más que razón, como en tiempos del renacimiento. Y Darío, 
el positivista americano, es el que más creía, a la vez, en su propuesta literaria, en la necesidad del regreso a los abismos de la psiquis individual, sensaciones más que razones.

La esencia del modernismo dariano es el artista capaz de mirarse a sí mismo: “¿tu corazón las voces ocultas interpreta?”, interroga Darío a Juan Ramón Jiménez, planteándole los requisitos para ser poeta. Libertad en el arte y personalismo estético. Y no pocos de los escritores que desde sus obras liquidaban cuentas con el positivismo en el final del siglo -Ibsen, Dostoyevski, Tolstoi- estaban entre sus raros de Los Raros.

Pero más allá de estas dilucidaciones, el mundo se estaba repartiendo entre las potencias, a finales del siglo XIX, en base a un darwinismo aún más feroz, el darwinismo geopolítico, un reparto del que España había sido excluida por quienes ahora dominaban la tecnología de punta, transporte, comunicaciones, armamentos. Lord Salibsury hablaba en mayo de 1898 de "naciones moribundas" que no debían estorbar la misión civilizadora de las grandes potencias en Africa, Asia y América.

Es a esa España moribunda desde hace siglos, que ha arrastrado en su cauda las semillas de su propia decadencia, a la que ahora hay que culpar, la raza "atrasada, imaginativa, y presuntuosa, perezosa e improvisadora, incapaz para todo” de que habla Joaquín Costa, y que según Maetzu sólo será regenerada si llega a ser un día vasca, o catalana. Es decir, que trabaje para ser moderna. Darío, también está de acuerdo. Pero a la vez exalta a la otra España, la de Goya, la de Cervantes, la de Quevedo, que lo asalta con sus legiones de mendigos desde que baja en la estación ferroviaria, y que encuentra viva en sus chulos, en sus manolas, mozos de cordel, cocheros, carreteros y desocupados desde que se asoma a la Puerta del Sol donde por toda novedad moderna circula un tranvía eléctrico.

Con la derrota, Darío ampara todo un concepto de España de siempre, que tiene un vago arraigo lírico en la propuesta restauradora de contrarreforma y reconquista, pero en contra punto a la advenediza pretensión imperial de Estados Unidos, bárbara y arrogante, y la extiende al concepto de América española -un eco también del hispanismo restaurador-. Reconstruir las glorias de España, en España y en todo ese universo descuadernado del viejo imperio americano, de panteras condecoradas y licenciados venales y presuntuosos, no es ya más sino un sueño necio. Y también lo sabe.

En Cantos de vida y esperanza, su libro más trascendental, están sus mejores poemas españoles, que son poemas de esperanza forzada, traspasados por la conmoción. En Salutación del optimista hay mil cachorros sueltos del león español, pero en Los Cisnes sólo se escucha el estertor postrero de ese león caduco. Ha llegado la era del cerdo que coloca en cada puerto del caribe sus acorazados:

$$
\begin{aligned}
& \text { ¿Seremos entregados a los bárbaros fieros? } \\
& \text { tantos millones de hombres hablaremos inglés? } \\
& \text { ¿Ya no hay nobles hidalgos ni bravos caballeros? } \\
& \text { ¿Callaremos ahora para llorar después? }
\end{aligned}
$$

El cisne, es el ave heráldica del modernismo. Es el ideal del arte, el de la poesía, la belleza, y a la vez el único símbolo que ahora puede oponerse a los bárbaros fieros que conquistan el mundo. Es en sus alas que Darío quiere dejar escrita su protesta, al menos. 
Y pone su fe inútil en la nobleza antigua de los bravos caballeros, el primero de ellos Don Quijote. Un cuento suyo, D.Q.. que si se publicó en Buenos Aires en el almanaque Peuser de 1899, debió haber sido escrito en Madrid en 1898, revela la magnitud de esa fe: el abanderado de la tropa acantonada en Santiago de Cuba, un enjuto manchego ya maduro en edad y de poco hablar, al que apenas se conoce por sus iniciales D.Q, se arroja al vacío cuando se recibe la orden de rendición ante los yankis; "y todavía, de lo negro del abismo, devolvieron las rocas un ruido metálico, como de una armadura”. Dejar constancia, por lo menos.

En las crónicas de la conquista, delante de los soldados españoles peleaba Santiago a caballo contra los indios, como había peleado contra los moros, matando él solo muchos cientos. Ahora, este otro caballero de armadura -rey de los hidalgos, señores de los tristes- no tiene ya otro recurso que despeñarse frente a la ignominia de la derrota.

Para quienes como Azorín y Baroja creían en la moral del hidalgo castellano, Don Quijote la encarnaba como ningún otro, aún en la derrota; para Unamuno, igual que para Maetzu, representaba más bien la decadencia, una rémora espiritual, y material, que seguía haciendo arcaica a España. El futuro, para Maetzu, estaba en algo muy parecido a la formidable maquinaria del progreso yanki, que había visto trepidar en Nueva York, como la había visto Darío, y no en el páramo manchego. Y como, de todos modos, creía Darío que debía ocurrir en España, si ya creía que estaba ocurriendo en Argentina. El progreso, para Maetzu, no estaba en los campos desolados de la España rural, sino en las ciudades iluminadas; las mismas ciudades feéricas que Darío adoraba -fulgor, velocidad-iconos del modernismo.

"Este país de obispos gordos, de generales tontos, de políticos usureros, enredadores y analfabetos, no quiere verse en esas yermas llanuras sin árboles, de suelo arenoso, en el que apenas si se destacan cabañas de barro, donde viven vida animal doce millones de gusanos, que doblan el cuerpo, al surcar la tierra con aquel arado, que importaron los árabes al conquistar Iberia”, dice Maetzu en Hacia otra España, y Darío le da la razón, y lo saluda entonces como "un vasco bravísimo y fuerte”.

Había también algo muy importante que dilucidar, y en lo que Darío y el modernismo fueron claves. El anquilosamiento de la lengua era una expresión de la rémora de transformación social que la restauración seguía imponiendo. Las rigideces de la vieja gramática y el purismo castizo eran la parálisis de la sociedad también, una expresión del ideal reaccionario de la vieja España hispanista, la España eterna que Darío añoraba, pero a la que ayudaría a enterrar con la revolución modernista en la lengua. Y en la aventura de cambiar la lengua, unos y otros, cualquier que fuese su camino -Valle Inclán iconoclasta, Machado después republicano, Maetzu por último falangista- sí que estaban de acuerdo.

Y junto con la propuesta de modernidad de la literatura - que por una graciosa paradoja se le llamó a veces decadente- Darío traía entonces a España algo más importante que su visión positivista: unas señales de identidad compartida. A la hora de la debacle él devolvió a España, en la renovación de la lengua común, la prueba de que España era parte de la cultura americana, una cultura mestiza de pluma debajo del sombrero, capaz de crear un idioma nuevo que regresaba a la península con Darío. Aquel era, en momentos de crisis pero también de búsqueda, un viaje de regreso que encarnaba una gran ruptura y 
una gran invención después de la cual ya nada sería lo mismo en la lengua. Así lo había advertido Clarín: "el poeta nicaragüense ha de traer cola y dejar huella, para unos beneficiosa y para otros funesta".

La piedra que venía rodando desde siglos no se había detenido en 1898 a la hora de la debacle, y el régimen sepulcral de la restauración sobrevivió todavía muchos años. Pero la corriente de cambio ya se había establecido. Darío, metido siempre dentro de su España contemporánea como periodista, como embajador de uniforme alquilado, como literato, estuvo siempre allí, en las tertulias de los cafés y las librerías, en las redacciones de los periódicos, en los cenáculos, en la inquerida bohemia, y en su propia soledad, en su pobreza y sus desamparos, hasta la cercanía misma de su muerte.

Juan Ramón Jiménez lo dejaba, con repugnancia y tristeza, cuando llegaba la hora en que empezaba a beber lo que en crudo eufemismo de dipsómano él llamaba su "veneno", y sólo ya enterrado en Nicaragua recordaría Unamuno que había tratado tan injustamente a aquel a quien se le veía la pluma debajo del sombrero. Y él, quizás borracho, lloraría a Castelar que había muerto enseñándole latín a su loro.

Era la España contemporánea suya y seguiría siendo la España negra de Goya, Valle Inclán y Buñuel juntos, y otra vez la suya. Aún en la semana trágica de 1909, cuando la piedra aún no terminaba de rodar, un carbonero alzado en las barricadas en Barcelona sería fusilado por haber bailado con el cadáver de una monja, otro aguafuerte de la serie infinita en aquel año de turbulencias en que tuvo que cerrar la misión de Nicaragua en la calle de Serrano después de verse forzado a vender su piano, porque nadie en Managua se acordaba de pagarle sus sueldos de embajador y no tenía ni para el coche.

En Barcelona se embarcó para ya nunca más volver, un 25 de octubre de 1915, gracias a un pasaje que le había regalado el marqués de Comillas, ya cuando arreciaban los vientos de la primera guerra mundial. Pobre y enfermo, custodiado por malandrines, ya a bordo de su camarote del Antonio López se despedía llorando, una despedida de toda la noche, de su hijo de pocos años y de su mujer, la campesina de Navalsauz que había conocido en el parque de la Casa de Campo en 1899 mientras paseaba con Valle Inclán y ella le daba a comer a los cisnes del estanque -otro paseo entre cisnes, como aquel entre tumbas -. Francisca Sánchez, la princesa Paca criada entre cabras en la sierra de Gredos, la que olía a cebolla, no la princesa de Éboli de sus tardes de Aranjuez.

El último de sus poemas españoles será un poema negro, y de los más hondos suyos, ése que relata una peregrinación fantasmagórica a Compostela en compañía de Valle Inclán -el propio marqués de Bradomín-, todavía un paseo final. Y Valle Inclán, en Luces de Bohemia, hace que el personaje Rubén Darío recite, entre esperpentos, la última estrofa de ese poema desolado, un infinito juego de espejos oscuros entre los dos:

\author{
...la ruta tenía su fin \\ y dividimos un pan duro \\ en el rincón de un quicio oscuro \\ con el Marqués de Bradomín.
}




\title{
LA FRATERNIDAD HISPANO-AMERICANA A DEBATE: EL DIÁLOGO CULTURAL DEL 98
}

\author{
Hispanic-American Brotherhood: Cultural Dialogue of 1898
}

\author{
EVA VALERO JUAN \\ UNIVERSIDAD DE ALICANTE eva.valero@ua.es
}

Profesora Titular de Literatura Hispanoamericana en la Universidad de Alicante y Directora del Centro de Estudios Iberoamericanos Mario Benedetti. Es autora de los siguientes libros: Lima en la tradición literaria del Perú, de la leyenda urbana a la disolución del mito (2003), La ciudad en la obra de Julio Ramón Ribeyro (2003), Tras las huellas del Quijote en la América virreinal (Bulzoni, 2010), Ercilla y La Araucana en dos tiempos. Del Siglo de Oro a la posteridad (Renacimiento, 2016). Entre los libros colectivos de los que es coeditora, destacan Mito, palabra e historia en la tradición literaria latinoamericana (Iberoamericana-Vervuert, 2013) y Raúl Zurita. Alegoría de la desolación y la esperanza (Visor, 2016). Es Secretaria de la revista América sin nombre.

\section{RECIBIDO: 16 DE ENERO DE 2017}

RESUMEN: Si uno de los objetivos de los estudios transatlánticos se ha fijado en el análisis de las conflictivas relaciones entre España y Latinoamérica tras la Independencia, precisamente es el período finisecular el momento clave en el que ese conflicto evoluciona hacia un nuevo diálogo cultural que, sin dejar de ser problemático y con muchos matices, significa una inédita reciprocidad y un nuevo renacer cultural e identitario a ambos lados del Atlántico. Teniendo en cuenta -como apuntan Francisco Fernández de Alba y Pedro Pérez del Solar- que "los cruces transatlánticos representan parte fundamental de los momentos fundacionales y míticos tanto de España como de las repúblicas americanas" (2006: 102), el 98 significa ese momento en el que "nuevas rutas, nuevos canjes, nuevos viajeros" (2006: 102) generan un riquísimo y por ello complejo diálogo en el que la reciprocidad de la influencia se comenzó a construir como un renovado puente de comunicación que, sin embargo, tendría sus grietas, esenciales todas ellas para profundizar en voces con frecuencia olvidadas, y en otras sin embargo muy conocidas.

PALABRAS ClaVE: diálogo cultural 1898, estudios transatlánticos, España, América Latina.
ACEPTADO: 14 DE MAYO DE 2017

ABSTRACT: If one of the objectives of the transatlantic studies has been fixed in the analysis of the conflictive relations between Spain and Latin America after Independence, it is precisely the finisecular period the key moment in which that conflict evolves towards a new cultural dialogue that, without leaving of being problematic and with many nuances, means an unprecedented reciprocity and a new cultural and identity rebirth on both sides of the Atlantic. Bearing in mind, as Francisco Fernández de Alba and Pedro Pérez del Solar point out, that "transatlantic crosses represent a fundamental part of the foundational and mythical moments of both Spain and the American republics" (2006: 102). 98 means a time when "new routes, new exchanges, new travelers" (2006: 102) generate a rich and therefore complex dialogue in which the reciprocity of influence began to be built as a renewed bridge of communication that, However, it would have its cracks, essential all to deepen in frequently forgotten voices, and in others nevertheless very well-known.

KEY WORDS: Cultural dialogue 1898, transatlantic studies, Spain, Latin America. 
Y bien, a fin de cuentas, ¿qué es la hispanidad?

Ah, si yo lo supiera

Unamuno

Penetrar en el imaginario cultural español e hispanoamericano que surge del año 1898, entendido como un conjunto de ideas, de imágenes y de representaciones colectivas, requiere comenzar recordando que en el transcurso del siglo XIX, y sobre todo en su segunda mitad, se fue intensificando progresivamente en España la idea de América como una prolongación de la propia identidad nacional. Esta visión de América se hizo especialmente patente a partir de la pérdida de las últimas colonias en 1898, y se desarrolló en el ámbito concreto del discurso nacionalista de los regeneracionistas. Como es bien conocido, tras la "derrota" la intelectualidad española generó el gran discurso en torno a España para tratar de diagnosticar las causas de los famosos "males de la patria”, proponer soluciones y redefinir la identidad nacional. En este debate, la idea de América tuvo un papel importantísimo: imaginaron una América que seguía siendo una utopía en un horizonte incógnito, pero distinta a la del pasado, pues la convirtieron en una especie de mito paliativo de las debilidades y obstáculos que se debían superar para sacar a España de la postración; un mito capaz de devolverle su orgullo y su lugar de gran nación en el ámbito internacional (cfr. Tabanera, 1997). Es decir, se trató de ver en el restablecimiento de la relación con la América de habla hispana una vía fundamental para la modernización de España y para la recuperación de su perdido prestigio internacional. Este objetivo se planteó a través de un discurso en el que la unión de los lazos entre la comunidad hispana de ambos lados del Atlántico -formulada sobre la base de los vínculos culturales, lingüísticos y sentimentales- permitía restablecer el orgullo de la soñada "patria grande", e incluso de la "raza" -conceptos ambos muy en boga en los discursos del período que nos ocupa-.

América, en la percepción de un importante grupo de intelectuales españoles, se convertía por tanto en un elemento esencial para la revitalización de España. De hecho, tras el 98 los españoles dieron un paso decisivo en este proceso en su intento de rehacer la familia hispanoamericana. Y lo hicieron en ese discurso de hermandad que realmente estaba forjado, sin embargo, sobre los mitos constitutivos de la hispanidad, aquellos que daban forma a la "España esencial" construida por los del 98 tras el derrumbamiento. En este discurso, no resulta difícil descubrir que lo que realmente los intelectuales españoles admiraban de América no era precisamente la realidad americana en su propia esencia -mestiza, heterogénea-, sino que alabaron y se fascinaron por lo que, desde su punto de vista, los españoles habían podido lograr en tierra americana y por su poder civilizador de aquellos pueblos precolombinos que, como sentenciara Menéndez Pelayo, eran, ni más ni menos, que "gentes bárbaras y degeneradas" (1948: 10). Además, la resistencia a admitir que desde su emancipación la realidad latinoamericana se había ido configurando como un mundo diferente al español, y a abandonar una visión ideal de España y de su tutelaje hispanoamericano, condicionó que muchos españoles del momento -como veremos en estas páginas- quisieran seguir viendo tan sólo lo que de español podía hallarse en el Nuevo Mundo. 
Para entender este discurso que surge en el seno del movimiento regeneracionista, resulta imprescindible partir del contexto del 98 y su significación histórica: para los españoles, la fecha del "desastre" y de la depresión nacional; y para los hispanoamericanos -pero sobre todo para los cubanos- la fecha liberadora que cerraba, por fin, el período del dominio español en América.

1898 es un año que marca una tremenda paradoja histórica: siendo el año de la pérdida de Cuba, Puerto Rico y Filipinas, al mismo tiempo es el año que propicia un diálogo cultural entre intelectuales de España y América Latina, en el que los escritores de la generación del 98 y los regeneracionistas tuvieron un papel fundamental. 1898 se convertía así, como tantas veces se ha repetido, en la fecha de la reconciliación o del inicio de una nueva hermandad, tras un siglo de hostilidad y animadversión entre la exmetrópoli y las nuevas repúblicas emancipadas. Ineluctablemente, el mapa político concluido en el 98 marcaba un momento en el que la vieja "Madre patria" debía convertirse en una hermana más en el conjunto de las naciones de habla hispana, idea que los intelectuales españoles pretendieron articular en el discurso "teórico" de una pretendida "fraternidad hispanoamericana".

Por otra parte, la derrota de España frente a EE.UU. en la guerra por la emancipación de Cuba supuso el inicio del monopolio del coloso norteamericano en todo el continente, un proceso que se activó sobre todo con la Unión Panamericana surgida de la Conferencia de Washington en 1890. Además, en Europa los países latinos habían sido vencidos en varias ocasiones en la segunda mitad del siglo XIX: a la derrota española se unía la francesa frente a Alemania en 1870 y la italiana en Adua en 1896 ${ }^{1}$. Todos estos acontecimientos fortalecieron, en los ámbitos intelectuales europeos, la polémica que venía gestándose desde mediados del siglo XIX con el surgimiento del panlatinismo napoleónico, entre las dos civilizaciones principales: la latina frente a la anglosajona y germánica. Ante el modelo anglosajón y sus valores -el materialismo, el utilitarismo, el culto a la riqueza, a la fuerza y a la competitividad-, y frente al peligro del panamericanismo estadounidense, en los decaídos países latinos de Europa tuvo una especial vigencia el panlatinismo -teorizado fundamentalmente por Michael Chevalier, consejero de Napoleón $\mathrm{III}^{2}-$, como exaltación de unos valores culturales comunes -el espiritualismo, el idealismo, las esencias de la cultura-, y como reivindicación y reactivación de "lo latino", cuya principal vía de desarrollo se veía en la necesaria unión cultural y técnica y en el acercamiento político entre estos países. Pero a su lado, y a veces sin delimitar con precisión el significado exacto de estos términos, emergió también el panhispanismo, que se venía elaborando desde los tiempos de la Restauración, cuando ya se comenzó a plantear y a promover un discurso de defensa de la "Unión hispánica", asentado sobre la idea de una "raza

\footnotetext{
${ }^{1}$ Derrota frente del ejército italiano frente al ejército etíope. Los soldados del rey Humberto I perecieron en un baño de sangre al intentar ampliar los límites de Eritrea hacia el extremo sudoccidental a costa del imperio etíope. Tras la derrota francesa en la guerra franco-prusiana de 1870, la nación gala quedó, como era lógico presumir, sin amigos ni apoyo internacional y el aspecto político interno durante el gobierno del Emperador Napoleón III, transformado en un auténtico caos.

${ }^{2}$ Sobre la problemática de la latinidad, a los trabajos clásicos de Arturo Ardao, Génesis de la idea y el nombre de América latina (1980) o John Phelan, "El origen de la idea de América” (1979), hay que añadir la imprescindible compilación de artículos reunidos bajo el título La latinidad y su sentido en América Latina (1986).
} 
española" que apelaba al origen común de españoles e hispanoamericanos. Destinado por tanto a revitalizar el sustrato hispánico en América Latina, el panhispanismo trató de enfrentar lo que desde España se sintió como un peligro a combatir: la penetración en las antiguas colonias españolas de América de la influencia, no sólo de Estados Unidos, sino también de otros países europeos, incluidos los latinos.

Como veremos, ambos términos -panlatinismo y panhispanismo- se confunden en determinados discursos del período de entresiglos, en los que parecen apelar a los mismos valores e ideales. Pero en su diferencia hay una clave política fundamental, relativa a la competencia entre los países europeos por la supremacía, no sólo intelectual, sino también económica en América Latina. Pensadores del cambio de siglo, tanto españoles como hispanoamericanos, utilizaron un término u otro ("lo latino" o "lo hispánico") dependiendo de la intencionalidad de su discurso, generando una ambigüedad que, a la postre, enmascaraba la hispanofilia propia de algunos de los discursos más destacados en torno a la identidad cultural que se desarrollaron en ambos lados del Atlántico.

En definitiva, estas polémicas definen la época del 98: latinos frente a anglosajones, panamericanismo frente a panhispanismo, son los debates que dan forma a un complejo contexto histórico en el que la reflexión sobre la identidad de las naciones en pugna o en reconciliación es el punto central. En este sentido, resulta interesante la reflexión de Miguel Rojas Mix:

Tras la huella de la Hispanidad la oposición latino/sajona se precisará como la del hombre hispano, frente al hombre medio usamericano. Si el homo hispanicus fue asimilado por Unamuno al Quijote o al Martín Fierro, el yanqui medio será simbolizado por Babbitt, el personaje de Sinclair Lewis. Representante del ingenuo materialismo del Middle West, activo, optimista, de buena voluntad, pero lleno de prejuicios, cordial, un poco vulgar, desea el bien de la humanidad, sin olvidar que lo principal es su propio negocio: es el prototipo del puritanismo hipócrita. (2000: 48)

En este entramado, la nueva hermandad que surge tras la extinción definitiva del antiguo "imperio" tiene ejemplos principales en autores hispanoamericanos que, participando de la ilusión por la emancipación de Cuba, vieron el peligro que suponía la penetración de la cultura anglosajona. Entre ellos, la voz de Rubén Darío sonó con contundencia. Baste con recordar los conocidos versos de "Los Cisnes" (1905), donde el vate nicaragüense lanzaba las grandes interrogantes históricas del momento:

\footnotetext{
¿Seremos entregados a los bárbaros fieros?

¿Cuántos millones de hombres hablaremos en inglés?

¿Ya no hay noble hidalgo ni bravos caballeros?

¿Callaremos ahora para llorar después?
}

Tiempo atrás, el 20 de mayo de 1898, Darío ya había expresado las mismas ideas cuando publicó en El Tiempo de Buenos Aires “El triunfo de Calibán”, donde planteaba la necesidad de unión de la raza latina frente a la prepotencia imperialista del enemigo común, encarnado en CalibánEE.UU.: 
No, no puedo, no quiero estar de parte de esos búfalos de dientes de plata. Son enemigos míos, son los aborrecedores de la sangre latina, son los Bárbaros. Así se estremece hoy todo noble corazón, así protesta todo digno hombre que algo conserve de la leche de la loba. (En Mattalía, 1996: 179)

Con la "sangre latina" vinculada a "la leche de la loba", Darío estaba utilizando en este caso "lo latino" para referirse a los tradicionales valores hispánicos, tal y como ocurrirá en el discurso de otros intelectuales a los que más adelante me referiré (si bien el poeta nicaragüense fue uno de los grandes paladines de una latinidad en la que la cultura francesa resultaba fundamental). Estos valores fueron adquiriendo una carga decisiva en el discurso sobre la identidad de intelectuales de ambos lados del océano, que formularon dicha vindicación partiendo de un impreciso concepto de "raza". Desde esta perspectiva, Darío continúa su discurso en “El triunfo de Calibán”: “De tal manera la raza nuestra debiera unirse, como se une en alma y corazón, en instantes atribulados; somos la raza sentimental, pero hemos sido también dueños de la fuerza; el sol no nos ha abandonado y el renacimiento es propio de nuestro árbol secular" (en Mattalía, 1996: 181). Y termina con una defensa de España, de sus valores morales, de su tradición literaria, que no implica una opinión contraria a la emancipación de Cuba sino a los peligros que entrañaba el que denominó, de forma rotunda, "el enemigo brutal", EE.UU:

Y yo que he sido partidario de Cuba libre, siquiera fuese por acompañar en su sueño a tanto soñador y en su heroísmo a tanto mártir, soy amigo de España en el instante en que la miro agredida por un enemigo brutal que lleva como enseña la violencia, la fuerza y la injusticia.

“¿Y usted no ha atacado siempre a España?” Jamás. España no es el fanático curial, ni el pedantón, ni el dómine infeliz, desdeñoso de la América que no conoce; la España que yo defiendo se llama Hidalguía, Ideal, Nobleza; se llama Cervantes, Quevedo, Góngora, Gracián, Velázquez; se llama el Cid, Loyola, Isabel; se llama la Hija de Roma, la Hermana de Francia, la Madre de América. (En Mattalía, 1996: 182)

Esta formulación finisecular del "antiimperialismo" había comenzado años antes en Cuba con José Martí, había continuado con el propio Darío en varios textos como el arriba citado y, en especial, con la oda "A Roosevelt" - de sus Cantos de vida y esperanza (1905) - y también, con diferente matiz, había sido desarrollada por José Enrique Rodó en su Ariel (1900). Todos estos textos coincidían en el tiempo con la crisis de la España del fin de siglo, y fruto de esa coincidencia fueron algunos desarrollos de este debate sobre la base de una marginalidad compartida por España e Hispanoamérica ante el imperialismo moderno. Marginalidad común que cimentó la afinidad entre los países hispanoamericanos y España, tal y como explicó José Gaos en su Antología del pensamiento de la lengua española en la Edad Contemporánea:

Pensamiento de la decadencia [en España] y pensamiento de la Independencia [en Hispanoamérica] presentan notorias afinidades de fondo y forma. Buscar las causas y encontrar los remedios de la decadencia nacional, resolver los problemas de la constitución y reconstitución de la patria son operaciones del mismo sentido... (1945: XXXV) 
Ante este panorama, conviene ahora precisar, a través de algunos discursos paradigmáticos, la mirada recíproca entre España e Hispanoamérica en este período fundamental para el transatlantismo en el que destacados intelectuales de ambos lados cimentaron la apología de la fraternidad. En esta construcción, la hispanofilia y los sentimientos de la "raza común” fueron la base fundamental para la reflexión sobre la identidad.

\section{AMÉRICA EN LA MIRADA ESPAÑOLA DEL PERÍODO DE ENTRESIGLOS}

Como ya he adelantado, la complicidad espiritual entre intelectuales de ambos lados del Atlántico a partir del 98 ayudó a crear una nueva conciencia de la importancia de América en la identidad cultural española. En esta restauración de la confraternidad con América Latina, la "generación del 98" desarrolló un papel decisivo, con Unamuno sin duda como figura principal. Julio César Chaves, en su libro Unamuno y América, apunta en este sentido que

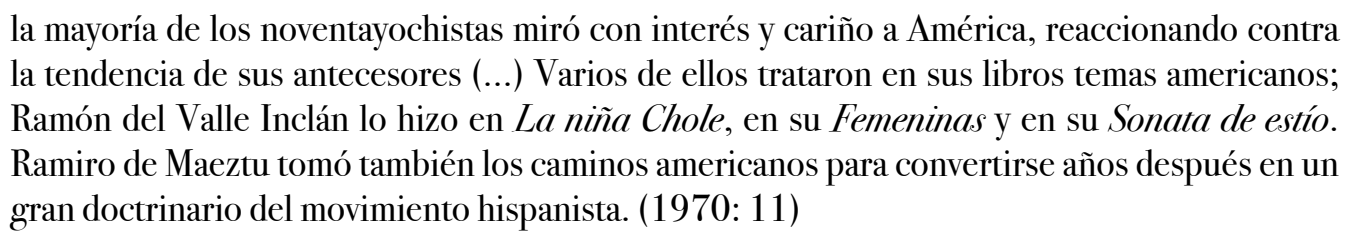

Entre la nómina de autores del fin de siglo español fue Ángel Ganivet el precursor de esa mirada americana que desde su Idearium español (1897) abrió una nueva etapa en las relaciones entre los países de lengua española. Desde su perspectiva, obviamente esta etapa no debía orientarse hacia la "confederación política de todos los Estados hispanoamericanos" sino hacia una “confederación intelectual” (1977: 98), de signo espiritual y cristiano común a España e Hispanoamérica, para contrarrestar los efectos de la expansión anglosajona. Ganivet, junto con Rafael M. de Labra ${ }^{3}$, trazó las líneas básicas de un programa concreto para revitalizar las relaciones entre España y América. Ambos consideraron este programa imprescindible para sacar a España de su frustración y devolverle un puesto relevante en el contexto internacional. La creencia en la comunidad cultural entre España y sus antiguas colonias era la base de este programa. Y el objetivo común de los intelectuales del 98 español quedaba muy claro en todas sus declaraciones al respecto: la necesidad de alentar y extender, tras el divorcio político, la “comunión espiritual” entre los hispanoamericanos sobre la base de la defensa del sustrato hispánico común.

Un sentido similar defendería otro intelectual del momento, Rafael Altamira, exiliado y fallecido en México, que fue miembro del Comité de Juristas para la creación de la Sociedad de Naciones y de un Tribunal Permanente de Justicia Internacional -por recordar sólo algunos de sus puestos más relevantes-, y cuya voz fue silenciada por las largas décadas de la dictadura en España. Seguramente por este motivo su obra, y también su acción americanista desde finales del siglo XIX, es una de las más desconocidas en el contexto trazado y, sin embargo, una de las más relevantes en lo

\footnotetext{
${ }^{3}$ Autor de Orientación americana de España (1910), impulsó la revitalización de esa comunidad cultural hispanoamericana considerada imprescindible para la rehabilitación nacional española.
} 
tocante al discurso y a la actividad transoceánica inaugurada en España hacia finales de la primera década del XX. Considero imprescindible por ello detenerme en las claves principales de interpretación de su americanismo ${ }^{4}$, por tratarse de una de esas figuras un tanto olvidadas que, siendo uno de los promotores principales del nuevo americanismo español a comienzos del siglo pasado, resulta paradigmático de ese transatlantismo que tiene en este momento un período principal de revisión.

En su libro España en América, tras analizar la influencia norteamericana, francesa, alemana e italiana en América Latina, Altamira dedicó un capítulo a "Lo que debe hacer y lo que ha hecho España”, donde expuso las razones que habrían de conducir al restablecimiento de la hermandad. Entre otros aspectos, el alicantino se apoyó en el lazo literario promovido por Rubén Darío para la gestación de una relación que él pretendía recíproca, aunque esa reciprocidad quede finalmente en la superficie de su discurso, pues son evidentes las grietas por las que se entrevé un paternalismo que persistía a pesar de todo. Fijémonos en cómo al final del texto invierte el sentido de su discurso y desvela que el objetivo último debía ser la necesaria penetración de España en América:

La boga alcanzada en nuestra juventud por Rubén Darío y por otros escritores de América, ha creado lazos nuevos entre ambas literaturas, interpolando elementos de una y otra, creando corrientes de recíproca influencia, y a la postre uniéndolas más y más y asegurando la penetración de la nuestra. (1908: 77) (la cursiva es mía).

La clave de la visión americanista de Altamira consiste en el hecho de que consideró que para impulsar la hermandad hispanoamericana era necesario comenzar deshaciendo los prejuicios arraigados en la sociedad latinoamericana que alimentaban el rencor hacia España; una labor que, desde su punto de vista, tan sólo se podía acometer a través de la acción de los profesionales de la enseñanza. Por ello, la política pedagógica fue uno de los proyectos primordiales para hacer efectiva su actividad americanista -recordemos que fue Director General de Primera Enseñanza desde 1911-, y dedicó todos sus esfuerzos a combatir, desde la enseñanza de la historia, la corriente hispanófoba, partiendo de la perspectiva de lo que denominó un idealismo progresivo. Es decir, un idealismo, o utopismo que, partiendo del reconocimiento de una decadencia indiscutible y del autoanálisis, pretendía “infundir creencia en la posibilidad de la regeneración” (1908: 41) y, al mismo tiempo, transmitirla a las naciones latinoamericanas para restablecer y normalizar la cooperación con España.

El americanismo de Altamira se fundamenta por tanto en la ideología regeneracionista, que formuló precisamente en el discurso inaugural del curso 1898-1899 de la Universidad de Oviedo (donde fue catedrático de Historia del Derecho), titulado Universidad y Patriotismo, y en su Psicología del pueblo español (1902). En estos primeros textos planteó la necesaria vinculación entre regeneracionismo y americanismo, dado que consideraba (como Ganivet y Labra) la proyección hacia

\footnotetext{
${ }^{4}$ He desarrollado este tema en el libro Rafael Altamira y la "reconquista espiritual"de América (2003). Recientemente ha aparecido un nuevo libro de Gustavo H. Prado que aborda en profundidad el viaje de Altamira a América entre 1909 y 1910: Rafael Altamira en América (1909-1910). Historia e historiografia del proyecto americanista de la Universidad de Oviedo (2008).
} 
Hispanoamérica como condición ineludible para la “modernización” de España, en el sentido de fortalecer una identidad hispana supranacional, y de impulsar unas relaciones no sólo culturales sino también, como más arriba he apuntado, económicas -un planteamiento deudor del primer panhispanismo formulado en la España de la Restauración-. Con esta idea, un importante grupo de pensadores españoles concibió un nuevo patriotismo en el que España debía ejercer de guía espiritual de América Latina aunque, aparentemente, no se negara la originalidad y la diversidad que la definen.

Por ejemplo, en sus Cuestiones hispanoamericanas Altamira planteó "el reconocimiento de esa solidaridad ideal que nos une por encima de las pasadas luchas, convirtiéndonos en colaboradores de una misma obra superior a todas las diferenciaciones nacionales"; una voluntad de unión que también sintió amenazada cuando advirtió que "el ejemplo de los Estados Unidos (otra vez) es, hoy por hoy, un obstáculo temible para la solidaridad que pretendemos establecer” (1900: 2-3).

Para fundamentar el objetivo reconciliador, la visión de Altamira sobre la historia de España en América durante la Colonia iba a ser fundamental. Por ello, dedicó una parte importantísima de su labor historiográfica a la reivindicación de la acción de España en sus colonias, es decir, a extender la idea de que la conquista había sido positiva para la civilización y que las violaciones de las leyes protectoras se debieron a algunos hombres y no a la Corona. Defendió -en sus palabras- "la obra útil, civilizadora, tanto en el orden material como en el espiritual, que realizaron los españoles en su contacto con las nuevas tierras descubiertas del lado del Atlántico y del Pacífico" (La huella de España 125). Y, si bien admitió la existencia de escasos errores en el pasado colonial, convirtió su visión de la Historia en instrumento ideal para realizar un alegato defensivo de España que, en última instancia, tenía como finalidad la recuperación de la confianza del pueblo español en el espíritu nacional y, nuevamente, en "el genio de la raza”. Se trataba, por tanto, de acudir a las glorias del Imperio para inyectar una buena dosis de optimismo en la España maltrecha del cambio de siglo ${ }^{5}$.

Para ello, utilizó argumentos justificativos que, en su intento de acabar con la "leyenda negra" y de enaltecer el poder civilizador de España en su historia, caían en la atenuación constante de los aspectos negativos de la conquista, dado que Altamira minimizó la opresión a la que se vieron sometidos los pueblos indígenas americanos durante todo el período colonial. Por ejemplo, en un resumen de las clases que dictó desde su cátedra de la Universidad Central de Madrid en el curso 1919/1920, y que tituló significativamente "Beneficios producidos en América por la Colonización”, Altamira lanzó una serie de ideas muy controvertidas, que denotaban una clara instrumentalización de la historia:

Las transgresiones de la legislación española en América son casos aislados que no autorizan para formular una afirmación de carácter general. Al lado de los esclavistas, escasos en número, fueron legión los misioneros que protegieron a los indios, y los gobernadores, los alcaldes, y los virreyes que cumplieron los fines de civilización protectora que la metrópoli se propuso.

\footnotetext{
5 Partiendo de este objetivo, Altamira escribe en su Psicología del pueblo español: "Restaurar el crédito de nuestra historia, para devolver al pueblo español la fe en sus cualidades nativas y en su aptitud para la vida civilizada, y aprovechar todos los elementos útiles que ofrecen nuestra ciencia y nuestra conducta de otros tiempos" (160).
} 
Puede concluirse que, tanto la legislación como la conducta de los españoles, fueron lo más humanitario y benévolo que en esta materia registra la historia. (Mecanoscrito del legado de Rafael Altamira. Archivo de la Residencia de Estudiantes 3-4)

Un párrafo como éste estaba negando toda la obra del Padre Las Casas, cuyas denuncias de las atrocidades cometidas por los españoles sobre los indígenas son sistemáticamente rectificadas por Altamira en su afán por reconciliar al pueblo español con su propia historia. Por ello, la cuestión del indio y de la legislación indiana fue uno de los aspectos cardinales de su revisión histórica, dado que estaba en el origen de la "leyenda negra" de España. Y evidentemente la rectificación debía comenzar por la obra de Las Casas, que germinó en la campaña antiespañola fomentada en Europa durante siglos:

En primer lugar, nos falta una revisión de las obras todas del padre Las Casas, el cual, por la acción altamente simpática que representa en cierto orden de su orientación, ha llevado tras sí las voluntades y ha hecho que se desconozca durante muchísimo tiempo toda la parte falsa, toda la parte de posición insegura que tenía él en su campaña (aun siendo, repito, en el fondo altamente simpática y humana), y toda la parte de exageración de sus escritos, de los cuales no tardaron en apoderarse las naciones que lucharon políticamente en Europa y América con nosotros, en aquella contienda literaria que llenó todo el siglo XVI y el XVII, (...) y que se hartó de inventar calumnias y repartirlas y esparcirlas por toda Europa para desacreditarnos. (1908: 139)

En el marco de esa acción vindicativa se encuentra, en definitiva, el hilo conductor de toda la acción americanista de Altamira, cuya importancia sin embargo está en haber sido un revulsivo fundamental para la estimulación y el surgimiento en España de instituciones culturales diversas que propiciaron un nuevo interés por las cosas de América ${ }^{6}$. Este hilo conductor puede rastrearse en todos sus libros y conferencias, con mayor insistencia en los de tema americano: Cuestiones hispanoamericanas (1900), España en América (1908), Mi viaje a América (1911), España y el programa americanista (1917), La huella de España en América (1924), Cómo concibo yo la finalidad del hispanoamericanismo (1927), etc.

En definitiva, el importante papel que los del 98 y el movimiento del americanismo regeneracionista asignaron a América y su acercamiento a España tiene mucho que ver con la imagen y la opinión del mundo hispanoamericano que algunos de ellos crearon. Muchos vieron en ese mundo un ejemplo de modernización, sobre todo se sintieron fascinados y entusiasmados por Argentina. La idealizaron como representación del progreso y del desarrollo económico, pero lo hicieron para plantear los logros que podía alcanzar la raza hispánica, creando por tanto una visión falseada de un país que desde fines del siglo XIX había recibido el aluvión masivo de la inmigración, italiana fundamentalmente. Vicente Blasco Ibáñez, Altamira o Adolfo González Posada, fueron algunos de los intelectuales que mostraron esa admiración.

\footnotetext{
${ }^{6}$ En junio de 1909 se fundó el Instituto Iberoamericano de Derecho, y, por aquellos mismos días, se estableció la Biblioteca América en la Universidad de Compostela. En Barcelona apareció la Sociedad Libre de Estudios Americanistas con el objetivo primordial de divulgar en España el conocimiento de la América Latina; en Cádiz se creó la Real Academia Hispanoamericana de Ciencias y Artes, y en la Universidad Central se estableció un Centro y Seminario de estudios hispanoamericanos.
} 
Este último, por ejemplo, planteó en España lo mucho que los españoles podían aprender de Argentina, cuya prosperidad, desde su punto de vista, provenía de su habilidad para adaptar el carácter español a los nuevos tiempos, de modo que América se construía en su visión desde el prisma de la españolidad. Otro tanto ocurre con Blasco Ibáñez. En 1909 visitó Argentina y quedó absolutamente deslumbrado por la grandeza del país y su riqueza cultural. Fruto de aquel deslumbramiento fue un artículo, publicado en España con el título "Porvenir de América", en el que formuló, de manera especialmente significativa, que la Península estaba anémica por "exceso de crianza", es decir, por haber transferido a sus hijas americanas toda su fuerza. En este mismo sentido, hay que recordar que aquella experiencia provocó que Blasco Ibáñez fundara las colonias de Nueva Valencia en Corrientes y de Cervantes en Río Negro. Ante la realidad de la emigración a la Argentina desde otros países, que el valenciano sentía como una amenaza a la raíz española -compartida por otros intelectuales argentinos como Manuel Gálvez o Ricardo Rojas (sobre los que volveré más adelante) - el sentido de su proyecto colonizador quedaba muy claro en las siguientes palabras de una carta al capitán del buque "Barcelona”, de 22 de octubre de 1911:

Mi hijo viene para secundarme en mi empresa de colonización, cuyo principal objeto es resucitar y mantener la legítima influencia del alma española en este progresivo país, tan solicitado por los extranjeros. (en Codinabas, 1998: 89)

América dejaba de ser un motivo de estudio en sus escritos (entre los que destaca Argentina y sus grandezas de 1910) para convertirse en una realidad vivida y soñada como una utopía. En este sentido, y para concluir con esta mirada de España a América en el período de entresiglos, parece idóneo recordar que Ganivet embelleció este desconocimiento secular sobre la realidad hispanoamericana con una hermosa analogía. En ella, esta América de la utopía es la isla de Sancho Panza, la ínsula Barataria, tan desconocida e imaginaria como la que los noventayochistas inventaron en el horizonte: "La mayoría de la nación ha ignorado siempre la situación geográfica de sus dominios: le ha ocurrido como a Sancho Panza, que nunca supo dónde estaba la ínsula Barataria, ni por donde se iba a ella, ni por dónde se venía" (en Ortiz, 1911: 150). En definitiva, la mirada transatlántica desde la España del 98 pretendió una nueva complicidad, pero el peso de su historia en América, la frustración nacional del momento, la necesidad de encontrar el asidero en las antiguas colonias para el renacer nacional, y en buena medida el desconocimiento de aquella realidad, mermaron la nitidez de esa mirada transatlántica. Por ello, no es difícil detectar una fluctuación entre la proyección de una confraternidad espiritual ideal y las emanaciones, de intensidad variable según los discursos, de un hispanismo patriótico que ofuscaba los intentos de comprensión de una realidad distinta, no hispana, sino hispanoamericana, o mejor, latinoamericana. Sin embargo, en el reconocimiento de ese esfuerzo de comprensión de una realidad distinta, en la necesaria valoración del contexto histórico en que se produce, y en el efectivo renacimiento de la aurora americana en el horizonte cultural español del siglo XX, se encuentra el camino para distinguir los sorprendentes matices de este panorama hispano-americano. Para ello, dirijamos ahora el objetivo a la otra orilla. 
Todos los planteamientos aludidos de los hombres del 98 español tuvieron acogida en América entre sectores que, frente a la amenaza anglosajona, reactivaron la raíz hispánica como sustrato fundamental del ser hispanoamericano, o bien propusieron potenciar el concepto de "lo latino". Como he adelantado más arriba, este concepto fue utilizado por algunos autores de manera muy ambigua, puesto que realmente en determinados discursos "lo latino" designaba "lo hispánico", y excluía al resto de culturas latinas como la italiana o la francesa. Claro está, el objetivo de este sector hispanófilo americano era afirmar y restituir la hegemonía española en Hispanoamérica, su legítimo tutelaje y liderazgo cultural que tenía por derecho histórico frente a la incursión de otros pueblos latinos a través de la inmigración o de la influencia cultural.

Así, la tendencia hispanófila se extendió por los más diversos países de América Latina, incluso por algunos de fuerte raíz indígena como el Perú, con la generación del novecientos o arielista, en las obras de Francisco García Calderón 7 , José de la Riva Agüero ${ }^{8}$ o Víctor Andrés Belaúnde ${ }^{9}$, por citar los nombres más destacados. También desde México, los miembros del Ateneo de la Juventud -entre ellos, Alfonso Reyes, Pedro Henríquez Ureña y José Vasconcelos- potenciaron un reencuentro con la tradición propia, formada sustancialmente por la tradición hispánica y por la asunción de los valores positivos de la cultura universal ${ }^{10}$. Y en el Río de la Plata la hispanofilia tras el 98 recobró una nueva significación a través del pensamiento de Darío y de José Enrique Rodó, quienes conferían a la antigua metrópoli un papel de renovación espiritual en aquella concepción del mundo contemporáneo que enfrentaba lo latino y lo anglosajón. Los representantes de la generación argentina del novecientos -entre los más destacados Manuel Gálvez ${ }^{11}$ y Ricardo Rojas ${ }^{12}$ - abogaron por la herencia española en la búsqueda que emprendieron de la propia identidad. Desde este posicionamiento, consideraron que los valores de esa herencia (la honradez, la hidalguía y la generosidad propias de la raza) permanecían vivos en el clima tradicional de las provincias y se diluían sin embargo en el ámbito de la capital, Buenos Aires, amenazada por la heterogeneidad y el cosmopolitismo que provocaba la inmigración ${ }^{13}$.

\footnotetext{
7 Entre sus obras, destacan De litteris (1904) con carta prólogo de Rodó; Profesores de idealismo (1909); y Les démocraties latines de l'Amérique (1912). Como ha señalado José Carlos Rovira "las ideas centrales de García Calderón construyen un pensamiento racista en el que defiende una vaga latinidad, originada por el empuje hispánico y la cultura francesa, una latinidad opuesta al espíritu anglosajón..." (1992: 28).

${ }^{8}$ Ardiente defensor de la tradición hispánica, representante del positivismo conservador y responsable del colonialismo literario en el sentido de la restauración del hispanismo, Riva Agüero veía en el aumento de la inmigración española e italiana el medio para fortalecer el predominio de la raza latina en el territorio nacional. Y en su recuperación del pasado consideró el tiempo de la colonia como "los tres siglos civilizadores por excelencia” (Riva-Agüero, 1962: 297-298).

${ }^{9}$ Asumió los planteamientos de los regeneracionistas españoles y de la generación del 98. [...] Tomando como referente El problema nacional, de Ricardo Macías Picavea, Colectivismo agrario en España y otras obras de Joaquín Costa, realizó un autoanálisis de los defectos del alma nacional y profundizó en las causas del fracaso político y económico.

${ }^{10}$ Cfr. Teodosio Fernández, 2000: 24-25.

${ }^{11}$ Véase Elsolar de la raza (1913).

12 Véase La restauración nacionalista (1909), Blasón de plata (1912) y La argentinidad (1916).

${ }^{13}$ Cfr. Teodosio Fernández, 2000: 27.
} 
El lógico límite de estas páginas me impide hacer un recorrido en profundidad por los textos de todos los pensadores citados, por lo que me detengo en dos ejemplos claros del discurso hispanófilo que utilizó la defensa de la latinidad para reivindicar los valores de la hispanidad: José Gálvez y Ricardo Rojas, quienes desde los planteamientos de Rodó, reformularon la argumentación hispanista frente al cosmopolitismo.

Si en su Ariel José Enrique Rodó partió de la apelación a los valores latinos para promover un sentimiento aristocrático y espiritualista que frenara la “degeneración democrática”, ambos pensadores argentinos propugnaron un regreso a la tradición española como escudo frente a los grandes contingentes de inmigrantes, sobre todo italianos, que llegaron a Argentina desde 1885 y que, desde su punto de vista, amenazaban con disolver en la masa heterogénea las raíces culturales de la argentinidad (cfr. Romero, Breve historia 113-126). Para la construcción de este discurso, lo latino y lo hispánico se acercan, e incluso a veces se confunden, cuando se trata de enaltecer valores culturales opuestos a lo anglosajón, pero se distancian radicalmente en el momento en que entra en juego la lucha por la supremacía de los países latinos de Europa en Hispanoamérica.

La confusión surge por el hecho de que intelectuales como Gálvez y Rojas utilizaron los conceptos de raza latina o latinidad cuando apelaron a dichos valores ideales comunes para contraponerlos con el modo de vida anglosajón, en el seno del mismo discurso en que plantearon, para la formulación concreta de la identidad cultural argentina, que lo hispánico debía prevalecer sobre el resto de influencias, incluidas las provenientes de países latinos. Un ejemplo muy elocuente de dicha ambigüedad conceptual se encuentra en El solar de la raza (1913), cuando Gálvez, tras afirmar que "somos en el fondo españoles”, escribe:

Creyente yo en nuestra admirable raza latina, y especialmente en la estirpe española a que pertenecemos, mi elección no podía ser otra. Son las imágenes del espiritualismo español las que debemos, perfectamente, presentar a nuestros conciudadanos. La influencia española es necesaria para nosotros, pues lejos de descaracterizarnos, como ciertas influencias exóticas, nos ayuda a afirmar nuestra índole americana y argentina (en Rovira, 1992: 155).

Pero regresemos al punto originario, el 1900, fecha bisagra en que se publicó Ariel de Rodó. Definido por Darío en el artículo "José Enrique Rodó” de 1916 como "el pensador de nuestros nuevos tiempos" y como "un filósofo platónico de la flor del paganismo antiguo, resucitado en tierras americanas" (en Mattalía, 1996: 231, 232), Rodó se situó con esta obra en el origen del debate sobre la identidad cultural latinoamericana ( $f r$. Rovira, 1992: 9-11). Ariel se presentaba como discurso dirigido "a la juventud de América”, en el que el maestro Próspero expone la necesidad de regeneración de los valores del espíritu y del idealismo, y las bases de una política pedagógica orientada a la reivindicación de la cultura, el culto a la belleza, a la inteligencia y a la aristocracia del espíritu. Frente a estos valores, Próspero analiza la cultura norteamericana como "encarnación del verbo utilitario", y alerta ante el mercantilismo que comenzaba a extenderse peligrosamente hacia el sur, amenazando con imponer "una América deslatinizada" (Rodó, 1997: 35). El espíritu de Ariel puede sintetizarse en las siguientes líneas: 
Ariel triunfante, significa idealidad y orden en la vida, noble inspiración en el pensamiento, desinterés en moral, buen gusto en arte, heroísmo en la acción, delicadeza en las costumbres. Él es el héroe epónimo en la epopeya de la especie; él es el inmortal protagonista... (Rodó, 1997: 57).

Pero al mismo tiempo que Rodó lanzaba en Ariel sus teorías sobre la selección espiritual, el carácter desinteresado y los nobles ideales enfrentados al utilitarismo del vecino del norte, también advertía sobre otro peligro para las condiciones de vida de América: la imposición de ese mismo sentido utilitario de la vida que procedía ya no de los Estados Unidos, sino de la inmigración y el cosmopolitismo:

El presuroso crecimiento de nuestras democracias por la incesante agregación de una enorme multitud cosmopolita: por la influencia inmigratoria, que se incorpora a un núcleo aún débil para verificar un activo trabajo de asimilación y encauzar el torrente humano con los medios que ofrecen la solidez secular de la estructura social, el orden político seguro y los elementos de una cultura que haya arraigado íntimamente -nos expone en el porvenir a los peligros de la degeneración democrática, que ahoga bajo la fuerza ciega del número toda noción de calidad... (Rodó, 1997: 25).

Ante estos peligros, Rodó planteó que "el cuidado de la independencia interior -la de la personalidad, la del criterio- es una principalísima forma del respeto propio" (Rodó, 1997: 36), y que sólo preservando y afianzando las bases de lo propio, podría asimilarse al inmigrante que llegaba a "hacer las Américas", a través de una efectiva integración en la que se impusiera "el genio de la raza":

El cosmopolitismo, que hemos de acatar como una irresistible necesidad de nuestra formación, no excluye, ni ese sentimiento de fidelidad a lo pasado, ni la fuerza directriz y plasmante con que debe el genio de la raza imponerse en la refundición de los elementos que constituirán al americano definitivo del futuro (Rodó, 1997: 37).

En estas líneas está contenida la oposición unidad-diversidad, localismo-universalismo, que se encuentra en la base de los debates sobre la identidad cultural latinoamericana. Y si Rodó expuso esta problemática desde un punto de vista globalizador de esa identidad común a toda Latinoamérica, una década más tarde, en los años que rodean el Centenario de la independencia argentina (1910), Gálvez y Rojas reaccionaron también contra el cosmopolitismo, afirmando su "arielismo" como influencia cardinal para el movimiento nacionalista del viejo grupo criollo en Argentina. La denuncia del materialismo provocado por la inmigración que se encuentra en Ariel es por tanto el resorte esencial sobre el que los nacionalistas argentinos propugnaron su "arielismo". Pero su ámbito de acción preferente se encontraba en la oposición al espíritu utilitarista de la gran cosmópolis (Buenos Aires), como espacio en el que la hibridación social planteaba el peligro de la creación de colectividades que intentaban mantener sus lenguas y costumbres.

Ante esta nueva situación, ya en Ariel Rodó se remontó al origen de las naciones uruguaya y argentina cuando recordó que, "para colmar el vacío moral del desierto", Juan Bautista Alberdi proclamó la famosa máxima: “Gobernar es poblar”. Pero transcurrido medio siglo, la realidad sociopolítica cambió visiblemente, por lo que Rodó apostilló: “Gobernar es poblar, asimilando, en primer 
término; educando y seleccionando después" (1997: 26). Es decir, para Rodó a comienzos del siglo $\mathrm{XX}$ ya no era viable la absorción indiscriminada de población, sino que se hacía imprescindible la integración y la educación del inmigrante en los valores propios de la nueva patria que les acogió. El tercer eslabón de esta cadena se encuentra en El solar de la raza, donde Gálvez propuso: "En la hora presente, gobernar es argentinizar". Teniendo en cuenta el resto de esta obra, el verbo "argentinizar" significaba para Gálvez homogeneizar la nueva sociedad en formación aplicando el proyecto educativo en los valores trascendentes de la "raza latina” propuesto por Rodó, pero asumiendo la herencia española como único camino posible para la búsqueda de la identidad propia. Lo latino y lo hispánico seguían confundiéndose así en una fluctuación que se encuentra también en las líneas precedentes de Rodó, en las que queda claro que la "fidelidad a lo pasado" para la construcción de la identidad significa la asunción de la preponderancia de la raíz hispánica.

Sobre esta base teórica, tanto Gálvez como Rojas integraron el idealismo de Rodó en un nacionalismo "regenerador”. “Al par que idealista, esta campaña es nacionalista”, escribió Gálvez. E invirtieron los términos del discurso primigenio sobre la identidad: el debate entre civilización y barbarie con el que Domingo Faustino Sarmiento había tratado de explicar la realidad argentina a mediados del siglo XIX. La oposición nacionalismo-internacionalismo se remonta así a su origen: la del campo y la ciudad. Y si en el siglo XIX se había tratado de combatir al desierto poblándolo, el cosmopolitismo les devolvía al "caos”, a la “corrupción” y a la "disolución”.

Frente a la posición antihispanista de Sarmiento y su defensa de la ciudad como espacio de la civilización -opuesto a la campaña, generadora de barbarie- Rojas mostró su antieuropeísmo en el libro que dedicó a Sarmiento, El profeta de la pampa (1945), donde describió las ciudades como centros exóticos, hostiles y bárbaros, y arremetió contra el cosmopolitismo sin patria, la barbarie. Para Rojas, la civilización debía buscarse en el regreso a la tierra, a los orígenes, a la provincia, de donde tanto él como Gálvez provenían: "La barbarie, siendo gaucha, y puesto que iba a caballo, era más argentina, era más nuestra. Ella no había pensado en entregar la soberanía del país a una dinastía europea" (Rojas 98), escribió en La restauración nacionalista. La civilización por tanto ya no se encontraba en la capital socialmente desintegrada, ni en la imitación de modelos europeos preconizados por Sarmiento. Si Sarmiento suprimió entre esos modelos el español, Gálvez y Rojas propugnaron lo contrario: el cultivo de la raíz hispánica que debía mantener su supremacía sobre el resto de influencias foráneas. Desde esta perspectiva, los nacionalistas se acercaban al pensamiento noventayochista español, en su búsqueda de las raíces de la raza nacional, como el propio Gálvez manifestó al escribir:

El pequeño grupo que formamos, ejerce aquí una misión semejante a la que tuvo en España aquella generación de ideólogos que surgió después del desastre. España, por medio de Ganivet, Macías Picavea, Costa, Unamuno y algunos otros, se observó a sí misma y llegó a conocerse profundamente. (En Rovira, 1992: 154)

El diálogo transatlántico se concreta aquí con los intelectuales que han ejemplificado la primera parte de estas páginas. Siguiendo este ejemplo, la celebración del Centenario de la Independencia en 
1909 planteó la necesidad de dirigir la mirada hacia el terruño, hacia la raíz de la cultura y el origen de la nación. Y en esta búsqueda, España ocupó un lugar preferente, si bien la visión hispanista en Gálvez y en Rojas presenta matices de diferenciación que conviene aclarar.

Rojas apeló al pasado telúrico y su hispanismo no fue regresivo, en el sentido de que su reivindicación no es la de la España conquistadora, sino la de la nueva España de los ideales regeneracionistas, opuestos al autoritarismo, a la educación dogmática, al poder clerical, a la superstición, etc. En esta reivindicación hispanista, hay que matizar además que la visión nacionalista de Rojas incluye, junto al sentimiento hispánico, la restitución de lo aborigen como centro del imaginario cultural y de los mitos nacionales, es decir, la defensa de un dualismo de origen hispanoindígena, desarrollada fundamentalmente en Blasón de plata (1910). Sin embargo, Gálvez invocó la España del pasado: "La decadencia del solar de la raza debiera ser para nosotros una fecunda fuente de ideales. En las ruinas suntuosas y tristes de la España vieja podemos hallar los grandes bienes que faltan a nuestra riqueza ascendente" (160). Por ello, propuso "evocar el ambiente de aquellas ciudades de provincia donde, al contrario de Buenos Aires y otras ciudades en pleno progreso, aún perdura el antiguo espíritu nacional, el sentimiento de la patria, la profundidad espiritual de la raza” (154). Y apeló únicamente a la raíz hispánica para definir la identidad argentina:

Contra las ridículas modas, contra las influencias extrañas que nos descaracterizan, pretende reaccionar el actual nacionalismo argentino. (...) Él nos exige dejar a un lado las tendencias exóticas y nos invita a mirar hacia España y hacia América. No odiamos a los pueblos sajones, a los que tanto debe el progreso argentino; no odiamos a la dulce Francia, cuyo espíritu elegante y armonioso tanto ha influido en nuestras cosas; no odiamos a esa ferviente Italia, que nos ha dado una parte de sus energías. Pero ha llegado ya el momento de sentirnos argentinos, y de sentirnos americanos, y de sentirnos, en último término, españoles puesto que a la raza pertenecemos. (En Rovira, 1992: 159)

Por tanto, la coincidencia entre Rojas y Gálvez se basa fundamentalmente en la denuncia del mero progreso material sin sentido espiritual que fomentaba el cosmopolitismo y la masiva inmigración que comenzó a producirse fundamentalmente desde 1885; inmigración que amenazaba con disolver en la masa heterogénea las raíces culturales de la argentinidad. Y aunque Rojas protestara en el prólogo a La restauración nacionalista sobre las acusaciones de xenofobia que provocaron algunas de sus manifestaciones, lo cierto es que declaraciones como la siguiente daban lugar a la polémica:

De las inmigraciones que pueden venirnos, es la mejor de todas la italiana (...) es el mayorazgo de la latinidad. (...) Mas, la inmigración italiana, a pesar de sus excelencias étnicas, económicas, históricas y sociales, se ha convertido en un peligro, por su cantidad en enorme desproporción con el escaso núcleo nativo (...). No olvidemos que si el país ha abierto sus puertas al extranjero ha sido por un doble movimiento de patriotismo y de solidaridad humana: necesitábamos crear económicamente la nacionalidad, cuya conciencia ya existía en tiempos de la Constituyente, y entregar, en generosa compensación, la tierra virgen al trabajo humano. Pero nosotros no abrimos las puertas de la nación al italiano, al francés, al inglés, en su condición de italiano, de francés o de inglés: se las abrimos en calidad de "hombre", simplemente. (1971: 236-237) 
El planteamiento equivalente se encuentra en El solar de la raza, cuando Gálvez exige a los recién llegados "el olvido de todas las patrias". Con esto, ambos intelectuales estaban liquidando la posibilidad de que el inmigrante pudiera enriquecer y nutrir la cultura argentina en formación con el aporte propio; estaban negando la realidad de aquel proletariado urbano formado por inmigrantes que, inevitablemente, introduciría sus voces y costumbres en la lengua y la cultura argentina; y estaban posicionándose en la afirmación de una dicotomía que resultaba insuficiente para tratar de explicar la nueva realidad argentina de comienzos de siglo, tal y como la presentó José Luis Romero: "Para el sociólogo, para el político y para el observador vulgar, el dilema que se ofrecía a la vida argentina era simple pero decisivo: o la sociedad criolla absorbía plenamente al conglomerado inmigratorio o éste disolvía la sociedad tradicional” (2000: 63).

Frente a esta posición de la antigua clase criolla, el Partido Socialista lanzó un manifiesto en 1909, en defensa de las clases obreras, en el que encontramos el planteamiento opuesto sobre el pretendido problema de la inmigración:

El movimiento obrero argentino es obra de hombres nacidos aquí y en otros países, como tiene que ser toda sana actividad colectiva en un país cosmopolita. El movimiento obrero da a todos los hombres del país un alto ejemplo de conciencia histórica y política, solidarizando a los hombres de igual condición social, cualquiera sea su patria de origen. El movimiento obrero hace obra de argentinización librando a nativos y extranjeros de prejuicios de raza, y haciéndolos trabajar de consuno en la elaboración de un más fuerte y más alto pueblo argentino. Circulan ahora en el mundo los sentimientos y las ideas con la misma libertad que los hombres y las mercancías. ¿Cómo podrían entonces alcanzar los nuevos ideales y los nuevos métodos? ¿Si copiamos de Europa las artes y las ciencias, si de allá traemos las semillas y las crías que refinan nuestros cultivos, no son también para este país una bendición las nociones y prácticas importadas que han de sacarnos del pantano de la política criolla? (Romero, 2000: 67).

Pero la corriente nacionalista, representando los intereses de la oligarquía que enfrentó las reivindicaciones obreras como un encuentro entre nativos y extranjeros, más que como conflicto de clases (cfr. Romero, 2000: 55-95), no aceptaba la adopción integradora de elementos culturales foráneos. Y su expresión más radical la encontramos de nuevo en el discurso de Gálvez, en un fragmento en el que el concepto de "latinidad" se muestra definitivamente como máscara engañosa de unas esencias ideales que en realidad escondían un pensamiento conservador en su defensa de la raíz única, la hispánica:

Raza latina, no obstante todas las mezclas. Nosotros vamos recogiendo las virtudes de la estirpe que nuestros hermanos de Europa comienzan ya a olvidar. Latinos, en mayoría irreemplazable, son los hombres que vienen a poblar el país; latino es nuestro espíritu y nuestra cultura. Pero dentro de la latinidad somos y seremos eternamente de la casta española (en Rovira, 1992: 159-160).

Frente a este discurso, es preciso señalar que la hispanofilia de Rodó fue sustancialmente distinta, y tal vez sea en el siguiente fragmento perteneciente al texto "La España niña" donde el 
uruguayo expresó con mayor claridad el lugar que ocupaba España en su pensamiento sobre América Latina:

Yo no he dudado nunca del porvenir de esta América nacida de España. Yo he creído siempre que, mediante América, el genio de España, y la más sutil esencia de su genio, que es su idioma, tienen puente seguro con que pasar sobre la corriente de los siglos [...] Pero yo no he llegado a conformarme jamás con que éste sea el único género de inmortalidad, o, si se prefiere, de porvenir, a que pueda aspirar España. Yo la quiero embebecida, o transfigurada en nuestra América: sí, pero la quiero también aparte, y en su propio solar, y en su personalidad propia y continua. [...] Me he habituado así a borrar de mi fantasía la vulgar imagen de una España vieja y caduca, y a asociar la idea de España a ideas de niñez, de porvenir, de esperanza. Creo en la España niña. (Rodó, 1967: 740).

Podríamos concluir que, en términos generales, el panlatinismo de Rodó fue reconducido por la corriente nacionalista argentina hacia un planteamiento hispanófilo que, en realidad, cerraba puertas a la incursión de las culturas de otros países latinos, fundamentalmente de Italia, cuya presencia en Argentina se hacía cada vez más patente.

Si regresamos al punto inicial de Ariel que Gálvez y Rojas desarrollaron en sus obras -la alerta frente a la inmigración y el cosmopolitismo-, reconocemos en la obra de Rodó el mismo sustrato esencial cuando planteó que el "genio de la raza" debía imponerse sobre la base de "fidelidad a lo pasado”. Pero Rodó, a diferencia de los nacionalistas, añadió que en el proceso de integración, el cosmopolitismo debía acatarse "como necesidad de nuestra formación”, no sólo en Ariel sino en otros muchos textos en los que abogó por la gran patria latinoamericana, como en el titulado "Sobre América Latina":

La América Latina será grande, fuerte y gloriosa si, a pesar del cosmopolitismo que es condición necesaria de su crecimiento, logra mantener la continuidad de su historia y la originalidad fundamental de la raza, y si, por encima de las fronteras convencionales que la dividen en naciones, levanta su unidad superior de excelsa y máxima patria, cuyo espíritu haya de fructificar un día en la realidad del sueño del Libertador. (Rodó, 1967: 1185)

Gálvez y Rojas, como hemos comprobado, fueron más allá en su discurso nacionalista, mostrando una oposición rotunda a la aportación de la cultura del inmigrante en los libros mencionados.

En esta encrucijada, parece conveniente alejarnos del Río de la Plata en busca de una voz que, desde la Cuba recién emancipada, se sitúa por los mismos años en el centro del mismo debate sobre la identidad. Si en la Argentina de comienzos del siglo XX la hispanofilia era posible tras un siglo de independencia, en Cuba la mirada hacia España era bien distinta, en el momento decisivo en que, conseguida la independencia política, se ansiaba la emancipación intelectual y cultural. En este contexto se alzó la voz de Fernando Ortiz, y precisamente lo hizo con motivo de la llegada de Rafael Altamira a Cuba en 1910, tras un viaje como embajador de la Universidad de Oviedo destinado a restablecer puentes, que le llevó a recorrer una buena parte de los países latinoamericanos, 
comenzando por Argentina ${ }^{14}$. A diferencia de las coincidencias ideológicas entre Altamira y los nacionalistas argentinos, su prédica hispanista en La Habana provocó una enérgica polémica con Ortiz. Y en algunas de las manifestaciones que animaron el debate, el intelectual cubano desenmascaró la ambigüedad de los conceptos latino e hispánico y el engaño al que inducían en algunos discursos cuando deliberadamente se los utilizaba de manera imprecisa:

Muchas veces los hispanizantes, los que mantienen como norma salvadora del porvenir cubano, que suponen en grave trance, la acentuación de la influencia española, desvían, acaso sin darse cuenta, los términos del problema que de aquel modo ellos quieren ver resuelto, diciendo: Cuba debe ser latina, no puede ni debe olvidar su latina raza; y así queda casi, por un momento, olvidada la teoría de la hispanización y parece que surge otro racismo, el latino, para robustecer la corriente racista española. [...] No es lo mismo civilización española, que civilización latina. [...] La latinización en labios hispanizantes puede ser más que un error: un engaño (Ortiz, 1911: 30 y 33).

... decir latinización es decir cosa muy distinta a hispanización. Si se trata de intensificar el sentido latino en Cuba habría que abogar por la adquisición de los mejores caracteres de la llamada civilización latina y entonces, sin olvidar los buenos elementos psicológicos españoles que ya tenemos (no sólo los buenos, sino también los malos) buscaríamos otros que no son españoles, así como la inventiva italiana, el sentido positivista de su renacimiento, el humanismo de su cultura, y la sutileza, espíritu de ahorro y modernidad de Francia, por ejemplos. No habría que hispanizarnos, habría que absorber lo mejor de la civilización latina... (32).

Con estas palabras Ortiz esclarecía el problema central del pensamiento nacionalista: los prejuicios de raza y el raquitismo cultural que conllevaban para la formación de la identidad colectiva. En el discurso nacionalista argentino, estos prejuicios alentaron el miedo y la alarma ante lo que la antigua clase criolla sintió no como invasión sobre aquella raza latina ideal que imaginó Rodó, sino simple y llanamente como amenaza de una gran masa extranjera. Pero el cosmopolitismo habría de imponerse y no fueron suficientes aquellas alarmas nacionalistas para silenciar la clamorosa voz heterogénea que se enfrentaba ante un reto no menos ideal: "la elaboración de un más fuerte y más alto pueblo argentino", en el que la diversidad cultural fuera el motor y no el obstáculo para la consolidación de su identidad como nación latinoamericana (ahora sí, en el sentido exacto del término).

Teniendo en cuenta todos estos matices, diferencias y ambigüedades en los discursos que cimentan la pretendida fraternidad entre españoles e hispanoamericanos desde 1898, resulta indispensable analizarlos a la luz de su heterogeneidad, para poder revisar con necesaria cautela esa doble mirada transatlántica en la que el reencuentro de España y Latinoamérica generó uno de los debates más ricos y duraderos que, hasta el día de hoy, sigue teniendo una vigencia extraordinaria: el de la identidad cultural de las naciones de habla hispana en el momento crucial que marca el 98.

\footnotetext{
${ }^{14}$ Sobre este viaje véase el citado libro de Gustavo H. Prado (2008), así como el capítulo IV (“El viaje americanista de Rafael Altamira”) del libro del mismo autor: El grupo de Oviedo en la historiografía y la controvertida memoria del krausoinstitucionismo astuariano (2008).
} 
La disolución definitiva del imperio no podía sino engendrar estos debates, cuando el problema de la identidad española coincidía en el tiempo con el nacimiento contemporáneo de la reflexión sobre la identidad latinoamericana. En tanto que ese nacimiento era compartido desde ambos lados del océano, el transatlantismo se concretó desde España como intento de reconciliación para el renacer de una "raza supranacional" que le permitiera emerger como gran nación en el mundo -con todos los problemas que este enfoque conllevaba-; y desde América, ese transatlantismo se formuló en la discusión sobre el papel que debía desempeñar la idea de España, en su historia pasada y presente, para la construcción identitaria. Creo que en la visión que proyectó Rodó de una España "transfigurada en nuestra América" (pero "en su propio solar"), y en la clarividencia de un Fernando Ortiz para desenmascarar el engaño panlatinista, o en su propuesta de un "regeneracionismo transculturado", están algunas de las claves principales de un diálogo transatlántico que ante todo es diverso y múltiple, y que precisamente por ello sigue siendo un territorio fertilísimo para la reflexión sobre este período de nuevas fundaciones hispano-americanas. 


\section{BIBLIOGRAFÍA}

Altamira, Rafael (1902). Cuestiones hispanoamericanas. Madrid: 1900. Archivo de la Residencia de Estudiantes (Madrid). Mecanoscrito del legado de Rafael Altamira.

Altamira, Rafael (1908). España en América. Valencia: F. Sempere y Compañía.

Altamira, Rafael (1911). Miviaje a América. Madrid: Librería General de Victoriano Suárez.

Altamira, Rafael. "La obra americanista de la Universidad de Oviedo". Revista de la Facultad de Letras y Ciencias de la Universidad de La Habana (1911b).

Altamira, Rafael (1920). "Conferencias del Sr. Altamira en su Cátedra de la Universidad Central. Curso de 1919 a 1920": Beneficios producidos en América por la Colonización (Resumen de las explicaciones de los días 8, 10 y 13 de octubre de 1919). Mecanoscrito del legado de Rafael Altamira que se encuentra en el Archivo de la Residencia de Estudiantes (Madrid).

Altamira, Rafael (1924). La huella de España en América Madrid: Editorial Reus.

Altamira, Rafael (1997). Psicología del pueblo español. Madrid: Biblioteca Nueva.

ARDAO, Arturo (1980). Génesis de la idea y el nombre de América latina. Caracas: C.E.L. Rómulo Gallegos, CN. de Cultura.

Chaves, Julio César (1970). Unamuno y América. Madrid: Ediciones Cultura Hispánica.

CoDinabas, Juan Bautista (1998). Vicente Blasco Ibáñez, viajero. Valencia: Diputación Provincial.

DARÍO, Rubén [1898] (1996). “El triunfo de Calibán”. Modernidad y fin de siglo en Hispanoamérica. (Sonia Mattalía, eda). Alicante: Instituto de Cultura Juan Gil-Albert: 179-182.

FERNÁNDEZ, Teodosio (2000). “España y la cultura hispanoamericana tras el 98”. Fuera del olvido: los escritores hispanoamericanos frente a 1898. Lourdes Royano, editora. Santander: Universidad de Cantabria: 11-31.

FERnÁNDEZ DE AlBA, Francisco y PÉREZ DEL SOLAR, Pedro (2006). "Hacia un acercamiento cultural a la literatura hispano-americana”. Iberoamericana, 21: 99-107.

GANIVET, Ángel [1897] (1977). Idearium español. El porvenir de España. Madrid: Espasa-Calpe.

GÁLVEZ, José [1913] (1992). El solar de la raza. Identidad cultural y literatura. José Carlos Rovira, compilador. Alicante: Instituto de Cultura Juan Gil-Albert y Comisión V Centenario.

GAOS, José (1945). Antología del pensamiento de lengua española en la Edad Contemporánea. México: Editorial Séneca.

GARCÍA PÉREZ, Juan (2000). "Entre el 'imperialismo pacífico' y la idea de 'fraternidad hispanoamericana': algunas reflexiones sobre la imagen de América Latina en la España de fines del siglo XIX”. (Leopoldo Zea y Mario Magallón, comp.) 1898 ¿desastre o reconciliación? México: F.C.E. 101-120.

LABRA, Rafael M. de (1910). Orientación americana de España. Madrid: Tipografía de Alfredo Alonso. 
MatTalía, Sonia (1996). Modernidad y fin de siglo en Hispanoamérica. Alicante: Instituto de Cultura "Juan Gil-Albert".

MenÉndeZ Pelayo, Marcelino (1948). Historia de la poesía hispanoamericana. Obras completas, 27. Madrid: CSIC.

OrTIZ, Fernando (1911). La reconquista de América. París: Sociedad de Ediciones Literarias y Artísticas.

Prado, Gustavo H. (2008). Rafael Altamira en América (1909-1910). Historia e historiografía del proyecto americanista de la Universidad de Oviedo. Madrid: CSIC (Colección América No 11).

Prado, Gustavo H. (2008). El grupo de Oviedo en la historiografía y la controvertida memoria del krausoinstitucionismo astuariano. Oviedo: KRK Ediciones.

PHELAN, John (1979). Elorigen de la idea de América. México: UNAM.

Riva-AgüEro, José de la (1962). Carácter de la literatura del Perú independiente. Obras Completas. Lima: Pontificia Universidad Católica del Perú, tomo I.

Rodó, José Enrique (1967). Obras completas. Emir Rodríguez Monegal, editor. Madrid: Aguilar.

Rodó, José Enrique [1900] (1997). Ariel. México: Editorial Porrúa.

Rojas Mix, Miguel (2000). "La generación del 98 y la idea de América”. Leopoldo Zea y Mario Magallón, compiladores. 1898 ¿desastre o reconciliación?. México: F.C.E.: 37-50.

ROJAS, Ricardo [1909] (1971). La restauración nacionalista. Buenos Aires: Peña Lillo Editor.

Romero, José Luis (1983). El desarrollo de las ideas en la sociedad argentina del siglo XX. Buenos Aires: Ediciones Solar.

Romero, José Luis (2000). “La República liberal (1880-1816)”. Breve historia de la Argentina. Buenos Aires: Fondo de Cultura Económica.

ROVIRA, José Carlos (1992). Identidad cultural y literatura. Alicante: Instituto de Cultura Juan GilAlbert y Comisión V Centenario.

TABanera García, Nuria. "El horizonte americano en el imaginario español (1898-1930)". Estudios Interdisciplinarios de América Latina y el Caribe, 1898-1939, 8/ 2 (1997): 67-87.

VAlero, Eva M. a (2003). Rafael Altamira y la "reconquista espiritual" de América. Cuadernos de América sin nombre, 8. Alicante: Universidad de Alicante.

VV.AA. (1986). La latinidad y su sentido en América Latina. México: UNAM. 


\section{GEOPOLÍTICA, (DE)COLONIALIDAD E IDENTIDAD:}

LA CONCIENCIA DIVIDIDA DE RUBÉN DARÍO

Geopolitics, (De)coloniality and Identity: the Divided Consciousness of Rubén Darío

\section{JARED LIST}

\section{DOANE UNIVERSITY jared.list@doane.edu}

E profesor asistente de español en la Universidad de Doane en Nebraska (Estados Unidos). Obtuvo su doctorado de la Universidad Estatal de Ohio en literaturas y culturas latinoamericanas. Su investigación y publicaciones incluyen temas acerca de la de-colonialidad y la producción literaria y cinematográfica centroamericana, incluyendo ensayos sobre los documentales abUSado: La redada de Postville de Luis Argueta y El cuarto de los huesos de Marcela Zamora Chamorro. Su proyecto de investigación actual examina la representación de la vida y la muerte en varios documentales centroamericanos

RECIBIDO: 17 DE ENERO DE 2017

RESUMEN: En este artículo, analizo los ensayos, crónicas y artículos periodísticos de Rubén Darío a través del marco de la colonialidad del poder y la colonialidad del saber desarrollado por Aníbal Quijano entre otros. Argumento que leyendo sus escritos políticos, observamos a un sujeto con una conciencia dividida. Por un lado, Darío reproduce el pensamiento eurocéntrico que caracteriza la colonialidad y por otro lado, critica y cuestiona tal paradigma. Para apoyar mi argumento, empleo las divisiones geopolíticas 'Este/Oeste' y 'Norte/Sur' para trazar las preocupaciones y pensamientos del poeta nicaragüense sobre los Estados Unidos y Europa. En otras palabras, examino desde dónde piensa Darío y cómo sus posiciones alinean con o se desvían de la colonialidad y/o la decolonialidad.

Palabras Clave: Rubén Darío, colonialidad del poder, de-colonialidad, geopolítica, conciencia dividida.

\section{ACEPTADO: 22 DE JUNIO DE 2017}

ABSTRACT: In this article, I analyze Rubén Darío’s essays, chronicles, and newspaper articles through the framework of the coloniality of power and the coloniality of knowledge developed by Aníbal Quijano among others. I argue that reading his political writings, we observe a subject with a divided consciousness. On one hand, Darío reproduces Eurocentric thinking that characterizes coloniality and, on the other hand, he criticizes and questions such paradigm. To support my argument, I use the geopolitical divisions 'East/ West' and 'North/South' in order to trace the Nicaraguan poet's concerns and thoughts regarding Europe and the United States. In other words, I examine from where Darío thinks and how his positions align with or deviate from coloniality and de-coloniality.

KeYwords: Rubén Darío, Coloniality of Power, Coloniality of Knowledge, De-coloniality, Geopolitics, Divided Consciousness 
Y en su visión de la España contemporánea Darío es precisamente atractivo por contradictorio, y porque, además, la realidad lo contradice, a su vez, muchas veces. En su selva plena de armonía los ruidos del mundo no siempre entraban tal como eran.

SERGio RAMÍreZ ${ }^{1}$

En este ensayo examino una serie de crónicas, ensayos y artículos periodísticos de Rubén Darío publicados en Crónica política, Escritos dispersos de Rubén Darío y Escritos inéditos. Mi propósito es mostrar que, a pesar de que muchos críticos arguyen que Darío es un pensador eurocéntrico, tal conclusión no lo representa completamente. Sus crónicas, ensayos y artículos periodísticos muestran un pensador más matizado, uno cuya posicionalidad se desorienta, especialmente frente al capitalismo imperial del Norte y la marginalización del Este -i.e. Europa. Los textos de Darío revelan un sujeto con una conciencia fracturada o dividida que, por un lado, reproduce el eurocentrismo y, por el otro, lo cuestiona. Para mí, está claro que a partir de 1898, hasta su muerte en 1916, hay una politización fuerte del trabajo de Darío. Su política refleja la inestabilidad geopolítica del hemisferio occidental tal como se revelaba en la guerra hispano-estadounidense, en la transformación económica de América Latina basada en el sistema capitalista y en sus propias experiencias en París. Durante este período de su vida, sus opiniones vacilantes (y a menudo contradictorias) sobre la modernidad, la raza, el capitalismo, Europa y los Estados Unidos son palpables en sus escritos. Tal vez la mejor manera de caracterizar este período de la vida de Darío es su oscilación entre una posicionalidad eurocéntrica (colonial) y una no-eurocéntrica (de-colonial). Usando el postulado de Aníbal Quijano sobre la colonialidad del poder y la colonialidad del saber para este ensayo podemos llegar a entender que Darío no era simplemente un sujeto eurocéntrico, sino un sujeto con una conciencia dividida y conflictiva, una conciencia que reflejaba la inestabilidad geopolítica y ontológica a finales del siglo XIX y a principios del siglo XX en América Latina, Europa y los Estados Unidos.

La metáfora de W. E. B. Du Bois de la 'doble conciencia' es una buena manera poética de metaforizar una posicionalidad ambigua y afligida con tal de que, para Darío, la 'doble conciencia' gire, no alrededor de la raza, sino del eje geopolítico de conocimiento. Su lucha no resultaba tanto de una clasificación fenotípica, sino de una jerarquización de conocimiento. A través de la producción literaria, el modernismo latinoamericano rompió las anteriores relaciones coloniales del conocimiento que aún perduraban en las políticamente libres naciones latinoamericanas. La popularidad de Darío como autor y poeta en Europa fortalecía un flujo bidireccional de conocimiento a través del Atlántico. Sin embargo, esto no significa que Darío no tuviese que enfrentarse con una historia de colonialidad. En sus escritos, vemos cómo él vacila entre paradigmas coloniales y decoloniales, en otras palabras, entre la afirmación del eurocentrismo y su rechazo -aunque tenemos que notar que, en Darío, existen mucho más ejemplos del eurocentrismo que de su rechazo. En este sentido, utilizamos el concepto ‘doble conciencia’ para describir la interpelación de Darío dentro de

\footnotetext{
${ }^{1}$ El epígrafe es de El señor de los tristes, sobre escritores y escritura de Sergio Ramírez (20).
} 
un marco colonial/de-colonial de conocimiento ${ }^{2}$. Para afirmar nuestro uso del término, encontramos una idea parecida en Colonialism and Culture: Hispanic Modernism and the Social Imaginary de Iris M. Zavala. Ella escribe: "La originalidad de Darío consistía en proyectar y observar la subjetividad moderna como auto-conciencia siempre perseguida por la otredad" $(68)^{3}$.

Mi pregunta ahora es cómo encajar la 'doble conciencia’ de Darío con la colonialidad del poder y la colonialidad del saber de Quijano. ¿Dónde o cómo caben el eurocentrismo, la clasificación social y el capitalismo global en la producción literaria dariana?, ¿podemos argumentar que Darío estaba situado dentro de un marco de-colonial; o nos lleva la investigación hacia la percepción común de que Darío era eurocéntrico en su modo de pensar? Mi propuesta es que la mejor manera de describir a Darío es como un sujeto colonial que, a lo largo de su carrera, revelaba preocupaciones de-coloniales; por tanto, un sujeto con una conciencia dividida. Sin duda, Darío se preocupaba profundamente por la geopolítica y el pensamiento. Su prosa refleja esta relación.

Para mostrar estas preocupaciones, podemos clasificar los ensayos, crónicas y artículos periodísticos darianos según sus divisiones geopolíticas. Estas relaciones geopolíticas son: una división geopolítica entre América Latina y los Estados Unidos y un eje geopolítico entre Europa y América Latina, en particular, entre España, Francia y América Latina. En las siguientes secciones desarrollaré estas divisiones geopolíticas y mostraré cómo revelan un escritor con una conciencia conflictiva, un hombre que parece lidiar con su propia identidad dentro y fuera de la colonialidad.

\section{NoRTE/SUR/ESTE/OESTE: LA “UNIÓN LATINA,” CONTRAPESO AL IMPERIALISMO ESTADOUNIDENSE}

El más fuerte sentimiento anti-imperialista y anti-colonial de Darío se expresa en sus obras que abordan los Estados Unidos. Podemos decir que sus obras más políticas son las que enfrentan las amenazas imperialistas estadounidenses. La división geopolítica entre el Norte y el Sur en el hemisferio occidental es severa. Como centroamericano, Darío fue expuesto a las políticas intervencionistas estadounidenses a temprana edad. El interés estadounidense en Centroamérica era el de la construcción de un canal transoceánico entre el Pacífico y el Atlántico. Hoy sabemos que el canal está en Panamá, pero antes de su construcción allí, los Estados Unidos tenía pensado hacerlo por Nicaragua.

Una de las crónicas de Darío detalla este proceso al cual se opone vehementemente porque lo considera perjudicial al futuro de la región, tal como afirma en su crónica “El canal de Nicaragua.” Él entiende la presencia del canal como beneficiosa para el desarrollo de Centroamérica y escribe: "Claro está que asunto de tanta importancia debe interesar a todos los Gobiernos de Centro-América,

\footnotetext{
${ }^{2}$ En The Souls of Black Folk, Du Bois define el concepto de 'doble conciencia' así: “Es una sensación pelicular, esta doble conciencia, este sentido de mirarse siempre a sí mismo a través de los ojos de otros, de medirse el alma por la cinta de un mundo que observa con desprecio y pena entretenido. Se siente su dobledad, --un americano, un negro; dos almas, dos pensamientos, dos fuerzas no reconciliables; dos ideales en disputa en un cuerpo negro, cuya fuerza terca solamente lo mantiene de ser despedazado" (7; mi traducción).

${ }^{3}$ Todas las citas originalmente publicadas en inglés son mis traducciones.
} 
pues la apertura de la vía interoceánica de Istmo traerá consigo un incalculable adelantamiento para las cinco Repúblicas” (Darío Crónica política 39). Le complace a Darío escuchar el deseo del presidente estadounidense Benjamín Harrison de realizar el proyecto. Incluso, Darío llega a decir que tiene confianza en que la construcción sucederá puesto que "[e]l hombre americano, emprendedor de suyo, tiene en sí el esfuerzo y la virtud del trabajo y el poder del oro para llevar a término las obras que proyecta y comienza” (Darío, 1924: 40). Mas, aún si la representación del vecino norteño de América Latina es exactamente ésa, un vecino - un país cuya presencia es bienvenida y beneficiosa; y aún si el impulso capitalista de los Estados Unidos es positivo, en líneas generales, esta crónica permanece del otro lado del espectro cuando se habla de la opinión de Darío sobre los Estados Unidos.

Lo que preocupa a Darío es que el Norte colonice cultural, lingüística y hasta geográficamente a América Latina. Esta preocupación se repite a lo largo de los escritos. Una crónica publicada en 1898, “El triunfo de Calibán” tal vez sea su obra más abiertamente geopolítica anti-imperialista. Él escribe la crónica poco tiempo después de un evento patrocinado por el Club español en el teatro La Victoria en Buenos Aires donde el futuro presidente italiano Roque Saenz Peña, el escritor francésargentino Paul Groussac y el italiano-argentino José Tarnassi dieron discursos que protestaban la agresión estadounidense en la guerra hispano-estadounidense (Jáuregui, 1998: 442-443). Los discursos parecen dar ímpetu a Darío en su propia opinión sobre los Estados Unidos, y dentro de las primeras dos frases del ensayo, leemos alto y claro su opinión. "No, no puedo, no quiero estar de parte de esos búfalos de dientes de plata. Son enemigos míos, son los aborrecedores de la sangre latina, son los Bárbaros” (Darío, 1938:160). A través de estas dos frases, él fija su posición, separando América Latina de los Estados Unidos. En su crítica de los Estados Unidos, podemos trazar varias razones por su desdén. Para él, los Estados Unidos es albergue de (a) una cultura materialista y consumista gobernada por ambición capitalista, (b) una sociedad espiritualmente vacía que ignora y marginaliza a sus propios autores y poetas y (c) un gobierno cuyas políticas promueven el imperialismo cultural, lingüístico y económico (i.e. colonización). En su crítica a los Estados Unidos, dos aspectos nos llaman la atención. El primero es que, como Martí, Darío apoya y propone la unificación de América Latina y la nombra "Unión Latina” (Darío, 1938: 161). El segundo aspecto notable es que, a diferencia de Martí, la "Unión Latina" dariana incluye las naciones con raíces latinas: España, Francia e Italia. Desarrollo esos dos aspectos abajo, al discutir las críticas darianas a los “cíclopes" del norte.

Los resultados de la modernización norteamericana le preocupan a Darío porque lo que está en juego es el futuro. El materialismo y consumismo estadounidenses permiten a Darío exigir una "Unión Latina" para resistir al monstruo creciente del norte. En su crítica, él intenta representar a los estadounidenses como bárbaros.

Parecíame sentir la opresión de una montaña, sentía respirar en un país de cíclopes, comedores de carne cruda, herreros bestiales, habitadores de casas de mastodontes. Colorados, pesados, groseros, van por sus calles empujándose y rozándose animalmente, a la 
caza del dollar. El ideal de esos talibanes está circunscrito a la bolsa y a la fábrica. (Darío, 1938: 160)

Aquí, Darío sitúa el materialismo en el marco de la colonialidad. Por eso, quiero decir que él usa dualidades eurocéntricas para establecer un juicio de valor sobre la cultura estadounidense. Él equipara los valores materialistas y capitalistas con la barbarie. Dentro de la telaraña de la colonialidad, recordemos que la dualidad 'civilizado/bárbaro (primitivo)' fue una de las herramientas para subordinar a los no-europeos a los europeos (Quijano, 2000: 222). Darío usa esta dualidad para encadenar los siguientes tres términos: bárbaro-capitalista-Estados Unidos. El resultado es la construcción de la diferencia que separa América Latina de los Estados Unidos, o el Sur del Norte. Aun así, el poder que los Estados Unidos ejerce alrededor del mundo y la arrogancia que lo acompaña perturban a Darío. Él los acusa de tener un ojo imperial. "Nos miran, desde la torre de sus hombros, a los que no nos ingurgitamos de bifes y no decimos all right, como a seres inferiores" (Darío, 1938: 160). ¿Podemos decir que esto es un ejemplo de doble conciencia? En esta instancia, él está describiendo al otro desde la perspectiva de su propia subjetividad y de las subjetividades vinculadas geográficamente con América Latina. Él tiene su propia auto-imagen pero reconoce la auto-imagen del otro construida por si mismo.

Darío continúa su crítica de los Estados Unidos, diciendo que es una cultura espiritualmente vacía, consumida por la lógica del capitalismo. No obstante, tenemos que notar que, para Darío, todos los aspectos de la cultura estadounidense no son perjudiciales. Como algunas de sus obras poéticas muestran, él admiraba a Walt Whitman, Ralph Waldo Emerson, Mark Twain y Edgar Allan Poe. En particular, él apreciaba las obras de Poe y lo incluye en su libro Los raros, incluso escribe el prólogo de la traducción española de "El cuervo"4. Así que cuando Darío critica a los Estados Unidos, se asegura de excluir a estos autores norteamericanos de su denigración.

Enemigos de toda idealidad, son en su progreso apoplético, perpetuos espejos de aumento; pero Sir Emerson bien calificado está como luna de Carlyle; su Whitman con sus versículos a hacha, es un profeta demócrata, al uso del Tío Sam; y su Poe, su gran Poe, pobre cisne borracho de pena y de alcohol, fue el mártir de su sueño en un país en donde jamás será comprendido. (Darío, 1938: 160).

Para Darío, estos autores tienen algo en común con él. Utilizan lo poético como contranarrativa a las narrativas dominantes del materialismo y capitalismo. Veamos por ejemplo, lo que Darío dice sobre Poe. Le llama un cisne borracho de dolor y alcohol y hasta mártir. Recordemos que el cisne es el símbolo modernista común de la belleza. Aún más, Poe es un cisne marginado en un país cuyos habitantes son interpelados por una lógica capitalista en lugar de una lógica poética. Encontramos importante este detalle porque subraya los flujos de saberes y su colonialidad. Hasta dentro de los Estados Unidos, saberes alternativos, incluso la religión, son subordinados a un saber constituido por el capitalismo, al consumo y al materialismo. "Tienen templos para todos los dioses y no creen en ninguno” (Darío, 1938: 160). Para Darío, el capitalismo aplasta cualquier forma de

\footnotetext{
${ }^{4}$ Véase el prólogo dariano de la obra de Poe en Quince prólogos de Rubén Darío, compilado por José Jirón Terán.
} 
espiritualidad (en los sentidos poético y religioso). Coloniza las mentes norteamericanas, salvo los pocos, aislados poetas escondidos entre las masas.

A pesar de todo, lo que asusta a nuestro poeta es el poder político de los Estados Unidos a escala global. Su apetito territorial insaciable amenaza cualquier forma de autonomía que América Latina quiera tener. La lucha por el territorio en la guerra hispano-estadounidense perturba a nuestro poeta. Aunque las obras de Darío apuntan a su apoyo por la independencia cubana tanto de España como de los Estados Unidos, llegamos a entender que él prefiere la presencia española en la región más que la nación de habla inglesa ${ }^{5}$. Refiriéndose a los Estados Unidos, él escribe: "No, no puedo estar de parte de ellos, no puedo estar por el triunfo de Calibán. Por eso mi alma se llenó de alegría la otra noche, cuando tres hombres representativos de nuestra raza fueron a protestar en una fiesta solemne y simpática, por la agresión del yankee contra la hidalga y hoy agobiada España" (Darío, 1938: 161). El plan de Darío para combatir esta "agresión Yankee" es unir los países de descendencia latina: las naciones de América Latina, España, Francia e Italia. El evento en el teatro La Victoria plasma el plan dariano. En la crónica, enfatiza que Groussac y Tarnassi hablan a favor de Francia e Italia, respectivamente. De este modo, Darío concluye que "[d]e tal manera la raza nuestra debe unirse, como se une en alma y corazón, en instantes atribulados; somos la raza sentimental, pero hemos sido dueños de la fuerza" (Darío, 1938: 162). Tal unión contrarresta lo que Darío percibe como una alianza entre Inglaterra y los Estados Unidos.

No obstante, no podemos ignorar la perspectiva eurocéntrica de Darío en este ejemplo. La crónica dariana representa América Latina como una extensión de Europa, en particular, de España, Francia e Italia. Lo indígena es ignorado y enterrado bajo la propuesta alianza geopolítica de Darío. Para argumentar a favor de tal alianza, Darío implica una cierta homogeneidad cultural, política, ideológica, lingüística, económica y religiosa entre América Latina y Europa. Por consiguiente, la colonialidad del poder y la colonialidad del saber emergen en el texto de Darío en la forma de eurocentrismo. Darío representa América Latina como extensión de su antiguo colonizador para proponer su "Unión Latina" - una coalición geopolítica entre las tres naciones europeas. Cuando vemos el título de la crónica, notamos la semejanza con la obra de José Enrique Rodó, Ariel. Como la obra dariana, Rodó alinea geopolíticamente América Latina con Europa ${ }^{6}$. Ambos autores coinciden en su conclusión que América Latina está en mejores circunstancias como Ariel que como Calibán. Darío escribe: "Miranda preferirá siempre a Ariel; Miranda es la gracia del espíritu; y todas las

\footnotetext{
5 En "El triunfo de Calibán,” Darío explica que ha "sido partidario de Cuba libre” (Escritos inéditos 162). Sergio Ramírez también nota el apoyo de Darío de la independencia cubana en El señor de los tristes.

6 Rodó usa el término nordomanía para referirse a los que querían que América Latina emulara a los Estados Unidos. Véase Ariel de Rodó para el argumento completo.
} 
montañas de piedras, de hierros, de oros y de tocinos, no bastarán para que mi alma latina se prostituya a Calibán” (Darío, 1938: 162) . Los Estados Unidos nunca comprarán a Darío.

\section{ESTE/OESTE: LA RELACiÓN TENUE DE DARÍO CON EUROPA}

Hasta este punto, he hablado sobre las dualidades que Darío emplea para establecer diferencias, pero ¿cómo entendemos la construcción de diferencia de Darío? Si la diferencia es empleada para rechazar el imperialismo o el colonialismo, es colonial esta diferencia? Y qué sucede cuando la diferencia es construida entre dos poderes imperiales -los Estados Unidos y Españadonde ambos países están luchando por el mismo territorio, Cuba? Walter Mignolo, demarca dos tipos de diferencia en su libro The Darker Side of Western Modernity: Global Futures, Decolonial Options: diferencia imperial y diferencia colonial. Ambas formas de diferencia se originan de lo que Carl Schmitt llama "pensamiento global lineal." Por "pensamiento global lineal” Schmitt refiere a la suposición de que Europa tiene derecho de conquistar el resto del mundo y, por ende, su intención imperial de dividir los territorios entre las naciones europeas (Schmitt, 2003: 87-90). Para Quijano, el pensamiento global lineal sería un pensamiento eurocéntrico. Mignolo nos dice que el pensamiento global lineal emergió durante el periodo moderno/colonial como resultado de la necesidad europea de un método para jerarquizar y clasificar territorios, poblaciones y saberes.

Para asegurarnos de lo que Schmitt y Mignolo quieren decir por el pensamiento global lineal, tomemos un ejemplo que Mignolo nos da. En el siglo XVI, el Papa Alejandro VI dividió longitudinalmente el mundo para resolver una disputa entre los españoles y los portugueses. El acuerdo entre los dos imperios llegó a ser conocido como el Tratado de Tordesillas. Lo que vemos en este ejemplo es que los dos imperios europeos reclaman el mundo como propio. El Papa, también dentro de un marco de pensamiento global lineal, propone el acuerdo. Aunque, a primera vista, el acuerdo sólo parece dirigirse a una disputa territorial, bien analizada la decisión del Papa también afecta al flujo de saberes. Regiones particulares experimentarían la colonización española mientras otras, la colonización portuguesa. Por eso, las diferentes regiones colonizadas se exponen a parecidos pero distintos paradigmas culturales, políticos, religiosos, económicos e ideológicos. Es decir, el pensamiento global lineal involucra la intersección entre geografías y saberes. Tal pensamiento "mapeó no sólo la tierra y las aguas del planeta sino también las mentes” (Mignolo, 79). Mapear mentes incluía la construcción de la diferencia imperial y colonial.

\footnotetext{
7 Para Carlos Jáuregui en su ensayo “Calibán, ícono del 98. A propósito de un artículo de Rubén Darío," Miranda representa una figura virginal/maternal que "extiende sus brazos al idealismo 'latino” (444). El artículo de Jáuregui también repasa y analiza extensivamente la crónica de Darío y su uso de Calibán. Jáuregui arguye que "El triunfo de Calibán” representa la crisis finisecular en América Latina puesto que la región se enfrentaba con las incertidumbres de la modernidad, el imperialismo y la identidad latinoamericana. Además de Jáuregui, Sergio Ramírez y Iris M. Zavala analizan el discurso dariano en "El triunfo de Calibán." Véase El señor de los tristes de Ramírez y El rapto de América y el síntoma de la modernidad de Zavala.
} 
La diferencia imperial es diferencia que existe dentro de los imperios o naciones dominantes o, como Quijano la llamaría, dentro de la colonialidad del poder. El conflicto entre España y Portugal representa este tipo de diferencia. Según Mignolo, la diferencia imperial se estableció en Europa en el siglo XVI. Otra vez, veámos el ejemplo de España y Portugal. Ambas establecieron las condiciones en las que podían subyugar todas las formas de saberes y epistemologías. Esta idea no es nueva. Otros estudiosos como Quijano y Santiago Castro-Gómez han examinado la relación entre el eurocentrismo, la epistemología y la jerarquía. Por ejemplo, como aprendemos en la obra de Mignolo, Castro-Gómez usa el término "punto cero" para mostrar la organización lineal y jerárquica de epistemologías diferentes. Por "punto cero" se entiende la jerarquización y la clasificación de epistemologías que privilegian una sobre las demás. En su La hybris del punto cero, Castro-Gómez escribe que "el punto cero es el del comienzo epistemológico absoluto, pero también el del control económico y social sobre el mundo. Ubicarse en el punto cero equivale a tener el poder de instituir, de representar, de construir una visión sobre el mundo social y natural reconocida como legítima y avalada por el Estado" (2005: 25). Así, Mignolo usa el concepto de Castro-Gómez para explicar el nacimiento de la diferencia imperial y colonial. "El punto cero es el sitio de observación del cual las diferencias epistémicas coloniales y las diferencias epistémicas imperiales se mapean” (2011: 80). El otro tipo de diferencia, diferencia colonial, también resulta del pensamiento global lineal. La diferencia colonial se refiere a los métodos usados para establecer diferencia entre los europeos y los sujetos colonizados. La clasificación y jerarquización racial eran algunos de los métodos fundamentales para establecer la diferencia colonial y reforzar el pensamiento global lineal (2011: 86-90). Podemos decir que la diferencia colonial depende de la clasificación social a través de la raza y la razón instrumental para subyugar los sujetos no-europeos. En este momento, teniendo en cuenta ambas diferencias imperial y colonial, volvamos al ensayo dariano "El triunfo de Calibán” para examinar la manera en la cual él presenta la diferencia (y la unidad) entre Europa y América Latina.

Para Darío, la historia de América Latina empieza en el otro lado del Atlántico, y en sus obras, el reconocimiento de (y hasta la lealtad a) España emerge; aunque Darío tiene cuidado de demarcar hasta qué grado afirma su lealtad a España. Por ejemplo, él apoya España en la guerra hispanoamericana. "[S] oy amigo de España en el instante en que la miro agredida por un enemigo brutal, que lleva como enseña la violencia, la fuerza y la injusticia” (Darío, 1938: 162). Para Darío, España no se parece en nada a los Estados Unidos. España no es "el fanático curial, ni el pedantón, ni el dómine infeliz, desdeñoso de la América que no conoce” (Darío, 1938: 162).

Su aprecio de España, en su mayor parte, se centra en su producción cultural a lo largo de los siglos. Como él lo expresa, "la España que yo defiendo se llama Hidalguía, Ideal; Nobleza; se llama Cervantes, Quevedo, Góngora, Gracián, Velázquez; se llama el Cid, Loyola, Isabel; se llama la Hija de Roma, la Hermana de Francia, la Madre de América" (Darío, 1938: 162). En primer lugar, notamos que la alianza geopolítica de nuestro poeta existe entre Italia, España y Francia -todas compartiendo un rasgo lingüístico común. No sólo repite Darío su propuesta de la “Unión Latina” aquí, sigue una lógica eurocéntrica por nombrar a España la madre de América Latina, lo cual implica una distorsión 
temporal entre las historias de América Latina y España y niega las historias y epistemes indígenas ${ }^{8}$. Más bien, es preciso enfatizar que Darío considera España como la hija de Roma. Debido a tal clasificación de las naciones dentro de una red familiar, vemos un flujo de saber y poder de RomaEspaña-América Latina. Este flujo de conocimiento que empieza en Roma es lo que Enrique Dussel subraya en su lectura de la perspectiva eurocéntrica de la historia de Hegel, o como Mignolo y CastroGómez dirían, Europa es el “punto cero” para Darío9.

Otra vez, encontramos encarcelado a Darío dentro de una matriz de colonialidad. En segundo lugar, notamos el uso de Darío de una dualidad eurocéntrica en su descripción de España. Esta dualidad-'civilizado/bárbaro'-como parte de la razón instrumental, es un intento de construir la diferencia colonial ${ }^{10}$. Si los Estados Unidos está lleno de bárbaros, Cíclopes y Calibanes, España es lo opuesto, lleno de hidalgos y nobleza, un ejemplo aparentemente perfecto de diferencia colonial. No obstante, nuestro ejemplo de diferencia colonial es más complicado de lo que parece. Primero, tenemos que considerar el lugar de enunciación. La enunciación no se emite ni desde España, ni Europa, de hecho; emerge de América Latina. Segundo, tenemos que recordar que la reafirmación de Darío o la exaltación de Europa no es ni menospreciar ni subordinar América Latina, sino criticar la dominancia y hegemonía estadounidense. Por consiguiente, Darío usa la diferencia colonial como intento de subordinar a los Estados Unidos. En los siglos XV, XVI y XVII, Europa usaba la diferencia colonial para distinguir entre los europeos y los no-europeos, o entre el eje geopolítico, 'Este/ Oeste.' En el caso de Darío, podemos ver otra división que cambia la antigua relación entre el Este, el Oeste y la diferencia colonial: una división geopolítica 'Norte/Sur'. Darío usa la diferencia colonial para alinear América Latina con Europa (el Oeste) para combatir los Estados Unidos (el Norte), por ende, la "Unión Latina” dariana. Para Darío aquí, el lugar de la colonialidad emana de los Estados Unidos, no de Europa. El uso de la dualidad 'civilizado/bárbaro' representa de una forma positiva la nación española mientras los Estados Unidos se representa de una forma negativa. Tal vez la mejor manera de entender este ejemplo es usar el adagio "combatir el fuego con fuego". Darío usa la diferencia colonial para luchar contra la diferencia colonial o, dicho de otra manera, él utiliza la colonialidad para luchar contra la colonialidad. La única diferencia es la inversión de la relación entre los términos. Tan paradójica como sea, su estrategia defensiva contra los Estados Unidos requiere una vuelta a su madre y abuela, España y Roma, respectivamente. Exploremos un poquito más la opinión de Darío sobre Europa.

\footnotetext{
${ }^{8}$ J. F. Normand en su ensayo “Las ideas políticas en Rubén Darío” menciona una de las obras poéticas de Darío en que Darío se refiere a sí mismo como hijo de América y nieto de España. Según Normand, tal afirmación opta por una alianza racial-política basada en la raza latina en lugar de una geopolítica y continental (438).

${ }^{9}$ Véase “Meditaciones anti-cartesianas: sobre el origen del anti-discurso filosófico de la modernidad” de Enrique Dussel para su análisis del entendimiento de Hegel de la historia, el arte, la religión y la filosofía. Su argumento es que Hegel es eurocéntrico en su modo de pensar.

${ }^{10}$ Erick Blandón escribe en su ensayo "Presencia de Rubén Darío en los discursos de mestizaje" que las dualidades de Sarmiento ‘civilización/barbarie’ influían en Darío, como observado a través de las referencias abundantes a la dicotomía a lo largo de sus ensayos, crónicas, cartas y poesía.
} 
Darío aprecia España y comparte el mismo sentimiento por muchos autores de la Generación del 98. Como hemos visto, él celebra la tradición literaria española y entiende América Latina como la progenie de España. Aún así, el estado actual de España durante la vida de Darío le preocupaba. En las crónicas “El crepúsculo de España” y “España de afuera,” Darío enumera algunos de los males de España y defiende la nación en medio de representaciones negativas de ella. El objetivo de Darío en "El crepúsculo de España” es declarar su solidaridad con España sobre los Estados Unidos y reclamar la reemergencia de España como nación poderosa, especialmente dado su disgusto con el nuevo superpoder emergente. "Mis simpatías han estado parte de esa ilustre monarquía empobrecida y caída; mis antipatías, de parte de esa democracia rubicunda, que abusa de su cuerpo apoplético y de su ciclópeo apetito" (Darío, 1968: 163). Otra vez, notamos la alianza geopolítica. Sin embargo, Darío enfatiza que todos los escritores latinoamericanos no comparten el mismo sentimiento de España. Escribe que algunos menosprecian el país por su vejez e inutilidad, pero no lo menosprecia, especialmente cuando mira “al yankee despedazándola” (Darío, 1968: 163). Aún más, el debilitamiento de España es el ímpetu de la crónica dariana. Anima a España a encontrar "una vida nueva" y recomienda un proceso de reconstrucción nacional, una reconstrucción edificada "sobre las viejas piedras del edificio caído” (Darío, 1968: 163). Existe un sentido de optimismo en el tono de la crónica, pero cuando leemos "España de afuera," ese tono se vuelve más oscuro. El futuro de España es desalentador.

Según Darío, España ha sido estereotipada como una nación subdesarrollada que no quiere modernizarse. Arguye que Francia es la culpable de tal caracterización. Escribe en el párrafo introductorio que Francia ha tenido éxito en transmitir una imagen de España en la que el país parece "invariable" e "incambiable" (Darío, 1968: 163). Perturbado por este estereotipo, nuestro poeta hace un esfuerzo para argumentar a favor de España y sus logros intelectuales. Encuentra injustificadas y falsas las afirmaciones de Francia, como si España hubiera sido víctima de una campaña de desprestigio. Francia ha difundido una imagen anticuada de España, vinculando la imagen de España con la de la Inquisición, la mendicidad, el torero, y el flamenco, según nuestro autor. Como resultado, la producción cultural española ha sufrido. Darío escribe que "el castellano y su literatura no cuentan, puede decirse, en el movimiento intelectual del mundo" (Darío, 1968: 165). Aunque la marginalización de España lo perturba, parece que Darío está más preocupado por las consecuencias geopolíticas de la relegación de España en Europa. Las preocupaciones de Darío son evidentes en su recuento de la presentación del doctor Luis H. Debayle en un congreso internacional de medicina en Budapest en 1909. Viniendo de Centroamérica, Debayle arguye que el idioma español tiene que ser incorporado junto con el inglés, francés y alemán como idiomas oficiales. No sólo 21 naciones hablan español como la lengua dominante, el español “'reúne condiciones excelentes para ser idioma internacional: es musical en su expresión y fácil en su aprendizaje" (citado en Darío, 1968: 165). Debayle continúa argumentanto que, incluso, el español facilita el aprendizaje del latín -un idioma importante en la medicina- puesto que aquél es derivado de éste. El argumento de Debayle subraya los flujos de saberes articulados alrededor de un común 
denominador lingüístico. Por eso, a pesar de la afinidad de Darío con España, es consciente de que la marginalización del país en Europa no es positiva para América Latina.

La defensa dariana y su fama en Europa tal vez salvaran a España de la relegación cultural absoluta. Esto es lo que María A. Salgado argumenta en su ensayo “Rubén Darío y la Generación del 98: Personas, personajes y máscaras del fin de siglo español.” Salgado postula que el modernismo se caracteriza por su egocentrismo, principalmente su énfasis en el poeta/autor y su cultivo de esa subjetividad. Anota como ejemplo las biografías y autobiografías numerosas que se publicaban durante el periodo. Podríamos decir que el proyecto dariano de Los raros es un ejemplo claro de este egocentrismo. Parte del proyecto de Darío era elevar el estatus de escritores latinoamericanos, norteamericanos y europeos ${ }^{11}$. No obstante, Salgado mantiene que la fama de Generación del 98 es el fruto del trabajo de Darío. Argumenta que "es precisamente por privar la visión dariana por lo que se puede concluir que fue Darío quien determinó en gran parte tanto la imagen que de los hombres de la Generación tuvieron sus contemporáneos como la que aún tenemos sus lectores actuales" (Salgado, 1999: 726).

El argumento de Salgado tiene que ver con nuestra lectura de Darío y la colonialidad del poder y la colonialidad del saber porque vemos una inversión geopolítica de producción cultural. Por un lado, las biografías darianas de los escritores de la Generación del 98 y su interés en España sirven como capital simbólico que promueve el estatus de la producción cultural española. Es decir, España se beneficia del prestigio literario de Darío alrededor del mundo. Tal relación entre Europa y América Latina se opone a las relaciones tradicionales de producción cultural y poder. Es la fama latinoamericana (i.e. Darío) la que aumenta la de España (i.e. los escritores de la Generación del 98). Sin embargo, por otro lado, el proyecto de Darío, al mismo tiempo, mantiene la antigua relación entre España y América Latina. La colonización de América Latina y su explotación se traducían en riquezas y poder global para España. Por lo mismo, América Latina acude a socorrer la reputación de España en Europa y el mundo. Por ende, aunque Darío no está subordinado a los escritores de la Generación del 98, el flujo de capital -como recursos primarios o como capital cultural- desde América Latina hasta España no cambia. Aun así, el objetivo de Darío de promover las obras de la Generación del 98, tal vez hubiera sido de interés para América Latina. La exclusión de la producción cultural y científica española establecería barreras que obstruirían el flujo y la producción de saberes latinoamericanos, dado el idioma compartido.

La presencia latinoamericana en Francia también es tema de varias crónicas darianas. Una de éstas es "Las letras hispanoamericanas en París" publicada primero en 1901, como una serie de crónicas periodísticas y después publicadas como capítulo en La caravana pasa de Darío ${ }^{12}$. El texto revela a un Darío preocupado por la reputación y presencia literaria y cultural latinoamericana en

\footnotetext{
${ }^{11}$ Darío publicó Los raros en 1896. La obra consiste en 20 retratos literarios de intelectuales de América del Norte, Europa y América Latina. No obstante, es importante notar que la mayoría de los intelectuales incluidos en el libro son europeos. Sólo incluye a un escritor latinoamericano, José Martí de Cuba. El título Los raros se refiere al individuo raro que, en la opinión de Darío, posee un don de pensamiento intelectual, filosófico y literario.

${ }^{12}$ Günther Schmigalles nos da las fechas de publicación en las notas del texto en "Las letras hispanoamericanas en París."
} 
Europa. Lo que nos importa en nuestro análisis de la (de)colonialidad en los textos darianos es que esta crónica empieza a dar cuenta del carácter de-colonial de nuestro poeta. Ya hemos visto en muchos casos cómo Darío es cualquier cosa menos de-colonial. Alaba Europa, piensa que es la progenitora de América Latina e, incluso, quiere reunir América Latina con su antiguo colonizador para contrarrestar el imperialismo estadounidense. Es más, el flujo de saber uni-direccional de Europa a América Latina constituye una fuente de ansiedad para Darío. En "Las letras hispanoamericanas en París," Darío critica la inhabilidad francesa (o falta de deseo) para distinguir entre América Latina y España. Para los franceses, "todo lo hispanoamericano se confunde con lo netamente español” (Darío, 2004: 7). Tal vez más asombrosa para nuestro poeta es la marginalización de la literatura latinoamericana en Francia. Darío argumenta que nadie en Francia conoce la literatura de su continente y nos hace pensar que la ignorancia no es debido a la falta de presencia latinoamericana en Francia, sino al egocentrismo francés (o el eurocentrismo). Porque, como nuestro poeta explica, "Y es digno de notar que gran parte de la élite de las letras de nuestras repúblicas vive hoy en París” (Darío, 2004: 7).

Lo que Darío destaca en este ejemplo es el eurocentrismo. Su crítica es de la noción de superioridad francesa y la relegación de toda la demás producción de pensamiento. Parte del proyecto literario de Darío es nombrar y detallar el pensamiento latinoamericano. Por ejemplo, su objetivo en "Las letras hispanoamericanas en París" es nombrar a los autores latinoamericanos que están o han estado desarrollando o perfeccionando su destreza. Las obras darianas que subrayan a los escritores latinoamericanos desafían el eurocentrismo, y nuestro autor lo sabe porque, como él dice, cuando los autores no-franceses perfeccionan demasiado bien su destreza, Francia empieza a desacreditarlos. "Cuando ese artista, ese escritor ó ese sabio, instalado en París, se convierte en un rival, cuando su producción llega á hacer competencia á la producción propia, se le atacará, se le demolerá, ó se le desdeñará” (Darío, 2004: 5). Entonces, ¿cuál es la solución para Darío y de qué manera es él decolonial?

Antes de continuar con Darío, primero, necesitamos una definición de la de-colonialidad. Si la colonialidad del poder y la colonialidad del saber se componen del eurocentrismo, la clasificación social racista y el capitalismo, la de-colonialidad sería, por ende, el desenrede y la superación de esos elementos. Nelson Maldonado Torres da una definición clara del término en su ensayo "On the Coloniality of Being: Contributions to the Development of a Concept”. Por de-colonialidad, él entiende "la confrontación con las jerarquías raciales, sexuales y de género que fueron establecidas o fortalecidas por la modernidad europea mientras colonizaba y esclavizaba poblaciones alrededor del planeta. En pocas palabras, con la decolonización estoy pensando de las oposiciones a la colonialidad del poder, saber y ser..." (Maldonado Torres, 2007: 261).

Los objetivos de-coloniales de Darío toman la forma de degradación del eurocentrismo. En su crónica "La producción intelectual latinoamericana: autores y editores” Darío usa un folleto recién 
publicado por el señor Alcover, el director del archivo nacional en Habana ${ }^{13}$. El folleto es una defensa de los autores latinoamericanos y sus intereses. Darío usa la opinión del señor Alcover para compartirla como propia. Para Darío, la producción literaria latinoamericana estaría en mejores circunstancias si autores, editores y naciones pudieran superar varios obstáculos. Estos impedimentos incluyen el alto coste asociado con la publicación de un libro, la falta de editores y libros y el deseo de validación europea. Veamos el ejemplo de Argentina: "Los autores argentinos de cierta autoridad no envían sus libros al resto del continente, sino con señaladísimas excepciones, pues no les interesa sin el juicio de los criterios europeos" (Darío, 1968: 345). Darío quiere reenfocar la mirada intelectual en América Latina. En otras palabras, la producción intelectual tiene que separarse de la mirada eurocéntrica que sigue relegando a autores latinoamericanos. De esta manera, la idea es desvincularse de la dependencia de Europa de modelos culturales. No obstante, al hacerlo, Darío todavía se preocupa por la reputación de América Latina en el contexto global y neocolonial.

\section{INTERROGACIONES DE-COLONIALES DE DARÍO: DEMOCRACIA, CAPITALISMO, NACIONALISMO}

A pesar de que hemos visto muchos ejemplos que muestran a Darío como sujeto eurocéntrico, encontramos otros donde él rechaza de forma abierta la colonialidad del poder: “¿Por qué?” y "La locura de la guerra." En estas crónicas, Darío critica el capitalismo, la explotación y las identidades nacionales. Su crónica “¿Por qué?” es tal vez su condena más fuerte de las consecuencias sociales de la modernidad y la economía-mundo ${ }^{14}$. Nuestro autor se preocupa por la creciente estratificación social entre las clases alta y baja y él culpa a la clase alta de la desigualdad. Sostiene que

Los bandidos están posesionados de los Bancos y de los almacenes. Los talleres son el martirio de la honradez; no se pagan los salarios que se les antoja a los magnates, y, mientras el infeliz logra comer su pan duro, en los palacios y casas ricas los dichosos se atracan de trufas y faisanes. Cada carruaje que pasa por las calles va apretando bajo sus ruedas el corazón del pobre. (Darío Crónica política 127)

Para Darío, la creciente estratificación social y la injusticia social es resultado del capitalismo. "Nada vale ya sino el oro miserable" (Darío Crónica política 125). En otras palabras, el capitalismo establece e impulsa relaciones sociales y producción cultural. Hemos visto esta queja particular antes en "El rey burgués," pero en este caso, su crítica es más fuerte. Arguye que la búsqueda de riquezas de la clase alta ha destruido cualquier noción de democracia. “ ¿No se llama democracia a esa quisicosa política que cantan los poetas y alaban los oradores? Pues maldita sea esa democracia. Eso no es democracia, sino baldón y ruina. El infeliz sufre la lluvia de plagas; el rico goza" (Darío, 1924: 126). Dicho de otra forma, la jerarquización social que se basa en la acumulación de capital impide un sistema político que se estructure alrededor del demos. Aquí, el argumento de Darío expande nuestra discusión sobre la colonialidad para incluir lo político, y en este ejemplo, la democracia.

\footnotetext{
${ }^{13}$ Véase el análisis de Ángel Rama de "La producción intelectual latinoamericana: autores y editores” de Darío en Rubén Darío y el modernismo.

${ }^{14}$ Véase El rapto de América y el síntoma de la modernidad de Iris M. Zavala para su análisis de “Por qué?”
} 
En su artículo "Transmodernity, border thinking, and global coloniality: Decolonizing political economy and postcolonial studies”, Ramón Grosfoguel discute la manera en que la colonialidad del poder y la colonialidad del saber regulan y manipulan formas de democracia. Para Grosfoguel, la democracia no puede existir por completo cuando el mundo se edifica sobre la colonialidad. La clasificación social y el eurocentrismo establecen una jerarquía socio-política donde algunos ciudadanos disfrutan de más derechos y privilegios que otros. Una de las preocupaciones mayores de Grosfoguel respecto a la democracia es la propagación occidental de la democracia liberal. Según él, "la forma liberal de democracia es la única aceptada y legitimada. Formas de alteridad democrática son rechazadas" (Grosfoguel, 2008: 17). Sostiene que las naciones no-occidentales tienen que aceptar la democracia liberal o enfrentar las consecuencias severas. Él caracteriza el siglo XXI hasta este momento como "democratiza o te disparo", una referencia obvia a la intervención estadounidense en Irak y otros lugares (Grosfoguel, 2008: 17). De todos modos, lo que Grosfoguel sugiere es la decolonización de democracia liberal como la única forma de democracia legítima, y por democracia liberal, Grosfoguel entiende una democracia que es "occidentalizada, racializada y centrada capitalistamente" (Grosfoguel, 2008: 17). La crítica de Darío de la nación es parecida. La disparidad socio-económica existente estorba cualquier forma verdadera de democracia. Aquí encontramos la crítica de-colonial en los escritos de Darío.

En "La locura de la guerra" de Darío, encontramos una crítica de la organización política dominante del mundo. Critica el concepto de nación, manteniendo que "[t]odo contribuye en el aparato de las naciones a engrandecer y atizar el odio humano” (Darío, 1924: 139). Por 'todo,' se refiere a los símbolos particulares e intereses presentes en la nación, por ejemplo, intereses monárquicos o elitistas, himnos nacionales y ciudades o pueblos poderosos. Para Darío, estos símbolos engendran un amor a la nación, o como le llama, patria (Darío, 1924: 141). La patria se convierte en una extensión del yo según la opinión de nuestro autor. Darío piensa que cuando nos interpelamos con la nación, nos interponemos con la naturaleza bajo los mismos pretextos. Esto quiere decir que "cielo, aire, tierra, fuentes, yerbas, hombres; todo esto que no atrae y nos retiene, después se convierte en un símbolo; esa es la patria” (Darío, 1924: 141). Tal vínculo le hace conjeturar a Darío que el amor a la patria es el amor al yo. En este sentido, la nación engendra motivos egoístas e individualidad en lugar de la reciprocidad y la solidaridad entre gentes y naciones. En consecuencia, podemos decir que dentro de la colonialidad, la organización política conocida como ‘nación' se emplea para dividir y ordenar poblaciones alrededor del mundo.

En el mismo ensayo, Grosfoguel arguye contra la nación y el nacionalismo de una forma parecida a la de Darío. Grosfoguel no ve los nacionalismos del tercer mundo como el modo de superar el eurocentrismo. Más bien, el "[n]acionalismo da soluciones eurocéntricas a un problema eurocéntrico global" porque "reproduce un colonialidad del poder interna dentro de cada estadonación y cosifica el estado-nación como el lugar privilegiado del cambio social" (Grosfoguel, 2008: 16). Sostiene que la organización política a través del estado-nación cae dentro del marco de pensamiento eurocéntrico. Para él, cualquier contestación nacional al eurocentrismo derrota su único propósito porque el concepto de estado-nación es una construcción eurocéntrica situada en la 
colonialidad del poder (Grosfoguel, 2008: 16). Aníbal Quijano propone la misma idea en su ensayo “Colonialidad del poder, eurocentrismo y América Latina” cuando escribe:

En Europa el proceso que llevó a la formación de estructuras de poder configuradas como Estado-nación, empezó con la emergencia de algunos pocos núcleos políticos que conquistaron su espacio de dominación y se impusieron sobre los diversos y heterogéneos pueblos e identidades que lo habitaban. De este modo el Estado-nación empezó como un proceso de colonización de algunos pueblos sobre otros que, en este sentido, eran pueblos extranjeros. (2000: 227)

Por consiguiente, el estado-nación es otra manifestación de la colonialidad. No obstante, tenemos que tomar en cuenta que Darío piensa que la idea de la guerra es un fenómeno natural; hasta usa a Darwin para apoyar su argumento. Para Darío, el conflicto y el triunfo entre pueblos y naciones datan de Caín y Abel. "Lo cierto es que la fatalidad humana es un poco darwinista, y uno de los primeros comentarios de la teoría del sabio inglés está inscrito en la quijada de asno del eficaz struglfolifero Caín” (Darío, 1924: 137). Nuestro poeta parece caer en la trampa de colonialidad, donde las dualidades son naturalizadas hasta el punto de parecer innatas. "[E]l cainismo es innato en el hombre y demostrativo en la misma naturaleza" (Darío, 1924: 139). Entonces, a pesar de que Darío critica la nación a causa de la violencia que genera, él justifica la violencia usando la teoría de Darwin, lo cual es sin duda otra contradicción. En consecuencia, vemos el reflejo eurocéntrico en el lugar de enunciación de Darío. Su crítica de la nación parece de-colonial, tratando de desenredar la injusticia y violencia; sin embargo, no puede superar totalmente el eurocentrismo porque, para él, “toda vida es un combate, es una fuerza, el número es ya una jerarquía” (Darío, 1924: 139). El mundo de Darío es un mundo de jerarquías, desigualdades y violencia pero, como hemos visto, este mundo no prohíbe que Darío formule visiones utópicas del futuro.

“¿Por qué?” y "La locura de la Guerra” son las dos crónicas donde mejor vemos la conciencia dividida de Darío y sus críticas de-coloniales. Vemos a un sujeto cuya introspección le hace cuestionar los paradigmas dominantes en el mundo alrededor de él, rechazando y aceptando a la vez la actual configuración eurocéntrica y capitalista del mundo bajo la colonialidad del poder. La introspección de Darío también continúa en su comprensión de la raza, un tema que no se ha analizado aquí pero que tiene igual importancia.

\section{CONCLUSIÓN}

A través del análisis de las crónicas, artículos y ensayos, de Darío podemos ver el carácter político de sus escritos. Su intento de divorciarse de la política -llamándose apolítico- fracasa, puesto que vemos a un hombre que estaba sumamente preocupado por el futuro de América Latina. El fin del siglo XIX y principios del siglo XX constituyó un periodo de gran incertidumbre para América Latina: naciones recién forjadas tenían que redirigir sus esfuerzos hacia el Norte en lugar de hacia el Este. La política extranjera estadounidense sobre el futuro de América Latina causó, en ese contexto, gran ansiedad a personas como Darío y Martí. Para Darío, su repuesta fue mirar otra vez al 
Este para obtener el apoyo europeo. Pero al mismo tiempo, criticó duramente los estereotipos peyorativos sobre América Latina emitidos desde Europa. Trazar el pensamiento de Darío en su prosa revela pues una red compuesta de flujos de pensamiento geopolíticos constituidos dentro del eurocentrismo. No obstante, el carácter oscilante, si no contradictorio, de sus escritos revela a un sujeto cuya conciencia está dividida. Rodeado e influido por un pensamiento eurocéntrico, le costaba a Darío no reproducirlo. Aun así, pudo romper el amarre eurocentrista y criticar la colonialidad, y como resultado, tenemos en sus textos instancias de un pensamiento de-colonial.

Para concluir, cerramos con un pasaje Quijano que describe en términos generales el concepto de doble conciencia en términos latinoamericanos.

Aplicada de manera específica a la experiencia histórica latinoamericana, la perspectiva eurocéntrica de conocimiento opera como un espejo que distorsiona lo que refleja. Es decir, la imagen que encontramos en ese espejo no es del todo quimérica, ya que poseemos tantos y tan importantes rasgos históricos europeos en tantos aspectos, materiales e intersubjetivos. Pero, al mismo tiempo, somos tan profundamente distintos. De ahí que cuando miramos a nuestro espejo eurocéntrico, la imagen que vemos sea necesariamente parcial y distorsionada. (Quijano, 2000: 226)

Este pasaje nos ayuda a entender mi argumento en este ensayo. Como ejemplifica a través de sus obras, Darío sabía que la experiencia latinoamericana no se parecía a la europea ni a la norteamericana. A pesar de su perspectiva de saber eurocéntrica, se hallan en su obra diferentes distorsiones de-coloniales. Viéndose en el espejo eurocéntrico, existían imágenes no reconciliables que lo separaban de ser un sujeto completamente colonial y eurocéntrico. De ahí su conciencia dividida entre dos mundos, los coloniales y de-coloniales. 
BIBLIOGRAFÍA

Blandón, Erick. "Presencia de Rubén Darío en los discursos del mestizaje”. Chasqui 40.2 (2011): 171-183.

CaSTRO-GÓmEZ, Santiago (2005). La hybris del punto cero: ciencia, raza e ilustración en la Nueva Granada (1750-1816). Bogotá: Editorial Pontífica Universidad Javeriana.

DARío, Rubén (1924). Crónica política. Ed. Alberto Ghiraldo. Madrid: G. Hernández y Galo Sáez.

DARío, Rubén (1938). Escritos inéditos. Ed. E. K. Mapes. New York: Instituto de las Españas.

DARío, Rubén (1968). Escritos dispersos de Rubén Darío. Ed. Pedro Luis Barcia. La Plata: Universidad Nacional de La Plata.

DARío, Rubén (1972). Los raros. Costa Rica: Editorial Universitaria Centroamericana.

DARÍO, Rubén (1997). Quince prólogos de Rubén Darío. Ed. José Jirón Terán. Managua: Instituto Nicaragüense de Cultura.

DARÍO, Rubén (2004). "Rubén Darío: Las letras hispanoamericanas en París”. La caravana pasa. Managua: Academia Nicaragüense de la Lengua/Fondo Editorial CIRA.

DuSSEL, Enrique (2010). "Meditaciones anti-cartesianas: sobre el origen del anti-discurso filosófico de la modernidad." Estudios transatlánticos postcoloniales: I. Narrativas comando/ sistemas mundos: colonialidad/modernidad. (Ileana Rodríguez y Josebe Martínez, edas.). Barcelona: Anthropos: 217-272.

Du BoIS, W. E. B (2005). The Souls of Black Folk. New York: Simon \& Schuster.

Grosfoguel, Ramón. "Transmodernity, border thinking, and global coloniality: Decolonizing political economy and postcolonial studies". Eurozine (2008).

Jáuregui, Carlos. “Calibán, ícono del 98. A propósito de un artículo de Rubén Darío.” Revista Iberoamericana 64.184-185 (1998): 441-449.

Maldonado-TorRes, Nelson. "On the Coloniality of Being: Contributions to the Development of a Concept.” Cultural Studies 21.2-3 (2007): 240-270.

Mignolo, Walter (2011). The Darker Side of Western Modernity: Global Futures, Decolonial Options. Durham: Duke University Press.

Normand, J. F. "Las ideas políticas de Rubén Darío." Revista Iberoamericana 2.4 (1940): 435-440.

QuiJano, Aníbal (2000). "Colonialidad del poder, eurocentrismo y América Latina”. La colonialidad del saber: eurocentrismo y ciencias sociales. Perspectivas Latinoamericanas. Ed. Edgardo Lander. Buenos Aires: CLASCO: 201-246.

RAMA, Ángel (1970). Rubén Darío y el modernismo. Caracas: Universidad Central de Venezuela.

RAMíREZ, Sergio (2006). El señor de los tristes, sobre escritores y escritura. San Juan: La Universidad de Puerto Rico.

RodÓ, José Enrique (1997). Ariel, Liberalismo y Jacobisnismo, Ensayos. México: Editorial Porrúa. 
SALGado, María A. "Rubén Darío y la Generación del 98: Personas, personajes y mascaras del fin de siglo español.” Hispania 82.4 (1999): 725-732.

SchmitT, Carl (2003). The Nomos of the Earth in the International Law of the Jus Publicum Europaeum. New York: Telos.

Zavala, Iris M. (1992). Colonialism and Culture: Hispanic Modernisms and the Social Imaginary. Bloomington: Indiana University Press.

ZAVALA, Iris M. (2001). El rapto de América y el síntoma de la modernidad. Barcelona: Montesinos. 


\title{
ESCRITORES LATINOAMERICANOS EN LA ESPAÑA DEL SIGLO XX
}

\author{
Latin American Writers in the XXth Century Spain
}

\section{CARMEN ALEMANY BAY}

\section{UNIVERSIDAD DE ALICANTE carmen.alemany@ua.es}

Profesora de Literatura Latinoamericana en la Universidad de Alicante, ha explorado distintas corrientes de la poesía latinoamericana contemporánea, con especial atención a las poéticas coloquiales y a la literatura escrita por mujeres. Entre sus libros recientes, destacan Residencia en la poesía: poetas latinoamericanos del siglo XX (2006), La narrativa de la alteridad en América Latina (a partir del boom) (2009) y Miguel Hernández, el desafio de la escritura. El proceso de creación de la poesía hernandiana (2013).

\section{RECIBIDO: 13 DE ENERO DE 2017}

RESUMEN: La presente investigación indaga en la influencia de algunos escritores latinoamericanos entre los intelectuales españoles a lo largo del siglo XX. Partimos de la presencia de Rubén Darío como primer renovador de las letras españolas y cómo, poco tiempo después, las estancias más o menos fluidas de escritores latinoamericanos en territorio español estimularán la literatura de este país. Nos referimos a Vicente Huidobro y posteriormente a la presencia de Pablo Neruda, César Vallejo y otros intelectuales durante la Guerra Civil española; sin olvidar la importancia de la polémica sobre el "meridiano intelectual" entre españoles y latinoamericanos. Tras la guerra, la relación entre los poetas españoles de la llamada "Generación del 50" y poetas representativos de la llamada poética coloquial fue patente. En los años sesenta, con la llegada del boom, se intensificarán las relaciones que finalmente desembocarán en el llamado boomerang.

Palabras Clave: Rubén Darío, Meridiano Intelectual, Neruda, Vallejo, Poética Coloquial, Boom, Boomerang.
ACEPTADO: 3 DE ABRIL DE 2017

ABSTRACT: This paper deals with the influence of some Latinamerican Writers had in some Spanish Intellectuals during the XXth Century. We start with the presence of Rubén Darío as the first renovator of Spanish letters and how the visits of latin american writers in Spain stimulated the development of literature in this country. We think about the influence that Vicente Huidobro, Pablo Neruda or César Vallejo had in Spanish literature during the Spanish Civil War, but also on the "meridiano intelectual" debate between Spanish and latin american writers. After the wat, the relationship between the "Generation of 50" and the latin american colloquial poets was strong and meaningful. In the sixties, after the boom of latin american novel, that relationships became stronger and lead to the called boomerang effect.

KEYWORDS: Rubén Darío, Meridiano Intelectual, Neruda, Vallejo, Colloquial Poetics, Boom, Boomerang.

Alemany Bay, Carmen.

"Escritores latinoamericanos en la España del siglo XX".

Kamchatka. Revista de análisis cultural 9 (Julio 2017): 65-82.

DOI: 10.7203/KAM. 9.9544 ISSN: 2340-1869 
Desde la llegada de Rubén Darío (1867-1916) a tierras españolas, la conciencia que se tenía de los escritores latinoamericanos cambió de forma considerable y, a partir de esos momentos, la intelectualidad española, poco a poco, tendrá que hablar con otros términos, al menos más igualitarios, al referirse a la literatura latinoamericana. Éste será sólo el comienzo de unos renovados lazos que se acrecentarán con la vanguardia, se incrementarán con el boom de la narrativa latinoamericana y se consolidarán con el último boomerang.

Cinco fueron las visitas prolongadas de Rubén Darío a España, y sobre todo las primeras sirvieron para afianzar la estética modernista en suelo español. La primera fue en 1892 para participar en los festejos del IV Centenario del Descubrimiento y el vate nicaragüense aprovechó su estancia en la capital madrileña para visitar las tertulias de Juan Valera y de Emilia Pardo Bazán e iniciar amistad con Gaspar Núñez de Arce y Ramón de Campoamor; es decir, con lo más granado de la literatura española de aquellos años. Fue recibido con respeto y aunque apenas se conocía su obra, se sabía de su prestigio literario; pero el conservadurismo literario español de muy finales del XIX no dejó en ningún momento de mirar de soslayo al nicaragüense.

A finales de 1898, Rubén Darío realiza su segundo viaje a la península como corresponsal de $L a$ Nación de Buenos Aires para cubrir la situación de penuria en la que había quedado España después de su derrota frente a los Estados Unidos, y ya sin colonias hispanoamericanas en su haber. En esta ocasión, su contacto con escritores e intelectuales españoles (Miguel de Unamuno, Marcelino Menéndez y Pelayo, Joaquín Costa y, entre los jóvenes, Valle-Inclán y Jacinto Benavente) será más destacable, y las relaciones con algunos de ellos darán como fruto la publicación en la capital de España de sus primeros libros; aunque los "paliques” de Clarín denunciasen el lenguaje no siempre purista del nicaragüense. Este viaje, sin duda, le abrirá las puertas para conocer otras ciudades europeas y residir algún tiempo en París, ciudad que conoció en 1893: "Yo soñaba con París desde niño, a punto de que, cuando hacía mis oraciones, rogaba a Dios que no me dejase morir sin conocer París. París era para mí como un paraíso en donde se respirase la esencia de la felicidad sobre la tierra”, como nos dice en su Autobiografía (Darío 1950-53: 102).

Tras un periodo en la capital francesa, en donde convivirá con escritores e intelectuales hispanoamericanos como Enrique Gómez Carrillo, Manuel Ugarte, Amado Nervo y Rufino Blanco Bombona, regresará -en 1905- a España, se instalará en Madrid pero también recorrerá otras geografías españolas. Éste será un tiempo de reconocimientos y de admiraciones que vendrán a enfatizar el ya conocido mérito del autor de Prosas profanas. Sin embargo, la apreciación intelectual, que estuvo acompañada asimismo de muchas reservas, fue fruto de la labor y del trabajo previo de no pocos poetas e intelectuales españoles que supieron visionar la renovación poética que estaba llevando a cabo el escritor nicaragüense. A finales del XIX, en 1893, y teniendo como referencia sólo uno de los libros clave de Darío, $A z u l$, el poeta Salvador Rueda, el que sería uno de los más fervorosos seguidores de la pluma del 
nicaragüense, no dudó en calificarlo como "gran versificador, padre de la forma y maestro de la rima”. En el friso del cambio de siglo, un intelectual de la talla de Ramiro de Maeztu supo no sólo valorar la trascendencia que este movimiento iba a tener, sino también que quien lo estaba abanderando poéticamente era Rubén Darío; se lamentaba asimismo de algunos juicios que no exentos de arbitrariedad veían con recelo unas transformaciones poéticas que eran parejas a los crecientes cambios sociales. A estas manifestaciones se unirá Juan Ramón. Una de sus primeras alusiones a aquel que será el más idolatrado de sus poetas, tendrá lugar en la temprana fecha de 1900: “uno de los más grandes poetas españoles de todos los tiempos y de los menos comprendidos y más injustamente atacados por enanos literarios [...] Aquí en España se han dicho las mayores atrocidades de este poeta singular, tan maravilloso y tan extraño en sus músicas íntimas y perfumadas” (1990: 166-167). Un año después, otro poeta, Manuel Machado, incidirá en lo ya señalado por parte de algunos poetas señeros: la miopía en la que vivían no pocos intelectuales españoles al no reconocer las innovaciones del lenguaje rubendariano.

En el bando de los reticentes se posicionó, de forma notable y por tanto destacada, Leopoldo Alas Clarín, quien nunca vio con buenos ojos ni la poesía modernista ni a su máximo exponente; sus razones, la destrucción de las bases por las que durante siglos se rigió la lengua española, fundamentalmente no acatar en su justa medida las normas gramaticales y la invención, desde su punto de vista innecesaria, de palabras. Desde las páginas del Madrid cómico, atacaba de este modo:

A bombo me resuena a mí no poco de lo que dicen de esas docenazas de poetas insignes americanos los críticos y viajantes literarios que por acá nos quieren unir con América por medio de un cable de ripios de aquende y allende del Atlántico [...] Pues bien, el tal Rubén Darío no es más que un versificador sin juicio propio, como hay ciento, que tiene el tic de la imitación, y además escribe, por falta de estudio o sobra de presunción, sin respeto de la gramática ni de la lógica, y nunca dice nada entre dos platos. Eso es Rubén Darío en castellano viejo (Lozano, 1978: 10 y $32-33)$.

Incluso Miguel de Unamuno, con el que posteriormente Darío mantendrá una relación matizada por acercamientos y alejamientos, espetó que al nicaragüense "se le veían las plumas de indio debajo del sombrero". No tardó demasiado en rectificar.

Con la aparición en una imprenta madrileña de Cantos de vida y esperanza. Los cisnes y otros poemas, escritos entre 1902 y 1905, hasta los más antimodernistas se plegaron a la grandeza del mayor modernista de todos los tiempos. El libro, cuidado y revisado por Juan Ramón Jiménez, recogía composiciones que el nicaragüense había publicado en revistas, generalmente españolas, y fue el poeta andaluz quien se encargó de recopilarlas, ya que Rubén Darío en estas fechas no podía controlar su afición etílica. Tras la publicación del libro, uno de los más contundentes juicios vino de la mano de Pedro Henríquez Ureña para quien Rubén Darío “ejerce hoy tal verdadera y poderosa influencia en la literatura de España, que ha llegado a ser el poeta representativo de la juventud de nuestro idioma en este momento" (Lasarte, 1991: 233). 
Tras numerosos intentos de curar su alcoholismo en tierras mallorquinas, isla en la que pasó no pocas temporadas allá por la segunda década del siglo XX, Rubén Darío morirá en su patria natal; desde España, Antonio Machado, escribirá el poema “A la muerte de Rubén Darío”:

Rubén Darío ha muerto en sus tierras de Oro, esta nueva nos vino atravesando el mar.

Pongamos, españoles, en un severo mármol, su nombre, flauta y lira, y una inscripción no más:

nadie esta lira pulse, si no es el mismo Apolo, nadie esta flauta suene, si no es el mismo Pan (1988: 598).

Estos versos eran la sentida respuesta a la muerte del nicaragüense, pero también a lo que Rubén Darío había afirmado del cantor de las tierras de Castilla unos años antes: “Antonio Machado es quizá el más intenso de todos. La música de su verso es la de un estoico. Sabe decir sus ensueños en frases hondas" (Darío, 1950-53: 414).

Con las visitas de Rubén Darío a España, la invasión latinoamericana o la primera llegada de los bárbaros $^{1}$, sólo fue el comienzo. Poco después de la muerte del nicaragüense, el chileno Vicente Huidobro (1893-1948), el creador del Creacionismo, tendrá a bien visitar España para mostrar y discutir su propuesta poética. Su paso por Madrid será determinante para la renovación poética; nuevamente, desde América Latina, aparece una voz poética que tambaleará los cimientos de la literatura española, de la poesía al menos. Su primer viaje a tierras ibéricas fue en 1918: la difusión de libros como El espejo de agua y Horizon Carré, así como la divulgación de sus ideas creacionistas, originarán el germen del futuro pero próximo movimiento ultraísta. El escritor chileno participará en las tertulias del Café Colonial en las que el sevillano Rafael Cansinos Assens reunía a jóvenes escritores y, como él mismo indicó tiempo después, la presencia del chileno en aquellos encuentros fue el revulsivo para que los escritores españoles se percatasen de las nuevas corrientes poéticas que habían empezado a instaurarse en Europa. Con estas palabras lo expresó Cansinos Assens:

el acontecimiento supremo del año literario que ahora acaba, lo constituye el tránsito por esta corte del joven poeta chileno Vicente Huidobro, que a mediados de estío llegó a nosotros, de regreso de París donde pudo ver las grandes cosas de la guerra y alcanzar las últimas evoluciones literarias. Pocas líneas en nuestra prensa señalaron la estancia del original cantor, que retraído y desdeñoso, sólo se comunicó con unos pocos para anunciarles sus primicias nuevas. Y, sin embargo, su venida a Madrid fue el único acontecimiento literario del año, porque con él pasaron por nuestro meridiano las últimas tendencias estéticas del extranjero; y él mismo asumía la representación de una de ellas, no la menos interesante, el creacionismo, cuya paternidad compartió allá en París con otro singular poeta, Pedro Reverdy (...) Huidobro nos traía primicias completamente nuevas, nombres nuevos, obras nuevas; un ultramodernismo (1927: 195-196).

\footnotetext{
${ }^{1}$ El apelativo de "bárbaros" lo tomamos del libro La llegada de los bárbaros. La recepción de la literatura hispanoamericana en España, 1960-1981 de Joaquín Marco y Jordi Gracia.
} 
Su estancia en España coincidió con la edición, en estas tierras, de cuatro libros fundamentales para la configuración del Creacionismo: Poemas árticos, Ecuatorial, Tour Eiffel y Hallalí. Sin embargo, y a pesar de la evidente novedad, la recepción crítica no fue tan entusiasta como la de los tertulianos del Café Colonial ${ }^{2}$.

Los siguientes viajes de Vicente Huidobro a España no revestirán la misma importancia que tuvo el primero, aunque -y quizá debido a la llamativa personalidad del escritor- dejaron su huella. En 1919, procedente de Francia y camino de Chile, el poeta creacionista mantuvo viva la relación con los escritores del círculo de Cansinos y algunos de ellos tuvieron el privilegio de conocer, de primera mano, los esbozos de su obra cumbre, Altazor, que Huidobro estaba escribiendo en francés y con el provisional título de Voyage en parachute (Morales). Un año después el poeta chileno regresará a tierras ibéricas, pero las relaciones que antaño fueron de admiración y de devoción se trasformaron en rechazo. Los motivos de aquellos reveses podríamos canalizarlos en una entrevista que Pierre Reverdy concedió a Enrique Gómez Carrillo para El Liberal de Madrid. En sus palabras dejaba entrever que él era el único inventor del Creacionismo y acusaba al chileno de antedatar la plaquette El espejo de agua (Buenos Aires, 1916), lo que generó un sinfín de discursos a favor y en contra del chileno (Morales) ${ }^{3}$. A partir de esos momentos, escritores de su círculo más próximo, como lo fue Guillermo de Torre, la cabeza más visible del ultraísmo español, no reparará en duras y continuadas críticas tal como dejó explicitado en Historia de las literaturas de vanguardia ${ }^{4}$.

\footnotetext{
${ }^{2}$ Los tres primeros libros fueron publicados por la editorial Pueyo de Madrid y Hallallí por ediciones Jesús López.

${ }^{3}$ En la nota 16 de su artículo explica detalladamente los derroteros por los que anduvo esta polémica: "La entrevista de Enrique Gómez Carrillo se publica en El Liberal de Madrid el 30 de junio de 1920. A partir de esa fecha se tejerán distintas historias en torno a la antedatación y un sinnúmero de argumentos a favor y en contra que quedarán debidamente esclarecidos por René de Costa y Richard L. Admussen en el artículo 'Huidobro, Reverdy y la edición príncipe de El espejo de agua', donde se demuestra la existencia de un ejemplar facilitado por el poeta chileno Braulio Arenas, recopilador de las primeras Obras Completas (1964) de Huidobro (en las que aseguraba poseer esa primera edición). Más tarde, De Costa reforzaría su aseveración con la edición facsimilar del libro en un encarte de la revista Peñalabra, IV, 12, Torrelavega, España, 1974 (acompañada de una 'Nota bibliográfica a la edición facsímil de El espejo de agua', luego reproducida en el libro del propio De Costa En pos de Huidobro. Editorial Universitaria. Santiago de Chile, 1980). Como corolario a esta tan larga polémica, René de Costa insiste en su demostración en el artículo `Punto y aparte a una absurda polémica', en Texturas, 8, Vitoria, 1998”.

${ }^{4}$ Andrés Morales, en la nota 17, reproduce las siguientes palabras de Guillermo de Torre: "En cuanto al segundo punto, la influencia del ismo huidobreano, cualquier observador objetivo del panorama literario en España hacia 1920 deberá reconocer que fue muy escasa, al contrario de lo que opinan sin fundamento, sin datos probatorios, quienes pretenden hacer derivar todo de ahí. En primer término, por el motivo poderoso de que los libros del chileno, impresos en ediciones privadas, a cuenta del autor, circularon de modo limitadísimo, únicamente entre las personas a quien él se los entregó. De suerte que un influjo más ancho sólo hubiera podido producirse por capilaridad, o bien -según de hecho sucedió- de modo lateral, indirecto, a través de transcripciones y conversaciones; en último extremo, la difusión debióse en buena parte al revuelo suscitado por la aludida polémica. En cualquier caso, tanto el conocimiento como el influjo de Huidobro quedaron diluidos, como uno más, entre otros que planeaban al comienzo del decenio de 1920 (Guillermo de Torre, Historia de las literaturas de vanguardia. Editorial Guadarrama. Madrid, 1974 (Tercera Edición), II, pp. 208-209)”. El texto en cursiva es de la autora del artículo.
} 
Para el autor español, Vicente Huidobro se apoderó del ideario del ultraísmo, oscureciendo de este modo el movimiento que él encabezaba; sin embargo, a esas alturas, el ultraísmo aún carecía de un ideario programático. Será un poeta argentino, Jorge Luis Borges, quien pocos años después logre sistematizar los fines y propósitos del ultraísmo. Desde París, en enero de 1920, Vicente Huidobro escribirá a Guillermo de Torre para responderle a una carta previa; su respuesta, teniendo como referente todo lo acontecido, no tiene desperdicio:

Me pregunta Ud. por qué no escribo a España, y bien puesto que soy un hombre franco y leal debo decirle a Ud. la verdad ruda: porque estoy asqueado de la conducta de esos literatillos de vuestra tierra para conmigo y no quiero saber nada de lo que pase por allá.

Creo que esto es bien simple y exepción [sic] hecha de Mauricio Bacarise [sic] y Ramón Prieto creo que la inmensa mayoría de los otros no son sino unos aprovechados arrivistas [sic] y unos bobos que desacreditan con sus confuciones [sic] y sus producciones ineptas la seriedad de algo que yo estoy obligado a defender más que nadie.

Maldita mil veces la hora que pasé por España y os revelé parte de mi secreto tan querido y tan digno por su verdad y su pureza de mayor suerte y mayor respeto.

Unos me han estropeado con la falsificación y la confución [sic] respecto a la poesía misma y los otros queriendo robarme lo que era mío para ponerlo en la cabeza de Apollinaire, de Reverdy o de cualquier otro imbécil (Huidobro).

Sí convendría aclarar en este punto que desde el año 1919 los ultraístas habían manifestado su interés por separarse de los lineamientos creacionistas, como queda explicitado en un texto de José Rivas Panedas publicado por la revista Cervantes y titulado "Protesto en nombre de Ultra": "el creacionismo, es algo bien concreto, al menos una cosa muy concreta al lado de nuestro Ultra, que no nos cansaremos de repetir, que no es un dogma ni un modo. El creacionismo sí” (Morales).

Sin embargo, y a pesar de todos esos inconvenientes, la valía de la propuesta creacionista se hizo eco en uno de los más destacados integrantes del grupo poético del 27, Gerardo Diego (1896-1987). En los comienzos de los años 20 se iniciarán los primeros contactos epistolares entre ambos poetas; así lo recuerda el autor de la Fábula de Equis y Zeda:

Yo comencé a conocer la poesía de Huidobro en enero de 1919 -antes sólo algún fragmento aislado y referencias críticas de Cansinos- y en seguida tenía ya copiados sus últimos libros, que me prestó Eugenio Montes, fervoroso huidobrista de aquella hora. A Vicente después de cruzarnos algunas cartas (claro está que yo fui el primero en escribirle para manifestarle mi entusiasmo), le conocí personalmente en Madrid en el invierno de 1920-1921 (Morales).

Como efecto dominó, la influencia de Huidobro recaerá en otro escritor español, Juan Larrea (1895-1980), a quien Gerardo Diego convenció de la excelencia poética de la obra de Huidobro, y no son pocos los críticos que advertirán que la obra del bilbaíno empezó a poblarse de formas más creacionistas. 
Tras estas amargas experiencias, Vicente Huidobro tardará algunos años en pisar nuevamente tierras españolas. Su presencia, como siempre, estará envuelta de polémica:

En los meses de enero y febrero de 1931 Huidobro reside una vez más en la capital de España. Asiste a recitales poéticos (entre los que cabe destacar Poeta en Nueva York realizado por Federico García Lorca), proyecta publicar nuevas revistas, polemiza con Luis Buñuel, se aleja de los escritores del grupo del 27 y publica dos de sus libros más importantes: Altazor y Temblor de cielo en dos casas editoriales de gran prestigio en el ámbito literario español (Morales).

Al igual que ocurrió en 1918, sus libros no merecerán mayor atención de la crítica. Sus últimas visitas a España serán durante la Guerra Civil española y su participación, al lado del bando republicano, será muy similar a la de muchos intelectuales de una y otra orilla del Atlántico: discursos, recitales en los frentes, entrevistas para medios internacionales, etc., sin olvidar su participación como representante de Chile en el II Congreso Internacional de Escritores para la Defensa de la Cultura celebrado en Valencia, en Madrid y posteriormente en París en 1937. Como botón de muestra del ímpetu que caracterizaba la personalidad de Vicente Huidobro citamos estas palabras de Andrés Morales: “incluso arenga a las tropas nacionalistas desde un coche blindado, mediante un altavoz, en los frentes de Madrid y Aragón instándoles a desertar del bando rebelde para 'pasarse` al republicano”.

Otros poetas latinoamericanos dejarán su huella en una España apocadamente vanguardista, uno de ellos será el joven de origen argentino Jorge Luis Borges:

Soy porteño: he nacido el mil novecientos en la parroquia de San Nicolás, la más antigua de la capital, al menos para mí. La época de la guerra la pasé en Ginebra, época sin salida, apretada, hecha de garúas y que recordaré siempre con algún odio. El diez y ocho fui a España. Allí colaboré en los comienzos del ultraísmo. El veintiuno regresé a la patria... (Vignale, 1927).

Cansinos Assens también recuerda el paso del poeta de Fervor de Buenos Aires por España, así como su colaboración en el movimiento ultra:

Jorge Luis Borges [...] pasó por entre nosotros como un nuevo Grimm, lleno de serenidad discreta y sonriente. Fino, ecuánime, con ardor de poeta sofrenado por una venturosa frigidez intelectual, con una cultura clásica de filólogos griegos y trovadores orientales que le aficionaba al pasado, haciéndole amar calepinos e infolios, sin menoscabo de las modernas maravillas, Jorge Luis Borges observaba, discutía cortésmente con sus camaradas juveniles y tomaba de la nueva lírica, llegada a nosotros en los libros de Huidobro, que por aquel entonces estaban perennemente abiertos sobre facistoles, la nueva lección de fuga y contrapunto con que al través de las edades se van remozando los eternos temas (1927: 280-281).

Sin duda, la actividad del joven Borges y su inteligencia dejaron deslumbrados a los ultraicos madrileños, así como a los ultraístas mallorquines (Jacobo Sureda, Juan Alomar y Fortunio Bonanova). Con los madrileños firmará varios manifiestos a favor del Ultra y a su llegada a Buenos Aires, en 1921, no dejará de comunicarse con sus colegas españoles, sobre todo con Guillermo de Torre. Sin embargo, ya en 
tierras argentinas el poeta empezó a delinear otras formas ultraicas que se desviaban de las gestadas en tierras españolas para convertirse en el mejor poeta ultraísta de todos los tiempos. En el año 1923, en una carta dirigida a su amigo el poeta mallorquín Jacobo Sureda, Borges dirá palabras tan significativas y aleccionadoras como éstas:

Acerca de publicaciones, sabes que el efervescente Torre acaba de prodigar sus millaradas de esdrújulas en un libro de poemas rotulado Hélices? Ya te imaginarás la numerosidad de cachivaches: aviones, rieles, trolleys, hidroplanos, arcoiris, ascensores, signos del Zodíaco, semáforos... Yo me siento viejo, académico, apolillado, cuando me sucede un libro así (Borges, 1987: 80).

Algunos años después de la escritura de esta misiva, Jorge Luis Borges cambiará las directrices ultraístas por otros modos de escritura más acordes a los tiempos que se vivían en Argentina y al pensamiento del autor: de una poética de índole vanguardista pasará a otra de calado más nacionalista, el criollismo. Con este paso, el ultraísmo tanto en España como en Argentina ya pertenecía a una expresión poética del pasado.

En pleno período de efervescencia vanguardista en América Latina, uno de los mejores poetas de la historia, el peruano César Vallejo (1892-1938) abandonará su país a finales de 1923. Si bien su destino será Francia, y desde París y otras ciudades galas escribirá crónicas para Mundial y Variedades (1925-1930), o trabajará en “Les Grands Journaux Ibero-Américains” (1925-1926), nunca le será ajena su relación con España. Un vínculo que se nutría en tierras francesas con la amistad que estableció con Juan Larrea, con quien publicó en 1926 dos números de la revista Favorables París Poemas; pero que se ahondará, desde el punto de vista literario, con la edición de Trilce a manos de José Bergamín quien no escatimará en halagos hacia tan monumental obra. Desde el punto de vista político y humano, el autor de Poemas humanos participará activamente en favor de la República y antes del final de la guerra española, a la que cantó en España, aparta de mí este cáliz, fallecerá el 15 de abril de 1938, en París, como ya él mismo había vaticinado en sus versos:

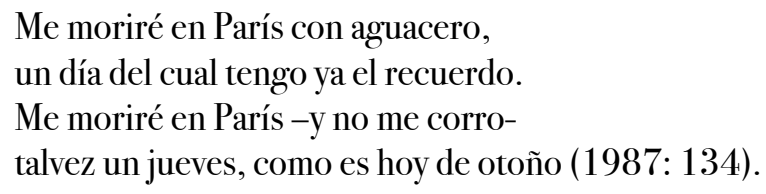

Su tristeza insondable, ni siquiera paliada por el fervor político, le hizo imaginar que moriría en otoño, y París le regaló la primavera para su muerte; ésta fue la única prebenda, ni siquiera le quitó la lluvia, quizá para no dejarlo como el mentiroso que no era. Louis Aragon, entre otros pocos amigos, posiblemente algún español, le despidieron en el cementerio de Montrouge.

Sin dejar de lado estos años de inmersión en la vanguardia, y coincidiendo con el momento de esplendor literario que la lengua española adquirió a ambos lados del Atlántico, algunos de sus más 
significativos creadores y un buen número de notorios intelectuales participaron, durante el año 1927, en una sonada polémica sobre la ubicación del liderazgo literario en lengua española. Este debate fue conocido por el título provocador del artículo (que apareció sin firma pero cuyo autor fue Guillermo de Torre) que la desencadenó: la polémica del meridiano intelectual. La discusión fue también un reflejo intensísimo de las relaciones entre América Latina y España de aquella época. El artículo en cuestión, "Madrid, meridiano intelectual de Hispanoamérica", que fue publicado en la revista madrileña La Gaceta Literaria, obtuvo inmediatas respuestas desde el otro lado del Atlántico. La revista argentina Martín Fierro fue la primera en responder de forma airada, pero a ella le siguieron las montevideanas La Pluma y Cruz del Sur, las cubanas Revista de Avance y Orto, o la mexicana Ulises; a estas manifestaciones se adhirieron relevantes personalidades del mundo intelectual como el peruano José Carlos Mariátegui y el cubano Alejo Carpentier, entre muchos otros.

La polémica no sólo se extendió en el mundo de habla hispana sino que la revista italiana La Fiera Letteraria también se hizo eco y se posicionó en este lance dialéctico. Con el avance de la polémica, otro periódico español del momento, El Sol, provocó que la cuestión del meridiano intelectual derivara hacia el controvertido papel de los nacionalismos. La polémica se dio por zanjada antes de la finalización de la década del veinte, pero en estos escritos entrecruzados quedó bien patente que el protagonismo que algunos intelectuales españoles querían seguir teniendo sobre América Latina era ya un lastre del pasado (Alemany, 1988).

En la década de los treinta, otro poeta latinoamericano convulsionará de nuevo la poesía española, Pablo Neruda (1904-1973). El chileno fue enviado a Barcelona en 1934 como agregado del consulado chileno pero muy pronto se trasladará a Madrid en donde vivirá una de las más plenas experiencias de su vida, como repitió a lo largo de su existencia. El poeta de Veinte poemas de amor y una canción desesperada se instalará en la llamada Casa de las Flores, un edificio del barrio de Argüelles, a las puertas de la Ciudad Universitaria, con la entonces su esposa Ma Antonieta Hagenaar y la hija de ambos, Malva Marina:

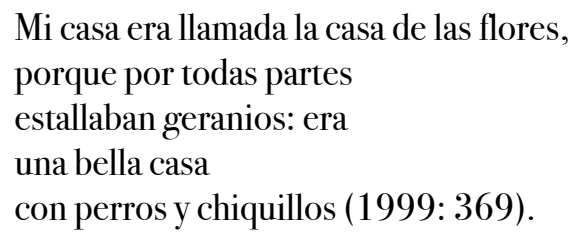

Muy cerca de la casa vivían Federico García Lorca y Rafael Alberti, y también Manuel Altolaguirre, José Bergamín, Luis Cernuda y Vicente Aleixandre. Miguel Hernández, más pobre, vivía más lejos, en los arrabales de Madrid. El grupo se reunía casi todos los días, sobre todo en la Cervecería de Correos, y allí comentaban sus creaciones y las de otros. La fuerza personal y poética de Neruda hará estragos entre los poetas del 27 y estos no tardaron en organizarle un homenaje en el mes de abril de 1934. El poeta 
chileno, en la capital de España, dice sentirse como en su propia casa, y a iniciativa de Manuel Altolaguirre funda la revista literaria Caballo Verde para la Poesía, en cuyo primer número publicará "Sobre una poesía sin pureza", un artículo-manifiesto en el que evidencia sus diferencias con el siempre puro Juan Ramón. Los poetas del 27 se debatirán entre esa impureza nerudiana, que se inmiscuía en sus poemas, especialmente en los de Miguel Hernández, y esa pureza poética que como clavo ardiendo imponía el autor de Diario de un poeta recién casado.

La llegada de la Guerra Civil española romperá estos juegos dialécticos que deben entenderse como minucias al lado de la catástrofe nacional. Pablo Neruda es retirado de su cargo consular en Madrid por haber participado en la defensa de la República y se trasladará a París donde frecuentará la casa de Rafael Alberti y entablará una estrecha relación con Alejo Carpentier y con los padres del surrealismo francés. Se le intenta expulsar de Francia por servir de correo entre la Unión Soviética y España, pero lo que hizo fue coordinar, bajo la dirección de André Malraux, el citado II Congreso Internacional de Escritores y en el que participaron escritores tan relevantes como Vicente Huidobro, César Vallejo, el cubano Nicolás Guillén y el mexicano Octavio Paz.

El final de la guerra tuvo, entre sus múltiples consecuencias, un exilio masivo de la cultura republicana a tierras americanas: Juan Gil-Albert, Max Aub, León Felipe, Ramón J. Sender, Ángel Crespo, Manuel Caballero Bonald, Joan Ferrater y un largo etcétera. Este desafío de la historia también trajo consigo alguna consecuencia positiva como fue vertebrar y difundir, tras muchos años de estancia en tierras latinoamericanas, una visión más certera de lo que era América Latina. No se olvide que en aquellos años de incultura civil, los libros de texto eran lo suficientemente iluminadores para hacernos una idea de la imagen que de América Latina quería darse en España: exaltación del idioma español, espíritu de cruzada, la América Latina católica, el día de la Hispanidad, indios con plumas que nada tenían que ver con los de Ecuador o con los mexicanos, y un tufillo a neocolonialismo que asfixiaba casi tanto como la vida cotidiana en la piel de toro.

Tras una lenta recuperación que abarcaría todos los ámbitos, a partir de los años cincuenta, poetas de ambas orillas mantendrán intercambios no sólo literarios sino también personales. Nos estamos refiriendo a las relaciones entre los poetas españoles de la "Generación del 50", o denominada también "Generación del medio siglo” -Ángel González, Claudio Rodríguez, José Ángel Valente, Ángel Crespo, José Agustín Goytisolo, Carlos Sahagún, Jaime Gil de Biedma, entre otros-, con los llamados poetas coloquiales latinoamericanos: Mario Benedetti, Ernesto Cardenal, Jaime Sabines, Roberto Fernández Retamar, Jorge Enrique Adoum, Enrique Lihn, Juan Gelman, y algunos más. Como ya señaló Luis Antonio de Villena, "Las generaciones del 50 de uno y otro lado del océano tienen muchos puntos en 
común” (1986:13)5; denominadores poéticos comunes que podríamos resumir en la presencia explícita del lector en el poema, la ruptura del lenguaje, el uso del humor y de la ironía, el uso de aforismos y sentencias, los juegos intertextuales, el uso de heterónimos y la inclusión de referencias más o menos culturalistas (Alemany, 1997: 71-150).

Las relaciones personales estuvieron marcadas fundamentalmente por la convivencia de poetas españoles y latinoamericanos en el madrileño Colegio Mayor de Guadalupe. De este modo lo explicó Manuel Caballero Bonald, quien junto con otros vivió esta experiencia:

El Colegio Mayor de Guadalupe era un colegio hispano-americano en teoría, pero donde residían españoles y donde convivieron en un momento determinado, aparte de José Agustín, Valente, Juan Goytisolo o Emilio Lledó y yo mismo, una serie de poetas hispanoamericanos desde Ernesto Cardenal a Carlos Martínez Rivas. Todos formamos de pronto -y estoy hablando de los años cuarenta y cincuenta, finales de los cuarenta más bien- como un grupo. Unos escribíamos, otros no, pero, de todas formas aquella convivencia produjo, de alguna manera una especie de unificación de objetivos (...) había una poética común que englobaba, de alguna forma, no sólo a los poetas de la "Generación del 50", sino también a algunos poetas hispanoamericanos (Concha $23)$.

Como afirma Kiko Mora, "El Colegio de Guadalupe en Madrid y Casa de las Américas en La Habana fueron probablemente los centros donde pudo gestarse una mayor fluidez comunicativa entre ambas generaciones"; como resultado de estos intercambios se fomentarían, al mismo tiempo y posteriormente, el interés de España por América Latina y viceversa. Como sigue apuntando Mora, otras acciones contribuyeron a la mutua relación:

la acción de la revista Cuadernos Hispanoamericanos que dirigía Félix Grande, o los viajes por motivos editoriales de Carlos Barral y Juan Luis Panero. De ahí los artículos de J. Agustín Goytisolo sobre Vicente Huidobro en Laye y su Antología de la poesía cubana, además de prólogos a ediciones de obras de Lezama Lima o Borges; la concesión del Premio "Casa de las Américas” de poesía a Félix Grande en 1967 por su libro Blanco Spirituals, o la Antología de la poesía colombiana, las colaboraciones en la revista Nueva Frontera y los prólogos a libros de Paz y Rulfo de Juan Luis Panero (2002: 87).

Llegados los primeros años de los sesenta, de nuevo y casi sin notarlo, un nuevo asalto de los bárbaros. Comenzó con el llamado boom de la narrativa latinoamericana, y en el origen de este fenómeno tuvo bastante que ver la editorial española, barcelonesa, Seix Barral. A través de su premio literario dio a conocer a los que tiempo después serían lo más granado de la narrativa de allende. Todo empezó cuando el peruano Mario Vargas Llosa recibió el Premio Biblioteca Breve en 1962 por La ciudady los perros, en

\footnotetext{
${ }^{5}$ El poeta y crítico, en la página anterior, argumentaba que "Observada desde una óptica española (y en comparación con la nuestra, Brines, Rodríguez, Gil de Biedma) se trataría de una generación más abierta. Lo primero porque si uno de sus pies está en la tradición, la poesía cívica, y el eticismo, el otro está decididamente en un gusto (no estridente) por la novedad, el movimiento y la experimentación, también lingüística; datos que -en las coordenadas españolas- apuntan más a los novísimos o Generación del 70".
} 
1964 se lo concedieron a Guillermo Cabrera Infante por Tres tristes tigres, y en 1967 le sería adjudicado a Carlos Fuentes por Cambio de piel. España pasó a ser para estos y algunos otros narradores el enlace con países europeos. La internacionalización de la narrativa latinoamericana se agrandará con la publicación en 1967 de Cien años de soledad, la novela que tanto tiempo entusiasmó y encandiló al lector español; pero no sólo ésta, muchos otros títulos venidos de allende coparán las estanterías de las librerías y bibliotecas españolas.

La industria editorial, mucho más que la crítica, será la encargada de esta divulgación sin precedentes de la narrativa latinoamericana en España, y como puente para Europa. Sin embargo, este proceso se centró en muy pocas figuras como el colombiano Gabriel García Márquez, el argentino Julio Cortázar, el mexicano Carlos Fuentes, el peruano Mario Vargas Llosa y quizá, con menos intensidad, José Donoso. Muchos de ellos fijaron su residencia en España durante largo tiempo: el colombiano Gabriel García Márquez tuvo que abandonar su Colombia natal en 1955 por denunciar la corrupción del dictador Rojas Pinilla y deambulará por Roma, por París y recalará en Barcelona; el peruano Mario Vargas Llosa también vivió por algún tiempo la bohemia parisina y se instalará, al igual que Márquez, en la ciudad condal; el mexicano Carlos Fuentes recorrerá numerosos países por sus quehaceres diplomáticos y Europa, con tránsitos por España, será para él algo más que un punto de referencia. Las editoriales españolas, con los narradores al alcance de la mano, comenzarán a promocionar las obras de otros modos más agresivos en pro del aumento de la venta de libros.

La fecunda producción editorial contribuyó asimismo a la recuperación de autores y obras olvidadas, muchas de ellas consideradas en América Latina como heterodoxas, marginales o rechazables por la preceptiva académica tradicional, y que los narradores más jóvenes reivindicaron como obras maestras.

La narrativa latinoamericana pasó a ser la referencia de la literatura escrita en español. Las innovadoras técnicas narrativas utilizadas por estos escritores, y desarrolladas gracias a la influencia de la mejor narrativa europea y norteamericana, dejaron pronto su huella en la estancada narrativa española de aquellos años. Andrés Amorós, recién comenzada la década de los setenta, en su Introducción a la novela hispanoamericana actual afirmaba:

la novela hispanoamericana actual está hoy a la cabeza de la narrativa universal y sería un grave error tener que esperar cien años para reconocerlo, como tantas veces sucede. En conjunto, y salvando las debidas excepciones (Cela, Delibes, los exiliados...), no admite comparación con la novela española. No es de extrañar, por tanto, que ejerza hoy una enorme -y creciente- influencia sobre los nuevos narradores españoles (1971: 24).

Y así de contundente se mostrará el citado crítico en la conclusión de su estudio: "En el actual momento de expansión e inseguridad de la novela española, creo que la narrativa hispanoamericana puede servirnos de ejemplo y modelo mucho mejor que la francesa e inglesa" (1971: 179). Esa misma 
idea será compartida por otro crítico español, Joaquín Marco, quien en Nueva literatura en España y América abordaba varios aspectos de la crisis de la novela en España:

La realidad es que la novela se halla en una crisis absoluta, principalmente la novela europea e incluso la norteamericana. Y los novelistas latinoamericanos son una breve excepción. En la polémica se han fundido varios temas: el de la función de la novela, el de la posición de la literatura ante la sociedad española, el del lenguaje, el de la influencia de los novelistas latinoamericanos entre nosotros y al revés, el del papel de la imaginación en la creación narrativa, el del "realismo", el del "realismo crítico", el de la esencia de la novela, el del editor, el del público, el de la crítica y, naturalmente, el de ser de derechas o de izquierdas (1972: 78).

En páginas posteriores afirmará que “durante 1971, salvo excepciones, no se ha planteado la rivalidad práctica entre novela latinoamericana (novela del boom, como algunos prefieren llamarla) y la novela española. Ésta se ha rendido sin condiciones" (1972: 92). El mismo crítico, en "Literatura latinoamericana en España: tres calas históricas" de su Literatura hispanoamericana: del modernismo a nuestros días, insistirá nuevamente en la primacía de la novela latinoamericana de los sesenta respecto a la española:

Los novelistas españoles no imitaron la nueva novela latinoamericana. Tampoco sería justo decir que el vendaval pasó sin dejar huellas. El aprecio por la imaginación, el afán por el descubrimiento de un lenguaje creativo, el cuidado de la estructura, la valoración de lo nuevo que la novela latinoamericana comportaba, vinieron a influir, acelerándolo, el proceso que cada escritor llevaba en sí, en su obra (1987: 41).

Sin embargo, no toda la crítica española fue tan receptiva como en los ejemplos expuestos, ni tampoco los narradores españoles fueron tan explícitos a la hora de remarcar esta influencia. Baste revisar el libro La llegada de los bárbaros. La recepción de la literatura hispanoamericana en España, 1960-1981, editado por Joaquín Marco y Jordi Gracia, para darse cuenta de las reticencias e incluso las polémicas que generaron esa invasión de los bárbaros; pero no cabe duda de que los lectores europeos, y especialmente los españoles, se entusiasmaron con aquellas historias llegadas de allende de los mares, en concreto aquellas que se originaron desde el llamado realismo mágico. En otra aportación más reciente, Eduardo Becerra apuntaba que "los ecos" de la narrativa del boom no sólo dejaron su impronta en los narradores españoles de los sesenta y setenta, sino también en otros más recientes:

Sería absurdo negar que los ecos de esa irrupción no se han dejado de notar dentro de la narrativa española, y por supuesto también de la hispanoamericana, en las décadas posteriores: títulos como La saga/ fuga de J. B., de Torrente Ballester, y Mazurca para dos muertos, de Camilo José Cela, donde nos encontramos inmersos en escenarios de ficción de rango mítico y ancestral y que continúan en propuestas como las de algunas obras de José María Merino, Julio Llamazares y la fantápolis de Celama de la reciente trilogía de Luis Mateo Díez; las presencias de Onetti en Luis Landero y Antonio Muñoz Molina, o de Borges en Carlos Cañeque, o de ciertos ecos cortazarianos en la obra de Juan José Millás lo ilustran (Becerra, 2004: 154). 
Pasados aquellos años, los nuevos narradores latinoamericanos de los noventa pregonarán que algunos de sus abuelos literarios - los narradores de los sesenta-, dieron una imagen falsa de la verdadera América, y pondrán en su punto de mira al Premio Nobel de literatura Gabriel García Márquez. Lo cierto es que el público lector de estas latitudes prefirió esa imagen, quizá más superficial, que les hablaba de una América repleta de maravilla y de hechos que, partiendo de la realidad, se resolvían en situaciones imaginarias que pareciera que sólo eran posibles en América Latina.

Tras el esplendor de los sesenta, la situación política y social, pero también la literaria, cambió a comienzos de la década de los setenta cuando brutales dictaduras se instalaron en los países del Río de la Plata y la inestabilidad política y económica será el denominador común en toda América Latina. El escritor argentino David Viñas apuntó, al comparar la década de los sesenta con la de los setenta, que de la "euforia de los 60" se pasó a "la depresión de los 70", para después afirmar "del bum desembocamos en el crash" (Viñas, 1981: 15). Estas palabras de Viñas hacen referencia a la situación política de América Latina pero también al cambio que se produjo en la narrativa; no fueron pocos los escritores que tuvieron que exiliarse (Mario Benedetti, Cristina Peri Rossi, Daniel Moyano, Antonio Di Benedetto y un larguísimo etc. se instalarán en España) y, por supuesto, en sus ficciones no fueron ajenos a esta situación de crash que era evidente en todos los países latinoamericanos.

La narrativa siguió ofreciendo, a pesar de insostenibles situaciones, notables narradores; pero sus historias, cargadas de amargura, de desaparecidos y de seres resignados ya no emocionaban tanto al público español, lo que provocó el consecuente despego de las editoriales. En el fondo de esta situación que estamos relatando aparece otra de índole económica y, específicamente, editorial. En Latinoamérica se produjo en la década de los setenta un mayor robustecimiento de las multinacionales del libro -muchas de origen español- que se nutrían de la crisis en las que habían caído las pequeñas y medianas editoriales. El sistema de ventas se concentró en ventas masivas a domicilio, o en tiradas espectaculares que se podían adquirir en kioskos, en supermercados o en las grandes superficies (Rama, 1981: 68); pero de este sistema sólo se beneficiaron los narradores consagrados de los sesenta. Si hiciéramos caso de lo que en las décadas de los setenta y los ochenta aparecía en las librerías españolas podríamos llegar a creer que la narrativa latinoamericana había desaparecido como si de un conjuro propio del realismo mágico se tratara: sólo los que por razones políticas, o no, estaban instalados en España o en Europa lograban dar a conocer algunos de sus libros; o bien, aquellos que seguían manteniendo la visión de una América mágica como la chilena Isabel Allende.

La década de los noventa comenzará con una fecha fetiche, 1992, y la celebración del V Centenario del Descubrimiento de América. Asistimos ya a un mundo globalizado en el que la narrativa ha ganado totalmente partida a otros géneros: del boom se pasará al boomerang.

La situación política, social y económica de los años sesenta y la de los años noventa, desde luego, no era la misma ni en América Latina ni en España; pero en el terreno literario, la recepción de la 
narrativa de ambas décadas tiene bastantes paralelismos. Se produce un nuevo florecimiento de la narrativa latinoamericana en España: editoriales como Alfaguara, Planeta o Lengua de Trapo, sin olvidar la mítica Seix-Barral, acuden a narradores latinoamericanos para llenar sus catálogos de novedades; se convocan premios en los que, al igual que en los sesenta, los hispanoamericanos se llevan casi la mejor parte. Por poner algunos ejemplos, dos premios Herralde los ganaron hace unos años el peruano Jaime Bayly y el chileno Roberto Bolaño; el Premio Internacional Alfaguara de Novela ha recaído en la mexicana Elena Poniatowska con La piel del cielo y, anteriormente, en la primera convocatoria (1998), en el cubano Eliseo Alberto y en el nicaragüense Sergio Ramírez. El remunerado premio Planeta, en sus últimas ediciones, ha tenido como finalistas a la cubana Zoe Valdés, a la chilena Marcela Serrano o al peruano Jaime Bayly; y como ganadores al peruano Alfredo Bryce Echenique y al chileno Antonio Skármeta. También han recibido mención en premios españoles otros escritores hispanoamericanos más jóvenes, y por tanto más desconocidos, como el chileno Patricio Riveros Olavarría, el colombiano Juan Gabriel Vásquez, el costarricense Carlos Cortés o el venezolano Juan Carlos Méndez Guédez.

La explicación de este resurgimiento puede que esté en las siguientes palabras de Eduardo Becerra: "En algunas de estas políticas de los sellos literarios peninsulares se ha intentado hacer explícito un esfuerzo por unir o al menos acercar lo más posible las narrativas de ambas áreas culturales" (Becerra, 2004: 160), lo que supone la puesta en práctica de lo que Carlos Fuentes denominó "Territorio de La Mancha" y que "constituye el intento más reciente de formular una imagen unitaria de las letras hispánicas"(Becerra, 2004: 155). Lo cierto es que la narrativa que actualmente se produce en ambas orillas tiene notables puntos en común. Las líneas temáticas más frecuentadas son muy similares: realismo fragmentado y alimentado por la cultura de masas (referencias a la televisión, al cine, y en los últimos años a internet), nueva novela histórica, novela negra, ciencia ficción etc.; asimismo, la relectura de la tradición, las relaciones intertextuales, la parodia y la ironía serán las técnicas formales más usuales, aunque esto mismo podría decirse de la narrativa que se produce en muchos de los países occidentales, y es que la globalización nos iguala en algunas cosas.

En un intento de conocer los nuevos valores de la narrativa, Lengua de Trapo publicó en 1999 Líneas aéreas, un volumen en el que se incluyen setenta relatos de setenta autores de veinte países americanos. El volumen supera ampliamente a otro intento, el de $\mathrm{McOndo}$, en el que se le ofrecía al lector español y al latinoamericano una muestra de narradores jóvenes, dieciocho, de ocho países de habla hispana, entre ellos España.

Lo cierto es que la manera de introducirse en el mercado español no ha variado mucho de la de sus abuelos del boom: algunos han decidido vivir en España o residir temporalmente en ella (el ecuatoriano Leonardo Valencia, el mexicano Jorge Volpi, los peruanos Fernando Iwasaki y Jorge Eduardo Benavides, el chileno Carlos Franz, la colombiana Consuelo Triviño, etc.); otros colaboran o han colaborado en revistas españolas, como la boliviana Erika Bruzonic o el uruguayo Gabriel Peveroni, que es coeditor de 
Zona de obras; muchos de ellos publican asiduamente en España, como los argentinos Rodrigo Fresán o Martín Rejtman, el cubano Ronaldo Menéndez, el uruguayo Daniel Mella, la peruana Patricia de Souza. La sensación es que sólo los que tienen la posibilidad de viajar con cierta frecuencia al continente europeo, o tienen la facilidad de meterse en los mass media de este mundo globalizado --término igualitario que crea desigualdades-, logran ser conocidos fuera de su país. Nuevamente, la imagen literaria que se tiene desde España de América Latina es la imagen que nos dictan los grandes poderes fácticos que se mueven sin ser notados.

La presencia de escritores latinoamericanos en España a lo largo del siglo XX ha supuesto, como decíamos al comienzo, la estabilización y consolidación de unos lazos literarios que sin duda han contribuido a una retroalimentación necesaria; porque como apuntó en alguna ocasión Carlos Fuentes, "formamos entre todos el universo transatlántico de la lengua". 
BIBLIOGRAFÍA

Alemany Bay, Carmen (1997). Poética coloquial hispanoamericana. Alicante: Publicaciones de la Universidad de Alicante.

Alemany Bay, Carmen (1998). La polémica del meridiano intelectual de Hispanoamérica (1927). Estudio y textos. Alicante: Publicaciones de la Universidad de Alicante.

AMORÓS, Andrés (1971). Introducción a la novela hispanoamericana actual. Madrid: Ediciones Anaya.

BECERRA, Eduardo (1999). Líneas aéreas. Madrid: Lengua de Trapo.

BECERRA, Eduardo (2004). "Visita al territorio de La Mancha". En cuarentena: nuevos narradores y críticos a principios del siglo XXI. (Antonio Orejudo, coord.) Murcia: Publicaciones de la Universidad de Murcia: 151-163.

BORGES, Jorge Luis (1987). Cartas de juventud(1921-1922). Madrid: Editorial Orígenes.

CANSINOS ASSENS, Rafael (1927). La nueva literatura: la evolución de la poesía (1917-1927). Madrid: V.H. de Sanz Calleja.

Cruchaga Santa María, Ángel. “Conversando con Vicente Huidobro”. El Mercurio (31/08/1919).

DARíO, Rubén (1950-1953). Autobiografía. Obras completas. Tomo I. Madrid: Afrodisio Aguado.

Fuguet, Alberto y Sergio GómeZ (1996). McOndo. Santiago de Chile: Grijalbo/ Mondadori.

GARCÍA DE LA CONCHA, Víctor. "El estado de la cuestión: encuentros con el 50. La voz poética de una generación”. Ínsula 494 (1988): 21-25.

Huidobro, Vicente. Cartas.

JimÉNEZ, Juan Ramón (1990). Mi Rubén Darío. Moguer: Fundación Juan Ramón Jiménez.

LaSARTe, Javier (1991). Pedro Henríquez Ureña: del ensayo crítico a la Historia Literaria. Alicante: Instituto de Cultura Juan Gil-Albert.

Lozano, Carlos (1978). La influencia de Rubén Darío en España. León (Nicaragua): Universidad Nacional Autónoma de Nicaragua.

Machado, Antonio (1988). Poesías completas. Madrid: Espasa-Calpe.

MorA, Kiko. "Corrientes submarinas. Las poéticas del 50 española e hispanoamericana (o viceversa)". América sin nombre. Relaciones entre la literatura española e hispanoamericana 3 (2002): 79-88.

Morales, Andrés. “Huidobro en España”. Cyberhumanitatis.

MARCO, Joaquín (1972). Nueva literatura en España y América. Barcelona: Editorial Lumen.

MARCO, Joaquín (1987). Literatura hispanoamericana: del modernismo a nuestros días. Madrid: Espasa-Calpe.

MARCO, Joaquín y Jordi Gracia (2004). La llegada de los bárbaros. La recepción de la literatura hispanoamericana en España, 1960-1981. Barcelona: Edhasa. 
Neruda, Pablo (1999). Obras Completas (De Crepusculario a Las uvas y el viento). Tomo I. Barcelona: Círculo de Lectores/ Galaxia Gutemberg.

Rama, Ángel (1981). "El boom en perspectiva”. Más allá del boom: literatura y mercado. México: Marcha editores: 51-110.

USLAR PIETRI, Arturo (1986). Godos, insurgentes y visionarios. Barcelona: Seix-Barral.

Vallejo, César (1987). Poemas humanos. España, aparta de mí este cáliz. Francisco Martínez García, editor. Madrid: Castalia.

VignALE, P. J. y César TiEMPO. “Algunas páginas de la Exposición de la actual poesía argentina”. Martín Fierro $39(28 / 03 / 1927)$.

Villena, Luis Antonio de (1986). “Prólogo”. José Emilio Pacheco. Poesía. Madrid: Júcar: 7-90.

VIÑAS, David (1981). "Pareceres y digresiones en torno a la nueva narrativa hispanoamericana". Más allá del boom: literatura y mercado. México: Marcha editores:13-50. 


\title{
¿HABRÁ MOROS EN LA COSTA? \\ LA PRODUCGIÓN GULTURAL CENTRO- AMERICANA LEÍDA DESDE ESPAÑA
}

Would there be Moors on the Coast? Central American Cultural Production as Read from Spain

\author{
ARTURO ARIAS \\ UNIVERSIDAD DE CALIFORNIA, MERCED (EEUU) aarias26@ucmerced.edu
}

Ocupa la cátedra John D. and Catherine T. MacArthur Foundation de Humanidades en la Universidad de California, Merced. Sus libros académicos incluyen Recuperando las huellas perdidas: El surgimiento de narrativas contemporáneas en Abya Yala (2015). Taking Their Word: Literature and the Signs of Central America. La controversia en torno a Rigoberta Menchú (2001). Mulata de tal de Miguel Ángel Asturias: Edición Crítica (2001). La Identidad de la Palabra: Narrativa Guatemalteca a la Luz del Siglo Veinte (1998). Gestos Ceremoniales: Narrativa Centroamericana 1960 -1990 (1998), e Ideología, Literatura y Sociedad Durante la Revolución Guatemalteca 1944 - 1954 (1980; premio Casa de las Américas de ensayo 1979).

RECIBIDO: 16 DE ENERO DE 2017

ACEPTADO: 14 DE MAYO DE 2017

RESUMEN: La literatura centroamericana hizo su aparición en la península española cuando Rubén Darío viajo hacia Madrid en 1892. París y Madrid se convirtieron en las metrópolis culturales de Centroamérica a partir de esa fecha. Sin embargo, su pertenencia a la región no fue reconocida como tal. En España esta producción fue leída desde una perspectiva hispano-céntrica que le fue útil a la península para resolver sus propias contradicciones de legitimación en el seno de Europa. En consecuencia, los escritores centroamericanos que publican con éxito en la península no pueden ser centroamericanos y cosmopolitas a la vez. En España se transforman en "hispanoamericanos." Lo anterior elide su centro-americanidad, impidiendo la validación de sus pertenencias afectivas regionales o nacionales a un espacio específico.

Palabras ClaVE: Literatura, Modernismo, Darío, Hispanoamérica, istmo, cosmopolitismo, Centroamericanidad, marginalidad.
ABstract: Central American literature first appeared in the Spanish peninsula when Rubén Darío traveled to Madrid in 1892. Paris and Madrid became since then the Central American cultural metropoles. However, their belongingness to the region was not recognized as such. In Spain, this production was read from a Hispano-centric perspective that was useful for the peninsula to solve its own issues of legitimization within Europe. As a result, Central American writers that publish successfully in Spain cannot be Central American and Cosmopolitan at the same time. In Spain, they become "Hispanic Americans". This elides their Central Americanness, preventing the validation of their regional or national affective belonging to a specific space.

KEYWORDS: Literature, Modernism, Darío, Hispanic America, isthmus, Cosmopolitism, Central Americanity, marginality.

Arias, Arturo.

“¿Habrá moros en la costa? La producción cultural centroamericana leída desde España”. Kamchatka. Revista de análisis cultural 9 (Julio 2017): 83-101 .

DOI: 10.7203/KAM. 9.9548 ISSN: 2340-1869 
En Esto no es una pipa, Saturno (2003), el escritor guatemalteco Eduardo Halfon (1971- ) retoma una serie de residencias de conocidos artistas guatemaltecos en el París de principios del siglo veinte. La primera viñeta relata el suicidio del pintor Carlos Valenti y cómo su compañero de estudio, Carlos Mérida, es interrogado por la policía francesa por sospechoso:

Dígame una cosa, Mérida, su amigo, ¿por lo menos era un buen pintor? Y hoy, tantos años más tarde, mi respuesta mantiene aún toda su validez. Carlos Valenti, contesté, es el más grande pintor de Guatemala. (22)

Siguen 14 capítulos en donde aparecen estos amigos obsesionados por el suicidio de Valenti. Nos enteramos del escultor Rafael Yela Günter, del músico Ricardo Castillo, del pintor Rafael Rodríguez Padilla. En la ficción de Halfon se recrean las acciones y pensamientos de Rafael Arévalo Martínez, Agustín Iriarte, Carlos Mérida, Eduardo De La Riva y otros más, interactuando con conocidos artistas y escritores residentes en París. Fuera de ser todos ellos guatemaltecos, amigos entre sí y destacados creadores cuyos cuadros cuelgan hoy en museos del mundo, sus partituras aparecen en los programas de orquestas sinfónicas, o bien son reconocidos autores, tienen en común tan solo su residencia como jóvenes aprendices del oficio en París. Desde luego en la "ciudad luz" no son reconocidos como jóvenes promesas, salvo por sus maestros europeos. Aparecen como extranjeros sospechosos de crímenes o fechorías: son el fantasma del extranjero oscuro e indeseable, recién salidos de un incomprendido mundo salvaje y exótico de nombre impronunciable.

Este ejemplo no lo cito para problematizar la obra de Halfon, la cual merecería capítulo aparte, sino para marcar su representación como síntoma: París y Madrid se convirtieron en las metrópolis culturales de Centroamérica hacia la última década del siglo diecinueve. Sin embargo, su transatlanticidad postcolonial no hizo la producción cultural del istmo ni más visible ni más reconocida. Transformó de manera categórica los rasgos formales de su producción, pero no por ello visibilizó ni generó reconocimiento para sus ubicaciones identitarias en la memoria cultural latinoamericana o europea.

La literatura centroamericana hizo su aparición en la península española cuando Rubén Darío viajo hacia Madrid en 1892 para la celebración del cuarto centenario del primer viaje de Colón a las Américas, y ha continuado su errática relación transatlántica hasta el presente con la recepción de obras tan variadas como las de Miguel Angel Asturias, Augusto Monterroso, Claribel Alegría, Rigoberta Menchú, Gioconda Belli o Sergio Ramírez a principios del veintiuno.

Pese a ello, en la península española existe una escasa conciencia de los rasgos que podrían diferenciar al istmo centroamericano del resto de América Hispánica. Es más, existe incluso escasísima conciencia de que los autores mencionados -y otros que han comparecido en el horizonte literario peninsular en los últimos cien años- son efectivamente centroamericanos, y no "latinoamericanos" (cuando no "sudacas") en la acepción más amplia de un tropo que simultáneamente invisibiliza su "cintura," en el decir de Neruda, y posibilita un corpus literario 
continental. En el presente artículo argumento que, con diferentes y contradictorias variantes, la perspectiva epistémica de la producción literaria centroamericana favoreció desde siempre una exploración (por contradictoria que fuera) de la problemática indígena, de la unión regional, y/o de otros fenómenos que diferenciaban al istmo del resto del continente, como mecanismo intuitivo de una diferencia colonial más sentida que comprendida o articulada críticamente. Sin embargo, la lectura de la misma desde la moderna perspectiva eurocéntrica favorecida por la península para resolver sus propias contradicciones de legitimación en el seno de Europa, ha elidido dicho posicionamiento y, por extensión, transformado la posible decodificación heterogénea de su lectura. El artículo intenta por lo tanto una redefinición de las consecuencias epistémicas de la recepción de dicha textualidad a partir de dos puntos nodales de índole temporal: principios del siglo veinte y principios del veintiuno.

\section{¿MODERNIDADES CENTROAMERICANAS, MODERNIDADES OCCIDENTALES?}

De acuerdo con Perry Anderson en The Origins of Postmodernity, el concepto de "modernismo" nació en el encuentro que Darío sostuvo en Lima con Ricardo Palma en 1888, publicado posteriormente en una revista guatemalteca. Una cronología de este encuentro ha sido publicada por Juan E. De Castro (2007), argumentando que el encuentro en cuestión representó dos enfoques diferentes en torno a la literatura. Palma aparece vinculado a "la reinterpretación y extensión del legado literario y cultural colonial” y Darío "a la incorporación de la literatura de la región a lo que Pascale Casanova ha llamado la república mundial de las letras, caracterizado por el cosmopolitanismo y la innovación continua” (2007: 49). El propio De Castro ironiza la posición de Anderson, quien afirmó que le debemos la acuñación del nombre del movimiento estético a un poeta nicaragüense publicando en una revista guatemalteca sobre un encuentro literario en una ciudad calificada por el propio Anderson como "una periferia distante... del sistema cultural de la época" (3; mi traducción, citado en De Castro, 48). De Castro afirma que en el artículo en cuestión, Darío vincula su movimiento al conjunto de Hispanoamérica en vez de asociarlo a un país específico. Agrega, más adelante, que Darío fue el primero en emplear una localidad periférica para la libre incorporación y modificación de las literaturas del centro (2007: 58). A De Castro le interesa el encuentro entre Darío y Palma para teorizar el inicio de una producción literaria postcolonial en el continente. A mí me interesa para problematizar las relaciones transatlánticas entre el istmo centroamericano y Europa, que obligan al autor centroamericano a elidir la especificidad de sus espacios etnoterritoriales para que puedan reconocerle su cosmopolitismo en Europa.

Ese complejo de sujeto periférico que Darío manifestó con claridad frente a lo español, y que pasa por una fetichización de la producción literaria francesa, proviene, a mi modo de ver, de su explícita centroamericanidad. Darío ostenta la misma actitud en Chile, durante la publicación de $A z u l$ (1888). El "galicismo mental” del cual Juan Valera acusa a Darío en su reseña de dicho libro es, a mi modo de ver, producto del mismo síntoma.

Sin embargo, antes de ser "cosmopolita," Darío fue enérgico militante de la unidad 
centroamericana, de acuerdo a los parámetros liberales de la época. Como señala Julia Medina, ${ }^{1}$ Darío "fue definido en su contexto local por los conflictos familiares que lo llevaron a la casa de sus parientes pudientes en la ciudad de León” (2005: 128). Agrega que su vocación poética "respondía a la demanda cultural de esta clase dirigente en el proceso de consolidar el proyecto nacional y universalizar esta experiencia.” Un poco más adelante señala:

Alineándose teóricamente con los libertadores, Darío profesa el panamericanismo a nivel local con el unionismo centroamericano. Consistente con su esmero creador, la proyección de estos espacios utópicos ofrece una alternativa imaginaria e inadvertida a los fracasos políticos del continente y sobre todo los de la región centroamericana y de Nicaragua. Al proponer un ideal estético que universaliza la expresión continental, el poeta encarna y denuncia la imposibilidad de lograr la modernidad política en Centro y Latinoamérica (Medina, 2005: 129).

Darío mismo comentó su salida de Nicaragua como una "huída" que explica como el resultado de encontrarse "asqueado y espantado de la vida social y política que mantuviera a mi país original en lamentable estado de civilización embrionaria" ${ }^{2}$. De allí en adelante mantendrá una tensión dinámica entre su identidad local y sus aspiraciones de inclusión postcoloniales, trauma típico, según la teoría lacaniana, de subjetividades divididas e incapaces de sobreponerse a la alienación de la marginalidad, que buscan evadir la abyección de sentirse sujetos periféricos o marginales. En el caso centroamericano, por residir en la "marginalidad de la marginalidad.”3

El trauma de Darío es generado por la imposibilidad de la condición centroamericana, cuyos patrones se reproducen entonces como ahora. Medina afirma que "el espacio ístmico de América Central, como encrucijada geográfica, en cierta medida, configura a Darío como profesional...," y le atribuye a este fenómeno su impulso estético. Sin contradecirla, yo veo en el mismo su voluntad de mimetizarse en sujeto cosmopolita, fetiche y desafío que se desprende del desamparo de la traumática marginalidad que lo marca y que operaría como mecanismo negativo históricamente persistente y multifacético, capaz de retenerlo en un espacio local que limitaría o incluso excluiría la difusión de sus prácticas escriturales, al reproducir patrones de invisibilidad en los centros hegemónicos de decisión cultural.

En efecto, si revisamos sus datos biográficos, confirmamos que el joven Darío se autodefinió como unionista, por vínculos familiares con un tío que combatió por el unionismo centroamericano. Pero lo hace ya de vuelta en Centroamérica, de manera que la fallida reunificación centroamericana es

\footnotetext{
1 “Vestíbulos del hombre público: Prólogos ‘desconocidos’ de Rubén Darío.” En su fascinante artículo, Medina estudia cuatro prólogos de Darío. El primero es la introducción a un folleto político (1890); el segundo, un prólogo a Historias de tres años de José Hernández Somoza (1893); el tercero,"Fotograbado: Prólogo a Tradiciones Peruanas de Ricardo Palma" (1893); y el cuarto, un prefacio escrito para una traducción de "El cuervo" de Edgar Allan Poe (19??). Medina se plantea este estudio porque en el primero, Darío articula su relación con la política regional centroamericana. En el segundo, refleja la inserción del escritor en su contexto político nacional. En el tercero, se posiciona dentro de la polííca cultural latinoamericana. Finalmente, en el cuarto se plantea en relación a la literatura estadounidense y su traducción e impacto en Hispanoamérica.

${ }^{2}$ La Nación (1913). Recopilado en Historia de mis libros.

${ }^{3}$ Ver mi teorización a ese respecto en Arias (2007).
} 
articulada discursivamente como la justificación de su desarraigo y auto-exilio. Cabe entonces la pregunta: ¿habrían cambiado las cosas para Darío de haberse consumado el triunfo del unionismo? Dadas las estructuras que unen semánticamente de manera sutil pero omnipresente los términos "Centroamérica," “atraso" y "marginalidad," lo más seguro es que no, aun si hubiera podido vivir un período de euforia post-triunfalista de manera análoga a la experiencia de Sergio Ramírez con el sandinismo (1979-90). Pero, al igual que éste último, lo más probable es que terminara como en efecto lo hizo: reconvirtiéndose en autoridad cultural cosmopolita, para así ocultar miméticamente el fantasma de la marginalidad centroamericana, la pesadilla de la cual trataba de despertar. Para Darío, la transición de sujeto centroamericano a sujeto cosmopolita no fue ni límpida ni simple. Medina nos recuerda que al regresar a Nicaragua en 1884,

Darío asumió el cargo de Editor de La Unión Centroamericana. Después de haber publicado Azul en 1889 vuelve a reafirmar esta afiliación como autoridad, mediante su dirección del periódico La Unión, órgano de la unificación ístmica (2005: 133).

Esta misma fuente, y la autobiografía del propio Darío, indican que en esos esfuerzos el autor nicaragüense forjó una comunidad intelectual ístmica que luego le sirvió de modelo para una continental y, ultimadamente, transatlántica, sin renunciar a las redes iniciales. Aun cuando el Darío residente en Europa se tratara de tú a tú con figuras literarias peninsulares, no perdió sus contactos con los intelectuales centroamericanos.

Darío no es entonces, como ha querido verlo la historiografía literaria continental, una figura "apolítica," desligada de su geopolítica local, dedicado tan sólo a hacer arte por el arte. Por el contrario, tiene un arraigo geopolítico y una causa a la cual dedica buena parte de su energía por medio del periodismo: la unión centroamericana.

Sin embargo, esos mismos gestos le producen invisibilidad simbólica en los centros cosmopolitas y en los centros postcoloniales de decisión cultural hemisférica (La Habana, México, Santiago, Buenos Aires). En un primer momento prioriza su militancia unionista por sobre su producción literaria. Pero esto cambió después de su visita inicial a Madrid en 1892 -pasando por La Habana donde entabló relación con Julián del Casal (a raíz de cuya experiencia las identidades nacionales y sexuales "quedan fuera de foco” según Francisco Morán (2006), quien se interesa más por el "pánico homosexual” de Darío pero quien agrega que en este contexto, y a raíz de su dificultad por digerir lo queer, Darío problematizó a su vez lo nacional como "apariciones-esto es, imprevisibles desplazamientos fantasmáticos,” 2006, 484) - y luego de su calurosa acogida en la capital española por José Zorrilla, Juan Valera, Emilia Pardo Bazán y Marcelino Menéndez Pelayo entre otros.

El mencionado viaje fue seguido casi de inmediato por su vuelta a San Salvador a causa de la muerte de su primera mujer. Tanto la temida intimidad con Casal, la acogida madrileña como la muerte que le siguió de inmediato, obligándolo a reconfrontar el sórdido ambiente salvadoreño de su adolescencia, se adhirieron y se consolidaron en su mente como nódulos referenciales a nivel emocional en su horizonte de posibilidades, en una especie de mélange traumático. Esto lo llevará a 
reprimir públicamente ese pasado militante al embarcarse en viajes y obras subsiguientes, y a permitir que su nacionalismo se evapore gradualmente. No queremos aquí adscribirnos a una postulación teórica de un "trauma originario," noción ya problematizada por Butler debido a sus presupuestos heteronormativos (Butler, en Osborne y Segal, 1993:37). Pero podríamos ver la situación de Darío como una necesidad emocional de abstraerse de su topografía identitaria, una respuesta a la centroamericanidad que es a su vez traumática en su intensidad emocional como mecanismo discursivo que articula la melancolía del luto incompleto.

De esta manera, la explicación de su subjetividad estaría implicada en los requerimientos miméticos de la época para ganar visibilidad, y para evitar ser patologizado por su topología originaria. Recordemos que en un espacio de pocos meses se vio obligado a casarse con Rosario Murillo, pero se fugó de esa nueva reactividad sublime viajando a Nueva York donde le presentan a José Martí, y luego a París, donde disfruta de la bohemia con el guatemalteco Enrique Gómez Carrillo y conoce a Jean Moreás y su ídolo Paul Verlaine, antes de dirigirse a Buenos Aires, donde vivirá los siguientes años. ${ }^{4}$ Entre la salida originaria a Madrid y su posterior establecimiento en Buenos Aires apenas habrá pasado un año. Pero ese año incluyó no sólo la construcción de redes transnacionales sino dos viajes transatlánticos a ciudades previamente fetichizadas en su imaginación. A partir de entonces París y Madrid dominarán su imaginario.

La práctica le indicó a Darío que las identidades nacionales tan sólo conducían a la invisibilidad cuando se provenía de la marginalidad de la marginalidad. Entonces, obsedido por el poder interpretativo en un sentido que hoy llamaríamos "transatlántico," Darío decide reconstituirse tout court como el portavoz de la literatura del continente en España. Abandona sus raíces localistas y protege su endeblez emocional con la retórica del arte por el arte, aunque permaneció sujeto a las fracturas y desintegración de su propia negatividad, articulando su producción como formas de melancolía incapaces de resistir la sentimentalidad, empapadas de poder afectivo. Como dice Medina, "en Nicaragua y en el contexto centroamericano, la articulación de este proyecto artístico purista ha demostrado requerir una postura política ambigua” (2005: 134).

Aquí podríamos agregar que en el caso de Darío, ciertos supuestos sobre la estructura formal de su poesía son ellos mismos función de una coyuntura histórica particular. Cada vez más inseguro acerca de quién es y hacia dónde va, Darío proyecta ese sentido de fragmentación hacia su topografía marginal, introduciendo lo que Rama ha denominado un "isocronismo cultural," o sea, la obsesión de integrarse a la trayectoria histórica de una modernidad anhelada pero aun desconocida en un registro simbólico que abarca y que rebasa lo literario (Rama, 1970). Lo anterior va a generar la paradoja del sujeto postcolonial capaz de revolucionar la vieja cultura de la metrópoli, ya que tuvo que absorberla primero como condición de ser pensado como sujeto para acceder al espacio intelectual. El mensaje que el sujeto postcolonial le devuelve a la metrópoli al retraducirles su propia cultura es entonces el

\footnotetext{
${ }^{4}$ Aunque no es nuestra línea de trabajo en el presente artículo, es importante mencionar el análisis de Morán al respecto del pánico homosexual que le produjo a Darío conocer a Verlaine, rodeado de sus jóvenes sátiros y priorizando sus inclinaciones sexuales por encima de su "gloria" poética.
} 
de que ellos padecen de un borrón cultural (erasure), al haber perdido sus rasgos identitarios, aquellos que la postcolonialidad tiene mejor absorbidos que ellos mismos. Darío reconoce su fascinación por él mismo como la exotización de la otredad, del sujeto "proveniente de ultramar." Sólo entonces puede convertirse en el ícono que desde hace casi 100 años, y aun hoy, es definido de esta manera:

Rubén Darío no sólo renovó la lengua castellana, sino que incorporó también la cultura española y americana al humanismo occidental. La fuerza de Darío en el mundo hispánico trasciende los términos en que estaba planteado el debate entre la visón europea de España y la visión española de Europa; entre un españolismo que pretende salvar a España incorporándola al destino de Europa y un hispanismo que trata de protegerla de la Europa liberal y democrática reviviendo una cristiandad medieval al estilo de las ideas del imperio ecuménico de Carlos V (Serrano Caldera, 2009).

En esta misma lógica, Jorge Eduardo Arellano nos recuerda que, recientemente, Pere Gimferrer incluso llegó a relacionarlo con Dante o Shakespeare por su

don a la vez de abarcamiento universal y de síntesis suprema -enciclopedia y microcosmosque, en algún verso memorable, podrá cifrar todo lo visible e invisible. Como Shakespeare o Dante, Rubén Darío es muchos hombres, y muchos poetas comprimidos en la tersa y tensa unidad final del verso (2006: 126).

Las implicaciones no problematizadas, sin embargo, son las que referencian el hecho de que para poder realizar esta metamorfosis, Darío tuvo qué borrar su topografía centroamericana, hacerla invisible. Lo local es el sacrificio que posibilita su inserción cosmopolita. Los debates centroamericanistas como espacios culturalmente fluidos donde un vasto conjunto de mecanismos discursivos construyen y deconstruyen cuestiones representacionales que definen y redefinen las prioridades, identidades y proyectos culturales de un espacio particularmente configurado, desaparecen de su horizonte simbólico referencial que articulaba raíces identitarias, aun si estas fueran un espejismo que reflejara sólo deslices de significados.

Como resultado de lo anterior, en España pasa a ser leído como poeta "hispanoamericano" y no como autor centroamericano. Esta homogeneización funde su identidad en un debate netamente español. Darío se transforma en un tropo para el debate de la generación del 98 acerca de la inserción de España en Europa, en oposición a la corriente aislacionista conservadora que prefiere la recuperación del feudalismo español y articula lo americano como escenario reificado. A Darío le interesa superar ambas posiciones. Para hacerlo tiene que autorepresentarse como el portavoz de la modernidad cultural hispana. Renuncia a su centroamericanidad en aras de la auto-reificación como ícono hispanoamericano sin inserción o pertenencia local específica. Este doble guiño explica por qué el Modernismo aparece como una reacción antimoderna pero dentro de la modernidad. Pero también por qué la región de origen del poeta se convierte en el espectro de un accidente biográfico sin trascendencia. El provincianismo español le evoca a Darío el trauma del provincianismo centroamericano marginal, razón por la cual intenta consolidar una actitud que trascienda ambos por 
medio del "galicismo mental" previamente mencionado5. París, como espacio imaginario y horizonte de expectativas no es ni la provincia española ni la centroamericana, fusionadas ambas para él en la obsesiva invisibilidad marginal, en cuyo espacio biogeográfico no quiere reconocerse ni ser la metonímica disjectī membra poètae de una región histórica singular que representa un particular espacio cultural. Esto es por tanto la clave para abrazar su proyecto epistémico, configurado por el cosmopolitismo de la modernidad.

El suyo es un gesto típicamente postcolonial: fusionar lo cosmopolita con lo provinciano y lo marginal, sin reconocer que esto último conforma parte de su imaginario. Al invisibilizarlo él mismo, estos rasgos que se inician en las raíces de su tradición y que configuran su identidad subjetiva quedan invisibilizados en una residualidad abyecta. Incluso sus posteriores intervenciones políticas, tales como la "Oda a Roosevelt" (1905), aparecen desligadas de cualquier expresión localista. Es una denuncia "hemisférica." De hecho, al conmemorarse recientemente el centenario de Cantos de vida y esperanza, la crítica Juana Martínez Gómez de la Universidad Complutense de Madrid afirma que el texto en cuestión está caracterizado “por la marcada españolidad de sus páginas" (11). Es ciertamente un texto estrechamente ligado a las afirmaciones de unión de España e Hispanoamérica. El momento transatlántico de Darío comienza en 1900, cuando afirma: "ha llegado el momento en que los vínculos morales se afiancen por otros más vitales y prácticos; y luego, en otro terreno, quizás no sería mala idea la de un panhispanoamericanismo por emergencias más que probables en el futuro" (Darío, 1977) en una crónica publicada en La Nación de Buenos Aires el 25 de abril de 1900. Agrega Martínez Gómez acerca de Cantos de vida y esperanza:

Fue, además, el primer poemario publicado por Rubén Darío en España en una época en la que todavía no se habían publicado, como sí ocurre ahora, muchos libros de autores hispanoamericanos y lo que dominaba en el ambiente literario español era el desconocimiento de la literatura escrita en el continente americano. El mismo Darío, durante su estancia española como corresponsal de La Nación de Buenos Aires entre 1898 y 1900, daba cuenta en sus artículos del "desconocimiento desastroso" entre intelectuales de aquí y de allá, a excepción, entre los españoles, de Juan Valera y Emilio Castelar (2006).

De esta manera, podemos ver que la transatlanticidad y la colonialidad de Darío van de la mano. Es en esta lógica que Susana Zanetti analiza los dos nocturnos de Cantos de vida y esperanza para concluir que son

...como puntos de llegada de un itinerario, para intentar nuevos registros y modulaciones de su voz, vuelta ahora a... las circunstancias políticas a menudo amenazantes, que el Darío atlántico busca acallar repensando la pertenencia y la identidad cultural... (2006: 27).

Los trazos de su imaginario geopolítico aun son percibidos fantasmáticamente por Zanetti. Pero un crítico español como Jorge Rodríguez Padrón apenas ve en ellos “confrontación de dos

\footnotetext{
${ }^{5}$. Algo de esto articula Bruno Bosteels en "Untiming Decadence in Latin America." Pese a ello, Medina argumenta que Darío "propone una modernización estética para compensar la imposibilidad de una superación política y social en la región” (2005: 136).
} 
tiempos diferentes... la poesía como tentativa del ser y del decir” (2006: 55) y las únicas notas comparativas en su lectura son con Sor Juana Inés de la Cruz, López Velarde, Lugones, Vallejo, Lezama Lima, Gorostiza y, especialmente, Borges. Ni por asomo aparece referencia alguna a la centroamericanidad. Sólo el temor de que se confunda revolución poética ("ruego al lector: lee revolución aquí con su valor de movimiento de las órbitas estelares” 2006: 63) con revolución política.

Parecería que la transatlanticidad apunta a la necesidad de borrar la marginalidad de la marginalidad de su horizonte conceptual como topos. En realidad, es el sentido de no-existencia, la deshumanización e inferiorización, las prácticas estructurales e institucionales de racialización y subalternización que siguen posicionando a los sujetos centroamericanos y a sus conocimientos, lógicas y sistemas de vida desde una mirada que favorece la perspectiva eurocéntrica, lo que los obliga a reconfigurar sus identidades como sujetos transatlánticos carentes de raíces locales. Por ello la colonialidad implica la voluntad de inscribirse dentro del patrón de poder eurocéntrico como sujeto apátrida. Es una matriz que se fundamenta en el uso y en la articulación entre sí del trabajo, conocimiento, autoridad y relaciones intersubjetivas a través del capitalismo como relación económica y social, y la idea de raza como patrón de dominación y subordinación; es decir la colonialidad del poder que explica Quijano. Por ello, la percepción española de Darío para los no profesionales de las letras suele ser la de un autor hispano accidentalmente nacido en un país poco recordable, pero que gracias a su residencia en París y en Buenos Aires, contribuyó a configurar la generación del 98.

\section{POST-IDENTIDADES POST-NACIONALES}

Saltemos un siglo. A partir de 1990, las fuerzas globalizadoras impactaron Centroamérica de manera marcada, introduciendo un nuevo modelo transnacional de economía y sociedad, como ya lo señaló William I. Robinson. El proceso globalizador no era unidireccional desde luego. Era un movimiento dialógico que tensionaba las prácticas locales, nacionales y globales, en las cuales la resistencia y/o modificaciones provenían de la misma heterogeneidad que marcaba las condiciones locales. Estas últimas nunca han sido pasivamente afectadas por la globalización. También la modifican y la adaptan a sus condiciones sui generis. Sin embargo, la debilidad innata de las economías centroamericanas, constreñida aun más por una década de guerras civiles, facilitó imposiciones externas que modificaron las maneras por medio de las cuales se producían y circulaban las culturas locales.

Quizás lo más evidente fue la aparición de mercados literarios regionales que ya no se conformaban a los viejos modelos nacionales. A la vez, estos últimos desaparecieron con una rapidez asombrosa (Robinson, 2003). La Editorial Nueva Nicaragua, creada por los sandinistas, se privatizó y pronto cambió de nombre. La Editorial Universitaria Centroamericana (EDUCA), creada en 1968 por los Consejos Superiores de las universidades nacionales del istmo, se privatizó a su vez y cambió de orientación. Las escasas editoriales universitarias nacionales que sobrevivieron apenas si pudieron 
mantener un fragmento de su anterior producción. Esto las expuso a presiones indebidas por parte de las nuevas autoridades universitarias, las cuales tuvieron que trabajar con austeridad inaudita, cuando no se apoyaron en políticas neoliberales que desvirtuó sus proyectos editoriales. El mercado del libro pasó a ser controlado casi en su totalidad por transnacionales españolas, las cuales a su vez formaban parte de corporaciones aún mayores de origen alemán o americano, pero implementando viejos mecanismos de dominación colonial en el globalizado mercado del libro (Robbins, 2003).

Los jóvenes administradores españoles, todos principiantes, y todos licenciados en finanzas o business sin conocimiento alguno de la literatura (y menos aun de la centroamericana) soñaban con graduarse exitosamente de Guatemala o de Costa Rica para pasar luego a México o la Argentina en vías de un soñado retorno a la casa matriz en Madrid o Barcelona. Además, sus funciones principales consistían en garantizar que se publicaran sobre todo materiales escolares por su mayor mercado, que los textos literarios publicados en Centroamérica no salieran de la región (ni siquiera a los mercados mexicanos o colombianos) y que las empresas generaran ganancias. Este patrón se convirtió en la nueva regla de juego, cediéndole apenas un mínimo espacio a pequeñísimas editoriales privadas que irrumpieron a lo largo de esta década.

Las transformaciones de la producción del libro y la emergencia de mercados del mismo, por mínimos que fueran, revolucionaron el desdén tradicional de los autores centroamericanos con los lectores, rasgo que aun los enmarcaba dentro de moldes románticos o vanguardistas hasta esa fecha. El mercado también se encargó de frenar las inclinaciones utópicas, mesiánicas o revolucionarias y transformó la propia auto-percepción de los escritores, quienes en el período inmediatamente anterior se consideraron voces proféticas que hablaban en el nombre de las masas. La falacia de mantener desde una perspectiva de izquierda el aura del letrado hablando por el sujeto subalterno en una edad post-aurática ha sido ya problematizada suficientemente por Beverley, Moreiras y Avelar, entre otros. Desde una perspectiva crítica, dicha concepción no tomaba en cuenta la diferencia colonial de la cual hablan Dussel o Mignolo.

Dentro de ese vasto contexto de rápidas transformaciones a nivel regional en los noventa, e incrustada dentro de problemáticas más amplias tales como el final de la guerra fría y el triunfo de la globalización neoliberal, la textualidad narrativa se transformó a su vez, registrando estas sutiles alteraciones como sólo lo hubiera podido hacer un sismógrafo muy fino. El estudio de las narrativas de este período debería posibilitarle a los críticos explorar las secuelas de las cataclísmicas guerras de la región, así como las transiciones que tuvieron lugar en el sedimento simbólico, el espacio no consciente de sus culturas, de manera análoga a como Jean Franco narra el ascenso y caída de la ciudad letrada ${ }^{6}$.

En Mil y Una Muertes de Sergio Ramírez, publicada en 2004, la narración tiene elementos

\footnotetext{
${ }^{6}$ Franco visualiza un ocaso en la importancia de la literatura luego del final de la guerra fría. Después del colapso de la utopía, según ella, queda poco de importancia que pueda ser enmarcado en la literatura, ya que ahora el mercado es el único barómetro para implementar criterios acerca de lo que se publica (The Decline \& Fall of the Lettered City, 274). En términos de Foucault, toda la literatura queda “fuera de la verdad"después del final de la guerra fría.
} 
multi-locales que empujan imaginariamente la representatividad hacia una topografía más amplia, y a sus personajes hacia una subjetividad post-nacional. Conforme Castellón, el fotógrafo nicaragüense que constituye el personaje principal, se mueve por Francia, Mallorca o Polonia, las funciones heterotópicas son reconocibles, pero no se limitan al espacio cronotópico primordialista de la Nicaragua somozista/sandinista. De manera similar, las últimas novelas de Gioconda Belli, El pergamino de la seducción (2005) y El infinito en la palma de la mano (2008) tratan del romance de Juana la Loca con Felipe el Hermoso, desde la perspectiva subjetiva de la reina, en el primer caso, y de los orígenes de Adán y Eva en el segundo. Belli puede representar las intrigas de palacio y las conspiraciones políticas como responsables de categorizar discursivamente como "locura" los celos o depresiones de la reina, recrear una Juana erótica inmersa en un melodrama de tragedia sicológica, o bien fabular sobre la vida de Adán y Eva en el paraíso empleando datos fantásticos de los Midrás judaicos, pero reinscribe el espacio de lo afectivo fuera de las asociaciones que en el período guerrillerista 1960-1990, fijaron la relación entre identidad, cultura y nacionalidad. Del ángulo que se le quiera ver, estamos ya bastante lejos de la textura cotidiana representada en La mujer habitada (1988), una narrativa que ataba las estructuras de lo afectivo al espacio, tiempo, memoria e ideología en el proceso de narrar la concientización de una mujer burguesa encuadrada en el ámbito revolucionario nicaragüense, que se convierte en militante sandinista y posteriormente en mártir de la causa luego de caer en acción. Dicho de otra manera, se ha invisibilizado lo nacional y puesto cualquier identidad en entredicho.

Esta mención emblemática de ciertas topografías de la novelística centroamericana contemporánea nos permiten visualizar que durante buena parte de la segunda mitad del siglo veinte, las representaciones identitarias problematizadas en las textualidades del istmo estuvieron atadas a la constitución de lo nacional y a la creación -o expectativas utópicas de creación- de un estado moderno, fijando la representatividad de los sujetos en un estrecho modelo que posicionaba todo aspecto identitario dentro de parámetros unívocos de nacionalismo utopista a los cuales de manera general se llegaba, al menos imaginariamente, por la vía guerrillera.

Sin embargo, a partir de finales de los años ochenta, donde se combina en la región el inicio de la era globalizada con el fin del período guerrillerista, tanto la representación topográfica como la de las identidades textuales se transforma. De pronto, los sujetos literarios comienzan a residir en heterogéneos espacios diferenciados de su atribuida nacionalidad de origen, y se reinventan a sí mismos como individuos de la más variada índole que al intentar forjar comunidades translocales, desnaturalizan los viejos discursos nacionalistas de autenticidad, como sucede con el fotógrafo Castellón en la novela de Ramírez o bien la reina Juana de España y esa pareja sin apellidos, Adán y Eva, en las de Belli. En estos textos, sujetos que antes estaban enraizados en representaciones locales simbólicas que connotaban nacionalidad, ahora aparecen insertos en disímiles y heterogéneos espacios donde intentan reciclar los fragmentos remanentes de su memoria cultural para reconfigurar algún nuevo tipo de identidad post-nacional.

Dijimos ya que en la región centroamericana una de las consecuencias colaterales de las fuerzas 
globalizadoras fue la creación de mercados literarios regionales dominados por corporaciones editoriales globalizadas que rompieron los viejos esquemas nacionales (y nacionalistas) de producción cultural. Su irrupción desplazó la posibilidad de circular localismos imaginarios como dimensión de la literariedad. La dimensión global de las editoriales que coparon el mercado regional subrayó la necesidad de disciplinar las memorias o adherencias afectivas que caracterizan las subjetividades locales dentro de un espacio translocal, en el cual lo territorial fue ordenado, normativizado y reproducido como legible dentro de los espacios regulados por el nuevo orden transnacional.

Como resultado de lo anterior, ese papel transgresivo que jugó la textualidad durante el período guerrillerista cedió su lugar a una producción que más amoldada a los parámetros del entretenimiento transnacional. En narrativas como las de Ramírez o Belli posteriores a 1990, es posible observar cómo los sujetos otrora enraizados en representaciones simbólicas locales reciclan su memoria cultural para reconfigurar identidades translocales. Como ya señaló Abril Trigo, los espacios afectivos conducen a una "memoria emocional," fenómeno que forma parte del proceso de constitución de la imaginación social. Es no sólo una reconstitución de la memoria y del deseo, sino una vía multi-direccional para articular respuestas reflexivas acerca de los acontecimientos del presente, a manera de construir un ethos alternativo (Trigo, 2008). Lo anterior es importante si consideramos que, actualmente, buena parte de la producción literaria centroamericana que circula y es consumida en números más altos, se da fuera de sus topografías regionales. Si la articulación de la memoria por medio de los elementos imaginario-simbólicos que conllevan a la escritura cumplió una función particular que enfocaba el espacio de lo nacional en el período anterior, en el presente período translocal el espacio ya no aparece como fijo, confinado dentro de parámetros nacionales, sino más bien como una serie de paisajes o topografías apiladas en la memoria del sujeto que cumple la función narrativa. Las fronteras ya no denotan la caída al vacío no-nacional, sino la entrada a nuevos espacios etno-territoriales que dinamiza la transformación del sujeto de la narración de uno nacional enclavado en la modernidad a uno transnacional que se reimagina a sí mismo interpretando el papel de sujeto post-nacional.

Posiblemente el mejor lugar para explorar este fenómeno complejo que forma parte de un conjunto de procesos mucho más amplios que trascienden lo centroamericano, sea en la producción narrativa de Sergio Ramírez. Al ganar el premio Alfaguara en 1998 con Margarita, está linda la mar, Ramírez se convirtió en el novelista centroamericano mejor conocido en el mundo hispanohablante. Una rápida mirada a Margarita, está linda la mar en efecto nos indica mucho de lo que cambió de un período a otro. La novela narra un extenso trecho de la historia nicaragüense, desde el día en que Rubén Darío vuelve a su patria en 1907 y le escribe un poema a Margarita Debayle en su abanico hasta el asesinato del dictador Anastasio Somoza García en 1956, casado para ese entonces con Salvadora Debayle, la hermana de Margarita.

Aunque el texto sigue de cerca los eventos históricos, la política ha quedado reducida a mero elemento de la trama, a diferencia de ¿̨e Dio Miedo la Sangre? (1977), que cubría un similar abanico histórico-desde 1930, cuando el coronel Catalino López fue emboscado en un cine por una columna 
del general Pedrón Altamirano, combatiente de Sandino, hasta 1961, cuando en un automóvil Bolívar lleva de vuelta a Nicaragua el cuerpo de su padre, el Indio Larios, y permite que el viento se lleve la correspondencia de éste último. Sin embargo, en la novela pre-revolucionaria, el accionar político transgresivo era el que proveía el momentum narrativo. De los trazos de su comunicabilidad afectiva surgía una hegemonía ideológica que interpelaba a los personajes (así como a los lectores) y los transformaba en sujetos identificados con la formación discursiva nombrada por la tensión somocismo/sandinismo como acto significante. El sujeto le confería así autoridad al imaginario nacional constituido por el vínculo con la lucha sandinista que rompía el proyecto de estado-nación somozista regulando la abyecta vida pública enmarcada por la dictadura. En consecuencia, la dimensión política del lenguaje discursivo llegaba a subvertir el proceso de lectura. El texto invitaba a romper el carácter normativo del estado, ubicándole al lector formas alternativas de sociabilidad y de reconstitución imaginaria de su comunidad, casi como si fueran rituales colectivos de lectura. Asimismo, este mismo accionar político evidenciaba que hasta los gestos más íntimos o privados, hasta los secretos mejor guardados, estaban expuestos al asedio continuo de la dictadura.

En Margarita, está linda la mar, por el contrario, pese a las preparaciones para el asesinato de Somoza narradas en forma de thriller, las cuales proveen la dinámica que mueve la trama, dominan discursivamente las soberanías móviles de los personajes como enunciadores concomitantes sometidos a transformaciones imprevisibles como resultado de su dialogismo textual. Todos están constituidos al margen de cualquier orden político-semántico. Mientras preparan el desenlace, conversan acerca de Darío como tropo del sujeto que se siente incómodo con su propia nicaragüeñidad e intenta huir por todos los medios de su país de origen. Dicha memoria activa y legitimiza la autoridad del imaginario social que forja las identidades y la complicidad de los conspiradores. Pese a que está a punto de ocurrir un asesinato político en la trama, la política misma no es sino trasfondo para el flujo evocativo del anecdotario dariano preñado de translocalidad, o bien de los haceres científicos y bohemios del sabio Debayle, en compañía de los poetas de la llamada "mesa maldita." Este proceso narrativo crea espacios que, pese a su naturaleza heterogénea, se diluyen en un horizonte espacial plano que anula la separación de casi 50 años entre los varios episodios de la trama. El discurso espacializado en torno a Darío, sus pulsiones y su cerebro, que amalgama ambas narrativas, le hace sombra a los detalles específicos de las implicaciones políticas del asesinato y niega el efecto político/transgresivo del mismo. La gesta de López Pérez se transforma en mero elemento anecdótico para hacer avanzar la trama, manteniendo un alto nivel de suspenso, pero sin problematizar sus implicaciones ni transgredir la normatividad contemporánea postnacional.

Agarrándose de su colorido reparto de personajes, el texto mitifica y fetichiza no sólo el pasado dariano con las contradicciones ya señaladas en este mismo artículo apenas suturadas, sino también el pasado somozista. Ambos sirven solo para reciclar la memoria cultural en torno a los orígenes de la nicaragüeñidad como identidad translocal que no sólo la desterritorializa, sino también la deshistorifica, paradójicamente en una novela histórica. Es como si los conspiradores, confrontando una fractura identitaria, sólo pudieran regenerarla por medio de la memoria cultural. Pese a que la subjetividad de los personajes y el período histórico en el cual maniobran no difiere mucho del de los 
personajes de ¿Te dio miedo la sangre?, en Margarita, está linda la mar su acción no conduce al lector idóneo a contemplar alternativas políticas para la reconstitución de la nación, como lo hacía la anterior novela, pese a que no era dogmática de ninguna manera: el texto nunca planteó la incorporación militante como solución discursiva. En la segunda novela, la reemergencia de las memorias culturales enterradas bajo la memoria histórica de la dictadura y el imaginario social que conlleva el presente temporal de la narrativa como experiencia cotidiana, estimulan los residuos lúdicos y libidinales no satisfechos por el anterior imaginario social.

Sin embargo, esos mismos aspectos distancian al lector del evento político que requeriría de una problematización radical enraizada en un imaginario utopista para motivar la entrega de los conspiradores. En Margarita, está linda la mar, estos actúan más bien como veteranos de guerra contando pícaras anécdotas personales como si ya hubiera pasado el auge del conflicto. No parecen estar en una situación-límite por el hecho de encontrarse a punto de actuar, y de sacrificar sus vidas, por una causa. Ese desfase evidencia la sutura entre las motivaciones contrarias tras el proceso escritural: por un lado, problematizar los pliegues políticos de la historia local; por el otro, entretener a lectores ubicados en una perspectiva postnacional en la cual la idea de transgresión o de territorialidad existe sólo como mecanismo de consumo lúdico arbitrado por el flujo global, a quienes el texto les ofrece minimalistas sabores exóticos para su moderado consumo.

Entendemos, desde luego, que esta no es una crítica al individuo llamado "Sergio Ramírez" quien se encuentra fuera del texto y lo precede, problematizando los flujos normalizantes y las resistencias reactivas, sino más bien a los mecanismos que delimitan las condiciones de posibilidad de cierto tipo de textos por encima de otros, o bien a los mecanismos editoriales que hacen que circulen ciertos modelos escriturales por encima de otros en espacios transnacionales. Conviene recordar los debates generados en torno a los polémicos artículos acerca de la "muerte del autor" que revolvieron en torno a los artículos de Roland Barthes y de Michel Foucault a principios de los años setenta del siglo pasado, y que han tenido secuelas hasta el presente. Las presentes condiciones de circulación comercial de textos literarios por medio de corporaciones globalizantes que intentan pre-envasar los mismos para mejor ubicarlos en los espacios de consumo equiparables, le resta poder de gestión a la existencia individual del letrado, quien pasa a convertirse tan solo en un nombre de marca que garantice la calidad del producto consumido. El sujeto escritor, el hombre de carne y hueso llamado Sergio Ramírez en este caso, desaparece en estas condiciones, atenuándose cualquier significación que pudo tener como letrado/ideólogo que marcó sus textos como modos singulares de pensar, o bien como metodología sui generis de estilos transgresivos cuya significación podría encontrarse en lo social, y cuya discursividad fuera capaz de hacer girar un modo de pensar colectivo en el espacio público social. En el contexto presente, la función autorial queda limitada a designar un producto de consumo masivo intercambiable con cualquier otro, y como cualquier otro.

En Mil y Una Muertes (2004) continúa presente el flujo histórico evocativo así como la presencia memoriosa de Darío, aunque ahora el objeto de representación se ha desplazado a Francia en la segunda mitad del siglo diecinueve. Los actos políticos presentes en el entramado son los de 
Louis Bonaparte, amigo y protector del fotógrafo nicaragüense Castellón, quien también bebió con Darío en Mallorca antes de terminar sus días en Polonia durante la segunda guerra mundial. El texto traza el deseo de un personaje llamado Sergio Ramírez por descubrir quien era ese enigmático fotógrafo desconocido en su país. Tenemos entonces la reapropiación simbólica del Darío transatlántico como mecanismo para relanzar la ilusión de una modernidad cosmopolita emblematizada por Castellón, sujeto doblemente mestizo por ser hijo de criollo y de negra miskita. Esto le permite al texto constituir otra modernidad imaginaria en la cual un nicaragüense con lealtades transatlánticas, el padre de Castellón, juega el papel de artífice de la llegada al poder de Louis Bonaparte en el mismo momento en que la invasión de William Walker disuelve su estado postcolonial, representación simbólica de la desaparición del imaginario nacional en el momento mismo en que emergen subjetividades postnacionales. Este texto se encuentra aun más lejano que Margarita, está linda la mar o que Sombras nada más (2002) en sus intenciones de comunicar una interpretación significativa de entramados políticos, más allá del placer, de la jouissance de narrar, legítima en sí misma y muy profesionalmente articulada en el texto.

Tradicionalmente, los cambios de período en América Central-como en otras partes-han sido marcados en los espacios culturales por cambios estilísticos. En este sentido, el espacio es articulado de manera diferente porque la textualidad emplea tropos retóricos para entender las continuidades y las mutaciones de las topografías, como señaló Ileana Rodríguez (2004). Esto podemos comprobarlo por medio de la transición entre ¿̨Te Dio Miedo la Sangre? y Margarita, está linda la mar. Esta ultima, al igual que Mil y Una Muertes, mezcla las atribuciones revolucionarias que enmarcan la función de autor del signatario de las mismas, con la eliminación de los aspectos contradictorios o conflictivos que emanan de esa misma función, para adecuar la textualidad a las nuevas cartografías postnacionales delineadas por las corporaciones editoriales globalizadas. Si bien Margarita, está linda la mar y Mil y Una Muertes retienen ciertas representaciones tradicionales de la memoria cultural nicaragüense en los procesos liminales de la narrativa (el legado de Darío, la dictadura del primer Somoza, el ejercicio de poder del propio Ramírez como vice-presidente sandinista), cuando nos fijamos en el estilo (punto de vista narrativo, uso del tiempo y de la voz) nos damos cuenta de que ambos textos están constituidos por nuevos signos verbales que articulan espacios imaginarios diferentes de lo que constituyó "lo social” en ¿Te Dio Miedo la Sangre?

Su obra reciente, si bien evoca memorias de la épica de la insurgencia, tragicómica, instrumentalizando la "voluntad de eludir la derrota" en palabras de Avelar (1999: 21), en la cual las anteriores contradicciones transgresivas y utopistas -desde una perspectiva editorial postnacionalhan sido neutralizadas. La imagen icónica del "escritor" ha sido recodificada para defender la inviolabilidad del campo ontológico del pasado héroe revolucionario, y a la vez reconfigurar al mismo como un sabio letrado desplazado de intereses nacionalistas que se intersecta con cualquier formación translocal. La nueva discursividad cancela el anterior modelo al alterar la relación entre lenguaje y sujeto. Sea que hablemos de Sombras Nada Más o de Mily Una Muertes, el personaje que ahora ocupa el centro del escenario es el letrado, interpelado desde y hacia una nueva posición 
subjetiva, de manera que este ethos tiene una función diferente a la de la función autorial que produjo los textos desde una posición que conllevaba como mercancía el fetichismo de su anterior autoridad como protagonista central de un proceso revolucionario.

En Sombras nada más, una mujer que reside desde 1979 en Miami le reprocha cómo fue representada en ¿Te dio miedo la sangre? pero reanudan su amistad interrumpida por la revolución. En Mil y Una Muertes el letrado vuelve sobre los pasos que dio en sus viajes como vice-presidente sandinista y reconstruye la vida de Castellón luego de su salida del poder, viajando por Mallorca mientras evoca los fantasmas de los grandes artistas que residieron en la isla. En ambos casos, el letrado ocupa el centro del escenario en una topografía europea. Pero ahora es un letrado emblemático. Su pasado local lo ha reconfigurado como tropo continental. Se ha desplazado del centro de la política al centro del texto. Transmite la sensación de que ha escogido memorializarse como mecanismo de validación postnacional para reconstituir su valor de cambio como sujeto icónico separado de una entidad territorial que anclaría su subjetividad dentro de parámetros localistas. Estos textos de postguerra dramatizan esos manojos de memorias sintomáticas de la nación ex-sandinista porque son sobre todo parábolas del héroe ejemplar homogenizado como hispanoamericano autoreferenciándose para convertir el evento narrado en la regularización del tropo del letrado postrevolucionario, también homogenizado como hispanoamericano, que construye así sus filiaciones con las redes transnacionales de flujos literarios que están sedimentándose como morfologías emergentes de un nuevo orden literario postnacional y que sólo exigen fidelidad a la producción translocal del libro.

Los dos últimos textos mencionados revelan que el triunfo final del guerrillero es virtual. Se materializa sólo en el imaginario textual. Consiste en un retrato del letrado como celebridad icónica reificada de naturaleza estrictamente simbólica, que viaja por el mundo cosmopolita-Miami, Polonia, Mallorca-tanto para evidenciar su prestigio de ancien combattant así como para recapturar la sensación (frisson) de poder que perdió con el cierre del ciclo revolucionario. Es una nueva manera de vivir imaginariamente la nación desde un espacio afectivo libre de patriotismo y de nacionalidad, un no-espacio ubicuo donde el escritor postnacional reterritorializa su presente sin nativismos, pero con tropos territoriales de una comunidad fantasmática cuya sustancia es la memoria y cuya materia es la riqueza del lenguaje que lo convierte, de nuevo, en portavoz de la cosmopolitalidad. Es también la única manera que le queda al letrado para ubicarse dentro de una formación espacial translocal que acoja su auto-representación, expresando así no sólo su deseo sino sobre todo su necesidad de fabricarse un nuevo mecanismo de revalidación y de coherencia cultural.

FINAL

La interrogante acera de la potencial pertenencia a espacios definidos como "nacionales" o regionales parecería encontrarse al final de su ruta. Pese a ello, continúa abierta en el pensamiento crítico. Sin embargo, precisiones y matices necesarios han sido aportados para conceptualizar la invisibilidad reinante en la problematización de la no-presencia de la centroamericanidad en espacios 
transatlánticos postnacionales, semiosis ad infinitum del no-ser que implica carencia de subjetividad en tanto que signo identitario, pese a la persistencia y sobrevivencia de sujetos que aun se autodefinen como centroamericanos. Podría ser la última oposición binaria que sobreviva: si un escritor centroamericano escoge identificarse como cosmopolita, se ve obligado a dejar su anterior identidad en el armario. No es posible ser centroamericano y cosmopolita a la vez, ser reconocido por su identidad geopolítica del lado europeo del Atlántico, salvo en momentos coyunturales de crisis, experiencias-límite tales como la década de los ochentas del siglo veinte. En este sentido, "transatlántico" designa el desarrollo, desplazamiento o bien el reajuste del contenido semántico de "postcolonial" en direcciones opuestas: la semiosis extroversiva que nos lleva a las costas europeas pero desnudando todo sentido de centroamericanidad, o bien la semiosis introversiva, que marca el regreso del sentido a su definición originaria de centroamericanidad, pero fuera de toda forma de representación transatlántica. Al reconocerse “allá” a un escritor y celebrársele, sea que lleve de nombre Rubén Darío, Miguel Angel Asturias, Augusto Monterroso, Sergio Ramírez, Gioconda Belli o cualquier otro, automáticamente se transforma en "hispanoamericano," reduciéndose su pertenencia afectiva, donde afloran esas ansiedades que lo atormentan y las que informan su creatividad, a mero anecdotario sin transcendencia. Afirmarse como centroamericano implica desafirmar las nociones dominantes, normativamente restrictivas, de transatlanticidad globalizada que continúa el impulso moderno hacia la homogeneidad. 


\section{BIBLIOGRAFÍA}

ANDERSON, Perry (1998). The Origins of Postmodernity. London: Verso.

Arellano, Jorge Eduardo. "Darío y sus Cantos de vida y esperanza." Anales de Literatura Hispanoamericana, 35 (2006): 123-152.

ARIAS, Arturo (2007). Taking Their Word: Literature and the Signs of Central America. Minneapolis: U of Minnesota Press.

AVELAR, Idelber (1999). The Untimely Present: Postdictatorial Latin American Fiction and the Task ofMourning. Durham: Duke U P.

BARTHES, Roland (1975). S/Z. New York: Hill and Wang.

BELLI, Gioconda (1988). La mujer habitada. Managua: Editorial Vanguardia.

BELLI, Gioconda (2005). Elpergamino de la seducción. Barcelona: Seix Barral.

BELLI, Gioconda (2008). El infinito en la palma de la mano. Barcelona: Seix Barral.

BeVERLEY, John (1999). Subalternity and Representation: Arguments in Cultural Theory. Durham: Duke UP.

BosteELS, Bruno. “Untiming Decadence in Latin America.” PMLA 124/1 (enero 2009): 277-279.

DARío, Rubén (1976). Autobiografía. Prólogo de E. Anderson Imbert. Argentina: Ediciones Marymar.

DARío, Rubén (1977). “La ‘Sarmiento’ en España.” Escritos dispersos de Rubén Darío, vol. 2. La Plata: U Nacional.

DARÍO, Rubén (2000). Historia de mis libros. Nicaragua: Ediciones Distribuidora Cultural.

De Castro, Juan E. "Rubén Darío visits Ricardo Palma: Tradition, Cosmopolitanism, and the Development of an Independent Latin American Literature.” Chasqui 36.1 (mayo 2007): 48-61.

DuSSEL, Enrique (1998). Ética de la liberación en la edad de la globalización y de la exclusión. Madrid: Trotta.

Foucault, Michel (1977). "What is an Author?" Language, Copunter-memory, Practice, ed. Donald F. Bouchard. Ithaca: Cornell U P,:113-138.

Franco, Jean (2002). The Decline \& Fall of the Lettered City. Cambridge: Harvard U P.

HALFON, Eduardo (2003). Esto no es una pipa, Saturno. Guatemala: Alfaguara.

MartíneZ GómEZ, Juana (ed. e introd.). "En el centenario de Cantos de Vida y Esperanza." Anales de Literatura Hispanoamericana, 35 (2006): 9-152.

MedinA, Julia. "Vestíbulos del hombre público: Prólogos 'desconocidos' de Rubén Darío." $A$ contracorriente. $3 / 2$ (invierno 2005): 127-155.

Mignolo, Walter (2000). Local Histories/Global Designs: Coloniality, Subaltern Knowledges, and Border Thinking. Princeton: Princeton U P.

Morán, Francisco. “CCon Hugo fuerte y con Verlaine ambiguo’: ¿El reino interior o los peligrosos 
itinerarios del deseo en Rubén Darío?”. Iberoamericana LXXII/215-216 (abril-septiembre 2006): 481-495.

MOREIRAS, Alberto (1996). "The aura of Testimonio." The Real Thing: Testimonial Discourse in Latin America, ed.Georg M. Gugelberger. Durham: Duke U P.

Osborne Peter y Lynne SEGAL. "Gender as performance: An interview with Judith Butler." Radical Philosophy 67 (1993): 32-39.

Quijano, Aníbal. “Colonialidad del Poder y clasificación social.” Journal of World Systems Research. XI/ 2, (verano/otoño 2000): 342-386.

RaMA, Angel (1970). Rubén Darío y el modernismo: circunstancias socioeconómicas. Caracas: U de Venezuela.

RAMÍREZ, Sergio (1977). ¿Te dio miedo la sangre? Caracas: Monte Avila.

RAMíREZ, Sergio (1998). Margarita, Está Linda la Mar. Madrid: Algafuara.

RAMíREZ, Sergio (2002). Sombras nada más. México: Alfaguara.

RAMíREZ, Sergio (2004). Mil y una muertes. México: Alfaguara.

RobBins, Jill. "Globalization, Publishing, and the Marketing of 'Hispanic' Identities." Revista Iberoamericana, III/9 (2003): 89-101.

Robinson, William I. (2003). Transnational Conflicts: Central America, Social Change, and Globalization. London: Verso.

RoDRÍGUEZ, Ileana (2004). Transatlantic Topographies: Islands, Highlands, Jungles. Minneapolis: U of Minnesota P..

RoDríGUEZ PADRÓN, Jorge. "Sobre la lectura de Cantos de vida y esperanza y otras cosas." Anales de Literatura Hispanoamericana 35 (2006): 55-68.

Serrano Caldera, Alejandro. "Rubén Darío: renovador de la palabra y la cultura." La Prensa digital. $(7 / 04 / 2009)$.

Trigo, Abril (2008). Memorias migrantes: Testimonios y ensayos sobre la diáspora uruguaya. Rosario/Montevideo: Beatriz Viterbo.

ZANETTI, Susana. "La pérdida del reino y los Cantos de vida y esperanza." Anales de Literatura Hispanoamericana 35 (2006): 21-30. 


\title{
LITERATURAS NACIONALES Y LITERATURAS NACIONALIZADAS. CONSIDERACIONES EN TORNO A LA RECEPCIÓN DEL BOOM HISPANOAMERICANO EN ESPAÑA ${ }^{1}$
}

\author{
National Literatures and Nationalized Literatures. Reflections on the Reception of \\ Latin American boom in Spain
}

\section{Mario SANTANA}

UNIVERSITY OF CHICAGO, ESTADOS UNIDOS msantana@uchicago.edu

Profesor de Literatura Española y en el Center for Latin American Studies de la Universidad de Chicago. Su investigación se ha concentrado en la literatura española y catalana de los siglos XIX y XX, con un énfasis particular en la narrativa y el cine. Está también interesado en la historiografía literaria, la teoría literaria (hermenéutica y recepción, narratología, aproximaciones sistémicas e institucionales a la literatura) y los estudios culturales. Posee los títulos de Filosofía (Universitat de Barcelona) y Literatura (Columbia University). Es autor del libro Foreigners in the Homeland: The Spanish American New Novel in Spain, 1962-1974 (Bucknell UP, 2000).

RESUMEN: Este artículo reflexiona en torno a la noción de literatura nacional a partir de la relación recepción que los escritores latinoamericanos del boom tuvieron en el campo literario español. ¿Cómo dar cuenta, a la hora de estudiar el proceso de la vida literaria nacional, de la presencia de textos literarios "extranjeros" que circulan ampliamente y sin necesidad de que medie traducción alguna? Para dar cuenta de las dificultades y contradicciones de esa relación se propone el concepto de literatura nacionalizada, poniendo el énfasis en los procesos de ‘nacionalización' que tienen lugar en un campo literario específico.

PALabras Clave: Boom, Latinoamérica, España, literatura nacional, literatura nacionalizada.

\begin{abstract}
This article reflects on the notion of national literature by analyzing the reception relationship that the Boom Latin American writers had in Spain. How can we account, when studying the process of national literary life, of the presence of "foreign" literary texts that circulate widely and without the need for any translation? In order to account for the difficulties and contradictions of this relationship, the concept of nationalized literature is proposed, emphasizing the processes of 'nationalization' that take place in a specific literary field.
\end{abstract}

KeYwords: Latin American Boom, Spain, National Literature, Nationalized Literature.

\footnotetext{
${ }^{1}$ Este ensayo es una versión revisada del capítulo primero del libro Foreigners in the Homeland. 
La atención al estudio de la dimensión transatlántica de la literatura en lengua española es un imperativo de la disciplina que adquiere una especial relevancia a partir de los años sesenta del siglo pasado, gracias al empuje sin precedentes con el que la literatura latinoamericana entra en la escena internacional con el denominado boom de la nueva novela. Este fenómeno, con dimensiones estéticas pero también económicas e incluso políticas, condujo a un cuestionamiento radical del concepto de literatura española construido por la historiografía cultural desde el siglo XIX, puesto que hizo ineludible el reconocimiento de que en España la literatura nacional se alimentaba de elementos supuestamente foráneos que desmontaban la hasta entonces pretendidamente autónoma y ensimismada evolución de la poética nacional.

Para algunos escritores y críticos españoles, la irrupción de la literatura latinoamericana causó un impacto inédito en la conciencia nacionalista de las letras castellanas: el éxito en España de escritores que procedían del otro lado del Atlántico fue percibido por algunos como una intrusión, una amenaza directa a su posición como herederos legítimos de la tradición escrita en lengua castellana. En un momento en que los escritores españoles estaban a punto de salir del marasmo cultural de la posguerra y se preparaban para participar en los círculos literarios del mundo occidental (recuérdense los numerosos encuentros entre escritores españoles y europeos, sobre todo franceses e italianos, que tienen lugar a finales de los 50 y principios de los 60) y aprovechar una expansión del mercado editorial sin precedentes, se vieron sorprendidos y sobrepasados por sus colegas latinoamericanos, una inesperada competencia que parecía arrebatarles no sólo su público lector sino también sus instrumentos de promoción (editoriales, premios literarios, etc.) e incluso, muy especialmente, su propia lengua literaria. No es exagerado pensar que desde el Siglo de Oro la literatura escrita en lengua española no había disfrutado de tan amplio reconocimiento y prestigio internacional. Es comprensible, pues -como se afirmó en 1970, rememorando a Emilia Pardo Bazán y su análisis del revuelo causado en la España decimonónica por la introducción del naturalismo-que la recepción de la novela latinoamericana fuera considerada por muchos la "cuestión palpitante" de la vida literaria española contemporánea² ${ }^{2}$.

Como resultado de este fenómeno, el concepto que de "literatura española” se tenía en España (y en gran parte del hispanismo académico) sufre una transformación bajo la presión conjunta de dos procesos paralelos. Por un lado, tenemos que en clave nacional interna (por así decirlo) las categorías de nación y literatura nacional son puestas en cuestión por la cada vez más extendida conciencia de la pluriculturalidad del Estado español, resultado del resurgimiento de las literaturas en otras lenguas (catalán, euskera, gallego) que se enfrentan al monolingüismo hegemónico que pretendía hacer pasar a la literatura castellana como única representante de las letras españolas. Por otro, la producción asociada con la denominada "novela del boom" demuestra que la literatura en la lengua "nacional" española se escribía no sólo también, sino incluso con más éxito de público y crítica, desde otros países. De entonces, a mi modo de ver, la expresión "literatura española” ya no puede seguir usándose sin unas necesarias precisiones: o bien refiere a la literatura de España, en cuyo caso abarca

\footnotetext{
2 De “Cuestión palpitante” hablan en este contexto tanto Pere Gimferrer (“De una guerra literaria”) como Juan García Hortelano (en Tola de Habich y Grieve, 1971:154).
} 
más allá de la producción en lengua española y debe incluir la literatura en todas las lenguas del Estado; o bien refiere a la literatura escrita en español, y entonces su estudio debe superar el horizonte marcado por las fronteras de una nación en particular.

Resulta sorprendente que los nombres de los escritores más canonizados de la literatura hispanoamericana apenas aparecen mencionados en la mayoría de estudios sobre la narrativa española contemporánea. Desde la perspectiva de los estudios de literaturas nacionales, se supone que los escritores "pertenecen" a los sistemas literarios de sus países de origen, y que por tanto no deben mezclarse con los de otras nacionalidades. Pero la realidad es que la vida literaria española desde los años sesenta apunta en otra dirección muy distinta: varios escritores latinoamericanos no sólo vivieron, escribieron y publicaron en España, sino que también se convirtieron en lecturas e influencias ineludibles para los escritores y lectores españoles (de ahí la cualidad "palpitante" de su presencia). Este fenómeno presenta un reto para el estudio de las literaturas nacionales: ¿dónde deben situarse esos escritores en relación al sistema literario español?, ¿cómo dar cuenta, a la hora de estudiar el proceso de la vida literaria nacional, de la presencia de textos literarios "extranjeros" que circulan ampliamente y sin necesidad de que medie traducción alguna?, ¿puede seguir pensándose en esos textos como "foráneos" una vez son apropiados por los lectores e incorporados al repertorio nacional de códigos y valores estéticos?

Para dar respuesta a estas cuestiones se hace necesario formular un concepto de literatura nacional que no esté limitado a la producción de sus propios ciudadanos (la literatura creada por los españoles) sino que tenga en cuenta la amplia gama de productos, tanto autóctonos como importados, que están disponibles dentro del mercado literario nacional. Esto nos permitiría analizar la literatura tal como es experimentada -y no sólo tal como es creada- desde un país particular, un imaginario cultural que se articula no sólo a través de textos, ya sean nativos o importados, en la(s) lengua(s) nacional(es), sino igualmente mediante el acceso a obras traducidas. Se podría decir que en la era de la globalización y las multinacionales de la edición resulta anacrónico seguir pensando en términos de espacios literarios nacionales. Sin embargo, lo que aquí se propone es que las literaturas nacionales constituyen al mismo tiempo espacios circunscritos y abiertos: limitados por la nación como entidad relativamente diferenciada en términos culturales, políticos e incluso económicos (piénsese por ejemplo en la cantidad de premios literarios y subvenciones que dependen de instituciones locales), pero al mismo tiempo permeables y receptivos a la apropiación de elementos externos. Así pues, creo que en este ámbito es necesario diferir, por un lado, de los proponentes de una perspectiva cosmopolita que preferirían abandonar simplemente el concepto de literatura nacional en aras de una concepción puramente universal (la Literatura con mayúsculas y sin adjetivos) o puramente lingüística (la totalidad de la literatura escrita en castellano en todo el mundo, por ejemplo: la lengua como verdadera patria de la literatura, como diría Carlos Fuentes). Y, por otro lado, conviene asimismo descartar la visión nacionalista según la cual lo único que cuenta a la hora de catalogar la literatura de una nación es la producción de sus propios ciudadanos (escrita, por supuesto, en la lengua nacional).

Se trataría, por lo tanto, de articular un instrumento que permita analizar la vida literaria -es 
decir, los procesos sociales de producción, distribución y consumo de literatura- o lo que Bakhtin y Medvedev definieron como el "entorno literario": "el conjunto de todas las obras literarias socialmente activas dentro de una época y grupo social determinado" (1985: 26) ${ }^{3}$. Para poder llevar a cabo este proyecto, es necesario dejar de lado algunas de las ideas que, fundadas en el nacionalismo cultural decimonónico, han sido dominantes a la hora de configurar los estudios literarios, y han llevado a una visión restrictiva y distorsionada de su objeto.

\section{EL ESPACIO LITERARIO: GEOGRAFÍA, LENGUA, IDENTIDAD}

Mientras que la dimensión temporal ha sido una constante fundamental en la historiografía literaria, las cuestiones espaciales han centrado la atención más reciente de un número importante de críticos $^{4}$. La necesidad de analizar el modo en que los productos culturales ocupan y funcionan en un espacio determinado ha sido entendida tradicionalmente en términos nacionales: a remolque (y como soporte) de la creación de los estados modernos, a las culturas se les ha asignado nacionalidad, y se han escrito historias literarias predicadas sobre la idea de que existen literaturas nacionales diferentes que merecen atención de manera independiente. Este legado del romanticismo sigue guiando no sólo los estudios literarios y los programas académicos, sino también toda una variedad de iniciativas públicas y privadas (becas de investigación, premios nacionales, etc.) que ayudan a sostener la vida literaria en cada país.

Contra el estudio convencional de las literaturas nacionales se pueden presentar al menos tres argumentos: a) uno lingüístico, según el cual es la lengua y no la geografía política lo que determina los contornos de una literatura; b) uno de carácter universalista, según el cual la literatura es expresión de una humanidad que trasciende las fronteras entre las sociedades; y c) uno social o identitario, para el cual la identidad de los textos literarios se construye en base a agrupamientos colectivos distintos a los que proporciona la nación. De acuerdo al primer argumento, la segmentación nacional estaría dividiendo artificialmente conjuntos que deberían entenderse unidos a partir del uso de una lengua y una tradición literaria comunes. Sería más apropiado, por tanto, hablar de una literatura en español, en francés, en italiano, etc. (por muy compleja y diversa que se quiera), cada una de ellas diferenciada de las literaturas escritas en otras lenguas. En esta línea, por ejemplo, Christopher Clausen proponía hace unos años el abandono del concepto de literatura nacional en favor de una "literatura en lengua inglesa" que abarcaría todos los productos literarios escritos en la múltiples variantes del inglés usadas en todo el mundo:

\footnotetext{
${ }^{3}$ Peter Scherber ofrece un análisis detallado del concepto de vida literaria en su ensayo "Literary Life as a Topic of Literary History". Las traducciones de textos en otras lenguas, salvo indicación contraria, son mías.

${ }^{4}$ Véase Reinhard Nethersole, 1990. El XII Congreso de la Asociación Internacional de Literatura Comparada (Munich, 1988) estuvo dedicado al tema general "Espacio y fronteras". La espacialidad de la literatura ha sido objeto de especial atención en la obra de Franco Moretti (quien recurre a los mapas a la hora de analizar el contenido diegético de la novela histórica o para trazar la expansión de los géneros literarios), en el análisis sociológico que Pierre Bourdieu hace del "campo literario", y en la conceptualización del "polisistema” literario desarrollada desde el estructuralismo dinámico de Itamar Even-Zohar. Véase también José Lambert (1991).
} 
Como medio que define el horizonte de inteligibilidad, la lengua proporciona una base más útil y fundada (aunque no absoluta) que la nacionalidad para distinguir una literatura de otra. Definir la literatura inglesa como "literatura en inglés, independientemente de dónde o por quién sea escrita", vuelve a reunir conceptualmente lo que ha sido artificialmente fragmentado, hace posible un genuino multiculturalismo en los estudios ingleses, hace que los escritores que no son británicos ni norteamericanos puedan acceder a una atención más amplia, y nos ayuda a pensar de manera más fructífera sobre las relaciones literarias entre autores, movimientos literarios, sociedades y periodos (1994: 61).

De manera similar, Carlos Fuentes ha defendido que la verdadera patria del escritor en español es el territorio imaginado por Cervantes en La Mancha, un territorio que desde entonces se habría expandido más allá de cualquier geografía nacional (1993: 35) . Todavía bajo el impacto de la recepción de la novela del boom, en 1972, el editor Carlos Barral cuestionaba igualmente la separación de las literaturas de España e Hispanoamérica al subrayar la unidad lingüística de las letras hispánicas y sugiriendo la existencia de dialectos literarios: "Desde un punto de vista serio de la historia literaria, a mí me parece que las literaturas en lengua española de nuestro tiempo constituyen un mosaico de literaturas dialectales equidistantes de un centro teórico, que es la lengua literaria del Barroco... En ese sentido, me parece tan dialectal la literatura que se escribe en Castilla como la que se escribe en Yucatán” (1972: 36). Sin embargo, la historia de una definición puramente lingüística del espacio literario ha estado marcada por las frecuentemente incómodas relaciones entre las diferentes escrituras nacionales en la misma lengua. En términos que podrían aplicarse con facilidad a la condición del escritor hispanoamericano en España, Washington Irving apuntaba hace casi dos siglos que las potencias coloniales no renuncian tan fácilmente a ejercer el derecho de propiedad exclusiva sobre su lengua materna, y que los conflictos culturales están a la orden del día cuando esas sociedades se encuentran ante productos literarios extranjeros en su propia lengua: "Se ha visto con sorpresa que un hombre proveniente de la salvaje América sea capaz de expresarse en un inglés aceptable. Se me ha visto como algo nuevo y extraño en literatura, una suerte de semi-salvaje, con una pluma en la mano en vez de la cabeza, y había curiosidad por oír lo que alguien así tenía que decir sobre la sociedad civilizada" $(1977: 3)^{6}$.

En los modelos ya desfasados y superados de hispanismo, las literaturas no peninsulares aparecían como apéndices o reflejos de una literatura seminal y, en cuanto tales, sus diferencias eran subordinadas a la identidad marcada por la metrópoli. De este modo, las literaturas

\footnotetext{
${ }^{5}$ Carlos Fuentes ha criticado la compartimentación de las literaturas en lengua española: "Yo no admito la división entre la literatura peruana, argentina, cubana, mexicana, o española. No admito la división del Atlántico. Yo creo que [Juan] Goytisolo, por ejemplo, pertenece a la misma empresa que nosotros, no porque él se volvió latinoamericano, ni porque nosotros nos volvimos españoles, sino porque estamos en una misma empresa de la imaginación y del lenguaje"(1981: 313); véase también su “Discurso de recepción del Premio Rómulo Gallegos” (1978: 18). La misma posición era defendida por Gabriel García Márquez en una entrevista de 1968: "No hablemos más por separado de literatura latinoamericana y de literatura española, sino simplemente de literatura en lengua castellana... [N]o sólo estamos escribiendo en el mismo idioma, sino prolongando la misma tradición”.

${ }^{6}$ Sin duda, no es casual que dos de los libros dedicados a analizar la recepción del boom en España aludan en su título al contraste entre lo propio y lo extraño, y que esto último sea visto a la vez con tintes amenazantes: La llegada de los bárbaros, editado por Joaquín Marco y Jordi Gracia, y el ya mencionado Foreigners in the Homeland.
} 
hispanoamericanas eran vistas como pertenecientes a un sistema secundario cuya función era ser reserva y epígono de la tradición literaria española, y juzgadas de acuerdo a los parámetros establecidos en base al supuesto modelo original. Dentro de este paradigma, la diferencia sólo podía ser entendida de manera retrospectiva (como muestra de una fase evolutiva ya superada en la literatura de la metrópoli) o como localismo regional (lo que limita el mestizaje a la adquisición de "color local" o al exotismo como valor añadido). Este modelo colonial de las relaciones interliterarias, dentro del cual la hibridación es mera desviación de la norma del arte metropolitano, tendría su réplica más evidente en un modelo postcolonial que, en el caso de los estudios hispánicos, postula la independencia de las literaturas latinoamericanas y aboga por el estudio separado de las prácticas culturales españolas e hispanoamericanas.

El argumento universalista en contra de las literaturas nacionales propone el estudio comparado y supranacional del fenómeno literario como expresión artística de una humanidad unificada, una concepción heredera de la Weltiteratur de Goethe (véase Claudio Guillén, 1993: 37-45). Desde esta perspectiva, las fronteras lingüísticas, geográficas o nacionales deben sortearse en aras de una entidad cultural que está por encima de esas divisiones. En última instancia, este universalismo fundamenta la esencia de la literatura en un desvelamiento artístico de la condición humana que es en gran medida ucrónico y utópico, es decir, desconectado de determinantes temporales y espaciales. Pero no es tanto una negación del nacionalismo, sino la propuesta de una forma más elevada de identidad colectiva: su principio básico no es que los grandes autores literarios no tengan ciudadanía, sino que en realidad son ciudadanos del mundo, los más altos representantes de una identidad humana común (aunque curiosamente a menudo ésta sea eurocéntrica).

El tercer argumento contra las literaturas nacionales, por último, responde al reto de la identidad no mediante su expansión vertical (como es el caso del universalismo) sino trazando de otra manera sus fronteras horizontales. A medida que la identidad proporcionada por el estado-nación se hace cada vez más problemática o débil, se propone la existencia de otros elementos acaso más profundos (la clase, el género, la etnicidad) en relación a los cuales se permitiría establecer diferencias entre los objetos literarios. Esta perspectiva, sin embargo, no parece ser sino una variación del modelo nacional (ambos apelan, después de todo, a la literatura como expresión propia y diferenciada de un determinado colectivo social), y reproduce por tanto sus mismas limitaciones.

Lo que tienen en común todas estas propuestas y contrapropuestas para definir los espacios culturales es que están construidas a partir de una concepción genética de la literatura: las obras culturales se asocian directamente con los procesos de creación y sus orígenes (¿quién las escribe?, ¿desde dónde?), mientras que la re-creación de los textos que se hace efectiva a través de los procesos de lectura y recepción queda relegada a ocupar una posición secundaria y subordinada. Esta identidad genética juega un papel fundamental en la definición de las fronteras culturales, especialmente cuando éstas se perciben como elementos determinantes de una fidelidad o una pertenencia. Según esta concepción, pues, para que una obra literaria pueda considerarse perteneciente a un determinado grupo, no es sólo necesario que tenga una existencia efectiva (es decir, que el libro esté disponible) dentro de esa comunidad, sino que tiene también que representar genuinamente su visión 
del mundo. Intentando responder a la pregunta de qué hacía que una novela escrita en inglés pudiera considerarse distintivamente americana, Julian Hawthorne decía 1884 que un libro americano "es un libro escrito por un americano, y por uno que escribe como un americano, es decir, con naturalidad... ¿Qué otra cosa puede ser una novela americana sino una novela que trata de personas, lugares e ideas desde un punto de vista americano?" (1884: 167). Este criterio decimonónico de lealtad "natural" a los rasgos supuestamente distintivos de una comunidad no ha sido del todo descartado, y con frecuencia en los estudios culturales se pone de manifiesto en una búsqueda compulsiva e irreflexiva de identidades.

En otro intento de identificar los elementos básicos de una literatura nacional, Naftoli Bassel ha identificado una compleja serie de rasgos relativos a raíces étnicas y mitológicas, identidad de lengua, estabilidad y dinamismo sistémico, tradición artística e influencias interliterarias. Y concluye:

Los criterios aquí apuntados excluyen de una determinada literatura nacional obras literarias temáticamente relacionadas con la vida de la nación pero escritas por autores que pertenecen a otros sistemas literarios; al mismo tiempo, incluyen orgánicamente obras temáticamente "ajenas" de escritores nacionales. . . . Ni el tema ni la nacionalidad de los personajes es decisiva; los elementos cruciales son más bien la conexión con la tradición literaria o la conciencia artística nacional, y la presencia de un "punto de vista" o una "forma de ver" nacional (1991: 773-74).

Tales criterios, sin embargo, presentan en mi opinión serios problemas cuando intentan aplicarse a ciertos autores que dificultan su clasificación mediante el distanciamiento (cuando no abierto desprecio) con respecto a lo que podría contar como su tradición o sus orígenes. Un problema semejante nos presenta la definición de una "genuina literatura del Tercer Mundo" propuesta por Georg M. Gugelberger, quien recurre a distinciones parecidas para elaborar un censo literario acaso bienintencionado ideológicamente pero en última instancia equivocado:

A modo de sugerencia preliminar y provocativa, me gustaría recordar al lector que no toda la literatura que proviene de esta gigantesca área geográfica, que abarca casi dos tercios del mundo, es necesariamente "literatura del Tercer Mundo". Hay escritores en Nigeria, por ejemplo, que producen "literatura" y hay otros que producen "literatura del Tercer Mundo". En Latinoamérica uno puede pensar en Borges y Neruda. Neruda es obviamente un escritor tercermundista, mientras que Borges pertenece a la literatura que asociamos con el canon establecido. El que Borges provenga de una nación del Tercer Mundo no es suficiente para convertirle en escritor tercermundista, aunque la precisa cuestión de por qué él decide escribir de manera no tercermundista es en sí relevante (1991: 507-08).

Lo que Gugelberger decide ver como la tradición del Tercer Mundo es una literatura de resistencia caracterizada como "realista” (“Esto implica hablar de hombres y mujeres no en abstracto sino en el aquí y el ahora”), “abiertamente política” y "alegórica y didáctica” (1991: 515). Estos rasgos, sin embargo, no son exclusivos de la literatura tercermundista y, en cualquier caso, la producción de esas áreas -para bien o para mal- van mucho más allá de lo delimitado por esas restricciones. En el caso de Borges, por ejemplo, Fernández Retamar ya ha argumentado convincentemente que su obra sólo puede ser explicada precisamente por su excentricidad con respecto al 
modelo metropolitano, es decir, por su propia (latino)americanidad, puesto que sólo desde la periferia es posible superar el provincianismo de la canonización europea ${ }^{7}$. No se trata de negar, por supuesto, la validez de ciertas consideraciones genéticas a la hora de analizar la producción cultural, o la existencia y la necesidad de promocionar el estudio de discursos contra-hegemónicos en las sociedades contemporáneas, pero resulta difícil ver cómo ciertos estereotipos culturales pueden servir de base para los estudios literarios.

Desde una perspectiva que funda la aproximación a la literatura en su origen y creación, el análisis del impacto de las obras en las relaciones interliterarias adquiere un alcance limitado: el estudio de la recepción entraría en escena una vez ya ha sido determinada la filiación de los objetos pertenecientes a cada literatura según algunos de los criterios de identidad antes mencionados, de modo que su función sería más bien catalogar la proyección intercultural de los autores y las obras ${ }^{8}$. El espacio literario queda así dividido en dominios mutuamente exclusivos: sólo los textos escritos por escritores españoles (y, para muchos, sólo aquellos en la lengua nacional) pertenecerían con propiedad a la literatura española. Bajo estas condiciones, es difícil recurrir a la interliteraridad para poner en cuestión en orden natural de las cosas, y las historias literarias tienden a convertirse en proyectos genealógicos al servicio de la catalogación de los habitantes nativos y la expedición de sus correspondientes certificados de nacimiento.

El concepto nacionalista de literatura tiende a descontar la importancia de los elementos foráneos y centrarse exclusivamente en la producción autóctona, de modo que no puede dar cuenta de la más amplia gama de objetos literarios que conforman la experiencia colectiva de una nación. Al igualar el mapa literario a una geografía de lugares de nacimiento, los fenómenos de la vida literaria quedan reducidos a sólo uno -y no necesariamente siempre el más significativo- de sus componentes: de acuerdo a la falacia genética, es sólo por referencia al origen de la obra literaria que es posible calibrar tanto su significado como su valor, y por lo tanto sólo aquellos que pueden compartir las condiciones del proceso creativo pueden entender cabalmente su resultado. El corolario lógico de esta concepción es que sólo aquellos textos genéticamente ligados a una determinada nación pueden ser legítimamente considerados parte de su literatura. La historia literaria de una nación, pues, debe interesarse sólo por la producción literaria de sus ciudadanos. Sin embargo, un repaso a todo lo relacionado con la recepción de la nueva novela latinoamericana en España demuestra que un sistema literario no puede limitarse a trazar un mapa de orígenes nacionales.

\footnotetext{
7 "Borges es un típico escritor colonial... No es un escritor europeo; no hay escritores europeos como Borges... Los escritores europeos pertenecen a tradiciones muy concretas y provincianas, llegando incluso al extremo de Péguy, por ejemplo, quien se jactaba de no haber leído otra cosa que autores franceses. Aparte de unos pocos profesores de filología, quienes cobran por ello, sólo hay un tipo de persona que realmente conoce en su totalidad la literatura de Europa: el colonial. Sólo en casos de desequilibrio mental puede un escritor argentino ilustrado vanagloriarse de leer sólo a autores argentinos o en lengua española. Y Borges no es un desequilibrado” (Fernández Retamar 1989: 28).

${ }^{8}$ Un ejemplo de este enfoque generalizado lo tenemos en el proyecto de una Historia de la Literatura Mundial desarrollado por el Instituto Gorky, donde las literaturas nacionales (en términos "nativos") son consideradas las "unidades básicas" de estudio, y las conexiones internacionales se limitan a "influencias literarias y similitudes tipológicas” (véase Vipper 1985).
} 


\section{LITERATURA NACIONAL: GENEALOGÍA Y NATURALIZACIÓN}

El énfasis concedido al origen de la obra literaria corre paralelo a lo que Roland Barthes identificó como el "vicio fundamental” de la historia literaria: “el privilegio centralizador concedido al autor". Según Barthes, "las consecuencias son graves: al centrarse en el autor, al hacer del 'genio literario’ la fuente misma de observación, relegamos los objetos propiamente históricos al rango de zonas nebulosas y remotas: sólo los alcanzamos a ver accidentalmente" (1992: 158-59). Ese objeto propiamente histórico de la investigación literaria, prosigue Barthes, no puede ser el acto creativo de autores individuales, sino la institución literaria. El objetivo de la historia literaria no puede ser simplemente catalogar los monumentos artísticos del pasado (una historia de las obras) o discernir cómo ciertos autores llegaron a escribir ciertos libros (una historia de la creación), sino que debe proporcionar una suerte de ontología histórica: “Lo que buscamos es una respuesta histórica: ¿qué era la literatura, qué funciones se le confiaban, qué lugar ocupaba en la jerarquía de valores, etc.?" (1992: 161). El modelo de una historia literaria institucional nos conduce, más allá de la problemática de los orígenes, a los ámbitos de la experiencia social, donde el consumo de bienes (culturales o no) no se limita a los producidos autóctonamente, especialmente en las economías modernas.

Estrechamente ligada a la primacía del origen está la primacía de la lengua nativa. Es un principio largamente establecido y aceptado en la crítica literaria (concebida bajo los auspicios de la filología) que la lengua nativa es el medio privilegiado de la expresión artística. En palabras de Claudio Guillén, "sería desafortunado pasa por alto que es la lengua materna la que ofrece el acceso más intenso, el más seguro e íntimo, a la emoción estética y a la comprensión de lo que es o no es poesía" (1993: 7). Sin embargo, este tipo de juicios sobre la lengua suelen casi siempre expresarse en relación al valor de la palabra poética, y es precisamente el fuerte peso que la preferencia por la poesía (frente a la narrativa) ha tenido en el desarrollo de la crítica lo que, creo yo, ha fundamentado una cierta sacralización de la relación entre lenguas y literaturas. Es más, la demarcación lingüística de las literaturas nacionales (es decir, la idea que sólo las obras escritas en la lengua nacional pueden considerarse como propiamente pertenecientes a la literatura de la nación) está condicionada por lo que André Lefevere ha denominado - en contraste a una concepción sistémica- una "concepción corpus" de la literatura: "Esta concepción se basa en dos nociones esencialmente románticas: la del genio y la del carácter sagrado del texto literario... Si la obra original es producto del genio, es por definición única; y si es única, no puede ser traducida” (1982: 144-45). La presunta sustancia intraducible de los textos literarios (aquí una vez más los ejemplos aluden a la armonía y el poder evocador de la poesía, y rara vez se debaten en este contexto las tramas narrativas, que parecen adaptarse más fácilmente a otros códigos) ha conducido a una sacralización del origen que se invoca para separar obras producidas en distintas lenguas, por mucho que desde el punto de vista de la recepción (en la experiencia de los lectores y en las librerías de cualquier contexto nacional) esas 
obras pueden coexistir sin mayor problema 9 .

Sería ingenuo descontar la importancia que tienen los productos autóctonos para la cultura, o el valor que los miembros de una comunidad pueden asignar a lo que perciben como representativos de su propia identidad y en contraste con el carácter importado de ciertos productos foráneos. Los lectores españoles, por ejemplo, pueden ciertamente tender a dar especial consideración (y en determinadas condiciones incluso una posición más elevada en la jerarquía de valores del sistema literario) a una novela escrita por un compatriota -ya sea porque los rasgos lingüísticos se identifiquen con un sociolecto nativo, o porque la situación narrativa o los personajes se vean como más cercanos a los propios modos de vida. Sin embargo, a veces ha ocurrido lo contrario: textos extranjeros son valorados precisamente porque cuestionan (o enriquecen) un colectivo imaginario, una estética caduca, o formas de vida que se perciben como restrictivas o estancadas.

El impacto que la literatura traducida puede tener en la configuración de las literaturas nacionales está todavía por analizar en profundidad. El estudio de los sistemas literarios necesita tener en cuenta el fenómeno de las constantes migraciones y los procesos que conducen a lo que podríamos considerar una verdadera naturalización, mediante la cual ciertos elementos culturales pueden ser importados y alcanzar una plena ciudadanía en otras configuraciones. Como ha argumentado Itamar Even-Zohar, las obras traducidas deben entenderse como parte integral de los sistemas literarios (1978: 45-51); los objetos literarios - entendiendo por ello no sólo los textos individuales sino también modelos poéticos, convenciones, códigos y valores- viajan y funcionan más allá de las fronteras de sus lugares de origen, y los textos extranjeros con frecuencia proporcionan préstamos necesarios para satisfacer necesidades que no están cubiertas por la producción autóctona.

El privilegio centralizador del origen nacional de la obra artística infravalora las concretizaciones históricas de la literatura en cuanto objetos de experiencia social de los lectores, ya que la nación no es nunca una esfera monádica, sino un espacio a través del cual se hace efectiva la intercomunicación con otras culturas y geografías. La historia literaria, según el programa originalmente propuesto por Felix Vodička en 1942, “debe entender la literatura de un determinado periodo como un conjunto existente de obras y a la vez, igualmente, como un conjunto de valores" (1982: 199) ${ }^{10}$. Aquí es crucial entender el énfasis en las obras y valores existentes (una idea que recuerda la insistencia de Bakhtin y Medvedev en los textos "socialmente activos" como objeto de una poética sociológica), puesto que para Vodička el corpus de una literatura está definido por el repertorio que está disponible a sus lectores:

La atención del historiador literario se centra en aquello que constituye el campo y el contenido de una literatura en un momento dado de su evolución. Nos referimos aquí a la

\footnotetext{
${ }^{9}$ De hecho, según el propio Guillén, “la traductología muestra, o más bien confirma, que la lengua no lo es todo en una obra de arte literario” (1993: 284; véase también Lefevere, 1982: 145). En este contexto, es importante notar que en la segunda mitad del siglo XX el estudio de la poética ha desplazado su foco de atención, y de un ejercicio centrado lingüísticamente en las propiedades intrínsecas de los textos ha pasado a ser más bien un estudio semiótico del carácter institucional de la literatura (véase van Rees 1983). Una dirección similar es la adoptada por Gerard Génette en Seuils.

${ }^{10}$ Sobre el concepto de “concretización” (o “actualización”), véase Vodička, 1982.
} 
literatura viva, la literatura que es parte activa de la conciencia de los lectores; no nos preocupan los valores literarios históricos que caen fuera del horizonte de interés intensivo del lector y que por ello carecen permanente o temporalmente de efecto estético... Estudiamos qué obras del pasado y qué autores contemporáneos eran favorecidos en cada momento, y cuál era la relación entre las tendencias literarias del presente y del pasado (1982: 203-04).

Ese repertorio de autores, obras y valores no es nunca el resultado exclusivo de la producción autóctona. El análisis de los éxitos de venta, tan a menudo ausente de los estudios literarios, proporciona un ejemplo claro de cómo el gusto (y el comercio) literario puede trascender barreras nacionales, geográficas y -mediante la traducción- lingüísticas. Si el programa de Vodička fuera a ponerse en práctica para estudiar la situación de la literatura española de los años sesenta y setenta, sería absurdo descartar la presencia literaria de escritores como Vargas Llosa o García Márquez, entre otros, simplemente porque provienen de otros territorios. Mario Valdés y Linda Hutcheon han criticado "cualquier construcción monolítica de una historia literaria nacional” y se han manifestado a favor de un modelo comparativo, puesto que "las personas [y los textos] pueden y a menudo participan al mismo tiempo en varias comunidades lingüísticas simultáneamente" (1994: 3-4). Una simple ojeada a los debates en las revistas literarias españolas de los 60 y 70 deja claro que alguien como Vargas Llosa fue en una presencia prominente y un modelo para los jóvenes escritores españoles. ¿Podemos acaso dejar de estudiar su posición en el sistema literario, no sólo su influencia sobre escritores individuales, sino también y sobre todo su contribución al sistema de valores y normas que configuraban las expectativas sobre el arte literario del momento en España? Este Vargas Llosa, tal como era leído y actualizado en la vida literaria española (a diferencia de la presencia efectiva que Vargas Llosa pudiera tener al mismo tiempo en Perú o en Francia) es sin duda un objeto de estudio tan legítimo para la historiografía literaria española como escritores autóctonos como Juan Benet o Juan Goytisolo ${ }^{11}$.

\section{UNA LITERATURA NACIONALIZADA}

La hermenéutica y la teoría de la recepción ponen de manifiesto que los textos deben ser leídos para alcanzar plena existencia, y que esa lectura siempre tiene lugar dentro de un marco de percepción. Cabe imaginar que ese marco depende de condiciones nacionales específicas, en la medida en que está condicionado por un complejo juego de factores socioculturales (tales como la alfabetización, las instituciones de transmisión y conservación del capital intelectual, el funcionamiento del mercado de productos culturales, etc.) que varían de una a otra sociedad. Al mismo tiempo, los objetos (textos, normas, hábitos, valores) que circulan a través de esos canales de

\footnotetext{
${ }^{11}$ El mismo argumento podría aplicarse, por ejemplo, en favor de un Kafka español, ya que el escritor checo adquirió prominencia a mediados de los años 60 como modelo para los jóvenes escritores y sus obras fueron publicadas en populares ediciones de bolsillo (La metamorfosis fue el primer libro de ficción incluido en la colección "El libro de bolsillo" de Alianza Editorial). Rebecca West ha defendido algo semejante a propósito de la recepción norteamericana de Italo Calvino (1987).
} 
comunicación cultural no son sólo los producidos desde dentro de la nación, y no están predeterminados por su centro originario de producción (los españoles leen a García Márquez, los colombianos leen a Cervantes) ni por su lengua original (mediante la traducción, textos de procedencia diversa son apropiados constantemente por diferentes sistemas).

Surge, pues, una dificultad cuando el estudio de literaturas nacionales ha de dar cuenta de la presencia de elementos extranjeros, puesto que hay que contar con una cierta dislocación o desplazamiento:

Se nos presentan especiales problemas metodológicos cuando analizamos la respuesta a una obra en un medio literario foráneo. Incluso la traducción es, en cierto sentido, una actualización efectuada por el traductor. La respuesta a una obra por parte de los lectores y críticos en un medio foráneo es muy frecuentemente bastante distinta de la respuesta a la misma obra en su medio nativo, porque la norma es allí también diferente. (Vodička, 1982: 207).

Ante este tipo de problemas, un recurso común es el intento de relocalizar el texto en su contexto original, y analizar la recepción extranjera en función del mayor o menor grado de distorsión que se produce cuando la lectura tiene lugar fuera del entorno por así decirlo "natural”. Pero mi argumento aquí va encaminado precisamente a sostener que tales actualizaciones extranjeras a menudo proporcionan un instrumento privilegiado para comprender los productos culturales y -lo que es más importante- para analizar el funcionamiento de las literaturas de acogida. Dos sistemas literarios distintos pueden contener elementos comunes -como la intersección de dos configuraciones geométricas- pero la posición de un mismo elemento en relación a uno u otro sistema será diferente, puesto que su concretización final dependerá de la disposición específica de cada entorno.

Sin embargo, identificar el problema no lo resuelve. Si ampliamos el espectro de las literaturas nacionales para incluir cualquier texto -ya sea autóctono o importado- que pueda encontrarse dentro de ellas, ¿no se corre el riesgo de intentar hacer un mapa tan vasto del espacio literario que puede acabar siendo tan inútil o confuso como el espacio mismo? La paradoja cartográfica diseñada por Borges en "Del rigor en la ciencia” podría ser aplicable aquí. David Perkins, por ejemplo, ve difícilmente posible una historia de la recepción que tuviera que dar cuenta no sólo de los intercambios espaciales de obras y valores literarios, sino también de los desplazamientos temporales (en cuyo caso el sistema literario español de los años sesenta debería incluir, por ejemplo, a Cervantes -figura especialmente reivindicada en esos años de distanciamiento del realismo de raigambre picaresca- junto a los ya mencionados Benet, Vargas Llosa o Kafka). Un proyecto de esta índole, dice Perkins, comporta una seria "complicación estructural": "Una historia de la recepción de la literatura inglesa debería contar con Shakespeare en cada periodo desde 1600” (1992: 25). Ahora bien, ¿por qué debemos aceptar que la reiterada presencia de Shakespeare a lo largo de la historia literaria inglesa destruye toda posibilidad de describir y explicar el devenir de esa literatura? Además, sería un error pensar que esa dificultad resulta simplemente de una presencia continua de un determinado autor en el repertorio literario inglés. Porque la reiteración de un determinado nombre - 
Shakespeare, Cervantes...- no implica que el objeto designado permanezca inalterado: el significante puede ser el mismo, pero su significación se ve transformada por los cambios temporales y espaciales (véase al respecto Jan Mukařovský, 1976: 4-6). En otras palabras, el Cervantes que funciona como parte viva del repertorio del siglo XVII no es el mismo que el Cervantes del repertorio del siglo XIX o el de la segunda mitad del siglo XX. Como ha indicado István Sötér a propósito de la literatura húngara, estas transformaciones operan también al nivel interliterario, de manera que "Baudelaire o Dostoievsky pueden ser considerados escritores del siglo XX, porque es entonces cuando son apropiados" y entran a formar parte de la vida literaria húngara (1980: 452).

Se podría objetar que, incluso si es posible encontrar algún tipo de delimitación nacional en las configuraciones de la vida literaria, tiene poco sentido dedicar esfuerzos a elaborar historias literarias nacionales en un momento en que la vida cultural parece encaminarse hacia una creciente globalización que acabaría convirtiendo esas historias en curiosos anacronismos. En mi opinión, sin embargo, sería poco prudente ignorar la influencia que las identidades nacionales tienen en la vida colectiva y por tanto sobre la existencia de la literatura como institución social. Anthony D. Smith ha advertido contra el exceso de optimismo sobre las posibilidades de una cultura global en el mundo contemporáneo, donde el nacionalismo parece mantener su vigencia a pesar del aumento de los intercambios internacionales:

De todas las identidades colectivas que los seres humanos comparten en la actualidad, la identidad nacional es quizás la más fundamental e inclusiva... La identidad nacional no es sólo global, sino también intensa. Aunque su importancia varía de una situación a otra, debe decirse también que interviene en la mayoría de los ámbitos de actividad vital de las personas y comunidades (1991: 143).

La experiencia de la literatura está condicionada no sólo por las condiciones materiales de la economía y el mercado editorial (que ciertamente se ha internacionalizado a medida que las multinacionales ya intervienen en la mayoría de las empresas editoriales de un país), sino también por otros componentes mentales, menos tangibles pero igualmente decisivos, de la vida social: mitos y símbolos, valores y memorias que conforman el patrimonio común de una nación. En este sentido, es importante notar que la entrada de editoriales extranjeras en el mercado de otro país no implica que su oferta sea la misma vaya donde vaya. Sus catálogos se adaptan a la demanda local: la expansión internacional tiene que seguir pagando tributo a las peculiaridades de la vida nacional.

Ya sea nuestro objeto de análisis la literatura de un estado-nación (España o Francia) o la de otro tipo de configuración nacional (el caso de naciones sin estado como Cataluña o el País Vasco, por ejemplo), lo cierto es que la vida cultural de sus ciudadanos va mucho más allá del juego exclusivo de elementos nativos. Podemos ignorar o lamentar la presencia de autores, obras y valores externos, y pretender que no existen dentro de los límites de la cultura nacional, de la misma manera que a veces se oculta que una lengua está llena de préstamos de otras, pero esa posición pertenece más al reino de la fantasía que al pensamiento crítico. Esto, por supuesto, no quiere decir que la confrontación con el imperialismo cultural (que lo hay) no tenga un espacio necesario en los estudios literarios, sino que tal crítica - para que pueda ser realmente efectiva- debe estar basada en un conocimiento más completo 
de las realidades del mundo cultural. Los préstamos literarios no pueden verse simplemente como influencias externas, sino como la respuesta (real, imaginaria, o incluso impuesta) a una necesidad de apropiación. Así pues, yo creo que es mejor entender el espacio literario no como algo nacional, sino nacionalizado (puesto que la pertenencia a este espacio no es una cuestión de esencias, sino resultado de procesos), y esta perspectiva sólo puede alcanzarse distanciándose de concepciones tradicionales sobre las relaciones interliterarias. El estudio de las conexiones entre sistemas literarios tiende a contemplarse como algo que pertenece al ámbito de la literatura comparada, y suele quedar por tanto fuera del campo de estudio de la literatura nacional. Pero esta dicotomía entre lo interno y lo externo está basada en una ficción: la ficción de la existencia de literaturas puramente nacionales.

El estudio de las influencias literarias requiere asimismo un replanteamiento, puesto que tiende a enfatizar la distancia temporal sobre la simultaneidad espacial. Si se concentra en el proceso creativo, el análisis de las influencias queda estrechamente ligado a la historia literaria entendida como genealogía: para establecer que un autor or texto A influye sobre un autor o texto B, debe presuponerse que A antecede y condiciona la producción de B. La perspectiva sistémica, sin embargo, sustituye el carácter unidireccional de la influencia (de A a B) por una interacción más dinámica (de modo que B puede también modificar la concretización de A). En este sentido, EvenZohar ha propuesto hablar de interferencias (en vez de influencias) a la hora de describir los traspasos de un sistema a otro (1978: 93). Por un lado, los préstamos literarios no son resultado de la casualidad, sino que son las condiciones particulares de un sistema las que crean el contexto necesario para que un determinado elemento se convierta en un referente capaz de influir en la vida literaria ${ }^{12}$. Por otro lado, la idea de interferencia enfatiza la dimensión sincrónica de la vida literaria, la extensión espacial donde tiene lugar la heteroglosia. Dentro de un sistema literario, tanto A como B aparecen a disposición del lector e interfieren entre sí. La temporalidad -por ejemplo, determinar si A aparece por primera vez en el siglo XVI y B en el XX-queda redefinida por la espacialidad, por la presencia simultánea en el espacio paratextual (un proceso que Borges ilustró debidamente en "Kafka y sus precursores") ${ }^{13}$.

Debemos, finalmente, cuestionar la tendencia a centrar el estudio comparado de las literaturas en el descubrimiento de paralelismos, de manera que para dar cuenta del impacto de un autor en otra literatura -por ejemplo, el de Gabriel García Márquez en la literatura española- sea necesario buscar en España un libro comparable a Cien años de soledad, y a partir de ahí proceder al análisis de las diferencias y semejanzas entre el "original” importado y su versión "autóctona”. La pregunta realmente importante no es ¿dónde está el García Márquez español?, sino más bien ¿dónde se sitúa el propio García Márquez en la constitución de la experiencia literaria de los lectores españoles? El escritor colombiano es un objeto legítimo, de hecho integral, para la historia literaria de la España de la segunda mitad del siglo XX, puesto que su obra constituye una presencia ineludible en el

\footnotetext{
12 Sobre cómo las ideas de Roman Jakobson sobre los procesos de préstamo lingüístico pueden aplicarse al estudio de la dinámica de los préstamos literarios, véase Galan (1985: 15-16).

${ }^{13}$ El concepto de paratexto proviene de Gérard Genette; para su aplicación a los estudios de recepción, véase Santana (2000: 64-68).
} 
repertorio literario del momento.

Las obras literarias, así como los códigos y valores que nos permiten entenderlas y juzgarlas, son susceptibles de ser nacionalizadas o naturalizadas desde el momento en que son producidas o importadas para su distribución y consumo dentro de un sistema determinado. Las historias literarias nacionales deben renunciar a los derechos de exclusividad sobre sus héroes locales, que en realidad acaban perteneciendo a las comunidades literarias que se los apropian mediante la lectura y reproducción de sus obras, lo cual puede suceder a la vez en diversos contextos, tanto diacrónica como sincrónicamente.

Asumamos, pues, que los préstamos literarios pueden cumplir una función que va más allá de su posible influencia sobre autores individuales; que esos elementos inicialmente foráneos pueden alcanzar una presencia dominante que condiciona no sólo la escritura sino también la mediación cultural y la experiencia literaria (ésta es la situación en que se encuentra la literatura latinoamericana en la España de los sesenta y setenta); que el funcionamiento de la literatura como institución social no depende de su genealogía, sino del horizonte de experiencia configurado por su repertorio. Si esto es así, debemos entonces concluir que las literaturas no pueden definirse exclusivamente en función del espacio (lengua, nación...) en que produce su escritura; las fronteras de una literatura quedan definidas fundamentalmente por el alcance de sus lecturas. 


\section{BIBLIOGRAFÍA}

BaKhtin, Mikhail M., y P. N. Medvedev (1985). The Formal Method in Literary Scholarship: A Critical Introduction to Sociological Poetics. Cambridge: Harvard University Press.

Barral, Carlos. "Puntualización de motivos: enfrentamientos novelísticos de continente a continente". Triunfo 522 (30 septiembre 1972): 36-37.

BARTHES, Roland (1992). On Racine. Berkeley: University of California Press.

BASSEL, Naftoli. "National Literature and Interliterary System”. Poetics Today 12 (1991): 773-79.

Bourdieu, Pierre. "Le champ littéraire”. Actes de la Recherche en Sciences Sociales 89 (1991): $3-46$.

Clausen, Christopher. “'National Literatures' in English: Toward a New Paradigm”. New Literary History 25 (1994): 61-72.

Even-Zohar, Itamar (1978). Papers in Historical Poetics. Tel Aviv: The Porter Institute for Poetics and Semiotics.

Even-Zohar, Itamar. Polysystem Studies. Número especial de Poetics Today 11.1 (1990).

FERnÁNDEZ Retamar (1989), Roberto. Caliban and Other Essays. Minneapolis: University of Minnesota Press.

Fuentes, Carlos (1978). "Discurso de recepción del Premio Rómulo Gallegos". Premio Internacional de Novela Rómulo Gallegos 1972-1976. Discursos de Carlos Fuentes y Luis García Morales. Caracas: Consejo Nacional de Cultura: 11-32.

FuENTES, Carlos (1993). "Mi patria es el idioma español”. Tres discursos para dos aldeas. México: Fondo de Cultura Económica: 29-46.

FuENTES, Carlos, et al. "Mesa redonda: la experiencia de los novelistas". Revista Iberoamericana 116-117 (1981): 307-21.

GaLAN, F. W. (1985) Historic Structures: The Prague School Project, 1928-1946. Austin: University of Texas Press.

García MárQuez, Gabriel. “Gabriel García Márquez. Entrevista de José Domingo”. Ínsula 259 (1968): 6-11.

GeneTte, Gérard (1987). Seuils. París: Seuil.

GimfERRER, Pere. "De una guerra literaria: ¿combatir en dos frentes?”. Destino 1697 (11/04/1970): 41 .

Gugelberger, Georg. “Decolonizing the Canon: Considerations of Third World Literature”. New Literary History 22 (1991): 505-22.

GuILLÉN, Claudio (1993). The Challenge of Comparative Literature. Cambridge: Harvard University Press.

HaWTHORNE, Julian. "The American Element in Fiction". The North American Review 139 (1884): 164-78.

IRVING, Washington (1977). Bracebridge Hall, or The Humorists: A Medley by Geoffrey Crayon, 
Gent. Boston: Twayne.

LAMBERT, José (1991). "In Quest of Literary World Maps”. Interculturality and the Historical Study ofLiterary_Berlin: Erich Schmidt: 133-44.

LEFEVERE, André. “Théorie littéraire et littérature traduite”. Canadian Review of Comparative Literature 9.2 (1982): 137-56.

MARCO, Joaquín, y Jordi GraCia (eds.) (2004). La llegada de los bárbaros: La recepción de la literatura hispanoamericana en España, 1960-1981. Barcelona: Edhasa.

MoretTI, Franco. “Modern European Literature: A Geographical Sketch”. New Left Review 206 (1994): 86-109.

MuKAŘOVSKÝ, Jan (1976). “Art as Semiotic Fact”. Semiotics of Art: Prague School Contributions. Cambridge: MIT Press: 3-9.

MUKAŘOVSKÝ, Jan (1978). “On Structuralism”. Structure, Sign, and Function: Selected Essays by Jan Mukaŕovský, (John Burbank y Peter Steiner, eds.). New Haven: Yale University Press: 3-16.

Nethersole, Reingard (1990). "From Temporality to Spatiality: Changing Concepts in Literary Criticism". Proceedings of the XIIth Congress of the ICLA, (Roger Bauer y Douwe Fokkem, eds). Munich: Iudicium: 59-65.

PerKInS, David (1992). Is Literary History Possible? Baltimore: Johns Hopkins University Press.

Santana, Mario (2000). Foreigners in the Homeland: The Spanish American New Novel in Spain, 1962-1974. Lewisburg: Bucknell University Press.

SCHERBER, Peter (1989). "Literary Life as a Topic of Literary History”. Issues in Slavic Literary and Cultural Theory. (Karl Eimermacher, Peter Grzybek, y Georg Witte, eds.). Bochum: Norbert Brockmeyer: 571-92.

SMITH, Anthony D. (1991). National Identity. London: Penguin.

SÖTÉR, István (1980). “L’application de la méthode comparative a l'histoire d'une littérature nationale". Proceedings of the VIIIth Congress of the ICLA. (Béla Köpeczi y György M. Vajda, eds). Stuttgart: Erich Bieber. Vol. 2: 449-55.

Tola de HABICH, Fernando y GRIEve, Patricia (1971). Los españoles y el boom. Caracas: Tiempo Nuevo.

VALDÉS, Mario J., y Linda HUTCHEON (1994). Rethinking Literary Theory-Comparatively. American Council of Learned Societies.

VAN REES, C. J. "Advances in the Empirical Sociology of Literature and the Arts: The Institutional Approach”. Poetics 12 (1983): 285-310.

VIPPER, Yuri B. "National Literary History in History of World Literature: Theoretical Principles of Treatment”. New Literary History 16 (1985): 545-58.

VODIČKA, Felix (1982). "The Concretization of the Literary Work: Problems of the Reception of Neruda's Works". The Prague School: Selected Writings, 1929-1946. (Peter Steiner, ed.). Austin: University of Texas Press, 1982. 103-34.

VodičKa, Felix (1976). "Response to Verbal Art”. Semiotics of Art: Prague School Contributions. 
(Ladislav Matejka e Irwin R. Titunik, eds.). Cambridge: MIT Press:197-208.

WEST, Rebecca. “L'identità americana di Calvino”. Nuova Corrente 34 (1987): 363-74. 


\title{
AL HILO DE LA LITERATURA LATINOAMERICANA: ESTUDIOS LITERARIOS/ESTUDIOS CULTURALES
}

To the thread of Latin American literature: literary studies / cultural studies

\author{
María Caballero WangüEMERT \\ UNIVERSIDAD DE SEVILLA mcaballero@us.es
}

Catedrática de Literatura Hispanoamericana en la Universidad de Sevilla. Su actividad docente en el Departamento de Filologías Integradas (Literatura Hispanoamericana) se compagina con la investigación. Ha publicado numerosos artículos de investigación, además de libros sobre autores argentinos -Borges, Mújica Láinez, Sarmiento- y puertorriqueños como Hostos y Marqués. Sus actuales investigaciones se centran en la narrativa -memorias, literatura femenina, literatura transatlántica-, el cine y la teoría literaria. Ha sido profesora invitada en Francia, Alemania y San Juan de Puerto Rico, donde acaba de presentar: El Caribe en la encrucijada. La narración puertorriqueña (2014).

Resumen: El presente trabajo constituye un recorrido bibliográfico por la crítica y la teoría literaria hispanoamericana de los últimos 50 años, sin afán de exhaustividad, como tarea colectiva (congresos etc) y personal. Sus hitos más significativos son: cómo se formó y fue derivando el canon literario en Hispanoamérica. Las teorías postcoloniales y su aplicación al Nuevo Mundo. Las orientaciones de la crítica y la teoría literaria en / sobre Latinoamérica. La irrupción y pervivencia de los estudios culturales. Nuevas modas críticas: estudios transatlánticos, tecno escritura, ecocrítica, crítica genética...

PALABRAS ClaVE: canon, crítica literaria, teoría literaria, teorías postcoloniales, estudios culturales.
ABSTRACT: The present work constitutes a bibliographical route by the criticism and the Hispano-American literary theory of the last 50 years. Its author did not pretendan exhaustiveness, but a collective task of congresses etc. Its most significant milestones are: how the literary canon was formed and was derived in Spanish America. Postcolonial theories and their application to the New World. The orientations of the critic and the literary theory in / on Latin America. The irruption and survival of cultural studies. New critical fads: transatlantic studies, tecno writing, ecocritics, genetic criticism ...

KEYWORDS: Canon, literary criticism, literary theory, postcolonial theories, cultural studies. 
Este juego divino que es la literatura lanza sus olas, retumbando, hasta los acantilados del yo, y a veces lo socava, o quema para siempre su víctima (...). Este juego divino busca una satisfacción ilimitada, un desquite contra lo físico. Quiere empujar fronteras del alma y del lenguaje. Se revuelve entonces y se castiga, purgándose a sí mismo. Unos lo han llamado estallido; otros, purificación; y los antiguos, catharsis. La emoción que expresa o que comunica lleva disueltas todas las pasiones, todos los anhelos, todas las reivindicaciones contra el pequeño suceder cotidiano (...). Emoción de vitalidad, de sentimiento, de belleza y de inteligencia van graduándose en el desarrollo hacia el arte (Reyes, 2005: 34).

La cita de Alfonso Reyes que elijo para abrir el trabajo me sirve para evaluar distancias entre la tradicional concepción de "ese juego divino" y las cuestiones que afloran en el debate actual. Siempre se dijo que la literatura utiliza la lengua como instrumento propio, de un modo específico: "la literatura existe en tanto que es esfuerzo para decir lo que no dice ni puede decir el lenguaje ordinario. Si significara lo mismo que el lenguaje ordinario, la literatura no tendría razón de ser" apuntó en su momento Todorov (1971: 15)-. Con todo, desde que Jakobson propusiera la literariedad como objeto de la ciencia literaria, la crítica dio vueltas en torno a un asunto bastante resbaladizo. Las dudas surgidas en el seno mismo del estructuralismo y el posterior desarrollo de los estudios semióticos, deconstruccionistas y de la teoría de la recepción entre otros, marcaron la denominada crisis de la literariedad. La especificidad del lenguaje literario como determinante de la literariedad fue puesta en entredicho, al tiempo que se subrayaba el papel del lector. Los planteamientos postmodernos en el marco de la cultura de masas aceleraron un proceso vertiginoso, a años luz de presupuestos todavía válidos a comienzos del pasado siglo.

Por otra parte, en los noventa y espoleada por el libro de Bloom, The Western Canon (1994) explotó con virulencia la polémica en torno al canon occidental, reseñada entre otros por Pozuelo Yvancos y Aradra Sánchez en su libro del 2000. Seminarios que cuajaron en libros como Canon y poder en América Latina, editado por Christian Wentzlaff-Eggebert y Martin Traine (2000); o números de revista, como el de Iberoamericana, compilado por José Manuel López de Abiada y Waldo Pérez Cino (2006) demostraron el interés y la fecundidad de un asunto peliaguado, siempre abierto y con muchos filos. Más allá del canon "con mayúsculas” cuyos componentes aspiran al parnaso de los clásicos, que soportan la relectura o la prueba del comentario, se habla de canon como valor de uso pragmático y provisorio, apoyado en agentes culturales -historias literarias, academia, premios...-. "Lo canónico se enlaza con la lectura y con la historia de sus concreciones históricas, de tal forma que cada país tiene su propio canon, al mismo tiempo que podemos hablar de un canon común” (Zavala 1998: 35). Así no es de extrañar que, históricamente la configuración de un canon se preste a manipulaciones.

Con estas palabras de introducción, en absoluto pretendo reabrir la polémica, sino terciar puntualmente y con la inevitable modestia en asunto tan espinoso; y ello por cuanto interactúa con los avatares de/sobre la crítica y teoría literaria hispanoamericana en el cambio de siglo. Como ya estudié en otro lugar (Caballero 1998 y Caballero Wangüemert 2000), el tradicional canon literario del Nuevo Mundo fue resquebrajándose desde los ochenta del siglo pasado, en función de una serie de 
binarismos que, a su vez, transparentaban el esfuerzo por rescatar la voz del otro -léase indio, negro, mujer, gay...-. Las consecuencias no se hicieron esperar.

\section{UN DEBATE INABARCABLE: LAS TEORÍAS POSTCOLONIALES Y SU APLICACIÓN A LATINOAMÉRICA}

Es este un asunto que me interesó desde antiguo, por lo que aprovecho aquí parte de mi trabajo anterior (Caballero 2010). Por cronología, la polémica en torno al canon literario se superpuso a los debates acerca de la postmodernidad, en cuyo origen está la crisis, la incredulidad ante los grandes relatos, la descentralización del gran discurso, de la gran historia, de la verdad... cuestiones ya señaladas por Lyotard, Vattimo, Deleuze, Derrida, Baudrillard y otros. Esa pluricodificación subsiguiente de la postmodernidad tiene una serie de rasgos bien conocidos -deconstrucción, collage, metadiscurso lúdico, diseminación, interculturalidad, intertextualidad...- suficientemente explorados por la crítica en las últimas décadas.

En ese marco, la crítica dio vueltas una y otra vez a un dilema: ¿cómo puede hablarse de postmodernidad en Latinoamérica si nunca alcanzó una modernidad, en el sentido occidental, europeo, de la palabra? (Herlinghaus/Walter 1994). ¿Será oportuno hablar de “modernidad periférica" (Sarlo 1988, Brunner 1988, Martín-Barbero 1987...) lo que eufemísticamente recubre la idea de retraso para el Nuevo Mundo? Desde el lado europeo, Alfonso de Toro entró también en el debate reconociendo que la postmodernidad tuvo su origen fuera del continente americano aunque, inmediatamente y como contrapunto señala: "Latinoamérica ha sido siempre transcultural, híbrida (... y) antes de la teoría postmoderna en Latinoamérica (que es de fecha muy reciente) se produjeron manifestaciones culturales postmodernas" (A. de Toro 1997: 27). En ese sentido, la postcolonialidad como categoría epistemológica tiene su lugar en la cultura postmoderna y se entiende como reescritura del discurso del centro en el que brilla por méritos propios el argentino Borges, uno de sus primeros representantes trasatlánticos. La postcolonialidad es un proceso, una red de discursos de

descentramiento semiótico-epistemológico y de una reapropiación de los discursos del centro y de la periferia y de su implantación recodificada a través de su inclusión en un nuevo contexto y paradigma histórico (A. de Toro 1999: 34).

Frente a los viejos esencialismos derivados de la búsqueda de identidad -el discurso identitario queda obsoleto-, frente al binarismo manejado en tono maniqueo desde las metrópolis, frente a la Otredad como categoría excluyente... se produce un descentramiento: la hibridez, el nomadismo serán los nuevos parámetros en el enfoque postcolonial, la nueva estrategia discursiva transdisciplinaria. Autores "de entremedio" como Said, Spivak y Bhabha hablan desde el centro sobre la periferia de donde provienen, deconstruyendo ese mismo centro y recodificándolo en un nuevo contexto. Y teóricos de la cultura latinoamericana como Brunner, García Canclini o Martín-Barbero... "escriben el mundo inscribiéndose a través de una escritura de la diferancia, una escritura mímicra o rizomática, de entremedio, en una estrategia metonímica de la presencia" (A. de Toro 1999: 44-45), términos que remiten a Lacan, Derrida y Deleuze, en gran medida utilizados por Bhabha. 
Ahora bien, el problema central parece ser el de los loci de la enunciación, como vieron Mignolo, Martín-Barbero y otros, es decir “desde dónde se habla”. Punto flaco -según algunos- de todo la teoría postcolonial. Tal vez sea Castro-Gómez (1999: 79-100) uno de los más críticos al reseñar la incapacidad de los estudios subalternos para representar su propio lugar de enunciación y reclamar, junto a Mignolo, investigaciones que determinen qué tipo de sensibilidades locales hicieron posible el surgimiento de las teorías postcoloniales en Latinoamérica: porque... "fue constituida como objeto del saber desde las mismas sociedades latinoamericanas a partir de metodologías como el enciclopedismo ilustrado, el romanticismo utópico, el positivismo, la hermeneútica, el marxismo, el estructuralismo y los estudios culturales" (Castro-Gómez 1999: 96). Frente a las narrativas "esencialistas, sujetas todavía a las epistemologías coloniales que ocultan las hibridaciones culturales, los espacios mixtos y las identidades transversas" -en palabras de Spivak- (Castro-Gómez 1999: 83), habría que apostar por un nuevo latinoamericanismo cercano a Anzaldúa, es decir, asentado en los Borderlands, espacios intermedios, los cruces fronterizos de orden epistémico-cultural que caracterizan el imaginario de los inmigrantes latinoamericanos en los Estados Unidos. Es la tesis de Moreiras, corroborada por Castro-Gómez si bien con reticencias (1999: 89). Porque para este crítico, la modernidad no fue un proceso regional sino mundial que

se constituye como resultado de la expansión colonialista de Occidente y la configuración de una red global de interacciones (... habría entonces que) entender la modernidad como un proceso des-re-territorializador de la vida social que nos permitiría superar la visión fatalista de la globalización que presentan los estudios subalternos y comprenderla como un fenómeno dialéctico en el que se combinan la homogeneización (desanclaje) y la liberación de las diferencias (reanclaje) (Castro-Gómez 1999: 94-95)

\section{CRÍTICA Y TEORÍA EN/SOBRE LATINOAMÉRICA: ESTUDIOS LITERARIOS/ESTUDIOS CULTURALES}

Pero no adelantemos acontecimientos. Las opiniones que acabo de citar en boca de Alfonso de Toro, Santiago Castro-Gómez y otros prueban cómo estos latinoamericanos, que trabajan en Europa, tienden una mirada trasatlántica sobre el Nuevo Mundo para terciar en un debate que les atañe. Y lo hacen al hilo de la crítica, el ensayo y la teoría literaria, tres fecundas vertientes sin fronteras nítidas: entre la simple reseña y la gran especulación teórica proyectada sobre el referente americano se despliegan infinitas variantes, que vienen afectando a gran parte de los latinoamericanistas. ¿Quién se atrevería a negar hoy que los textos de Rama o Cornejo Polar han diseñado una teoría de América Latina, en términos globalizadores? 
La crítica en y sobre Latinoamérica en el siglo XX fue en su inicio deudora de tendencias y metodologías del Viejo Mundo: estructuralismos, historicismo, estilística, feminismos... Pero su pléyade de intelectuales rápidamente la contextualizó: revoluciones, dictaduras, el retorno a las raíces de la vanguardia, la poesía social, la literatura fantástica, el realismo mágico, el testimonio y la revisión de la historia... Todo ello afectó a la naciente y poco frecuentada teoría literaria cuyos puntales son $E l$ deslinde. Prolegómenos a la teoría literaria (1944), de Alfonso Reyes y Para una teoría de la literatura hispanoamericana (1975), de Fernández Retamar. Cuestión suficientemente estudiada y en la que no entraré ahora. Aunque sí diré que la mayoría de los críticos concuerdan con lo expresado por Raúl Bueno:

La anhelada teoría de la literatura latinoamericana la están produciendo mayormente la crítica y la historia literarias latinoamericanas, por medio de los dispositivos que ellas mismas se procuran ante la demanda de fidelidad y rigor que le hacen las literaturas de que se ocupan; demanda de nuevos conceptos, categorías y modelos que representen y expliquen con exhaustividad, con certeza, los singulares fenómenos y objetos literarios de los que se hacen cargo (Bueno 1989: 301).

Imposible reseñar la crítica de y sobre Latinoamérica: abruma la marea bibliográfica, así como la falta de distancia cronológica para tentar posibles valoraciones. A lo que se añade la diversificación de enfoques, producto de la mayoría de edad de una literatura que ha generado su propia crítica. Aun así, me gustaría hacer un comentario al hilo de congresos y números monográficos de revistas de los últimos años, una cala a partir de 1990, que incluya algunos libros emblemáticos. Y lo haré con una finalidad: mostrar cómo el maniqueísmo inherente a planteamientos binaristas -rescatar la voz del otro, el marginal...--ha dado paso en el marco de la postmodernidad y por obra y gracia tanto de teóricos postcolonialistas -Bhabha, Said, Spivak-, como del postestructuralismo y la semiótica trasplantados a Norteamérica -Foucault, Lacan, Derrida, Deleuze...- a posiciones más complejas, caracterizadas por la hibridez y la des/reterritorialización donde los sujetos se mueven en el entre. Ya no es posible sustentar con honradez los viejos debates que oponían los estudios culturales (Estados Unidos) a la crítica nacida en Latinoamérica. Las cuestiones son mucho más complejas porque, como ya se adelantó, el canon norteamericano de la postmodernidad/postcolonialidad ha sido generado en gran medida por los subalternos procedentes de las colonias (India, Latinoamérica...), que se instalaron en universidades americanas. A ello se añade la mirada trasatlántica -Rincón, A. de Toro, Herlinghaus...- siempre atenta a las cuestiones teóricas.

Vamos a los datos. Comenzaré por aludir a las actas del coloquio organizado en Darmouth por Beatriz Pastor y Raúl Bueno en el 89, que se publicaron en la Revista de Crítica Literaria Latinoamericana en 1990-91 y dan cuenta del interés por el tema al evaluar quince años de crítica literaria en Latinoamérica. Importa también el volumen de la misma revista que recoge el II Encuentro latinoamericano en Berkeley, así como el de Nuevo Texto Crítico correspondiente a 1995, es decir, las ponencias del coloquio celebrado en Berlín en noviembre del 91. Bajo el título: Celebraciones y lecturas: La crítica literaria en Latinoamérica se discutieron los caminos de esa crítica a partir de 
1945.

En este último, se reflejan una serie de procesos nuevos que impelen a renovar el concepto hegemónico de lo literario, ya no identificado con lo escrito y culto. En consecuencia, se discute la fiabilidad del canon: las esencias culturales no son representadas por el modelo tradicional, sino creadas y mantenidas por él. Para superar las ideas de homogeneidad, totalidad, continuidad y especificidad se insiste en que la crítica literaria sea crítica cultural. Esta necesidad de redefinir la crítica se manifiesta en el proceso de cambio de paradigmas. Ahora se incide en las obras que muestran dinámicas de desterritorialización, procesos de hibridación cultural o la oralidad subterránea de las nuevas culturas urbanas del subcontinente. Asimismo se habla de las condiciones de producción del conocimiento: el lugar, el momento y la coyuntura en que los textos se plantean o silencian. La discutida cuestión de la identidad aparece en las ciencias humanas, no como una esencia intemporal que se expresa, sino como una construcción imaginaria que se relata.

Interesante el número de la Revista Iberoamericana con sede en Pittsburgh -Crítica culturaly teoría literaria latinoamericanas - coordinado por Mabel Moraña, quien presenta el volumen considerándolo:

...como una exploración de algunos de los tópicos más importantes que guían los debates actuales sobre la producción cultural y particularmente literaria de América Latina. Dichos debates se enfocan sobre todo en la revisión de parámetros teóricos, métodos de aproximación historiográfica y cuestiones ideológicas replanteadas dentro del marco de los cambios que vienen produciéndose en la disciplina y en el más amplio marco de las ciencias sociales en las últimas décadas (Moraña 1996: 675).

El esfuerzo realizado es representativo. Literatura y sociedad siempre estuvieron en contacto en el Nuevo Mundo. El auge de la sociología y la crítica marxista durante más de cincuenta años en el siglo veinte lo confirman. Aunque la reorganización sociopolítica de fin de siglo -caída del muro de Berlín y neoliberalismo como puntas de iceberg- lleve aparejada una revisión cultural que afecta a todo el universo. Porque universales fueron los fenómenos que se iban sucediendo: la expansión de la cultura mass-media, el derrumbe del socialismo internacional, el resurgimiento de los nacionalismos étnico-religiosos con sangrantes confrontaciones; el impacto en las grandes ciudades de las interminables olas migratorias que la lógica de mercado incrementaba. El fenómeno de la globalización hizo impensable que la literatura del Nuevo Mundo quedara al margen. Este volumen de la Revista Iberoamericana es un ejemplo del estado de la cuestión. Los trabajos se aglutinan en tres grandes bloques: 1. Estudios culturales latinoamericanos: nuevas cartografías; 2. Género y políticas de la representación en Latinoamérica; 3. Poscolonialismo/ Subalternismo/ Heterogeneidad/ Posmodernidad.

A nadie le extraña hoy comprobar que la sacralidad de la literatura del romanticismo hacia aquí y la concepción de la escritura como arma solidaria con los países latinoamericanos en autores del continente, marcados por el exilio interior o exterior de los sesenta/setenta, fueran sustituidas por un clima de escepticismo postmoderno. El fenómeno fue denunciado, entre otros, por Hernán Vidal en su libro Crítica literaria como defensa de los derechos humanos (1994). A su vez y simplificando 
mucho, esa postmodernidad que en Europa tuvo sus valedores en Lyotard y Vattimo, en Norteamérica cuajó en una línea más cercana a la crítica lingüística, representada por De Mann y los deconstructivistas. Los ochenta estuvieron signados por una auténtica avalancha bibliográfica en esta línea. Y los noventa acuñaron un nuevo término para un concepto más abarcador: el postcolonialismo, que ya no se define en términos lingüísticos, ni siquiera literarios, sino que supone una mirada mucho más radical sobre la cultura de los países hispanos. Está en las antípodas de la teoría de la dependencia y de la transculturación tal como lo definiera Rama. Echa por tierra las periodizacionas habituales en la historia de la literatura y obliga a empezar de nuevo desde parámetros conceptuales muy distintos.

Los tres grandes apartados, en que se dividen los trabajos recogidos en el volumen de la Revista Iberoamericana que señalo, están interrelacionados: los estudios culturales están engendrando nuevas cartografías en todo el mundo, y Latinoamérica en absoluto es una excepción. Los análisis de Román de la Campa sobre este asunto me parecen excepcionalmente lúcidos. Me refiero a "Latinoamérica y sus nuevos cartógrafos: discurso poscolonial, diásporas, intelectuales y enunciación fronteriza” donde, tras recordar el consabido influjo de Foucault, Derrida y Paul de Man en la teoría postmoderna, intenta delimitar esa cartografía postcolonial, procedente pero no identificada con la postmodernidad. Como ya se sabe, sus padres fueron Said, Spivak y Bhabha y su mejor cultor e intérprete Walter Mignolo. La reflexión iniciada en el Grupo Latinoamericano de Estudios Subalternos (GLES) -al que pertenecen el mismo Mignolo, Milagros López, J. Ramos, Patricia Seed, Norma Alarcón y J. Beverley- puede servir de puente entre postmodernidad y postcolonialismo.

El feminismo y ciertos trabajos en torno al género, que sufrieron un boom hace ya años en los Estados Unidos, impulsaron un postcolonialismo difícil de definir pero centro del debate en la crítica y la teoría de la literatura latinoamericana, muy anclada en los estudios culturales. El abanico de ramificaciones de estos últimos es impresionante: mediáticos (Martín-Barbero), sociológicos (Ortíz, Lechner), antropológicos (Mato), marxistas (Dussel, Quijano), sobre culturas populares (García Canclini), filosóficos (Castro-Gómez), estéticos (Nelly Richard), intelectuales y literarios (Rama, Sarlo, Santiago, Ramos, Schwarz), feministas (Costa, Lamas)... Además hay varios trabajos que perfilan cánones y contra cánones, por ejemplo los de Yúdice, Moraña, Reynoso, Beverly, Mato o Castro-Gómez. En el congreso de LASA del 2001 se debatieron cuestiones como el fin de la alianza de los estudios culturales, los resquemores ante su institucionalización en los departamentos de letras, estudios de área o estudios étnicos de los Estados Unidos; y la subsiguiente imposición al mundo latinoamericano cuya realidad no tiene tanto que ver con los paradigmas teóricos diseñados. Todo ello en un marco más amplio, de carácter mundial, donde Beverley ha venido importando de la India los estudios subalternos, o Mignolo toma como paradigma para el estudio de lo latinoamericano el pensamiento fronterizo o border thinking, derivado de los intelectuales chicanos.

Tres años antes -marzo del 98-, la incansable Mabel Moraña había organizado en Pittsburgh un nuevo simposio para seguir discutiendo estos asuntos. Las actas correspondientes -Nuevas perspectivas desde/sobre América Latina. El desafío de los estudios culturales (2000)- proponen una 
mirada conjunta tras hacerse eco, una vez más, de los desencuentros entre las reflexiones surgidas desde América Latina y las planteadas sobre ella desde Estados Unidos. El volumen consta de ocho secciones: globalización y multiculturalismo (García Canclini, Martín-Barbero, Ortíz), estudios culturales (Rincón, Román de la Campa, Herlinghaus), crítica, ideología y estudios culturales (Vidal, Kaliman, Moreiras), memoria y territorialidad (Franco, Ramos, Richard, Moraña), márgenes sociales, género, ciudadanía (Debra Castillo, Zimmerman), intelectuales, esfera pública y políticas culturales (Sarlo, Achugar), culturalismo y crítica del canon (Antelo, Castro-Klaren), saberes locales, movimientos sociales y construcción de sujetos (Ileana Rodríguez, William Rowe, Harrison). Los temas y autores dan la pauta de por dónde van los tiros en el debate crítico internacional: conceptos como "identidad" que la globalización ataca, están necesitados de una redefinición en términos no esencialistas. Por otra parte, la creciente importancia del pensamiento virtual mueve a plantear un asunto como la autoría, que nunca se configura independientemente del lugar desde donde se escribe o habla. Y se anatematiza la figura del letrado criollo - por letrado y por criollo- ejemplificada en los grandes ensayistas: Henríquez Ureña y Reyes, pero también Rama y Cornejo Polar, cuya muerte marcaría simbólicamente el fin de todo un linaje intelectual.

Así se fueron encrespando las tensiones entre academia norteamericana y países latinos: los primeros giran más hacia las humanidades, los otros se centran en lo social. En Estados Unidos se privilegia el postcolonianismo o la subalternidad, en Latinoamérica la transculturación o reconversiones culturales de tipo antropológico. Los medios son muy distintos y las metodologías también. Lo curioso es que surgieron críticas desde la misma academia, como la de Said:

La universidad norteamericana, con su munificencia, su utópica calidad de refugio y su destacada diversidad, ha defendido a los intelectuales (literatos, filósofos o especialistas en Historia) cuyas responsabilidades suponen valores y principios. Sus estilos se han visto dominados por unas jergas que producen una repugnancia casi inimaginable. Los cultos del posmodernismo, del análisis del discurso, del Nuevo Historicismo, de la ideología de la deconstrucción o del neopragmatismo los llevan a posiciones conservadoras (Said 1996: 466-7).

Entre paréntesis, habría que comentar que él mismo ha sido fruto de la academia y parte de las jergas. Lo propio sucede con García Canclini considerado por muchos como niño bonito de los estudios culturales, un oportunista aupado por el sistema. Aun así, como crítico radicado en México, se permite un irónico muestrario de los desencuentros con el mundo anglo en su artículo "La épica de la globalización y el melodrama de la interculturalidad”. Allí escenifica un diálogo entre un experto en Cultural Studies y un antropólogo hispanoamericano. Ambos funcionan con esencialismos implícitos, focalizando al otro como tal sin advertir que:

...los estudios culturales existían en América Latina desde hacía varias décadas, aunque no llevaran ese nombre, y que las búsquedas transdisciplinarias, el estudio de la multiculturalidad y sus vínculos con el poder tenían formatos distintos que en Estados Unidos, y a la vez diferentes en México o Perú, donde lo intercultural pasa en gran parte por la presencia indígena, o en el Caribe, donde es central lo afroamericano, o en el Río de la Plata, en que el predominio de la cultura europea simuló una homogeneidad blanca. Cuando se pregunta 
quiénes son nuestros otros, la respuesta no es la misma en toda América Latina, ni en todo Estados Unidos (García Canclini 2000: 38).

Son evidentes las fisuras, incluso el malestar hacia los estudios culturales a fines del siglo XX. Precisamente el número 197 de la Revista Iberoamericana coordinado por Daroqui y Cróquer desde la universidad Simón Bolívar de Caracas llevaba por título Mercado, editoriales y difusión de discursos culturales en América Latina. El volumen subraya cómo la intrínseca relación de la literatura con los medios condiciona la recepción, es decir, los modos de lectura de un lector hipertextual asediado por un aluvión de imágenes, sonidos, textos y estímulos. El artículo de Gisela Kozak Rivero, “¿Adónde va la literatura? La escritura, la lectura y la crítica entre la galaxia Gütemberg y la galaxia electrónica” analiza el cambio de rol sociocultural de la literatura en los últimos años: "la caída de la posición del escritor como conciencia crítica de la sociedad, las nuevas tecnologías y los afanes antiestéticos de los Estudios Culturales no han pasado en balde" -dice (Kozak Rivero 2001: 693)-. Pero lo interesante viene a continuación, al hilo de una serie de comentarios a Sarlo, Martín-Barbero y otros:

Vemos dos cambios básicos respecto a los debates anteriores sobre la crítica literaria latinoamericana. El primero atañe al objeto mismo de estudio: hasta las últimas décadas estaba perfectamente claro que la crítica tenía un objeto de importancia central en la cultura, la producción literaria. Lo que había que discutir eran los enfoques teóricos, metodológicos e ideológicos desde los cuales se debía enfrentar el análisis de dicho objeto. Ahora el objeto y la idea de un enfoque teórico-metodológico coherente son los blancos mismos de la discusión. En este sentido, el latinoamericanismo ha sufrido un vuelco al tener que orientarse por derroteros esencialmente distintos a los que le eran propios: la nación, las diferenciaciones entre alta cultura, cultura popular y cultura de masas, la literatura, los proyectos educativos han sido objeto de un radical replanteamiento (Kozak Rivero 2001: 696-7).

Por supuesto los críticos huyen de términos como "esteticismo" o "esencialidad" y la polémica sobre el canon tuvo mucho que ver con eso. Lo que hay detrás, según algunos, es el temor a una cierta idea del hombre que arranca del humanismo. En último término, lo que los estudios culturales combatieron fue su legitimidad; pero, a su vez, hay muchas reticencias hacia ellos. Reticencias que cuajaron en un volumen de Nuevo Texto Crítico (2000-2001), coordinado por Bergero y Ruffinelli, cuyo título es transparente: Estudios literarios/estudios culturales. Veintiún críticos responden, de modo personal y creativo, a un cuestionario de los editores que se plantean cómo pensar el debate desde otras geografías u otros ángulos, por supuesto trasatlánticos. Los más aguerridos atacan directamente el problema (Antelo, Jitrik, Morales, Sarlo, Richard). Un pequeño grupo (Monleón, A. del Sarto, Young, Vidal, Zimmermann) da cuenta del estado de la cuestión en la academia norteamericana. Por fin, los teóricos consagrados se arriesgan con especulaciones más osadas, profundizando en propuestas anteriores (Pizarro, Trigo, A. de Toro, Franco, García Canclini, R. de la Campa, Ríos). El resultado es un volumen interesante por lo crítico -en el doble sentido del término- y por la preocupación de reabrir un diálogo con la literatura. Así Bergero se pregunta "cuáles serían los puentes para pensar de nuevo la literatura a partir de los aportes de las diferentes puertas de acceso ofrecidas por los estudios culturales" (Bergero 2000-2001: 17).

Los hay muy críticos: tal vez los estudios culturales acabaron con la literatura. Por ejemplo, 
Sarlo teme que sea "deglutida" por el flujo de lo cultural y opina se debería "relocalizar" la especificidad de la crítica literaria y los valores estéticos. Jitrik distingue claramente la literatura de los estudios culturales y opina que:

Los estudios culturales han logrado derrotar las vieja idea de las bellas artes e, incluso, la más moderna, que tanto preocupó a gente como Paul Valéry, de un discurso específico y diferenciado, en cuyas claves y misterios -porque el lenguaje de la literatura es misterioso en su consistencia y en lo que produce- siempre se trata de indagar (Jitrik 2000-1: 104).

Monleón constata que en la academia estadounidense todo vale igual:

Cuando la literatura era concebida como el lugar privilegiado de la cultura, cuando no su máxime y única expresión nacional, este forzoso camino tenía una cierta coherencia epistémica; con el arribo de los estudios culturales, el paradigma se modifica sustancialmente y un periódico, un libro de historia, un concurso televisivo o una antología de anuncios publicitarios tiene tanta o más validez que El Cid campeador o El matadero (Monleón 2000-1: 115).

La actualidad del tema en nuestro mundo postmoderno se pone de manifiesto en mil publicaciones, hasta el punto de que la Revista Iberoamericana volverá a dedicarle un número monográfico en el 2003: Los estudios culturales latinoamericanos hacia el siglo XXI, coordinado por Alicia Ríos, Ana del Sarto y Abel Trigo. Un número denso en su aparente brevedad, en el que críticos como Castro-Gómez se encargan de poner en su lugar los estudios culturales al hilo de lo que, en su caso, pretende ser una extensa reseña al libro de Carlos Reynoso, Apogeo y decadencia de los estudios culturales. El boom editorial de los Cultural Studies parece más que demostrado ateniéndose a las bases de datos (WorldCat y ERIC): entre 1996 y 98 se registran más de 654 títulos. Pero ¿qué aportan realmente esos estudios? Castro-Gómez es muy duro al respecto:

Para legitimar de algún modo su fachada científica, los estudios culturales se apropian de teorías y métodos provenientes de la antropología, la sociología, la lingüística, la crítica literaria, la filosofía y la ciencia política. Pero con toda esta materia prima lo único que logran coser es una monstruosa colcha de retazos, desprovista de la más mínima rigurosidad metodológica. Y lo que es peor: la debilidad teórica pretende ocultarse bajo la pirotecnia de lenguaje y la sofisticación retórica (Castro-Gómez 2003: 345).

En consecuencia, critica agriamente a Spivak y García Canclini. En realidad, es lógico que no se primen los conocimientos en una materia que sólo atiende a su dimensión política para transformar el mundo, acorde a su origen inglés anclado en facultades de ciencias sociales. Castro-Gómez concluye que precisamente su debilidad teórica tiene mucho que ver con el tránsito hacia Estados Unidos de los estudios culturales: se abandona el marxismo y estructuralismo de corte althusseriano y se produce un acercamiento a Derrida, Lyotard, Deleuze y Baudrillard al inscribirse ahora en las facultades de humanidades. Es decir, "se empiezan a distanciar del rigor analítico de las ciencias sociales y adquieren un perfil más textualista, no muy interesado en el control empírico y metodológico de sus afirmaciones” (Castro-Gómez 2003: 346). 
Hay que asumir, entonces, el cambio cualitativo del estatuto cultural en el marco globalizador; cambio que implica "desterritorializar" y "destradicionalizar”. De modo que la cultura ya no es más propiedad de antropologías, sociologías ni humanidades; es sólo el espacio de articulación entre diversas disciplinas, un área de conocimiento común desde la que abordar otras formas de producción de conocimientos para comunicarse con ellas; un campo transdisciplinario en el que se estudian los fenómenos que desbordan a cada una de ellas. Y concluye: "la cultura que estudian los estudios culturales tiene menos que ver con los artefactos culturales en sí mismos (textos, obras de arte, mitos, valores, costumbres, etc) que con los procesos sociales de producción, distribución y recepción de esos artefactos" (Castro-Gómez 2003: 351).

En Estados Unidos el hipertexto, en franca dependencia de amplias redes informáticas, hibrida sonidos, imágenes y textos escritos. Salta a la palestra un nuevo tipo de profesional, cuyo saber es más fragmentario, aun cuando sepa rentabilizarlo con una gran versatilidad creativa. Está muy cerca de la cultura tecnomediática, que genera una nueva ciudadanía y un nuevo espacio público en medio de megacorporaciones con capacidad de control de la opinión pública mundial; hasta el punto de que Martín-Barbero acuña un nuevo sintagma para definir la interculturalidad en que vivimos: raíces en movimiento... "una de las realidades más fecundamente desconcertantes del mundo que habitamos: como afirma el antropólogo catalán Delgado, sin raíces no se puede vivir pero muchas raíces impiden caminar. Así la diversidad cultural se hace interculturalidad en los territorios y las memorias; pero también desde las redes la diversidad resiste, enfrenta e interactúa con la globalización (...) que exaspera y alucina a las identidades básicas” (Martín-Barbero 2003: 374). La identidad narrativa, tradicionalmente aferrada a una geografía, se debilita desde el marco multicultural generando una fiebre de memoria, y el vacío de utopías se rellena con la utopía tecnológica, en absoluto neutra. A consecuencia de todo ello, surge un nuevo tipo de textualidad que cuestiona la noción misma de lectura:

Nos hallamos también ante un tipo de textualidad que no se agota en el computador; el texto electrónico se despliega en una multiplicidad de soportes y escrituras que, de la televisión al videoclip y del multimedia a los videojuegos, encuentran una compleja y creciente complicidad entre la oralidad y la visualidad de los más jóvenes (Martín-Barbero 2003: 383). 
¿Respuestas? La transdisciplinariedad sería la única respuesta de la globalización a la crisis del conocimiento moderno. Mato lo plantea así en su trabajo "Prácticas intertextuales latinoamericanas en cultura y poder. Sobre la entrada en escena de la idea de Estudios Culturales Latinoamericanos en un campo de prácticas más amplio, transdisciplinario, crítico y contextualmente referido". Transcribo el larguísimo título porque apunta al problema de los estudios culturales: el referente cada vez es más amplio, se desdibuja más. Todavía peor: se está configurando un nuevo canon desde este campo, básicamente en inglés -se escriba donde se escriba- y que, producido en el contexto de las instituciones académicas de Estados Unidos, se legitima en los estudios de posgrado y se difunde a través de editoriales. Ello abre una fisura cada vez mayor con la crítica que se ejerce en universidades latinoamericanas, con menos medios y realidades muy distintas. Mato llama la atención sobre un fenómeno que considera político: lo que se mueven son relaciones de poder. El resultado afecta al canon:

El caso es que, dadas esas relaciones transnacionales de carácter jerárquico y que involucran relaciones de poder, el canon y/o los paradigmas de qué son y qué no son los CS, e incluso los LACS, cuáles orientaciones de trabajo (éticas, epistemológicas y políticas) son incluidas (y cuáles no) en la conformación del campo, se forma en buena medida en Estados Unidos y/o en el contexto de relaciones de diversa índole con la academia estadounidense, la cual ha canonizado particularmente algunas obras de Martín-Barbero y de García Canclini (Mato 2003: 392).

Nelly Richard arremete contra la especialización y apuesta por... "ensamblar el localismo del fragmento y el pluralismo de lo híbrido en una nueva performatividad de lo combinatorio" (Richard 2003: 442), aun reconociendo que a veces se hilvana una suma de elementos tan discontinua como abarcadora, lo que produce un cierto caos, justificado por la productividad de los intercambios profesionales. No obstante, no todas las disciplinas deben estar al mismo nivel -dice- y concuerda con Beatriz Sarlo en que... "una cultura humanística puede ser defendida como necesidad y no como lujo de la civilización científico-técnica” (Sarlo 1994: 196). Ante la alarmante pobreza epistemológica de los estudios culturales se atreve a reclamar el rescate de la dimensión críticoestética de la cultura. De hecho, en su propia crítica se ha movido entre el arte y la literatura, si bien desde el concepto de marginalidad, categoría discursiva que se convierte en plataforma de reflexión creadora, tanto de su ejercicio crítico como del arte sobre el que se vierte. En la década del setenta publicó Márgenes e instituciones. Arte en Chile desde 1973 donde toma como punto de referencia las búsquedas estéticas de los artistas de avanzada, muy comprometidos con la política, y marginales incluso dentro de sus países.

\section{LA PERVIVENCIA DE LOS ESTUDIOS CULTURALES}

Estaría fuera de lugar reseñar todos y cada uno de los trabajos presentados. Como tampoco es posible continuar haciendo un vaciado de los números más significativos de revistas como Nuevo Texto Crítico, Revista Crítica Literaria Latinoamericana o Revista Iberoamericana. No obstante, sí 
me gustaría nombrar al menos ciertas orientaciones o tendencias perceptibles en los monográficos de estas publicaciones durante los últimos quince años, a fin de dibujar los avatares de la crítica y teoría literarias en esta etapa, de seguir respondiendo a la pregunta que en 2001 se hiciera Kozak Rivero: “¿Adónde va la literatura?”. Con la prudencia necesaria, eso sí, porque carecemos de la necesaria perspectiva para pontificar al respecto.

Si los 2000 se abrieron con la preeminencia de los estudios culturales (Moraña en Revista Iberoamericana 2000, Bergero y Ruffinelli en Nuevo Texto Crítico 2001, Ríos, Del Sarto y Trigo en Revista Iberoamericana 2003), la década confirmó una doble tendencia: por un lado, su predominio y por el otro, la suspicacia con que muy tempranamente ciertos críticos avisaron de las consecuencias de esta deriva, en pro de la dimensión crítico-estética de la cultura ya reivindicada por Sarlo. Castro Gómez fue uno de los más duros en su planteamiento, como quedó claro en la cita recogida páginas atrás: su principal debilidad estriba en la carencia del mínimo rigor metodológico, lo que se oculta bajo la "pirotecnia del lenguaje y la sofisticación retórica" (2003: 345). Otros como Yúdice en su libro El recurso de la cultura. Usos de la cultura en la era global (2002) han virado desde sus presupuestos iniciales que ayudaron a consolidar en los 90 el campo de los estudios culturales latinoamericanos. Ahora rechaza el postcolonialismo, la subalternidad y la teorización de tendencias, para incidir en cuestiones concretas acerca de cómo se construyen los procesos democráticos de la sociedad civil; es decir, de la política y prácticas culturales en un mundo global.

Un rápido repaso a los títulos de algunos monográficos de la Revista Iberoamericana de Pittsburgh da la pista al lector de la pervivencia de este enfoque: Representaciones de la nación: lengua, género, clase y raza en las sociedades caribeñas (coord. B. Ruíz, 2003); Políticas familiares: género y espacio doméstico en América Latina (coord. L. Area, 2004); Imaginarios femeninos en Latinoamérica (coord. A. Ortega y S. Rosano, 2005); Hibridismos culturales: la literatura y la cultura de los latinos en los Estados Unidos (coord. A. Sandoval-Sánchez y F. R. Aparicio, 2005), por cierto, con un correlato anterior en Nuevo Texto Crítico 2002/ 3 (Genealogias of Displacement. Diaspora/ Exile/ Migration and Chicana/ o/ Latina/ o/ Latin American/ Peninsular Literary and Cultural Studies, coord. J. Aladro, N. Klahn, L. Martínez-Echazábal y J. Poblete); Palabra, música y cultura en Latinoamérica (coord. A. Bruzual, 2006); Los estudios lésbico-gays y queer latinoamericanos (coord. L. Martínez, 2008); Monstruosidad y biopolítica (coord. G. Giorgi, 2009)...

Ya en la siguiente década el tema se retoma sectorialmente: Literatura y estudios culturales centroamericanos contemporáneos (coord.B. Cortez y L. Delgado Aburto, 2013). En este último caso, con el subsiguiente toque de atención hacia "la diversidad cultural y étnica, la experiencia transnacional que forma parte fundamental de la vida, el contexto y el paisaje de su región" (2013: 14). Y desde un compromiso ineludible: salir al paso de quienes ven Centroamérica como un espacio sin producción intelectual. Por el contrario y según los coordinadores de este número, "cabría afirmar que el ámbito de los estudios culturales centroamericanos es plural, descentrado temática y metodológicamente, muy vivaz y en devenir” (2013: 23). 
Las limitaciones de mi trabajo hacen imposible comentar en profundidad los matices de los estudios culturales a lo largo de estos monográficos. Pero quisiera, para poner de manifiesto lo perdurable de ciertas propuestas, tender una rápida mirada a la sección monográfica, "El humanismo después de los estudios culturales”, a cargo de Ignacio M. Sánchez Prado como presentación del número que coordina en la Revista de Crítica Literaria Latinoamericana (2008). Este último insiste en la importancia de los fundadores -Reyes, H. Ureña, Zea, Vasconcelos, Freyre, Picón salas...-"cuyo eje de reflexión fue la toma de conciencia del sujeto americano respecto a su conciencia en la historia" (Sánchez Prado 2008: 7), y despliega su razonamiento frente a sincretismos y mestizajes homogeneizadores:

Si uno ha de identificar la contribución central de los paradigmas reunidos bajo la égida de los estudios culturales latinoamericanos, es posible que ésta radique en su capacidad de dar cuenta de la gran variedad de subjetividades históricas y emergentes que operan a lo largo y ancho de nuestra América (Sánchez Prado 2008: 7).

Dentro del corpus de artículos, "Las humanidades en la encrucijada de la globalización”, de Abel Trigo, es uno de los más esclarecedores a la hora de plantear el desplazamiento y transformación de la experiencia de lo literario. ¿Crisis de la modernidad? ¿Consecuencia de la revolución tecnológica digital? Porque, efectivamente, las nuevas tecnologías están abocando al autoaprendizaje e incrementando la función lúdica: "se embrollan las fronteras entre aprendizaje y entretenimiento, entre emisión y recepción, entre lo real y lo virtual” (Trigo 2008: 37). Podría uno preguntarse ¿potencia internet el espíritu crítico? Tal vez no tanto... "Lo verdaderamente novedoso es la propagación de una nueva formación cultural (...). No se trata tanto de que la cultura reemplace a la política, como que lo simbólico se convierte en el motor del sistema económico, como mercancía y como medio de producción y de esa forma la economía termina confundiéndose con lo libidinal" (Trigo 2008: 45). No se consumen objetos sino imágenes, mensajes y símbolos que nos dicen cuánto valemos y quiénes somos... El trabajo de Trigo es una derivación de los viejos marxismos.

\section{¿UN REPUNTE DE LO LITERARIO EN EL CAMPO DE LA CRÍTICA?}

Asumiendo estos límites y como contrapartida de la larguísima vigencia de los estudios culturales, me gustaría señalar un tímido repunte de lo literario, si pudiera hablarse así. He aquí algunos títulos que lo avalan: Revistas literarias/ culturales latinoamericanas del siglo XX (coord. J. Schwartz y R. Patiño, 2004); Héroes de papel: avatares de una construcción imaginaria en América latina (coord. A. Chibán, n. Giraldi-Deicas y T. Mozejko, 2005); Crímenes, cadáveres y cultura: siguiendo las pistas de la novela negra (coord. W. Nichols, 2010); Entre el margen y el canon: pensamientos discursivos alrededor del comic latinoamericano (coord. A. Merino, 2011); La ciencia ficción en América Latina: entre la mitología experimental y lo que vendrá (coord. S. Kurlat Ares, 2012); El ensayo literario hispanoamericano de fin y cambio de siglo: continuidades y diferencias 
(coord. R. de Grandis, 2012); Derrota, melancolía y desarme en la literatura latinoamericana de las últimas décadas (coord. A. Ma Amar Sánchez y T. Basile, 2014)... eso por no hablar de los monográficos dedicados a países y de los misceláneos.

De alguna forma, estos números de la Revista Iberoamericana tienen su paralelismo en Nuevo Texto Crítico (La narrativa del milenio en América Latina (2008). Y de forma más rotunda, en el último número de la Revista de Crítica Literaria Latinoamericana dedicada a Gongorismo americano (2016). Narrativa histórica que sustenta la construcción de América Latina... Otra vuelta de tuerca a géneros clásicos como el policial y la ciencia ficción... Una apertura al cómic, entre la escritura y lo gráfico... Ensayo en el que habría que resaltar la vigencia de la crónica, subespecie vinculada al devenir de microhistorias de América Latina. Ensayo que, cada vez más, opta por las formas ficcionales y autobiográficas, olvidando los viejos asuntos de la tan traída y llevada búsqueda de identidad (tal vez con la excepción del ensayo femenino cubano de fines del XX empeñado en dejar huella de las traumáticas transformaciones de todo tipo que la isla vivió). Ensayo que enlaza con sus orígenes: "la nueva denominación y su sentido en Montaigne es resultado de su autoconciencia en los usos de los géneros y de su necesidad de salirse de ellos, impelido por la exigencia de hacer emerger (...) la escritura del yo"(De Grandis 2012: 496). Todo ello apoyado en la tensión discursiva del autor mediante la cual el nuevo género quedó asociado a la tentativa, a la libertad de juicio y la impronta personal. Si eso fue así desde Montaigne, ahora alcanza su clímax en los textos de Pitol, Villoro o Roberto Bolaño... Tal vez lo más novedoso de este volumen sea el artículo de Stefano Tedeschi, "El blog ¿una nueva frontera para el ensayo?” (2012: 657-680) en el que estudia hasta cuatro niveles de circulación del mismo. Y concreta su trabajo en algunos que, como El Boomerang, enlazan los blogs personales de Alberto Fuguet, Edmundo Paz Soldán y Sergio Ramírez, entre otros.

Por fin, me gustaría reseñar cuatro números monográficos que señalan otros tantos derroteros de la crítica y teoría literarias latinoamericanas en las últimas décadas: Otros estudios trasatlánticos. Lecturas desde lo latinoamericano (Revista Iberoamericana, coord. N. Gerassi-Navarro y E. M. Merediz, 2009), que pudiera tener su epígono, si bien de ámbito restringido en Francia en Latinoamérica/ Latinoamérica en Francia (Revista de Crítica Literaria Latinoamericana, coord.. J. A. Mazzotti, 2013); Tecnoescritura: literatura y tecnología en América Latina (Revista Iberoamericana, coord. J. A Brown, 2007); Ecocrítica en América Latina (coord. G. Heffes, 2014) y Crítica genética y literatura latinoamericana: apuntes teóricos y lecturas críticas (coord. D. Balderston y Ma J. Rossi, 2014).

Lo trasatlántico es una moda consolidada hace tiempo en la crítica a nivel mundial y en la hispanoamericana en particular. De hecho, este número surge tras el impulso de Julio Ortega, quien desde Brown University ha sido uno de sus gurús, con publicaciones consolidadas como el dossier de Iberoamericana: América Latina, España y Portugal, Ensayos sobre letras, historia y sociedad (2003) y cuyo proyecto transatlántico puede consultarse en la red. Tres años después y en la misma revista, F. Fernández de Alba y P. Pérez del Solar presentaban “Hacia un acercamiento cultural en la 
literatura hispanoamericana" en el dossier Transatlántica: Idas y vueltas de la literatura y cultura hispanoamericana en el siglo $X X$ (2006: 99-107). Más allá de la óptica histórica y los precedentes de Chaunu, O 'Gorman y algunos célebres historiadores, la emergencia de los estudios transatlánticos desde la teoría literaria apunta a 1992 y el auge de los estudios culturales se rearma en torno "a una espacialidad compleja, atravesada por sujetos, objetos, hegemonías y fuerzas múltiples" que son su base (Gerassi-Navarro y Merediz 2009: 616). Este volumen vuelve los ojos también a la génesis colonial del proceso, o a la presencia africana en el Nuevo Mundo arrancando de 1492. Hay que flexibilizar el espacio atlántico, tanto en su dimensión geopolítica como en la discursiva:

el concepto de tercer espacio, el multifacético viaje transatlántico que usa el Nuevo Mundo como espacio de transformación, la apertura al Pacífico y a las posibilidades que ofrecen los estudios comparativos/ continentales exponen los aciertos y los obstáculos con que se enfrentan los estudios transatlánticos. Cuestionan tanto la geografía como la aplicación de modelos que pueden resultar ajenos a los discursos literario- críticos o a los diseños políticoculturales latinoamericanos (Gerassi-Navarro y Merediz 2009: 625).

Las coordinadoras reconocen que los estudios transatlánticos no presentan, necesariamente una metodología nueva, sino más bien proponen recuperar espacios marginados, relaciones excluidas e incluso desfamiliarizar el ángulo de estudio, con el objetivo de trascender una geografía limitadora e interrogar el lugar desde donde se enuncia, sabedoras de que las miradas se refractan en varias direcciones.

\section{TECNOESCRITURA, ECOCRíTICA, CríTICA GENÉTICA}

Por lo que se refiere a la tecnoescritura, es decir, a la relación entre literatura y tecnología en América latina, el volumen coordinado por Andrew Brown en 2007 para la Revista Iberoamericana arranca de cuestiones más trabajadas, como la presencia/ influjo de la fotografía en la escritura, hasta las más innovadoras como el fenómeno lisaymona en el sitio de internet poesía.com, o la identidad posthumana, a partir de propuestas como la de Jerry Hoeg en su libro Science, Technology, and Latin American Narrative in the Twentieth century and Beyond (2000). La tesis de fondo para este y otros estudiosos del tema es que "la tecnología ofrece una perspectiva única e importante de cómo la modernidad, y la posmodernidad, se está articulando y rearticulando en América latina”. Por eso, el objetivo del volumen es "considerar las múltiples dinámicas en que literatura y tecnología se encuentran como partícipes de realidades culturales en un flujo constante” (Brown 2007: 737- 738). En el caso de cierta narrativa, es el discurso mismo el que simula los medios representativos posibilitados por la tecnología: algo comprobable de Lugones y Bioy a Paz Soldán, Courtoisie o cierto César Aira.

La conciencia medioambiental de críticos como A. Candido, E. Dussel, L. Boff... precedió la aparición de la Ecocrítica en los años 90, al relacionar determinadas epistemologías con su contexto cultural, económico e histórico con el que establecen conexiones profundas. De forma institucional, esta disciplina nació en Estados Unidos de la mano de The Ecocriticism Reader, de Cheryl Glotfelty y Harod Fromm (1996) y, un poco antes, con la fundación en 1992 de la Association for the Study of 
Literature and the Environment (ASLE), que incidía en la "nature writing" y se polarizaba en textos románticos. En la última década han proliferado congresos y publicaciones marcadas por voces postcoloniales y marginales en términos étnicos, culturales y sexuales. La categoría de lugar (la representación de la naturaleza en la literatura) es central para la Ecocrítica, que extiende esta noción a conceptos como frontera, animales, ciudades, regiones geográficas específicas, ríos, montañas, desiertos, indígenas, tecnología, basura y cuerpos... y la aplica a textos desatendidos habitualmente por la crítica. Para ello

parte de un número amplio de teorías disciplinarias con el fin de explorar cuestiones respecto a las construcciones simbólicas de las especies y su relación con el medioambiente. Una pregunta pertinente en esta fase es, por ejemplo, ¿cómo los discursos literarios y culturales han definido lo humano? Esta perspectiva, de hecho, cuestiona los principios contrarios, opuestos y dominantes propios del pensamiento occidental, dualismos que dividen el significado de la materia, mente y cuerpo, hombres y mujeres, extrapolando a la humanidad de la naturaleza (Heffes 2014: 12)

Entre otras publicaciones convendría reseñar la de C. Flys Junquera, J. M. Marrero Henríquez y j. Barella Vigal, Ecocríticas. Literatura y medioambiente (2010) con un perfil de divulgación de la materia para el público de habla española. Puntos de contacto con el ecofeminismo, versiones como ecología social y eco-marxismo, hay que reconocer que "el giro medioambiental dentro de los estudios literarios y culturales se encuentra impulsado más por cuestiones temáticas que por un método o paradigma de análisis específico" (Heffes 2014: 18). La autora señala tres desafíos en esta corriente: superar la división naturaleza/ cultura, reconocer que la crisis medioambiental es cultural y en consecuencia, subrayar desde las mismas humanidades los aspectos bioculturales del comportamiento humano. Una lectura ecológica de textos latinoamericanos subyace a Hispanic Journal (1998), Ixquic (2000) y Anales de Literatura Hispanoamericana (2004), entre otros. La pregunta sería

cómo utilizar estas herramientas de indagación cultural en una tradición tan extensa y rica como es la latinoamericana, qué rasgos específicos aparecen en ella, y hasta qué punto la utilización de esta disciplina teórica es pertinente para la reflexión y análisis profundos de un corpus variado y disímil como el que emerge de nuestra historia social, cultural y literaria? (Heffes 2014: 21).

La coordinadora de este número apuesta por la Bioecocrítica, una conjunción de ecocrítica y biocrítica que exceda al aparato teórico proveniente de la Academia norteamericana e inglesa. El rendimiento de tal apuesta está aún por ver. Y esta supuesta orientación innovadora de la crítica no deja de ser una deriva de los estudios culturales que se resisten a morir.

En cuanto a la crítica genética, el número 246 de la Revista Iberoamericana de Pittsburgh, coordinado por Balderston y Rossi (2014), es como el subtítulo adelanta, un panorama de "aportes teóricos y lecturas críticas”, arrancando de sus inicios en la vieja Francia. Ahora se reescribe la labor editorial del proyecto Archivos ligado en su origen a Amos Segala y continuado después por Fernando Moreno en Poitiers. Pero sobre todo, se repasan los archivos de manuscritos 
latinoamericanos que han ido forjándose en las universidades norteamericanas, comenzando por la más importante, Princeton University, pero también la Library of Congress de Washington, Texas, Michigan State... En Brasil, La Habana, Caracas... y tantas otras va surgiendo la inquietud de formar el archivo literario nacional y latinoamericano. En Europa, la biblioteca Nacional de France y la universidad de Poitiers, entre otras, están en la misma línea. Se abre un inmenso panorama de trabajo para futuros investigadores a partir del cuidado del patrimonio que suponen textos literarios hispanoamericanos. La metodología no es nueva: hay que revisar los actos de invención del escritor y agruparlos en tres tipos posibles:

Primero está todo lo que entra bajo la categoría de "notas", ya sea documentación, observación, recuerdos o ideas para desarrollar; segundo, lo que está comprendido en la categoría de concepción de la totalidad de una obra, su plan; la idea activa que es la composición -la elaboración de escenarios y esbozos; la organización de una estructura o el desarrollo de un sistema de restricciones (...). Finalmente está lo que se comprende bajo la categoría del escribir propiamente dicho -reescritura, correcciones y el punto final de un texto si es que llega. De hecho, lo "incompleto" tiene un lugar considerable en las reflexiones genéticas, tal como lo tiene en toda producción literaria, e indudablemente eso constituye una de las cuestiones más interesantes a propósito de la definición de qué es lo que hace una obra (Neefs 2014: 22).

El volumen reúne contribuciones de ambos lados del Atlántico y que trabajan sobre autores muy diversos, desde clásicos franceses como Flaubert, hasta los hispanoamericanos en un amplio abanico de posibilidades (Alberdi, Güimaraes Rosa, Donoso, Saer, Pizarnik o Claribel Alegría y Clarice Lispector).

\section{LA CRÍTICA LITERARIA HISPANOAMERICANA COMO TAREA PERSONAL}

Pasando a otra dimensión, reseñar contribuciones críticas a nivel individual es una tarea imposible que excede estas páginas. Aun así cabe subrayar que, desde el ámbito americano, parece haberse puesto de moda otra vuelta de tuerca sobre los fundadores, sean estos decimonónicos o del siglo XX. Ejemplo de los primeros, la concepción del premio de ensayo Ezequiel Martínez Estrada de Casa de las Américas a Víctor Barrera Enderle, por su libro Lecturas insurgentes. La formación de la crítica literaria hispanoamericana (1810-1870) (2007) Por lo que se refiere al pasado siglo, El poder de la palabra. Ensayos sobre la modernidad de la escritura cultural hispanoamericana (2007), de Guillermo Mariaca, tras contraponer juicios estéticos e ideológicos, recuerda cómo el canon atiende a la literatura culta en función de criterios de política cultural. Y vuelve a asentar las bases de la fundación del canon (H. Ureña), la fundación de la teoría (A. Reyes), la fundación de la crítica (J. C. Mariátegui), el canon de la modernidad (A. Rama), la teoría de la modernidad (O. Paz) y la crítica de la modernidad (Fernández Retamar); para cerrar con un repaso sobre la modernidad y la crítica literaria hispanoamericana.

No obstante, y para equilibrar en parte la balanza muy centrada en el lado transatlántico más occidental, me gustaría hacer algún comentario al trabajo de Alfonso de Toro, incansable gestor y organizador de congresos en el Instituto Iberoamericano de Leipzig, punto de acogida de muchos de 
los críticos citados, y director de proyectos de investigación en torno a los asuntos que se tratan aquí. Su trayectoria fue siempre puntera: del estructuralismo a la semiótica y a la teoría de la cultura postcolonial, siempre atento a las últimas tendencias teóricas. El campo de aplicación de sus estudios ha sido ambicioso: el análisis textual, la novela española e hispanoamericana, el teatro, Borges, el debate sobre las teorías postmodernas y postcoloniales, la narrativa histórica, Frida Kahlo... fueron objeto de su atención en clases y publicaciones. Los nuevos enfoques postcoloniales amplían el campo de estudio, lo que es visible en sus textos más recientes: Espectacularidades (2008) y Dispositivos espectaculares latinoamericanos: nuevas hibridaciones-transmedializaciones-cuerpo (2008), del que es editor.

Algo similar sucede con Borges. Las actas de congresos sobre el argentino, quien le apasionó desde muy temprano, culminan -por el momento- en su Borges poeta (2010). Como autor, tienen un espléndido exponente en su libro Borges infinito-Borges virtual: pensamiento y saber de los siglos $X X y X X I(2008)$.

Por fin, su interés por la teoría le ha llevado a dirigir proyectos de investigación en cuyo seno se debatieron las cuestiones más candentes de postmodernidad y postcolonialidad -término que le gusta más, para evitar las connotaciones de "postcolonialismo"-. Postmodernidad y postcolonialidad: breves reflexiones sobre Latinoamérica (1997), El debate de la postcolonialidad en Latinoamérica: una postmodernidad periférica o cambio de paradigma en el pensamiento latinoamericano, editado junto a Fernando de Toro (1999), y Cartografías y estrategias de la postmodernidad y la postcolonialidad en Latinoamérica: Hibridez y Globalización (2006) constituyen un sólido corpus de trabajos con el que se lanza a la arena de las disputas sobre canon/corpus, estudios culturales y teoría cultural. En el marco de los estudios transatlánticos, incorpora voces del otro lado (García Canclini, Martin-Barbero, Brunner...) que, a su vez, han asimilado tanto a los teóricos postcoloniales (Said, Bhabha, Spivak) como a estructuralistas, semióticos y deconstruccionistas europeos (Foucault, Derrida, Deleuze, Lyotard...), entablando con todos un fructífero diálogo. Y, a partir de ahí, comienzan a aparecer sus aplicaciones prácticas: volúmenes como Estrategias postmodernas y postcoloniales en el teatro latinoamericano actual: hibridez, medialidad, cuerpo (2004), coeditado junto a René Ceballos y Claudia Angehrn; y Expresiones liminales en la narrativa latinoamericana del siglo XX: estrategias postmodernas y postcoloniales (2007), coeditado con el mismo Ceballos.

Un breve comentario sobre Cartografías y estrategias de la postmodernidad y la postcolonialidad en Latinoamérica. Hibridez. Globalización. Bajo este título recoge Alfonso de Toro veinticuatro ponencias, fruto de un proyecto de investigación, que constituyen una reflexión transdisciplinaria sobre Latinoamérica y la diversidad de sus discursos. Muchas de las aportaciones (García Canclini, Martín-Barbero, Mendieta, Sieber y, desde luego, el extenso y pormenorizado trabajo del antólogo y director del proyecto insisten y profundizan líneas anteriores en varios sentidos. Por ejemplo y respecto a “modernidad y Latinoamérica” habrá que ampliar el término a una dimensión periférica y descentrada, porque ambos procesos están de algún modo entrelazados y no conllevan un antagonismo epistemológico tan grande. García Canclini subraya que los debates de la 
postcolonialidad se centran en conceptos como nomadismo y desterritorialización, frente a viejos planteamientos de identidad nacional. Y establece una taxonomía, fruto de su empeño en reordenar las relaciones local/global: lo local enajenado en las colonias, rediseñado por la americanización, desconectado y, por fin, lo glocal. En el marco de la globalización, que implica nuevos modos de estar juntos, rescata este último término que nació en el mundo de los negocios japonés a fines de los ochenta, para definir las estrategias de los nuevos mapas culturales y como permanente reformulación de lo local frente a lo global. En palabras de Rincón, tendría mucho que ver con la

relocalización de las culturas dentro del proceso de interconexiones globales, sobre la base del carácter compuesto, híbrido, transicional de todas las culturas, dentro del flujo de las corrientes contemporáneas de experiencias históricas (Rincón 2004: 122).

Lo cierto es que la circulación transnacional de la cultura en Latinoamérica implica un proceso transcultural y transdisciplinario. Como recuerda el colombiano asentado en Berlín, gracias a los medios todo llega en el momento de su emergencia, pero su asimilación no es simultánea: tesis de su conocido libro La no simultaneidad de lo simultáneo. Postmodernidad, Globalización y Culturas en América Latina (1995) que revisa ahora, casi diez años después de publicado, en un sustancioso trabajo panorámico.

En su artículo "Mediaciones comunicacionales y discursos culturales", Martín-Barbero remacha que las identidades nacionales hoy son multilingüísticas y transterritoriales. Algo que tiene mucho que ver con el mercado. "Lo que estamos intentando pensar es la hegemonía comunicacional del mercado en la sociedad: la comunicación convertida en el más eficaz motor del desenganche e inserción de las culturas -étnicas, nacionales o locales- en el espacio/tiempo del mercado y las tecnologías globales” (Martín-Barbero 2006: 144). Mediaciones, nuevos modos de simbolización, producción y circulación cultural, entre los que destaca la televisión /cine que definió un tipo de ciudad dispersa, de imagen múltiple -según Benjamin-. Ahora la metáfora acuñada es "zappar”, metáfora de la fragmentación y el flujo; y el espacio doméstico se transforma en espacio virtual, pleno de posibilidades. Curiosamente, para este colombiano la televisión es el instrumento con que las comunidades construyen su propia imagen, su "territorio del lugar" anclado en la memoria y que interactúa con la dinámica global. Así, el desenraizamiento producto de la hibridación cultural desemboca en una mundialización "desde dentro" y una relocalización política de la diferencia cultural del lugar. Estamos muy lejos del paradigma de lo nacional como instrumento para pensar el mundo...

"Hacia una teoría de la cultura de la hibridez como sistema científico transrelacional, transversal y transmedial' muestra ya cuajada una ambiciosa teoría de la cultura, síntesis de aportaciones anteriores y en línea con Bajtín, Bhabha, Deleuze, Derrida, Baudrillard, Welsch y otros. Importa la productividad (potencialidad y recodificación) de esa teoría de la cultura, que es el resultado de tender puentes entre estudios culturales y crítica literaria -ambos definidos y reformulados dentro de una red de disciplinas y de conocimiento-; en ese sentido, el trabajo de Alfonso de Toro supone un paso adelante en relación a lo que veníamos comentando, muy a tono con 
el fin de los binarismos, y con la estrategia postmoderna del entre, del tercer espacio. Su premisa: la literatura perdió "gran parte de su fascinación y relevancia sociopolítica (...) de allí se desprende la pregunta fundamental de para qué estamos y quién nos necesita”... (A. de Toro 2006: 197). )Desde qué base epistemológica pensamos/escribimos? "La teoría debería asumir una función de puente, de relacionar, entrelazar la transversalidad de la cultura (... - en el sentido de Welsch-...), deberá ser una práctica colectiva transdisciplinaria y transcultural del análisis de un objeto cultural” (A. de Toro 2006: 200-201).

Una última acotación que me parece pertinente: si el lugar de nacimiento -boom, diría yo- de los Estudios Culturales produce un rechazo (Norteamérica/Latinoamérica),

habría que anotar que, al parecer, a los líderes de la discusión de los estudios coloniales y postcoloniales en E.E.U.U. no les produjo ningún problema el partir de postulados filosóficos de Foucault (Said), de Lacan y Derrida (Bhabha) o de Marx y Derrida (Spivak), sino más bien un beneficio para sus propias aproximaciones. Lo mismo podemos decir de muchos y centrales trabajos de García Canclini, Brunner, Monsivais, Martín-Barbero... (A. de Toro 2006: 207).

A partir de aquí se despliega toda una teoría de la cultura -por supuesto nunca sometida a una lectura hegemónica- que “sería un lugar privilegiado de análisis, de descripción y de interpretación de las construcciones culturales y sus diversas articulaciones o representaciones en sistemas discursivos" (A. de Toro 2006: 211). Teoría transversal con evidentes consecuencias en la academia, y que debería plantearse al menos en tres niveles: el de principios constituyentes de base; el de objetos textuales/discursivos; y el socio-histórico-topográfico. Teoría cuya fundamentación en el macronivel descansa en dos conceptos (hibridez y transversalidad) que, a su vez se articulan en otros (transmedialidad, cuerpo/sexualidad) en el micronivel correspondiente:

Los criterios de hibridez, transversalidad, transmedialidad y cuerpo fomentan un análisis e interpretación transdisciplinaria, transcultural y transtextual, por ejemplo, el diálogo entre diversos códigos culturales y estéticos de la cultura latinoamericana, europea, norteamericana, afro-americana, africana, musulmana o asiática (A. de Toro 2006: 216).

Planteamiento ambicioso, gran panel que pasará a desglosar pormenorizadamente en el resto del trabajo, de tono absolutamente postmoderno -cuestionamiento del Logos occidental, de las categorías Origen y Verdad - y que desemboca en un diálogo muy postcolonial alrededor de tres áreas o estrategias: transdisciplinariedad, transculturalidad y transtextualidad. "Modelos de diversa proveniencia disciplinaria y teórica (...) al servicio de la apropiación, decodificación e interpretación del objeto analizado" -para la primera-. "Modelos, o fragmentos o bienes culturales que no son generados ni en el propio contexto cultural (cultura local o de base) ni por una propia identidad cultural" - para la segunda-. "Diálogo o recodificación de subsistemas y campos particulares de diversas culturas y áreas de conocimiento" en los que importa lo estético, la función social o su productividad, y no cosas como el origen o la autenticidad -para la tercera-. Evidentemente son reformulaciones de conceptos que tienen una historia con la que se dialoga -por ejemplo, la 
transculturalidad, que no implica mestizaje, pérdida o cancelación de lo propio como en Ortiz, sino proceso continuo e híbrido-. Ya que el prefijo trans- incide en ese "diálogo desjerarquizado, abierto y nómada que hace confluir diversas identidades y culturas en una interacción dinámica”, en un proceso disonante, de alta tensión...- (A. de Toro 2006: 218-219). Una muy pormenorizada teoría sobre la hibridez y sus estrategias -siempre esbozadas al hilo de la translación -completa el trabajo: la hibridez como categoría epistemológica construida por la diferancia (Derrida) y la altaridad (Taylor), en términos no de exclusión del otro, sino de negociación permanente y abierta. Hibridez como categoría científica y ciencia transversal; como categoría y estrategia cultural; como forma de organización mediática; como categoría urbana, de circulación de mercado; como tecnología y ciencia... Lo importante son los pasajes, esa dinámica abierta y nómada: el rizoma como red, la arruga, el pliegue de Deleuze; le différend, es decir, esa visión del pensamiento como islas o significados a la deriva de Lyotard; el pensamiento débil y el concepto de perlaboración, como reescritura, de Vattimo... son los ingredientes -formas vacías en realidad- con que construye su teoría... para concluir con unas palabras de indudable operatividad en un mundo marcado por los desplazamientos:

La identidad, lo auténtico se negocia hoy en día en la diversidad de las orillas y en los puntoscruces del encuentro de culturas (y no a través de oposiciones, sino por medio de operadores tales como allí, aquí, en medio, simultáneamente): se vive simultáneamente en diversos mundos, en un intermedio, en un espacio extra-territorial (A. de Toro 2006: 228).

La labor de Alfonso de Toro está enfocada a tender puentes entre su propia exégesis crítica y la Academia norteamericana. Para cerrar este brevísimo esbozo crítico de lo producido en Europa, quisiera citar al menos dos volúmenes: el libro de Genara Pulido, Constelaciones de teorías. El giro culturalista en los estudios literarios latinoamericanos (2009) y el de Ingrid Galster, Hispanoamérica y el posmodernismo. Teoría literaria, feminismo, textos coloniales y novela histórica (2015). Este último decepciona porque recién aparecido en L'Harnattan de Paris, es en realidad un texto que reúne viejas conferencias de los 90 que, por fin, se tradujeron y publicaron ahora. Como panorama de conjunto, muy útil en su momento, habría que destacar la primera conferencia, de 23-de febrero de 1994, sobre "La teoría literaria hispanoamericana entre la dependencia y búsqueda de autonomía. La discusón sobre el posmodernismo" (Galster 2015: 15-41).

El libro de Genara Pulido, especialista en teoría literaria y profesora de la universidad de Jaén, es un estudio de conjunto muy cercano a mis propios trabajos, que no cita pero debe conocer. Me refiero a los que se centran en el binomio "canon/corpus" $(1998,2000)$ e incluso a una primera versión, online, del que aquí se presenta. Está dividido en dos partes: I. Estudios literarios (crítica, teoría, historiografía y literatura comparada) y II. Estudios de la cultura... En la última parte se recuerda que, como corolario de todo lo expuesto se produjo, tiempo ha, el cuestionamiento del canon literario "oficial” vigente en la primera mitad del pasado siglo, para generar nuevas cartografías en/de América Latina. El lector está ante uno de los más serios, enjundiosos y útiles panoramas del mercado, punto de partida para poner cierto orden en los complejos asuntos que hemos intentado al menos dejar planteados. 


\section{PARA CONCLUIR SIN CERRAR O PARA CERRAR SIN CONCLUIR...}

Es obvio, en nuestra época la pregunta sigue siendo cómo articular cultura y literatura hispanoamericanas, el reto es cómo conciliar la globalización del planeta con las diferencias multiculturales. Los interrogantes y propuestas para la crítica, conformadora en tantas ocasiones de una teoría hispanoamericana, siguen siendo muchos. Quise hacer una cala bibliográfica en determinado momento de nuestra historia, pero estamos ante un mar sin orillas y el bombardeo de publicaciones es imparable.

Es indudable el consenso: más allá de viejos esencialismos, la cultura se presenta como un área de conocimiento común desde la que abordar otras formas de producción de conocimientos; un campo transdisciplinario en el que se estudian los fenómenos que desbordan a cada una de las disciplinas, entre ellas la literatura. Tal vez tenga razón Alfonso de Toro cuando asegura que

conservar el concepto de disciplina tradicional y la forma tradicional de producción científica conlleva no sólo el peligro inminente de la pérdida de legitimación y relevancia socio-culturalpolítica de las disciplinas en cuestión, sino aún peor, su silencio, ya que las disciplinas en su forma actual y con sus instrumentos no son capaces de abarcar, de describir e interpretar la cada vez más compleja y peligrosa realidad contemporánea” (A. de Toro 2006: 196).

¿Crítica? ¿Teoría? Tal vez la tarea crítica de muchos años bajo determinado prisma consiga dibujar una teoría de la literatura hispanoamericana, cada vez más atendida de los noventa hacia aquí. El texto necesitará sus exégetas, mientras sigan abiertos los debates teóricos en el marco de seminarios, grupos multiculturales y congresos celebrados a lo largo de la cartografía mundial y se diseñen nuevas historias de la literatura como las de Pizarro y Jitrik, que tratan de fijar para la posteridad los avances, fruto de las fisuras en ese canon tradicional diseñado y reelaborado continuamente por los críticos. Está clara la preocupación por el estatuto de lo literario, tan imposible de definir y en la base de un canon latinoamericano que se agiganta con las aportaciones del corpus cada vez más variopinto, y que enriquece y desintegra a la vez lo que tradicionalmente se consideró literatura. No han dejado de sorprender los gritos de alerta de críticos como Jitrik, Sarlo o Richard muy atentos al referente desde el análisis marxista, la sociología o los estudios culturales. En ese sentido, tal vez el ataque más contumaz y provocador de cuantos he leído siga siendo el de Morales en Nuevo Texto Crítico (2000-2001). Muy autobiográfico, narra su experiencia de estudiante y profesor latino en los Estados Unidos, y no teme mostrar su alarma ante lo que ve:

una crisis de identidad en los profesores de disciplinas humanísticas, especialmente en los de literatura, que -ante la marginación que la literatura misma sufrió por parte de la hegemonía de los medios audiovisuales masivos (expresiones excelsas de la lógica cultural del mercado)vieron de pronto su profesión sin sustento epistemológico ni ético. La hegemonía de la letra y de lo letrado y toda su venerable tradición renacentista, quedaron súbitamente anuladas por un universo de imágenes y sonidos que apelan a un espectador muy bien educado en el arte de dejarse manipular y también en el olímpico desprecio de las aburridas letras, que tienen el insufrible defecto de que forzosamente deben ser leídas una por una y de atrás para adelante (Morales 200-2001: 122). 
¡Sin comentarios! No han de extrañar frases como "el precio que la modernidad ha pagado por su riqueza es, pues, la bancarrota espiritual de sus habitantes”, ni que se pregunte: “¿es ésta la modernidad que queremos para nuestros pueblos tercermundistas?” (Morales 2000-2001: 129). Tampoco que se haga hincapié en el "olvido de la esencial dimensión estética del discurso literario" (Morales 2000-2001: 125). Por esta vía, ciertos críticos de los estudios culturales confluyen con las minorías, bien escasas pero por ello interesantes, que han peleado en soledad a lo largo de los años de su carrera literaria por defender otros valores. Estoy pensando en Graciela Maturo que trabajó el análisis de textos latinoamericanos desde la fenomenología, el símbolo, las tradiciones populares y, asombrosamente, el catolicismo militante. En los últimos años recogió parte de sus estudios en un libro, La razón ardiente. Aportes a una teoría literaria latinoamericana (2004). Allí bullen sus propuestas por otra parte muy contundentes:

En este campo ofreceríamos, frente al desborde irracionalista creciente en la teorización crítica norteamericana, la posibilidad de una actitud fenomenológico-hermenéutica acorde con el sentido ético, constructivo y abierto del latinoamericano (...), pero advertimos, el exceso irracional violenta la esencia humanista de la cultura hispanoamericana, latinoamericana (Maturo 2004: 234).

Maturo entiende como un deber ético-político la profundización de un pensamiento propio, porque la realidad latinoamericana es distinta, histórica y ontológicamente, con arraigadas esencias culturales. Ello deberá reflejarse en una crítica "integradora, pluralista y comprensiva del signo lingüístico en su especificidad”, que se distancie tanto del inmanentismo como de la sociología, ambos reductores, el primero por no incluir los contextos y el segundo por circunscribirse a determinados en detrimentos de otros, como el religioso. Considera el símbolo como la manifestación más específica de lo literario, y la literatura latinoamericana, transcultural y dialógica, una cultura marcada por el humanismo cristiano y los pueblos primitivos, campo propicio de reconocimiento de ese acto fundante, el mestizaje. América es trasmoderna en virtud de ese mestizaje... ¿Disonancia? Un testimonio tan respetable como otros y que me permito traer aquí en aras del pluralismo que según casi todos define nuestra postmodernidad. 
BIBLIOGRAFÍA

Aladro, J., N. Klahn, L. Martínez-Echazábal y J. Poblete (coords.) Dossier "Genealogias of Displacement. Diaspora/ Exile / Migration and Chicana / o / Latina / o / Latin American/ Peninsular Literary and Cultural Studies”. Nuevo Texto Crítico 29-32 (2002-3).

AmAr SÁNCHEZ, A. Ma y T. BASILE. (Coords.) Dossier: 'Derrota, melancolía y desarme en la literatura latinoamericana de las últimas décadas". Revista Iberoamericana 80/247 (2014).

ANDREW BROWn, J. (Coord.). “Tecnoescritura: literatura y tecnología en América Latina”. Revista Iberoamericana. $73 / 221(2007)$.

AREA, L. (Coord.) Dossier: "Políticas familiares: género y espacio doméstico en América Latina". Revista Iberoamericana 70/ 206 (2004).

BARRERA ENDERLE, (V.). (2007). Lecturas insurgentes. La formación de la crítica literaria hispanoamericana (1810-1870). La Habana: Casa de las Américas.

Внавна, H.K. (1994). The Location of Culture. London/New York: Routledge.

Balderston, D. y Ma J. Rossi, (Coords.) Dossier: “Crítica genética y literatura latinoamericana: aportes teóricos y lecturas críticas”. Revista Iberoamericana 80/246 (2014).

BAUDRILLARD, J. (1981). Simulacres et simulation. Paris: Galilée.

Benjamin, W. (1983). Das Passagen-Werk. Frankfurt: Suhrkamp.

Bergero, A. J.. "Estudios literarios/culturales. Disciplinariedad y nuevas configuraciones epistémicas" Nuevo Texto Crítico 25/28 (2000-2001): 5-22.

Bergero, A. J. y Ruffineldi, J. (eds.). Dossier "Estudios literarios/Culturales”. Nuevo Texto Crítico $25 / 28$ (2000-2001).

Bloom, H. (1994). The Western Canon. The Books and School of the Ages. New York: Harcourt Brace \& Co.

BRUNNER, J.J.; CATALÁN, C. y BARRIOS, A. (1989). Chile, transformaciones culturales y conflictos de la modernidad. Santiago de Chile: Flacso.

Bruzual, A. (Coord.) "Palabra, música y cultura en Latinoamérica”. Revista Iberoamericana $72 / 217$ (2006).

BuENO, R. "Sentido y requerimientos de una teoría de las literaturas latinoamericanas", en Revista de Crítica Literaria Latinoamericana 29 (1989): 301-314.

CABALlero WangüEmert, M. (1998) 'El canon literario hispanoamericano: un canon fluctuante”, en Boletín de la Academia Puertorriqueña de la Lengua Española. San Juan de Puerto Rico: 167-194.

Caballero WangÜEmert, M. (2000). "Canon y corpus. Una aproximación a la literatura hispanoamericana”. Canon y poder en América Latina. (Ch. Wentzlaff-Eggebert y M. Traine, 
eds.) Universidad de Colonia, Centro de Estudios sobre España, Portugal y América Latina: 33-77.

Caballero Wangüemert, María (2010). "Puerto Rico en la encrucijada postcolonial: un país entre dos mundos". Homenaje al profesor Alfonso de Toro. Passagen: Hibrydity, transmedialité, transculturalidad. (René Ceballos, Claudia Gatzemeir, Claudia Gronemann, Cornelia Sieber, Juliane Tauchnitz, eds.). Hildesheim: Zurich, New York, Olms:159-174.

Cancini Troncoso, H.; Klengel, S. y LeOnZIO, N., (eds.)(1999). Nuevas perspectivas teóricas y metodológicas de la historia intelectual de América Latina, Madrid: Iberoamericana.

Castillón, C.; SantibáÑeZ, C. y Zimmerman, M. (eds. (2005). Estudios culturales y cuestiones globales. Latinoamérica en la coyuntura transnacional. Santiago de Chile: Bravo y allende eds / LA CASA.

CAstro-Gómez, S. (1999). "Epistemologías coloniales, saberes latinoamericanos: el proyecto teórico de los estudios subalternos".El debate de la postcolonialidad en Latinoamérica: una postmodernidad periférica o cambio de paradigma en el pensamiento latinoamericano. Frankfurt: Iberoamericana: 79-100.

Castro-Gómez, S. y Mendieta, E., (eds.) (1998). Teorías sin disciplina: Latinoamericanismo, poscolonialidad y globalización en debate, México-San Francisco: Porrúa-University of San Francisco.

CASTRO-GÓmEZ, S.. “Apogeo y decadencia de la teoría tradicional. Una visión desde los intersticios”. Revista Iberoamericana. 69/ 203 (2003): 343-354.

CEDEÑO, J. (coord.). 'Literatura y globalización en América Latina”. Revista de Crítica Literaria Latinoamericana 69 (2009).

Cervera, V; Hernández, B. y AdSUAR, Ma D. (eds.) (2005). El ensayo como género literario. Murcia: Universidad de Murcia.

Chibán, A, N. Giraldi-Deicas y T. MozejKo. (Coords.) Dossier: "Héroes de papel: avatares de una construcción imaginaria en América Latina”. Revista Iberoamericana. 71/213 (2005).

Cortez, B. y L. Delgado Aburto. (Coords.) Dossier: 'Literatura y estudios culturales centroamericanos contemporáneos”. Revista Iberoamericana 79/242 (2013).

Daroqui, J. y Cróquer, E. (Coords.) Dossier: "Mercado, editoriales y difusión de discursos culturales en América Latina”. Revista Iberoamericana 67/197 (2001).

DeleuZe, G. y GuATtari, F. (1976). Rhizome. Paris: Minuit.

DERRIDA, J. (1967). De la grammatologie. Paris: Seuil.

DE TORO, A. (ed). (1997). Postmodernidad y postcolonialidad: breves reflexiones sobre Latinoamérica. Frankfurt: Iberoamericana.

DE Toro, A. y de Toro, F. (eds.). (1999). El debate de la postcolonialidad en Latinoamérica: una postmodernidad periférica o cambio de paradigma en el pensamiento latinoamericano. 
Frankfurt: Iberoamericana.

De Toro, A. (ed.) (2006). Cartografías y estrategias de la postmodernidad y la postcolonialidad en Latinoamérica: Hibridez. Globalización. Madrid: Iberoamericana.

De Toro, A. (ed.) (2008). Dispositivos espectaculares latinoamericanos: nuevas hibridacionestransmedializaciones-cuerpo. Hildesheim: Olms.

Fernández de Alba, F. y PÉrez Del Solar, P. (eds.) Dossier “Transatlántica: idas y vueltas de la Literatura y Cultura Hispano-americanas en el siglo XX”., Iberoamericana 21 (2006): 99-107.

FernándeZ Retamar, R. (1975). Para una teoría de la literatura hispanoamericana. La Habana,:Casa de las Américas.

Flys Junquera, C.; Marrero HenríqueZ, J. M y Barella, J. (eds.) (2010) Ecocríticas: literatura y medio ambiente. Madrid/ Frankfurt: Iberoamericana / Vervuert.

GALSTER, I. (2015). Hispanoamérica y el posmodernismo. Teoría literaria, feminismo, textos coloniales y novela histórica. Paris: L'Harmattan.

GaRCía CANClinI, N. (2000). “La épica de la globalización”, en Nuevas perspectivas desde/sobre América Latina: el desafio de los estudios culturales. (M. Moraña, eda.). Santiago de Chile, Cuarto Propio/Instituto Internacional de Literatura Iberoamericana: 35-48.

García CANCLINI, N. (1999-2000). La globalización imaginada. Barcelona: Paidós.

GARCÍA CANCLINI, N. (2006). "Globalización e interculturalidad: próximos escenarios en América Latina”.. Cartografías y estrategias de la postmodernidad y la post-colonialidad en Latinoamérica: Hibridez. Globalización. (De Toro, Alfonso, ed.) Madrid: Iberoamericana:129-141.

Gerassi-Navarro, N. y E. M. MerediZ. (Coords.) Dossier: “Otros estudios transatlánticos. Lecturas desde lo latinoamericano". Revista Iberoamericana 75/228 (2009).

Giorgi, G. (Coord.) Dossier: "Monstruosidad y biopolítica”. Revista Iberoamericana 75/227 (2009).

Glotfelty, Ch. (1996). "Literary Studies in an Age of Environmental Crisis". The Ecocriticism Reader. Landmarks in Literary Ecology. (Glotfelty, Ch. y Fromm, H., eds.) Athens/ London, The University og Georgia P. XV-XXXVII.

DE GRANDIS, R. (Coord,) Dossier: "El ensayo literario hispanoamericano de fin y cambio de siglo: continuidades y diferencias". Revista Iberoamericana 78/ 240 (2012).

Heffes, G. (2013). Políticas de destrucción/ Poéticas de la preservación. Apuntes para una lectura (eco) crítica del medio ambiente en América Latina. Rosario: Beatriz Viterbo.

HefFes, Gisela. (Coord,) Dossier "Ecocrítica en América latina”. Revista de Crítica Literaria Latinoamericana. 40 / 79 (2014).

Herlinghaus, H. y Walter, M. (1994). Posmodernidad en la periferia. Enfoques latinoamericanos 
de la nueva teoría cultural. Berlín: Langer.

HoEg, J. (2000).Technology, and Latin American Narrative in the Twentieth Century and Beyond. Bethlehem: Leihigh UP.

JITRIK, N. (2000-1). "Historicidad, literatura y estudios culturales". Nuevo Texto Crítico. Estudios literarios/Culturales 25/28 (2000-2001): 9-105.

Klahn, N. y W. Corral (eds.) (1991). Los novelistas como críticos. México: Fondo de Cultura Económica.

KozaK Rovero, G.. “¿Adónde va la literatura? La escritura, la lectura y la crítica entre la Galaxia Gütemberg y la galaxia electrónica”. Revista Iberoamericana. 197 (2001): 687-707.

Kurlat Ares, S. (Coord,). Dossier: 'La ciencia ficción en América Latina: entre la mitología experimental y lo que vendrá”. Revista Iberoamericana. 78/238-9 (2012).

LÓPEZ de ABIADA J. M. y Pérez Cino, W. Dossier "Pensar el canon literario. Teoría y ejercicio crítico". Iberoamericana 22 (2006).

LYOTARD, J. F. (1983). Le différend. Paris,:Minuit.

MARIACA, G. (2007). El poder de la palabra. Ensayos sobre la modernidad de la crítica cultural hispanoamericana. Santiago de Chile: Tajamar.

Martín-Barbero, J. (1987). De los medios a las mediaciones. Comunicación, cultura e ideología, Barcelona: Gustavo Gili.

Martín-Barbero, J. (2003). “Identidad, tecnicidad, alteridad. Apuntes para re-trazar el Mapa nocturno de nuestras culturas". Revista Iberoamericana203 (2003): 370-382.

Martín-Barbero, J. (2006). "Mediaciones comunicacionales y discursos culturales”. Cartografías y estrategias de la postmodernidad y la postcolonialidad en Latinoamérica: Hibridez. Globalización. Madrid: Iberoamericana:143-161.

MartínEZ, L. (Coord.) Dossier: “Los estudios lésbico-gays y queer latinoamericanos”. Revista Iberoamericana 74/225 (2008).

MATO, D. (ed.) (2001) Estudios latinoamericanos sobre cultura y transformaciones sociales en tiempos de globalización, Buenos Aires: Consejo Latinoamericano de Ciencias Sociales (CLACSO).

MATO, D. (2002). Estudios y otras prácticas intelectuales latinoamericanas en cultura y poder, Buenos Aires: CLACSO.

MATO, D. (2003). "Prácticas intelectuales latinoamericanas en cultura y poder". Iberoamericana 203 (2003): 389-400.

Maturo, G. (2004). La razón ardiente. Aportes a una teoría literaria latinoamericana, Buenos Aires: Biblos.

MazzotTI, J.A. (Coord.). Dossier “Francia en Latinoamérica/ Latinoamérica en Francia”. Revista de 
Crítica Literaria Latinoamericana 39/ 78 (2013).

Merino, A. (Coord.) Dossier: "Entre el margen y el canon: pensamientos discursivos alrededor del comic latinoamericano". Revista Iberoamericana 77/234(2011).

MoJICA, S. (comp.) (2000). Culturas hibridas-No simultaneidad-Modernidad periférica. Mapas culturales para la América Latina, Berlín: Wissenschaftlicher Verlag Berlín.

Monleón. "Los estudios culturales y los Departamentos de español". Nuevo texto Crítico Estudios literarios/Culturales. 25/28 (2000-2001):107-120.

Morales, M. R. "Oración al pie de la letra (Letanía de deseos sobre literatura, crítica, mercado y atraso". Nuevo Texto Crítico. Estudios literarios/Culturales. 25/28 (2000-2001):121-132.

MoraÑA, M. (Coord.). Dossier: "Crítica cultual y teoría literaria latinoamaricana". Revista Iberoamericana 52/ 176-177 (1996).

Moraña, M. (coord.) (2000). Nuevas perspectivas desde/sobre América Latina. El desafío de los estudios culturales, Santiago de Chile: Cuarto Propio/Instituto Internacional de Literatura Iberoamericana.

Moreiras, A. (2001). The Exhaustation of Difference. The Politics of Latin American Cultural Studies, Durham, N.C.: Duke University Press.

NEEFS, J. “Cómo se hace una obra: ética y genética”. Revista Iberoamericana. 246 (2014): 19-30.

Nemoianu, V., Royal, R. (eds.) (1991). The Hospitable Canon. Essay on Literature Play, Scholardy Coice and Popular Pressures. Philadelphia-Amsterdam, John Benjamins Pub. Co,: 111-135.

NiCHOLS, W. (Coord.) Dossier: "Crímenes, cadáveres y cultura: siguiendo las pistas de la novela negra”. Revista Iberoamericana 76/231 (2010).

Ortega, A. y S. Rosano. (Coords.) Dossier: "Imaginarios femeninos en Latinoamérica". Revista Iberoamericana $71 / 210(2005)$.

Ortega, J. (2003). "Presentación dossier: Travesías cruzadas: hacia la lectura transatlántica". Iberoamericana. 9 (2003): 105-108.

ORTEGA, J. (2003b). “Post-teoría y estudios transatlánticos”. Iberoamericana 9 (2003):109-117.

PIÑA, C. (2008). Literatura y (pos)modernidad. Teorías y lecturas críticas. Buenos aires: Biblos.

Pastor, B. Y BuEno, R. (coords.). Dossier "Latinoamérica: nuevas direcciones en teoría y crítica literarias”. Revista de Crítica Literaria Latinoamericana. 33 (1990-91).

PASTOR, B. Y BuENO, R. (coords.). Dossier “II Encuentro latinoamericano en Berkeley”. Revista de Crítica Literaria Latinoamericana. 42(1995).

Pozuelo Yvancos, J. M. y Aradra Sánchez, R. M. (2000). Teoría del canon y Literatura Española. Madrid: Cátedra.

Pulido, G. (2009). Constelaciones de teorías. El giro culturalista en los estudios literarios 
latinoamericanos. Vigo: Academia.

Ramos, J. (1990). Desencuentros de la modernidad en América Latina, México: Fondo de Cultural Económica.

REYES, A. (1963). “El deslinde. Apuntes para una teoría literaria”. Obras Completas. México: Fondo de Cultura Económica.

ReYES, A. (2005). Teoría literaria. México: Fondo de Cultura Económica y Cátedra A. Reyes.

ReYNOSO, C. (2000). Apogeo y decadencia de los estudios culturales. México DF: Gedisa.

RICHARD, N. "El conflicto entre las disciplinas". Revista Iberoamericana 69 /203 (2003): 438-452.

Rincón, C. y Schumm P. (eds.) Dossier "Celebraciones y lecturas. La crítica literaria en Latinoamérica”, Nuevo Texto Crítico 14-15 (1995).

RiNCÓN, C. (1995). La no simultaneidad de lo simultáneo. Bogotá: Universidad Nacional.

RinCón, C. (2006). "Sobre el debate acerca del postmodernismo en América Latina. Una revisión de La no simultaneidad de lo simultáneo. Postmodernidad, globalización y culturas en América Latina”. Cartografias y estrategias de la postmodernidad y la postcolonialidad en Latinoamérica: Hibridez. Globalización. Madrid: Iberoamericana: 93-126.

Ríos, A.; Del SARTO, A. y Trigo, A. (Coords.)Dossier 'Los estudios culturales latinoamericanos hacia el siglo XXI”. Revista Iberoamericana 69/203 (2003).

Rowe, W. y Schelling, V. (1989). Memory and Modernity. Popular Culture in Latin America, México, Grijalbo.

RuffinelLi, J. (ed.) Dossier "La narrativa del milenio en América Latina". Nuevo Texto Crítico 41-42 (2008).

Ruíz, B. (Coord.) Dossier: "Representaciones de la nación: lengua, género, clase y raza en las sociedades caribeñas”. Revista Iberoamericana 69/205 (2003).

Sabena, J. y Stein, T.P. Dossier: "Gongorismo americano". Revista de Crítica Literaria Latinoamericana. 42/ 83 (2016).

SAID, E. (1996). Cultura e imperialismo. Barcelona: Anagrama.

SÁNCHEZ, I. M. (coord.) Dossier "El humanismo después de los estudios culturales”. Revista de Crítica Literaria Latinoamericana 68 (2008).

SANDOVAl-SÁNCHEZ, A. y F. R. APARICIO. (coords.) Dossier: "Hibridismos culturales: la literatura y la cultura de los latinos en los Estados Unidos”. Revista Iberoamericana 71/212 (2005).

SARLO, B. (1988). Una modernidad periférica: Buenos Aires 1920 y 1930. Buenos Aires: Nueva Visión.

SARLO, B. (1994). Escenas de la vida posmoderna. Intelectuales, arte y videocultura e Argentina. Buenos Aires: Ariel. 
SCHWARTZ, J. y R. PATIÑO. (Coords.) "Revistas literarias/ Culturales latinoamericanas del siglo XX”. Revista Iberoamericana 70/ 208-9 (2004).

SklodowsKa, E. y HelleR, B. (eds.) (2000). Roberto Fernández Retamar y los estudios latinoamericanos. Pittsburgh, IILI.

SOSNOWSKI, S. (1999). La cultura de un siglo: América Latina en sus revistas. Buenos Aires: Alianza.

TEDESCHI, S. "El blog: ¿una nueva frontera para el ensayo?”. Revista Iberoamericana 78 / 240 (2012).

Trigo, A. (2008). "Las humanidades en la encrucijada de la globalización”. Revista de Crítica Literaria Latinoamericana 34/68 (2008): 33-53.

VIDAL, H. (1994). Crítica literaria como defensa de los derechos humanos. Irvine: University of California.

Wentzlaff-EgGebert y Traine, M. (eds.) (2000). Canon y poder en América Latina. Universidad de Colonia, Centro de Estudios sobre España, Portugal y América Latina,

YÚDICE, G. (2002). El recurso de la cultura. Usos de la cultura en la era global. Barcelona, Gedisa.

ZaVAla, I. "El canon y la escritura en Latinoamérica”. Casa de las Américas 212 (1998): 33-40. 
2. Articulación de la colonialidad del saber /poder 


\section{MEMORIA TRANSATLÁNTICA, ENSAYOS FUNDACIONALES Y ESPECTROS DE LA HISTORIA}

Transatlantic Memory, Foundational Essays and Spectres of History

\section{JAVIER SANJINÉS}

UNIVERSITY OF MICHIGAN sanjines@umich.edu

Abogado, ensayista y crítico literario, Javier Sanjinés es catedrático de Literatura Latinoamericana y de Estudios Culturales en el Departamento de Lenguas y Literaturas Romances de la Universidad de Michigan (Ann Arbor, EE.UU). Doctor en Literatura Hispanoamericana y Luso-Portuguesa por la Universidad de Minnesota (EE.UU), ha publicado numerosos ensayos de crítica en revistas literarias de reconocido prestigio internacional.

RESUMEN: El trabajo analiza la importancia de algunos ensayos fundacionales en la construcción de un discurso crítico latinoamericano y subraya los maridajes transatlánticos en sus planteamientos fundamentales, incidiendo en el impacto perturbador que lo europeo tuvo sobre la conciencia andina. Desde ese punto de vista se analiza en primer lugar la aportación de Alcides Arguedas, con Pueblo enfermo y en su debate con Tamayo. En segundo lugar se analizan los debates en torno a la obra de Carlos Montenegro y Jose María Arguedas y se contextualizan sus intervenciones en un proceso más amplio de construcción de la conciencia andina. En último lugar, se revisa la aportación de Mariátegui en sus Siete ensayos de interpretación de la realidad peruana, y su construcción de una ontología del presente capaz de redefinir las relaciones entre el tiempo y el espacio.

PaLabras CLAVE: Ensayos fundacionales, Alcides Arguedas, José María Arguedas, Montenegro, Mariátegui.
ABSTRACT: The paper analyzes the importance of some foundational essays in the construction of a Latin American critical discourse and emphasizes transatlantic marriage in its fundamental approaches, emphasizing the disturbing impact that the European had on Andean consciousness. From that point of view, we first analyze the contribution of Alcides Arguedas, with Pueblo enfermo and in his debate with Tamayo. In the second place, we focus on the debates about the work of Carlos Montenegro and Jose María Arguedas and their interventions are contextualized in a wider process of construction of Andean consciousness. Finally, we review the contribution of Mariátegui in his Siete ensayos de interpretación de la realidad peruana, and its construction of an ontology of the present capable of redefining the relations between time and space.

KEYWORds: Foundational essays, Alcides Arguedas, José María Arguedas, Montenegro, Mariátegui. 
En un artículo muy sugerente sobre cómo se recordaba el pasado en el Perú de la Colonia temprana (1995), Sabine MacCormack relata que, a comienzos del siglo XVII, un caballero culto de Lima compartía una variedad de temas eruditos con su amigo el Corregidor de Hatunjauja, incluyendo las creencias andinas sobre la inmortalidad del alma y la resurrección del cuerpo. A propósito de ellas, el Corregidor le contaba al caballero una historia que había experimentado hace algún tiempo atrás. En uno de sus recorridos por el valle de Jauja, había encontrado a un anciano indígena que cargaba un atado de quipus que era similar a los que habían empleado los incas para guardar información numérica y narrativa. Interpelado por el Corregidor acerca del por qué de los quipus, el anciano replicó que eran las cuentas que guardaba para el Inca cuando éste retornara del otro mundo y pidiera una relación pormenorizada de lo acaecido en el valle durante su ausencia.

Aunque el relato del anciano puede interpretarse como una mera superstición, como el alucinado producto de una mente inculta, la historia narrada por el Corregidor muestra, sin embargo, que mucho después de la invasión española, cuando la mayor parte de la gente que había presenciado el acontecimiento estaba ya muerta, el pasado inca seguía siendo recordado como una realidad viviente.

No hay duda de que, registrado en quipus, este pasado indígena no era el que interesaba a los españoles y a los criollos de la época. Al vivir al interior de una jerarquía de valores conformada inicialmente en Castilla, en la que la dignidad se alcanzaba por linaje, riqueza y educación, criollos y españoles afincados en los Andes desdeñaban el conocimiento andino del pasado y adoptaban la “memoria transatlántica” regulada por el pasado histórico, por el pasado europeo. Así, reemplazados los quipus por documentos escritos en español, la memoria del pasado subalterno cedía ante el peso del razonamiento eurocéntrico, el cual terminaba imponiéndose sobre la sociedad colonizada.

El impacto perturbador de lo europeo sobre la conciencia andina fue mayúsculo. Afirma MacCormack que el peso histórico hispano sobre los Andes erradicó casi por completo la voz del narrador quechua (1995: 18). Así, de manera inevitable, los historiadores colonizados compusieron sus narraciones según principios retóricos y conceptuales muy diferentes a aquéllos que gobernaban la cultura quechua. De esta manera, quedaron en juego, bajo la colonización española, dos diferentes memorias, dos diferentes maneras de comprender el pasado andino. Sin duda, se dio la diferencia inicial del idioma y la manera en que éste era registrado, ya sea por medio de quipus o por la escritura europea. Más aún, las dos visiones, la metropolitana y la subalterna, divergieron en contenido, porque el orden social y económico andino estaba condicionado por un conjunto de fuerzas absolutamente nuevo, cuando los españoles tomaron control de la política de los Andes. Finalmente, las preguntas que los españoles se hacían sobre el pasado difirieron radicalmente de aquéllas planteadas por el pueblo andino, debido a que ellas provenían de un contexto cultural y de una experiencia histórica diferentes.

El problema que atañe a este trabajo no tiene que ver tanto con el hecho de que el pensamiento metropolitano, originado en Castilla, distorsione la historia local, sino con la aplicación de categorías historiográficas que desatienden lo que no les es familiar. En efecto, la falta de familiaridad con el 
tiempo circular andino y con el funcionamiento del sistema económico de complementariedad y de reciprocidad, lleva a los historiadores a concentrarse sólo en temas que son accesibles desde la memoria europea del pasado, regulada por el tiempo histórico. Por tanto, el conocimiento del proceso histórico europeo, que, como digo, comenzó en España, reprime y relega a un segundo plano el conocimiento andino del pasado.

Difundido por la cultura letrada, este proceso histórico tiene una larga e importante trayectoria que, en el caso latinoamericano, culmina en los conocidos ensayos "fundacionales" de nuestras naciones, ligados al “capitalismo de imprenta” estudiado por Benedict Anderson.

Uno de tales ensayos, apreciado como polémico por sectores de la élite cultural andina de habla hispana, es Pueblo enfermo, de Alcides Arguedas, criollo paceño que ubica la realidad boliviana desde métodos de observación que corresponden a la modernidad europea, y distancia temporalmente al indio porque lo aparta del presente y lo funde con el espacio andino. Por ello, me parece que la “espacialización del tiempo" es una de las características salientes de esta gama de estudios que, aferrados a la modernidad europea, desconoce o rechaza la peculiar presencia del pasado andino en el presente.

Veamos, pues, el relegamiento del pasado indígena en la obra de Arguedas. El conocido escritor boliviano concibe como "irracional" el hecho de que los acontecimientos humanos también tienen su carácter sobrenatural y embrujado. Nada más alejado de lo sobrenatural, de lo que hoy la mirada subalterna observa como "tiempo de los dioses", que el razonamiento lógico de ensayos como el de Arguedas, concebido por el autor para explicar la imbricación de las razas con la peculiar geografía boliviana.

Publicado en Barcelona, Pueblo enfermo causa un impacto no del todo favorable en la élite boliviana de principios del siglo XX. El ensayo establece una relación mecánica entre el hombre y el medio ambiente, y postula una visión predominantemente fatalista de la realidad boliviana. El medio geográfico, determinante en la constitución de los agrupamientos humanos, y las razas, que también determinan la psicología colectiva de los pueblos, son los ejes a partir de los cuales se desarrollaba, en el momento en que Arguedas escribe su ensayo, un análisis de la realidad nacional lleno de prejuicios. De este modo, el ser del indio llevaba el sello de la fatalidad, estando determinado exclusivamente por la acción mecánica e inmodificable que la meseta altiplánica ejercía sobre él. "La pampa y el indio no son sino una sola identidad", escribe Arguedas. Luego, afirma: "El aspecto físico de la llanura...ha moldeado el espíritu del indio de manera extraña. Nótese en el hombre del altiplano la dureza del carácter, la aridez de sentimientos, la absoluta ausencia de afecciones estéticas” (1937: 180). Y esta relación determinista entre el hombre y el medio ambiente, que luego se hace extensiva a la explicación del atraso de la República por la accidentada geografía del territorio, ignora otros ingredientes históricos, económicos y sociales -el escritor no hace mención alguna a cómo el 
indígena percibía su pasado-que tenían igual o mayor importancia que los factores espaciales que Arguedas expone. De acuerdo a esta visión, el ser humano había perdido toda su capacidad para transformar la naturaleza. Esta pérdida era comprobable en el desequilibrio profundo que Arguedas ve entre el territorio y la calidad de la población. Por ello, Arguedas saca en conclusión que no había la estabilidad y la armonía necesarias para que se produjese el progreso, ni que echase a andar el ansiado tiempo histórico de la modernidad. Si Europa era una vasta llanura uniforme, Bolivia era un espacio agreste y caótico. Así, el medio geográfico determinaba tanto la posibilidad como la imposibilidad de establecer el desarrollo.

La importancia que la elaboración del argumento espacio-temporal ocupa en mi análisis, me lleva a redundar en la fuerza que la territorialización del indio tiene en el ensayo de Arguedas. En el territorio fragmentado e incomunicado de la Bolivia de principios del siglo XX, Arguedas expresa la necesidad de racionalizar el espacio, de darle un sentido que supere las supersticiones religiosas y otras prácticas “pre-lógicas”, inútiles y absurdas. Tanto hacendados como indígenas son rechazados por el autor porque resultan ser expresiones socio-económicas de un pasado ilógico que no permite echar a andar el tiempo histórico de la modernidad y del progreso. De acuerdo con esta manera de pensar, sólo la superación de vetustos sistemas de explotación y de aprovechamiento de los recursos naturales daría lugar a la historia humana que imprime el sistema de explotación capitalista.

Bajo esta concepción de la historia, que observa lo local desde afuera, desde visiones deterministas y evolutivas donde prima el conocimiento eurocéntrico, se puede comprender el lugar que Arguedas le asigna al indígena. Éste no es más que una forma de conocer y de habitar el territorio. Recordemos que si la "pampa y el indio forman una sola identidad", el determinismo de Arguedas lleva a pensar que el indio no vivía en un territorio, sino que era el territorio. De esta manera, para Arguedas la naturaleza no es el telón de fondo donde suceden las acciones, sino un todo que incluye al indio, que lo cosifica y territorializa. Bien lo expresa Leonardo García Pabón cuando afirma que, para Arguedas, "hablar de naturaleza es hacerlo también del indio y viceversa. Expresa este crítico boliviano que "la mirada racionalizadora de Arguedas, que propugna una nueva territorialización de la geografía, también va a abrir el camino a propuestas de racionalización del indio, es decir, a su ‘civilización', su integración en el orden racional del Estado”. Se trata, como García Pabón explica, de “propuestas asentadas en la necesidad de 'educar' al indio, de las que se encargarán otros intelectuales bolivianos como Franz Tamayo" (1998: 123).

Adversario intelectual de Arguedas, Tamayo se desvía del concepto europeo de “civilización”, aceptado por el positivismo de la época, y propone mirar más estrechamente la cultura local. Si la “civilización” es el estadio al que se llega mediante la instrucción, Tamayo propone supeditarla al ejercicio de la voluntad. La educación, entonces, no es el bagaje de conocimientos que almacenamos en el cerebro, sino aquello que forjamos con la voluntad. Más que las ideas y los conocimientos adquiridos con la inteligencia, lo que interesa es el aprendizaje de las costumbres propias. Así es cómo Tamayo llega a oponer la educación a la instrucción. Para él, la instrucción es objetiva, racional, pero intrascendente porque no permite descubrir la esencia de la nación; por el contrario, la 
educación es subjetiva y transcendente porque llega a las profundidades del alma y del carácter, a las fuerzas vivas de nuestra existencia.

Creación de la pedagogía nacional, el ensayo "fundacional" de Tamayo, busca descubrir la voluntad, el carácter nacional. Y a la realización de tal propósito, poco lograríamos, afirma Tamayo, con enviar a Europa comisiones pedagógicas que van a observar modelos ajenos que no ayudan en nada al descubrimiento de la propia vitalidad. En efecto, cotejadas la instrucción y la educación, la solución a la que llega el ensayo de Tamayo no puede ser más paradojal: la instrucción racional conduce a la momificación; la educación de la propia vitalidad, al hallazgo de la existencia. No es pensando sino actuando que llegaremos a la aprehensión verdadera de la existencia. Y de esta desestimación de la razón surge la sospecha irracionalista de que la inteligencia, alejada de las fuerzas vitales de la existencia, falsifica la realidad (Albarracín, 1981: 78).

La educación es, por consiguiente, el despertar de la vitalidad nacional, y equivale al despertar de las energías de la raza. En los primeros ensayos de Creación de la pedagogía nacional, Tamayo otorga primacía a los aspectos internos, endógenos, de la cultura. El carácter nacional no se halla ni en el criollo, ni en el mestizo, quien frecuentemente degenera en "cholo" (apelativo peyorativo que se da al mestizo apegado a las costumbres indígenas) revoltoso, sino en el indio subyugado. El indio tiene virtudes que no poseen ni el mestizo, ni el blanco. Es autónomo y fuerte, concreto y disciplinado. Es capaz de desplegar, aunque todavía está poco desarrollado, el esfuerzo que demanda la vida social organizada. Toda su labor es fecunda, productiva, a pesar de la hostilidad en la que vive y el desprecio de los otros sectores sociales. En suma, el indio es el depositario de la energía nacional.

Pero este discurso sobre lo autóctono, que pretende recuperar al indígena, también recrea la fractura que observáramos en Arguedas, es decir, la fractura del orden colonial, porque no puede resolver los sentidos encontrados del "interior" indígena, con su peculiar visión comunitaria, regida por el tiempo circular, y del "exterior" criollo-mestizo, regido por modelos de observación europeos. El discurso tamayano sobre lo autóctono refleja estos impulsos contradictorios. En efecto, al referirse a la energía vital indígena, Creación de la pedagogía nacional promueve la "diferencia" con los modelos europeos positivistas. Sin embargo, cuando propugna el desarrollo del intelecto mestizo, combina la diferencia indígena con formas occidentales que, aunque provienen del irracionalismo europeo que, a principios del siglo XX, contradecían el positivismo, corresponden a una mirada exógena de la cultura local, a la cual Tamayo intenta devolver toda su fuerza y originalidad.

El doble discurso del ensayo de Tamayo tiene una característica interesante: mientras afirma vehementemente que el dominio espiritual o cultural es un territorio soberano que no debe ser entregado a la civilización occidental, por otra parte forja un nuevo "modelo" cultural que se aparta del imaginario occidental sólo en apariencia. No es el positivismo afrancesado que guía la "comunidad imaginada" de este ensayo, sino el vitalismo irracional alemán que toma prestado de Nietzsche y de Schopenhauer. En tal sentido, es muy difícil afirmar que Tamayo imagina una comunidad verdaderamente autóctona (en realidad, y como explicaré más tarde, no puede lograrse dicha comunidad si no se equilibra el tiempo con el espacio, y si no se trae el pasado al presente). 
Tamayo no promueve la "doble crítica", a la que Walter Mignolo se refiere para expresar la "epistemología fronteriza" (2000: 66-71) desde la cual la avanzada conciencia del pensador colonizado aprehende, a la vez, la conciencia del colonizador y del colonizado, mientras que el colonizador sólo conoce su conciencia monotópica y visualiza los acontecimientos desde su propia y exclusiva perspectiva eurocéntrica. En otras palabras, aunque el ensayo de Tamayo se empecina en que creamos que ha sido corregida la mirada del observador liberal-positivista, el punto de vista sigue siendo el mismo del colonizador europeo. Tamayo no fue un pensador periférico que pensase desde la propia realidad colonial, sino un pensador metropolitano temperado que no dejó de aplicar a la realidad colonizada los métodos de observación europeos.

\section{II}

Siguiendo el derrotero de estos ensayos fundacionales de la primera mitad del siglo XX, me parece que no ha sido suficientemente observada una de las maneras más interesantes de aproximar la tradición histórica europea al conocimiento local de las sociedades postcoloniales: me refiero al empleo de los géneros literarios (epopeya, drama, comedia, tragedia y novela) con el propósito de organizar y de dar sentido a acontecimientos humanos que se suceden ordenadamente en el tiempo. Esta relación de la historia con la literatura viene de una manera de pensar la cultura de honda raigambre europea (Said, 2002: 453-473). De Tucídides a los estudios en torno a la Nueva Ciencia de Giambattista Vivo, grandes historiadores, interesados algunos de ellos en incorporar la estética a sus investigaciones, asimilaron los géneros literarios a su reflexión de lo histórico.

Sin embargo, y a pesar de lo útil que puede ser el empleo de categorías estéticas en la organización del pensamiento histórico, el apego a las coordenadas espacio-temporales de las grandes construcciones sistémicas de Occidente puede también ser problemático porque entorpece la comprensión local de sociedades dependientes y profundamente fragmentadas como son las postcoloniales. En este sentido, el apego a la historia y a la alta cultura letrada de Occidente puede incluso oscurecer la adecuada comprensión de lo local. Emito este juicio a propósito de Nacionalismo y coloniaje, el ensayo de Carlos Montenegro que echa a andar, en Bolivia, la ideología del “nacionalismo revolucionario", ligado a la Revolución democrático burguesa de 1952. A pesar de sus indudables logros, pienso que este ensayo, que introduce el tiempo histórico de la modernidad en la reflexión boliviana de lo nacional, no supera el colonialismo que ataca y denuncia. Su inclinación hacia la cultura letrada de Occidente le impide ver con igual detenimiento las disparidades y las disyunciones que afectan a la sociedad boliviana.

Pero antes de referirme a Nacionalismo y coloniaje, me parece prudente decir algo más sobre la relación entre historia y literatura. Erich Auerbach, cuyo libro Mímesis se ubica en la década de 1960 entre los ensayos críticos más importantes del siglo XX, asigna al trabajo filológico la tarea de revisar minuciosamente los documentos del pasado, con el objetivo de no tergiversar la perspectiva histórica de la época y de la sociedad que es objeto de análisis. Auerbach, quien tradujo el trabajo de Giambattista Vico al alemán, queda profundamente influenciado por el pensador italiano, 
particularmente por su teoría de la unidad de los períodos históricos. La "nueva ciencia" de Vico es el arte de leer los poemas heroicos griegos no como si fuesen escritos por algún racionalista del siglo XVIII, sino como producto de un momento histórico específico de construcción de la realidad, marcado por la metáfora y la poesía, y distanciado de la lógica deductiva. Hago esta acotación con el único propósito de acentuar el rigor y la seriedad con que esta tradición filológica se fija en lo propio y construye orgánicamente las tradiciones culturales histórico-literarias que interpretan los diferentes momentos constitutivos de Occidente. ¿Sucede lo propio cuando, en el otro lado del Atlántico, se pretende interpretar tradiciones históricas y culturales diferentes y hasta contrastantes?, ¿deberían las sociedades postcoloniales ser interpretadas con las mismas categorías mentales que sirven para interpretar la realidad europea?, ¿no estaremos ejercitando una violencia epistemológica sobre el objeto de estudio?

Nacionalismo y coloniaje hace uso de los diferentes géneros literarios (epopeya, drama, comedia, tragedia y novela) para organizar y dar sentido prospectivo a las diferentes etapas de la historia boliviana republicana. En el ensayo de Montenegro se nota de inmediato la insistencia del ideólogo por abrir un nuevo horizonte de expectativas al pueblo boliviano, horizonte que, al romper con las limitaciones del pasado oligárquico, se apega a coordenadas espacio-temporales europeas que privilegian la novela, género burgués revolucionario por excelencia, y buscan apartarse de las experiencias del pasado pre-revolucionario, a las que Montenegro considera como constitutivas del pensamiento colonialista de la "antinación”.

A principios de la década de 1940, Montenegro buscaba "la verdad del devenir boliviano" ([1943]: 13), alejándose del criterio "antibolivianista" de la historiografía oficial, que, al interpretar la realidad desde el punto de vista "retrógrado" de la oligarquía, había olvidado que el pueblo es la fuente nutricia de la nacionalidad. De este modo, si el criollaje oligárquico --la antinación -no pudo superar el colonialismo, sino que lo reprodujo, era hora de forjar una nueva construcción social, teleológica y prospectiva, que fuese capaz de representar los intereses de los sectores populares: me refiero a la nación. En este proceso, resulta instructivo observar que Montenegro se hallaba, en 1943, lejos del análisis de la nación emprendido después por la Teoría de la Dependencia. A pesar de ello, y teniendo en cuenta que el pensamiento de Montenegro responde a un momento populista en que la teorización geopolítica postcolonial no estaba todavía desarrollada, me parece que uno de los aspectos más atractivos del ensayo de Montenegro es precisamente su interés en forjar un horizonte de expectativas que, al romper con la experiencia del pasado, se abre al futuro de la construcción nacional, anticipando así la Revolución Nacional de 1952.

Al catalogar los aspectos más importantes del tiempo histórico propuesto bajo el horizonte de expectativas creado por Nacionalismo y coloniaje, salta a la vista la antinomia entre "nación" y “antinación”. Ella se origina en la necesidad que Montenegro tiene de contrarrestar el caótico presente oligárquico liberal con el promisorio futuro democrático popular. Esta expectativa futura responde, entonces, al puente que Montenegro, el ideólogo del "nacionalismo revolucionario", tiende entre el ideal utópico y la degradada realidad. Dicho puente es la noción de progreso. 
Puesto que la noción de progreso abre el paso a la temporalización de la historia, no está de más observar que, en el caso boliviano, la relación que Montenegro establece entre la historia y los géneros literarios, permite a la temporalización y a la prognosis también poner en movimiento la trama de Nacionalismo y coloniaje. Así, la épica nacional de principios del siglo XIX cede ante el drama y la comedia de aquellos gobiernos que tergiversan, con sus grotescas políticas caudillistas, la posibilidad de construir lo nacional. De este modo, la única posibilidad de recuperar el actuar racional se da en el momento de relacionar la épica primigenia con "el impulso vitalista que no es otro que el de la novela" ([1943]: 241).

Ligada al tiempo histórico de la modernidad, la novela está, pues, intrínsecamente relacionada con la construcción del Estado nacional. Debido a que Montenegro observa la realidad andina desde la novela burguesa, me parece que la propuesta de su ensayo no deja de plantear serios problemas epistemológicos.

En 1941, dos años antes de que se publicara Nacionalismo y coloniaje, José María Arguedas, el notable escritor peruano, refuta, en su novela Yawar Fiesta, la solución urbana que Mariátegui le había dado al problema indio. Profundamente descolonizadora, Yawar Fiesta hace precisamente lo que Montenegro deja olvidado: pasar la novela por el registro de la realidad no sólo andina, sino de la compleja dinámica, ya señalada por José Carlos Mariátegui, originalísimo intelectual marxista del momento, entre la sierra y la costa. En el momento en que escribe su novela, Arguedas refuta a Mariátegui y descalifica la legitimidad de los sectores sindicales urbanos para mediar en la solución del problema indio. En otras palabras, Arguedas niega que las comunidades indígenas deban seguir el derrotero ideológico de la modernidad sindical y proletaria urbana. Así, la complejidad de esta discusión supera ampliamente la mirada de Montenegro, quien no logra producir el tipo de pensamiento descolonizador que ya se está dando en los Andes en el momento en que escribe su Nacionalismo y coloniaje.

Concluyo, pues, estas breves reflexiones en torno al ensayo de Montenegro con una última observación a propósito de la mimesis. Dado que, en la obra de Montenegro, el “devenir histórico”, el horizonte de expectativas, adopta la linealidad temporal del modelo europeo que le sirve de instrumento de análisis, su libro torna la mimesis en mímica (Bhabha, 2002: 113-122). Mímica es mirar lo propio sin observar los vericuetos y los pliegues de la realidad; es decir, ver lo propio a través de un "pre-texto" -en el caso de Montenegro el modelo letrado occidental de observación de la realidad- que allana las diferencias porque impone un "antes" que anticipa el significado y que simplifica peligrosamente la lectura de la realidad. Así, Nacionalismo y coloniaje le sobreimpone a la realidad la lectura de un modelo que, repito, hoy está siendo seriamente cuestionado por posiciones emergentes que reclaman el derecho a existir desde los nuevos debates epistémicos, políticos y éticos. Estos debates, que no pueden ser reducidos a universales abstractos como la categoría hegeliana de la totalidad, adoptan hoy la perspectiva de los movimientos sociales que, desde ese rearticulador presente que emplea el pasado como recurso, se resisten a ser explicados bajo los principios uniformes de las filosofías de la historia. 
Creo que estas observaciones realizadas en torno al ensayo de Montenegro pueden ser ampliadas a las convicciones nacionalistas de la clase media urbana. En efecto, gran parte de la intelectualidad de clase media tiene dificultades para comprender el choque epistemológico que la teorización descolonizadora del presente introduce en la comprensión historicista de Occidente. Convendrá, entonces, ahondar en los desequilibrios espacio-temporales que hoy nos obligan a cuestionar la aplicación irreflexiva e irrestricta del historicismo europeo y de la memoria transatlántica.

\section{III}

Los tres ensayos fundacionales hasta aquí estudiados están relacionados con propuestas modernizadoras donde el tema del espacio oculta o relega a un segundo plano el aspecto del tiempo, particularmente el peso que los pasados en conflicto ejercen sobre la construcción del presente. Pero esta pérdida, este ocultamiento del tiempo, no es un hecho que afecte exclusivamente a nuestros más importantes ensayistas, sino un fenómeno generalizado que atañe a la cultura occidental, a su manera de plantear las cosas.

No hace mucho tiempo atrás, el historiador Harry Harootunian se interesaba en reavivar el tema de la temporalidad, en revelar las consecuencias que su opacamiento tenía para el análisis social e histórico. Su revelador trabajo "Some Thoughts on Comparability and the Space-Time Problem" (2005: 23-52) repara críticamente en el hecho de que gran parte de los "estudios de área" tienen un impuso totalizador y holístico que privilegia el espacio por sobre el tiempo. Para Harootunian, el "giro espacial" que muestran los estudios más recientes en torno a la modernidad, incluyendo los que se entregan al análisis de las relaciones entre el centro y la periferia, la globalización y el imperio, redundan en la fijeza, en la posicionalidad y en la asincronía, de manera tal que la necesidad de establecer una relación más equilibrada entre el tiempo y el espacio parece haber quedado olvidada o relegada a un segundo plano. Vivimos, según Harootunian, una "espacialización de la teoría social" que está afirmada en el descubrimiento retrospectivo de la centralidad del espacio y de la comunicación en la constitución de los diferentes órdenes sociales (2005: 24). Apelando a categorías espaciales universalizadoras -actualmente la globalización domina nuestra agendas de investigación-la arena de la acción social ha desplazado cualquier otro tipo de causalidad explicativa de los fenómenos sociales. Son los espacios universales, totalizadores, que ahora explican el mundo cambiante de la modernidad. De esta manera, la "sincronicidad estática de lo espacial” (2005: 30) se ha impuesto sobre la reflexión temporal capaz de cuestionar los universales y de enjuiciarlos críticamente desde ópticas diferentes, renovadoras, que analizan los desfases que los vericuetos de lo local introducen en el derrotero del historicismo europeo.

La primacía de lo universal sobre lo local está firmemente postulada en el pensamiento eurocéntrico de Max Weber. Gracias a su teoría comparativa de las formaciones religiosas y a la construcción de una tipología sociológica con pretensiones de universalidad, Weber logra establecer 
la primacía de un Occidente unificado que se impone sobre las otras regiones del mundo. Todo ello fundado en una comparación geopolítica pretendidamente atemporal.

Contemporáneo de Lenin, y escribiendo antes de la Primera Guerra Mundial, Weber construye un poderoso argumento que enfrenta y, en última instancia, desplaza la noción marxista del modo de producción capitalista. De igual manera, el pensamiento sociológico de Weber oculta el conflicto social que el modo de producción capitalista genera cuando se impone sobre la realidad y domina el flujo de la vida cotidiana. A fin de oscurecer dicho conflicto, de esconderlo, el libro de Weber sobre el protestantismo y el capitalismo, publicado en 1904, muestra cómo la religión, portadora de todo el significado de la cultura, garantiza la continuidad de la racionalidad capitalista que construye la modernidad. Promoviendo la continuidad y ocultando las fisuras y rupturas que el capitalismo introduce en la vida cotidiana, Weber logra imponer su visión progresista de la modernidad como un acontecimiento mundial irrefutable. Así, el pensamiento de Weber muta las rupturas históricas entre el pasado y el presente, transformándolas en otro tipo de rompimiento, más geográfico que temporal, entre Occidente y el resto del mundo. De esta manera, vastos grupos humanos, tenidos como "pre-lógicos", como "pre-existentes", quedan estratégicamente alejados de la Historia, de la modernidad. Con Weber, la colonización adquiere el carácter de una modernidad avanzada. De igual modo, queda allanado el camino para transformar las colonias, presentándolas como "lugares" de cultura pre-moderna, cuyo problemático distanciamiento de la modernidad sólo puede ser superado mediante el rechazo de la herencia indígena y la adquisición de la racionalidad desarrollista. En vez del capitalismo (la acumulación en el tiempo), la modernidad (la espacialización del tiempo) termina siendo un lugar fijo, geográfico, distante de este otro espacio (vastas regiones del mundo) relegado, apartado, tenido como "pre-moderno". Así, Europa queda liberada, eximida, de romper con su pasado, mientras que el resto del mundo tiene que adaptarse a la modernidad europea, transatlántica, no pudiendo reclamar su identidad, ni siendo capaz de asumir su propio pasado. Al quedar sustituido el capitalismo por la modernidad, quedan también reemplazadas por la cultura las relaciones sociales de producción y de intercambio económico.

El "giro espacial” está también relacionado con la moderna organización del Estado-nación. En su La production de l'espace, Henri Lefebvre anota que es examinando la nación y el nacionalismo como nos aproximamos de manera concreta a la historia del espacio ([1974]: 132). Explica Lefebvre que para aquellos teóricos que conciben la nación como un “territorio con fronteras naturales”, como un ente natural elaborado y procesado por la imaginación de quienes lo ocupan y lo dominan hegemónicamente, el espacio termina siendo un justificativo ideológico para la construcción burguesa del "nacionalismo absoluto" que "esconde las contradicciones de clase y postula una unidad ficticia que reduce los grandes temas nacionales y regionales a cuestiones lingüísticas y culturales de importancia menor" (132). En efecto, es la "espacialización del tiempo" que ha llevado a teóricos como Benedict Anderson a relacionar la unidad del Estado-nación con la fijeza del espacio, desentendiéndose su teoría de la "comunidad imaginaria" de la verdadera conexión temporal, no simplemente cultural (el acontecimiento histórico de la imprenta) entre el capitalismo y el nacionalismo. 
En su conexión con el espacio, la nación-Estado comprende dos momentos, dos acontecimientos temporales que, aunque fundamentales, no son siempre visibles, y que llevan a Lefebvre a afirmar que "el tiempo vive dentro del espacio" ([1974]: 114). Se trata del mercado y de la violencia del Estado.

Lentamente construido a lo largo del tiempo histórico, del tiempo lineal y teleológico, el mercado es un conjunto de relaciones comerciales y de redes comunicacionales. Allí donde las ciudades dominan los espacios rurales, la formación social, económica y política del mercado nacional es diferente de aquél que, más apegado a la economía feudal pre-capitalista, se desarrolla en las zonas rurales.

El mercado nacional depende del nacimiento del "espíritu de burgo" que organiza el espacio social en relación con las fuerza productivas existentes y con las relaciones de producción. En el curso de su crecimiento, las fuerzas productivas no se expanden en un espacio pre-existente, vacío, neutro, o solamente determinado geográfica, climática o antropológicamente. Por ello, ni la naturaleza -clima y ubicación geográfica--, ni la cultura pueden explicar la producción del espacio social. Debido a la importancia que este hecho tiene para la aparición del "espíritu de burgo" europeo, me permito a continuación describirlo con mayor detalle.

Es en la Italia del siglo XIII donde surge la historia más rica de ese movimiento temporal que, al dejar atrás la etapa del feudalismo, prepara lentamente la era industrial de los siglos XVIII y XIX. Aunque es cierto que Italia está ya atrasada en el momento histórico en que irrumpe la era industrial, es en Toscana donde la oligarquía urbana (comerciantes y burgueses) transforma, poco a poco, los dominios señoriales (los latifundios) que poseen por compra o por herencia. En estas tierras se instala un colonato que comienza a percibir las ganancias de una parte de la producción de la tierra que trabaja. El movimiento que entonces se produce, y que construye una nueva realidad social, no es exclusivamente geográfico -citadino o rural-sino una relación dialéctica entre la ciudad y el campo que engendra esa fuerza productiva nueva: el "espíritu burgués". Fundado gracias a la colaboración de la oligarquía urbana con ese sector campesino aventajado, el espíritu de burgo va constituyéndose lentamente en el motor del desarrollo europeo. La creciente riqueza obtenida -la plusvalía-permite también embellecer el espacio, construir palacios y grandes monumentos. Los artistas, particularmente los pintores, aprenden a expresar en obras de arte la confianza que el mundo europeo comienza a tener en el futuro perfecto, en el horizonte de expectativas que ellos imaginan como algo racional y ordenado. Surge así la teoría de la perspectiva. De este modo, y en una estrecha relación dialéctica con el tiempo, emerge la nueva representación del espacio: la perspectiva visual que aparece en la obra de pintores y a la que dan forma los arquitectos y los geómetras, quienes urden espacios homogéneos y bien delimitados. El conocimiento, que surge de la práctica, se va formalizando y va adquiriendo, poco a poco, su encadenamiento lógico. En Toscana, como también sucede en Florencia y en Siena, los habitantes de las ciudades y de los pueblos comienzan a experimentar un "espacio social” que más que geográfico, imbrica dialécticamente el espacio con el tiempo. 
No hay duda de que, hacia mediados del siglo XIX, otros países europeos más "avanzados" introducen nuevos conceptos que no sólo permiten profundizar aún más esta dialéctica espaciotemporal, sino que también ayudan a ocultarla. Con el pensamiento teórico denominado "economía política" y con los avances introducidos por la práctica industrial, se van expandiendo los mercados. Los productos y los circuitos comerciales que los mercados crean van "espacializando el tiempo", fetichizándolo, ocultando su manera de producir riqueza. Bien sabemos que la fuerza del trabajo de Marx reside precisamente en develar, en desenmascarar, las insuficiencias que la mismísima economía política oculta detrás de su visión desarrollista de los acontecimientos humanos.

Junto con la expansión geográfica, espacial, del mercado, se da también la creciente violencia del Estado. Un poder político militarizado (burgués o imperialista) se las ingenia para combinar los recursos del mercado mundial con el crecimiento de las fuerzas productivas. De este modo, no debe sorprender que el crecimiento económico, aparentemente "espontáneo", esté conectado a la violencia del Estado-nación. En efecto, son los momentos constitutivos del mercado y de la violencia que construyen ese espacio social que llamamos Estado-nación.

Ahora bien, la apertura del globo terráqueo, especialmente la creación del mercado mundial, tiene como resultado la presencia de los constantes y violentos choques entre las diversas culturas. Este drama sincrónico queda registrado inevitablemente en una narrativa diacrónica que desde entonces se empecina en interpretar los acontecimientos históricos en un tiempo cronológicamente uniforme que los ubica linealmente, es decir, en una progresión que va de la barbarie a la civilización.

No cabe duda de que este tiempo histórico marca el curso de todas las narrativas nacionales, sean éstas europeas o propias de las sociedades dependientes postcoloniales, como lo vimos en el análisis de los tres ensayos "fundacionales" de la nación boliviana. Sin embargo, propongo, en la parte final de este trabajo, concentrarme en Los siete ensayos de interpretación de la realidad peruana, del ensayista y pensador peruano José Carlos Mariátegui, uno de los más importantes ejemplos de memoria contra-hegemónica. En su ensayo, donde el horizonte de expectativas de la modernidad entra en crisis, es decir, donde el futuro no puede ser conocido por adelantado, la memoria local, colectiva, contrarresta con gran agudeza el sentido lineal y progresivo de la memoria universal impuesta por el historicismo europeo.

IV

Nacido de la conciencia de que Perú está enclavado en una realidad muy diferente a la que presentan las sociedades occidentales, el pensamiento de Mariátegui es particularmente sensible al hecho de que la realidad peruana de principios del siglo XX combina, en un mismo territorio, diferentes tiempos que superponen diversos estadios de la historia, desde el primitivismo indígena hasta la industrialización moderna. Para Mariátegui, este Perú abigarrado no reclama la elaboración de una teoría modernizadora apegada al historicismo europeo, sino un mito colectivo que, como auténtica "apuesta", tenga la capacidad de luchar por la realización de valores, pero sin que nada 
garantice su consecución. Existe, pues, un trasfondo marcado por el espontaneísmo en su pensamiento. Ello puede observarse en la relación que establece entre la "apuesta mística", la comunidad indígena y el pasado como recurso del presente. ¿Cómo se explica esta "apuesta" que aproxima al presente la comunidad indígena arcaica y sus valores constitutivos?

Al confrontar el proceso peruano con el europeo, Mariátegui observa que el criollo latifundista quiere saltar esa etapa fundamental del desarrollo capitalista que hemos visto muy someramente en el ejemplo de la Toscana italiana: quiere volverse empresario sin pasar por la necesaria desintegración de la propiedad feudal. A juicio de Mariátegui ello es irrealizable porque se lo impide una manera de ser señorial y rentista que no puede transformase en un carácter auténticamente burgués. ¿Cuál sería, entonces, la vía a seguir?, ¿debe el latifundista desaparecer?, ¿quizás pasar por la dura escuela de la pequeña propiedad? Afirmarlo habría llevado a Mariátegui a sostener el típico ideal liberal de la creación de una numerosa pequeña burguesía agraria. Perfectamente consciente de esta solución liberal, Mariátegui se aparta radicalmente de dicha ideología para proponer una solución utópica, cuyo protagonista y realizador no viene a ser el propietario rentista, criollo o mestizo, sino el campesino indígena.

Los indígenas, pues, con sus formas sociales y culturales del pasado prehispánico, habrían de proporcionar los elementos necesarios para solucionar el problema de la tierra planteado por la dominación española y, luego, por el liberalismo. Se vislumbra, entonces, cuáles son para Mariátegui las modificaciones que la situación nacional impone al esquema marxista europeo: primero, la burguesía peruana no es propiamente tal sino un grupo liberal aristocrático u oligárquico-liberal incapaz de crear, debido a su condición de ser el sector social más ligado a la economía colonial y periférica, las condiciones típicas del capitalismo; segundo, el protagonista de la revolución socialista no podría ser el proletariado clásico, sino otro, ampliado, capaz de incorporar al campesinado indígena.

Mariátegui parte de la idea de Manuel González Prada, cuyo pensamiento socialista le antecede, de que la cuestión indígena es, antes que filantrópica y cultural, eminentemente económica y agraria. Se trata del reparto de la tierra en beneficio de una masa que, en sus cuatro quintas partes, es indígena y campesina. Por supuesto que a Mariátegui no se le escapa el hecho de que el comunismo moderno es algo muy diferente del comunismo incaico, que lo único que puede asimilarlos es "su incorpórea semejanza esencial, dentro de la diferencia esencial y material de tiempo y espacio” ([1928]: 66). Se ve, pues, en la dialéctica entre tiempo y espacio que impone la realidad peruana, la modificación que el espacio andino introduce en la conceptualización temporal, lineal del marxismo europeo. Si se necesita importar el socialismo, habrá que hacerlo descubriendo la tierra adecuada, las condiciones geo-culturales precisas que permitan su crecimiento: el socialismo no puede ser pensado como un calco. Es una creación europea que exige, sin embargo, el conocimiento preciso del terreno en el que se pretende aplicarla.

Así descrito el problema, surge en Mariátegui la necesidad de pensar el ayllu, la comunidad indígena, no como una estructura análoga a las del socialismo moderno, sino como algo diferente que 
solamente puede ser entendido si se parte de un cuidadoso análisis del espacio local en el cual está inserto, es decir, del análisis histórico, espacio-temporal, de la propiedad agraria del Perú. Sin embargo, y a pesar de la necesidad de llevar a cabo el análisis razonado de cómo debe incorporarse la comunidad indígena, la estructura no moderna de la modernidad, Mariátegui expresa su convicción de que el resurgimiento indígena no proviene de un proceso de “occidentalización” material de la tierra quechua, sino del mito.

Esta convicción no deja de sorprender y da lugar a la crítica que tilda a Mariátegui de incongruente y de arcaico. En efecto, hay una cierta falta de lógica en el pensamiento de Mariátegui porque, por un lado, afirma que, en el caso peruano, donde no ha podido prosperar el espíritu de burgo, los terratenientes no son capaces de "saltar" a la condición de empresarios capitalistas. En efecto, afirma que el latifundismo criollo no ha podido cumplir la etapa de desintegración del feudo. Pero, por otro lado, afirma, pero no explica lógicamente cómo es que los indígenas, marginados y explotados, podrían pasar de su condición servil a la organización socialista. Es decir, en un caso cree en la necesidad del proceso de occidentalización feudo-desintegración-empresa, y, en el otro caso, considera que los indígenas pueden pasar por alto todo ello a fin de lograr el socialismo. A pesar de esta aparente incongruencia, me pregunto si realmente existe una contradicción entre ambas afirmaciones. Debo decir que no lo creo. Con su conceptualización de la comunidad indígena, Mariátegui simplemente afirma que el poder movilizador de los mitos, de los espectros del pasado, trasciende el liberalismo para confundirse con el poder de las masas indígenas.

Queda, sin embargo, la necesidad de organizar un sujeto popular capaz de llevar a cabo la revolución socialista. No es que el indígena deba tomar el rol del proletariado, sino que éste debe adoptar un carácter mucho más amplio e inclusivo. En otras palabras, si la apuesta mística va más allá del liberalismo individualista y conecta a Mariátegui con la masa indígena, su marxismo le obliga a repensar el sujeto de la revolución y a asignar un rol gravitante a los campesinos. Pero esto no quiere decir que el marxismo campesino deba excluir al proletariado industrial. Todo lo contrario: Mariátegui insiste en la importancia del proletariado y habla de un partido de clase, un partido de trabajadores que debe estar compuesto por obreros y por campesinos.

En suma, el pensamiento de Mariátegui clama por la revolución total en el Perú. A fin de lograr dicho propósito, sus ensayos optan por la fuerza y el arraigo del sentimiento mesiánico, por la necesidad imperativa de incorporarlo a su proyecto revolucionario. Consciente de que cualquier posibilidad exitosa del marxismo en el Perú debe pasar por la confluencia con la cultura andina, Mariátegui introduce en su pensamiento la apuesta mística de la comunidad indígena. En efecto, la defensa de la comunidad robustece su rechazo del capitalismo. Gracias a la contemporaneidad de esta estructura no-contemporánea, Perú puede seguir una evolución histórica diferente de la que tuvo lugar en Europa. Es así que Mariátegui se ubica en un terreno radicalmente diferente, contrahegemónico, de análisis y de reflexión: el problema no es desarrollar el capitalismo, ni repetir la memoria transatlántica, la historia de Europa en América Latina, sino lograr la construcción de una vía autónoma. Por ello, puede decirse que el rasgo esencial de su pensamiento es la recusación del progreso y el rechazo de la imagen lineal y eurocéntrica de la Historia universal. 
Me parece que uno de los hallazgos más importantes de Siete ensayos de interpretación de la realidad peruana es la necesidad de contrarrestar el horizonte de expectativas de la modernidad con el mayor "espesor" del presente. Este presente histórico está, como Harootunian lo ha visto bien ([1924]: 471-494), repleto de temporalidades mixtas. Es importante reconocer que este presente marca la coexistencia y la inmanencia de los momentos contemporáneamente no-contemporáneos de los espectros del pasado. Estos espectros no son fenómenos arcaizantes, sino temporalidades que también condicionan el desarrollo del capitalismo modernizador, pero que son suprimidos y ocultados por el futuro perfecto y por las expectativas de progreso. Bajo esta utopía racionalizadora, las élites locales insisten tozudamente en que todas las sociedades se nivelen de acuerdo con los parámetros de la civilización occidental.

Mariátegui comprende plenamente que uno de los aspectos de la modernización a ultranza consiste en desplazar la "no contemporaneidad" lejos del mundo "civilizado" y ubicarla exclusivamente en el espacio de las sociedades subdesarrolladas que, si se las juzga desde la modernidad europea, son un "todavía no" que debe evolucionar. Oponiéndose a este procedimiento falsamente unificador y reduccionista del eurocentrismo, Mariátegui busca en sus ensayos superar la aculturación que refuerza la externalidad del tiempo histórico, conflictuándola con su reflexión en torno a las temporalidades mixtas que cohabitan el territorio peruano.

Por otra parte, Mariátegui también se da cuenta de la necesidad de complejizar el marxismo ortodoxo. En efecto, en su análisis de la realidad peruana se percibe la clara conciencia de que el espejismo del futuro une el capitalismo con las versiones eurocéntricas del marxismo clásico. Por ello, intuye Mariátegui, al estudiar la evolución del Perú, que las diferencias entre la evolución y la revolución no son tan grandes como parecen, sobre todo cuando ambas ubican la utopía social en el tiempo histórico, teleológico, del futuro perfecto. Mariátegui, quien problematiza esta visión progresiva de los acontecimientos humanos, opone a la prognosis el “engrosamiento” del presente.

Es el tiempo del "ahora", del presente, que nos revela la contemporaneidad de lo nocontemporáneo. Es el flujo constante de temporalidades mixtas entremezcladas que ocultan el capital y "nuestra" problemática modernidad. De esta manera, se puede decir que la Historia, con mayúscula, se inscribe en el tiempo lineal e histórico de la modernidad; la memoria colectiva (Halbwachs), por el contrario, más acorde con los vericuetos de un pasado que se resiste a desaparecer, vuelve a equilibrar el tiempo con el espacio y da lugar a lo que Henri Lefebvre denomina "espacio social".

"Espacio social” es la posibilidad de que el pasado deje su huella, que se inscriba en el espacio andino y se transforme en "ahora", en tiempo presente. Gracias a Mariátegui, podemos comprender en carne propia la idea de la contemporaneidad no-contemporánea, planteada por Ernst Bloch. En efecto, esta idea, que Mariátegui urde en su explicación del espacio andino, reintroduce en dicha región periférica el tema del pasado como presente. Espacializado, ocultado por el Estado oligárquico-liberal, este tema reaparece con toda su fuerza en Siete ensayos de interpretación de la realidad peruana. Así, en el capítulo dedicado a explorar el factor religioso en el Perú, Mariátegui 
propone que la contemporaneidad de lo no-contemporáneo - los mitos andinos traídos al presentenos ayude a reflexionar sobre la necesidad de volver al tema de la temporalidad, y, de igual manera, a la temporalización de las formas que rigen aquellos espacios sociales donde lo no-contemporáneo ha sido rezagado, ocultado por el modernizador Estado-nación.

Mariátegui se da perfecta cuenta de que la desigualdad acompaña toda la historia del capitalismo. De esta manera, la desigualdad no es simplemente una etapa que deba ser superada por el desarrollo --los esquemas desarrollistas de las agencias internacionales siguen creyendo en ellosino una de las principales condiciones de reproducción del capital. Puesto que el desarrollo capitalista no es ya una posibilidad para Mariátegui -nunca pudimos interiorizar el "espíritu de burgo" - nuestro derrotero histórico y vivencial es diferente. Por ello, Mariátegui recurre a los espectros del pasado para explicar la "diferencia". Estas experiencias dramatizan un tipo otro de "embrujamiento" de la realidad que se da con las laberínticas migraciones del campo a la ciudad, y que traen al presente fantasmas del pasado que se resisten a desaparecer, que cohabitan con lo moderno, y que entremezclan las temporalidades.

Es claro que la historia europea -la memoria transatlántica, ajena a la de las colectividades locales- ignora esta operación que negocia el pasado con el presente, donde pasado y presente no son lineales, sucesivos, sino producidos simultáneamente; son temporalidades desiguales que coexisten y que dialogan críticamente con el "allá" de la modernidad, aunque ésta las desdeñe como algo lógicamente indefinible, pre-existente y condenado a desaparecer.

Si se las observa desde el punto de vista del quipuscamayoc, del anciano indígena que abre las reflexiones de este trabajo, es claro que la historia y la memoria europeas terminan siendo algo externo, muerto. Esta sensación de externalidad queda reforzada por la presencia de los acontecimientos cronológicamente ordenados. Por ello, podemos ver, en los ensayos fundacionales que describo en las primeras secciones de este trabajo, que el tiempo histórico tiene por objetivo relocalizar la memoria de la colectividad, hacer que ella abandone los vericuetos de su pasado, que se reubique dentro de la narrativa homogeneizadora de la nación.

Opuesta al propósito homogenizador del Estado-nación, la memoria andina que rige el ensayo contra-hegemónico de José Carlos Mariátegui tiende a producir el efecto inverso: la artificialidad del tiempo histórico contrasta con esa memoria transtemporal que entremezcla las experiencias pasadas con aquéllas que se viven en el presente. Si la historia, pensada desde afuera, desde el esquema occidental, se ocupa de la evolución y del cambio, con rupturas que acortan el tiempo, la memoria colectiva cultiva las similitudes y alarga el tiempo para asegurar que el pasado pueda incrustarse en el presente.

Al reflexionar sobre las diferentes temporalidades que conviven en el presente, Mariátegui comienza en América Latina la difícil tarea de crear un discurso de la modernidad que, opuesto al discurso sobre lo autóctono, gestado por las élites nacionales, sea capaz de comprender la historia de nuestro presente como una unidad de desiguales temporalidades; un presente, un "tiempo-ahora" diferente y en tensión con el espacio geopolítico global. Mariátegui es quizás la primera conciencia 
americana en percibir que no se trata de seguir ciegamente proyectos globalizadores que sólo conciben el mundo como el espacio de los intercambios mercantiles.

Finalmente, este pensador peruano da el primer paso en pos de la construcción de una ontología del presente que sea capaz de repensar la relación entre el tiempo y el espacio. Esta ontología debe abrirse a las temporalidades mixtas que pueblan el presente y que son "ahoras" que no admiten ser ubicados linealmente, como si fuesen partes de la ordenada concatenación de los acontecimientos históricos. 
BIBLIOGRAFÍA

AlBARRACín, Juan (1981). El pensamiento filosófico de Tamayo y el irracionalismo alemán. La Paz: Akapana.

ANDERSON, Benedict (1983). Imagined Communities. Londosn: Verso.

ARGUEDAS, Alcides (1937). Pueblo enfermo.Santiago de Chile: Ediciones Ercilla.

ARGUEDAS, José María (1941). Yawar Fiesta. Lima: Editorial Horizontes.

AUERBACH, Erich (1968). Mimésis. La represéntation de la réalité dans la literature occidentale. París: Éditions Gallimard.

BнAвHA, Homi (2002). "Of Mimicry and Man: The Ambivalences of Colonial Discourse". Race Critical Theories (Philomena Essed y David Goldberg, eds.). Oxford: Blackwell Publishers Ltd.: 113-122.

BLOCH, Ernst (1991). Heritage of Our Times. Berkeley y Los Angeles: University of California Press.

GARCíA PABÓN, Leonardo (1998). La patria íntima. La Paz, Bolivia: CESU/Plural editores.

HaLbWaChS, Maurice (1968). La mémoire collective.Paris: Presses Universitaires de France.

Harootunian, Harry. "Some Thoughts on Comparability and the Space-Time Problem”. Boundary $232: 2$ (2005): 23-52.

Harootunian, Harry. "Remembering the Historical Present". Critical Inquiry 33 (2007): 471-494.

LEFEBVRE, Henri [1974] (2000). La production de l'espace. Paris: Anthropos.

MacCormack, Sabine. “ 'En los tiempos muy antiguos...' Cómo se recordaba el pasado en el Perú de la Colonia temprana”. Procesos. Revista Ecuatoriana de Historia 7 (1995) 3-33.

MARIÁTEGUI, José Carlos [1928] (1979). Siete ensayos de interrpretación de la realidad peruana. Lima: Biblioteca Amauta.

Mignolo, Walter (2000). Local Histories/Global Designs. Coloniality, Subaltern Knowledges, and Border Thinking. New Jersey: Princeton University Press.

Montenegro, Carlos [1943] (1994). Nacionalismo y coloniaje. La Paz: Editorial Juventud.

SAID, Edward (2002). Reflections on Exile and Other Essays. Cambridge, Mass: Harvard University Press.

Tamayo, Franz [1910] (1975). . La creación de la pedagogía nacional. La Paz: Biblioteca del Sesquicentenario de la República.

WEBER, Max [1904] (2002). The Protestant Ethic and The Spirit of Capitalism. New York: Penguin Books. 


\section{LA RAPSODIA POSTCOLONIAL COMO ACTIVISMO}

GLOBAL: EL MOVIMIENTO ZAPATISTA Y LA GUERRA

\section{DE LA PALABRA}

Postcolonial rhapsody as global activism: the Zapatista Movement and the war of the word

\section{HÉCTOR DOMÍNGUEZ RuVALCABA}

ThE UNIVERSITY OF TEXAS AT AUSTIN ruvalcaba@austin.utexas.edu

Héctor Domínguez-Ruvalcaba es profesor investigador en la Universidad de Texas en Austin, especializado en sexualidades, género y violencia en la literatura y la cultura latinoamericanas. Es autor de De la sensualidad a la violencia de género (2014) y Nación criminal: narrativas del crimen organizado y el estado mexicano (2015) y Translating the Queer (2016) y coautor de Desmantelamiento de la ciudadanía, políticas de terror en la frontera norte (2011).

RECIBIDO: 16 DE ENERO DE 2017

RESUMEN: Este ensayo interpreta las declaraciones de la Selva Lacandona emitidas desde 1994 por el Ejército Zapatista de Liberación Nacional como un periplo que parte de una síntesis de la teología de la liberación y la guerrilla marxista latinoamericana a una postura expresada como la aglutinación de discursos que componen las culturas de la resistencia globales. Entiendo la primera como una ideología anticolonial, en la medida que concibe su lucha como un deseo de liberación de la dependencia de los países latinoamericanos de los imperialismos modernos. Podemos considerar la pluralidad de discursos en que el zapatismo ha desembocado, tras su vínculo con grupos diversos de resistencia, como una forma postcolonial de hacer política. Propongo aquí analizar la interlocución de los comunicados zapatistas como una política de redes cuyo centro se establece precisamente en Chiapas. Más que un punto de convergencia coyuntural, La Selva Lacandona pasa a ser un punto de quiasmo de una diversidad de agendas políticas que se han llamado altermundistas.

Palabras Clave: Zapatismo, colonialidad, liberación, autonomía, globalización, resistencia.

\section{ACEPTADO: 25 DE MAYO DE 2017}

ABSTRACT: This essay interprets the Selva Lacandona Declarations, published since 1994 by the Zapatista Army of National Liberation as a journey departing from a synthesis of Liberation Theology and the Latin American Marxist guerrilla towards a posture expressed as the agglutination of discourses encompassing the global resistance cultures. I understand the first as an anticolonial ideology, as it deems its fight a Latin American liberation desire from dependency on modern imperialism. We can consider the plurality of discourses Zapatismo has become a postcolonial form of doing politics, after its link with a diversity of resistance groups. My aim here is to analyze the Zapatista communications with the web politics whose center is located in Chiapas. More than a convergence juncture the Selva Lacandona becomes a chiasm of a diversity of political agendas of the so-called alter-world.

KEYwORDS: Zapatismo, coloniality, liberation, autonomy, globalization, resistance. 


\section{LO ANTICOLONIAL}

Los términos redención y salvación se han instalado desde los albores de la colonización como principios que han de regir las políticas públicas con respecto a las comunidades indígenas de Latinoamérica. Digamos de entrada que la idea de la liberación del indígena halla su sentido en el marco de la colonialidad. El discurso de la liberación es primordialmente cristiano en este contexto. En una carta dirigida al Subcomandante Marcos, Enrique Krauze atina a decir que el proyecto de la nación mexicana es una promesa cristiana, aludiendo a la moral asumida por los clérigos que han encabezado o reflexionado sobre las diversas liberaciones en la historia de México. "Los sentimientos de la nación” de José María Morelos le da un punto de apoyo para exigirle al guerrillero una moral de la insurgencia (Krauze 1996: 93-94). El discurso de la teología de la liberación que se ha instalado en Latinoamérica desde los años sesenta, viene a ser la versión moderna de esta moral insurgente invocada por Krauze. La moral anticolonial convierte en un deber público la protección al colonizado, lo cual se manifiesta como un gesto de redención e indemnización.

De acuerdo con Marco Estrada Saavedra, un factor importante para la organización de las comunidades indígenas en Chiapas fueron los grupos eclesiales de base, que, en consonancia con la orientación social de la iglesia católica a partir del Concilio Vaticano II, promovieron la construcción de una Civitas Christi o sociedad basada en una política cristiana liberadora (2007: 240). Se trata de un proyecto civilizatorio que surgió en el contexto de la desarticulación de la servidumbre de los indígenas en los ranchos ganaderos y cafetaleros de Chiapas, donde la reforma agraria emprendida por la revolución en la primera mitad del siglo XX no tuvo mayor efecto. De acuerdo con la antropóloga Aída Hernández Castillo, la reforma agraria de 1992, durante el régimen de Carlos Salinas de Gortari, detonó la preocupación de los indígenas de Chiapas por la reaparición de un sistema de servidumbre del cual se habían desprendido recientemente con el reparto de tierras en el régimen de Luis Echeverría (1970-1976), que habría de completar la tarea de Lázaro Cárdenas (1934-1940) que en realidad no afectó a la práctica del acasillamiento o servidumbre que mantenía a la población indígena de esta región fuera de los beneficios de la revolución (Hernández Castillo 2001: 188-189; Reyes Ramos, 1992: 59-62). Así, el proyecto civilizatorio de las comunidades eclesiales de base consiste en una propuesta de descolonización, si entendemos esta relación de servidumbre como un rasgo de la explotación colonizadora que tiene sus raíces en la Nueva España. Para la población indígena, ni independencias ni revoluciones han cambiado su situación laboral precaria. La teología de la liberación es civilizatoria en tando que se plantea como objetivo el desarrollo social y económico de las comunidades; y liberacionista porque parte de la idea de la redención de los indígenas a quienes se trata de defender contra los abusos de los caciques y el gobierno.

Al mismo tiempo, algunos grupos guerrilleros marxistas de la corriente maoísta, que provenían genealógicamente del Frente de Liberación Nacional (grupo guerrillero de los años setenta) y constituidos en su mayoría por jóvenes estudiantes de origen urbano, empezaron a organizarse en la región. Tanto catequistas como guerrilleros son agentes exógenos que llevan a cabo un proyecto de 
redención. Si bien los guerrilleros lanzaron un llamado a la violencia como única vía para lograr la transformación social y los grupos catequistas mantuvieron el principio de transformación pacífica, la relación entre ambos, lejos de ser hostil, ha sido colaborativa. En última instancia, ambas corrientes fueron determinantes para la construcción de lo que actualmente conocemos como los caracoles, las comunidades zapatistas regidas por juntas de buen gobierno, independientes del grupo guerrillero.

Inmediatamente después del levantamiento zapatista el primero de enero de 1994, prácticamente todos los sectores de la sociedad civil llamaron a la paz y al diálogo, y al unísono reconocieron que el país entero tiene una deuda histórica con los pueblos indígenas. Este discurso moral es asimismo un discurso colonial en su origen y método, y en su gesto mentor y paternal que reproduce la posición piadosa de la iglesia, la cual interviene como factor mitigante de la violencia colonizadora. Pero el aplazamiento indefinido del pago de dicha deuda no hace sino confirmar el carácter utópico del discurso anticolonial. La liberación termina siendo sólo la enunciación de esta promesa incumplida.

El sujeto indígena ha sido desde los primeros años de la colonia un motivo de querella teológica y legal. La Brevísima historia de la destrucción de las indias de Fray Bartolomé de las Casas funda el discurso liberador contra el discurso colonial. En síntesis, se trata de denunciar la inhumanidad con que el europeo se toma la libertad de suspender la libertad del indio. Aquí tropezamos con una distinción que la experiencia colonial hace visible: el liberalismo y la liberación son mutuamente excluyentes. El discurso de la teología de la liberación, producido desde una práctica hermenéutica que conjuga el pensamiento marxista con la doctrina cristiana, plantea la redención del indio (tanto en su registro marxista como en su registro cristiano) de su esclavizamiento colonial, del cual el liberalismo es su modalidad moderna. Por extensión, el neoliberalismo y el discurso de la resistencia constituyen un reposicionamiento de esta confrontación histórica. La contradicción colonial se define entonces entre una doctrina del mercado que reclama la libertad para explotar recursos y fuerza de trabajo a fin de acumular capital como la clave del progreso, y un discurso redentor que reclama la libertad del sujeto colonizado con respecto al engranaje de la producción capitalista sustentada en la doctrina liberal. La tensión entre liberalismo y liberación es el nodo conflictivo con que se narrativiza la historia de la nación mexicana. Los zapatistas reclaman ser parte de esta tradición, reconsiderando el conflicto colonial, ahora concebido en términos de una amplia red de resistencias frente al neoliberalismo.

La línea que separa al liberalismo de la liberación puede comprenderse desde la distinción entre sacrificio y el don de sí que establecen algunos teólogos de la liberación como Benedito Ferraro y Franz Hinkelammert (Ferraro 1991: 43-46; Hinkenlammert 1991: 43). Para ellos, el sacrificio no es una muerte liberadora, es la muerte opresora, el morir que no transforma la condición oprimida, mientras que el don de sí es una muerte asumida con una razón para entregar la vida y contiene "un elemento de superación del sacrificio" (Hinkelammert 1991: 43). Esto sugiere, entonces, que para la teología de la liberación la identidad del indio no solamente consiste en la autoconciencia identitaria sino que esta conciencia es colonizada (despojada, desplaza y oprimida) y por lo tanto, la descolonización, que lo llevaría a humanizarse en la libertad, requiere un don de sí como parte 
constitutiva de su autoconciencia. Vemos entonces que el sujeto indígena se concibe como sujeto mártir cuya inmolación se asimila a un proceso histórico de descolonización. Este conocerse como sujeto sufriente lo remite entonces a la ética del insurgente esbozada por Enrique Krauze en la carta al subcomandante Marcos arriba mencionada. El sujeto indígena de la liberación es un sujeto en resistencia, su cultura no se comprende sin el conflicto de lo colonial con que lo conocemos y se conoce a sí mismo, se trata, entonces, de una cultura producida por el mal colonial, donde incluso la referencia a sus fundamentos ancestrales tiene una función legitimadora del deseo de emancipación. Cuando Bernardo Boff afirma que la teología de la libración identifica al pobre con Dios, establece un lugar epistemológico desde el cual se articula el clamor de la víctima del colonialismo frente a un Dios que escucha y actúa a través del don de sí. Esta base interlocutoria es la que da sentido a las Comunidades Eclesiales de Base: el acto de resistencia es una plegaria a Dios y una acción divina (Boff 1991: 47). Desde su ética, es bueno todo lo que se resiste al mal histórico de la dominación, por lo tanto el bien se funda sobre la condición de haber sido víctima del mal colonial que describe a un sujeto liberador, el que ejerce el don de sí.

Como la economía, las prácticas culturales y la política, la idea liberadora ha llegado del mismo centro metropolitano de donde viene el colonizador. Ambos son parte de la totalidad occidental y son los actores principales del drama de la modernidad. La liberación del indígena, entonces, puede plantearse como un deseo político surgido del propio pensamiento occidental, que forma parte del proceso de colonización, precisamente como su contradicción interna. Me interesa subrayar esta relación de interioridad porque el pensamiento de la liberación no puede entenderse como algo ajeno a la cultura colonizadora sino como parte de su propia dinámica. Si la procedencia del discurso anticolonial es occidental -desde la denuncia de De las Casas hasta las redes de solidaridad europea y norteamericana con los pueblos indígenas del presente- la posición colonizadora ha implicado una actividad cognitiva que entiende el mundo en términos de colonizadores y colonizados. La descolonización depende para su realización de este binomio. La liberación es un efecto reflexivo de occidente sobre sus colonias, por ello lo difícil será encontrar un discurso ajeno a la tradición europea en el campo de las luchas sociales en América Latina.

A lo largo de la historia de Latinoamérica, la emancipación produce contradicciones que muchas veces convierten las propuestas liberadoras en principios de opresión. Se trata de discursos que fundamentan totalitarismos y refuerzan significados con que se reactualizan (modernizan) las formas de explotación de los grupos subalternos. Ni el estado independiente ni la república del final del siglo XIX ni la que se funda la revolución llegaron a hacer efectiva la descolonización del indígena. La promesa incumplida de redención, siempre aplazada a conveniencia de las élites, tiene entonces el sentido de reactualizar los procesos colonizadores, hecho que explica la obstinada permanencia de la colonialidad del poder (Quijano, 2000).

La posición anticolonial por excelencia se sustenta en el discurso cristiano. Tiene su raíz en el escándalo piadoso ante la violencia sistemática que produce lo que Todorov llama el mayor genocidio de la historia de la humanidad (1999: 5). Tenemos entonces que su origen es querellante, remite a las controversias jurídicas y a las definiciones identitarias. La "Primera declaración de la Selva 
Lacandona" (EZLN, 1993) abre precisamente con una querella en la que resume quinientos años de colonialismo:

Somos producto de 500 años de luchas: primero contra la esclavitud, en la guerra de Independencia contra España encabezada por los insurgentes, después por evitar ser absorbidos por el expansionismo norteamericano, luego por promulgar nuestra Constitución y expulsar al Imperio Francés de nuestro suelo, después la dictadura porfirista nos negó la aplicación justa de las leyes de Reforma y el pueblo se rebeló formando sus propios líderes, surgieron Villa y Zapata, hombres pobres como nosotros a los que se nos ha negado la preparación más elemental para así poder utilizarnos como carne de cañón y saquear las riquezas de nuestra patria sin importarles que estemos muriendo de hambre y enfermedades curables, sin importarles que no tengamos nada, absolutamente nada, ni un techo digno, ni tierra, ni trabajo, ni salud, ni alimentación, ni educación, sin tener derecho a elegir libre y democráticamente a nuestras autoridades, sin independencia de los extranjeros, sin paz ni justicia para nosotros y nuestros hijos (EZLN).

El resumen de la historia de la nación se hace desde la perspectiva de la resistencia al colonialismo, al cual refiere como esclavitud, expansionismo, imperio y dictadura: los diversos nombres para los depredadores de la patria. Los primeros comunicados hablaban en nombre de la nación, la cual se presenta como un cuerpo victimizado y escanciado por el efecto de la explotación imperialista. Lo que queda claro es que no hay forma de acceder a la soberanía nacional ni a la democracia mientras subsista la colonialidad. El texto de la "Primera declaración..." establece que el efecto colonizador es la precariedad, la negación no sólo de la subjetividad del colonizado sino también de los beneficios de la civilización: salud, educación, democracia, en suma, su ciudadanía en el mundo moderno. Es este estado de precariedad el principal detonador del levantamiento armado.

El discurso de la precariedad, sobre todo la del indio, despierta una mayor atención sobre las condiciones económicas que dieron lugar a esta situación paupérrima. Hay un consenso social en considerar que esta precariedad es un flagelo, así como también lo hay en oponerse a la solución violenta a este conflicto. Al manifestarse la sociedad civil en contra de la opción armada, lo que queda claro es que el discurso revolucionario anticolonial, la lucha armada que derribaría al sistema que produjo tal precariedad, no tiene lugar como razón política para los diversos sectores sociales. "La segunda declaración de la Selva Lacandona” (junio de 1994) deja claro que es este consenso el que predominó tras las primeras semanas del levantamiento: "Mantendremos el respeto al cese al fuego para permitir a la sociedad civil que se organice en las formas que considere pertinentes para lograr el tránsito a la democracia en nuestro país" (EZLN). Esta decisión de dar marcha atrás al proyecto guerrillero implica el reconocimiento de que la guerrilla no forma parte del proyecto nacional, que el problema de los pobres sólo tiene efecto en el discurso de la moral política y que la voluntad de resolverlo tendrá que ser negociada por las vías institucionales.

Esta propuesta de negociación se concreta en una serie de eventos de diálogo entre representantes del gobierno y el EZLN, con la intermediación del Obisto de San Cristóbal de las Casas, Samuel Ruiz. De 1994 a 1996, estas reuniones de negociación reiteraban la retórica del paradigma nacional, estableciendo una relación metonímica entre indio y nación: resolver el 
problema indígena es resolver el problema de la nación, de la cual el indígena es su parte fundante. Esta identificación del indio con la patria se materializa en la iniciativa de ley resultado de estos diálogos, Los Acuerdos de San Andrés (1996). Ahí se ofrece una definición del indígena (extraída del Convenio 169 de la Organización Internacional del Trabajo, suscrito por México) que se funda en la idea de territorialidad: "descienden de poblaciones que habitaban en el país en la época de la conquista o la colonización y del establecimiento de las actuales fronteras" (EZLN, 2000: 58). Esta delimitación territorial converge con una delimitación epistémica: "La conciencia de su identidad indígena deberá cosiderarse como un criterio fundamental para determinar los grupos a los que se aplican las disposiciones de los pueblos indios" (EZLN, 2000: 58). No basta entonces con estar asociado a una territorialidad históricamente determinada sino también a una autoconciencia identitaria, de lo que se desprende que es indio el que además de descender de un grupo originario de la tierra se define a sí mismo como tal. Ahora bien, el conocimiento de sí mismo como indígena implica para la perspectiva liberacionista el reconocimiento de la colonialidad. Se trata entonces de una identidad construida desde la experiencia histórica narrativizada en términos de desplazamiento, despojo y explotación.

Antonio García de León llama “cultura del desalojo” a la práctica implementada desde tiempos de la colonia de expulsar a grupos indígenas de las tierras fértiles valiéndose de peones mestizos o pertenecientes a otras etnias indígenas (2002: 30). Para este historiador, tales actos de despojo violento explican las rivalidades interétnicas en Chiapas. De donde se puede comprender que la identidad indígena se establece a través de una relación conflictiva con las fuerzas colonizadoras. La podemos conceptualizar como una definición histórica del despojado, por lo que los Los Acuerdos de San Andrés pueden interpretarse como un intento de restituir su territorio y su derecho a la identidad al sujeto desplazado.

De acuerdo con Adolfo Gilly, existe en las rebeliones indígenas de la historia de México "la resistencia a aceptar que la tierra se convierta en mercancía; la negativa a enviar al mundo de los intercambios mercantiles entre otras cosas aquello que dentro de la comunidad es sustrato cultural e histórico de los intercambios directos entre personas" (1997: 19). El rechazo a que la tierra se convierta en mercancía implica más que la visión sagrada de lo telúrico, la percepción de la modernidad capitalista como una catástrofe: "si la tierra es mercancía todos terminaremos por serlo enteramente y junto con nuestra comunidad, inseparable de su territorio, habremos vendido nuestro cuerpo y perdido nuestra alma" (Gilly, 1997: 20). Mientras que la revolución mexicana había ofrecido una posibilidad de restitución del territorio al indígena a través del ejido, las enmiendas a la Ley de Reforma Agraria implementadas por el presidente Salinas de Gortari en 1992 significaron a los ojos del indígena otro despojo expresado en la suspensión de repartos de tierra y de subsidios agrícolas en aras del neoliberalismo (Álvaro Marín). Se trata, ante todo, de una amenaza de desastre espiritual y económico letal para la identidad y el ser todo del indígena. Por ello, antes de entender la liberación como un proyecto de transformación del estado ha de plantearse como un proyecto de conservación del indígena, de su salvación, en términos políticos y teológicos, frente a la opresión neoliberal. 
En 1996, Los acuerdos de San Andrés fueron presentados -con algunas modificaciones- por una comisión de diputados y senadores (COCOPA) ante el Congreso de la Unión, el cual la aprobó y turnó al presidente Ernesto Zedillo, quien la modificó de tal forma que no fue satisfactoria para el EZLN, pues no reconocía la soberanía indígena sobre su territorio. Esto marca el rechazo de los zapatistas de las opciones institucionales que el gobierno y diversos sectores sociales principalmente de la izquierda- habían propuesto después del levantamiento. Los zapatistas declaran no tener ninguna aspiración al poder, entendido esto como una declinación a participar en las luchas políticas oficializadas.

A partir de este fracaso, se desató una controversia en torno a la constitucionalidad del indígena como sujeto legal (en oposición a los mexicanos que no se identifican como tal), y las dificultades que implicaría para la aplicación de las leyes el hecho de introducir la noción de usos y costumbres como marco jurídico de excepción. Roger Bartra, por ejemplo, hace ver que los sistemas normativos tradicionales indígenas son de procedencia colonial, pues se trata de un sistema de usos y costumbres establecidos (tal vez negociados) durante la colonia española para estas comunidades, con lo que nos invita a reconsiderar la noción de lo indígena cuestionando la legitimidad de las normatividades que el zapatismo desea refundar. El análisis de las etnografías de las normatividades indígenas disponibles le permiten a Bartra presentar al indígena como una identidad sustentada dentro de las relaciones coloniales, es decir, el indígena ha sido identificado como sujeto legal para los intereses del poder colonial (1999: 30-35).

Al referirse a la maquinaria del estado, todos los comunicados y pronunciamientos usan la expresión "mal gobierno", mientras que a los organismos que rigen a las comunidades zapatistas los denominan "juntas de buen gobierno". Esta es una manera de mantener viva la interpretación de que el estado no ha dejado de ser colonial en cuanto a su relación con la población indígena: sea cual sea su estrategia orientada a resolver los problemas de los pueblos originarios, su destino fatal ha de ser el de no comprender ni actuar en favor de ellos. Esta posición maniquea atribuye al estado mexicano una incapacidad de comunicarse y a la vez hace percibir al indio como sujeto hermético (Paz, 2002), o un sujeto que no puede hablar si antes no ha adquirido los valores y significaciones del poder hegemónico (Beverley). Esta incomunicabilidad, de acuerdo con Eduardo Galeano, apenas puede resolverse si el sujeto no indígena guarda silencio y aprende a escuchar al otro: "Marcos, el portavoz, llegó de afuera. Les habló, no le entendieron. Entonces se metió en la niebla, aprendió a escuchar y fue capaz de hablar. Ahora habla desde ellos, es voz de voces" (1996). Si el hablar desde el indio es hablar la voz de voces, lo que Galeano está destacando es el aspecto colectivo del saber indígena.

Este hablar desde el indio se expresa con una nueva retórica que ya se puede advertir en la Cuarta Declaración de la Selva Lacandona (1 de enero de 1996): "No morirá la flor de la palabra. Podrá morir el rostro oculto de quien la nombra hoy, pero la palabra que vino desde el fondo de la historia y de la tierra ya no podrá ser arrancada por la soberbia del poder” (EZLN). A partir de la "Cuarta Declaración de la Selva Lacandona" se reconocen léxicos y formas metafóricas pertenecientes a la poesía precolombina según la hemos leído en versiones de Miguel León Portilla y Ángel María Garibay. La voz del indio se manifiesta de la misma forma en que se ha codificado en la 
comunidad lectora. Se trata con ello de presentar una escenificación verbal, donde el indio habla con la retórica literaria que lo ha identificado en la alta cultura mexicana. Esto nos sugiere que el lenguaje de la cuarta declaración apela a la ancestralidad como forma de resistencia ante la dominación del libre mercado, como Ileana Rodríguez analiza las estrategias discursivas de Rigoberta Menchú, donde el discurso de la ancestralidad cumple con una función estratégica de empoderamiento (Rodríguez, 2009).

Por su parte, Octavio Paz destaca el carácter simbólico e histriónico de la irrupción zapatista que es a sus ojos ante todo una irrupción mediática--como un ritual, una política teatralizada (2002: 30). Más que una visión del otro indígena, el punto de vista del intelectual nos descubre el carácter de su propia mirada: a los ojos del hombre liberal moderno, un levantamiento contra la colonización que esta modernidad implica se percibe como un simulacro, como una representación ritualizada, quizá sin concederle mayor fuerza que la de un efecto publicitario. Andrés Openheimer encuentra que el discurso indígena de los zapatistas surge en el momento que los dirigentes guerrilleros se dieron cuenta de que la guerrilla marxista tradicional había dejado de tener simpatizantes, de ahí que cambió la retórica de la lucha de clases por la retórica del indio. Los pobres adquieren entonces un marco de representación de identidad étnica. El punto de quiebre en el discurso político se observa claramente en la “Cuarta Declaración...”. La guerrilla dejó de usar las armas y empezó a usar la palabra ritual y los atavíos, para llegar a ser una curiosidad de moda para las celebridades de Hollywood (Openheimer, 1996: 54). En una entrevista concedida a Laura Castellino en la revista Gatopardo, el Subcomandante Marcos reconoce: "nunca como en este momento está claro que el atractivo reside en el símbolo... porque el misterio, la máscara, atraen todo eso que también fue cultivado por los medios" (2008: 68). Parece ser entonces que el discurso político propuesto por los zapatistas instaura la voz del indio como una serie de gestos y asonadas simbólicas que se despliegan en el escenario mediático y en ello basan su fuerza política.

Esta reducción a la simulación que implican las observaciones de Paz, Openheimer y el propio Marcos puede sin embargo rastrearse en la misma asignación de papeles en el plano de la representación y el conocimiento (es decir, las acciones epistémicas) impuestas desde occidente al indígena. Es parte de la colonialidad del poder, según Aníbal Quijano, el hecho de que al indígena de las Américas se le haya reprimido su modo de producción de conocimiento, significados y símbolos, en suma, se ha reducido su subjetividad al término de primitivo, con el que los europeos se refieren a los miembros de las razas amerindias y africanas (Quijano, 2000: 542). Al parecer, la lucha anticolonial (anti-neoliberal) del zapatismo ha sido recibida como una teatralización en la cual va perdiendo su propia significación histórica o se asimila a las prácticas culturales colonialistas: transformada en espectáculo y en mero símbolo de liberación, la amenaza del colapso del orden neoliberal queda sin efecto.

\section{LO POSTCOLONIAL}

La revolución zapatista ha suspendido y aplazado indefinidamente la lucha armada y ha instalado en su lugar una cultura política que mantiene como principio definitorio un discurso de 
resistencia ante la estructura colonial en turno, el neoliberalismo. El estado mexicano, entonces, se comprende, desde la perspectiva zapatista, como una entidad sometida a esta política neoliberal y por lo tanto como un dispositivo de la condición colonizada. Sin embargo, el modelo de dominación neoliberal no se identifica con un estado determinado y en todo caso consiste en la supremacía del mercado a lo largo y ancho de la cartografía mundial. Esta recomposición cartográfica del poder reestructura las relaciones de explotación y las concepciones políticas de la resistencia en el mundo contemporáneo. Esta nueva cartografía no significa, sin embargo, que haya una indiferenciación de todas las localidades, sino una emergencia de particularidades que a pesar de componer un mundo dominado por el común denominador del neoliberalismo, acusa formas implícitas y explícitas de resistencia. Asistimos, pues, a una recomposición social que hace de las multitudes un campo más que de acciones políticas, de gestos políticos vaciados de la fuerza que implicaría una lucha liberadora. Lo que puede afirmarse después de la observación de estas particularidades diversas es que el neoliberalismo impone una reducción de las relaciones sociales a comunidades fragmentadas y desplazadas con políticas precarias que esquemáticamene (es decir, fuera de las complicaciones de las doctrinas cristiana y marxista) reiteran las ideas de redención y salvación.

En la "Quinta Declaración de la Selva Lacandona” (julio de 1998) la única fuerza que el movimiento zapatista reconoce poseer es la de la razón, sustentada en valores universales occidentales:

No nos alzamos y nos hicimos rebeldes por creernos más fuertes y poderosos. Nos levantamos en demanda de democracia, libertad y justicia porque tenemos la razón y la dignidad de la historia de nuestro lado. Y con esto en las manos y en el pecho, es imposible quedarse impávido frente a las injusticias, traiciones y mentiras que en nuestro país son ya un "estilo de gobierno" (EZLN).

El poder de la razón adolece de falta de fuerza. El movimiento zapatista es en este sentido más que una lucha política (lucha por el poder), una lucha que nace y termina en el terreno del razonamiento. La "Quinta declaración..." parece ser al final una explicación de por qué hay objetivos que no podrán cumplirse. Por lo menos no promete ningún futuro posible sino un horizonte deseado. El movimiento se ha convertido en el foro de expresión de los deseos políticos y dejó de ser el escenario de la lucha política (esto es, la lucha por los cambios posibles). La utopía se mantiene en pie siempre y cuando no abandone el terreno de la representación y la interpretación y espere paciente a que el peso de la razón cambie la historia. El providencialismo marxista entra en contacto con la inercia fatalista de los discursos políticos mexicanos.

Cabe preguntarse si esta lucha es realmente una fuerza que amenaza a las estructuras del capital o si el zapatismo se instaura como uno de los movimientos que hacen posible la globalidad de lo político, una especie de producto de alto valor moral en el mercado mundial de las ideologías. El hecho de convertirse en lugar de enunciación de las múltiples agendas ideológicas que circulan entre las redes con que se estructura la comunidad activista mundial, sugiere que el problema indígena se desplaza a ser una de las diversas agendas en acción a nivel global y no la agenda central que la cuarta y quinta declaraciones proclaman. Al distenderse las zonas de confrontación con el estado, los 
zapatistas se repliegan al proyecto de autonomía, se empeñan en la experimentación de las juntas de buen gobierno, en la construcción de los caracoles, a manera de una didáctica de cómo vivir fuera del estado, el mal gobierno. Se trata de una distensión que a la vez se proyecta como un modelo de política sin estado que pretende diseminarse globalmente.

El movimiento zapatista expresa como objetivo central la construcción de la autonomía, lo que sería inconcebible sin la red de diversas agendas políticas a nivel global. En este sentido, se puede decir que participa de un movimiento político antisistémico y multivalente sin que se proponga a sí mismo como un modelo de organización. Sin embargo, no todas las posiciones ideológicas que asumen una actitud crítica ante los sistemas establecidos forman parte de esta diversidad que los zapatistas acotan. La política no legitimada entre los zapatistas en la "Sexta declaración de la Selva Lacandona" es la electoral, precisamente la que permite la subsistencia del estado democrático de corte liberal republicano. El común denominador de los grupos incluidos en su red de apoyo es el hecho de haberse declarado en resistencia ante esta forma de estado y sobre todo ante su sustento económico, el capitalismo. Dos entidades se identifican como los enemigos de las comunidades zapatistas: el mal gobierno y el neoliberalismo. Su definición como parte del movimiento-mundo se basa en el hecho de mantenerse en resistencia contra el sistema neoliberal, que es el programa económico oficial. La articulación del gobierno mexicano con la economía global tiene su lado inverso en la articulación de estas redes de resistencia. La oposición a la política electoral, incluida la izquierda que se ha constituido en partido y que cuenta con registro legal, se debe a que esta opción ha perdido legitimidad como izquierda al vincularse con un gobierno que apoya la política neoliberal. "La sexta declaración..." convoca a toda fuerza democrática que no se vincule al sistema democrático oficial:

O sea que, como quien dice, invitamos a las organizaciones políticas y sociales de izquierda que no tengan registro, y a las personas que se reivindiquen de izquierda que no pertenezcan a los partidos políticos con registro, a reunirnos en tiempo, lugar y modo que les propondremos en su oportunidad, para organizar una campaña nacional, visitando todos los rincones posibles de nuestra patria, para escuchar y organizar la palabra de nuestro pueblo. Entonces es como una campaña, pero muy otra porque no es electoral (EZLN).

La salida de lo electoral, el cuidado de no relacionarse con los partidos registrados, anuncia una descalificación de las prácticas democráticas hegemónicas. Decididamente anticapitalista, el movimiento zapatista no reconoce las formas convencionales de democracia del estado liberal y en su lugar establece una práctica anarquista basada en acuerdos tomados minuciosamente en las asambleas comunitarias. En este sentido se convierten en un experimento social al que han de poner atención tanto escépticos como simpatizantes, construyendo una red de representaciones aparentemente múltiples, no obstante reducibles a un número de tendencias discursivas y modos de circulación de signos más o menos homogéneos. En la acumulación de diferencias de la polifonía de movimientos políticos que la red zapatista representa (en cada declaración un número mayor de agendas políticas aparece acreditado) podemos reconocer un modo relacional de cohesión: el mal gobierno y el neoliberalismo son el obstáculo para el desarrollo de su identidad, su cultura y su existencia. Las 
comunidades zapatistas reciben delegaciones de organizaciones con múltiples causas, quienes le informan al vocero Subcomandante Marcos de sus agendas y le piden que los mencione en su discurso, convirtiendo al zapatismo en un portavoz de las diversas resistencias. En los discursos de $L a$ otra campaña que podemos encontrar en youtube.com, podemos distinguir estas agendas como argumentos que se acumulan para el fin de reforzar la idea de que la democracia electoral es una farsa y que hay otra forma de lucha posible. Pero concebir un telos político nacional no es precisamente el objetivo de esta campaña. El movimiento atiende problemas concretos de comunidades concretas y calla del objetivo final: escapar del control del estado y socavar el sistema económico imperante. Quedan, pues, poco explicitados los objetivos de la lucha, aunque no hay duda de sus repudios, como Marcos lo expresa en una una carta a Enrique Krauze fechada en febrero de 1994: "hay un buen número de personas que sabemos lo que no queremos, aunque tal vez sea más unánime el sentimiento de no tener una maldita idea de lo que sí queremos” (Marcos, 1993).

El zapatismo nos ofrece un quiasmo de proposiciones políticas. Es un recorrido por los diversos discursos que se dan cita en la Selva Lacandona. La "Sexta declaración..." imagina una red de indígenas de todo el mundo y se propone como una lucha internacionalista de grupos subalternos. No se dirige a los partidos políticos sino a la sociedad civil, la cual cuenta con sus simpatías por componerse de gente humilde como los indígenas. Queda claro en la "Sexta declaración..." que la vía electoral de la democracia representativa está cancelada. Descartadas las maneras legales y formales de hacer política, y tras dejar las armas en paz, el zapatismo ejerce su acción disidente desde el plano de las redes de apoyo. No obstante, en octubre de 2016, el Consejo Nacional Indígena decidió conformar un Concejo Indígena de Gobierno para proponer una candidata indígena a la presidencia para los comicios de 2018. Esta vuelta al escenario de la política electoral parece corregir los planteamientos de la "Sexta declaración...". En el documento titulado "Concejo Indígena de Gobierno" de la página del Congreso Nacional Indígena afirman que no están compitiendo contra los partidos políticos y que no persiguen el poder, que la candidata elegida cumplirá la función de vocera de Concejo Indígena de Gobierno (Martín Pérez, 2017). En su discurso ofrecido en rueda de prensa tras ser nombrada vocera, María de Jesús Patricio Martínez afirma que no quiere sentarse en la silla maliciada de la presidencia, y que su propósito es divulgar ante la sociedad civil organizada y no organizada la agenda de defender el territorio, la tierra, de la devastación neoliberal. La estrategia consiste en usar la plataforma electoral como un foro para divulgar un tema urgente: la defensa de la vida frente al capitalismo depredador del orden neoliberal ("Vamos a luchar por la vida..."). Por una parte "La sexta declaración..." afirma la ilegitimidad del sistema electoral, pero por la otra el Congreso Nacional Indígena se sirve de este sistema como un marco donde tomar por asalto la esfera pública con el fin de poner a consideración de la población un tema que afecta a indígenas y no indígenas. Se trata, entonces, de un plan de alcanzar una mayor visibilidad de las políticas indígenas, de acuerdo con sus declaraciones. Primordialmente, la difusión del zapatismo abarca la cartografía de Internet. Su influencia, entonces, se centra las redes académicas y activistas de organizaciones no gubernamentales definidas por lo general por su particularización de agendas políticas: derechos humanos, ecología, género, etc. Se ha llamado altermundismo a esta forma de hacer política a partir 
de redes cibernéticas de defensa. ¿Significa esta vuelta a los escenarios de la política formal una nueva etapa en las estrategias del zapatismo? En el momento en que esto se escribe no podemos saberlo.

El ejercicio político zapatista es el de los comunicados, las redes de apoyo, las asambleas que recorren el largo proceso de tomar decisiones hasta que la comunidad haya llegado a una determinación en cuanto a los diversos asuntos de interés colectivo. Esta forma de ser de la autonomía zapatista se ha convertido en una parábola de la democracia que nutre las narrativas de documentales, etnografías, reportajes, crónicas, testimonios y ensayos hasta lograr uno de los más amplios archivos políticos del presente. El zapatismo es un proceso social que no puede explicarse sin la intensa tarea de representación a la que está sometido. El zapatismo es un acto de lectura de un complejo de signos emergidos en la zona paupérrima del mundo indígena, que se realiza en los espacios privilegiados de producción de conocimientos, ejerciendo una resignificación constante en los centros metropolitanos del saber (Nugent, 1995). Este desplazamiento de las armas a los signos, del territorio nacional al flujo virtual del Internet, también implica un distanciamiento de los modos de hacer política en el contexto de lo nacional. Esto es, se trata de una política que rebasa los métodos de lucha de la izquierda contra la derecha en el mundo moderno para plantear una forma de contienda implacable que consiste en la circulación de información de manera inmediata y constante (Rovira , 2009: 87).

Este divorcio con la izquierda formal parte acaso de una visión que Dussel expresaría en su propuesta sobre qué ha de hacer la filosofía en América Latina: “que la 'voluntad de poder' incluya como su opuesta a la 'voluntad dominada" (1975: 21). Esto es, el zapatismo (contrariamente a su declaración de no buscar el poder) se concibe a sí mismo como una "voluntad de poder" y desdeña a los partidos políticos como "voluntades dominadas" en tanto que juegan las reglas del estado. Si el zapatismo se define primariamente como anti-prísmo, de manera que parte del discurso inicial tenía como eje constante la referencia al partido-gobierno, los enemigos inmediatos, los que han sido señalados como sus principales perseguidores lo constituyen grupos paramilitares priístas: tales son las voluntades dominadas, las que no implican una voluntad de poder. La ética de la resistencia se centra en una observancia del desvinculamiento con la institucionalidad.

Una voluntad no dominada, entonces, es la que proyecta la autonomía. En vista de que los movimientos universalistas liberadores no han sido capaces de la descolonización, entonces se hace necesario anteponer la política singularista, donde ningún universalismo ético o político parece tener validez (Roger White, 2009). De acuerdo con Lotringer Sylvere y Christian Marazzi “Autonomy is the body without organs of politics, antihierarchic, anti-representative. It is not only a political project, it is a project for existence" y más adelante añaden: "autonomy has not frontiers. It is a way of eluding the imperatives of production, the verticality of institutions, the traps of political representation, the virus of power... to allow parts to co-exist side by side, in their singularity" (2007: 8). En su desprendimiento del estado y de los proyectos liberadores universalistas (en su caso, el cristianismo de la teología de la liberación y el socialismo), las comunidades zapatistas terminan representándose como autonomías. Por ello la aglutinación de las diversas agendas políticas que 
podemos advertir en la "Sexta declaración" no perfecciona al pensamiento universalista sino que lo cancela, estableciendo la proliferación de particularidades como única forma de expresión política.

La autonomía sería, entonces, la política de la particularidad tal como Peter Hallward la concibe: una creación de sí mismo, desprendida de la dependencia relacional que la dominación colonial implica. La liberación parte del reconocimiento de la dominación para infundir el deseo de desarticularla y así dar paso a la singularidad. Esta singularidad se concibe como un apartarse de los criterios exógenos en vista de la destrucción ejercida por los diversos proyectos de liberación o de recolonización. La inmanencia a que Hallward nos remite encuentra sus criterios en la propia acción ejercida con la ausencia de otros (2001: 7). Lo que se nos ha presentado hasta ahora es el deseo utópico -o acaso su realización precaria- de un autogobierno o lo que se llama buen gobierno, gobierno puro, sin mancha de la perversión colonial. La liberación es ante todo una promesa religiosamente sostenida, es decir sostenida bajo la fe comunitaria. El modo profético comunitario de los comunicados de los zapatistas va más allá de lo político. La propia decisión de no integrarse a la maquinaria política oficial da lugar a esta interpretación: no es al reino de este mundo (el mundo capitalista) al que los zapatistas quieren pertenecer sino al de la tierra prometida de los Caracoles, el cielo de la autonomía. 


\section{BIBLIOGRAFÍA}

BARTRA, Roger (1999). La sangre y la tinta. Ensayos sobre la condición postmexicana. México: Océano.

BOFF, Leonardo (1991). "El lugar central de las víctimas en la teología de la liberación”. Sobre ídolos y sacrificios. René Girard con teólogos de la liberación (Hugo Assmann, ed. ). San José, Costa Rica: Departamento Ecuménico de Investigaciones: 46-47.

Concejo Indígena de Gobierno.

DuSELL, Enrique (1975). Liberación latinoamerica y Emanuel Levinas. Buenos Aires: Bonum.

ESTRADA SAAVEDRA, Marco (2007). La comunidad rebelde y el EZLN. Un estudio histórico y sociológico sobre las bases de apoyo zapatistas en las cañadas tojolabales de la Selva Lacandona (1930-2005). México: El Colegio de México.

EjÉrcito Zapatista de Liberación Nacional (2000). “Acuerdos de San Andrés”. Acuerdos de San Andrés. (Hernández Navarro, Luis y Ramón Vera Huerta, eds.). México: Era.

EJÉRCitO ZAPATISTA DE LiBERACiÓN NACiONAL. “Declaraciones de la selva Lacandona”.

FERRARO, Benedito (1991). "Cuestiones teológico-pastorales: ¿por qué una teología no sacrificial?" Sobre ídolos y sacrificios. René Girard con teólogos de la liberación. (Hugo Assmann, ed.) San José, Costa Rica: Departamento Ecuménico de Investigaciones: 43-46.

GalEano, Eduardo. "Viene el zapatismo de lo más lejos del tiempo y de lo más hondo de la tierra". Lajornada. (7/08/1996).

GARCÍA DE LEÓN, Antonio (2002). Fronteras interiores. Chiapas: una modernidad particular. México: Océano.

GILLY, Adolofo (1997). Chiapas: la razón ardiente. Ensayo sobre la rebelión del mundo encantado. Mexico: Era.

HALLWARD, Peter (2001). Absolutely postcolonial : writing between the singular and the specific. Manchester, New York: Manchester University Press.

Hernández Castillo, Aída (2001). Histories and Stories from Chiapas. Border Identities in Southern Mexico. Austin: The University of Texas Press.

HinKElammeRt, Franz (1991). “Distinguir claramente entre sacrificio y don de sí”. Sobre ídolos y sacrificios. René Girard con teólogos de la liberación. (Hugo Assmann, ed.) San José, Costa Rica: Departamento Ecuménico de Investigaciones: 43.

Krauze, Enrique (1996). Tiempo contado. México: Océano.

MARíN, Álvaro. "Reforma agraria salinista 1988-1994”. Sociedad Mexicana: Universidades y Cultura.

MARTín PÉREZ, Fredy. “EZLN elige a “marichuy' como candidata para 2018”. El Universal $(28 / 05 / 2017)$.

NugENT, Daniel. "Northern Intelectuals and the EZLN". Monthly Review 47:3 (1995).

PAZ, Octavio (2002). "The Media Spectacle Comes to Mexico". The Zapatista reader. (Tom Hayden, ed.) New York: Tuder's Mouth Press-Nation Books. 
Quijano, Aníbal. "Coloniality of Power, Eurocentrism, and Latin America", Nepantla: Views from South 1:3 (2000), 533-580.

Reyes Ramos, MAría Eugenia (1992). El reparto de tierras y la política agraria en Chiapas, 1914-1988. México: Universidad Nacional Autónoma de México.

RodríGUEZ, Ileana (2009). Liberalism at Its Limists. Crime and Terror in the Latin American Cultural Text. Pittsburgh: The University of Pittsburgh Press.

ROVIRA, Guiomar (2009). Zapatistas sin fronteras. Las redes de solidaridad con Chiapas y el altermundismo. México: Era.

SubCOMANDANTE Marcos. “A: Enrique Krauze” (Febrero de 1993).

Subcomandante Marcos (2008). Corte de caja: entrevista al Subcomandante Marcos. México: Alterno.

LOTRInGER, Sylvere y Christian MARAzzi (2007). “The return to politics”. Autonomía. Postpolitical Politics. (Sylvere Lotringer y Christian Marazzi, ed.) Los Angeles: Semiotext(e).

Todorov, Tzvetan (1999). The Conquest of America. The Question of the Other. Norman: The University of Oklahoma Press.

"Vamos a luchar por la vida: Marichuy Patricio, candidata indígena del EZLN."

White, Roger. "Post Colonial Anarchism”. 


\section{COLONIALISMOS, POSCOLONIALISMOS Y PODERES HEGEMÓNICOS EN LA FRONTERA NORTE DE MÉXICO:}

ARTE, LITERATURA Y RESISTENCIA CULTURAL

Colonialisms, postcolonialisms and hegemonic powers on the northern border of Mexico: art, literature and cultural resistance

\section{NÚRIA VILANOVA}

AMERICAN UNIVERSITY, WASHINGTON, ESTADOS UnIDOS vilanova@american.edu

Profesora de cultura latinoamericana, literatura y cine, dedica su investigaciónal impacto del cambio social y la migración en la producción cultural. Trabaja en narrativas textuales y cinematográficas de violencia, desigualdad y pobreza, particularmente en la región andina y en la frontera mexicano-estadounidense. Después de terminar su doctorado en la Universidad de Liverpool, Reino Unido (1993), vivió y trabajó en varios países latinoamericanos por más de quince años. Es autora de Textos Fronterizos: Ficción del Norte de México (San Diego University Press, 2007) y El impacto del cambio social en la literatura peruana (1970-1990) (Edwin Mellen, 1998). Actualmente está trabajando en un tercer libro sobre la representación de los pueblos indígenas en el cine latinoamericano.

RECIBIDO: 16 DE ENERO DE 2017

RESUMEN: Este artículo explora el desarrollo económico, demográfico y social de la frontera norte de México y el papel que ha jugado ésta en su historia colonial, en relación al surgimiento y desarrollo de su literatura. La obra del tijuanense Luis Humberto Crosthwaite ilustra cómo esta historia colonial es subvertida y transformada en parodia, mediante la cual, la frontera adquiere su propia hegemonía y soberanía.

Palabras clave: Cambio social, frontera, México, Tijuana, colonialismo, poscolonialismo.
ACEPTADO: 14 DE MAYO DE 2017

ABSTRACT: This article explores Mexico Northern border economic, demographic and social development, and the role this has played in its colonial history in relation to the emergence and development of its literature. Tijuana's writer Luis Humberto Crosthwaite work captures how this colonial history is subverted and transformed into parody. In this way, the border becomes hegemonic and sovereign.

Key words: Social Change, Border, México, Tijuana, Colonialism, Postcolonialism. 
No es fácil enfrentarse a la página en blanco para escribir de nuevo sobre este espacio temido, abusado, maltratado, deseado y adorado que es la frontera norte de México. La extrema violencia que esta larga franja de más de tres mil kilómetros sufre de manera persistente no es noticia reciente, ni resultado inmediato de controvertidas decisiones políticas. Las fronteras son espacios de gran complejidad demográfica y socioeconómica y la frontera norte de México lo es de manera exacerbada al ser la zona de contacto entre América Latina y los Estados Unidos. Es difícil, y generalmente incómodo, volver, desde el estudio y la investigación, a este espacio cruzado por tantos fuegos, cuando las víctimas inocentes de este castigado territorio se cuentan por miles.

Hablar de cultura, de arte y de literatura no presupone hacer abstracción del espacio físico, social, económico y político en el que estos se desarrollan y ubican. Precisamente, las dinámicas que conforman la vida diaria y la van moldeando son, de una manera u otra, parte inseparable de toda expresión humana, artística, cultural y social. Partiendo de la idea de que el espacio territorial y las dinámicas humanas que lo van diseñando se entretejen con los diversos textos artísticos que surgen en él, este artículo se propone explorar el impacto del colonialismo en la creación literaria de la frontera norte de México. El objetivo es examinar cómo las diversas fuerzas coloniales que en algún momento de su historia han tenido impacto en la frontera norte -España y Estados Unidos- y el poder hegemónico del Estado mexicano nacional y central, actúan en diversos períodos como un elemento generador, modificador y dinamizador de las expresiones artísticas de la zona.

La frontera norte se ha configurado, en gran medida, como un espacio cruzado por estos colonialismos y poderes hegemónicos que, si bien han dictado el destino de ésa, también han ejercido una permanente fuerza de renovación a través de la resistencia. La tensión entre subordinación y resistencia es esencial para comprender la rica e innovadora producción cultural, artística y literaria de la zona. El objetivo principal de este ensayo es argumentar que la prolífica creatividad y el espíritu innovador que se ha desarrollado en la frontera norte mexicana durante su historia y que ha florecido de manera notoria en los últimos veinticinco años es, junto a otros factores, la respuesta a la permanente subordinación $\mathrm{y}$, a la vez, al abandono a los que el espacio fronterizo ha estado históricamente sometido.

Tras una breve introducción histórica, el artículo explorará el desarrollo económico, demográfico y social de la región y el papel que ha jugado en la frontera su historia colonial, en relación al surgimiento y desarrollo de su literatura. Finalmente, se detendrá en la obra de Luis Humberto Crosthwaite para analizar algunos de sus textos, en los que esta historia colonial es subvertida y transformada en parodia, mediante la cual, la frontera adquiere su propia hegemonía y soberanía.

TIERRA DE NADIE Y DE TODOS: UN ESPACIO INABARCABLE, SIEMPRE INCÓMODO, SIEMPRE AJENO. UNA BREVE INTRODUCCIÓN HISTÓRICA

En sus inicios, la historia colonial del norte de México estuvo marcada por una dinámica propia, independiente y desligada del México central y hegemónico. Las características geográficas de la 
zona, determinadas por la combinación de montañas y desiertos áridos, marcaron, en gran medida, la evolución económica, social y demográfica de este vasto territorio que, ya entrado el siglo XIX, se convertiría en la frontera entre México y Estados Unidos, tal y como la conocemos hoy en día.

Hace menos de un siglo que este vasto territorio, que hoy es centro de atención por su extrema violencia, por su gran complejidad demográfica, así como por su vitalidad económica y su dinamismo cultural y artístico, era una zona escasamente poblada. Ciudades como Tijuana, que actualmente se encuentran entre los centros urbanos de mayor y más rápido crecimiento demográfico de América Latina, eran prácticamente inexistentes hace cien años, cuando en otras partes del mundo, como en Inglaterra, tenían lugar los procesos de urbanización, que serían paradigmas de la modernidad. Tijuana, igual que otras ciudades latinoamericanas y asiáticas, se desarrolló de manera extremadamente rápida y abrupta, quintuplicando su población en menos de cincuenta años. En el contexto demográfico de México, las ciudades de la frontera norte fueron ciudades marginales hasta bien entrado el siglo XX. Sin embargo, hacia el año 1940 seis ciudades fronterizas ya se encontraban entre las treinta y seis más grandes del país. En 1970, Juárez, Mexicali y Tijuana estaban entre las quince primeras. Desde esta fecha, su crecimiento ha sido cada vez más acelerado (Arreola y Curtis, 1993: 12).

\section{LAS CIUDADES EN SUS ORÍGENES}

Los orígenes y desarrollo de las ciudades fronterizas fueron variados, así como también lo ha sido su población, gozando de una gran diversidad tanto de grupos indígenas autóctonos, como de migraciones a través del tiempo. Sin embargo, y a pesar de que cada una de las ciudades fronterizas tiene su propia dinámica y sus propias características, no es menos cierto que desde la época de la colonia española, las ciudades de la frontera norte mexicana comparten una serie de rasgos que las distinguen de otras ciudades a nivel nacional. La distancia con el centro de México, históricamente hegemónico, su proximidad a los Estados Unidos (desde el establecimiento de la actual frontera en 1848) y la resistencia a los poderes coloniales son los grandes determinantes que darán a la frontera norte mexicana un carácter muy especial.

La mayoría de las ciudades se establecieron entre la segunda mitad del siglo XIX y los inicios del XX, aunque algunas tienen su origen en los asentamientos de la colonia española. La aridez del lugar había configurado este amplio espacio fronterizo del norte de México y lo había convertido en una zona muy poco poblada, de habitantes predominantemente nómadas. El desierto significó un obstáculo importante para la expansión colonial cuando Hernán Cortés y sus hombres intentaron adentrarse a la zona poco después de haber conquistado Tenochtitlán en 1521. Sin embargo, unos años más tarde, hacia mediados del siglo XVI, la explotación minera de yacimientos de plata recién descubiertos alrededor de ciudades como Guanajuato, Zacatecas y San Luis Potosí, originó el desarrollo económico, comercial y de servicios de la zona norte de México, desencadenando, consecuentemente, un cambio demográfico significativo en la región. Motivados por la propia expansión económica, el temor a intrusiones extranjeras y el deseo de exploración colonial, la Corona 
española fomentó el desplazamiento y asentamiento de personas llegadas de España y del centro de México a esta zona en expansión1.

La colonización de la zona se hizo a través de los tres tipos de asentamiento que correspondían a los pilares de la Conquista: la misión (la Iglesia), el presidio (los militares) y la villa (la sociedad civil). La finalidad de las misiones era convertir a los diversos grupos indígenas al catolicismo. Sin embargo, en muchas ocasiones, también acabaron siendo centros de contratación laboral (Ganster y Lorey 2008: 24). Paso del Norte (hoy Ciudad Juárez) y San Juan de los Esteros/Refugio (hoy Matamoros) fueron misiones fronterizas que hoy se han convertido en importantes centros urbanos. Por su lado, los presidios eran asentamientos militares estratégicos, que funcionaban como fortalezas para detener las incursiones indias en la zona (Bataillon 1997: 91). Finalmente, las villas eran el centro del asentamiento y de la administración civil, bajo la supervisión de un consejo local. Entre las villas más importantes, se cuentan las de Camargo y Reynosa. Algunos de estos asentamientos evolucionaron hasta convertirse en ciudades importantes. Sin embargo, otros centros urbanos significativos, como Tijuana y Nuevo Laredo surgieron con el establecimiento de la frontera actual en 1848.

Durante la segunda mitad del siglo XX, el campo y la ciudad se vieron completamente transformados por los acelerados procesos de urbanización, vinculados a la masiva migración hacia el norte. A principios de siglo XX, México era una sociedad básicamente agraria. Sin embargo, un siglo después, el setenta y cinco por ciento de la población se encontraba ya en zonas urbanas. En pocas décadas, los extensos territorios baldíos fronterizos se coparon de carreteras, fábricas, casas y gente. El sociólogo inglés Raymond Williams argumenta que "Una historia interna de campo y ciudad tiene lugar, a veces de manera muy intensa, en sociedades coloniales o neo-coloniales. Esto es curiosamente irónico, ya que la ciudad en la mentalidad occidental está generalmente asociada hoy en día a procesos de desarrollo modernos y avanzados, cuando en realidad, a nivel mundial, el crecimiento de ciudades más intenso en el siglo $\mathrm{XX}$ ha tenido lugar en los continentes "subdesarrollados" o "en vías de desarrollo" (...) al otro extremo del proceso imperialista, se están desarrollando ciudades extremadamente superpobladas como resultado directo de un proceso económico impuesto y sus consecuencias internas.” (Williams 1993: 286-87) (La traducción es mía).

No hay duda que, como ocurre en Asia y en África, la explosión urbana y demográfica en América Latina se debe, en gran medida, a las consecuencias directas de las políticas económicas establecidas en los países hegemónicos. Sin embargo, es importante tener en cuenta que el desarrollo urbano más reciente, incluyendo el crecimiento desbordado de ciudades como Tijuana y Juárez en la frontera norte, tiene sus propios orígenes y dinámicas, vinculados a decisiones políticas, de desarrollo

\footnotetext{
${ }^{1}$ En los tiempos de la colonia española, la frontera actual se extendía hacia el norte. Sin embargo, en este artículo se tienen en cuenta los asentamientos coloniales españoles en la demarcación fronteriza actual. Para desarrollar una visión histórica de la región, se han consultado las siguientes fuentes: Alegría Olazábal (1992); Arreola y Curtis (1993); Bayardo Gómez (1991); Guerrero (1981); Martínez (1982); Zorrilla (1993); Ganster y Lorey (2008 2n ed.) y Visión histórica de la frontera norte de México (1994, 2n ed.).
} 
y de gestión económica tanto a nivel local como nacional. Como veremos seguidamente, el crecimiento de estas dos ciudades emblemáticas ha sido rápido y caótico. Entre otros factores, su aislamiento con respeto al Distrito Federal, su proximidad a los Estados Unidos y el anonimato de su población migrante y sin raíces locales, son factores que han contribuido en convertirlas en refugios permisivos para el narcotráfico, el crimen organizado y la explotación humana. Las consecuencias de esta permisividad afloraron dramáticamente durante el sexenio del presidente Felipe Calderón (2006-2012), el cual declaró la guerra abierta al narcotráfico, con la supuesta finalidad de terminar con los paraísos del crimen. La encarnizada batalla entre la policía y los sicarios de los carteles puso a las ciudades de la frontera, principalmente a Juárez, en el punto de mira por su reciente escalada de violencia.

Sin querer subestimar la gravedad y complejidad en la que se ven sumidas las ciudades de la frontera norte, e intentando no caer en falsos romanticismos, cabe decir que un aspecto positivo de su proceso económico, demográfico y social es el surgimiento de una sociedad innovadora y vigorosa, en la que el arte y las expresiones culturales proliferan con una intensidad y vitalidad poco usual. Son precisamente los mismos rasgos específicos que configuran las nuevas sociedades urbanas fronterizas los que fomentaran una vitalidad creativa única y singular.

\section{SIEMPRE HACIA EL NORTE: MIGRACIÓN Y FRONTERA}

La emigración hacia el norte marcará definitivamente la configuración urbana, económica y social de la mayor parte de las ciudades de la frontera mexicana, muy particularmente de Tijuana y de Ciudad Juárez. El flujo constante de gente que cruza la frontera de México a Estados Unidos es una de las características que define el espacio real y simbólico de la frontera. En los últimos treinta años, la migración ha transformado el espacio fronterizo, lo ha convertido en una zona constantemente patrullada y fortificada con gigantescas vallas de aluminio. También ha sido, sin duda, el motor de desarrollo de importantes ciudades como Tijuana, Ciudad Juárez, en México, o El Paso, en Texas. Sin embargo, la migración hacia el norte no es un fenómeno reciente. Tiene sus orígenes en el siglo XIX cuando la creciente demanda de mano de obra en los Estados Unidos coincide con el deterioro de las condiciones laborales de los trabajadores mexicanos durante el porfiriato (1876-1910) (Gutiérrez 1995: 44)². La Revolución Mexicana (1910-1920) empujó hacia el norte a muchos mexicanos que buscaban paz y estabilidad. Hacia 1920, la población mexicana nacida en los Estados Unidos había crecido considerablemente, de 78,000 en 1890 a 478,000 en 1920. En aquel entonces, los inmigrantes mexicanos y los méxico-americanos (personas de origen mexicano, nacidos en los EEUU) trabajaban en los sectores no cualificados, con sueldos bajos, del mercado laboral del suroeste (Gutiérrez 1995: 45). Hacia finales de los años veinte, la Depresión forzó el regreso o la deportación de muchos inmigrantes mexicanos.

\footnotetext{
${ }^{2}$ El porfiriato hace referencia al período que va del año 1876 al 1910 cuando el general Porfirio Díaz estaba en el poder en México.
} 
En los años cuarenta, la demanda laboral creció de nuevo con la expansión de la agricultura y la ganadería en el suroeste una vez superada la gran crisis de los años treinta. Más adelante, la Segunda Guerra Mundial volverá a disparar la demanda laboral vinculada a la industria del armamento. En 1942, se creó el programa Bracero (1942-1964), que proporcionó trabajo legal a los trabajadores dispuestos a desempeñarse en la agricultura en algunas zonas del suroeste. Este fue un momento clave en la historia de la inmigración mexicana a los Estados Unidos, ya que, desde entonces, la inmigración, tanto documentada como indocumentada, no ha cesado. De hecho, antes de 1960, la mayoría de inmigrantes a los Estados Unidos provenían de Europa. Hacia 1980, esta tendencia había cambiado por completo y alrededor del cincuenta por ciento de los inmigrantes al país americano provenía de la vecina América Latina (de éstos, el setenta por ciento era mexicano). Sin duda, la proximidad geográfica fomenta dichos flujos de migración. Miles de personas se verán empujadas a viajar hacia el norte por cuestiones económicas, en primer lugar, y también por la violencia política en Centroamérica, en los años ochenta.

En las décadas de los años ochenta y noventa se experimentaron importantes transformaciones en el patrón migratorio, siendo la más destacada el gran aumento del número de inmigrantes. Algunos cambios en el modelo productivo estadounidense, la crisis económica mexicana de finales de los años ochenta y principios de los noventa, y las nuevas leyes de inmigración en los Estados Unidos -the Inmigration Reform and Control Act (IRCA) - aprobada en 1986, causan el surgimiento de una nueva dinámica en la migración. Ésta se verá reflejada en una reformulación de la demografía migratoria, que incluirá a un mayor número de mujeres y niños, así como también a personas originarias de algunas áreas de la geografía mexicana que, tradicionalmente, no habían producido migrantes. Sin embargo, las regiones del centro y el oeste mexicano siguen siendo las que aportan el mayor número de emigrantes. Además, el fortalecimiento de la frontera física a través de las bardas de aluminio, el endurecimiento de las leyes para los inmigrantes no documentados, así como la incorporación de la familia en el nuevo patrón de migración fomentó que los inmigrantes se instalaran de manera más permanente y, por lo tanto, fueron menos temporales en los Estados Unidos (Lozano Ascencio 1997: 305-20).

Sin embargo, tal y como argumenta Néstor García Canclini, hoy en día la migración es menos definitiva y más móvil que en el pasado, debido a los avances en los medios de transporte y de comunicación que han contribuido de manera definitiva en facilitar los desplazamientos (García Canclini 1999: 256). James Clifford también atribuye estos cambios y avances tecnológicos al carácter cada vez más inestable y temporal de muchos empleos. En sus propias palabras, las situaciones temporales empujan a muchos inmigrantes a "establecer identidades trans-regionales, mantenidas por medio de los viajes y los circuitos telefónicos, para evitar poner el futuro a riesgo en un solo país" (Clifford 1997: 256) (La traducción es mía). Sin embargo, la otra cara de la moneda es que los inmigrantes no documentados sienten que cada vez corren más riesgos al cruzar la frontera. Por lo cual, la dinámica de los desplazamientos en ellos opera de manera contraria. 
El número de trabajadores e inmigrantes no documentados ha crecido sin parar desde los tiempos del programa Bracero. A pesar de las leyes que han intentado frenar el fenómeno, entonces y ahora, los inmigrantes no documentados siguen arriesgando sus vidas para cruzar la línea prohibida y probar su suerte al otro lado. El impacto del flujo migratorio hacia los Estados Unidos en el norte fronterizo de México es profundo y múltiple. Ciudades como Tijuana y Ciudad Juárez -los dos núcleos urbanos más significativos - no sólo son centros de paso y la última parada para los inmigrantes provenientes del sur, sino que también se convierten en importantes recipientes de migración, tanto temporal como permanente. Los efectos de la migración penetran todas las esferas políticas, económicas, sociales y culturales de la franja fronteriza. La configuración demográfica y sus dinámicas sociales y culturales son determinantes para comprender los procesos artísticos y literarios que tienen lugar en la región. Una sociedad extremadamente móvil y anónima, marcada por la ausencia de una memoria colectiva local y por la re-jerarquización social es esencial para entender la mayoría de los fenómenos que tienen lugar en la zona de la frontera, desde la violencia originada en las redes desbocadas del crimen organizado, hasta la vital y desprejuiciada libertad de creación que caracteriza las propuestas más innovadoras del momento. La tensión plasmada en la frontera, entre el espacio históricamente penetrado, sea como lugar de paso, para algunos, o de asentamiento permanente, para otros, con su constante movimiento y vaivén de bienes tangibles y simbólicos, como hábitos, modas, tradiciones y costumbres, por un lado, y por otro lado, la fuerte y genuina personalidad de este espacio, marcada por su resistencia a diluirse en los dictados hegemónicos y por la gran vitalidad original que la caracteriza es el núcleo de este ensayo, que argumenta que los procesos culturales, artísticos y literarios que tienen lugar en la zona son, en gran medida, el resultado de una dinámica propia forjada precisamente en dicha tensión.

\section{DESARROLLO INDUSTRIAL Y EXPLOSIÓN DEMOGRÁFICA: EL NORTE, SIEMPRE EL NORTE}

Una de las formas de penetración hegemónica es el capital. Desde principios de los años sesenta, Tijuana y Ciudad Juárez se convertirán en centros industriales relevantes en el contexto mexicano. El Programa Nacional Fronterizo (PRONAF, 1961) del gobierno nacional significará un primer paso, según el economista de Baja California Alejandro Mungaray, para lograr la modernización de las ciudades del norte fronterizo, cuyo objetivo será conseguir una mayor unidad regional en términos económicos y políticos, instrumentada desde el centro (Mungaray 1998: 266-72).

A principios del siglo XX, Tijuana y Ciudad Juárez se habían convertido en centros de entretenimiento y diversión para muchos estadounidenses que con sólo cruzar la frontera ingresaban a un espacio de permisibilidad donde el sexo, el alcohol y el juego no estaban regulados por el peso de la ley. Con la ley Volstead (1918-33), que prohibía la comercialización y consumo de alcohol en los Estados Unidos, la sórdida reputación de estas ciudades no hizo más que aumentar. ${ }^{3}$ Cuando en

\footnotetext{
${ }^{3}$ El artículo de Tim Girven, "Hollywood's Heterotopia: U.S. Cinema, the Mexican Border, and the Making of Tijuana" (1994) desarrolla la percepción de Tijuana como ciudad de ocio y su proyección como tal en el cine estadounidense.
} 
1933, la ley fue revocada, muchos bares, casinos y salones de Baja California y de Ciudad Juárez se vieron forzados a cerrar. Esta nueva etapa en dichas ciudades se vio reforzada por el empuje moralista pos revolucionario del presidente Lázaro Cárdenas, que obligó el cierre de los casinos y establecimientos de juego en todo el país. Tijuana y Ciudad Juárez fueron rescatada en términos financieros por la apertura de una zona de libre comercio, gracias al auge comercial del momento.

Otra ola de población importante en esas ciudades se dio después de la Depresión económica de los Estados Unidos en los años treinta, que coincidió en el tiempo con la expansión de construcciones militares, muchas de ellas a lo largo de la frontera con México, debido a la Segunda Guerra Mundial (Arreola y Curtis 1993: 26). Una vez más, también en esta ocasión las ciudades fronterizas proporcionaron diversión y entretenimiento a sus vecinos del norte. Hacia los años cincuenta, la emigración interna mexicana hacia las ciudades del norte se masificó. Era el principio de la drástica transformación de dichas ciudades.

Tijuana y Ciudad Juárez protagonizaron en los años sesenta la implementación del Programa de Industrialización Fronteriza (PIF), que siguió al PRONAF, mencionado arriba. Esta iniciativa industrial será un hito en la dinámica económica, social y cultural de la zona, ya que estableció un nuevo patrón económico y comercial mediante la instalación de grandes plantas de ensamblaje industrial, de capital estadounidense, destinadas a la exportación, y conocidas como maquiladoras. La frontera norte de México empezó a experimentar un crecimiento económico más vinculado a los Estados Unidos que a su propio país. Esto se debió en parte a la ausencia de una estrategia industrial a nivel nacional y de un plan de desarrollo integral en México.

Con el establecimiento de las maquilas, el crecimiento demográfico se disparó vertiginosamente ${ }^{4}$. Incluso en épocas de crisis en la economía mexicana, como en 1982, y de 1994 a 1995, la tasa de empleo siguió creciendo en el sector de las maquilas, donde la mayoría de trabajadores son mujeres. Las mujeres han sido en México el grupo de trabajadores que ha ocupado la mayoría de empleos no cualificados y peor pagados. A pesar de que, en los últimos años, la economía de las maquiladoras ha experimentado una cierta recesión, éste sigue siendo un sector esencial de la economía de la frontera norte mexicana. Es todavía prematuro pronosticar el impacto de la crisis actual que sacude a México, a Estados Unidos y a gran parte del mundo. En el caso de México, ésta se ve además empañada por la gran ola de violencia que sacude el norte fronterizo. No cabe duda, sin embargo, que estamos atravesando otro momento clave en la constante transformación de la zona, especialmente de sus centros urbanos.

Cabe matizar que, a pesar del profundo impacto que las maquiladoras han tenido en el crecimiento de la población de la frontera, esto no ha alterado el patrón de emigración a los Estados Unidos, que ha seguido creciendo a lo largo de estos años. Mike Davis afirma muy certeramente que “el surgimiento de una economía dinámica de las maquiladoras, que emplea cerca de un millón de trabajadores, siendo el sesenta por ciento mujeres, ha hecho muy poco para erradicar el flujo de

\footnotetext{
${ }^{4}$ Según datos muy del Gobierno del Estado de Baja California, Tijuana tenía un total de 65,000 habitantes en 1959; 340,000 en 1970; 747, 500, en 1990; 1,200,000 en el 2000 y más de 1,500,000 en el 2008.
} 
trabajadores que cruzan la frontera norte, ya que México produce un millón más de trabajadores anualmente de los que puede absorber su economía" (Davis 2000: 24). De todas maneras, aunque la inmigración interna hacia la frontera no haya conseguido frenar los flujos migratorios a los Estados Unidos, no se puede desestimar que el impacto del proceso industrial en la inmigración interna en las ciudades fronterizas mexicanas, principalmente Tijuana y Juárez, ha supuesto, sin duda, la reconfiguración del mapa político, económico, social y cultural de la zona.

\section{MIGRACIÓN Y RECONFIGURACIÓN SOCIAL/CULTURAL: MEMORIA Y ANONIMATO}

Como ya se ha comentado, las zonas urbanas de la frontera norte vieron un crecimiento demográfico sin precedentes a partir de los años cincuenta y, especialmente, desde los setenta, debido a la llegada masiva de migrantes que provenían, principalmente, del resto del país y de Centroamérica. Si las cinco ciudades más importantes de la frontera mexicana --Mexicali, Tijuana, Ciudad Juárez, Matamoros y Nuevo Laredo- contaban con 350,000 habitantes en 1950, en el año 2000 esta cifra se había disparado a cuatro millones. Hay que tener en cuenta que es muy significativo que la mayor parte de la población de estas ciudades habrá nacido en otro lugar, lo que supondrá una profunda reformulación de las prácticas sociales y culturales que se desprenderá de este vertiginoso crecimiento económico ${ }^{5}$. Una de las implicaciones de una población mayoritariamente ajena y desenraizada del lugar donde habita es que la memoria social se reformula constantemente en un proceso que continuamente borra el pasado. Mientras que la memoria es determinante en el proceso de desplazamiento (desterritorialización) de los migrantes, como individuos sociales y culturales, la historia social de una memoria territorializada -la que se da en un asentamiento estable y permanente - es esencial para crear lo que se podría llamar una tradición local. "La memoria -comenta Michael De Certeau- es el sentido del otro" (De Certeau 1988: 87). En otras palabras, una memoria territorializada es aquella que es compartida por un grupo de individuos; es un nudo cultural que vincula a sus habitantes a las tradiciones de un territorio común. Estos espacios compartidos históricamente suelen estar habitados por las mismas familias, suelen dominar en ellos los mismos apellidos, que serán una marca inexorable de identificación individual. Estas jerarquías sociales tradicionales, tan importantes en otras partes de México, se ven truncadas en la frontera norte por una población temporal, que está mayoritariamente en movimiento. Con el desplazamiento, los individuos dejan atrás su memoria territorializada y se neutralizan en el anonimato social. Este anonimato social será determinante para comprender la libertad, el desprejuicio y la diversidad de miradas y de prácticas del que goza la creación artística y literaria que se da en las grandes urbes de la frontera norte, estrechamente vinculada a la ausencia del corsé social que dicta tendencias y condiciona la innovación creativa. En definitiva, la carencia de una memoria social territorializada tendrá como resultado una sociedad más libre, más desprejuiciada, menos resistente al cambio y más heterogénea, en la cual el peso de la tradición es aliviado por la ausencia de memoria. Este carácter tan particular,

\footnotetext{
${ }^{5}$ Es interesante ver cómo ciudades como Matamoros, cuyo número de inmigrantes es menor que el de Tijuana y Juárez y que, por lo tanto, cuenta con una población originaria del lugar mucho más amplia, tendrán una dinámica social más tradicional y conservadora, marcada, en gran parte, por este hecho.
} 
marcado por el anonimato social, del que gozan Tijuana y Ciudad Juárez, no deja de manifestar una forma internalizada de resistencia cultural, de larga tradición en zona fronteriza.

Sin embargo, el anonimato, fiel aliado de la libertad de creación y, consecuentemente, de la innovación creativa, tiene múltiples facetas y algunas de ellas acarrean terribles consecuencias. El anonimato, en este sentido, puede convertirse en un cómplice corrosivo de la exclusión y la violencia. $\mathrm{Al}$ desaparecer la memoria colectiva, con ella se desvanecen las redes de protección individual. El anonimato muestra su cara más dolorosa cuando se apagan vidas de inmigrantes intentando cruzar el desierto de Arizona, o las rápidas autopistas de San Diego, o bien cuando en los baldíos terrenos de Juárez aparecen los cuerpos torturados y ya sin vida de jóvenes mujeres trabajadoras.

La frontera ha estado permanentemente modificada por los diversos intereses que ha despertado para los Estados Unidos y para el propio México. Las ciudades de diversión de los años veinte siguieron ofreciendo espacios de entretenimiento accesible y libre, a la vez que se transformaban para recibir a miles de trabajadores, muchos de ellos temporales, para explotar las grandes plantas maquiladores. También acabaron convertidas en paraísos de impunidad para el pujante negocio del narcotráfico. La violencia del crimen organizado y de los carteles y bandas de sicarios se fueron, también, apoderando de ellas. Entonces y ahora, las ciudades de la frontera norte, Tijuana y Juárez, particularmente, han sido profundamente estigmatizadas. Gran parte de su reputación proviene de la mirada hacia ellas del centro hegemónico de México.

\section{LA FRONTERA CULTURAL: LA MIRADA ESTIGMATIZANTE DEL MÉXICO HEGEMÓNICO}

Por México hegemónico entiendo tanto las políticas de Estado que provienen del gobierno central mexicano, como el discurso oficial que ha permeado la sociedad y también las miradas de intelectuales mexicanos que tienen su impacto tanto a nivel nacional como internacional.

La frontera norte es también conocida como la herida abierta. Esta metáfora hace referencia a la pérdida de una importante parte del territorio mexicano en manos de Estados Unidos, que pagó a mediados del siglo XIX con la condición de que jamás México pudiera reclamar dicho territorio. En su conjunto, México perdió para siempre Texas, California, Nuevo México, partes de Arizona, de Colorado, de Nevada y de Utah. En el imaginario mexicano, la franja norte fronteriza donde terminaba la patria fue desde entonces un lugar incómodo, una herida abierta, más asociado a los Estados Unidos que al propio México. En su artículo "La cultura de la frontera”, el crítico mexicano Carlos Monsiváis comenta que el norte siempre ha sido para el México central un espacio al servicio de sus intereses en cuanto a su relación con los Estados Unidos. Ya vimos anteriormente la dificultad que tuvo la corona española para incorporar el norte en su proyecto colonial de la Nueva España. Durante los años que siguieron la independencia de España (1810) hasta la firma del Tratado de Guadalupe (1848), que concluye la anexión de los estados mencionados a los Estados Unidos, el espacio que hoy constituye la frontera norte fue un campo de batalla que exacerbó la desconfianza y el recelo hacia la zona por parte del centro de México. 
Estos sentimientos prevalecieron a lo largo de la historia, a pesar de que la relación entre el centro del país y los estados del norte fronterizo han pasado por diversos momentos que, en mayor o menor medida, la han ido modificando. Sin entrar en mucho detalle, es importante mencionar que un período clave será el de la Revolución Mexicana (1910-1920), no sólo por el importante papel que jugó el norte en la contienda, hay que tener en cuenta que los llamados Caudillos del Norte que lideraron la Revolución provenían en su mayoría del norte -Venustiano Carranza (Coahuila), Pancho Villa (Chihuahua) y Álvaro Obregón (Sonora)-, sino también porque la Revolución le proporciona a México un modelo de identidad nacional que permeará el imaginario de todos los mexicanos. Desde entonces, ser mexicano posee un profundo sentido que cruza la vasta geografía del país, su compleja política, sus diversas culturas y sus contrastadas clases sociales. El concepto colonial de mestizaje epitomizará esa identidad mexicana, que a lo largo de los años será más un mito internalizado que una realidad convincente. ${ }^{6}$ Hechos como el levantamiento zapatista en Chiapas en 1994 desenmascaran la realidad para revelar el mito. Se puede afirmar que, a pesar de la distancia, real y simbólica, y el recelo que han caracterizado las relaciones entre el norte fronterizo y el centro del país, esta mitificada identidad unívoca mexicana incorpora, de alguna manera, la frontera norte.

Es muy interesante, sin embargo, constatar cómo esta región ha tenido sus propias dinámicas desvinculadas e independientes del resto del país. En este sentido, es significativo tener en cuenta que, en 1989, cuando la hegemonía del Partido Revolucionario Institucional (PRI), que gobernó el país durante setenta años (1920-2002) era todavía incuestionable en la mayor parte del país, Baja California se convirtió en el primer estado gobernado por un partido de la oposición, el Partido de Acción Nacional (PAN), y que obtendrá el poder en el gobierno nacional en 2002 y en 2006.

Desde la Revolución, el estado mexicano asumió el papel de patrocinador hegemónico de la cultura nacional (Sheridan 1994: 387). El estado mexicano pos revolucionario se hizo cada vez más poderoso y, a su vez, más despótico. Una política cultural exquisita, proyectada tanto a nivel nacional como internacional, la cooptación de muchos intelectuales que, de otro modo, se hubieran opuesto abiertamente al régimen y una política exterior progresista fueron los paliativos de un gobierno autoritario políticamente, que siguió fomentando tremendas desigualdades económicas y que monopolizó la cultura del país, en todas sus expresiones artísticas y literarias. Una de las características de la política cultural del estado mexicano ha sido su centralismo. La poderosa institución estatal, Consejo Nacional para la Cultura y las Artes (CONACULTA), gestiona un importante presupuesto que fomenta y divulga una cultura mexicana elitista, exquisita e

\footnotetext{
6 El mestizaje, entendido como una mezcla racial que resulta en una nueva identidad, es un concepto altamente problemático, ya que borra profundos y arraigados conflictos vinculados a las relaciones económicas, sociales y culturales entre grupos diversos a nivel racial y cultural en una sociedad determinada. Además, atrapa a diversas identidades bajo un mismo e inequívoco concepto, que cubre las distintas especificidades y singularidades de los grupos indígenas. Véase Cornejo Polar (1997a: 268-70; 1997b) y Saldaña-Portillo (2001: 405).
} 
internacionalista, que incluye principalmente arte visuales, danza, música y literatura en un mezcla genuina y exitosa de vanguardia y cierto nacionalismo sofisticado. ${ }^{7}$

Hacia 1970, se empezaron a experimentar cambios en el patrón centralista de CONACULTAy sus fondos empezaron a verse diversificados hacia las provincias, muy especialmente hacia la frontera norte. En 1982 se construyó en Tijuana un edificio monumental, muy cerca de la línea fronteriza, que alberga el mayor centro cultural de la zona, el Centro Cultural de Tijuana (CECUT), donde tienen lugar algunas de las iniciativas culturales y artísticas más innovadoras no sólo de la zona fronteriza, sino de México en su conjunto. En 1985, bajo el mandato del presidente Miguel de la Madrid, el gobierno mexicano puso en marcha el Programa Cultural de las Fronteras, que tenía como objetivo reforzar la identidad nacional mexicana en el norte del país, en un momento de profunda crisis económica a nivel nacional y de expansión vertiginosa de las maquiladoras en la zona. Este programa también tenía como objetivo no declarado una mayor presencia del poder central, en una zona en la que la oposición política avanzaba a pasos gigantescos. ${ }^{8}$ La descentralización cultural por parte del Estado mexicano siguió y durante el gobierno de Carlos Salinas de Gortari (1986-1994) se creó el Programa de Descentralización, de CONACULTA, y su revista cultural llamada simbólicamente Fronteras (1989). También surge en estos años una importante colección literaria llamada Letras de la República, creada por la misma institución, y donde publican por primera vez muchos de los escritores emergentes de la frontera norte que hasta entonces debían desplazarse al Distrito Federal si deseaban ser publicados y seguir una carrera de escritor.

Se puede afirmar que el Tratado de Libre Comercio del Atlántico Norte (TLC) promovió la proliferación de muchos programas e iniciativas, que serán esenciales para el desarrollo artístico, cultural y literario de la zona. Tal y como lo sugieren Castillo y Tabuenca, "no es descabellado pensar que, anticipándose a la aprobación legislativa del TLC, el programa cultural de la frontera proyectaba un México culto y unido para contrarrestar inquietudes nacionales sobre la absorción y apropiación del país por parte de Estados Unidos” (Castillo y Tabuenca 2002: 20). (La traducción es mía). Mediante la integración simbólica y cultural de su frontera norte, México proyectaba la tan ansiada imagen de país unido y soberano ante la implementación de un acuerdo económico y comercial tan controvertido como el TLC.

La llegada del PAN al poder el 2002, después de la larga hegemonía del PRI, no significó un cambio substancial en la política cultural del Estado mexicano. La tendencia a la descentralización cultural ha seguido su desarrollo entrado el siglo XXI. Se podría cuestionar, sin embargo, la eficacia y sinceridad de una descentralización que viene orquestada y dirigida desde el centro. Aún con esta duda pendiente, lo que es cierto es que la inversión que el Estado mexicano ha llevado a cabo en la

\footnotetext{
${ }^{7}$ El Estado también apoya la cultura popular -festivales, artesanías, danza y música- vista como la herencia folklórica que es necesario preservar. La división entre alta cultura y cultura popular es tan marcada que la primera siempre ha tenido un papel subordinado frente a la segunda. Para ampliar sobre este tema, véase Rowe y Schelling (1991).

${ }^{8}$ Socorro Tabuenca argumenta que el objetivo principal del Programa Cultural de las Fronteras era exhibir un México cultivado y culto ante las inminentes negociaciones para la consolidación del Tratado de Libre Comercio (TLC) entre Canadá, Estados Unidos y México.
} 
frontera norte ha contribuido de manera muy significativa a la proliferación artística que se ha dado en la zona desde hace unos veinte años.

\section{ARTE, LITERATURA Y LA FRONTERA}

Desde la década de los setenta, la frontera norte de México ha experimentado una importante proliferación de expresiones artísticas y literarias, cuyo común denominador es su carácter innovador y desprejuiciado. Este fenómeno está íntimamente ligado al desarrollo industrial de la zona, a través de las maquiladoras, a la explosión demográfica que éste significó y al cambio cultural, impulsado, en parte, por la política cultural descentralizada del Estado mexicano. Subyace, a su vez, en la mayoría de propuestas artísticas actuales, un carácter vanguardista relacionado, en gran parte, con el carácter transitorio de la población, la ausencia de una memoria social históricamente establecida el lugar, la configuración de una sociedad móvil que, consecuentemente, tenderá a ser menos prejuiciosa y más libre, la distancia que en términos reales y simbólicos aleja a la frontera del centro hegemónico del país y la proximidad con los Estados Unidos.

Además del apoyo brindado desde el Estado central, diversas instituciones de la zona, como universidades, centros de investigación y fundaciones culturales, entre otras, también respondieron a la expansión económica y demográfica con ayudas importantes a la producción artística de la zona. El crecimiento de las zonas urbanas de la frontera conllevó una ampliación en la demanda educativa, impulsando el surgimiento de nuevos centros lectivos y bibliotecas. A su vez, surgieron nuevas y exitosas compañías de teatro y de danza -dos expresiones artísticas muy arraigadas a la zona- y también aumentó el número de asociaciones culturales y artísticas. Se crearon, además, un buen número de importantes premios a la labor literaria y artística. Hay que reconocer, sin embargo, que, a pesar de la bonanza, el panorama cultural tenía también sus puntos débiles, uno de ellos era la visión externa que tenía mucha de la gente que desde el Estado central gestionaba la política cultural de la zona, otro, por supuesto, el no tener todos los recursos necesarios para poder lograr un buen nivel de producción y difusión. En el fondo, para muchos, la frontera seguía siendo un espacio marginal, cuyos frutos eran percibidos también como marginales ${ }^{9}$.

A pesar de todo ello, ha habido en los últimos años iniciativas muy interesantes que han encontrado la manera de consolidarse. Como veíamos antes, varios aspectos han contribuido a su éxito y proyección. Sin duda, el más importante será el carácter innovador y vanguardista de muchas de estas iniciativas que ha venido dado por varios elementos que se combina entre sí. Por un lado, como ya ha sido mencionado, por la ausencia de una tradición fuertemente arraigada y, por lo tanto, por una mayor libertad y diversidad de perspectivas y modos de expresión, que se traducen en una mentalidad más abierta y menos juiciosa tanto por parte del creador como por parte de la sociedad/ público receptor. A su vez, hay que tener en cuenta la prevalencia de una mentalidad emprendedora,

\footnotetext{
${ }^{9}$ Es interesante el contraste al que hacen referencia Castillo y Tabuenca, cuando comentan que en Estados Unidos los grupos y espacios culturales marginales reciben más apoyos, precisamente por las políticas que intentan disuadir la discriminación. Véase Castillo y Tabuenca 2002: 16.
} 
ante la ausencia de redes sociales y de parentesco. También es esencial la distancia física y, principalmente, simbólica, con el centro de México. Por un lado, la política de descentralización cultural ha permitido una mayor circulación y divulgación de la producción cultural de zonas alejadas del Distrito Federal, como la frontera norte. De tal manera que, muchos escritores y artistas ya no se ven obligados, como en el pasado, a trasladarse a la Ciudad de México para seguir su carrera literaria. Por otro lado, a nivel simbólico, la distancia implica la reformulación del imaginario mexicano del que se ha nutrido la cultura hegemónica, incluyendo la idílica relación con el glorioso pasado azteca y toda la simbología y mitología que lo mantiene vivo. El alejamiento del norte con el centro permite, precisamente, este distanciamiento también cultural.

La otra cara de la distancia con el centro de México es la proximidad física con los Estados Unidos, particularmente con áreas urbanas de vanguardia como son Los Ángeles, entre otros centros importantes de California. Una ciudad como Tijuana no solamente va a recibir el impacto de esta cercanía, sino que ésta le proporcionará la posibilidad de participar de muchos e importantes proyectos co-nacionales, que han proliferado mucho en los últimos años, tanto por lo que se refiere a las artes visuales, como el cine, la música, la danza y la literatura. Son, precisamente, estos campos artísticos los que más han aumentado en los últimos años. Sin extenderme ahora a dar un panorama más amplio del desarrollo artístico de la zona, quisiera detenerme ahora, para finalizar el artículo, en la obra de Luis Humberto Crosthwaite (Tijuana, 1962), uno de los escritores más emblemáticos de la frontera norte.

Sus obras están permeadas por el espacio de la frontera y caracterizadas por el frenético movimiento de Tijuana, que está impreso en su narrativa. La frontera es, así, un territorio que estimula la creación de su discurso literario y se convierte en un espacio no solamente representado en el texto, sino también articulado en él. El movimiento, el ruido, el alboroto y el bullicio, pero también la desolación, la soledad y el anonimato se sienten y se leen en las páginas de Crosthwaite. Tijuana, paradigma urbano de la transitoriedad, es un espacio que se renueva constantemente por el fluido vaivén de gente, de bienes, de signos y de significaciones diversas. El dinamismo de Tijuana es la fuerza que da forma a la ficción de su autor más representativo. Por las páginas de Crosthwaite deambulan agresivas patrullas fronterizas, personajes perdidos que buscan en la frontera su última esperanza, legendarios cantantes, músicos y artistas del pasado, que toman vida de nuevo en la nostalgia de la ficción y un numeroso coro de gente diversa y extraña entre sí, a los que les une el espacio-límite de la frontera. Entre su extensa obra, las obras más relevantes para el objetivo de este trabajo son el cuento: “Where have you been Juan Escutia?” (1988), y la novela La luna siempre será un amor dificil (1994). Ambas recrean la historia de México, con la ironía y el sarcasmo que caracterizan la obra de Crosthwaite. Resematizan sus heridas más profundas y al hacerlo, la resignifican ${ }^{10}$.

El cuento sobre Juan Escutia evoca, como indica su título, a uno de los héroes más populares de la historia de México, y se desarrolla alrededor de tres soldados estadounidenses que cruzan la

${ }^{10}$ Parte de este argumento está desarrollado en Vilanova, Núria, 2006. 
frontera, buscando la diversión en Tijuana. Su llegada al lado mexicano está descrita grotescamente como una invasión. Los "niños héroes", que resistieron heroicamente a los invasores estadounidenses en su defensa del castillo de Chapultepec en el siglo XIX, son rememorados sarcásticamente y la historia real es trasladada a la frontera y a la actualidad para ser resignificada desde una perspectiva burlesca y, por lo tanto, desmitificadora.

El 13 de septiembre nunca fue importante para el grupo B. Era una fecha como cualquier otra. Nos ponían de pie por estatura y todos formaditos entonábamos el ciña oh patria de la misma manera. En la secundaria sólo hubo un cambio, radical para nuestros oídos. Uno de los maestros de historia, el más despiadado, nos puso frente a frente con la realidad (ah, ¿̨qué no lo sabían?): los niños héroes fueron derrotados en aquella famosa batalla, los gringos los hicieron caca. Seis años de asambleas y jamás lo habían dicho. Claro que hubo indignación. (Marcela y el Rey al fin juntos en el paseo costero: 25)

En medio de la euforia de las celebraciones patrias del mes de septiembre, el narrador y sus compañeros descubren que los legendarios "niños héroes" habían sido, de hecho, derrotados por las tropas estadounidenses. Salvaron la bandera mexicana y prefirieron morir antes que rendirse, pero, a fin de cuentas, habían sido aplastados por el enemigo. Las siguientes preguntas implícitas subyacen a la extrañeza de los adolescentes: ¿puede un héroe ser vencido?, ¿por qué las naciones conmemoran sus derrotas?, ¿por qué las naciones construyen sus míticos héroes de derrotas históricas? La decepción que sufren los escolares al descubrir la historia más allá del mito está sutilmente marcada por estas preguntas subyacentes. La jocosidad que envuelve los textos de Crosthwaite supone también un cuestionamiento mordaz de la manera que la historia de México ha sido absorbida en el imaginario nacional.

En La luna siempre será un amor difícil, el norte de México es percibido sarcásticamente como una franja territorial atrapada entre tres imperios: el moderno y próspero imperio del norte, cuyo peso real y simbólico México apenas puede sobrellevar; el imperio español, decadente y pasado; y el soberano y brillante imperio azteca, que sólo vive en el imaginario colectivo del pueblo mexicano. El sarcasmo que recorre toda la obra, se hace patente en los propios títulos de los diversos capítulos que componen la novela, con frases como: "En el Imperio Nortense donde la vida es superior y si no al menos lo parece”. De una manera entrecortada e impredecible, muy característica de las obras de Crosthwaite, la historia narra la relación entre el conquistador español Balboa y su novia indígena Florinda, nombre que adopta la muchacha al cambiar su original Xótchil. Desde la antigua Tenochtitlán, la pareja de enamorados se dirige hacia el norte, en busca de un futuro más próspero. Finalmente, la pareja se instala en la actual Tijuana, fácilmente reconocible en la ficción, aunque la ciudad nunca sea mencionada. Florinda empieza a trabajar en una maquiladora y, tras varios fracasos, al otro lado de la frontera, Balboa al final tendrá que abandonar el sueño americano. La novela es una parodia grotesca y divertida de los imperios, su auge y su decadencia. Florinda añora su pasado indígena en Tenochtitlán, mientras que Balboa resiente no haber hecho caso a sus padres que, todavía en España, le aconsejaban que persiguiera una carrera profesional más lucrativa y productiva que la de conquistador. 
Los tres imperios -el azteca, el español y el estadounidense- interactúan en un constante juego satírico en el que el conquistador español es conquistado, la muchacha indígena es doblemente colonizada, por Balboa y por el Imperio Nortense, y éste se erige como el único poder real que tiene sometidos a todos los demás:

\section{En el Imperio Nortense donde la vida es mejor y si no al menos lo parece}

$\mathrm{Al}$ abrir la cajuela del carro de su tío Decorodo, en donde Balboa había cruzado La Frontera de la Nueva España, todas las maravillas del mundo entraron y lo envolvieron como en una inmensa caja de Pandora. No tenía duda, había descubierto El Dorado (......).

-Nomás cuídate de La Migra; son seres espeluznantes, mitad hombre, mitad bestia (...)

Convertido en un inmigrante indocumentado, el conquistador Balboa se enfrenta a un destino inevitable como lavaplatos en un restaurante mexicano.

La novela se erige como una grotesca ficcionalización sarcástica de los hechos históricos, recreados por el autor, que se entretejen con los mitos del pasado evocados desde la actualidad. Detrás de la máscara de la parodia, la recreación de la historia de México no está carente de claras alusiones a la trágica realidad que golpea día a día a los migrantes en su viaje hacia una ansiada vida mejor. Como muchas otras obras de Crosthwaite, La luna siempre será un amor difícil es una burlesca recreación que disfraza la frustración y el dolor humanos que se viven en esta frontera de la esperanza y la muerte.

La luna siempre será un amor difícil plasma mediante la imaginación creativa y el sarcasmo literario la resistencia de la frontera a ser reducida al espacio cruzado por intereses políticos y económicos de poderes hegemónicos. La historia transatlántica de España, la del México independiente y la del poderoso vecino estadounidense se dan cita, como en la novela de Crosthwaite, en este espacio fronterizo para modificarlo y moldearlo. La frontera se erige en su arte y su literatura como un lugar propio, reivindicado y desestigmatizado, capaz de resemantizar su propia historia para mostrar su personalidad diferenciada. 


\section{BIBLIOGRAFÍA}

Alegría OlazÁbal, Tito (1992). Desarrollo urbano en la frontera México-Estados Unidos. México, D.F.: Consejo Nacional para la Cultura y las Artes.

ARREOLA, Daniel D. y James R. CurTiS (1993). The Mexican Border Cities: Landscape Anatomy and Place Personality. Tucson: University of Arizona Press.

Bataillon, Claude (1997). Espacios mexicanos contemporáneos. México, D.F.: El Colegio de México/Fondo de Cultura Económica.

Bayardo Gomez, Patricio (1990). El Signo y la Alambrada: Ensayos de Literatura y Frontera. Tijuana: Entrelineas Edition.

CLIFFORD, James (1997). Routes: Travel and Translation in the Late Twentieth Century. Cambridge: Harvard University Press.

Cornejo POLAR, Antonio (1997a). "Mestizaje, transculturación, heterogeneidad"- Kaliman, Ricardo J. (ed.) Memorias de JALLA Tucumán. Tucumán: Universidad Nacional de Tucumán: 267-270.

Cornejo POLAR, Antonio. "Mestizaje e hibridez: el riego de las metáforas". Revista Iberoamericana 63/180 (1997b): 341-44

DAVIS, Mike (2000). Magical Urbanism. Latinos Reinvent the U.S City. Londres: Verso.

De CERTEAU, Michael (1988). The Practice of Everyday Life. Berkeley: University of California Press.

GanSTER, Paul y David E. LOREY (2008) The U.S. Mexican Border into the Twenty-First Century. Lanham: Rowman \& Littlefield Publishing Group, Inc.

GARCíA CANCLINI, Néstor (1999). La globalización imaginada. Buenos Aires/México/Barcelona: Paidós.

GIRVEN, Tim. "Hollywood's Heterotopia: U.S. Cinema, the Mexican Border and the Making of Tijuana”. Travesía: Journal of Latin American Cultural Studies, 3: 1 \& 2 (1994): 93-133.

GuTIÉRREZ, Alfonso René (1995). Walls and Mirrors: Mexican-Americans, Mexican Immigrants, and the Politics of Ethnicity. Berkeley: University of California Press.

Lozano Ascencio, Fernando (1997). Sonorenses en Arizona: Proceso de formación de una nación binacional. Hermosillo: Unisón.

MarTíNEZ, Óscar J. (1982). Cüudad Juárez: El auge de una ciudad fronteriza a partir de 1848. México City: Fondo de Cultura Económica.

MungaraY, Alejandro. "Maquiladoras y organización industrial en la frontera norte de México". Comercio exterior 48:4 (1998), 266-72. 
SaldaÑA-Portillo, Josefina (2001). "Who's the Indian in Aztlán? Re-Writing Mestizaje, Indianism, and Chicanismo from the Lacandón”. Rodríguez, Ileana (ed.) The Latin American Subaltern Studies Reader. Durham: Duke University Press: 402-23.

VILANOVA, Núria (2006). "Fronteras coloniales: mitos, ficción y parodia en el norte de México". Usandizaga, Helena, (eda.). La palabra recuperada: mitos prehispánicos en la literatura latinoamericana. Madrid: Iberoamericana: 241-56.

VIlanova, Núria (2007). Border Texts: Writing Fiction from Northern Mexico. San Diego: San Diego University Press.

VVAA (1994). Visión histórica de la frontera norte de México. I-IV. 2a ed. Mexicali: Universidad Autónoma de Baja California.

WiLLIAMS, Raymond (1993). The Country and the City. Londres: Hogarth Press,

ZorriLla, Juan Fidel (1993). Tamaulipas: Una historia compartida 1810-1921. Ciudad Victoria: Universidad Autónoma de Tamaulipas. 


\section{UNA REVISIÓN HISTÓRICO-POLÍTICA DE LA PRODUCCIÓN LITERARIA PUERTORRIQUEÑA. ENTREVISTA CON FERNANDO FELIÚ MATILLA}

A historical and political review of Puertorriquean Literatura. Interview to Fernando Feliú Matilla

\section{ENDIKA BASÁÑEZ BARRIO}

\section{UNIVERSIDAD DEL PAÍs VASCO endika.basanez@ehu.eus}

Realiza su tesis doctoral en la Universidad del País Vasco con una Beca de Investigador en Formación del Gobierno Vasco, por lo que ejerce tareas docentes de manera episódica en la Facultad de Letras de Vitoria-Gasteiz (Departamento de Filología Hispánica, Románica y Teoría de la Literatura). Ha realizado recientemente una estancia de investigación predoctoral en la Universidad de Puerto Rico.

RESUMEN: A lo largo de la siguiente entrevista, el profesor, historiador, crítico e investigador la de la Universidad de Puerto Rico, el catedrático en literatura puertorriqueña don Fernando Feliú Matilla, nos permite establecer una visión histórica de la génesis artística llevada a cabo en la Isla a través de los diferentes contextos socio-políticos que han tenido lugar en la misma desde la aparición de una literatura puertorriqueña propia y distintiva hasta la anexión de Puerto Rico a los Estados Unidos de América como Estado Libre Asociado en 1952 y su impronta en la génesis isleña. Si bien la entrevista tiene como objeto principal la literatura boricua, también se debaten en la misma el falocentrismo cultural presente en la cultura puertorriqueña, las relaciones políticas entre San Juan y Washington D.C., la influencia de los textos diaspóricos en la producción isleña o la situación del panorama artístico actual en Puerto Rico.

PALABRAS CLAVE: Literatura hispanoamericana; Literatura puertorriqueña; Estados Unidos; emigración; política.
ABSTRACT: Throught the following interview, professor Fernando Feliú Matilla, who holds a chair in Puerto Rican Studies and Literature, offers his personal point of view after years of research about Puerto Rican literature written in the 20th century. The interview is developed from a historical perspective, which means that it starts right from the moment Puerto Rico was still a Spanish colony in the Americas, until the present day, being Puerto Rico a Free Associated State of the United States of America (also known as American Commonwealth of Puerto Rico). Besides the literature, professor Feliú Matilla also gives his opinion about the absence of female writers in Puerto Rican literature, the relationships between San Juan and Washington D.C., the cultural movements that Puerto Rican literature written nowadays is influenced by, and many other different topics such as Caribbean literature written in the United States and its connection with Puerto Rican art.

KeYwords: Hispanic Literature; Puerto Rican Literature; USA; immigration; politics. 


\section{DE LOS ORÍGENES A LA FIRMA DEL ESTADO LIBRE ASOCIADO}

ENDIKA BASÁÑEZ. ¿Cuál es el momento histórico en que los latinoamericanistas sitúan los inicios de una literatura puertorriqueña escrita propia y distintiva? ¿Está usted de acuerdo con dicha fecha histórica?

FERNANDO FELIÚ. Generalmente se ubican los inicios de la producción literaria puertorriqueña durante la segunda década del siglo XIX, aproximadamente. Para 1820 en algunos periódicos ya se publicaban poemas, breves ensayos, cuentos tal vez. Eran cosas muy breves, apuntes, pero ya empezaba a formarse una identidad nacional, se empezaban a formar algunos rasgos distintivos de una literatura propia, diferenciada de la española, a pesar de la imposición colonial. Pienso en las coplas del jíbaro, quizá uno de los poemas más importantes de la época fundacional. Roberto Ramos Perea encontró una obra de teatro, que no recuerdo ahora cómo se llama, data de mil ochocientos "treintayalgo" técnicamente sería, entonces, anterior al primer libro "puertorriqueño" que es el jíbaro. El problema de la periodización de ese momento histórico es que siempre se hace un antes y un después a partir de la publicación de un libro y, en este caso, ese corte temporal es el 43, cuando aparece El Aguinaldo, publicado por unos jóvenes puertorriqueños, algunos puertorriqueños, otros no: había venezolanos, había españoles que publicaron un libro que, según ellos presentan, es netamente puertorriqueño. Sin embargo, cuando salió el libro, que consta de cuentos y poemas, no hay prácticamente ninguna alusión a Puerto Rico en el texto. Eso provocó que un año después, en el año 1844, un grupo de estudiantes puertorriqueños en Barcelona, entre ellos Manuel Alonso, contestara a El Aguinaldo con otro libro que se llama El Álbum Puertorriqueño que sí sigue una vertiente más criollista, particularmente en las partes del libro que se encargó Alonso de redactar. En 1849, aparece El Jibaro de Manuel Alonso que se considera el primer libro puertorriqueño, netamente puertorriqueño. Se publicó en Barcelona, tuvo problemas con la censura y por la mediación del arzobispo logró que se difundiera, y volviendo al tema de la pregunta, sí hay una fecha concreta ubicada en tiempo y espacio: 1843. Sin embargo, hay una producción literaria anterior en periódicos que se tiende a ver como los inicios de la identidad de unos caracteres nacionales. [...] ¿Que viene primero el huevo o la gallina? Es que importancia se le da, entonces, al libro como piedra angular de la formación de un desarrollo literario. Lo mismo ocurre en España, a pesar de que existen las jarchas, a pesar de que existe la poesía popular, se fija El Cid como el punto de partida que marca ya un antes y un después. Es una tendencia muy normal y muy universal, es muy difícil de romper y no sé, de hecho, si se puede, ni siquiera, romper. Lo que hay que ver entonces es esa evolución en su contexto y no menospreciar a aquellos textos publicados en periódicos porque ayudaron a la formación integral de esos autores que luego escribieron los libros. Y así lo veo yo, a menos que no se encuentren otros textos que están por ahí perdidos y, posiblemente nos den otra luz. 
ENDIKA BASÁÑEZ. ¿Cómo influye el colonialismo español en dicha producción literaria temprana?

FERNANDO FELIÚ. Influye directamente porque la autoridad colonial española imponía unas restricciones de prensa bastante severas con lo cual la expresión de una nacionalidad puertorriqueña, de una identidad puertorriqueña, se veía marcadamente limitada. Entonces los autores, en muchos casos anónimos, como las coplas del jíbaro, que luego un tal Miguel Cabrera reclamó su autoría -del que no se sabe casi nada-, esos autores anónimos tenían que vadearse entre formas de ironía, de sarcasmo, para evadir la censura. Sin proclamar una diferencia porque lo que se buscaba era proclamar la igualdad. Es decir, lo que no se toleraba era expresiones de una identidad divergente a la española. Viene siendo una exaltación de la independencia de Puerto Rico, exaltación de lo autóctono, eso se veía con peligro... Entonces una literatura que quería exaltar la diferencia, pero tenía que enmascararla de forma tal que no pasara como diferencia, sino que se viera como una literatura puertorriqueña inscrita en el contexto de literatura general española o, no literatura española sino de la afiliación política, económica y cultural con España. En ese sentido, sí directamente la censura. y por supuesto la influencia del colonialismo, se nota en los libros que circulaban, los que se dejaban circular. Aquellos que podían circular que fueron las influencias en muchos de estos escritores. Aun así, ellos se manejaban por textos que compraban en el extranjero o por periódicos que ya poco a poco a finales de los 70 , principios de los 80 , ya filtraban e incorporaban traducciones de Émile Zola, de Flaubert, ... poco a poco se fue difundiendo el romanticismo, el realismo, el naturalismo de una forma mucho más periódica y más fácilmente constatable.

ENDIKA BASÁÑEZ. ¿Existe constancia de influencias de los movimientos culturales propios de la época en la génesis textual puertorriqueña iniciadora que se lleva a cabo? ¿Se halla esta así influida por los movimientos culturales propios de la época a pesar de su condición de isla caribeña?

FERNANDO FELIÚ. El romanticismo llego aquí, incluso Las coplas del Jibaro se pueden ver ya desde mil ochocientos "veintialgo" como una manifestación de un criollismo literario, y el criollismo es una vertiente del romanticismo que destaca lo autóctono, porque en lo autóctono esta "el alma del pueblo”. O sea que el romanticismo en Puerto Rico, como en el resto de Hispanoamérica, llega más o menos a la par, a partir de la década de 1820 cuando se pregona la independencia de Hispanoamérica. En ese sentido estuvimos muy a la par temporalmente. Pero sí, hubo una marcada influencia incluso en muchos breves ensayos publicados en periódicos hay autores que reflexionan sobre el romanticismo y lo parodian, se burlan un poco de él. La antología crítica de Ramón Luis Acevedo tiene un estricto de un comentario sobre los románticos que indica que el autor, anónimo también, conocía la literatura romántica. La entendía bastante bien y se burlaba un poco del exceso de cursilería, lo tenía bastante claro. O sea que sí, aquí no fuimos ajenos a pesar de la condición, más que insular -a pesar del atraso con respecto al desarrollo histórico de otros países-, Cuba y Puerto Rico se mantuvieron siendo colonia hasta finales del XIX mientras que en 1830 prácticamente todo Hispanoamérica era independiente. Pero literariamente hablando, si piensas en las fechas -El Jibaro 
se publica en el 49, Facundo, civilización y barbarie se publica en el 45- o sea que la diferencia es de 7 u 8 años, que no es una cosa que sea enorme. Temporalmente no estamos tan, a pesar de lo que mucha gente cree, no estamos tan fuera de contexto del ritmo histórico.

\section{LA CUESTIÓN GENERACIONAL Y LA IMPRONTA DE LOS TREINTISTAS}

ENDIKA BASÁÑEZ. El siglo XX y, fundamentalmente su segunda mitad, se convierte en el periodo sincrónico en que la literatura puertorriqueña se universaliza a través de su difusión editorial al resto de los estados latinoamericanos y a España, y a través de las traducciones a otras lenguas, a las naciones europeas y a los Estados Unidos. No obstante, durante su primera mitad encontramos a la generación denominada del 30 o treintistas por la comunidad latinoamericanista en la que se producen textos de gran relevancia e influencia en la dirección política del país y en las particularidades de la identidad puertorriqueña. En primer lugar ¿qué opina de la división de la historia de la literatura puertorriqueña por décadas como la nombrada generación del 30 o las posteriores del 40 ó $70 ?$ ¿Cree que existen motivos, con independencia de los docentes, para agrupar a una serie de autores dentro de generaciones debido a la sincronía de la escritura y/o impresión de sus textos tal y como ocurre en la actualidad con la difusión de la literatura puertorriqueña?

FERNANDO FELIÚ. Ese es un esquema muy típico de las historias de las literaturas, que tienden a periodizar a partir de fechas particulares entendiendo por generación la mayoría de ellas -incluyendo la de Puerto Rico-, no como la fecha de nacimiento de un grupo de personas sino más bien como una fecha de nacimiento en común en la cual influyen unos acontecimientos históricos que marcan el desarrollo de ese grupo colectivo. Es muy complejo, es muy limitante limitar la literatura a generaciones porque en el caso de, por ejemplo, Enrique Laguerre -al que se le vincula a la generación del 30, uno de los más conocidos con la novela La llamarada de 1935: quizá una de las novelas más famosas de la década del 30-, muere a los 100 años, o sea que él mismo supera el concepto generación. Pedreira, que murió por un virus, una cosa un poco rara, muere a los 40 años. Si hubiera vivido más, muy posiblemente, hubiera reflexionado sobre su propia obra y seguir otro derrotero totalmente distinto, vete tú a saber... En ese sentido el concepto generación es más limitante: es muy limitante. ¿Qué alternativa hay? Buscar modelos alternos, es decir, buscar líneas de fuga temáticas que corran paralelas, que corran simultáneamente entre varios textos. Como, por ejemplo, puede ser el problema de la caña de azúcar, el problema de la música, de la comida... Hay varias formas de verlo y la tecnología seria uno de ellos. La tecnología, la relación entre lo real y lo escrito, el campo y la cuidad. Son paradigmas que se pueden ver diacrónica y sincrónicamente y que romperían un poco ese esquema tan rígido de las generaciones que es muy difícil de romper porque, no es que aquí lo hagamos mal, es que prácticamente... piensa en la generación del 98, piensa en la generación del 27 y luego está la del 14, la de Gómez de la Serna también... o sea que somos muy dados a la periodización por generaciones. Por otro lado, tiene sus ventajas también porque te da un centro centrípeto al rededor del cual aglutinar una serie de escritores y obras, ayuda a organizar centrípetamente, a partir de un núcleo, y se van generando, a partir de ese núcleo, como una metáfora 
de la sideral, como una planetaria. Gira sobre un centro, que en el caso de la generación del 30 fue Pedreira, y así, ¿no? En cuanto a la importancia de la generación del 30, fue enorme porque fue, de hecho, la primera generación que vivió y se crió bajo la dominación estadounidense, eso número uno; número dos, es la generación que ve el desencanto de a presencia estadounidense. Son lo que vieron que los estadounidenses vinieron a quedarse, no vinieron a liberar. Ellos viven la desilusión de la pérdida de una entidad que ellos ven que se está socavando por razones históricas. Había campañas de americanización claras que te obligaban a cantar en inglés el himno estadounidense mientras que los símbolos patrios, el himno de Puerto Rico y la bandera, se veían con mucha suspicacia. Hubo una represión muy marcada a los grupos independentistas o sea que ellos reaccionaron, lógicamente, en parte a todo esto. Ahora, más allá de eso, ellos fueron la primera generación que se encargó de problematizar y sistematizar el archivo histórico. El archivo histórico no como un lugar donde se archive sino como el legado histórico, el acervo. Ellos fueron los primeros en sistematizar el estudio a partir de un concepto clave que es la identidad: qué somos, cómo somos y por qué somos como somos. Pedreira sería el buque insignia, precisamente por eso: porque lo periodizaron y organizaron en ese proceso y canonizaron unas obras por encima de otras. Todo canon incluye y excluye simultáneamente y así El Jibaro queda consolidado, mientras que otros textos como Tapia, La cuarterona, Las coplas del jibaro también quedaron relegados a la prehistoria de la literatura puertorriqueña [...] O sea que en ese proceso de canonización ellos casi se apropiaron de un corpus y lo manejaron un poco a su antojo para imponerle un valor ideológico y así eso explica que muchos textos pre-Llamarada, muchas novelas, hayan pasado inadvertidas. Porque una de las primeras historias de la literatura puertorriqueña, la de Manrique Cabrera del 53, es de la generación del 30 y él empieza con ese criterio generacional.

ENDIKA BASÁÑEZ. En relación al legado intelectual de los treintistas ¿Cómo cree que afecto el Insularismo así como el resto de la producción del 30 en la posterior vida artística de Puerto Rico?

FERNANDO FELIÚ. Lo marco profundamente porque si lo que se busca en un ensayo, pienso en Pedreira particularmente porque la generación del 30 es un todo muy heterogéneo y, sobre todo que había dos mujeres, Mar Guarzo y Concha Menéndez, que tampoco estaban completamente de acuerdo con algunos de los postulados de él, o sea que tampoco se puede tomar la generación del 30 como un todo homogéneo porque no fue así. La forma en la que hemos visto la generación del 30 es un poco peligrosa. Se ha etiquetado todo de la misma forma y hay que matizar algunas cosas que son importantes, las diferencias, por ejemplo. De cualquier manera, en el caso de Pedreira, como el Insularismo, causó un revuelo enorme -y lo sigue causando-. Pedreira logró lo que quería, si como dice Montein el ensayo problematiza y genera debate, pues entonces Pedreira lo logró... con creces porque seguimos todavía volviendo al Insularismo. Él se adelantó. Aparte, era un gran ensayista, escribía muy bien, muy modernista, un poco afectado en su discurso, pero era un gran ensayista. $\mathrm{O}$ sea que se marcaron profundamente el resto y, además, todos estuvieron vinculados al Departamento de Estudios Hispánicos, al recién creado Departamento de Estudios Hispánicos. En la Universidad 
de Puerto Rico el Departamento de Estudios Hispánicos se convirtió, no en un foco de enseñanza, sino de investigación y desarrollo y casi de resistencia cultural porque se destacaba una hispanidad, en el contexto de la americanización.

ENDIKA BASÁÑEZ. ¿Influyó, bajo su punto de vista, la situación particular del dominio geopolítico estadounidense vivido en la Isla desde la pérdida de las últimas colonias de ultramar españolas para la aparición de dicha generación?

FERNANDo Feliú. Sí, claro, influyó poderosísimamente porque ellos, los treintistas, buscan rescatar una identidad de un punto de vista nostálgico que es la hispanidad y que se está perdiendo. Hay una nostalgia ahí, en ese mundo pre-98 que ya ha perdido su esencia, por eso, en gran medida, se exalta el cultivo del café, ¿no?, porque se ha impuesto la caña... El símbolo del café, de la hacienda... de la hacienda se pasa a la central, de la altura de la montaña se pasa a la bajura del llano. El jíbaro sigue siendo tema pero ya es el jíbaro en forma de peor, no es el jíbaro cafetalero como el de $L a$ charca. Hay una añoranza, en parte, porque mucho de ellos vienen de familias hacendadas, burguesas. Y también es una forma de escape ante una realidad con la que no comulgan. Hay un poco de romanticismo, también, de actitud ante la vida: buscamos el pasado de una forma un poco nostálgica cuando lo curioso es que también se están desarrollando los movimientos obreros. O sea que era una literatura un poco anacrónica y reaccionaria en ese sentido porque, en vez de apoyar el desarrollo social mediante el socialismo, mediante los sindicatos obreros, las propuestas de Albizu, [...] esta literatura en vez de unirse a esa tendencia lo que hace es buscar otra forma de fuga, otra línea de fuga que es opuesta al socialismo, no opuesta porque se incorpora el tema del socialismo en $L a$ llamarada con Marte -digo con el personaje Marte-, pero la propuesta es regresar al campo, regresar a la montaña, regresar al cultivo del café -que era una propuesta un poco anacrónica en ese momento tan anacrónica como la que propone René Marqués en La Carreta que propone dejar Nueva York y regresar-. Cuando lo cierto es que la gente, muchos regresaron y muchos se quedaron. Era una negación de esa presencia puertorriqueña en Nueva York, un rechazo a ella. Entonces son posturas un poco anacrónicas en ese sentido. No hay que olvidar el exilio español que coinciden temporalmente Guillén, Salinas, mi abuelo,... coinciden temporalmente en la década del 30 y del 40 con el desarrollo de una cultura universitaria muy fuerte con profesores de primerísima calidad que recibieron muchas veces con los brazos abiertos a los exiliados españoles, muchos de ellos muy prominentes: Guillen, Salinas... Lorca no, porque lo mataron sino probablemente hubiera acabado por aquí o un año, dos años aquí y luego en Nueva York, como ocurrió en muchos casos como el caso de Galíndez que acabó en Columbia. O sea que el exilio, esos republicanos liberales que llegaron, como mi abuelo, encajaban con el perfil de la generación del 30 porque ellos también defendían una hispanidad, defendían una democracia, que se había perdido con Franco, defendían unos valores liberales, etcétera, que encajaban muy bien con esa generación del 30. Fueron un matrimonio casi de conveniencia y esos intelectuales también se dedicaron, aunque no todos, pero algunos como Tomás Navarro Tomás o Federico de Onís, a investigar la literatura puertorriqueña. O sea que también dieron otra mirada, critica, a un cuerpo literario o cultural que estaba llamando la atención desde los 
puertorriqueños. Desde luego, se potenció mucho el estudio de la literatura, de la cultura, de la lengua, de la música puertorriqueña en esas décadas.

ENDIKA BASÁÑEZ. ¿Sería posible establecer una división entre la lectura de las obras de los treintistas y la política estadounidense que gobernó y gobierna la vida política en Puerto Rico tras los diversos acuerdos llevados a cabo entre sendas regiones?

FERNANDO FELiÚ. Sí y no. Sí en el sentido en el que ellos funcionaban autónomamente desde la Universidad de Puerto Rico. Eran burgueses, eran asalariados, pero, por otro lado, era una relación curiosa porque en algunas ocasiones se tenían que enfrentar a los Estados Unidos, a la política de los Estados Unidos, porque se criticaba a los Estados Unidos. Muchos de ellos habría que verlos con detenimiento, pero a muchos el FBI los seguía o los tenían bajo mira. Igual que con el exilio: gente como mi abuelo no, porque no era comunista, pero Granel, Eugenio Fernández Granel, era comunista y el FBI lo tenía mirado, a veces me sorprende que haya podido entrar a este país. O sea que en ese sentido sí, los vínculos con la política eran no muy... Corrijo: los vínculos con el contexto de dominación estadounidense eran muy fuertes, pero también fueron muy fuertes con los planteamientos de otro de los treintistas, de Luis Muñoz Marín, poeta y luego político, que en la década del 40 consolida el poder del Partido Popular Democartico. El ideario de Pedreira, en gran medida, coincide con muchos de los postulados del Estado Libre Asociado, de lo que luego fue el ELA, de lo que en los 50 fue el ELA. Autonomía lingüística, desarrollo de la hispanidad, una apertura a las corrientes europeístas... Pero Pedreira murió, no se le puede echar en cara que votara por Muñoz Marín. El Partido Popular Democrático toma mucho de ellos, por lo menos Muñoz Marín, que era amigo directo de muchos de ellos.

\section{LA GRAN Migración PUERTORIQQUEÑA HACIA LOS ESTADOS UNIDOS Y LA FIRMA DEL ELA}

ENDIKA BASÁÑEZ. El fracaso de la operación Manos a la Obra impulsada por el gobierno de los Estados Unidos en la Isla, fundamentalmente agrícola, conllevo el éxodo masivo a principios de la segunda mitad del siglo XX con la gran migración puertorriqueña entre la que se desplazaron a Nueva York y a otras ciudades estadounidenses un gran número de intelectuales boricuas, dando así lugar a una producción literaria de migrantes en la que estos se encargaron de reflejar sus experiencias al otro lado del estrecho de la Florida como José Luis González o Pedro Juan Soto, englobados bajo la generación del 40. A pesar de la firma del ELA en 1952 y aunque dichos autores se hallaran en Nueva York y por lo tanto en su propio país, reflejan la discriminación y la marginalidad sufrida por pertenecer a la etnia hispana y tener acento español en su dicción inglesa. ¿Supuso por tanto el ELA una utopía política en lugar de un nexo de unión entre los isleños y el pueblo anglo-estadounidense?

FERNANDo FELIÚ. Fue una estrategia política. El ELA fue una estrategia política de Muñoz Marín para sentar las bases de una relación pseudo-colonial con un grado de autonomía limitado, como por ejemplo el inglés, que no es idioma oficial, y si lo es nunca ha sido oficial real; se habla 
español, pero la aduana, la moneda, el control de fronteras lo tiene EE.UU. O sea que el ELA fue una especie de concreción de una especie de alianza mutua entre Puerto Rico y EE.UU. que Muñoz Marín se inventó y que nos llevó a un callejón sin salida. Porque es un Estado Libre Asociado, ELA, que es totalmente contradictorio. Si es libre no es estado, si es estado no es libre, si es libre no es asociado, si es asociado no es estado. Como quiera que lo mires es una total contradicción. Lo que sí provocó fue la migración masiva durante la década del 40 que llevo a muchos campesinos a migrar a la ciudad, sobre todo de migrar a barrios, arrabales, caseríos, como La Perla en el Viejo San Juan, donde ocurrió La carreta, y de ahí a Nueva York. Sí: fue un éxodo tremendo, fueron miles. Entonces los autores llamados del 40, 45 o 50 -otra vez el problema generacional-, vivieron esa circunstancia directamente, es decir, porque ellos son el grupo que, a diferencia de los del 30, fueron militares, sirvieron en el ejército. Pedro Juan en la II Guerra Mundial, Emilio Díaz Valcárcel en Corea. Pedro Juan estudio literatura en Nueva York. O sea que es una generación, un grupo de escritores con un perfil un poco distinto al de la del 30. Son escritores más bien urbanos, ellos ampliaron el mapa literario puertorriqueño hasta Nueva York, o sea con ellos entra el tema de la inmigración, entre el tema del puertorriqueño en EE.UU. y se le da un nuevo giro a la relación colonial con Puerto Rico. Bueno, un nuevo giro literario porque aparece entonces el personaje desubicado, desarraigado, que no necesariamente tiene nostalgia del pasado puertorriqueño sino que tiene una incertidumbre de "cómo coño voy a vivir en Nueva York". O sea que es una generación bastante distinta, predomina además el cuento. Es una generación que consolida el cuento como arte. Había cuentistas en el 30, estaba Frau y Gustavo Graid también, pero realmente la generación del 40 es la generación que consolida las bases del cuento: Spiks, En una ciudad llamada San Juan, Nueva York y otras desgracias... Díaz Valcárcel, José Luis González, René Marqués, Pedro Juan Soto, los cuatro fueron cuentistas. Es una generación de prosa realmente y es una generación que, resiente más que la del 30 el ELA, porque resiente ese colonialismo descarado que la del 30, cuando se publican los textos a los del 30, no se había llegado a ese momento. Ya en el 50, cuando publican los del 40 o 45, ya se ven las consecuencias de la relación política con EE.UU., ya se ve la inmigración masiva, se ve la ruina económica, se ve la presión, el racismo, se ve la persecución hacia los independentistas, la manipulación de la información, esas campañas de descrédito hacia muchos de ellos. O sea que sí, fue una generación muy distinta.

ENDIKA BASÁÑEZ. Si puerto Rico mantiene el estatus de ELA y la ciudadanía norteamericana ¿por qué cree usted que en los Estados Unidos continentales los autores desplazados sufrieron marginalidad si se trata teóricamente de individuos norteamericanos pertenecientes a una misma nación? Y, precisamente, ¿cómo cree que afectó la firma del ELA en la producción literaria en la generación del 40 ?

Fernando Feliú. Porque fue la concreción de esa relación colonial. Para ellos fue la concreción de, una vez ya se firmara el ELA, no había vuelta atrás: ya estábamos metidos en este barco hasta que nos hundamos. Para ellos fue una fecha clave en su biografía porque la mayoría pertenecen a una ideología bastante liberal, de izquierdas, incluso Pedro Juan soto y José Luis González... este, por 
cierto, marxista declarado se fue que vivir a México y murió en Puerto Rico -vino a Puerto Rico algunas veces, pero se consideraba mexicano prácticamente-. O sea que el exilio y lo político lo vivieron de una forma mucho más intensa que los del 30, a pesar de que los treintistas había independentistas, como Luis Pares Matos, pero el tema político en ellos fue mucho más patente porque era una realidad inmediata que lo los llevaba a ello, y por supuesto Nueva York, Nueva York de nuevo. El mapa literario puertorriqueño ya se amplía a Nueva York, ya la ruta queda completa. $L a$ carreta marca muy bien eso independientemente que el final sea... En fin, La carreta lo marca excepcionalmente bien. Pero es una generación en la que el inglés aparece como aspecto literario, el idioma inglés, las palabras en inglés, expresiones en inglés, nombres de calles en inglés... el inglés aparece ya como parte de la cultura puertorriqueña y la mezcla, el mal llamado spanglish, ese viraje de uno a otro, de un idioma a otro. En ese sentido, creo que la generación del 40 fue radicalmente distinta a la del 30, incluso aventuraron con temas como la homosexualidad, como el cuento al asedio de Emilio Díaz Valcárcel, temas como el loco de la guerra, el veterano de la guerra de Corea, los efectos de la guerra psicológicos y físicos, los tres tocas en ese tema: José Luis González y Pedro Juan y también Emilio Díaz Valcárcel. "Napalm” es un cuento basado precisamente en los estragos psicológicos que causaba esa guerra química. Y el puertorriqueño como carne de cañón, por supuesto.

ENDIKA BASÁÑEZ. ¿Cree usted que en la obra de la generación del 40 existe una ideología a favor de la independencia de Puerto Rico implícita en sus relatos y el conjunto de su obra por extensión?

FERnando Feliú. Sí, sí, sí, ¡Totalmente! Es un alegato muy anti-estadounidense. Acuérdate también que ese grupo de escritores ve la bomba de Hiroshima. Ya no solamente EE.UU. como el poder colonial que domina Puerto Rico sino ya, en un contexto mucho más amplio, EE.UU. como el gran dictador del siglo XX. Es decir, la bomba de Hiroshima, colocar a Trujillo, colocar a Batista, luego en el 70 colocar a Pinochet, etcétera... Esos son los casos más conocidos, pero hay decenas de otros casos. Ya en el 40 y en el 50 es obvio que EE.UU. ya tiene complejo de policía del mundo en el mal sentido de la palabra. Acuérdate de las campañas de McArthy contra el comité de actividades antiamericana, esta gente reacciona a EE.UU. no solamente como poder colonial que oprime Puerto Rico sino, en un sentido mucho más amplio, como un poder invasor en Cuba, en Puerto Rico, en Guatemala, en Nicaragua... Dios santo, los Chamorro, los Somos los pusieron EE.UU. Es una generación ya que tiene un sentido más universalista, ya el jibaro deja de ser tema, ya entonces hay otro tipo de dinámica, es en la ciudad. Hay una marcada influencia de Hemingway, de John Dospasos incluso también del existencialismo de Sartre y de Camus, la frialdad del anonimato en una ciudad en la cual todos somos anónimos. La escritura rescata el anonimato, le da voz al marginado... Este es el caso, sin duda, de Pedro Juan Soto en Spiks. 
ENDIKA BASÁÑEZ. La generación del 40 es aún recordada por los hispanistas como un grupo de autores que renovó la cuentística puertorriqueña. ¿Cuáles cree que fueron las mayores influencias que dichos autores recibieron para dar lugar a dicha renovación? ¿Cree que su desplazamiento a los EE.UU. y a Europa fue clave para el proceso de renovación literaria en la su génesis?

Fernando Feliú. Sí, bueno, son varias preguntas en una. Vamos por partes. Autores que influyeron, que marcaron esta generación, como ya dije -John Dospasos, Hemingway y Faulkner, los tres estadounidenses ¿no? ¿Por qué? Porque los tres, sobre todo Dospasos, tienen Nueva York como tema privilegiado, pero inevitablemente estos son escritores cultos, muy cultos. Son gente que conoce la literatura española, que han leído literatura inglesa, que conocen el caso de René Marqués, de Terency Williams, de Eugene O’Neill. En el caso de los cuentistas, que son todos de los que te comenté antes, pero también por ahí los españoles clásicos. no se puede saltar El Quïote así como que... las influencias son los de siempre, los novelistas de siempre, del XIX y parte del XX, más los existencialistas franceses y también, por qué no, los propios puertorriqueños que ya hay una tradición precedente. O sea, Laguerre, Pedreira, que reaccionan en contra o favor es otra cosa, pero la influencia está ahí. No sé hasta qué punto, Cela, sería interesante ver, Pascual Duarte, ... Sí hay conexiones entre la novela Figuraciones en el mes de marzo de Emilio Diaz Valcárcel y Tiempo de silencio, una de las mejores novelas españolas de la segunda mitad del siglo XX.

\section{FALOCENTRISMO EN EL CANON LITERARIO PUERTORRIQUEÑO Y LA PROTESTA DE LAS MINORÍAS}

ENDIKA BASÁÑEZ. Anecdóticamente ni en la generación del 30 ni en la del 40 aparece ninguna figura femenina; no obstante, si analizamos la historia de la literatura puertorriqueña encontramos figuras como Julia de Burgos, quien fuera pionera en su obra artística en la introducción de temas feministas avant la lettre para la sociedad puertorriqueña sincrónica y que ha vivido obviada por gran parte de la crítica literaria excluyéndola de toda generación. ¿Por qué cree que las generaciones de escritores puertorriqueños han sido establecidas de forma falocéntrica?

FERNANDO FELIÚ. Buena pregunta y difícil de contestar. Yo creo que la misma respuesta es la misma pregunta. Se han escrito falocéntricamente, ahora ¿por qué? Porque son así y también por otras razones. Muchas de las obras de Julia y Clara Lair, etcétera, y, sobre todo, Marina Arzola -que es una de mis favoritas-, han sido publicadas, pero tampoco han llamado la atención de la crítica, no mucho al menos. [...] Es una literatura muy machista, muy paternalista que ha relegado a las escritoras a un segundo plano desde el siglo XIX. O sea que en ese sentido sí, la incorporación de ellas al canon suele ser problemática y mínima, ¿por qué mínima? Porque se conoce de Julia de Burgos lo de siempre, "Rio grande de Loiza”, “Julia y yo”... poemas así. Sin embargo, para mí lo mejor de Julia es su último libro, El mar y yo, que es el más profundo, es el que menos se conoce. No es que no se conozca, es el que menos se le vincula a ella, se le vincula con lo erótico, con el tema del río, lo erótico, la sexualidad... en la década del 30 y también el perfil de Julia de Burgos no encajaba con el perfil del intelectual. Esta es una mujer pobre, nace en Carolina, prácticamente iba descalza a la 
Universidad, consiguió estudiar en la Iupi, en la Facultad de educación. pero no fue profesora del Departamento de Estudios Hispánicos. Estuvo un poco ajena a los centros de poder cultural. Fue una figura marginal también por eso. Si hubiera dado clase de Estudios Hispánicos otro hubiera sido el cuento...

ENDIKA BASÁÑEZ. No obstante, su figura actualmente se la recuerda un poco como el inicio y el ocaso de la cultura puertorriqueña porque prácticamente nace cuando aún no se había firmado la ley Foraker y ella muere un año después de que se firma el ELA con lo cual actúa como cierto tótem de la cultura puertorriqueña su figura y su biografía, ¿no cree?

FERNANDO FELIÚ. Ella lo simboliza en gran parte, vive ese afincamiento al colonialismo mediante leyes ¿no? La ley Foraker, particularmente, sí. Luego en la década del 20, la americanización, la década del 30, ya en Nueva York -que ella tiene poemas en Nueva York-. Recuerdo que su biografía es tan triste que incluso, después de muerta, hubo que cortar el cadáver para que cupiera en el ataúd porque ella era una mujer alta, media casi uno ochentayalgo. No cabía en el ataúd, hubo que cortarle las piernas y meterlo todo junto. Y así llegó aquí, mutilada.

ENDIKA BASÁÑEZ. Las protestas a favor de los derechos de las minorías étnicas y sexuales generadas en EE.UU. durante la década de 1960 dieron paso a la reivindicación de la diversidad étnica, racial y cultural de la sociedad estadounidense, ciertamente heterogénea. Según el profesor de la universidad de Nashville William Luis en su Hispanic Caribbean Literature written in the United States dichas protestas resultaron ser un factor clave para la consolidación de la literatura hispanocaribeña escrita en los EE.UU. ¿Cómo cree usted que afectaron dichas protestas para la génesis literaria boricua diaspórica?

Fernando Feliú. Las protestas en la década de los 60 fueron mundiales, en Puerto Rico también hubo, en el 71 hubo una huelga estudiantil enorme, incluso hubo un muerto. Pero sobre todo los puertorriqueños mientras estudian en el extranjero viven esas protestas. Por ejemplo, las hermanas López-Baralt, Mercedes y Luce, vivieron el Madrid del último franquismo, vieron las cargas de la policía, eso me lo ha dicho Mercedes [López-Baralt], Luis Rafael Sanchez también. Por otro lado, los que estuvieron en Nueva York pues también fueron parte de ese 68, o sea que sí, fueron parte de él, inevitablemente influyeron. En qué medida influyeron ahora mismo no lo puedo precisar, pero sí influyeron porque ellos fueron gran parte de ese movimiento en gran medida, aunque tal vez el 68 les pillo ya con 40 años, no con 20, pero lo vieron desde una posición más racional, más académica, eso no quita que simpatizaran con ella.

ENDIKA BASÁÑEZ. La gran generación de autores de ascendencia puertorriqueña nacidos en Nueva York, así como en otros estados -fundamentalmente de la costa este- dio paso en la segunda mitad del siglo XX a la aparición del grupo étnico-intelectual conocido como nuyorican o neorican. 
¿Considera que su producción pertenece a la historia de la literatura puertorriqueña o la ve más próxima por el uso hegemónico del inglés en sus textos y sus materiales narrativos a la historia de la literatura anglo-estadounidense?

FERNANDO FELIÚ. Yo la veo más próxima a la literatura puertorriqueña, es literatura puertorriqueña con los nuyoricans, con esa poesía, esa literatura escrita en Nueva York ocurre un poco con la literatura escrita por los republicanos en el exilio... ¿dónde la colocas? Es una vertiente $d e$, es parte $d e$, es simultánea a... ¿cómo la colocas? Son literaturas que rompen un poco, precisamente por la complejidad de su producción, desde dónde se escribe, hacia quién se dirige... Plantean un problema de límites territoriales porque no se pueden circunscribir totalmente a la generación del 30 porque tienen rasgos que no encajan con el 30 para nada, pero tampoco encajan con John Dospasos aunque sí se podría incorporar, [...] Son muchos de ellos escritores bisagra, que pueden incorporarse en más de una tradición: en la literatura puertorriqueña, en la estadounidense o, más particularmente, en la estadounidense femenina. Santa María Esteve, Nicolás Amor, pero también está por así Sandra Cisneros, que es chicana, pero coincide temporalmente el mismo desarrollo en la década del 70. O sea que sí, yo creo que son textos de muy difícil clasificación, pero, de igual modo, creo que es literatura puertorriqueña. Si es respuesta sí o no: sí. Yo creo que es literatura puertorriqueña. Que se pueda incorporar como literatura estadounidense es otra cosa. De la misma manera los textos del exilio. El contemplado de Pedro Salinas, por ejemplo, es un texto que se escribe mirando al mar en el 42 o 43 ¿está escrita en Puerto Rico? Sí. ¿El objeto es puertorriqueño? Sí. ¿Es literatura puertorriqueña? Hasta cierto punto, sí, aunque esté escrita por un español; en el caso de La Muñeca, de Dulate Sanjurjo, es puertorriqueña sin embargo la novela no dice absolutamente nada, la palabra Puerto Rico ni aparece en la novela, ¿es literatura puertorriqueña? Sí por la autora, pero no por el contenido. O sea que es sumamente difícil de categorizar.

ENDIKA BASÁÑEZ. ¿Cree que la producción neorricana afectó de alguna manera a los autores isleños? ¿Se interesaron estos por la génesis diaspórica estableciendo así una retroalimentación entre la isla y los EE.UU. continentales?

FERNANDo Feliú. Sí porque ya hoy, en 2016, desde hace años hay una tradición literaria puertorriqueña en Nueva York. Mi tío fue parte de esa tradición, Alfredo Matilla. La primera antología de poesía nuyorican la compiló, en parte, él mismo, o sea que sí. Y esa gente, esos autores, como Víctor Hernández Cruz marcaron e influyeron directamente sobre todo a un tipo de poesía joven como, por ejemplo, Guillermo Rebollo Gil, que incorporan la oralidad callejera, el tono desfachatado y ese apego por el ritmo musical. O sea que sí, esa generación, ese grupo de los 70, de los $80 \ldots$ Sí. Piri Thomas también marcó un hito, aunque no solo en EE.UU., aquí también. En efecto, la poesía puertorriqueña en Nueva York ha influido directamente en muchos poetas jóvenes, cuando digo jóvenes me refiero a treinta y pico, cuarenta años máximo. Dicho, además, por uno de ellos, Guillermo Rebollo Gil: yo le entrevisté y él lo reconoció. Reconoció que Alfredo Matilla, mi tío, ha 
marcado su obra profundamente porque él estudió, Guillermo Rebollo Gil, con mi primo, con el hijo de Alfredo Matilla, y a través de mi primo él conoció la obra de estos puertorriqueños en Nueva York y se adentró en ese mundo y él lo rescata y lo incorpora.

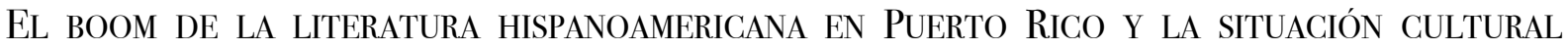
ACTUAL

ENDIKA BASÁÑEZ. ¿Cómo afecto el boom de la literatura latinoamericana de la década de 1960 a la literatura puertorriqueña y, de manera más precisa, a la producción puertorriqueña de la diáspora?

FERnANDo Feliú. La hizo más compleja, la complejizó porque la década del 60, García Márquez, Vargas Llosa, Donoso, Cabrera Infante y Fuentes, los más conocidos, fueron muy experimentales. Jugaban con planos temporales y espaciales, desdoblamiento de narradores, se usaba más de un narrador, incluso se usaba un narrador en segunda persona, el tú, lo que es una pequeña obra de arte. O sea que se hizo más compleja la literatura, se complejizo notablemente. Y prueba de ello es La guaracha macho Camacho: una novela muy intelectual en un sentido, es una novela muy compleja que tiene una estructura muy sofisticada y muy compleja [...]. Entonces ahí entró, al menos fue muy importante, el papel de las librerías que difundieron esta literatura, como por ejemplo La tertulia. [...] Aquí en Puerto Rico librerías como La tertulia difundieron ese boom de los 60, esos textos, y no solo textos ya tan nominales, la narrativa, sino ya textos de critica cultural, como por ejemplo Para leer el pato Donald. Textos que ya incorporaban el análisis de la cultura popular. Esos textos de esa complejidad, esa crítica cultural ya se ventilaba, ya corría por aquí. Y, por supuesto, lo obvio: han leído a García Márquez... la influencia directa de la lectura no solamente de los intelectuales sino la difusión porque ya eran textos que circulaban, no era nada difícil leer Cien años de soledad en Puerto Rico en aquella época, ni era difícil leer a Carlos Fuentes, la censura no llegaba a tanto. Eran escritores que muchos se conocían, habían compartido congresos, no es que fueran amigos, pero se conocían... entonces el mundo era ancho y ajeno, pero no tanto.

ENDIKA BASÁÑEZ. Mientras en la producción exódica existe un claro predominio del inglés, en la Isla la lengua hegemónica de los textos artísticos es y ha sido el español. ¿Cree que el uso de la legua española implica un compromiso político de los autores boricuas isleños que se resisten a la trasculturalizacion anglo-estadounidense?

FERNANDO FELIÚ. En gran medida sí, pero más importante que eso es la óptica desde la que se utiliza el español porque también Laguerre usaba el español y no encaja en ese proceso de transculturalización. Sin embargo, Luis Rafael Sánchez usa el español, pero en La guagua aérea incorpora el inglés. Se usa el español como defensa del idioma nuestro, puertorriqueño, el castellano, pero no se utiliza necesariamente para reivindicar una hispanidad pretoriana, como en la generación del 30. Se usa como afirmación de resistencia, pero sin llegar al extremo de caer en el purismo. Ya se 
dan por sentada expresiones tomadas del inglés: parking, ketchup... hace mucho tiempo se dan por sentadas y son parte del idioma, y no digo del puertorriqueño, son parte del español, en general. En ese sentido, los puertorriqueños somos un poco avant la lettre, la contaminación o incorporación de préstamos lingüísticos del inglés -que yo veo mucho en otros lugares como en Madrid, de hecho cada vez lo veo más en Madrid cuando voy-, aquí eso ya existía desde hace más de un siglo. Como te digo no es que se use el español, es la perspectiva desde la cual se usa, para mí es lo más importante. Porque todos sabemos hablar español, pero la óptica es muy distinta: la de Laguerre es muy distinta de la de José Luis González y la de José Luis González es distinta a la de Luis Rafael Sánchez, por ejemplo.

ENDIKA BASÁÑEZ. Pero en el caso de Spiks tenemos una oralidad típicamente puertorriqueña, quizá en ese caso es más explícito la reivindicación identitaria del habla del jíbaro, el campesino que abandona su tierra para dirigirse a San Juan y de allí a Nueva York...

FERNANDo Feliú. Sí, claro. Sin olvidarse que Spiks también incorpora frases en inglés porque los personajes están en EE,UU., o sea que tienen que... sería anacrónico, impensable que Pedro Juan escribiera Spiks sin incorporar algún termino en inglés, alguna frase, alguna oración. Muy astuto Pedro Juan incorpora esa modalidad del inglés porque ya es parte de los personajes, es parte de la vida en Nueva York, ese cambio del español al inglés (y viceversa).

ENDIKA BASÁÑEZ. La identidad puertorriqueña resulta un aspecto ciertamente complicado de análisis ya que Puerto Rico es un país latinoamericano bajo una situación geopolítica particular con los EE.UU. desde la guerra hispanoamericana de 1898. ¿Cree que existe una identidad propia y distintiva típicamente puertorriqueña a pesar de que la Isla se halle bajo el estatus del ELA, ergo bajo la influencia cultural de los EE.UU.? ¿Y en este sentido, cuáles serían en su parecer las características distintivas de la identidad boricua?

FERNANDO FELIÚ. Yo creo que sí, yo creo que existe una identidad puertorriqueña. Lo que pasa es que es una identidad bastante diluida por otros factores. Es decir, no es una identidad que se pueda considerar desde el punto de vista literario -la tradición literaria puertorriqueña-, como la argentina o cualquier otra, no es de siglos, es de 150 años y para de contar. Pero si lo vemos así ninguna literatura en ninguna zona hispanoamericana tiene una identidad claramente asentada... Ahora, si no lo vemos de ese punto de vista y lo vemos por particularidades importantes, entonces, sí. Hay un acento puertorriqueño que no es el acento cubano, hay una idiosincrasia puertorriqueña que no es la idiosincrasia argentina, bonaerense ¿no? La comida, la bebida, incluso la manera de establecer relaciones sociales. Por ejemplo, en Puerto Rico, desgraciadamente, dependemos demasiado del auto mientras que en Buenos Aires, en México, la transportación pública es bastante buena y eso da una apertura, un ritmo de vida muy distinto al que seguimos aquí porque esto se organizó pensando en el auto, prácticamente. La prueba la tienes que en el Viejo San Juan no entra, 
casi no se puede circular porque las calles nunca se hicieron pensando en automóviles grandes como los de ahora y menos uno grande como el que adquirí para llevar a mis tres hijos. O sea que sí, yo creo que hay una cultura puertorriqueña, decir que no la hay sería una mentira. Uno piensa desde España o desde Europa... uno piensa en Caribe y piensa en Cuba porque Cuba opaca al resto. México y Argentina y Perú opacan también al resto de Hispanoamérica. Pero sí, si trascendemos eso, estoy de acuerdo.

ENDiKa BASÁÑEz. Textos como En Nueva York y otras desgracias de José Luis González o Spiks de Pedro Juan Soto resultan parlantes per se en cuanto al tratamiento recibido por el puertorriqueño desplazado a Nueva York. ¿Cuál es la difusión de estos textos entre la población isleña? ¿Cree que los sistemas educativos dedican el espacio oportuno para los escritores puertorriqueños de la diáspora?

FERNANDO FELIÚ. Lo dedican, sí, pero muchas veces depende quién, si es la escuela privada o es la escuela pública. Lo dedican, pero muchas veces son textos que, dependiendo del colegio no se pueden incorporar porque hablan mal de EE.UU. o porque dicen coño o porque hay un personaje lésbico o un personaje que es gay. Hay una marginación todavía y el problema de esos textos de la diáspora es el mismo problema de muchos otros textos, y es que hay una desidia para leer. Quizá en un sentido se lee más que antes porque se lee en la computadora, se lee en el iPhone... pero no se lee necesariamente lo que se debe leer. O sea que yo creo que es el problema de todo que es que la gente no lee, los que leen son una minoría. Una minoría que no sé si cada vez es más o menos, más grande o más pequeña, pero se lee poco. A diferencia de otros países como en España: en Madrid yo veo a la gente leyendo en el metro, aquí no ves tanta gente leyendo en el pequeño metro que tenemos, en el tren urbano. Se lee menos aquí, se lee poco.

ENDIKA BASÁÑEZ. Llegada la década de 1970 autoras puertorriqueñas como Lidia Vega o Carmen Lugo Filippi dan lugar a un corpus textual centrado en materiales narrativos vinculados a la mujer boricua hasta ahora ignorados por gran parte de los autores previos a dicha generación en pro de cuestiones políticas y la búsqueda de una identidad propia bajo el dominio estadounidense. ¿Considera que dicha generación resultó ser primordialmente feminista o el contenido de sus obras resulta tan heterogéneo e implícitamente político como la de sus antecesores?

Fernando Feliú. Si nos atenemos a las escritoras, Ana Lidia Vega, Carmen Lugo Filippi, la más conocida Rosario Ferré con su Papeles de Pandora, si nos atenemos a ellas: sí, es una generación, es un grupo de escritoras que se distingue por recalcar aspectos de la condición femenina: el aislamiento, la marginación, la sexualidad... por poner unos ejemplos. Ahora, no son únicamente feministas, ese feminismo que proponen muchas veces está vinculado a la política, a una denuncia social que muchas veces rebasa lo puertorriqueño. Ya se critica a los EE.UU., no por haber tirado la ley Foraker sino por la bomba de Hiroshima o por la invasión o por la represión [...] Para 
ellas aislar en feminismo del contexto general amplio sería impensable y yo creo que lo hicieron muy bien, porque yo creo que, aunque toquen lo puertorriqueño, eso es parte también de una forma global. De hecho, textos como Papeles de Pandora son textos sofisticados porque hay una marcada influencia del boom, son textos que se nota una madurez, se nota un desarrollo, se nota una conciencia de escritor y de escritora... En el 76 aparece La guaracha macho camacho y aparece Papeles de Pandora y aparece la novela Bingo de Manuel Ramos Otero en Nueva York, un escritor muy bueno y no tan conocido, precisamente, no por su homosexualidad, sino porque estaba fuera del circuito más directo de la Isla.

ENDIKA BASÁÑEZ. Por último, ¿hacia dónde se dirige la literatura puertorriqueña en la actualidad? ¿Cree que ha perdido el matiz político y reivindicativo, en sus diversas causas, hacia un enfoque más comercial?

FERNANDo Feliú. En un sentido sí, hay un enfoque más comercial del cual la propia Rosario Ferré cayó en él; La casa en la laguna la publicó en inglés, por ejemplo. También hay una literatura que no es abiertamente política pero sí incluye el tema político de la cotidianidad, pienso en $L a$ belleza bruta de Francisco Font Acevedo, pienso en Mundo cruel de Negrón. El tema político está presente ahí pero ya son temas más centrados, el tema político está presente implícitamente no explícitamente, como anteriormente. No por censura ni por nada sino porque muchos se cansaron del tema político abiertamente como Pedro Cabilla lo ha dicho abiertamente que se hartó de la identidad que quería hacer literatura que no tuviera nada que ver con eso, entonces recurre a unos artilugios bastante sofisticados como retomar la fábula o las historias tremendas o historias desalmadas. Por ejemplo, Mayra Santos es una buena escritora, pero quizá publica a veces apresuradamente, comete errores en algunos textos históricos, graves errores. Hay una veta comercial y hay un vedetismo intelectual del que le gusta figurar en televisión, en la radio, hay un cierto vedetismo ahí que a mí me repatea un poco. 
3. Migraciones y exilios 


\section{LAS MIGRACIONES COLONIALES DEL CARIBE A ESTADOS UNIDOS Y EUROPA OCCIDENTAL: COLONIALIDADES DIFERENCIADAS EN CUATRO CENTROS DEL SISTEMA-MUNDO}

Colonial Caribbean Migrations to Western Europe and the USA: Differentiated Colonialities in Four Metropoles of the World-System

\section{RAMÓN GROSFOGUEL}

\section{BERKELEY UNIVERSITY grosfogu@berkeley.edu}

Sociólogo puertorriqueño y profesor en Berkeley University, es uno de los grandes autores del pensamiento decolonial latinoamericano. Es autor de diferentes libros y múltiples artículos sobre el tema, entre los que destacan Colonial Subjects. Puerto Ricans in a Global Perspective (2003), El giro decolonial: reflexiones para una diversidad epistémica más allá del capitalismo global (comp, 2007) o Unsetling postcoloniality: coloniality, transmodernity and border thinking (2007).

RESUMEN: Este artículo compara cuatro migraciones caribeñas hacia las cuatro metrópolis que dominan el Caribe hoy. Se trata de las migraciones desde territorios no-independientes del Caribe: desde Martinica/Guadalupe hacia Francia, Puerto Rico hacia los Estados Unidos, Surinam/Caribe Holandés hacia Holanda y Caribe Británico hacia el Reino Unido. El artículo no solamente compara los procesos de emigración sino también los procesos de incorporación al llegar a las cuatro metrópolis. La comparación nos da una idea fundamental acerca de las diferencias entre estas metrópolis en términos de ciudadanía, mito fundacional de nación, racismo, y política pública hacia las minorías racializadas.

Palabras Clave: Caribe, migración colonial, colonialidad, Sistema-mundo.
ABSTRACT: This article compares four Caribbean migrations towards the four Metropoles that dominate the Caribbean today. In particular, it deals with migrations from non-independent territories in the Caribbean: from Martinique/ Guadaloupe to France, Puerto Rico to the USA, Surinam/Dutch Caribbean to The Netherlands, and British Caribbean to the United Kingdom. The article not only compares the emigration processes but also the incoporation processes once they arrive to the four metropoles. The comparison gives us a fundamental idea about the differences between the four metropoles in terms of citizenship, foundational myth about the nation, racism and public policy towards racialized minorities.

KEY WORDS: Caribbean, Colonial Migration, Coloniality, World-System. 


\section{INTRODUCCIÓN}

Los bordes construidos por el sistema-mundo capitalista son organizados a nivel transnacional a través del eje de la división internacional del trabajo entre centros, periferias y semi-periferias (Wallerstein, 1979). Esta división del trabajo implica diferentes formas de trabajo y estructuras políticas. Mientras las formas de trabajo "libre" se desarrollaron históricamente en los centros, las formas coercitivas de trabajo se desarrollaron en las periferias. El sistema-mundo capitalista ha dependido históricamente de la fuerza de trabajo barata de la periferia. La formación de un sistema global interestatal compuesto por estados soberanos que emergió a mediados del siglo XVII se convirtió en la forma de organización política del sistema-mundo moderno (Wallerstein 1984). Este sistema interestatal global fue central en la producción y reproducción jerárquica de la división internacional del trabajo. Los estados del centro dominaron los estados de la periferia y la semiperiferia a través del militarismo, el colonialismo y el neo-colonialismo. En el siglo XIX las monarquías soberanas se transformaron en estados-naciones. Los estados dejaron de representar a las monarquías y en su lugar comenzaron a representar la "comunidad imaginada" (Anderson 1983) mejor conocida como la “nación”.

La ciudadanía se convirtió en un mecanismo importante en la formación de las fronteras que dividen los centros y las periferias en la economía-mundo capitalista. Estas fronteras restringieron la extension a las mujeres, clases trabajadoras y poblaciones no-europeas de los privilegios, recursos, y derechos ciudadanos que gozaban las élites del sistema-mundo compuestas principalmente por hombres europeos. A través del tiempo, estos derechos ciudadanos fueron lentamente extendidos a las clases trabajadoras europeas/euro-norteamericanas y más recientemente a las mujeres. Sin embargo, estas fronteras siempre fueron permeables. Los centros metropolitanos siempre mantuvieron una mano de obra barata de las "colonias" al interior de los imperios. En los siglos XVIII y XIX, había trabajadores escoceses e irlandeses en Londres, bretones en Paris, y esclavos africanos en Nueva York. El racismo es un mecanismo central en el mantenimiento de una fuerza trabajadora sin los mismos derechos que los trabajadores blancos. A través del racismo se construyó una fuerza trabajadora colonial que servía de mano de obra barata no solo en las regiones periféricas sino también en los propios centros metropolitanos (Wallerstein,1979). Aquellas poblaciones coloniales con ciudadanía metropolitana dentro de los centros fueron subordinados y mantenidos en un status de ciudadanos de segunda clase a través de la "geocultura" (Wallerstein, 1991) del racismo en el sistema-mundo capitalista. Dependiendo de los ciclos del sistema-mundo, el racismo operaba para producir una fuerza de trabajo barata o para excluir poblaciones del mercado de trabajo. Generalmente, el primer mecanismo se usaba para periodos de expansión del sistema-mundo, y el segundo para periodos de contracción.

Desde sus inicios a fines del siglo XV, el sistema-mundo capitalista se fue expandiendo hasta incluir todo el planeta a fines del siglo XIX (Wallerstein, 1979). Esta expansión se entrelazó con otras relaciones jerárquicas. La expansión simultánea de capitalistas compuestos por hombres 
blancos europeos estructuró un sistema capitalista entrelazado con estructuras jerárquicas patriarcales, sexuales y raciales en el sistema-mundo moderno/colonial.

La jerarquía etno/racial a escala mundial implicó una "formación global racial/colonial” de significados, discursos y estructuras alrededor de la jerarquía de raza. Esta "formación global racial/ colonial" ha existido desde la formación del sistema-mundo capitalista en el siglo XVI. Por varios siglos, el racismo biológico fue el discurso racial dominante. Sin embargo, después de la Segunda Guerra Mundial hubo un cambio importante en la "formación global racial/colonial". Los discursos racistas biológicos acerca de la inferioridad genética de los "Otros" entraron en crisis a través de la Europa continental. La ocupación nazi deslegitimó los discursos racistas biológicos en los países continentales de la Europa Occidental. Sin embargo, la deslegitimación de los discursos racistas biológicos no implicó el fin del racismo como ideología central del sistema-mundo capitalista. Luego de la derrota de las ocupaciones nazi en Europa Occidental a mediados del siglo pasado y de la conquista de los derechos civiles por la lucha de las minorías en Inglaterra y los Estados Unidos en los años sesenta, los discursos dominantes de la "formación global racial/colonial" se transformaron de racismos predominantemente biológicos en racismos predominantemente culturales. Los movimiento anti-racistas fueron un determinante crucial en retar los discursos racistas biológicos. El racismo cultural se hizo parte de la nueva geocultura del sistema-mundo capitalista a partir de la década del sesenta.

Las migraciones coloniales del Caribe de la posguerra hacia las metrópolis provee una experiencia importante para examinar esto asuntos. Este artículo trata del rol de lo que se ha llamado el "nuevo racismo" (Barker 1981) en la reproducción de las "fronteras históricas imaginadas" que excluyen a los pueblos coloniales de acceder a derechos iguales dentro de los centros metropolitanos del sistema-mundo capitalista. Las poblaciones coloniales caribeñas migraron masivamente hacia Holanda, Estados Unidos, Francia e Inglaterra después de la Segunda Guerra Mundial. Estas migraciones tienen varios procesos en común. Primero, ellas forman parte de un proceso global de migraciones de trabajadores coloniales para proveer una fuerza de trabajo barata en los centros metropolitanos durante la expansión económica de la posguerra. Segundo, se trata de migrantes con las ciudadanías metropolitanas. Tercero, estos migrantes tienen una larga historia de relaciones racistas/coloniales con las metrópolis. Cuarto, con la contracción de la economía-mundo capitalista luego de mediados de los años setenta, la primera y segunda generación de migrantes coloniales caribeños comenzaron a ser excluidos de los mercados de trabajo. Quinto, estos migrantes han sido objeto de los "nuevos discursos racistas" que intentan mantenerlos en posiciones de subordinación dentro de los centros metropolitanos usando los nuevos discursos "racistas culturales". Dadas estas similitudes las preguntas que intento tratar en este artículo son: ¿porqué los puertorriqueños, surinameses, antillanos holandeses, antillanos franceses y caribeños británicos experimentan discriminación y, en muchas instancias, marginalización a pesar de compartir la ciudadanía metropolitana?, ¿cuales son las diferencias entre cada metrópolis con respecto la experiencia de discriminación y racismo que viven los migrantes caribeños coloniales?, ¿cómo estas diferencias muestran diferencias entre los cuatro centros metropolitanos? 
Para responder a las preguntas planteadas utilizaré tres conceptos cruciales: nación, raza y colonialidad. Estos conceptos están entretejidos. No se pueden entender sin articular uno con el otro. Primero, el concepto de nación es central para el entendimiento de los procesos de ciudadanía, identidad y los modos de incorporación socio-políticos de los migrantes. Para hablar de derechos (civil, político, social) y de las obligaciones de ciudadanía implicados (Marshall, 1964), necesitamos entender los mitos fundacionales, las tradiciones inventadas (Hobsbawn, 1990), y la "comunidad imaginada" (Anderson 1983) que los estados, elites, clases y grupos etno-raciales dominantes construyen. Un borde/frontera se construye entre los que pertenecen y los que son excluidos de las representaciones de la "nación". La "nación” es frecuentemente imaginada en los centros metropolitanos como equivalente a los valores y comportamientos de las clases medias blancas. La construcción de la identidad nacional está entretejida con las categorías raciales.

Segundo, el racismo no es universal, ni es el mismo dondequiera que existe. Como muy bien señala Stuart Hall (1980), el racismo siempre es un fenómeno histórico específico. Hay dos interpretaciones del racismo y sus mutaciones de significados. Una es la noción tradicional ligada al racismo científico, es decir, el racismo genético o biológico. El segundo es lo que se conoce como "nuevo racismo" o "racismo cultural". Taguieff (1987) y Balibar (1991) en Francia, Gilroy (1987, 1993) en Inglaterra y Essed en Holanda (1996) usan esta noción para referirse a un racismo de "absolutismo étnico" , o racisme différencialiste. En este tipo de discurso racista la palabra "raza" no es ni siquiera usada. El "racismo cultural" asume que la "cultura" metropolitana es diferente de la "cultura" de las minorías étnicas entendiendo esta diferencia de manera absoluta y esencialista: “somos tan diferentes que no podemos vivir juntos", "las minorías están desempleadas o viven en niveles altos de pobreza debido a sus valores y comportamientos culturales", o "las minorías pertenecen a unas culturas tan distintas que no pueden entender las normas culturales de nuestro país". Sin embargo, el "racismo cultural" esta siempre relacionado a una noción de "racismo biológico" en la medida en que la cultura de los grupos es naturalizada en términos de una noción jerárquica entre culturas superiores e inferiores asociadas a los cuerpos biológicos de las personas. El "racismo cultural" esta siempre articulado en relación los discursos de pobreza, de oportunidades en los mercados de trabajo y de marginalización. El problema de pobreza o el desempleo de las minorías racializadas es construido como un problema de hábitos o creencias, es decir, como un "problema cultural”, asumiendo inferioridad cultural y, por tanto, naturalizando/fijando/esencializando la cultura de los "Otros". Argumentos como los de la "cultura de la pobreza" se articulan muy bien con la nueva "formación racista cultural”. Los puertorriqueños en los Estados Unidos y los caribeños en Inglaterra fueron de los primeros grupos en ser racializados en esta perspectiva. Los estudios clásicos de la cultural de la pobreza usaron a los puertorriqueños como ejemplo (Lewis, 1966). La forma particular en que los discursos "racistas culturales" se desarrollaron en cada metrópolis depende de 
las diferentes formaciones nacionales y experiencias coloniales. Por tanto, los mitos fundacionales de la “nación” son cruciales para entender como el "nuevo racismo" se articula.

Existen diferencias importantes entre el mundo anglo-sajón y los países de la Europa continental que hay que puntualizar a la hora de comparar los diversos discursos racistas metropolitanos. Primero, los Estados Unidos surgen de una sociedad colonial con la esclavitud como una de las formas de trabajo mas importantes. Desde su formación, los Estados Unidos han tenido una presente, subordinada población negra dentro de sus fronteras territoriales. Segundo, a diferencia de Francia y Holanda, los Estados Unidos e Inglaterra no fueron invadidos por los nazis durante la Segunda Guerra Mundial. Este factor es crucial para entender la construcción de los diversos discursos racistas de la posguerra. Temprano en la posguerra Francia y Holanda desarrollaron un discurso oficial contra el "racismo biológico", mientras que Estados Unidos e Inglaterra no vinieron a problematizar el "racismo biológico" hasta mas tarde.

En los Estados Unidos, el cambio de un racismo biológico a un racismo cultural surge en los sesenta como respuesta a la lucha por los derechos civiles de los afro-americanos y otras minorías racializadas como los indígenas, los chicanos y los puertorriqueños. Una vez conquistada la enmienda constitucional a los derechos civiles en 1964, se tornó política y legalmente difícil continuar articulando un discurso racista basado en un reduccionismo biológico tradicional. En Inglaterra, el discurso racista biológico no fue problematizado hasta las luchas antirracistas de los caribeños y los surasiáticos en los sesenta y la subsiguiente aprobación de las leyes contra la discriminación racial del Race Relations Bill de 1968. La discriminación sobre la base de discursos racistas biológicos fue criminalizada. Por tanto, los discursos racistas se transformaron y adquirieron nuevas formas y sentidos. El "racismo cultural” se convirtió en el discurso dominante sobre raza en Francia, Holanda, Inglaterra y los Estados Unidos. El racismo cultural constituye el discurso racial más importante de la “formación racial/colonial global” hoy día.

Una característica común de las migraciones coloniales del Caribe es que cada una a su manera contribuyó a la emergencia de una crisis en la "identidad nacional” en las metrópolis. Esto a su vez esta relacionado con el tercer concepto que enfatizaremos en este trabajo, la "colonialidad del poder" (Quijano, 1991) que persiste a pesar de la caída de las administraciones coloniales como forma dominante de relaciones entre los Europeos/Euro-Americanos y los no-Europeos en el sistema-mundo capitalista. La "colonialidad" se refiere a la reproducción y persistencia de las viejas jerarquías etno-raciales coloniales en un mundo "poscolonial" y "posimperial". El fin de las administraciónes coloniales en el sistema-mundo moderno/colonial no significa fin de la "colonialidad". Con las masivas migraciones coloniales de la posguerra, la "colonialidad del poder" se reproduce al interior de los centros metropolitanos. Ninguna migración colonial caribeña pasó desapercibida en el imaginario Europeo/ Euro-americano. Estos migrantes son coloniales debido a su larga relación colonial con la metrópolis y su continua representación estereotipada en el imaginario Europeo/Euro-americano, materializado en su localización subordinada en el mercado de trabajo metropolitano. La representación de los sujetos coloniales como vagos, criminales, estúpidos, inferiores, desconfiables, primitivos, sucios, bárbaros, y oportunistas tiene una larga historia colonial. 
Independientemente del mito fundacional específico de la nación y su particular construcción racial, las preguntas son: dada sus compartidas ciudadanías metropolitanas, ¿que implicaciones tuvieron los mitos fundacionales de la "nación" del estado metropolitano en el acceso a derechos y trato igual para los migrantes coloniales del Caribe?, ¿cómo estas migraciones cuestionaron los mitos fundacionales de la "nación” metropolitana? Como Paul Gilroy ha dicho en innumerables ocasiones para el caso británico, negro y británico eran identidades incompatibles. ¿Qué rol jugo el racismo en la construcción de los bordes nacionales imaginados?, ¿cómo todo esto afectó la identidad de los migrantes caribeños en las metrópolis?, ¿qué estrategias desarrollaron los migrantes caribeños en su lucha contra la exclusión/discriminación por la inclusión/incorporación con igualdad ciudadana? ¿Cómo los mitos fundacionales se resignificaron a través del tiempo?

\section{ESTADOS UNIDOS}

En los Estados Unidos el mito fundacional central es el "sueño americano" (“American Dream"). Los Estados Unidos se supone que son la tierra de las oportunidades para los migrantes de todas partes del mundo donde “mientras más duro trabajas más exitoso serás”. Una presuposición de este mito es que si fracasas es debido a que no has trabajado suficientemente y, por tanto, tiene que haber algún problema con el individuo. La constitución de 1776 fue concebida sobre la base de "Nosotros el pueblo" ("We the people") en lugar de "Nosotros los ciudadanos" ("We the citizens"). Aquí la noción de "Pueblo" se refiere a los derechos de un grupo en oposición a los derechos individuales. Esto implica que la ciudadanía es percibida más en términos de "derechos de pueblo" que como "derechos individuales", excluyendo a todos aquellos que están fuera de la "comunidad imaginada" de la "nación". Esto permitió el reconocimiento de los derechos etno-raciales de los inmigrantes europeos. Un país compuesto por inmigrantes multiétnicos como los Estados Unidos nunca tuvo la reproducción de la ciudadanía en términos de un diferencialismo etno-cultural; centrado en los lazos de sangre como la nación alemana, ni en la unidad política centralizada expresada por políticas asimilacionistas forzando una unidad cultural como la nación francesa (Brubaker 1992). Ser americano fue identificado desde un principio con ser "blanco", significante que se convirtió en la identidad unificadora de todos los inmigrantes multiétnicos de origen europeo. El mito del "melting pot” fue hegemonizado por una etnicidad anglo-sajona y se refería a la fusión de todos bajo la categoría de "blancos". Por consiguiente, la construcción de raza se convirtió en una categoría decisiva para que la gente fuera incluida dentro o excluida fuera de la "nación”. Desde el establecimiento de la constitución de los Estados Unidos en el siglo XVIII, los negros y los indígenas fueron excluidos de la Carta de Derechos. El termino "étnico" fue usado para referirse a los europeos y a todos aquellos considerados como "blancos", mientras que las poblaciones de color fueron racializadas en categorías de no-europeo y excluidas de los derechos constitucionales.

Es dentro del contexto de estos mitos fundacionales de la nación que podemos entender cómo la ciudadanía define los "bordes imaginados", es decir, quién es incluido dentro y quién es excluido fuera; de la "comunidad imaginada". En los Estados Unidos, la ciudadanía tiene rasgos muy particulares. Los derechos civiles, definidos en términos de derechos de propiedad, y los derechos 
políticos, definidos en términos de derecho al voto, siempre han sido mas fuertes que los derechos sociales. El mito del "sueño americano" de adquirir éxito social a través de trabajar duro, deja un espacio muy estrecho en el imaginario social para la noción de derechos sociales. Esto es clave para entender el estado de bienestar subdesarrollado que siempre tuvo los Estados Unidos comparado a los países metropolitanos de Europa Occidental. Sin embargo, cualquiera sean los derechos éstos son percibidos o imaginados como merecidos solamente por las poblaciones "blancas", mientras que las minorías etno-raciales siempre fueron vistas como intrusos u oportunistas que quieren tomar ventaja de estos derechos. En los Estados Unidos, la clasificación social de las personas ha sido hegemonizada por elites de hombres blancos a través de un largo proceso de dominación racial/ colonial. Las categorías de la modernidad tales como ciudadanía, democracia, e identidad nacional han sido históricamente construidos a través de dos ejes jerárquicos: 1) entre el capital y el trabajo; y 2) entre europeos y no-europeos (Quijano, 1991). Los hombre blancos hegemonizaron estos ejes de poder. Siguiendo el concepto de "colonialidad del poder" desarrollado por el sociólogo peruano Aníbal Quijano (1991), incluso después de la independencia política, cuando el control jurídicomilitar del estado pasó del poder imperial hacia el nuevo estado independiente, las elites "blancas" continuaron controlando las estructuras políticas y económicas. Esta continuidad del poder de los tiempos coloniales a los tiempos "poscoloniales" permite a las elites "blancas" clasificar a las poblaciones y excluir a la gente de color del ejercicio completo y pleno de sus derechos ciudadanos en la "comunidad imaginada" llamada la "nación". Los derechos políticos, civiles y sociales que la ciudadanía provee a los miembros de la "nación” fueron selectivamente extendidos a través del tiempo hasta incluir a la clase obrera "blanca". Sin embargo, los grupos pertenecientes a las "colonias internas" se mantuvieron como ciudadanos de segunda clase nunca teniendo acceso pleno a los derechos ciudadanos (Gilroy, 1987). Ser Americano era incompatible con ser negro, indio, puertorriqueño, asiático; chicano, etc. Por tanto, la lucha por los derechos civiles de estos sujetos racializados fue construida alrededor de la noción de igualdad, reclamando derechos iguales como minorías étnicas discriminadas dentro de los Estados Unidos. El resultado de estas luchas fue la implementación de derechos por la igualdad de los grupos minoritarios basados en programas de discriminación positiva.

En los Estados Unidos, la palabra "étnico" se ha referido históricamente a diferencias culturales dentro de los grupos blancos euro-americanos (por ejemplo, italianos, irlandeses, alemanes) mientras que las categorías raciales han sido usadas para referirse a la gente de color (por ejemplo, negros, asiáticos, hispanos) borrando las diferencias étnicas dentro de estos grupos racialmente clasificados. Desde los sesentas, étnico en los Estados Unidos sufrió una transmutación convirtiéndose en un eufemismo para referirse a raza. Con la mutación discursiva de los años sesentas de discursos racistas biológicos hacia una predominancia de discursos racistas culturales, en lugar de caracterizar a los grupos racializados sobre líneas raciales, las palabras "étnico" y "migrante" se convirtieron en los nuevos términos preferidos. Este discurso dominante fue elaborado por Nathan Glazer y Daniel P. Moynihan en su clásico estudio publicado en 1963 y titulado Beyond the Melting Pot: The Negroes, Puerto Ricans, Jews, Italians and Irish in New York City. La experiencia de la 
gente de color en los Estados Unidos es concebida por estos autores como equivalente a la experiencia de los migrantes blancos europeos de principios del siglo 20. A través de transmutar la “discriminación racial” en "discriminación étnica”, los puertorriqueños y los afro-americanos podían pasar por las mismas etapas de los otros grupos "étnicos” y eventualmente ser incorporados económicamente con éxito similar a la experiencia de los blancos europeos en los Estados Unidos. Desde esta perspectiva, si fracasaban en su proceso de incorporación se debe a alguna condición patológica en su cultura o en sus hábitos, es decir; su "cultura de la pobreza". La perspectiva de Glazer y Moynihan borra la historia de opresión racial/colonial de los afro-americanos y los puertorriqueños: la larga historia de esclavitud y apartheid de los afro-americanos que creó barreras político/raciales hacia su movilidad social exitosa y el régimen colonial en Puerto Rico que expropió de sus tierras e incorporó como mano de obra barata en la agricultura y en la manufactura a miles de puertorriqueños. Los puertorriqueños y los afro-americanos no son simplemente "migrantes" o grupos "étnicos", sino sujetos raciales/coloniales dentro del imperio estadounidense.

¿Qué derechos tuvieron los migrantes puertorriqueños ? ¿Cómo fueron percibidos por las poblaciones metropolitanas? Esto está relacionado con la historia y particularidad del tipo de colonialismo practicado por Estados Unidos en Puerto Rico. La extensión de la ciudadanía a la colonia de Puerto Rico en 1917, institucionalizó la formación de ciudadanos de segunda categoría. Los puertorriqueños estaban supuestos a tener acceso igual a los derechos ciudadanos. Sin embargo, como un grupo colonial racializado dentro de los Estados Unidos, su acceso a estos derechos siempre fue limitado. La construcción racial de los puertorriqueños como vagos y criminales contribuyó a la actual marginalización de este grupo en el mercado de trabajo. Imposible de localizar a los puertorriqueños en una categoría racial fija (a los ojos anglo-americanos "ni eran blancos ni eran negros"), los euro-americanos los percibían como un grupo racialmente distinto. Los puertorriqueños se convirtieron en una nueva categoría racial diferente a los blancos o los negros, y compartiendo con estos últimos una posición subordinada frente al euro-americano. La película West Side Story a comienzos de los sesenta, marcó un punto crucial donde los puertorriqueños se tornaron en una raza distinta, sin ser confundida más con los asiáticos, negros o chicanos en el imaginario racial norteamericano. Esta racialización fue resultado de una largo proceso histórico de subordinación racial/colonial en la isla así como en la metrópolis (Vazquez 1991; Thompson 1995). El racismo experimentado por los afro-puertorriqueños en muchas instancias fue mas fuerte que el experimentado por los euro-puertorriqueños. Sin embargo, no importa cuan rubio tenga el pelo o azules los ojos, en el momento en que una persona se identifica a sí misma como puertorriqueña, entra en el laberinto de "otredad racial”. Los puertorriqueños de todos los colores se han convertido en un grupo racializado en el imaginario norteamericano marcado por estereotipos racistas tales como "vagos", "criminales", "estúpidos", "oportunistas" y "sucios". Aunque los puertorriqueños forman un grupo multi-racial, ellos se han convertido en una nueva "raza" en los Estados Unidos. Esto muestra el carácter social en lugar de biológico de las clasificaciones de raza. La clasificación despectiva de los puertorriqueños como "spics" en el campo simbólico de Nueva York, designa el capital social negativo asociado a la identidad puertorriqueña. 
Los puertorriqueños fueron incorporados como fuerza de trabajo barata en la industria manufacturera de Nueva York durante los cincuenta y sesenta del siglo pasado. Los procesos de desindustrialización en las zonas metropolitanas después de 1970 con la contracción económica del sistema-mundo capitalista, desplazó masivamente a los puertorriqueños fuera de los trabajos en la manufactura convirtiéndolos mayoritariamente en una fuerza de trabajo redundante en los guettos urbanos de las ciudades del noreste. Los puertorriqueños como grupo no pueden entrar a los niveles altos de la nueva economía de servicios debido la segregación residencial en que viven. La segregación residencial los excluye de las mejores escuelas públicas lo que les hubiera permitido elevar su capital humano requisito indispensable para ascender socialmente en la economía de servicios. Por otro lado, los puertorriqueños no pudieron ni siquiera entrar a los trabajos de mano de obra barata de la nueva economía de servicios debido a la presencia de una fuerza de trabajo aún mas barata proveniente de los "nuevos inmigrantes" en las ciudades norteamericanas. La construcción racista de los puertorriqueños como "vagos” y “criminales” contribuyó a su actual marginalización en los mercados de trabajo.

En sus demandas de igualdad de derechos civiles y laborales durante los sesenta, los puertorriqueños fueron considerados por los patronos como una fuerza de trabajo mas costosa comparado con los "nuevos migrantes". Los patronos hoy día reclaman una preferencia mayor por los trabajadores inmigrantes que trabajan largas horas sin los derechos laborales, que los "vagos" trabajadores de las minorías internas que relaman sus derechos. El "racismo cultural" es la nueva forma discursiva de la exclusión racial en los Estados Unidos. Por consiguiente, la situación de muchos puertorriqueños hoy no es meramente la de una fuerza de trabajo barata, sino la de ser una población masivamente excluida de acceso a empleos (Grasmuck y Grosfoguel, 1997). Los puertorriqueños tienen hoy día una de las tasas de pobreza mas altas en los Estados Unidos, cercanas a un tercio de la población total y en algunas ciudades cercanas al 40 por ciento.

\section{FRANCIA}

En Francia el mito fundacional de la nación está ligada a los ideales de la revolución francesa de 1789, es decir, a la noción de les Droits de l'Homme, donde se establece un contrato social directo entre el Estado y los individuos (Balibar, 1994). La gente es francesa o no-francesa, definida en términos de una noción de asimilacionismo cultural que divide a la gente entre ciudadanos y extranjeros. De acuerdo al discurso oficial francés, no se puede ser franco-martiniqués o francovasco. Por tanto, la categoría de etnicidad o de minorías étnica no está reconocida en la tradición francesa. No existe reconocimiento oficial de grupos étnicos dentro de la "comunidad imaginada" de la nación francesa.

Como ciudadanos franceses de descendencia africana, los caribeños de las Antillas francesas han ocupado una posición ambigua dentro del imperio francés. El impulso asimilacionista del estado francés intentó borrar las raíces históricas y culturales de las Antillas francesas por medio de políticas colonialistas en las esferas educativas, culturales y sociales. Las escuelas públicas en las Antillas 
francesas fueron establecidas en la década de 1880 y su representación en la asamblea nacional francesa existe desde 1848 (Abou 1988; Blérald 1988; Giraud 1992). Esta es una incorporación colonial muy distinta a las políticas coloniales francesas en África donde las escuelas públicas fueron establecidas mucho mas tarde y donde la representación en la asamblea nacional fue en la mayoría de los casos después de 1945 (Marshall, 1973). Sin embargo, los antillanos les han inculcado por siglos que sus ancestros son los galos, grupo étnico imaginado por la "nación" francesa como sus antecesores. Los orígenes africanos de la cultura de los antillanos no sólo era ignorado sino despreciado en las escuelas francesas.

Estas políticas asimilacionistas en el Caribe francés fueron muy útiles para la administración colonial francesa en Africa. Negros caribeños educados como "franceses" fueron enviados de las colonias antillanas a las colonias africanas como oficiales estatales y militares del imperio francés (Helenon 1997). Eran un tipo de "middleman minority" que servían un rol similar a los empresarios étnicos que describe Bonacich (1973) en la literatura sociológica para referirse a intermediarios étnicos entre los grupos dominantes blancos y los grupos raciales subalternos. El propósito era que los de abajo canalicen su descontento no contra los de arriba sino contra los intermediarios. En este caso particular se ejercía este rol de "middleman minority" a través de oficiales negros antillanos en posiciones intermediarias al interior del estado colonial francés en África. En lugar de tener un oficial francés blanco, los antillanos eran enviados como representantes oficiales del estado francés en sus colonias africanas. Servían de intermediarios entre los blancos franceses y las masas africanas. En lugar de tener un blanco francés reprimiendo a los africanos, los antillanos eran enviados como oficiales coloniales. Cumplían un rol similar a los empresarios hindúes en el imperio británico en África, es decir, que los antillanos en el imperio francés eran enviados como "muro de contención" para canalizar el descontento contra los oficiales coloniales franceses. Felix Éboué, un afro-guyanés que fue nombrado gobernador de Chad, y Louis-Placide Blacher, un martiniqués nombrado gobernador de Níger, eran los ejemplos mas dramáticos de esta estrategia de "middleman minority" del estado imperial francés en África.

Como un intento de reconstruir su imperio luego de la Segunda Guerra Mundial, los franceses no solo incorporaron a las Antillas francesas como Departamentos Franceses con derechos iguales, sin que además nombraron a Gaston Monerville, un afro-guyanés presidente del Consejo de la República. Los antillanos fueron usados como una vitrina simbólica para la "nueva cara" de Francia en sus colonias africanas durante la posguerra y sirvieron como un ejemplo simbólico para sus políticas coloniales de la posguerra. El mensaje subliminal era igual que durante las políticas de "middleman" en las colonias africanas antes de la Segunda Guerra Mundial: si te asimilas a la cultura francesa como los antillanos hicieron, tendrás los mismos derechos, oportunidades y privilegios que ellos tienen dentro del imperio.

Durante el período de la posguerra, cualquier alusión a raza o racismo era identificado en el discurso oficial del estado francés con las posiciones extremistas de los Nazis. La palabra "raza" fue casi eliminada del discurso público francés. Lo que antes se definía como "diferencias raciales" comenzó a ser construido en términos de "diferencias culturales". Comenzando en la década de los 
cincuenta, la noción de "raza" fue "metamorfoseada" en "diferencia cultural" entendida de manera reduccionista al concebir la cultura como naturalizada y esencializada. Esto precedió y fue muy similar a lo que pasó en los Estados Unidos durante la era posterior a la enmienda constitucional de los derechos civiles en 1964. Lo interesante es que debido a la deslegitimación de los discursos racistas biológicos durante la ocupación nazi, este proceso de metamorfosis de los discursos racistas ocurrió en Francia mucho antes que en los Estados Unidos.

La guerra de Argelia fue un punto crucial del imperio colonial francés. Representó la caída final del colonialismo francés en África. Sin embargo, la caída del colonialismo no equivalía al fin de la colonialidad. Las viejas jerarquías coloniales se reproducen ahora dentro del territorio metropolitano. Los norafricanos (árabes) y africanos fueron incorporados como mano de obra barata en el mercado privado de trabajo. Ellos se convirtieron en la fuente principal de mano de obra barata en las industrias manufactureras de ciudades como Paris y Marsella. Los norafricanos se convirtieron en el objetivo obsesivo de los nuevos discursos racistas (Taguieff 1987). El "nuevo racismo" en Francia reclama que los hábitos culturales de los norafricanos les impiden ser incorporados exitosamente a la sociedad francesa. Algunos movimientos de extrema derecha, han llegado tan lejos como a decir que los norafricanos son tan diferentes culturalmente a los franceses que co-habitar es imposible y que, por tanto, deben ser deportados de Francia.

La migración de antillanos despegó masivamente durante la década del sesenta (Giraud y Marie, 1988). Hubo una división del trabajo entre los migrantes coloniales al interior de la metrópolis. Mientras los norafricanos ocupaban la posición de mano de obra barata en el mercado privado de trabajo, los antillanos eran incorporados como mano de obra barata en la administración pública francesa. La expansión económica de la posguerra incrementó los empleos públicos. Muchos trabajos en la parte baja de la administración pública francesa no eran atractivos para los "blancos" franceses. Esto creó una escasez de empleos en este sector local y estimuló un reclutamiento masivo, organizado directamente por el estado francés, en los departamentos de las Antillas francesas (Martinica, Guadalupe y la Guyana Francesa). A diferencia de muchos norafricanos, los antillanos tenían la ciudadanía francesa lo cual les permitió ser incorporados masivamente en la administración pública francesa.

La transición francesa de políticas imperiales hacia políticas "posimperiales" puede ser conceptualizada en términos de la "colonialidad el poder" de Anibal Quijano (1991). Esta perspectiva, contrario a otros acercamientos teóricos, enfatiza en la continuidades dentro de las discontinuidades entre el pasado colonial y el presente "poscolonial". Aunque el colonialismo desapareció como institución política de gestión europea sobre el mundo no-europeo, la colonialidad se reprodujo con nuevos dispositivos. Las migraciones de trabajadores coloniales de la posguerra reprodujo las viejas jerarquías coloniales/raciales pero esta vez dentro de la metrópolis misma (Balibar, 1992). Los norafricanos fueron concebidos como los "Otros" inasimilables, indeseables, ruidosos, sucios, y culturalmente subdesarrollados. Los antillanos, una vez mas, ocupan la posición intermediaria. Eran los "Otros" asimilables que servían de ejemplo, de vitrina simbólica hacia los "Otros” inasimilables. Su incorporación masiva en la parte baja del servicio público del estado francés 
gozaban de ciertos privilegios que los migrantes incorporados como mano de obra barata en el mercado de trabajo privado no contaban. Este modo de incorporación en el espacio público aislaba a los antillanos de las fluctuaciones y discriminación del mercado privado de trabajo. Los antillanos están localizados en posiciones estratégicas y sensitivas de la administración pública francesa como oficinas de inmigración, transportación pública y hospitales. Sin embargo, la situación de los antillanos no es ideal. Ellos son incorporados en aquellos puestos públicos que los "blancos” no les interesa tales como oficinistas, conserjes, ayudantes de enfermeras, choferes, secretarias, etc. Aquellos antillanos que cuentan con altas calificaciones casi nunca son considerados para ascenso hacia los altos niveles de la administración pública francesa. El racismo francés a creado un "techo" arriba del cual los antillanos raramente pasan (Galap, 1993; Marie, 1993). Este "racismo" está articulado a un discurso cultural "meritocrático". Los antillanos son excluidos de ascensos en la administración pública a través de discursos sobre la "falta de cualificaciones", "falta de conocimientos", y/o "falta de experiencia". La experiencia antillana muestra cómo el tener la ciudadanía francesa no es suficiente para detener la discriminación racista. La falta de ciudadanía no es lo que mantiene a los norafricanos en la parte baja del mercado laboral privado y a los antillanos en la parte baja del mercado laboral público. Existe una exclusión racista de aquellos que no corresponden a las representaciones dominantes francesas de la "comunidad imaginada" de la “nación”.

El hecho que los antillanos trabajen con "blancos" franceses en la administración pública y que residan junto a africanos en vivienda pública les da una localización ambigua en la jerarquía etno/ racial de Francia (Marie, 1992). Algunos antillanos viven la ilusión de compartir los privilegios de la jerarquía etno-racial cuando trabajan junto a franceses en los empleos públicos mejor compensados y con mejores condiciones laborales que el mercado laboral privado. Pero cuando regresan a sus casas confrontan a los "otros" no-blancos (árabes y africanos) como vecinos que les recuerdan de su propia “otredad" en la sociedad francesa. Esta discontinuidad entre aquellos con los cuales trabajan y aquellos con los cuales residen localiza a los antillanos en una posición no sólo intermedia sino ambigua. Los antillanos "pertenecen" a la "nación" cuando se trata de recibir los beneficios de los empleados públicos en Francia, pero no "pertenecen" cuando se trata de ascenso de empleos en la administración pública o de localización residencial (Galap, 1993). Incluso este sentimiento de "pertenencia" tiene que ser cualificado por su posición subordinada en empleos bajos de la administración pública francesa. Ellos son la mano de obra barata de la administración pública francesa que gana los salarios más bajos y que hacen los trabajos más duros y tediosos. Esta ambigüedad se traduce en que, por un lado, los antillanos afirman su nacionalidad francesa frente a los árabes y africanos en cuestiones de identidad y, por otro lado, forman alianzas con árabes y africanos en cuestiones de brutalidad policíaca o discriminación de vivienda en los suburbios de París. Es importante entender las estrategias disponibles o desarrolladas por los migrantes antillanos en Francia. ¿Qué tipo de reclamos han desarrollado?, ¿han luchado por derechos iguales como ciudadanos minoritarios, como un grupo nacional diferente dentro de una nación o como miembros de la nación metropolitana? 
En la metrópolis, la primera generación de antillanos descubrieron que la "Mére-Patrie" no les da una bienvenida como franceses. Por el contrario, los discrimina y los maltrata como ciudadanos de segunda clase (Marie 1993). El asimilacionismo francés es percibido como un mito vista desde la experiencia antillana en la metrópolis. Los antillanos desafiaron la ciudadanía asimilacionista individual anti-étnica desarrollando un movimiento de afirmación identitaria durante la década de los ochenta (Girard y Marie 1988). Este movimiento se expresó a través de la organización de asociaciones que reclaman una identidad étnica separada dentro del sistema francés, retando el universalismo abstracto de la ideología asimilacionista francesa.

Es importante destacar que la localización intermediaria de la primera generación de antillanos en la jerarquía etno-racial de Francia no es necesariamente compartida por la segunda generación de antillanos en la metrópolis. Debido al alto desempleo y la reducción de empleados públicos en Francia durante la contracción de la economía-mundo en los ochenta y los noventa, los jóvenes antillanos de segunda generación no fueron incorporados en los empleos públicos como sus padres. Por tanto, los jóvenes antillanos no están aislados de la discriminación y de las condiciones difíciles del mercado privado laboral. Ellos son vulnerables al racismo que muchos argelinos, marroquíes y senegaleses experimentan en el mercado de trabajo en Francia. Esto tiene implicaciones muy importantes en términos de la emergencia de ·nuevas identidades" en los suburbios parisinos. Hoy día la segunda generación de antillanos reclama más una identidad como "negros" que como "antillanos". El término "negro" en Francia, al igual que en Inglaterra en los sesenta, incluye una variedad de grupos oprimidos. Una importante fusión cultural está ocurriendo hoy día en los barrios parisinos entre jóvenes argelinos, marroquíes y antillanos. Esta fusión cultural transnacional entre estos grupos coloniales se manifiesta políticamente en forma de revueltas, festivales culturales y el hip-hop francés. Sin embargo, no hay una indicación clara de hacia donde se dirige esta fusión cultural. En los noventa, los jóvenes antillanos han sufrido el deterioro de las condiciones laborales experimentando junto a los jóvenes árabes y africanos un alto índice de desempleo en comparación a los jóvenes blancos franceses.

Más recientemente, los explosivos levantamientos de las comunidades de migrantes discriminadas en Francia en el otoño del 2005 sirve de barómetro sobre cuán explosiva es la situación actual. Jóvenes franceses de origen árabe, caribeño y africano se lanzaron a las calles a quemar carros y edificios públicos durante varias semanas en protesta frente a la brutalidad policiaca. Ante la muerte de dos jóvenes electrocutados mientras eran perseguidos por la policía, los jóvenes de las periferias urbanas de Francia respondieron con motines por todo el país. El levantamiento hizo añicos el mito de la igualdad del sistema republicano francés y puso sobre la mesa el racismo rampante de la sociedad francesa. Es significativo que el estado francés acudiera a una ley de estado de sitio usada en las colonias (por ejemplo, durante la guerra de Algeria) para reprimir el levantamiento. Esta ley nunca fue utilizada en territorio francés metropolitano ni siquiera durante los acontecimientos de mayo de 1968. Resulta revelador que la ley haya sido siempre utilizada contra las poblaciones coloniales francesas y es indicativo del carácter colonial de estas poblaciones francesas no-blancas al interior del territorio metropolitano francés el que se haya acudido a ésta para enfrentarlos. 


\section{HOLANDA}

En Holanda, el mito fundacional de la "nación" se construye alrededor de la noción de los "cuatro pilares". Se trata de la imagen de una sociedad que se concibe a partir de cuatro columnas separadas: católicos, protestantes, liberales y socialistas (Liphart 1968). El principio organizativo se basa en la división del país entre organizaciones religiosas (católicos y protestantes) y agrupamientos seculares constituidos por intereses de clase (clases medias liberales y clases trabajadoras socialistas).

A pesar de que los "cuatro pilares" fueron desmantelados desde la década del sesenta (Middendorp ,1991), la "comunidad imaginada" de la "nación” sigue construyéndose alrededor del mito de los "pilares" (Rath, 1991). Por consiguiente, la "nación" holandesa se construye como tolerante, antirracista, respetuosa de las diferencias, y como el centro de las ideas liberales y del estado de bienestar más avanzado del mundo (Essed,1996). Esta auto-definición nacional fue cuestionada luego de las migraciones masivas de Suriname y las Antillas Holandesas hacia Holanda desde comienzos de los años setenta. Primero, Holanda impulsó la independencia de Suriname en gran parte por las presiones de la población holandesa para crear mecanismos jurídicos que impidieran la migración surinamesa (Bovenkerk, 1975; Biervliet, 1981). La prensa holandesa tomó esta presión pública de corte racista y desarrolló una campaña para detener la migración surinamesa. Al igual que con el caso británico, la imposición de la independencia creó el efecto paradojal de generar una ola migratoria todavía más grande por miedo a no poder migrar y perder la ciudadanía holandesa una vez cerradas las fronteras. Aproximadamente, un tercio de la población total de Surinam migró hacia la metrópolis en un periodo de seis años (1973-1979). Segundo, los ciudadanos negros holandeses son vistos en el imaginario "colonial" de los blancos holandeses como indeseables, vagos, sucios, criminales, e inadaptados a la cultura holandesa (Bovenkerk, 1978; Bovenkerk and Breuning-van Leeuwen, 1978; Verkuyten, 1997). Como acorde con el mito nacional no existe tal cosa como racismo holandés (esto se supone que sea un problema británico y estadounidense), la referencia a "raza" fue transmutado en la noción de "minorías étnicas" que son construidas como un "problema social”. La política pública se transformó de políticas pluralistas culturales hacia políticas asimilacionistas y neoliberales. Previamente a 1980, el estado promovía instituciones y asociaciones de grupos étnicos particulares a través de las políticas del estado de bienestar. Estas instituciones tenían sus propios trabajadores sociales y programas comunitarios compuestos por grupos minoritarios específicos. El objetivo era "transformar" gradualmente el "estilo de vida" de los grupos minoritarios y adaptarlos al "estilo de vida" de la "nación" que era imaginado como equivalente al de las clases medias holandesas (Rath, 1993: 224).

Comparada con las políticas previas a 1980, las políticas estatales posteriores eran menos orientadas hacia el estado de bienestar y mas orientadas hacia el mercado de trabajo y la educación (Lutz,1993). A comienzos de la década del ochenta, los holandeses enfatizaron en la construcción de políticas hacia las minorías étnicas bajo la presuposición de que sus "problemas" se debían a un asunto socio-cultural de falta de adaptación a la cultura y la forma de vida holandesa (Lutz, 1993; 
Rath, 1993). Por consiguiente, intentaron desarrollar políticas estatales de "integración controlada" a través de la cooptación de organizaciones comunitarias que servían de intermediarios entre el gobierno y la comunidad. El estado subsidiaba cualquier organización, religiosa o no, que pudiera convertirse en socios sociales en la política de "integración étnica”. A fines de los ochenta, la política estatal volvió a cambiar transformando la definición de las políticas hacia las "minorías étnicas" de una perspectiva basada en la premisa de que las minorías representan un "problema sociocultural" hacia una construcción como "problema económico" (Lutz 1993; Rath 1993). En lugar de concebir al estado como un regulador de la integración socio-cultural, el "mercado" se convirtió en el espacio mágico donde "étnicos" y "nacionales" entran en contacto, ayudando a los "étnicos" a adaptarse y asimilarse a los "nacionales". Esto eliminó el énfasis en subsidiar organizaciones comunales. El énfasis pasó hacia la "magia" del mercado como regulador de la incorporación socio-cultural de las minorías. Las nuevas políticas economicistas fueron construidas como parte de las políticas para el desmantelamiento del estado de bienestar en la década del noventa. Minorías étnicas como los surinameses y los antillanos eran representados como "abusadores" de la "generosidad" del estado de bienestar (Bovenkerk, 1978; Essed, 1996). Concebidos como externos a la "comunidad imaginada" de la "nación" holandesa, la legitimidad de acceso al estado de bienestar por parte de los surinameses y los antillanos fue cuestionada. Por tanto, la lógica neoliberal de las nuevas políticas es dejar que el "libre mercado", en lugar del estado, regule el bienestar de los grupos marginados.

El racismo cultural en Holanda opera bajo la ideología de la "minorización” (Rath, 1993; Essed,1996; Verkuyten, 1996). Este término, articulado por el sociólogo holandés Jan Rath, se refiere a una forma de discriminación que, a diferencia de las formas tradicionales de racismo biológico, excluye y discrimina sobre la base de ser una "minoría étnica”. En Holanda, esta construcción significa que ser un "étnico" es equivalente a tener un comportamiento indeseable y una falta de adaptabilidad a las normas y la cultura holandesa. Como bien señala Jan Rath:

\begin{abstract}
Minoristaion, being an ideology of dominance, differs fundamentally from ethnicisation or ethnic categorization, which treats ethnics as belonging per se on an equal basis, whereas in the Dutch case "ethnic belonging" is reinterpreted as a form of non-conformity and thus undesirability... Minorisation also differs fundamentally from racialization in the strict sense of the term. After all, minorisation is not a matter of "naturalisation". Contrary to "races", "ethnic minorities" (in the Dutch sense of the word) are not "represented as having a natural, unchanging origin and status, and therefore as being inherently different"(1993: 222).
\end{abstract}

De acuerdo a la definicion de Rath, el problema en Holanda no es uno de racismo sino de "minorización”. Aunque estoy de acuerdo con Rath en que la "minorización” no es equivalente a los discursos racistas biológicos tradicionales, esto no quiere decir que no tenga nada que ver con racismo. La "minorisación” es una forma de racismo cultural donde la superioridad e inferioridad es construida en relación a la cultura apropiada de la clase media holandesa. Aquí la inadaptabilidad cultural descansa en las características inferiores esencialistas de la cultura de los "Otros". La cosificación de la cultura en una jerarquía de culturas superiores e inferiores es una forma de naturalización de las diferencias, lo cual esta entrelazado con los viejos discursos racistas biológicos de la época colonial. Los surinameses y los antillanos tienen una larga historia de racialización y 
colonización con Holanda. Ellos no entran neutralmente al mercado de trabajo holandés. Ellos son los “otros" racializados que son ahora nombrados eufemísticamente como "minorías étnica” en lugar de "minorías racializadas" como resultado de las mutaciones en los discursos raciales de la posguerra en Holanda. Los discursos raciales son ahora metamorfoseados a través de la ideología de "minorización". Como el propio Rath admite:

This ideology contributes to the positioning of migrant workers outside privileged social positions. As long as "ethnic minorities" are defined as people that conform inadequately to the Dutch way of life, they are not considered to be fully-fledged members of the "Dutch imaginary community" and are consequently granted less access to scarce resources (1993: 222).

Esta exclusión está vinculada a la noción de raza a través de un discurso acerca de "la conducta y normas culturales aberrantes e inadaptadas". Los caribeños holandeses en Holanda están racializados con estereotipos similares a los discursos racistas biológicos (vagos, criminales, oportunistas, parásitos, etc.) pero a través de la mediación de un discurso culturalista. Estos estereotipos racistas sirven para esconder la discriminación que los caribeños experimentan en Holanda. Este discurso racista cultural explica la exclusión que experimentan los caribeños en el mercado de trabajo a base de sus hábitos y valores culturales. Discursos muy parecidos a los de la "cultura de la pobreza" en los Estados Unidos.

Al igual que los puertorriqueños en los Estados Unidos, las poblaciones del Caribe holandés sufren de una alta marginalizacion en el mercado de trabajo de Holanda (Grosfoguel 1997). Las viejas jerarquías etno-raciales del viejo imperio colonial holandés se reproducen nuevamente, pero esta ves al interior de la metrópolis misma. A pesar de las mutaciones en los discursos raciales y de la caída del colonialismo como sistema político, la "colonialidad del poder" de las relaciones sociales actuales demuestra la fuerza de las continuidades de las jerarquías coloniales/raciales holandesas a través del tiempo. Esto se manifestó en la década de los noventa con estereotipos racistas hacia los migrantes antillanos. En la prensa y en los medios de información son representados como criminales y oportunistas que vienen a Holanda a aprovecharse del estado de bienestar y a realizar actividades criminales. Estos estereotipos han conllevado cambios en la ley por la cual los migrantes antillanos tienen ahora que inscribirse en las ciudades holandesas donde establecen su residencia.

En la ciudad de Rotterdam la xenofobia y el racismo ha llegado a niveles donde el gobierno municipal ha pasado decretos prohibiendo la residencia de migrantes en la ciudad. Debido a las crecientes protestas contra dicho decreto racista, la ciudad ha cambiado el decreto por uno en que se prohíbe la residencia de familias o personas con menos de cierto nivel de ingreso, medida dirigida indirectamente a prevenir la residencia de nuevos migrantes en la ciudad. Las medidas han ido dirigidas principalmente contra los migrantes marroquíes y antillanos que son hoy representados en la opinión pública como las poblaciones con "problemas de adaptación” debido a sus comportamientos y valores culturales "foráneos" a la cultura holandesa. Este racismo cultural rampante, que en contraste con el racismo biológico no menciona la palabra raza, permite a los holandeses reclamar la 
inexistencia de racismo en Holanda. Sin embargo, como hemos visto los problemas de la "colonialidad" continúan con mucha fuerza.

Más recientemente, la elección en el 2002 de un político racista anti-inmigrantes de extrema derecha Pim Fortuyn (asesinado unos días antes de su elección) y la reacción de las poblaciones blancas holandesas en el 2005 ante el asesinato a manos de un islamista de Van Gogh, cineasta holandés que hizo un film escribiendo textos del Corán en cuerpos desnudos, han golpeado fuertemente el mito fundacional de tolerancia de la nación holandesa. Los holandeses eligieron por amplia mayoría a un líder neo-fascista cuya retórica racista estaba enfocada hacia los migrantes y grupos de blancos holandeses salieron en masa a quemar mezquitas y atacar musulmanes de origen marroquí y turco. Esto hizo añicos el mito de tolerancia holandesa. Las minorías holandesas viven una época de incertidumbre e inseguridad ciudadana. Los actos racistas de violencia han continuado durante estos años. Esto ha afectado a los migrantes caribeños de varias maneras. Primero, que hay un gran número de musulmanes que son de origen surinamés. Segundo, y más importante, es la creciente intolerancia y discriminación de los holandeses hacia todo lo que ellos consideran extranjero ("allochtone") frente a los holandeses autóctonos ("autochtone"). En la categoría de "allochtone" entran todos los que no cumplen con el estereotipo de lo que es un "holandés" el cual es identificado cultural y fenotípicamente como un blanco de clase media. Antillanos y surinameses que son legítimos ciudadanos holandeses son clasificados por las estadísticas holandesas de población y la política pública como "allochtone". Estas clasificaciones forman parte del racismo cultural a la holandesa. Si bien no existe un discurso racista biológico dominante, el debate holandés sobre los "otros" pasa por la afirmación de que se trata de culturas inferiores y atrasadas. A continuación un diálogo en la televisión holandesa con Pim Fortuyn'

PHILIP WILLIAMS: This is not the story I'd come to Holland for, but here he was, dying in a radio station carpark. Pim Fortuyn, admired and hated, a man who provoked reaction, now a victim of extremes. Just last Friday, I went to his powerbase in Rotterdam to interview a man who, prophetically, was well aware of the dangers his views might provoke.

PIM FORTUYN: It is dangerous for me, without security, in the big cities to walk on the street. That's dangerous for anybody who is a little bit famous in this country.

PHILIP WILLIAMS: Until today, the worst he'd suffered was a urine-soaked cake. His fame came seemingly from nowhere - with no political experience, he led a party that demolished the establishment in the Rotterdam city elections in March. Pim Fortuyn's message was as simple as it was for many offensive - there are too many immigrants. They're responsible for the crime. Close the borders, Holland is full. Although even Fortuyn's party clearly thought Australia's treatment of illegal immigrants was daringly radical.

PHILIP WILLIAMS: We lock up unwanted arrivals, illegal asylum seekers. Is that what you would propose for here?

PARTY SPOKESMAN: To the left of Australia. (ALL LAUGH.) We'll think about it. Nice suggestion.

PHILIP WILLIAMS: But they needed no help when it came to ideas about Islam. According to

1 Australian Broadcasting Corporation. 
Pim Fortuyn, it's a medieval, backward religion.

PIM FORTUYN: Yes, it is a backward culture. I have written a complete book about it and you can read it also in English by Mr Huntington. You don't say to Mr Huntington he is a racist.

PhILIP WiLLIAMS: For the 600,000 Dutch Muslims, Fortuyn's attacks were deeply offensive.

IBRAHIM SPALbURG, MUSLIM LEADER, ROTTERDAM: We were very angry and we are very upset, and also we did something - we didn't just accept it. We went to the court.

PHILIP WILLIAMS: Do you understand, though, how many people here, many Muslims, many foreigners, feel outraged by that, feel scared, frightened, and really see you as a very dangerous man?

PIM FORTUYN: Perhaps you have heard what they are saying about us and about our culture? Study. You know.

PHILIP WILLIAMS: I'm talking about the people who live here in Holland.

PIM FORTUYN: You know what they tell about our culture, about modernity.

PHILIP WILLIAMS: I'm talking about people who walk around with Dutch passports, on the streets, people with Dutch passports, they are Dutch, they're Muslim and they are afraid of you.

PIM FORTUYN: Some of them, that are also Muslims in the city who are not afraid of me, but who are a fan of me, who have voted in the local elections to me. What's the problem?

ARIE VAN VEEN, BuTCHER: He use normally words we can - every man can understand them. But most Fortuyn fans were ordinary Dutch men and women like this Rotterdam butcher. At last, someone was saying what people like him thought - too many immigrants causing too much crime.

Aquí se ve claramente la inferiorización racial de la poblaciones no-blancas vía su “criminalización” en el espacio público y la movilización de estereotipos culturalistas de corte racista. El lenguaje usado sirve de código para referirse a las poblaciones negras y musulmanas sin ser acusados de racistas. De ahí que el racismo culturalista anda siempre entretejido con el racismo biológico. A los ojos de los holandeses blancos, el racismo culturalista sirve para camuflar el racismo biológico todavía rampante en Holanda. El negacionismo de los holandeses con respecto a las jerarquías etno-raciales y el racismo de la época colonial reproduciéndose al interior de la metrópolis, es indicativo de cuan lejos están de una solución a los conflictos etno-raciales.

\section{Gran Bretaña}

En Gran Bretaña la noción de imperio, esto es, de britanidad, define la "comunidad imaginada" de la "nación”. Ser británico es equivalente a ser blanco inglés. De acuerdo a esta definición, cualquier alusión a "negro británico" representa un oxímoron. Como dice Paul Gilroy para el caso británico: 
Nationalism and racism becomes so closely identified that to speak of the nation is to speak automatically in racially exclusive terms. Blackness and Englishness are constructed as incompatible, mutually exclusive identities. To speak of the British or English is to speak of White people (1993: 27-28)

Las migraciones del sur de Asia y del Caribe hacia Inglaterra provocaron una crisis en la “comunidad imaginada” británica. Al igual que en Holanda y los Estados Unidos, las migraciones coloniales caribeñas jugaron un rol significativo en cuestionar la identidad nacional británica. El reclamo de los negros británicos de pertenecer a la "comunidad imaginada" era muy radical para la construcción racista de la nación británica. Los trabajadores blancos de Polonia e Irlanda eran aceptados, pero un flujo masivo de migrantes negros, aún con ciudadanía británica, era algo que los blancos británicos de todos los estratos sociales no estaban dispuestos a tolerar.

Para el gobierno esto creaba una situación contradictoria entre el rechazo racista de los británicos a la migración masiva de trabajadores negros coloniales que respondía a las necesidades del mercado laboral metropolitano y el intento de los gobiernos laboristas de la posguerra de construir una nueva asociación imperial entre la Gran Bretaña y los gobiernos de las colonias (Dean, 1987). Muchos sujetos de las colonias eran enviados a la metrópolis como estudiantes de manera que cuando volvieran a sus países de origen llevaran las ideas y los valores imperiales británicos favoreciendo a occidente en su lucha contra el comunismo. Las experiencias negativas del racismo y la hostilidad de los blancos británicos hacia la presencia de negros entraba en conflicto con esta estrategia educativa de la guerra fría, afectando los intentos británicos de reconstituir su imperio colonial por medio del "British Commonwealth". Sin embargo, los gobiernos británicos secretamente intentaron detener los flujos migratorios de las colonias (Harris, 1993; Carter, Harris y Joshi 1987; Layton-Henry 1992; Rich 1986). Hubo algunas razones por las cuales los esfuerzos eran escondidos del público. Primero, imponer controles migratorios contra sujetos coloniales crearía una crítica negativa internacional que afectaría las relaciones de Gran Bretaña con los gobiernos coloniales del "British Commonwealth" y por consecuencia afectaría su imagen simbólica internacional. Después del Acta de Nacionalidad Británica de 1948, la ciudadanía fue extendida a todos los sujetos coloniales del imperio británico. Era una vergüenza internacional prohibir la entrada de negros ciudadanos británicos mientras se aceptaban trabajadores europeos blancos sin ciudadanía británica. Segundo, aún más vergonzoso y controversial era la asociación entre controles migratorios contra trabajadores negros y el racismo, sobretodo inmediatamente después de una guerra contra el genocidio racial del régimen hitleriano (Layton-Henry 1992: 71). Estas contradicción evitó que el gobierno británico tomara medidas antimigratorias mucho antes de cuando lo hicieron. Este contexto permitió la migración masiva del Caribe británico y del sur de Asia hacia Inglaterra durante los cincuenta y comienzo de los sesenta, especialmente después que el congreso norteamericano pasara una ley en 1952 limitando la migración caribeña.

A mediados de los cincuenta, hubo intentos de controles migratorios por parte del gobierno conservador. Cyril Osborne intentó introducir una enmienda para controlar la migración de los sujetos coloniales. La misma fue rechazada por la vergüenza internacional que ocasionaba en vista de 
la celebración del 300 aniversario de dominación británica en Jamaica y la visita de la reina (Carter, Harris y Joshi, 1987: 343). La medida fue presentada nuevamente como un borrador en el gabinete por el Secretario de Gobierno en Octubre de 1955. Las mismas objeciones a la enmienda Osborne fueron nuevamente levantadas. Pero además, nuevas objeciones fueron propuestas en la reunión del gabinete del 3 de noviembre de 1955. Primero, ellos se dieron cuenta que no había consenso en la opinión pública contra esta enmienda racista. Segundo, las migraciones de las colonias fueron reconocidas como un medio de incrementar los recursos laborales de Gran Bretaña (Ibid: 344). Por primera vez hubo argumentos en reuniones de gabinete acerca de los beneficios económicos que los migrantes brindaban. Tercero, se reconoció que la migración podía ser detenida creando trabajos en las colonias. La ventaja de esta alternativa era que no iba a afectar al capital británico y la reconstrucción del imperio en los territorios coloniales. Por consecuencia, el gabinete británico decidió no aprobar la enmienda.

Desde la extensión de los derechos ciudadanos británicos a los sujetos de las colonias con la Acta de Nacionalidad de 1948, hubo voces disidentes contra la presencia de migrantes coloniales. En muchos círculos de poder, incluyendo los laboristas británicos, hubo un cuestionamiento a esta legislación basándose en una construcción racializada de la identidad británica. Esta última incluía y excluía grupos a base del color de la piel. Pertenecer a la identidad nacional británica era sinónimo de ser blanco, mientras que los migrantes ciudadanos británicos eran identificados como negros. Estas identidades racializadas continuaron durante la década del cincuenta.

Los motines anti-negros en los barrios de Nottingham y Notting Hill en Londres fueron el punto culminante que transformó la opinión pública británica en favor de controles migratorios hacia los migrantes negros. Desde ese momento era cuestión de tiempo para que los controles fueran aprobados. El primero de julio de 1962, el gobierno aprobó una enmienda para controlar la migración prohibiendo el flujo continuo de migrantes de los territorios coloniales hacia la "Madre Patria”. La Gran Bretaña fue la única metrópolis en imponer controles estatales sobre migrantes coloniales caribeños. Aunque la migración de las colonias se redujo significativamente después de esta prohibición, la existencia de una minoría negra británica era ya un proceso irreversible.

El éxito y la influencia de las luchas por los derechos civiles de los afro-americanos a comienzos de la década del sesenta, estimuló las luchas de los negros británicos. El Race Relations Bill de 1968 fue un logro importante del movimiento anti-racista en Inglaterra. Sin embargo, esta enmienda fue un punto culminante en el cambio de discursos racistas biológicos hacia discursos racistas culturales. El "nuevo racismo" fue articulado por el líder conservador británico Enoch Powell a fines de los sesenta. Éste era un racismo donde la palabra "raza" no era mencionada y donde el racismo biológico era abiertamente criticado. A la acusación de ser racista, Powell respondía:

If, by a racialist, you mean be conscious of differences between men and nations, some of which coincide with difference of race, then we're all racialist....But if, by a racialist, you mean a man who despises a human being because he belongs to another race, or a man who believes that one race is inherently superior to another in civilization or capability of civilization, then the answer is emphatically no... I do not talk about black and white. I would 
very much doubt if you can find a passage, you might find one, where I have used the term black and white. I certainly have never talked about differences in quality. Never. Never. Never" (citado en Smithies y Fiddick 1969: 119, 122).

El nuevo racismo fue articulado en términos de la alta propensión de los negros hacia el crimen, la inasimilabilidad de los negros hacia la cultura británica, y las diferencias culturales irreconciliables. Estas diferencias culturales eran entendidas como fijas, naturales, y esenciales, o como Paul Gilroy ha señalado, como un "absolutismo étnico". El nuevo racismo está entretejido con una definición sectaria de la "nación". Como dijo Powell en respuesta a aquellos que le criticaban sus concepciones racistas: "It is even a heresy to say that the English are a white nation" (citado en Stacey 1970: 200). Por tanto, una de las consecuencias fue detener la entrada de "negros" al país y, si fuera posible, repatriarlos a todos. Como señalaba Powell: "Suspension of immigration and encouragement of reemigration hang together, logically and humanly, as two aspects of the same approach" (citado en Slithies y Fiddick 1969: 38).

Parte de la retórica del nuevo racismo es transmutar argumentos racistas en una retórica acerca del crecimiento poblacional como el factor principal que justifica las políticas restrictivas contra los migrantes negros. Powell articulaba su justificación para detener los migrantes negros de la siguiente manera:

I would have thought that a glance at the world would show how easily tensions leading to violence arise where there is a majority and a minority... with sharp differences, recognizable differences, and mutual fears.... when the members of the minority are small, then this danger hardly exists. It is as the numbers of the minority (which in some areas is the majority) rise, that the danger grows. Consequently the whole of this issue to me... is one of numbers (citado en Stacey 1970: 56).

El nuevo racismo articulado por Powell fue posteriormente desarrollado por Margaret Thatcher. La asociación entre crimen y negritud fue políticamente movilizada durante la administración Thatcher para desmantelar el estado de bienestar (Hall et. Al. 1978). Los negros en Inglaterra hoy experimentan una marginalización en el mercado de trabajo similar a los caribeños en Holanda y los puertorriqueños en Nueva York. La administración de Thatcher fue nefasta para los caribeños y los migrantes en Inglaterra. La eliminación del estado de bienestar y las políticas neoliberales quitaron el colchón que amortiguaba la discriminación en el mercado de trabajo y en el mercado de vivienda. La administración laborista de Tony Blair no ha significado un cambio significativo de dichas políticas. Por el contrario, Blair ha seguido en los noventa las políticas thatcheristas neoliberales de las décadas del setenta y el ochenta. Por tanto, la situación no sólo no ha cambiado sino que ha empeorado para las minorías caribeñas en Inglaterra. Sin embargo, no ha habido crecimiento significativo demográfico de las poblaciones caribeñas en Inglaterra. Recientemente hubo un aumento de caribeños con el volcán de Montserrat donde alrededor de 8000 refugiados fueron trasladados a Gran Bretaña. Pero estos números no han sido lo suficiente para conllevar un aumento demográfico de importancia. Hoy día gran parte de las migraciones del Caribe 
británico se dirigen hacia los Estados Unidos. Aquellos que quedaron en Gran Bretaña son hoy día una minoría racializada todavía en busca de igualdad.

Los acontecimientos de julio de 2005 en Londres donde islamistas británicos atacaron el sistema de transporte, ha puesto sobre la agenda de Gran Bretaña el asunto de la exclusión producida por el racismo de las poblaciones ciudadanas minoritarias. El hecho de que el acto terrorista haya sido realizado por jóvenes británicos de origen pakistaní y jamaiquino, dramatiza el fracaso del sistema multicultural británico. Hay muchísimos jóvenes caribeños convirtiéndose al islam como alternativa espiritual ante el racismo cotidiano. Esto último de en sí mismo no constituye nada negativo, el asunto es cómo esta búsqueda en tradiciones espirituales no-occidentales está fuertemente ligada a la discriminación e insatisfacciones sufridas por estos jóvenes en Gran Bretaña. Ante la exclusión en el mercado laboral, el islam se presenta como una alternativa y como modo de vida. Hay que enfatizar siempre, para evitar estereotipos e injusticias, que los terroristas islámicos son minorías dentro de los musulmanes británicos. La situación difícil que viven los caribeños británicos hoy día ha quedado invisibilizada ante la emergencia del islamismo militante dentro de Gran Bretaña.

\section{CONCLUSIÓN}

Podemos observar de la discusión anterior cómo el racismo funciona en dos direcciones: para justificar la reproducción de una mano de obra barata y para excluir poblaciones del mercado de trabajo. Históricamente, los caribeños fueron incorporados en el mercado de trabajo metropolitano durante una expansión sistémica del capitalismo durante la posguerra, pero sin recibir los mismos ingresos, empleos o status que las poblaciones dominantes europeas o euro-americanas. Pero en tiempos de crisis, los caribeños son marginalizados del mercado de trabajo. En ambos casos, un discurso racista cultural ha sido movilizado para justificar su incorporación como mano de obra barata o su marginalizacion del mercado de trabajo a base de un discurso sobre los comportamientos, hábitos, actitudes o valores culturales inadecuados a la comunidad imaginada dominante.

Las fronteras de exclusión del la nueva "formación racial/colonial global” de la posguerra se construye bajo premisas racistas culturales en sustitución de los viejos discursos racistas biológicos. A través de la esencialización y naturalización de la cultura, los discursos racistas culturales comparten las premisas de los discursos racistas biológicos. La construcción cultural de la "nación” es una frontera central de exclusión racial que es movilizada hoy día por las poblaciones metropolitanas contra los migrantes coloniales caribeños. La colonialidad de las relaciones sociales de poder muestran cómo las viejas jerarquías están todavía presentes en las metrópolis.

Las migraciones coloniales del Caribe representan un buen ejemplo de cómo los bordes de exclusión articulados por los discursos racistas culturales son un fenómeno global que no es exclusivo de un sólo país metropolitano. La "identidad nacional” está entretejida con premisas racistas en las cuatro metrópolis discutidas en este trabajo. Aquellos que pertenecen son imaginados como compartiendo los valores y comportamientos de las clases medias blancas de las respectivas metrópolis. La incorporación de los migrantes coloniales del Caribe a las metrópolis ha sido una 
experiencia traumática no solo para éstos como víctimas del racismo sino también para las poblaciones blancas metropolitanas. El ser simultáneamente ciudadanos metropolitanos y sujetos coloniales cuestionó las representaciones dominantes de la nación como equivalentes a ser "blancos". Sin embargo, estas mismas fronteras de exclusión creadas por los discursos racistas culturales no son movilizadas exclusivamente contra los migrantes coloniales caribeños. Estos mismos discursos son movilizados hoy día contra los mejicanos en los Estados Unidos, los turcos en Alemania, los marrroquís en Holanda, los argelinos en Francia, los paquistaníes en Inglaterra y los dominicanos en España. Se trata de una ideología global basada en un imaginario colonial que se acentúa cada día en la medida en que la colonialidad global capitalista no sea resuelta de una vez por todas. 


\section{BIBLIOGRAFÍA}

ABOU, Antoine (1988). L'ècole dans la Guadaloupe Coloniale. Paris: Editions Caribéennes.

ANDERSON, Benedict (1983). Imagined Communities. London:Verso.

APPADURAI, Arjun (1996). Modernity at Large. Minnesota: University of Minnesota Press.

BALIBAR, Étienne (1991). “Is there a Neo-Racism?” (E. Balibar and I. Wallerstein, eds), Race, Nation, Class: Ambiguous Identities. London: Verso: 17-28.

BALIBAR, Étienne (1992). Les Frontières de la démocratie. Paris: Editions La Découverte.

BALIBAR, Étienne (1994). Masses, Classes, Ideas. New York and London: Routledge.

Balibar, Étienne y Wallerstein, Immanuel (1991). Race, Nation, Class: Ambiguous Identities. London: Verso.

BARKER, Martin (1981). The New Racism. London: Junction Books.

BiERVLIET, Win (1981). "Surinamers in The Netherlands" (S. Craig, ed), Contemporary Caribbean: A Sociological Reader. Trinidad: The College Press,: 75-99.

BLÈrALD, Alain-Phillipe (1988). La Question nationale en Guadaloupe et en Martinique. Paris: L'Harmattan.

BonacICH, Edna. “A Theory of Middleman Minorities". American Sociological Review XXXVIII, 4 (1973): 583-594.

BOVENKERK, Frank (1975). Emigratie uit Suriname. Universiteit van Amsterdam: Afdeling Culturele Antropologie, Antropologisch-Sociologisch Centrum.

BovenKerk, Frank (1978). Omdat zij anders zïn. Patronen van rasdicriminatie in Nederland. Meppel: Boom.

Bovenkerk, Frank y Breuning-VAN LEEUWEN, Elsberth (1978). "Rasdiscriminatie en rasvooroordeel op Amsterdamse arbeidsmarkt”. (F. Boverkerk; ed.) Omdat zï anders zïn. Patronen van rasdiscriminatie Nederland. Meppel: Boom, 17-35.

BruebaKer, Rogers (1992) Citizenship and Nationhood in France and Germany. Cambridge: Harvard University Press.

CARTER, Bob; HaRris, Clive; and JoShi, Shirley. “The 1951-55 Conservative Government and the Racilization of Black Immigration”. Immigration and Minorities, VI, 3 (1987): 335-47.

DEAN, D.W.. "Coping with Colonial Immigration, the Cold War and Colonial Policy: The Labour Government and Black Communities in Great Britain, 1945-51”. Immigration and Minorities, VI, 3 (1987): 305-34.

EsSED, Philomena (1996). Diversity: Gender, Color and Culture. Amherst: University of Massachussetts Press.

GaLAP, Jean (1993). "Phenotypes et Discrimination de Noirs en France: question de méthod”. Migration-Formation 94 (1993): 39-54

Gilroy, Paul (1987) “There Ain't No Black in the Union Jack': The Cultural Politics of Race and Nation”. Chicago: Chicago University Press. 
GILROY, Paul (1993). Small Acts. London: Serpent's Tail.

GIRAUD, Michel (1992). L'ècole aux Antilles. Paris: Karthala.

GIRAUD, Michael y MARIE, Claude-Valentin. "Identité culturelle de 1'immigration antillaise". Hommes et Migrations. 1114 (1988): 90-106.

Glazer, Nathan and Moyniham, Daniel P. (1963) Beyond the Melting Pot. Cambridge: The MIT Press.

GORDON, Milton M. (1964). Assimilation in American Life. Nez York: Oxford University Press.

GrasmucK, Sherri y Grosfoguel, Ramon. "Geopolitics, Economic Niches, and Gendered Social Capital Among Recent Caribbean Immigrants in New York City”. Sociological Perspectives, XI, 2 (1997): 339-63.

Grosfoguel, Ramón. "Colonial Caribbean Migrations to France, The Netherlands, Great Britain and the United States”. Ethnic and Racial Studies, XX, 3 (1997): 594-612.

HALL, Stuart (1980). "Race, Articulation and Societies Structured in Dominance" (UNESCO, ed.), Sociological Theories: Race and Colonialism. Paris: UNESCO: 305-45.

HaLL, Stuart, et. al. (1978). Policing the Crisis: Managing, the State, and Law and Order. London: MacMillan.

Harris, Clive (1993). "Post-War Migration and the Industrial Reserve Army" (W. James and C. Harris, eds). Inside Babylon: The Caribbean Diaspora in Britain. London: Verso: 7-54.

HÉLÉNON, Veronique (1997). Les administrateurs coloniaux originaires de Guadaloupe, Martinique et Guyane dans les colonies françaises d'Afrique, 1880-1939. Tesis doctoral inédita. Ecole des Haute d'Etudes en Sciences Sociales.

HobsbaWn, Eric J. (1990). Nations and Nationalism since 1780. Cambridge: Cambridge University Press.

LAYTON-HENRY, Zig (1990). The Politics of Immigration. Oxford: Blackwell.

LEWIS, Oscar (1966). La Vida: A Puerto Rican Family in the Culture of Poverty-New York and San Juan. New York: Random House.

LiJPHART, Arend (1968). The Politics of Accomodation: Pluralism and Democracy in The Netherlands. Berkeley: University of California Press.

LuTZ, Helma (1993). "Migrant Women, Racism and the Dutch Labour Market". (J. Wrench and J. Solomos, eds). Racism and Migration in Western Europe. Oxford: Berg:139-42.

MARIE, Claude-Valentin (1991). “L'Europe: de l'empire aux colonies intérieures”. (P. A. Taguieff, ed) Face au racisme. Tome 2: Analyses, hypotèses, perspectives. Paris: La Déecouverte: 296-310.

MARIE, Claude-Valentin (1993). "Par des fréquents transbords". Migrants-Formation 94 (1993): $39-54$

Marshall, Thomas H. (1964) Class, Citizenship and Social Development. Garden City, NY: Doubleday. 
Marshall, D; Bruce (1973). The French Colonial Myth and the Constitution Making in the Fourth Republic. New Haven: Yale University Press.

MidDENDORP, C.P. (1991). Ideology in Dutch Politics. The Netherlands: Van Gorcum.

MILES, Robert (1989). Racism. New York: Routledge.

QuiJano, Aníbal. "Colonialidad y modernidad/racionalidad”. Perú Indígena, XXXIX (1991): 11-21.

Quijano, Aníbal (1993). “Raza', 'etnia', y 'nación’ en Mariategui: cuestiones Abiertas”, (R. Forgues, ed.). José Carlos Mariategui y Europa: El otro aspecto del descubrimiento. Lima, Peru: Empresa Editora Amauta, S.A.:167-87.

RATH, John (1991). Minorisering: de sociale constructie van 'ethnische minderheden'. Amsterdam: SUA.

RATH, John (1993) "The Ideological Representation of Migrant Workers in Europe: A Matter of Racialization?" (J. Wrench and J. Solomos, eds) Racism and Migration in Western Europe. Oxford: Berg: 215-32.

Rich, Paul B. (1986). Race and Empire in British Politics. Cambridge: Cambridge University Press.

SMITHIES, Bill y FIDDICK, Peter (1969). Enoch Powell on Immigration. London: Sphere Books.

STACEY, Tom (1970). Immigration and Enoch Powell. Great Britain: The Chaucer Press.

TAGUIEFF, Pierre-André (1987). La force du prejugé. Paris: Editions La Découverte.

ThOMPSON, Lanny (1995). Nuestra isla y su gente: La construcción del otro en Our Islands and Their People. Puerto Rico: Centro de Investigaciones Históricas and Departamento de Historia, Universidad de Puerto Rico.

VÁzquez, Blanca. "Puerto Ricans and the Media: A Personal Statement". Centro, III, 1 (1991): $5-15$.

VerkuYTEn, Maykel. "Cultural Discourses in The Netherlands: Talking about Ethnic Minorities in the Inner City". Identitites, IV, I (1997): 99-132.

Wallerstein, Immanuel (1979). The Capitalist World-Economy. Cambridge: Cambridge University Press.

Wallerstein, Immanuel (1984). The Politics of the World-Economy. Cambridge: Cambridge University of Press.

Wallerstein, Immanuel (1991). Geopolitics and Geoculture. Cambridge: Cambridge University Press. 


\section{EL MASHREQ FRANCÉS EN MÉXICO. PATRONAZGO, PROPIEDAD Y LA LECTURA DE LOS CUERPOS EN LA POSCOLONIA}

The French Mashreq in Mexico. Patronage, Property and Body readings in Postcolony

\section{Camila PaStor de María y Campos}

CENTRO DE INVESTIGACIÓN Y DOCENCIA ECONÓMICAS, MÉXICO camila.pastor@cide.edu

Recibió su doctorado en antropología de la UCLA (Universidad de California, Los Ángeles). Su trabajo de investigación se encuentra en la intersección de varias disciplinas y debates contemporáneos: los procesos transnacionales, la mediación, la representación y la jerarquía en contextos postcoloniales. Su actual proyecto de libro recurre a la antropología histórica para explorar las trayectorias de migrantes que han circulado entre el Medio Oriente y Mexico y Centroamérica desde finales del siglo diecinueve. Ha impartido cursos de licenciatura y de posgrado en la UCLA, el CIDE y el Colegio de Mexico y el Instituto Mora.

RECIBIDO: 16 DE ENERO DE 2017

RESUMEN: Este texto explora la ambivalencia en la producción estructural y discursiva de las posiciones de clase de migrantes que han circulado entre Líbano, Siria y México a lo largo del siglo veinte. Su argumento central es que la inscripción de su subalternidad como sujetos del mandato francés sobre el Mashreq, durante la primera mitad del siglo veinte, ha sido constitutiva de su acceso a una posición privilegiada en el contexto mexicano.

Palabras Clave: Mashreq, México, Francia, subalternidad, patronazgo.
ACEPTADO: 15 DE MAYO DE 2017

ABSTRACT: This paper explores the ambivalence in the structural and discursive production of the class positions of migrants that have circulated between Lebanon, Syria and Mexico throughout the twentieth century. Its central argument is that the inscription of their subalternity as subjects of the French mandate on the Mashreq during the first half of the twentieth century has constituted their access to a privileged position in the Mexican context.

Key Words: Mashreq, México, France, Subalternity, Patronage. 
La globalidad, como fenómeno postcolonial, implica encuentros entre regiones con distintas historias coloniales y poscoloniales además de procesos transnacionales estructurados por las prácticas simultáneas de múltiples imperios en interacción. Este texto explora la ambivalencia en la producción estructural y discursiva de las posiciones de clase de migrantes que han circulado entre Líbano, Siria y México a lo largo del siglo veinte. Mi argumento central es que la inscripción de su subalternidad como sujetos del mandato francés sobre el Mashreq, durante la primera mitad del siglo veinte, ha sido constitutiva de su acceso a una posición privilegiada en el contexto mexicano. La relación de 'la colonia' Sirio-Libanesa con las autoridades francesas fue clave en el proceso de anclar la trayectoria colectiva en un presente 'francés', en el imaginario popular. Las prácticas de patronazgo imperial de Francia se enlazaron con las complejas dinámicas de una sociedad profundamente estructurada por una conquista violenta, tres siglos de administración colonial española, medio siglo de guerras de independencia y de reforma, la época dorada del Porfiriato francófilo, la Revolución mexicana, el nuevo contrato social y autoridades posrevolucionarias.

Un sector prospero de la población migrante hizo grandes esfuerzos por cultivar lazos políticos y afectivos con la administración francesa, especialmente en las décadas de los treinta y los cuarenta, suplicando en numerosas ocasiones que se les concediera el 'mismo estatus que a Argelia', es decirdeseaban que Líbano fuera no solamente un mandato, sino una colonia de Francia. ¿Cómo interpretar sus repetidas solicitudes, de esa invitación reiterada a que se les colonizara? Como potencia colonial global, el gobierno de Francia ejercía una influencia poderosa ante las autoridades mexicanas posrevolucionarias. Imperando no solo en geografías, sino en estéticas, 'Francia' y 'lo francés' operaban tanto en el contexto colonial Libanés, como en el contexto poscolonial mexicano, como marcadores de clase. En México, la francofilia y el eurocentrismo de la elite criolla que permaneció en el poder, aunque al margen del estado, después de la revolución, se enlazaron con la practica (pos)colonial de marcar distinciones de clase a través de un discurso racializador, contribuyendo a la lectura de la población migrante del medio oriente, como 'gente decente'.

\section{HACIA UN ATLÁNTICO MORO}

Para entender a America Latina en los siglos XIX y XX hay que enmarcar sus procesos regionales en una historia moderna temprana, fundacional para la modernidad global, en tanto sienta las circulaciones que conforman una globalidad colonial, como señalan Dussel, Briggs, Mignolo y Castro-Klaren (2010). También es necesario entender a la región como inserta, desde los márgenes, en los procesos decimonónicos que desplazaron a los centros globales hacia una modernidad industrial y sus lógicas. La alternativa que propone este capitulo es interrogar los proyectos coloniales de los siglos XIX y XX, en torno a los cuales gira gran parte de la producción académica postcolonial, en su relevancia global.

Así como Epps indica lo indispensable de triangular con África y Mignolo señala el tránsito que parte de un imaginario que enfrentaba 'occidente' a 'oriente', para deslindar un 'hemisferio occidental' y finalmente un 'Atlántico norte' (Mignolo 2010), aquí se propone atender a circulaciones no contempladas por un imaginario Atlántico, que se circunscribe al binomio de lo 
ibérico y lo indígena. Imaginario gestado en los proyectos independentistas del siglo XIX que enfrentaban a criollos y peninsulares (Anderson 1991, Guerra 1998); los 'sirios' estaban presentes en la tipología de la barbarie del Jesuita José de Acosta en 1588 (Del Valle 2011) y el Gran Turco y 'lo moro' hacían parte de la geografía de la diferencia de un Guamán Poma de Ayala, allá en 1616 (Dussel 2010).

Quisiera también poner en duda que lo Atlántico en los siglos XIX y XX se agota en las tensiones entre lo ibérico y lo anglo. Coincidiendo con el llamado de Epps a mirar hacia el sur y hacia el este y el de Ella Shohat y Robert Stam (2012) a pensar un Atlántico moro, el texto pone sobre el horizonte transatlántico las migraciones del este del mediterráneo hacia las Américas además de un tercer 'foco' hegemónico- la practica imperial francesa- para explorar un proceso de subalternización que resulta en la conformación de sujetos mashrequíes, subalternos de la administración francesa, como una elite en México y Centro America.

El proyecto imperial francés tiene varias intenciones. Una es participar de lleno en la apuesta europea de la repartición territorial del mundo - esa apuesta en la que los europeos son los jugadores y el mundo es el botín (Foucault 2007). En este contexto de reparto decimonónico, las nuevas repúblicas americanas ya no son una zona que pueda desmenuzarse y distribuirse. Bajo el ojo vigilante de Estados Unidos y su incipiente hegemonía hemisférica, operan en otra temporalidad, que no es la del colonialismo (europeo), sino la del intervencionismo (norteamericano). Así, las administraciones francesas se limitaron a 'intervenir' en México, primero para proteger los intereses de sus ciudadanos, en 1838-39 y 1862-1866 y, unas décadas después, a favor de sus protegidos de Medio Oriente, quienes junto con tantas otras personas, ideas y mercancías circulaban, globalmente, a partir del ultimo tercio del s. XIX.

Tales intervenciones generaron la posibilidad de que estos migrantes reclamaran, dada su subordinación a Francia, la condición de élites frente a las poblaciones americanas. En el caso de Siria y Líbano la subalternidad se formalizo en 1919, con la concesión de estas áreas a Francia en calidad de mandato, tras la derrota Otomana durante la primera guerra mundial. Este proceso solo fue posible dadas las intertextualidades, subalternidades e inteligibilidades fundadas en la violencia del encuentro entre el reino Católico de Castilla y León y el mundo americano.

Los migrantes, a su vez, vertían sus energías en 'contar la misma historia' (Rodríguez 2010) que los criollos nacionalistas, en demostrarles que no estaban en guerra con ellos. Es asi que todos cuentan la misma historia, pasada por el tamiz de las narrativas expansionistas de los imperios industriales y sus ciencias raciales. Los notables migrantes no solo se convierten en interlocutores validos para las élites mexicanas postcoloniales, sino en equivalentes sociales y socios potenciales, en la misión colonizadora de modernizar a las naciones de America Latina, en particular a esos elementos que, a diferencia de los criollos y migrantes mediterráneos, han tenido poco contacto con la civilización (léase la Europa cristiana). 


\section{EL MaHJAR MEXICANO}

Los migrantes del Mashreq que viajaron hacia las Américas entre 1920 y 1930 llegaron a México durante un periodo de inestabilidad y caos provocados por la Revolución Mexicana. ${ }^{1}$ Algunos se unieron a los conflictos armados, otros establecieron amistades y complicidades con líderes revolucionarios sobrellevando tanto pérdidas como ganancias económicas. ${ }^{2}$ Este artículo analiza las consecuencias del conflicto y las oportunidades que generó para los migrantes. Se exploran dos prácticas discursivas entretejidas, tal y como emergen en el momento postrevolucionario: la producción de equivalencias raciales y la de estructuras de patronazgo. Sugiero que las tradiciones mashrequíes de patronazgo se entrelazaron con la protección imperial de Francia y la compleja dinámica poscolonial de una sociedad mexicana profundamente estructurada por una conquista violenta (1519-1521); tres siglos de administración colonial Española (1521-1821); medio siglo de guerras de reforma y luchas de liberación en contra de ocupaciones norte americanas (1846-1848) y francesas (1862-1867); el régimen porfiriano francófilo (1876-1910); la Revolución Mexicana (1910-1926) y las autoridades y contratos revolucionarios (1924-2000). Estos fenómenos produjeron una serie de discursos institucionales que describen, legitiman e inscriben diferencias y desigualdades.

La intersección de estas formaciones discursivas, las ambigüedades del estatus que tuvieron los migrantes como ‘sujetos mandatarios' y la diversidad socioeconómica de la migración temprana, les permitieron a los migrantes mashrequíes cultivar varias formas de patronazgo al interior de la población migrante y aun mas allá de la misma. La relación de 'la colonia' mashrequí en México, con las autoridades francesas, jugó un papel estratégico enlazando a la población migrante, a un presente francés, en el imaginario popular.

Como potencia imperial global, el gobierno francés ejercía una poderosa influencia sobre las autoridades mexicanas posrevolucionarias a las cuales trataban como soberanas, pero marginales, en el juego de poder global. Imperando no solo en geopolítica, sino también en estética, 'Francia' y ‘lo francés' eran, tanto en el Mashreq, bajo mandato, como en el México poscolonial, marcadores de clase e índices de prestigio y buen gusto. Por otro lado, a medida que avanzaba la crisis económica y política de la Gran Depresión, los ataques a los migrantes, en su calidad de extranjeros, se hacían cada vez más frecuentes. Tanto en los medios oficiales como en los populares surgieron nuevas retóricas reclamando un proyecto nacional populista y la materialización del contrato social revolucionario excluyendo a los migrantes, incluso acusándolos de constituir nacionalidades y razas ‘indeseables’.

La élite migrante insistía en que el gobierno francés y el mexicano debían reconocer la existencia de distintas clases al interior de la población migrante. Postulando la distancia de clase

\footnotetext{
${ }^{1}$ Mashreq es el término árabe que denota la región abarcada por los actuales estados de Líbano, Siria, Jordania e Israel. Dadas las connotaciones coloniales de otros términos en uso- el Levante, el Oriente Árabe, y el hecho de que los estados naciones actuales no existían como tal antes de 1947-1948, prefiero identificar a esta migración como Mashrequí.

${ }^{2}$ Alonso Palacios (1983), Cherem en Hamui de Halabe (1989), Díaz de Kuri y Macluff (1995), Velcamp $(2001,2007)$ han documentado cuidadosamente las actividades de los migrantes mashrequíes en México durante el periodo revolucionario.
} 
como una diferencia en términos de raza, secta y nacionalidad, argumentaban que, quienes no formaban parte de la élite migrante, no tenían lazo alguno con el Mashreq. Esta élite se presentaba a si misma ante las autoridades como libanesa, cristiana y perteneciente a 'la raza blanca caucásica'. Mi argumento principal es que la inscripción de las élites migrantes como sujetos subalternos del mandato francés sobre el Mashreq, durante la primera mitad del siglo veinte, estructuró de manera fundamental el acceso de esta población a posiciones privilegiadas en México. Este lazo estableció, a mediados de siglo, las condiciones que han permitido la extraordinaria acumulación de recursos lograda por algunas familias mashrequíes a raíz de dos momentos de crisis económica: el de la entre guerra y el de las reformas neoliberales de finales de los años ochenta. ${ }^{3}$

Cultivar un vínculo político y afectivo con las autoridades francesas en México requería de constantes pruebas de lealtad por parte de familias notables que hablaban en representación de 'la colonia'. Esta élite migrante, de sujetos ejemplares, financió iniciativas francesas en otros territorios colonizados, llegando incluso eventualmente a solicitar la dominación colonial directa, rogando que el estatus del Líbano fuera 'el mismo que el de Argelia'. Estas súplicas ocurrieron en un momento decisivo en el proceso de sacarle ventaja a la Revolución; a mediados de los años veinte, cuando se estableció la Comisión Franco Mexicana de Reparaciones. La Comisión negoció el pago de compensaciones por parte del gobierno mexicano a aquellos ciudadanos franceses que habían sufrido pérdidas durante los encuentros armados. La ‘protección’ ambivalente que las autoridades francesas extendieron a los sujetos provenientes de territorios bajo mandato francés, durante este proceso, detonó un amargo debate en torno a los derechos de los protegidos de Francia y los derechos de las autoridades mandatarias, para negociar con gobiernos poscoloniales en su nombre. ${ }^{4}$

El análisis intenta trazar un conjunto de conversaciones: entre gobiernos; entre sujetos mandatarios y autoridades coloniales; entre migrantes y la opinión popular mexicana. Todas ellas contribuyeron a la hibridación de prácticas cotidianas de racialización, derivadas de la legislación novohispana -las cuales aun sostienen una jerarquía racial de riqueza y prestigio en México- con las ideologías raciales propagadas por las nuevas ciencias sociales coloniales y las prácticas imperiales francesas, capitalizadas por la población migrante. El eurocentrismo y la francofilia de una élite criolla conservadora que se mantuvo en el poder, aunque al margen del estado después de la Revolución, se enlazaron con el hábito (pos)colonial de marcar distinciones de clase a través de la racialización. El resultado ha sido una lectura local de los cuerpos mashrequíes como 'españoles', cuando logran establecer que son 'franceses'; alquimia que propone una equivalencia entre la racialización de los migrantes como 'blancos' con su derecho a privilegios (pos)coloniales.

\footnotetext{
${ }^{3}$ Alonso Palacios señala que en el caso de la migración mashrequí a Puebla, el paso del comercio a la industria ocurre a través de la compra de industrias textiles españolas, mexicanas y francesas en quiebra en el periodo de 1925-1940 (Alonso Palacios 1983: 140). La fortuna Slim dio su gran salto con la compra de Teléfonos de México durante el proceso de privatización de finales de los anos ochenta.

${ }^{4}$ Los Comités de Reparaciones eran fuente de tensión entre las autoridades mexicanas y francesas, no solo porque ponían en juego sus respectivas soberanías y la entrega de dineros, sino por el antecedente de la Guerra de los Pasteles- como se llamo a la intervención francesa en México (1862). Esta había sido justificada por los reclamos desatendidos de pasteleros franceses que habían perdido sus enseres en molotes. Agradezco a Rodolfo Pastor haberme señalado este detalle.
} 


\section{GENEALOGÍAS DE LA CATEGORÍA DE ‘RAZA’ EN MÉXICO}

Las primeras relaciones de la Nueva España, narradas por conquistadores y frailes, describen a los pobladores de las Américas, a los 'indios', como ‘moros', equiparándolos con esos 'otros', tan ajenos, pero claramente humanos. ${ }^{5}$ En la medida en que aumentaba la brutalidad de la conquista y las poblaciones mesoamericanas desaparecían, diezmadas por la guerra, las nuevas enfermedades, la explotación y el colapso del orden social, soldados en búsqueda de botín, conquistadores necesitados de mano de obra y hombres de fe a la caza de conversos, comenzaron a debatir la humanidad de 'los naturales de la Nueva España' ${ }^{6}$

Una vez que las autoridades religiosas y administrativas concluyeron que las poblaciones colonizadas en efecto tenían alma, se diseñaron políticas públicas para su 'protección' y para humanizar la explotación de su fuerza de trabajo. Dada la 'escasez' y 'fragilidad' de los indios, se importaron esclavos de África para las tareas agrícolas mas pesadas y para el servicio doméstico. Así, la diversidad de la población novohispana fue enriquecida por la trata de esclavos, principalmente de origen africano, aunque ocasionalmente esta incluía también esclavos y sirvientes provenientes de Asia y el sudeste asiático. ${ }^{7}$

La legislación colonial produjo una intersección de las formaciones raciales y las formaciones de clase del nuevo mundo, proponiéndolas casi como equivalentes. La administración hacía una distinción legal entre indios y españoles. Desde un principio, se concibió a la Nueva España como un reino constituido por dos repúblicas paralelas: las Repúblicas de Indios y las Repúblicas de Españoles. Una vez que comenzó la importación de esclavos africanos en el siglo dieciséis, se reconocían y regulaban tres 'razas' puras: la española, la india y la africana. La teoría legal colonial definía los atributos particulares de cada raza: la posibilidad, o no, de ser dueño de propiedad, o de ser tenido por propiedad; las ocupaciones que podían ejercer legalmente; la localidad de residenciaen Pueblos de Indios o Pueblos de Españoles.

Los discursos novohispanos relativos a la distinción racial reflejan ideologías medievales, propias de la modernidad temprana española en torno a la jerarquía y la nobleza. Como señala Guillaumin (1980: 46), las casas nobles de la Europa medieval usaban la idea de 'raza', junto con los

\footnotetext{
${ }^{5}$ Entre la gran cantidad de crónicas que narran el contacto inicial y el proceso de conquista, muchas hablan de los indios como moros, ver por ejemplo la Segunda Carta de Hernán Cortés y el relato del Conquistador Anónimo. Este último compara, entre otras cosas, las costumbres matrimoniales de unos y otros: 'Toman muchas mujeres, y tantas cuantas pueden mantener, como los Moros, aunque como se ha dicho, una es la principal y señora; los hijos de esta heredan, y los de las otras no’. Conquistador Anónimo. Edición mexicana de 1938: 44. Asimismo el jurista Alonso de Zuazo compara las fiestas matrimoniales y la circuncisión que se practicaban en Tenochtitlan con hábitos moros.

6 Ver, entre muchos otros, Israel (1975). La defensa de los indios la encabezaron hombres de religión, como Fray Bartolomé de Las Casas y Vasco de Quiroga.

${ }^{7}$ Se conocen casos de filipinos. Un caso ampliamente documentado es el de la llamada china poblana, una muchacha originaria de Cochin que llego a México como esclava y eventualmente se transformo en el emblema de la identidad nacional mestiza. Es necesario ser cuidadosos con la terminología colonial, sin embargo; el término chino, por ejemplo, hacia referencia a una categoría etno-racial y ocupacional que no tiene relación con el término contemporáneo que denota una nacionalidad.
} 
nombres de familia y escudos de armas, para marcar sus linajes y la herencia de propiedades señoriales. Estas ideologías se vieron complicadas por el proceso de reconquista y la noción de limpieza de sangre que emergió junto con la problemática de la pureza religiosa, en la España del siglo quince. Fueron incorporadas luego como una dimensión regulatoria en las políticas de la corona en torno a la migración al nuevo mundo, las cuales prohibieron la entrada de moros, judíos y conversos a la Nueva España, en 1543 (Toussaint 1946: 9).

El discurso colonial español en torno a la idea de 'raza' se transformó una vez más con el surgimiento de las 'taxonomías del Hombre' de la Ilustración, que por primera vez sugerían que los grupos humanos eran formaciones naturales. Las taxonomías fueron características del conocimiento ilustrado del siglo dieciocho. Este postulaba un conjunto creciente de leyes que rigen el mundo material, produciendo un vastísimo sistema de clasificaciones que abarcaba tanto los aspectos morfológicos y geográficos de los reinos animal y vegetal como la materia inerte, los sistemas legales, las formas sociales históricas y contemporáneas. La meta de los pensadores ilustrados era imponer un orden inteligible al desorden de un mundo que comenzaba a rebasar tanto a la voluntad real como a la divina providencia.

Según la legislación novohispana, solo indios y españoles tenían derecho a ser dueños de propiedad, lo cual los marcaba como categorías sociales privilegiadas en las que otros ansiaban introducirse. En su descripción de un caso de ‘confusión’ racial presentado ante una corte eclesiástica de la Nueva España en 1789, Carrera señala la importancia de los registros bautismales a finales del siglo dieciocho: "los registros bautismales de padres y abuelos eran necesarios para comprobar la descendencia y ser admitido a universidades, profesiones, algunos gremios y ordenes de nobleza; para evadir el pago de tributo (que era requerido de indios y mulatos) y el encarcelamiento por deuda; y por su puesto, para comprobar derechos como heredero" (2003:4). La discusión de Carrera apunta a la difícil pregunta de que clase de relación existió entre la teoría legal y la práctica novohispana en distintos momentos del periodo colonial.

La historiografía ha propuesto que desde principios del siglo diecisiete, las consecuencias sociales de la categorización etnoracial, más que obedecer a una causalidad sistemática, constituyeron un debate. También señala que Carlos III, quien gobernó el imperio hasta 1788, contravino muchas restricciones anteriores, decretando el acceso universal de sus súbditos a milicias y universidades; que incluso se burlaba del sistema, facilitando la venta de títulos de nobleza y limpieza de sangre (Pastor Fasquelle). Es interesante señalar que no fue sino hasta finales del siglo dieciocho que la corona española prohibió los matrimonios entre la nobleza indígena y española y negros africanos o castas mixtas, por medio de una Real Cédula de 1776. Dicha prohibición puede interpretarse como un índice de la transformación de la problemática racial, hacia una concepción 'científica' de estas 
categorías como grupos hereditarios irreversibles, lo cual produjo una nueva problemática del mestizaje. ${ }^{8}$

NARRAR LA NACIÓN: RUPTURAS Y CONTINUIDADES ENTRE EL ORDEN RACIAL COLONIAL Y POSTCOLONIAL

En la Nueva España también se distinguía entre la población española nacida en la penínsulalos llamados peninsulares, y los españoles que habían nacido en las colonias- los criollos. Los peninsulares monopolizaban los altos cargos de la burocracia virreinal y dominaban en el comercio. Las ventajas que esta preeminencia les concedía subordinaban a la mayoría criolla a esa metrópolis distante, fuente del poder. Fue esta creciente desigualdad, según algunos estudiosos, la que detonó las guerras de independencia, cuyos líderes fueron criollos de la burocracia menor tanto militar como eclesiástica (Anderson, 1991). Otros han propuesto que fueron las reformas borbónicas ilustradas, con sus proyectos de eliminar fueros y privilegios, las que hicieron monarquistas independentistas de los sectores conservadores de la élite criolla.

Las élites criollas estaban divididas en sectores liberales y los conservadores. Ambas facciones eran fundamentalmente eurocéntricas sin embargo, y su imaginación política estaba principalmente estructurada por el proceso francés. Las élites liberales hacían suyo el proyecto liberal de la Ilustración, discutiendo su implementación y radicalización en la Revolución francesa. Las élites conservadoras celebraban la restauración napoleónica. El poder de este último sector se hizo visible en la forma de gobierno que se implementó inmediatamente después del triunfo del movimiento independentista: en 1821, México se declaró Imperio y anexó unilateralmente a Centro America. Una rebelión en 1823 destronó al emperador Iturbide y declaro la República Mexicana. Las guerras de liberación y de reforma que duraron más de medio siglo en México (1810-1868), acarrearon nuevos debates sobre distinción y ciudadanía. En toda America Latina, los peninsulares fueron expulsados por decreto de los territorios liberados y los criollos se convirtieron en líderes de las nuevas naciones. Mientras unos planificaban la república, otros tramaban instalar a la monarquía de Francia en México. La intervención francesa de 1862 inauguró el Segundo Imperio Mexicano, materializando los sueños de los monarquistas en la trágica y efímera aventura mexicana de Maximiliano. Los franceses fueron rechazados por fuerzas republicanas en 1867; Maximiliano, Duque de Habsburgo y Emperador de México fue ejecutado mas tarde ese mismo año, y la república fue establecida de manera definitiva.

Se debatían e implementaban ideas de gobierno liberales, y la reforma legislativa se convirtió en una de las preocupaciones centrales de los gobiernos independientes. Una serie de constituciones fueron propuestas por distintas facciones y luego abandonadas cuando sus rivales llegaban al poder. En una constitución de 1811, Ignacio López Rayón abolió la esclavitud y declaró que "quienes

\footnotetext{
${ }^{8}$ Carrera (2003:14) señala la regulación, pero argumenta que es en respuesta a un problema colonial- el mestizaje. Yo adopto la lógica de Guillaumin para argumentar que el 'mestizaje', que existe como practica desde el momento de contacto, solo es producido como un problema una vez que se introduce la idea de la irreversibilidad hereditaria de la 'raza'.
} 
nacieran después de la feliz independencia de nuestra nación no encontrarán otro obstáculo más que sus defectos personales. No podrá haber oposición alguna que derive de la clase de su linaje" (Lomnitz en Gaonkar 2001: 304) ${ }^{9}$. La extensión de la ciudadanía a las poblaciones no europeas fue ambigua desde un principio sin embargo, y paso por muchas formulaciones. El primer código legal provisional del Imperio Mexicano especifica que "las distintas clases del estado serán preservadas con su respectiva distinción, pero sin prejuicio en el empleo público, que es común a todos los ciudadanos" (Lomnitz en Gaonkar 2001: 305). La nomenclatura de castas fue abolida en 1822, y la delicada diversidad de grupos mezclados opacada por la categoría única de mestizo. Las categorías étnicas desaparecieron de los archivos regionales, reemplazadas por categorías de trabajadores. ${ }^{10}$

Como en otras épocas y lugares, propiedad y ciudadanía estaban íntimamente ligadas. La constitución centralista conservadora de 1836 definió nuevas formas de exclusión- a través del control sobre propiedad, y la 'calidad moral': "Los derechos de ciudadanía se suspendieron para todos aquellos que fueran menores, sirvientes domésticos, criminales y analfabetos; eran perdidos irrevocablemente por todos los traidores y deudores a los cofres públicos. Todos los ciudadanos debían tener un ingreso anual de 100 pesos, y bastante mas si querían ser electos a un cargo publico" (Lomnitz en Gaonkar 2001: 306). No es necesario señalar que estas condiciones reproducían e incluso profundizaban las distinciones coloniales, aunque estas pasaran a ser expresadas por medio del nuevo lenguaje 'racional' de la ciudadanía liberal. Menores y mujeres siguieron excluidos aun por la constitución revolucionaria de 1917; y el voto femenino tuvo que esperar hasta 1957.

A pesar del contraste en ideales e intenciones, las intervenciones liberales tuvieron consecuencias muy similares. Lomnitz indica que "En el periodo republicano temprano, los liberales identificaron las formas corporativas de propiedad como un obstáculo a la ciudadanía. En especial, atacaron la propiedad de las comunidades indígenas y de la Iglesia. Sin embargo, la expropiación de las propiedades corporativas comunales y eclesiásticas en 1856 no resultó en el fin anticipado, que era el de crear una ciudadanía propietaria, sino en una aun mayor concentración de la riqueza de tierras en manos de una oligarquía” (Lomnitz en Gaonkar 2001: 320). Los indios perdieron sus privilegios coloniales sin adquirir los derechos ciudadanos de los propietarios culturalmente europeos.

La ciudadanía tiene varias dimensiones: es una categoría de participación política, de derechos e igualdad ante el estado; y sus definiciones legales e institucionales son constantemente elaboradas en la práctica cotidiana (Lomnitz en Gaonkar 2001: 306). Los cambios tempranos a la letra de la ley en el México independiente no reorganizaron el poder, la propiedad y la influencia de manera más equitativa, aunque cambiaron los términos en los que se narra la nación. Establecieron un campo discursivo en el cual es posible la separación ideológica del periodo 'colonial' y el 'independiente',

\footnotetext{
${ }^{9}$ El énfasis y la traducción son míos.

${ }^{10}$ Ver Von Mentz (1988). Aunque González Navarro encuentra, al analizar documentos oficiales regionales, que a pesar de la abolición de las castas en 1822 se siguieron usando categorías raciales esporádicamente hasta 1945. En Morner. (1970:151).
} 
facilitando su análisis discontinuo por parte de académicos y gobernantes. Las distinciones que perduran entre ciudadanos mexicanos y nacionales mexicanos fueron parcialmente legitimadas por las guerras de reforma, que llevaron a algunos mestizos al poder. Entre ellos a Benito Juárez, uno de los reformadores más radicales, y unas décadas después a Porfirio Díaz, el gran dictador modernizador. A lo largo de los 34 años que este se mantuvo en la presidencia, periodo conocido como el Porfiriato, Díaz devolvió el poder a los sectores conservadores de la elite criolla. Cuando volvieron como burguesía a través de las políticas porfirianas, se entregaron con entusiasmo a una modernidad industrial francesa y sus nuevas ideologías raciales, 'científicas'.

La transformación de nociones anteriores y quizás más complejas de 'raza' en las definiciones modernas y 'científicas' de las razas como grupos humanos 'naturales' coincidió con la expansión imperial de Francia y Gran Bretaña en el siglo diecinueve. ${ }^{11}$ Estos colonialismos militares y su tráfico de personas se conjugaron con las nuevas ciencias sociales y el estudio científico de las razas, de manera que los nuevos saberes contribuyeron a la definición del sujeto colonizado como un 'Otro” en términos civilizatorios, biológicos y morales. ${ }^{12}$ Los científicos raciales del siglo diecinueve redescubrieron la antigua ciencia griega de la fisiognomía, que le permitía al experto deducir las características morales de un sujeto a partir de su morfología. La capacidad atribuida a lo 'natural' de reflejar lo moral adquirió una fuerza particular en un universo conceptual en el que se entendía a lo natural/material como regido por leyes inmanentes. Esta fusión de la lógica ilustrada, la lógica colonial, y la lógica de la antigua Grecia convertía a los sujetos físicamente imperfectos en seres completamente desechables; ya que su desviación de la norma se entendía no como una variante dentro del orden divino, sino como resultado de una imperfección inmanente y transferible a la próxima generación. No es extraño que el surgimiento de los nuevos estudios raciales y fisiognómicos resultara en el desarrollo de la eugenesia; que inspiró campañas estatales de esterilizaciones forzadas entre las 'razas' y las 'clases' indeseables en los Estados Unidos a principios de siglo veinte, y aun mucho después en la India, Guatemala, y otros sitios.

Francófonas y francófilas, las élites porfirianas, cuyos dirigentes a menudo habían estudiado en el extranjero o al menos viajado por Francia, Alemania y Gran Bretaña, tiñeron las cartografías raciales mexicanas con estas nuevas dimensiones, importadas, como todo lo bueno, de Europa. Aunque las ciencias raciales también despuntaban en Estados Unidos, al vecino del norte aun se le percibía como un rival en expansión pero carente de refinamiento, y no precisamente un modelo cultural a emular. ${ }^{13}$ Con la expansión de la hegemonía norteamericana a lo largo del siglo veinteacompañada del auge de las ciencias biológicas y la globalización de su autoridad, la cohesión somática de las ‘razas’ ha sido definida como hereditaria y finalmente, genética (Guillaumin 1980). El

\footnotetext{
${ }^{11}$ La colonización francesa de Argelia comenzó en 1830; el gobierno británico relevo el monopolio de la East India Co. En 1833; ver Guillaumin (1980: 45). También Pierre-Charles (1980), Silverblatt (2000), Young (1995), Jacobson (1998).

12 Como Said ha argumentado al definir el orientalismo. También ver las criticas al interior de la antropología sobre su relación con la expansión colonial, por ejemplo las de Talal Asad.

${ }^{13}$ Sobre el desarrollo de las ciencias raciales en EEUU ver Brodkin (1998) y O’Connor (2006). Sobre las actitudes de las élites porfirianas sobre EEUU, varias entrevistas por la autora.
} 
conocimiento producido en los Estados Unidos- uno de los pocos estados modernos que, junto con la Alemania Nazi y la Sudáfrica del Apartheid, ha hecho del concepto de 'raza' una categoría administrativa- dominó los debates sobre 'raza' hasta finales de los años sesenta.

\section{MEJORAR LA RAZA, LA PREFERENCIA PORFIRIANA}

Las políticas públicas durante el Porfiriato daban preferencia a los extranjeros en general y a aquellos que fueran Católicos en particular, como inversionistas, colonos y portadores del progreso y la civilización (Guerra 1988, 1998). Aunque la percepción de Francia como modelo e ideal por parte de las élites mexicanas data del siglo dieciocho, tuvo consecuencias particulares durante el régimen porfirista. José Yves Limantour, hijo de un comerciante francés, fue Secretario de Finanzas desde 1893 hasta 1911. Estuvo a la cabeza del equipo de tecnócratas que asesoraban a Don Porfirio, conocidos como los Científicos. Cuando el general fue depuesto en 1911, se exilió a Paris, donde le hicieron la corte familias de la élite Mexicana, residentes y de paso, hasta su muerte. ${ }^{14}$

Las políticas porfirianas eran legitimadas a través de un discurso racial y civilizatorio desarrollado por las élites criollas, quienes se consideraban a si mismas, por supuesto, europeas. Estas injertaron al hábito local de la distinción etnoracial, las nociones coloniales británicas y francesas del diecinueve que postulaban el ser 'blanco' como inherente al ser europeo, índice de una superioridad física, intelectual y moral. Se decía entre las buenas familias que a Don Porfirio mismo lo había 'blanqueado' su matrimonio con Carmelita, hija de una familia de la elite tradicional, quien lo sensibilizo a hábitos y preferencias estéticas/materiales europeas. ${ }^{15}$

A finales del siglo diecinueve, los proyectos coloniales europeos hicieron de la blancura una condición para el progreso de las naciones. En México esto no era impensable, dada la formación social heredada de la experiencia colonial, inscrita en las nuevas constituciones independientes. Con el fin de blanquear la nación, se echó a andar un gran proyecto social que involucraba una modernización industrial y social, pero que- dadas las nuevas ideas raciales- solo podría sustentarse con un cambio importante en la composición demográfica del país. Se diseñaron ambiciosas políticas para atraer la inmigración de colonos europeos que se establecieran en áreas escasamente pobladas, con la esperanza de que un influjo importante de razas blancas contribuyera a mejorar la raza, a transformar a la población mexicana en una raza físicamente más resistente y moralmente más industriosa (vide González Navarro en Morner 1970).

La meta del blanqueamiento por medio de la inmigración derivo, en la década de 1880, en incentivos y beneficios a los migrantes. Las Leyes de Colonización y Naturalización de 1883 buscaban atraer colonos agrícolas, facilitando la inmigración y ofreciéndoles libre acceso a la tierra.

\footnotetext{
${ }^{14}$ Entrevista con TCY: 'Mis papás se hicieron novios en Paris. No ves que mi papá estaba estudiando en Leeds o en Liverpool- y mi mamá hizo un viaje con sus tíos. Como Carmelita y Don Porfi estaban en Paris- cuando el exilio, y ahí las buenas familias les hacían la corte y los iban a visitar cuando iban de viaje a Europa. Como mi mamá era prima de Carmelita, llegaron a verlos, y mi papá también estaba de visita- pues ahí se conocieron y se hicieron novios. Tengo la foto, están los dos muy guapos, en el Bois de Boulogne’.

${ }^{15}$ Entrevista con TCY- 'Fíjate que decían de Don Porfirio que Carmelita lo blanqueó’.
} 
Las Leyes de Extranjería y Naturalización de 1886 le permitían a los extranjeros residentes en México durante dos años pedir la nacionalidad. Especificaban también que los migrantes que llegaran a trabajar para el gobierno mexicano serian tratados como ciudadanos mexicanos, y le otorgaban la nacionalidad mexicana a los extranjeros que fueran dueños de propiedad. ${ }^{16}$ González Navarro señala que para 1896, considerando que el proyecto había resultado demasiado caro e ineficiente y había tardando demasiado en llevarse a cabo, se abandonó la estimulación de una inmigración masiva.

Gran cantidad de migrantes llegaron a México durante este periodo, que coincidió, a fin de cuentas, con las más espectaculares migraciones globales en la historia de la humanidad. Los migrantes, sin embargo, se concentraban en los centros urbanos, donde se podía hacer dinero. Me narraron el siguiente caso durante una entrevista: Los abuelos, que habían salido del Líbano, aceptaron un terreno para poder participar en el proyecto porfiriano de colonización. Una vez legalmente establecidos, rápidamente vendieron la tierra y unas cabras que también les habían entregado, y se dirigieron al pueblo comerciante más cercano. Díaz de Kuri y Macluff nos recuerdan que durante el Porfiriato "los extranjeros residentes en el país se dedicaban, en su mayoría, al comercio, y se concentraban en las grandes ciudades, ejerciendo gran influencia en las costumbres y moda locales. Estos inmigrantes procedían en su mayoría de España, los Estados Unidos, Francia e Inglaterra" (1995: 62). Ignacio Mariscal, Ministro de Asuntos Exteriores, reportó que había 1,500 ‘sirios' viviendo en la Ciudad de México en 1906, en su mayoría ilegales (Velcamp 2007: 40). Para 1924, M. Perier del Consulado de Francia en México, calcula que había 30,000 libaneses viviendo en México, "lo que los hace por mucho la colonia extranjera más importante después de la española" (AMAE 408: 11)17.

Había distintos tipos de migrantes, sin embargo, y algunos eran evaluados como más deseables que otros por los burócratas, los medios, y la opinión pública. Las categorías etnoraciales formaban parte de la heredada lógica colonial de estratificación, y los recién llegados eran rápidamente y sistemáticamente clasificados. ${ }^{18}$ Migrantes españoles, franceses, alemanes y británicos dominaban el paisaje empresarial del siglo diecinueve, especialmente los ramos de la minería, la banca y las ventas a mayoreo. Aunque la historia oral sugiere que estos migrantes con frecuencia establecían alianzas matrimoniales con las élites locales, también cultivaban la transmisión de sus lenguas y tradiciones. Esto no es extraño, siendo que mucha de su ventaja en el mercado derivaba del prestigio de poder apropiar y encarnar tales categorías europeas, índices de su linaje o 'raza', y por ende su derecho a la civilización.

En este contexto, el acceso que tenían los migrantes mashrequíes a las costumbres y la lengua de Francia, así como a documentos de identidad emitidos por autoridades francesas y la protección

\footnotetext{
${ }^{16} \mathrm{Si}$ los migrantes que fueran propietarios deseaban conservar su extranjería, necesitaban declararlo ante las autoridades pertinentes (Velcamp 2007).

${ }^{17}$ Mi trabajo de archivo forma parte del trabajo de campo que llevé a cabo para mi tesis doctoral en Beirut en el 2005. Tuve la oportunidad de consultar el microfilm del Archive du Ministère des Affaires Étrangères, correspondiente al tiempo del mandato francés sobre el Líbano que se encuentra en la Universidad de Kaslik, Jounieh, Líbano. De aquí en adelante me refiero a él como AMAE.

${ }^{18}$ Lesser y Munasinghe han discutido el mismo fenómeno en los casos de Brasil y Trinidad respectivamente.
} 
consular de las mismas, representaban enormes ventajas en potencia. El proceso era complicado, implicaba ciertos riesgos. Al cultivar su extranjería, los migrantes se hicieron vulnerables, especialmente después de los cambios constitucionales de 1927 y durante la crisis global de la Gran Depresión, cuando grupos de grandes y pequeños comerciantes se movilizaron para pedir la expulsión de ‘clases' y 'razas' indeseables. La racialización moderna difería fundamentalmente de la práctica colonial tardía en su naturalización de las categorías raciales, las cuales se volvieron así mucho más difíciles de subvertir. La relación de los migrantes con Francia fue siempre un proyecto en construcción, estructurado por la gama de discursos entre las autoridades francesas en torno a la naturaleza y las reglas de su protección, la negociación internacional del estatus de 'mandato', la ambivalencia propia de la colonialidad y el ajuste constante de fronteras nacionales-civilizatorias.

\section{PROSPERIDAD Y REVOLUCIÓN, 1910-1924}

La Revolución Mexicana que derrocó al porfiriato en 1911 implicó inestabilidad y destrucciones. Como otras guerras, también produjo oportunidades inesperadas, y algunos migrantes mashrequíes prosperaron. Alfaro Velcamp sugiere que en la región Lagunera en el norte de México la 'ciudadanía' francesa y el acceso a redes personales que se extendían a ambos lados de la frontera con Estados Unidos representaban ventajas para los migrantes mashrequíes, especialmente en operaciones de contrabando y mercado negro. Esta hipótesis es problemática dado que los migrantes nunca fueron ciudadanos de Francia; y que no solo los migrantes sino la población fronteriza en general tenían una historia y redes sociales que la frontera aun no ha logrado domesticar.

Un reporte escrito en 1924 por M. Perier, Ministro de Francia en México, describe el crecimiento de los establecimientos comerciales mashrequíes en Yucatán, la Ciudad de México, y otras regiones del país durante y después de la Revolución:

Desde hace unos quince años, sus empresas han prosperado de manera sorprendente. De Yucatán, sobre todo las ciudades de Mérida y Progreso, donde fundaron sus primeros establecimientos, y donde el aislamiento de la región los protegía de la competencia, en la última quincena de años aproximadamente han extendido sus redes sobre todo el territorio mexicano. Su lucha desleal contra el comercio francés, favorecida, además, por la guerra, ha dado fruto: poco a poco las casas francesas son expulsadas de las ciudades del interior, han sido y siguen siendo reemplazadas por casas sirias o libanesas. Hasta en la ciudad de México, donde nuestros compatriotas durante tanto tiempo desafiaron exitosamente estos avances, nuestros protegidos comienzan a volverse amenazantes: todo un barrio en el centro de la ciudad, el barrio de La Merced, esta compuesto enteramente de tiendas de textiles que pertenecen a los turcos, como aun les llaman aquí (AMAE 408: 11-12).

El texto confirma la creciente influencia mashrequí en todo México, pero no menciona ningún mecanismo que la explique- aunque el eufemismo de la 'batalla desleal' podría referirse a la practica de ajustar precios y el contrabando que menciona Velcamp. Otras quejas mencionan como otra fuente 'injusta' de su riqueza su costumbre de utilizar una fuerza de trabajo familiar que no exigía remuneración. 
Bella Cherem ha propuesto que los mashrequíes pudieron aprovechar el caos y lograr una movilidad social importante porque se quedaron en México durante el periodo revolucionario, cuando otras comunidades de comerciantes extranjeros se dieron a la fuga. Los migrantes del Mashreq ocuparon los nichos comerciales que habían quedado vacíos al marcharse los migrantes europeos adinerados, y pasaron de mendigos a príncipes. El problema con este argumento es que supone que todos los migrantes mashrequíes eran pobres al llegar a México. Es cierto que muchos, quizás la mayoría de ellos fueron en un primer momento marginales (Ver Dabbah de Lifschitz en Hamui 1989: 123). Sus lugares de residencia y sus narrativas indican su falta de acceso a los hábitos y espacios de las élites. El desplazamiento mashrequí de los comerciantes europeos a través de las oportunidades y vías extra-legales de acumulación facilitadas por la guerra civil resuelve solo parte del misterio. Como Velcamp señala, la Revolución enriqueció a algunos mashrequíes; sin embargo todas las descripciones relatan un ascenso colectivo.

\section{WASTA EN EL MAHJAR: LAS GANANCIAS DE LAS ÉLITES CONVERTIDAS EN BENEFICIOS “COMUNITARIOS’}

Es necesario explorar otra dinámica que ha sido fundamental para que las ventajas políticas y económicas aseguradas por las élites migrantes se convirtieran en beneficios que podríamos llamar 'comunitarios'. Quisiera proponer que la lógica del wasta, término árabe que como la palabra mexicana palanca, indica el poder que tiene un sujeto para acceder a recursos por medio de una relación clientelar con un mediador más poderoso que si mismo, constituye el eslabón perdido. El wasta, que podría definirse como la visión subalterna de la dinámica del patronazgo, juega un papel central en una cultura mashrequí contemporánea organizada por 1) relaciones jerárquicas y 2) un estado insuficiente.

Para poder hablar de patronazgo primero hay que reconocer que la población migrante nunca fue homogénea; no todos los mashrequíes que llegaron a México eran 'pobres' o subalternos. A principios de siglo, los millets, o comunidades religiosas protegidas del Imperio Otomano- es decir judíos y cristianos- abarcaban un abanico socioeconómico. Díaz de Kuri y Macluff han señalado que "Aunque en menor cantidad, también llegaron personas con altos niveles de estudio: maestros, abogados, periodistas y diplomáticos que hablaban, además del árabe, francés o algún otro idioma. Estos viajeros no tuvieron ninguna dificultad, y si ayudaron en los tramites a sus compañeros de viaje (Díaz de Kuri y Macluff 1995: 64). La cantidad de medios impresos en árabe en la Ciudad de México a principios de siglo indica la presencia de una población respetable capaz de producir y consumir tales textos.

La élite migrante estaba bien equipada para mediar entre las élites locales y sus compatriotas menos afortunados. El patronazgo se caracteriza por operar a través de relaciones personales. De hecho da Matta ha argumentado que la fuerza del patronazgo en sus formas modernas poscoloniales esta precisamente en la posibilidad de trasladar las relaciones privadas al ámbito publico. En estos contextos, las relaciones intimas: relaciones de amistad y compañerismo cultivadas por hombres y mujeres poderosas, les permiten acumular aun más poder y recursos. Díaz de Kuri y Macluff nos 
ofrecen un ejemplo de esta dinámica: "Eran famosas las comidas ofrecidas por Don Antonio Letayf en su rancho San Joaquín. A esas reuniones acudían el presidente Carranza, miembros del cuerpo diplomático y un grupo de comerciante libaneses” (Díaz de Kuri y Macluff 1995: 63).

Podríamos pensar que Don Antonio había hecho su propia fortuna, si las mismas autoras no nos proporcionaran una clave adicional, en una entrevista con Alberto Bitar Letayf, sobrino de Don Antonio, que narra la llegada de su padre a México: "De familia libanesa muy acomodada, había llegado de Paris, en donde estudiaba, a pasar sus vacaciones con sus primos, los Letayf” (Díaz de Kuri y Macluff 1995:225). Los eventos en el Rancho San Joaquín le permitían a un señor de la elite libanesa migrante reunir alrededor de su mesa a las autoridades revolucionarias y algunos de sus compatriotas, cultivando su wasta en varias direcciones. Don Antonio fue también el primero en casarse con una señora de la elite porfiriana; es decir, el primero en integrarse por medio del matrimonio a las élites locales. Al parecer, la elite comercial sirio-libanesa sobrevivió la revolución con la misma soltura que las élites porfirianas en general, incorporándose a la sociedad posrevolucionaria en calidad, una vez más, de privilegio. ${ }^{19}$

Otra casa que me mencionaron repetidamente en entrevistas como un sitio que facilitaba oportunidades de patronazgo fue la de Silvia Kuri de Ayub. Casada con Antonio Ayub, un comerciante originario del pueblo de Duma en el Líbano, la mesa de Silvia era legendaria como un espacio acogedor, abierto a migrantes de todo tipo de fortuna y tradición religiosa, donde podían establecerse relaciones y cultivarse el wasta. Las reuniones en espacios 'privados' siguieron jugando un papel fundamental aun después de la institucionalización de la revolución, como demuestra la historia de cómo los melkitas llegaron a tener su propia iglesia en la Ciudad de México:

Te voy a contar lo de Porta Coelli... ${ }^{20}$ Entonces todos los que eran melquitas se juntaban, pero sin ver que fueran melquitas o no, ellos todos eran amigos. Entonces... llega un padre del Líbano que se llamaba el padre Chami. Llega, pues lo conoce mi papá y todo el mundo. Muy agradable, una persona muy fina, pero no tenia iglesia. Entonces hay una comida en casa de Silvia Ayub. Silvia, siempre estuvo con todos... Hace una comida en su casa, con el Presidente Alemán, con los secretarios, y como representante de la colonia libanesa, mi papá... Decían una persona con personalidad, mi papá. Estando platicando en la mesahablaban de religión. Estaba el Arzobispo de México, simpatiquísimo, feo como el solo pero muy simpático, que fue el que abrió las puertas mucho más a la iglesia... Entons estaba ahí y le dice monseñor a mi papá, 'Don Luis, como esta el padre Chami?' 'Hay pobre' dice, 'de un lado a otro. Señor Presidente, no me podría dar una iglesita que esta ahí en Venustiano Carranza? Es un archivo, de ustedes'. 'Don Luis, ahí esta el de bienes nacionales'. Entonces se voltea mi papa a ver al de bienes nacionales y le platica el caso del padre. 'Si Don Luis lo espero mañana'. Entonces el despacho de mi papa estaba en un lado y la Secretaría. Se fue a verlo, muy amable, le dijeron que si, pero que tenían que quitar el archivo. Entonces se juntaron todos los kwetli y juntaron dinero. Por ejemplo, en la cena en la casa llegaron, dicen bueno yo doy tanto, los Hajj y todos... Se fueron ahí y vieron que eso estaba bastante

\footnotetext{
19 Esto se ha señalado en el caso de muchas familias porfirianas de ascendencia europea; ver Lomnitz y Pérez Lizaur (1994); Margarita Urias et al. (1978).

${ }^{20}$ Porta Coelli es el nombre de la iglesia que les fue entregada a los melkitas en el centro de la Ciudad de México.
} 
(descuidado). Limpiaron todo, arreglaron todo... Pero ves, en ese ambiente, es como se logró. ${ }^{21}$

Miguel Alemán fue presidente de México entre 1946 y 1952. En el caso de como una iglesia colonial que pertenece al estado fue restaurada por migrantes melkitas para convertirse en un espacio comunitario migrante, el papel que jugo el patronazgo es claro.

\section{LA REVOLUGIÓN Y EL CONTRATO SOCIAL}

La Revolución Mexicana trajo a una nueva elite al poder, y con ella nuevas nociones de 'la nación’. Mientras los jefes militares competían por el poder, sus ideólogos- José Vasconcelos siendo el más conocido- formulaban la nueva nación: nación de mezclas, que derivaría su fuerza de la fusión singular de la grandeza del pasado indígena y la tradición española. ${ }^{22}$ Ya que la nueva ideología nacional declaro a todos los mexicanos, todos los miembros de la nación, como mestizos por definición, la diversidad 'racial' y las practicas de diferenciación por medio de índices raciales ‘desaparecieron’ de los debates académicos y oficiales. Aunque el estado construido a lo largo de los siguientes setenta años por el Partido Revolucionario Institucional efectivamente generó oportunidades de movilidad sin precedentes, especialmente a través del empleo en la enorme burocracia estatal, no desmantelo las prácticas sociales de distinción etnoracial. A pesar de que la reforma agraria y la nacionalización de varias industrias y recursos recorto algunas fortunas, y de la incorporación masificada y sectorializada de grupos corporativos subalternos- campesinos, trabajadores, y las clases populares por el estado nación, la revolución no revocó las fuentes de riqueza de las élites tradicionales. ${ }^{23}$

Las élites regionales habían migrado a la Ciudad de México cuando comenzaron los desordenes revolucionarios, y aunque muchas familias perdieron parte de sus haciendas, el régimen porfirista había estimulado la diversificación de inversiones y la urbanización de las élites como corolarios de sus políticas de modernización (Wolf 1956, Nutini 1995, Urias 1978). Fueron las élites históricas las que desarrollaron el sistema industrial y bancario incipiente. La institucionalización de la Revolución desplazó a las élites porfirianas al sector privado, desde donde se beneficiaron de las políticas proteccionistas de sustitución de importaciones durante las siguientes cuatro décadas. Estos mexicanos 'europeos' también retuvieron un papel fundamental en las instituciones culturales nacionales, especialmente las nuevas dependencias a través de las cuales la alta cultura (Europea) se le hace llegar a las masas.

El celebrado mestizo podía ser, como tantos que ascendieron por la burocracia militar y administrativa, 'racialmente' mixto o de ascendencia desconocida, pero una condición de su movilidad era ser culturalmente europeo. Oficialmente, las poblaciones indígenas aun existen, manejadas y marginalizadas por el estado posrevolucionario a lo largo del siglo veinte (vide

\footnotetext{
${ }^{21}$ Entrevista con $\mathrm{S}$.

22 Brackette ha trabajado el tema; su caso es Guyana.

${ }^{23}$ Sobre los cambios al contrato social por la revolución, ver Lomnitz 2001 y Brachet-Marquez 1994.
} 
Hernandez 2001). Entre todos los sectores de la población, tanto en contextos urbanos como rurales, el contraste entre indios, mestizos y la 'gente de origen español sigue organizando distinciones, un índice racial de la posición de clase; y disciplinando las fronteras etnoraciales y de clase (vide Nutini 1994, 1997.) Estas categorías son contextuales, y su contenido varia regionalmente, como han señalado una y otra vez quienes trabajan temas de campesinado y cultura; en particular el trabajo sobre indios y ladinos de los años setenta. ${ }^{24}$

\section{Propiedad, RaZa y Las Clases ‘INDESEABLES’ DURANTE la Gran DePresión}

En los años veinte y treinta, los migrantes de Oriente Medio comenzaron a enfrentarse con hostilidades en sus destinos americanos. ${ }^{25}$ En estas dos décadas, países a lo largo y ancho del continente comenzaron a implementar restricciones sobre la migración (Klich en Hourani y Shehadi 1992, Euraque en Klich y Lesser 1998, Alfaro-Velcamp 2007, Vargas 2007). El movimiento hacia las Américas había sido documentado y regulado desde la época colonial, pero la crisis global de la Gran Depresión resulto en oleadas sucesivas de restricciones, y una racialización inspirada en la medicalización norteamericana del concepto de raza. Ya a principios de siglo, la migración se debatía en los Estados Unidos, al igual que la pobreza urbana de sus centros industriales, no en términos económicos sino raciales. El gobierno norteamericano introdujo cuotas migratorias desde 1921, cuando la saturación de su mercado de trabajo industrial volvía innecesarios los grandes flujos migratorios (Brodkin 1998 y O'Connor 2001). Expertos como Madison Grant y el eugenista Charles B. Davenport organizaron la Galton Society en 1918, "para fomentar la investigación, promover la eugenesia, y restringir la inmigración”. La saturación laboral se expresaba como hostilidad hacia las 'razas' inferiores y por lo tanto indeseables del sur de Europa (Brodkin 1998: 29). Este lenguaje ‘científico’ paso a los debates públicos como un discurso moderno, con gran autoridad, incluso en otras regiones del continente.

Por otro lado, en la medida en que avanzaba la crisis, en toda América Latina los comerciantes se organizaban, exigiéndoles a sus gobiernos que restringieran la migración y deportaran a los migrantes residentes. Los gobiernos respondían a estas presiones; México restringió la entrada de migrantes de Europa del este y el medio oriente en 1927. ${ }^{26}$ Las restricciones especificaban la exclusión de categorías nacionales específicas. El grado el que se colapsaron o naturalizaron 'raza’ y ‘nación’ siguiendo el modelo norteamericano variaba según las regiones Latinoamericanas. Mientras que se adopto fielmente en Colombia por ejemplo, en México y Centro America las restricciones oficiales guardan un parentesco más cercano con la lógica postcolonial de definir la 'raza' a partir de la 'clase'. Las categorías raciales y nacionales se aplicaban, y por lo tanto eran producidas como categorías económicas; enlazando 'raza' y propiedad.

\footnotetext{
${ }^{24}$ Para México, ver la producción de Stavenhagen, Wolf, Tax. Medina 1997 trabaja el caso de Belice.

${ }^{25}$ Las migraciones modernas del Medio Oriente a las Américas comenzaron en la década de 1870.

${ }^{26}$ Para Guatemala: AMAE 410: 269-270; Salvador: AMAE 411: 220. Colombia ver Vargas (2007).
} 
Los documentos oficiales a principios de los veintes articulan la intersección de categorías nacionales y de clase; con la excepción de negros y chinos, para quienes la intersección es más bien entre clase y 'raza'. En México, se comenzó a exigir que ciertas categorías nacionales tuvieran capitales cada vez mayores para poder cruzar las fronteras. En octubre de 1922, quien quisiera entrar a México debía tener consigo la suma de 50 pesos o el equivalente en otra moneda, así como dinero suficiente para llegar a su destino dentro de México. Chinos y negros debían presentar la suma de 500 pesos (Alfaro Velcamp 2007: 100). Dada la historia regional y la dinámica migratoria global, en la práctica esta cláusula excluía a la mayor parte de viajeros de origen asiático o africano; y podríamos concluir que se trata simple y llanamente de un racismo oficial. Lo que encuentro fascinante en este caso es el condicionamiento de la categorización racial por un criterio de propiedad en la clasificación oficial mexicana. Un sujeto chino o negro portador de la cantidad estipulada seria, en principio, bienvenido en el México posrevolucionario. El proceso recuerda las construcciones de la ciudadanía en el diecinueve.

Cada vez con mayor frecuencia, solo se les permitía desembarcar en puertos Latinoamericanos a aquellos pasajeros que viajaran en primera y segunda clase; eventualmente, solo a los que viajaran en primera. ${ }^{27}$ Un observador francés describe a los mashrequíes como la mayoría de estos migrantes autorizados en $1924 .{ }^{28}$ En la medida en que las condiciones económicas se deterioraban a lo largo de la década, México impuso restricciones y eventualmente suspendió la inmigración de nacionalidades de Oriente medio; excepto los ricos, y quienes tuvieran parientes que hubieran inmigrado legalmente. Es importante señalar las condiciones económicas, políticas y demográficas específicas en las que se dan estas restricciones, aunque el patrón sea común a todo el continente. Con el colapso del imperio Otomano en 1919, las restricciones imperiales sobre le emigración dejaron de ser aplicadas. Quienes desearan emigrar no necesitaban recurrir ni a sobornos y traficantes de personas, ni a la protección consular de alguna potencia europea para adquirir documentos de viaje. ${ }^{29}$ La reacción mexicana de 1926-1927 respondió a los influjos de 1924 y 1925, los dos años en que se registraron los mayores números de inmigrantes mashreqis a México en el siglo y medio de historia de esa migración.

En el discurso popular cada vez mas poblaciones fueron racializadas de manera híbrida y ambivalente. No solo se colapsaba a judíos y árabes en la misma categoría de semíticos; árabes y judíos eran indistinguibles en el discurso popular y de la prensa de los migrantes de Europa del este. En Colombia, por ejemplo, la polaquería era una referencia al conjunto de árabes, judíos y migrantes europeos empobrecidos. ${ }^{30}$ En México, un articulo en el diario El Universal reporto en 1923 que un

\footnotetext{
${ }^{27} \mathrm{El}$ AMAE contiene numerosos ejemplos.

28 “L'importance et l'activité de la colonie syro-libanaise au Mexique s'accroissent sans cesse. Il n'est point de bateau venant d'Europe qui n’apporte ici un contingent nouveau de nos protégés du Proche-Orient: la Compagnie Générale Transatlantique profite particulièrement de cette émigration a telles enseignes que les Syro-libanais forment environ les 3/4 des passagers de première et de seconde classe qui débarquent de ses paquebots a Vera-Cruz. A l'heure actuelle, les Syro-libanais établis au Mexique sont plus de 30,000, ce qui fait d'eux la colonie étrangère de beaucoup la plus importante en nombre après la colonie espagnole". AMAE 408: 41.

${ }^{29}$ Sobre las prohibiciones otomanas, ver Klich en Hourani y Shehadi 1992.

${ }^{30}$ Vargas, comunicación personal.
} 
árabe, ucraniano de nacionalidad, había sido muerto por una muchacha de la clase humilde porque había intentado ultrajarla (Alfaro Velcamp 2007: 101). Este tipo de referencias parecen indicar que la categoría de 'árabe' se usaba en la narrativa popular mexicana, según la tradición local, como una categoría etnoracial que indicaba tanto una ocupación- la del comercio ambulante, como un grado de prosperidad- en este caso, escasa.

En estos mismos medios, se hacían cada vez mas frecuentes las descripciones de los migrantes como vectores de suciedad y enfermedades. Las metáforas de lo sucio, la enfermedad y la criminalidad resultaban excelentes pretextos para vigilar con mas ahínco las fronteras, reificándolas; y para instigar pánicos morales (vide Hall, Gilroy y Hall et al.). En marzo de 1926, México aprobó una ley migratoria que extendía la lista de causas médicas por las cuales se podía rechazar a los migrantes. Un oficial francés de hecho reporto la creciente vigilancia en los puertos mexicanos, señalando la necesidad de que se hicieran inspecciones sistemáticas en el momento de partida (AMAE 409: 38). La misma ley estipulaba que los migrantes debían presentar documentos oficiales al entrar y salir de México; y demostrar que tenían la cantidad de 10000 pesos para satisfacer sus gastos mientras estuvieran en el país.

En julio de 1927, se prohibió la entrada de las nacionalidades mashrequíes a México. Las autoridades alegaban que los migrantes presentaban varias amenazas económicas a ‘la nación’. Se argumentaba que los migrantes de estas nacionalidades no contribuían a la creación de la riqueza nacional, siendo además causa de hacinamiento en las zonas urbanas, y que habían entrado al país bajo falsos supuestos. El Departamento de Migración decretó lo siguiente:

...suspendiendo la inmigración de trabajadores de origen sirio, libanés, armenio, palestino, árabe y turco... estimándose que la calidad de inmigrante trabajador la tiene todo extranjero de las señaladas nacionalidades que al llegar al país no posean un capital de diez mil pesos como mínimo; el acuerdo anterior que durara en el bienio de 1928-29 exceptúa de la restricción anterior a los cónyuges de los que hayan emigrado legalmente, así como a sus ascendientes y descendientes, siempre que tengan un modo honrado de vivir (En Alonso Palacios 1983: 76) 31

Algunos de los argumentos de las autoridades no tenían fundamento, por ejemplo la acusación de que la mayoría de los migrantes hubieran ingresado al país bajo el falso supuesto de ser trabajadores agrícolas es falsa. Según Alfaro Velcamp, durante la migración mashrequí temprana, solo el $2.6 \%$ de los migrantes declararon que eran agricultores.

La prohibición detonó una avalancha de reacciones por parte de las autoridades francesas y la elite migrante, quienes estaban indignados. La respuesta afectiva de la colonia y la estrategia francesa de intervención fueron descritas por Perier el seis de agosto de 1927:

Un decreto del Ministerio de Gobernación acaba de suspender a partir del primero de septiembre y durante 28 meses la inmigración de sirios y libaneses. Una viva emoción reina entre nuestros protegidos establecidos en México, quienes temen que el gobierno decida

\footnotetext{
31 Énfasis mío.
} 
próximamente su deportación masiva. Haré un llamado urgente al Ministro de Asuntos Exteriores y al Ministro de Gobernación. Estoy recabando hechos y argumentos que me permitirán mostrar que la inmigración siria y libanesa ha sido, en conjunto, provechosa para este país y que no puede invocarse ninguna buena razón para justificar tales medidas (AMAE 410: 173).

La preocupación de los notables no era gratuita. Aun Perier solo logro que el Secretario de Gobernación prometiera que re-examinaría la cuestión (AMAE 410:180). A pesar de que insistió, alentado por los migrantes y la compañía francesa de vapores transatlánticos que los transportaba, solo obtuvo permiso para que viajara un último grupo de migrantes en el vapor 'Cuba'; la respuesta de las autoridades mexicanas fue que no podía plantearse la abrogación del decreto de inmediato (AMAE 410:183). Para que los migrantes en potencia estuvieran al día en cuanto a las restricciones, se estableció en 1927 un consulado mexicano, atendido por un diplomático de carrera en Beirut. ${ }^{32}$

\section{REVOLUCIONAR LA EXTRANJERÍA Y LA NACIONALIZACIÓN}

En su afán de vigilar las fronteras de la nación, los gobiernos posrevolucionarios desarrollaron, como contraparte a las restricciones a la migración, una serie de restricciones sobre el proceso de naturalización. La Ley Sobre Extranjería y Nacionalización estipulaba que tanto los hijos como las esposas mexicanas de los migrantes eran considerados extranjeros. ${ }^{33}$ Los extranjeros que desearan naturalizarse podían intentarlo a través de la Secretaria de Relaciones Exteriores; pero el porcentaje de solicitudes aprobadas era ínfimo. ${ }^{34} \mathrm{Al}$ igual que cuando se expulsó a los peninsulares tras la independencia, los extranjeros se volvieron vulnerables en un México revolucionario cuyas autoridades buscaban legitimarse invirtiendo las políticas porfirianas.

En su trabajo reciente sobre el desarrollo del nacionalismo mexicano durante la revolución y las décadas posrevolucionarias (1911-1940), Pablo Yankelevich ha señalado que los mashrequíes eran acusados de contrabando. Argumenta que los gobiernos de Pascual Ortiz Rubio (1930-1932) y Abelardo L. Rodríguez (1932-1934) mostraron especial interés en la vigilancia de las actividades comerciales de los inmigrantes (Yankelevich 2004). Ortiz Rubio, como los miembros de su gabinete y sus misiones diplomáticas, provenía de la antigua élite porfiriana y muchos de ellos eran 'extranjeros' españoles y franceses. La agresión de la administración hacia las actividades comerciales

\footnotetext{
${ }^{32}$ Un M. Lera, que había sido cónsul en St. Nazaire, fue enviado por el gobierno mexicano en respuesta a una petición del Ministro de Asuntos Exteriores de Francia; se notifico al Alto Comisario y a la Compagnie Transatlantique de su llegada. (AMAE 410: 180).

${ }^{33}$ Diaz de Kuri y Macluff (1995): “En la fracción II del artículo Segundo de la Ley Sobre Extranjería y Naturalización se estipula: Son extranjeros: II Los hijos de padre extranjero o de madre extranjera y de padre desconocido, nacidos en el territorio nacional hasta llegar a la mayoría de edad, si se mantienen bajo la patria potestad. VI Las mexicanas que contrajeron matrimonio con extranjero, conservando su carácter de extranjeras aun durante su viudez. Se consideran mexicanos los extranjeros nacionalizados o naturalizados, así como sus hijos": It was not until October 171953 that the Diario Oficial de la Federación published the reform to article 34 of the Constitution, granting adult Mexican women the right to vote. In this law they are clearly still considered juridical minors"

${ }^{34}$ Yankelevich y Jacobs, comunicación personal.
} 
mashrequíes podría interpretarse como un intento de consolidar su propia legitimidad- a pesar de su propia extranjería- a costa de poblaciones con una presencia más reciente en la región.

Las medidas oficiales invocaban el contrato social posrevolucionario. En 1932, se estableció el Registro Nacional de Extranjeros, una enorme base de datos en la que debían inscribirse todos los extranjeros residentes en el país que fueran mayores de quince años. En 1934, el Presidente Rodríguez extendió las restricciones sobre la migración mashrequí. Los migrantes debían tener consigo 10,000 pesos o poseer conocimientos técnicos aprobados por la Secretaria de Economía para entrar a México. Se aceptaba a inversionistas que trajeran mas de 20,000 pesos y tuvieran la intención de especializarse en quehaceres industriales o agrícolas, pero no se permitiría la entrada a quienes fueran comerciantes, por ningún motivo (Velcamp 2007:119). En octubre de 1935, la Secretaria de Economía preparo una encuesta de la propiedad en manos de extranjeros en México, citando el artículo 27 de la Constitución del 17, el cual estipula que solo los mexicanos, nacidos en el país o naturalizados, tienen derecho a adquirir propiedad en México (Velcamp 2007:119).

Las observaciones de Yankelevich sobre los lazos entre la legitimidad política y las fronteras cambiantes de la 'nación' son importantes. Sin embargo, existen descripciones detalladas del contrabando mashrequí que provienen de otras fuentes y agentes. Los mashrequíes inspiraban resentimiento entre algunos mexicanos, pero otros migrantes- especialmente quienes habían monopolizado el sector textil en el que los mashrequíes eran una presencia ascendiente, se quejaban amargamente. Perier, Ministro de Francia en México observo en 1924:

Han tenido gran éxito: dedicándose casi exclusivamente al comercio de textiles, sedas y mercería, le hacen una fiera competencia a los "Barcelonettes" y representan, para la actividad tan prospera de nuestros compatriotas, una amenaza de la mayor gravedad. Las quejas que recibo con tanta frecuencia por su causa no me dejan ninguna duda sobre su proceder: completamente carentes de probidad comercial, no dudan en eludir sus compromisos cuando perciben que tal actitud pudiera traerles ganancias sustanciales. La mas evidente de sus ventajas se deriva de su introducción en contrabando de sedas y telas de lujo. Sus frecuentes viajes a Francia no tienen otro objetivo: el escaso volumen de estas mercancías les permite fácilmente llevarlas en su equipaje y negarle al fisco los derechos enormes que recaen sobre estos productos, lo cual les garantiza, además de una ganancia segura, la posibilidad de captar una clientela por medio de precios que son impracticables para los comerciantes honestos. Pasajeros de primera clase en nuestros buques, logran, gracias a sus intrigas y a su sentido de la corrupción, establecer complicidades tanto con el personal de abordo como con el de la aduana, de manera que prácticamente importan gratuitamente una gran parte de la mercancía que es objeto de su tráfico. Es sobre esta improbidad, de la cual parecen haberse hecho una regla inflexible, que reposa la prosperidad de sus negocios (AMAE 408: 12).

Por supuesto es problemática la forma en que el reporte generaliza las prácticas de algunos a la población migrante en general, naturalizando una moral dudosa como atributo del 'carácter oriental'. 


\section{Leer los Cuerpos en la Poscolonia. La Estética del Poder en el México POSREVOLUCIONARIO: 1924-2002}

La reacción de la elite migrante a la prohibición sobre la inmigración a México es extraordinaria. La prohibición causo un revuelo de consternación, como hemos visto. Se tramaron toda clase de estrategias para prevenir que entrara en efecto; una de las cuales resultó en la siguiente petición, enviada por los representantes del Partido Nacionalista Libanés fundado por Don Julián Slim, el 9 de agosto de 1927, al Secretario de Gobernación:

Señor Secretario de Gobernación:

En debida satisfacción al pueblo de México elevamos a usted esta instancia para el efecto de que sea reconsiderado el acuerdo limitativo. Séanos permitido exponer las consideraciones que fundan nuestra solicitud, permítasenos examinar la parte en que se funda el acuerdo de limitación: "Que la inmigración de individuos de origen sirio, Libanés, palestino, árabe y turco ha llegado a su limite en que su influencia se deja sentir en la economía nacional de manera desfavorable por su aglomeración en los centros urbanos".

Cierto es que en los centros urbanos se encuentran numerosos comerciantes ambulantes. Esos vendedores no son de origen Libanés, con ellos no tenemos liga de ninguna naturaleza y por el contrario nos causan perjuicio en nuestro giro comercial. Nos permitimos manifestar que los pocos libaneses que están viniendo al país (pues a ultimas fechas se ha restringido muchísimo esa inmigración), llegan recomendados a parientes o amigos que los ocupan en sus comercios o industrias.

El libanés es un colono útil y provechoso al desarrollo comercial y reclamamos el derecho de que se nos haga justicia. El libanés es de raza estética, forma parte de la raza blanca caucásica. Siempre ha vivido independiente, conservando sus tradiciones morales, monógamo, con vida austera y con un vivo y profundo amor a la libertad.

Deseando solamente que usted, señor, adquiriendo todas las averiguaciones, espulgando nuestra manera de ser y de vivir en publico y en privado, adquiera el conocimiento completo de los comercios libaneses, en vista de ello estamos seguros, porque es usted noble en sus actos y honrado en sus procedimientos, tendrá la dignidad de modificar su acuerdo limitativo por lo que a los libaneses se refiere (Díaz de Kuri y Macluff 1995:65-66).

El documento proyecta la ficción de que una población 'libanesa' puede, y debe ser reconocida como distinta de todos los demás mashrequíes en base a distinciones de clase, raza y religión. ¡Sin relación alguna a los comerciantes ambulantes! Cuando todas las descripciones especifican las relaciones de parentesco y patronazgo que ligaban a los comerciantes establecidos y los ambulantes, a quienes extendían crédito, recomendaciones, etc. M. Charpentier, en su censo de la colonia de 1921, toma nota cuidadosamente de cómo vendedores ambulantes y comerciantes establecidos pertenecían con frecuencia a la misma unidad doméstica (AMAE 407: 61). La carta le niega la nacionalidad libanesa a los mashrequíes 'pobres'; también a los musulmanes, quienes no tienen la obligación de la monogamia.

La clasificación sistemática de los mashrequíes y/o árabes como blancos en México, en muy distintos sitios y espacios institucionales y a pesar de su efímera racialización como semíticos y razas indeseables durante la Gran Depresión, es fascinante. Propongo que su racialización ambivalente resulta de la intersección de varios discursos coloniales y poscoloniales. Por un lado, el discurso 
oficial posrevolucionario sobre el papel de la 'raza' en la definición de la nación y el acceso a la riqueza nacional- un discurso poscolonial en metamorfosis, saturado de contradicciones inherentes a sus intentos simultáneos de tomar distancia de la practica colonial/porfirista y absorber una modernidad euro americana hegemónica. Por otro, los discursos en torno al estatus de los migrantes como protegidos de Francia; y finalmente, la lectura local de sus cuerpos 'blancos' en la interacción cotidiana. El papel de la condición poscolonial de México y la especificidad de la herencia colonial española en esta alquimia se hace mas evidente cuando notamos que en otros destinos, los migrantes mashrequíes han sido sistemáticamente excluidos de la categoría racial de 'blancos'. Como me recordó un cura Maronita durante nuestra entrevista, Australia y Estados Unidos son dos de los destinos de las migraciones del medio oriente donde los migrantes no tienen esta ventaja. En esos otros contextos poscoloniales, en lugar de ser blancos, son negros. ${ }^{35}$

El Registro Nacional de Extranjeros establecido por el gobierno mexicano en 1932 genero miles de tarjetas individuales de registro que sintetizan un mar de información; estas incluyen un apartado que especifica la 'raza' de los migrantes. Las tarjetas piden información sobre la fecha de entrada y el puerto de llegada, la dirección del migrante en México y su 'constitución física'- altura, el color de ojos, pelo y piel, la forma de las cejas, el mentón, la boca, el bigote, la barba y la nariz. También piden que se registren algunos 'datos complementarios': la fecha y el lugar de nacimiento, su estado civil, ocupación, lengua materna y otras lenguas, y luego en un subconjunto, nacionalidad actual, religión, y raza. Se adjunta una foto del migrante. Los cuerpos de los migrantes son descritos individualmente, con mucho cuidado; algunos tenían ojos café claro y pelo café oscuro, otros pelo negro entrecano, pelo castaño oscuro, o gris, lacio. El dato de interés es que aun cuando todos los colores que describen al migrante son oscuros, incluso cuando le describen como de piel morena, la raza que se le atribuye a los mashrequíes es invariablemente blanca; sajona en un caso. ${ }^{36}$ Los oficiales en el registro parecen haber seguido una clasificación local- la cual asignaba sistemáticamente a los migrantes del Mashreq a la categoría de blancos.

El argumento de la elite migrante en 1927 comparte la lógica evidente en el desarrollo de las instituciones migrantes a lo largo del siglo veinte; la construcción de una nación 'libanesa' que se distingue de sirios, palestinos y árabes en general en términos de clase, secta, calidad moral- $¡$ y raza! La idea que de los 'libaneses' son blancos caucásicos es particularmente interesante en el contexto mexicano, donde la blancura es un atributo del colonizador. El discurso mashrequí hace referencia a una taxonomía racial 'científica' para establecer la belleza de los migrantes, y por lo tanto su calidad de ciudadanos deseables. Estos argumentos parecen haber formado parte de un sentido común de la elite mashrequíes inteligible en México- y de hecho validado por mexicanos de muchos sectores. Una mujer mexicana educada en escuelas de monjas francesas durante los cuarenta y cincuenta recordaba de memoria una lección de primaria, y recito durante nuestra entrevista: “Árabes: pueblos de raza

\footnotetext{
${ }^{35}$ Como han descrito también Gualteri y Hage.

36 Estas observaciones se basan en una pequeña muestra publicada por Díaz de Kuri y Macluff. Pienso consultar próximamente el conjunto de las tarjetas en el Archivo General de la Nación.
} 
blanca que habitan la región mediterránea. Son pastores, que dependen de sus rebaños...”. Evidentemente, los oficiales del Registro estaban de acuerdo.

\section{LA Protección De Francia}

Los migrantes del Mashreq buscaban la intervención de Francia, en su calidad de poder mandatario, en circunstancias diversas. En casos individuales de necesidad o infortunio, cuando buscaban permiso para migrar, solicitaban repatriación, o ayuda para localizar a parientes migrantes desaparecidos. Las emergencias colectivas también eran expuestas ante las autoridades mandatarias, quienes se lanzaban a negociar para proteger espacios de culto o al conjunto de los migrantes ante los cambios legislativos en las Américas. Los notable migrantes jugaban un papel clave en este proceso, y sus estrategias dejan entrever que sus mediaciones representaban también inversiones en su propio beneficio. Los sujetos de los territorios bajo mandato no eran ciudadanos de Francia. A pesar de que circulaban con una diversidad fantástica de identificaciones oficiales emitidas por autoridades francesas, casi todas dejaban bien claro que se trataba de sujetos o ciudadanos de un mandato. De hecho la distancia entre los derechos de estos protegidos, como les llaman los documentos franceses, y los de quienes eran ciudadanos o sujetos propiamente coloniales dio lugar tanto a interminables discusiones entre oficiales franceses, como a negociaciones internacionales entre potencias mandatarias. ${ }^{37}$

La transición de las identidades oficiales de los sujetos otomanos y su oportunidad de adquirir las nuevas nacionalidades de su región de origen fueron objeto de negociaciones precisas en el Tratado de Lausanne. Se estipularon ventanas de tiempo razonables para que los migrantes declararan sus nuevas identidades- revirtiendo automáticamente a la ciudadanía turca quienes no lo hicieran. Se hicieron esfuerzos por circular esta información entre la población migrante. Sin embargo parecería que la ambigüedad era políticamente más fecunda, y cultivarla era más importante para ciertos migrantes y administradores que la racionalidad del sistema. Otros insistían sobre la necesidad de apegarse al estado de derecho- si es que algo así existe en contextos coloniales. La práctica de conceder pasaportes franceses y británicos a algunos notables entre los protegidos- en particular aquellos con largas historias familiares de colaboración con autoridades consulares de las potencias europeas en el contexto otomano, y las aseveraciones de uno que otro protegido que aseguraba ser ciudadano, causaban constantes confusiones. Los agentes británicos se quejaban amargamente de la ambigüedad del estatus de los protegidos franceses, y hacían esfuerzos para aclarar si debían o no tratarles como ciudadanos. Dada la complejidad de las practicas francesa de protección, no era difícil para los migrantes alegar- y quizás creer- que el hecho de tener en su posesión documentos de identidad extendidos por las autoridades consulares era un índice del favor de Francia.

\footnotetext{
${ }^{37}$ Como lo indica la correspondencia del AMAE.
} 


\section{COMO ARGELIA}

A partir de que fue conferido a Francia el mandato sobre el Mashreq, se desarrolló un debate constante entre distintos sectores de la población migrante en cuanto a la legitimidad y la efectividad de la protección francesa. José Hilu se quejaba ella en su periódico Al-Khawater. La mayoría hacían grandes esfuerzos para expresar su gratitud y su solidaridad. Los años de la llamada 'rebelión druza', es decir, de la resistencia armada al mandato, fueron un momento propicio para que instituciones y familias exhibieran su lealtad. Por ejemplo el telegrama enviado por J. Dumit y Habib Karam al Ministerio de Relaciones Exteriores de Francia el 2 de diciembre de 1925: "TolucaMex. Sociedad Fraternal Sirio Libanesa protesta enérgicamente contra propaganda antifrancesa en America Latina y los asesi..atos de cristianos pedimos que envíen refuerzos... suplicamos mantener vuestra autoridad sobre Siria Líbano" (AMAE 408:190). Cuando Antonio Ayub, el marido de Doña Silvia, fue presidente de la Liga Sirio-Libanesa-Palestina Mexicana en 1932, encontró la oportunidad para escribirle al Ministro de Asuntos Exteriores de Francia y agradecerle la protección extendida a sus conciudadanos por la Legación de Francia en México, en particular el apoyo de M. Meuhreg, el dragomán o intérprete de la legación (AMAE 617: 135).

Entre los ciudadanos prominentes de la 'Colonia Sirio-Libanesa' que hacían el papel de intermediarios notables, la correspondencia francesa menciona con frecuencia a dos hermanos, José y Julián Slim. Julián parece haber tenido ciertos roces con las autoridades francesas de vez en cuando. ${ }^{38}$ José, por el contrario, cultivaba su wasta cuidadosamente. Una serie de telegramas documentan sus intercambios con oficiales de alto rango entre 1926 y 1929; en los que celebra las victorias militares de Francia sobre sus sujetos en el Mashreq, financiando incluso las guerras coloniales de Francia en Siria y Argelia. Su generosidad era reconocida y celebrada por las autoridades francesas:

México, 8 de diciembre 1927

[Envío] un cheque de 2000 sobre el Banco de Montreal, remitido por un ciudadano libanés, M. Joseph Slim, quien destina el monto a las victimas del desastre que lamentablemente desoló Argelia. No deje de agradecerle a M. Joseph Slim, quien constantemente ofrece pruebas solicitas de su amor a Francia, por su generosidad. El Departamento seguramente no ha olvidado que el año pasado, nuestra Legación transmitió, de su parte, la suma inicial de 1000 francos a ser pagada al primer soldado francés que penetrara en la Soueida reconquistada, luego la suma de 50,000 francos hacia la amortización de la deuda publica (AMAE,Vol. 410 p 280). ${ }^{39}$

Este gesto material proyectaba a M. Slim como un leal ciudadano francés- ciudadano del imperio, tan preocupado por la suerte de la Francia metropolitana como con la de sus múltiples territorios coloniales.

Cuando José Slim viajaba al Líbano, su reputación le precedía. Perier le pidió al Secretario mismo, el Sr. Aristide Briand, que le recomendara: "M. Joseph SLIM... tiene la intención de viajar al

\footnotetext{
38 Por ejemplo en el caso del Comité de Repartición, del cual formó parte.

${ }^{39}$ Soueida es un poblado sirio.
} 
Gran Líbano, su tierra natal, durante el curso de la primavera próxima. Perteneciendo a una familia Maronita que se ha distinguido por su lealtad a la causa francesa a lo largo de la guerra y la cual, dados sus intereses y su situación, figura entre las mas notables de nuestros protegidos en México, M. Joseph Slim no ha cesado de ofrecer testimonios sinceros de su amor por nuestro país, y sus regalos, constantemente reportados al Departamento, son ejemplares. De esta manera, quisiera recomendar muy especialmente a este Libanés con intereses en Djezzine, al M. Ponsot" (AMAE 410: 286). En enero de 1928, hubo una discusión entre M. Perier, Ministro de Asuntos Exteriores y el Ministro de Asuntos Exteriores de Francia sobre la posibilidad de condecorar a José Slim con la Cruz de Caballero de la Legión de Honor (AMAE 411: 4-5). ${ }^{40}$ El caso llego hasta el gabinete presidencial antes de ser descartado. El motivo del rechazo fue que, a pesar de de su devoción, lealtad, y generosidad a la causa francesa, are "absolutamente imposible conferir la Cruz de nuestra Orden Nacional a un protegido de Francia" (AMAE 411: 6).

Sin desalentarse, José Slim siguió ofreciendo regalos extravagantes a los franceses y felicitándolos por toda clase de logros y hazañas. ${ }^{41}$ En marzo del mismo año, el mismo caballero dono dos mil francos para aliviar el sufrimiento de las victimas de inundaciones en Argelia. Esta vez recibió agradecimientos incluso de parte del Gobernador de Argelia (AMAE 411: 44). Cuando Assolaut, Lefeire y Lotti cruzaron el Atlántico, M. Slim expreso su gran admiración (AMAE 411: 212). Quizás Don José podía darse el lujo de ser tan generoso porque no tuvo descendencia, sin embargo sus agasajos resultaron inversiones cosechadas por otros miembros de la familia. Es interesante señalar que, como deja claro la recomendación de Perier, los oficiales trataban a las familias como unidades leales o desleales, especialmente en el caso de los notables. El hecho de pertenecer a una unidad familiar era ya una señal de calidad moral, como hace evidente el censo de M. Charpentier. En este caso, Julián, hermano de José Slim tuvo seis hijos, entre ellos Carlos Slim, ahora no solo el hombre más rico de México, sino dueño de una de las más grandes fortunas en todo el mundo.

Aun dadas tantas y tan grandes muestras de aprobación e interés en la continuidad del mandato, es sorprendente que la elite migrante haya llegado al grado de pedir la colonización formal del Líbano:

México, 2 de mayo 1929

He sabido que la colonia libanesa de México se prepara a enviarle al gobierno francés una petición señalando la precariedad de su situación en este país y suplicando, para acabar con ella, que la republica del Líbano sea anexada a Francia en condiciones análogas a las que la unen a Argelia a la Metrópolis.

\footnotetext{
${ }^{40}$ La Orden es el mayor honor en Francia, establecida por Bonaparte en 1802.

41 "En la feliz ocasión de la llegada de Costes Lebrix que ha producido un efecto maravilloso en este país como ciudadano libanés les ruego aceptar diez mil francos para apoyar el desarrollo de la aviación francesa verdadera mensajera de ciencia y paz de nuestra Francia en el mundo. Respetuosamente. José Slim” (AMAE 411: 20).
} 
Bajo estas condiciones, los libaneses se convertirían en ciudadanos franceses y podrían recurrir a la protección de Francia bajo el mismo concepto que nuestros nacionales. ${ }^{42}$

¿Como entender que una población suplique ser colonizada? Queda claro que el patronazgo de Francia podía traer inmensos beneficios a los migrantes, y que una frontera movediza separaba aun a los más ilustres de los protegidos de los colonizadores. Era impensable reconocer a un mashrequis como francés. La cuestión de su ciudadanía, tan ambiguamente manejada a través de los documentos de identidad, adquirió una relevancia particular durante el proceso de los Comités de Reparaciones.

\section{El Comité Franco-MeXicANo DE REPARACIONES Y LA COMISIÓN DE REPARTICIÓN}

Las Convenciones Franco-Mexicanas que negociaron las reparaciones pagadas por el gobierno mexicano a los residentes franceses por daños y pérdidas sufridos durante los conflictos revolucionarios se llevaron a cabo en 1924 y 1930 . Inicialmente, parecía que todo andaba bien en cuanto a los migrantes. En un telegrama del primero de octubre de 1924, un oficial francés recomienda la difusión de las buenas noticias: “Considero que seria buena política llamar la atención, tanto de las poblaciones sirio-libanesas como de la prensa francesa, sobre el hecho de que, gracias a nuestro esfuerzos constantes, hemos obtenido del gobierno mexicano que la Convención coloque los intereses, tan considerables aquí, de nuestros 30,000 protegidos franceses, sobre pie de perfecta igualdad con los de los franceses" (AMAE 408:19). Para finales de diciembre de 1928 sin embargo, la situación se había complicado. La Cámara de Comercio Libanesa de México envío una petición a Monsieur Raymond Poincaré, Presidente del Consejo de Ministros, con copia a los Ministros de Finanzas y de Asuntos Exteriores (AMAE 411: 118). Se quejaban del maltrato del personaje que llevaba las negociaciones, a quien acusaban de corrupción y nepotismo, recalcando la injusticia de su desprecio por los intereses de la colonia.

Los intentos de negociación por parte de Francia a lo largo de 1929 no dieron muchos resultados. El 14 de enero, un reporte parece indicar una esperanza: “Al inicio de la sesión todas las reclamaciones eran consideradas como improcedentes. Hoy, una sentencia concerniente a un protegido francés reconoció la validez de las reclamaciones de los sirios y libaneses que hayan optado por una u otra nacionalidad” (AMAE 411: 128). Pero según la actualización de abril, el gobierno mexicano se había mantenido firme en su rechazo de la negociación francesa en nombre de los migrantes. La situación genero desazón entre los sujetos mandatarios:

Uno de los puntos a los que regresan... es la ineficacia de la protección que Francia puede extender a los miembros de las colonias libanesas en el extranjero. En lo que concierne a este país y hasta la entrada de México a la Sociedad de Naciones los hechos les daban desafortunadamente cierta razón, pues los gobiernos mexicanos pretendían no reconocer o no reconocían sino de mala gana a los sirios y los libaneses su carácter de protegidos

\footnotetext{
42 “Mexico, 2 Mai 1929. Il m’est revenu que la colonie libanaise du Mexique se prépare à adresser au gouvernement français une pétition signalant la précarité de sa situation dans ce pays et demandant, pour y mettre fin, le rattachement de la république du Liban a la France dans les conditions analogues a celles que unissent l'Algérie a la Métropole. Dans ses conditions les Libanais deviendraient des ressortisant francais et pourrainet se prevaloir de la protection de la France au meme titre que nos nationaux" (AMAE 411: 170; 181-182).
} 
franceses puesto que este derivaba de una institución internacional de la que México estaba excluido. Hoy la situación es otra y cuando esta legación le presento al gobierno mexicano las reclamaciones de los sirios y libaneses que sufrieron danos por causa de las guerras revolucionarias no se enfrenta más que a las penurias del presupuesto mexicano, pero ya no a objeciones de principio. Es por lo mismo por lo que se le da tanta importancia a llevar a cabo estas reclamaciones, pues si tiene éxito, una forma muy tangible de protección se le habrá extendido a los intereses sirios en México (AMAE 618: 175-176).

Por un lado, la intervención a favor de los migrantes representaba una oportunidad para legitimar el mandato francés sobre el Mashreq ante una población influyente y adinerada. Por otro, una vez que México se unió a la Sociedad de la Naciones, las autoridades estaban obligadas a reconocer el mandato de Francia, conferido por esa autoridad.

Cuando, en enero de 1937, las autoridades francesas al fin fueron notificadas de que el presupuesto Mexicano de ese año contemplaba una partida de 123.856 piastres 88 a titulo de las reclamaciones francesas; 118 piastres 82 para los franceses y 5.675 piastres 06 para los sirio libaneses, surgió el problema de su repartición (AMAE 618: 217-218). Como el gobierno mexicano se había rehusado a considerarlas, las reclamaciones de los migrantes nunca fueron sometidas al examen de las comisiones arbitrales Franco-Mexicanas (AMAE 618: 222). El 31 de julio de 1937, después de seis meses de negociaciones entre las subdirecciones de America y África, se publicó en el Boletín Oficial del Alto Comisariato en Beirut el decreto 108 L.R. del Alto Comisario, emitido el 21 de julio. El decreto determinaba la composición de poderes de una Comisión que repartiría las compensaciones otorgadas por el gobierno mexicano a los sujetos del mandato (AMAE 618: $217-218$ y 231$)$.

Esta Comisión Mixta de Repartición, compuesta por varios notables de la colonia libanesa en México y presidida por un oficial de la Legación de Francia en México se reunió en la Ciudad de México en 11 sesiones, del 12 de agosto hasta el 30 de Septiembre. La Comisión baso sus deliberaciones en un estudio llevado a cabo en febrero de 1932 por un oficial de la legación, M. Delage. Siguiendo sus recomendaciones, revisaron sesenta y tres casos de reclamaciones, de los cuales 32 fueron desechados (AMAE 618: 222, 272). De los 31 casos restantes, eventualmente otros 20 fueron invalidados. La mayoría de los rechazos y las invalidaciones se debían a uno de dos motivos- ya que los reclamantes hubieran llevado su caso a las autoridades mexicanas directamente, o que sus perdidas las hubieran causado violencias no reconocidas como 'encuentros armados'. 


\section{BIBLIOGRAFÍA}

ALFARO-VELCAMP, Theresa (2007). So far from Allah, so close to Mexico: Middle Eastern immigrants in modern Mexico. Austin: University of Texas Press.

AMAE. Archive du Ministère des Affaires Étrangères, correspondiente al tiempo del mandato francés sobre el Líbano que se encuentra en la Universidad de Kaslik, Jounieh, Líbano.

ANDERSON, Benedict (1991). Imagined communities: reflections on the origin and spread of nationalism. London; New York: Verso.

ASAD, Talal (1973). Anthropology \& the colonial encounter. London: Ithaca Press.

Betech DE Dueck, Bertha, y Germán DeHESA (2005). Rachelle: las voces del destino. México: Editorial Diana.

Brachet DE MÁRQuEZ, Viviane (1994). The dynamics of domination: state, class, and social reform in Mexico, 1910-1990, Pitt Latin American series. Pittsburgh: University of Pittsburgh Press.

BrANCHE, Jerome (2008). Race, colonialism, and social transformation in Latin America and the Caribbean. Gainesville: University Press of Florida.

BrodKIn, Karen (1998). How Jews became White folks and what that says about race in America. New Brunswick, N.J.: Rutgers University Press.

CARRERA, Magali Marie (2003). Imagining identity in New Spain: race, lineage, and the colonial body in portraiture and casta paintings. Austin: University of Texas Press.

CaStro-KLaREN, Sara (2010). Estudios transatlánticos: geo-políticas en una perspectiva comparada. En Rodríguez, Ileana y Josebe Martínez (eds). Estudios transatlánticos postcoloniales 1, Narrativas comando/ sistemas mundo: colonialidad-modernidad. Barcelona, México D.F. Anthropos/Universidad Autónoma Metropolitana.

Conquistador Anónimo (1938). Relación de Algunas cosas de la Nueva España, y de la gran ciudad de Temestitan, México. Escrita por un compañero de Hernán Cortés. Editado por E. O’Gorman y J. Fernández. San Angel, Mexico City: Alcancía.

Conquistador Anónimo (1986). Relación de la Nueva España, Espejo Navegante. Madrid: Ediciones Polifemo.

CORTÉS, Hernán (1985). Cartas de relación / Hernán Cortés; edición de Mario Hernández. Madrid: Historia 16.

DABBAH DE LIFSCHITZ, Linda (1989). “La Inmigración de los Judíos de Alepo”. Los Judios de Alepo en México ( L. Hamui de Halabe, ed.). Mexico City: Maguen David.

DEL VALLE, Ivonne (2011). "José de Acosta: entre el realismo político y disparates e imposibles, o por que importan los estudios coloniales.” Rodríguez, Ileana y Josebe Martínez (eds). Estudios transatlánticos postcoloniales 2, Mito, archivo, disciplina: cartografías culturales. Barcelona, México D.F. : Anthropos /Universidad Autónoma Metropolitana.

DÍAZ DE KURI, Martha, and Lourdes Macluf (1995). De Líbano a México: crónica de un pueblo emigrante. Mexico. 
DuSSEL, Enrique (2010). "Meditaciones anti-cartesianas: sobre el origen del anti-discurso filosófico de la modernidad”. Rodríguez, Ileana y Josebe Martínez (eds). Estudios transatlánticos postcoloniales 1, Narrativas comando/ sistemas mundo: colonialidad-modernidad. Barcelona, México D.F.: Anthropos/Universidad Autónoma Metropolitana.

EPPS, Brad. 2010. “Al sur y al este: la vertiente africana de los estudios transatlánticos postcoloniales”. Rodríguez, Ileana y Josebe Martínez (eds). Estudios transatlánticos postcoloniales 1, Narrativas comando/ sistemas mundo: colonialidad-modernidad. Barcelona, México D.F. : Anthropos/Universidad Autónoma Metropolitana.

FouCault, Michel (2007). Nacimiento de la biopolítica. Curso en el Collége de France (1978-1979). Buenos Aires, Fondo de Cultura Económica

GAONKAR, Dilip Parameshwar (2001). Alternative Modernities. Durham, NC: Duke University Press.

GILrOY, Paul (1993). The black Atlantic: modernity and double consciousness. Cambridge, Mass.: Harvard University Press.

GUALTIERI, Sarah (2009). Between Arab and White: race and ethnicity in the early Syrian American diaspora. Berkeley: University of California Press.

GUERRA, François-Xavier (1998). La sucesión presidencial de 1910: la querella de las élites, Fondo 2000. México, D.F.: Fondo de Cultura Económica.

GUERRA, François-Xavier, and Annick LEMPERIERE (1998). Los espacios públicos en Iberoamérica: ambiguedades y problema: siglos XVIII-XIV, Sección de obras de historia. México: Centro Francés de Estudios Mexicanos y Centroamericanos: Fondo de Cultura Económica.

GuILLAUMin, Colette (1980). "The idea of race and its elevation to autonomous, scientific and legal status". Sociological theories: race and colonialism. Paris: UNESCO.

Guillaumin, Colette. "Race and Nature: The System of Marks". Feminist Issues 2 (1) (1982)..

HALL, Stuart (1980). "Race, articulation and societies structured in dominance". Sociological theories: race and colonialism. Paris: UNESCO Press.

Hamui de Halabe, Liz, y Fredy Charabati (1989). Los Judios de Alepo en México. Mexico: Maguén David.

Hourani, Albert Habib, Nadim SHEHADI, y CENTRE fOr LEbANESE StudiEs (1992). The Lebanese in the world: a century of emigration. London: Centre for Lebanese Studies in association with I.B. Tauris.

ISRAEL, Jonathan I. 1975. Race, class, and politics in colonial Mexico, 1610-1670., Oxford Historical Monographs. London: Oxford University Press.

JACOBSON, Matthew Frye. 1998. Whiteness of a different color: European immigrants and the alchemy of race. Cambridge, Mass.: Harvard University Press.

KATZEW, Ilona. 2004. Casta painting: images of race in eighteenth-century Mexico. New Haven: Yale University Press.

KLICH, Ignacio. 2006. Árabes y judíos en América Latina: historia, representaciones y desafíos, 2006, at Ciudad Autónoma de Buenos Aires, Argentina. 
KLICH, Ignacio, and Jeff Lesser. 1998. Arab and Jewish immigrants in Latin America: images and realities. London; Portland, OR: F. Cass.

KuZNESOF, Elizabeth Ann. 1995. Ethnic and gender influences on 'Spanish' Creole Society in Colonial Spanish America. Colonial Latin American Review 4 (1).

LEÓN, Nicolas. 1924. Las Castas del México Colonial o Nueva España. Vol. 1, Noticias EtnoAntropológicas: Talleres Gráficos del Museo Nacional de Arqueologia, Historia y Etnografía.

LOMNITZ, Larissa Adler de, y Marisol Pérez Lizaur. 1987. A Mexican elite family, 1820-1980: kinship, class, and culture. Princeton, N.J.: Princeton University Press.

Macluf, Lourdes, and Martha Díaz de Kuri. 2002. De Líbano a México: la vida alrededor de la mesa. México.

MCCAA, Robert. "Calidad, Clase and Marriage in Colonial Mexico: the Case of Parral, 1788-1790". Hispanic American Historical Review 64 (3) (1984):477-501.

MentZ, Brígida Von (1988). Pueblos de indios, mulatos y mestizos, 1770-1870: los campesinos y las transformaciones protoindustriales en el poniente de Morelos. México, D.F.: CIESAS.

MignOLO, Walter (2010). "La colonialidad a lo largo y a lo ancho: el hemisferio occidental en el horizonte colonial de la modernidad". Rodríguez, Ileana y Josebe Martínez (eds). Estudios transatlánticos postcoloniales 1, Narrativas comando/ sistemas mundo: colonialidadmodernidad. Barcelona, México D.F.: Anthropos /Universidad Autónoma Metropolitana.

MÖrNER, Magnus (1970). Race and class in Latin America. New York: Columbia University Press.

MUNASINGHE, Viranjini (2001). Callaloo or tossed salad?: East Indians and the cultural politics of identity in Trinidad. Ithaca, N.Y.: Cornell University Press.

NoDIn Valdés, Dennis (1978). The Decline of the Sociedad de Castas in Mexico City, University of Michigan, Michigan.

NutinI, Hugo G. "Class and Ethnicity in Mexico: Somatic and Racial Consideration". Ethnology 36 (3) (1997):227-38.

NuTini, Hugo G., and Claudio Lomnitz. "The Wages of Conquest: The Mexican Aristrocacy in the Context of Western Aristocracies”. Ethnos. 62 (3-4) (1995):151.

O'CONNOR, Alice (2001). Poverty knowledge: social science, social policy, and the poor in twentiethcentury U.S. history, Politics and society in twentieth-century America. Princeton, N.J.: Princeton University Press.

PierRe-Charles, Gerard (1980). Racialism and Sociological Theories. In Sociological Theories; Race and Colonialism. Paris: UNESCO.

RoDRíGUEZ, Ileana (2004). Transatlantic topographies: islands, highlands, jungles, Cultural studies of the Americas v. 17. Minneapolis: University of Minnesota Press.

RoDRíGUEZ, Ileana, and Josebe MARTíNEZ (eds). (2010). Estudios transatlánticos postcoloniales 1, Narrativas comando/ sistemas mundo: colonialidad-modernidad. Barcelona, México D.F. : Anthropos /Universidad Autónoma Metropolitana. 
RODRÍGUEZ, Ileana, and Josebe MARTíNEZ (eds). (2011). Estudios transatlánticos postcoloniales 2, Mito, archivo, disciplina: cartografías culturales. Barcelona, México D.F.: Anthropos / Universidad Autónoma Metropolitana.

SAID, Edward W. (1978). Orientalism. New York: Pantheon Books.

ShOHAt, Ella y Robert STAM (2012). Race in Translation: Culture Wars around the Postcolonial Atlantic. NYU Press.

Twinam, Ann (1999). Public lives, private secrets: gender, honor, sexuality, and illegitimacy in colonial Spanish America. Stanford, Calif.: Stanford University Press.

Vargas, Pilar y Luz Marina Suaza (2007). Los Arabes en Colombia. Del rechazo a la integracion. Bogotá: Planeta.

WOLF, Eric R. "Aspects of group relations in a complex society: Mexico”. American Anthropologist 58 (1956):1065-1978.

YANKELEVICH, Pablo. “La política de expulsión de españoles indeseables en México (1915-1934)”. Revista de Indias 63 (228) (2003):495-518.

YANKELEVICH, Pablo. "Extranjeros indeseables en México (1911-1940). Una aproximación cuantitativa a la aplicación del artículo 33 constitucional”. Historia Mexicana 211 (2004) : 693-744.

YANKELEVICH, Pablo. "Explotadores, truhanes, agitadores y negros. Deportaciones y restricciones a estadounidenses en el México revolucionario". Historia Mexicana 228 (2008):1155-1200.

YounG, Robert. 1995. Colonial desire: hybridity in theory, culture, and race. London; New York: Routledge. 


\section{PRENDER DE GAJO: SuJETOS TRASPlantados E IMAGINARIOS GLOBALES EN LUISA FUTORANSKY}

Prender de gajo: transplanted subjects and global imaginaries in Luisa Futoransky

\section{MARTA SIERRA \\ KENYON COLLEGE, ESTADOS UNIDOS sierram@kenyon.edu}

Profesora titular en el Departamento de Lenguas y Literaturas Modernas en Kenyon College, Estados Unidos. Sus publicaciones versan sobre la relación entre la geografía y los estudios literarios, los estudios postcoloniales, los estudios de género y de la mujer, entre otros. Entre sus publicaciones se cuentan Geografías Imaginarias: Espacios de Resistencia y crisis en América Latina. Marta Sierra, editor, (Chile: Editorial Cuarto Propio, 2014); Postales femeninas desde el fin del mundo. El sur y las políticas de la memoria. Karina Bidaseca, Marta Sierra, (Buenos Aires: Ediciones Godot, 2012); Gendered Spaces in Argentine Women's Literature (New York: Palgrave-Macmillan, May 2012). Actualmente se encuentra trabajando sobre un proyecto titulado, On Mappings: Artistic and Literary Cartographies in Latin America, un estudio comparativo acerca del uso estético del mapa en el arte y la literatura.

\section{RECIBIDO: 17 DE ENERO DE 2017}

Resumen: La obra de Luisa Futoransky se construye como una "literatura menor" tal como la definen Deleuze y Guattari. Sus poemas y novelas emplean el collage como una forma de "subalternizar" el lenguaje literario a fin de cuestionar las grandes narrativas nacionales. Sus textos expresan un pensamiento de fronteras que está traspasado por inquietudes feministas. En el presente trabajo se analiza el modo en que la memoria transatlántica construye el lugar de la "subalternización" en los textos de Futoransky. Por medio de un análisis del uso del collage y otros mecanismos narrativos y poéticos, el trabajo propone leer la obra de Futoransky a partir de una estética desterritorializadora que se caracteriza por: la disolución del sujeto, el uso del collage, la cita como un mecanismo posmoderno; la estética desfamiliarizadora, el humor y el artificio, y la memoria como la fuente de una estética trasatlántica. El trabajo analiza el modo en que Futoransky explora las tensiones en la relación entre memoria y lugar a partir de un análisis de las tensiones entre lo global y lo local.

PALABRAS ClaVE: Futoransky, literatura menor, subalternización, desterritorlización.

\section{ACEPTADO: 22 DE JUNIO DE 2017}

ABSTRACT: The works by Luisa Futoransky are representative of what Deleuze and Guattari define as a "minor literature", a literature that questions the relationship between nation and literary canon. Her novels and poems use collage as a way to represent this "minor literature", a medium to create a subaltern voice in her literature. Hers is a literature that lives in the borderlands, experiencing the border from a feminist perspective. In this essay, I propose a reading of Futoransky's works from a transatlantic and subaltern perspective. Her aesthetic project breaks the bonds between language and territory. The main strategies analyzed here are: the dissolution of the subject, the use of collage and quotation as postmodern techniques to destabilize meaning, humor, and a poetic memory that challenges national borders. This paper analyzes how Futoransky explores the tensions between memory and place from the complexities of global and local dynamics.

KEYWORDS: Futoransky, Minor Literature, Subalternization, Deterritorialization. 
"Mi realidad es la de ser sapo de otro pozo, a perpetuidad" confiesa Luisa Futoransky (entrevista personal, 2007). Tanto su poesía como su narrativa nos revelan este constante estado de desubicación, en el mejor sentido de la palabra. Uno de sus poemarios se llama Prender de gajo, título que expresa de manera cabal la condición de sujeto trasplantado desde la cual Futoransky concibe su obra. Radicada desde hace más de 25 años en París, de sus publicaciones destacan sus novelas, Son cuentos chinos (1983), De Pe a Pa (1986), Urracas (1992) y El Formosa (2009); sus colecciones de poesía Trago fuerte (1963), El corazón de los lugares (1964), Babel, Babel (1968), Partir, digo (1982), La parca, enfrente (1995), Prender de gajo (2006), Seqüana barrosa (2007) y sus ensayos compilados en Pelos (1990). Armados a partir de una estética fragmentaria y profundamente escéptica, sus textos generan la primera impresión de ser posmodernos. Sin embargo, en sus irónicas referencias al modo en que megalópolis como París o Pekín coartan movilidades, o a cómo los desplazamientos globales en sus diferentes manifestaciones presentan itinerarios para sujetos de primera o segunda clase, la obra de Futoransky abre un espacio desde el cual interrogar situaciones contemporáneas de colonialismo y subyugación. Inderpal Grewal y Caren Kaplan han propuesto un análisis de la posmodernidad que considero iluminador de la propuesta estética de Futoransky. La postmodernidad produce "hegemonías dispersas", aquellas subjetividades múltiples que reemplazan el sujeto europeo unitario. Teorías como las del posmodernismo crítico de Nelly Richard, Grewal y Kaplan señalan que es en el seno de la cultura postmoderna y de sus complejas relaciones sociales, económicas y políticas, desde donde se puede llevar a cabo una crítica a los modelos hegemónicos de modernidad que han regido el imaginario global desde el siglo XVI. Los textos de Futoransky que aquí analizo despliegan frente a nuestros ojos la complejidad de las hegemonías dispersas de lo posmoderno y mi propuesta es leer sus textos desde un doble paradigma que incluya el registro de lo poscolonial y lo feminista.

Sus primeras novelas y colecciones de poemas se contextualizan en la tradición orientalista que se inicia con los modernistas en que la construcción cultural de lo "oriental” (mediada sin dudas desde París) se ofrece desde una perspectiva radicalmente latinoamericana. Pero en Futoransky vemos también algo nuevo: la voz y la mirada de la mujer de ese oriente que es tanto un espacio de liberación como de opresión. No hay así nada romántico en la mirada sobre China que arrojan novelas como Son cuentos chinos y De Pe a Pa. Todo lo contrario. Sus textos son narrativas desterritorializadoras, collages narrativos que ironizan sobre cualquier representación nostálgica del lugar. Sitiada, restringida por espacios burocráticos y laberínticos, el personaje de Laura que protagoniza ambas novelas, tiene una aguda consciencia de su “ubicación”, lingüística, espacial, genérica:

Los viajes y el prestigio que todavía tienen en parte para mí los lugares exóticos. Hasta que llego y no lo son más. Porque el lugar nunca está aislado en su exotismo, sino complicado en una infraestructura de eternas burocracias, lo que varían son los grados de densidad y asfixia; oficinas, trámites, casas de pensión, policía, permisos de residencia; esto no se puede y lo de más allá tampoco, lo mismo en todas partes (1991: 42-43).

En De Pe a Pa Futoransky transita el viaje inverso al de los textos modernistas hispanoamericanos: de Pekín a París. Instalada así en esta gran capital cultural, Futoransky reescribe el gran texto- 
ciudad de París, una referencia central de la escritura hispanoamericana desde el siglo XIX. Marcy Schwartz señala, acertadamente, que el "París de los exiliados", en el sentido de exilio que plasmó Cortázar en su ficción, es en Futoransky la experiencia “a flor de la piel” de la mujer o el migrante. París emerge así como "Un mapa al que se clavan las banderitas en carne viva de la gente que sigue andando por pasión de sobrevivencia, con la dureza del exilio a cuestas” (1986: 24).

La escritura de Futoransky se adscribe a lo que Deleuze y Guattari denominan una "literatura menor", textos que socavan las tradiciones estéticas de las "grandes" literaturas, aquellas con una tradición literaria largamente establecida, un canon con contornos nítidamente delineados (1986: 18). Esta literatura es, por excelencia, la literatura del fragmento y el collage, una serie de estratos y territorialidades dispersas, una textualidad producto del ensamblaje de tradiciones heterogéneas (Deleuze y Guattari1998: 4). Los textos del escritor polaco radicado en Argentina por décadas, Witold Gombrowicz, son la representación más clara de este proceso de minorización, de desterritorialización. No resulta desacertado leer a Futoransky dentro de esta tradición, ya que como en Gombrowicz sus textos canibalizan la lengua nacional, de la misma manera que piratean las construcciones territoriales sobre las cuales descansa la utopía del monolingüismo nacionalista. El lenguaje de estas literaturas menores se constituye como una memoria o una articulación fragmentada de los idiomas originales, que rasga palabras, distorsiona significados y descontextualiza. Los textos narrativos y poéticos de Futoransky se arman a partir de los fragmentos de un lenguaje coloquial y literario canibalizado. Este uso anómalo del lenguaje coloquial es deliberadamente sintomático de cómo su proyecto literario busca atacar la relación de contigüidad (altamente cómplice de la amnesia, diría seguramente Futoransky) entre lengua y memoria. Como lo señala la misma Futoransky: "Llegás con una lengua, escribís, soñás con su precipitado, pensás por oleadas en la lengua donde vivís. Superponés, yuxtaponés. Pero las articulaciones y bisagras son las de tu lengua. Cantar, contar, imprecar y blasfemar también” (entrevista personal, 2007).

Una de las estrategias estilísticas más recurrentes en Futoransky es el collage. Su escritura revela la profunda relación con la estética vanguardista que ya había empleado el collage no sólo debido a sus posibilidades lúdicas, sino también para expresar situaciones de cosmopolitismo y multilingüismo. Marjorie Perloff señala al respecto que el collage cuestiona las relaciones lógicas que estructuran el lenguaje cotidiano a través de la interrupción espacial y temporal de la representación artística: lo cotidiano se resignifica a partir de una "interpenetración” de realidades que pueden o no tener características análogas (1983: 42). "Grafomanías" son sus textos, podríamos decir citando a la voz narrativa de Son cuentos chinos, materiales dispersos que van armando el texto de la novela o del poema:

Lo que hacía conscientemente era acumular cuartillas de conversaciones que oía en el día, de pláticas telefónicas, de lo que veía en el periódico, de lo que me contaba María Josefa cuando volvía del trabajo. Era pura grafomanía: el objetivo era acumular un mínimo de cien cuartillas, ponerlas en la mesa para hacer, después una novela. Era tener una masa de material, como plastilina o barro, porque me di cuenta de que mi esterilidad de los últimos años, mi incapacidad de escribir, partía de una serie de equivocaciones, de la creencia errónea de que una novela surge de la inspiración, de que tienes una idea que te hace escribir una novela 
desde la primera línea hasta el final de un jalón. Eso no es cierto; una novela se escribe muchas veces. (1991: 125-126)

Sin embargo, y aunque los textos parezcan transmitir, a primera vista, la impresión de puro juego lingüístico, se esconde en este distanciamiento entre significante y significado, en esta “desterritorialización” diríamos siguiendo a Deleuze y Guattari, el intento consciente de desmantelar nociones de valor, de género, de canon. Los textos de Futoransky llevan a cabo este proceso por medio de una recurrente reflexión acerca del lugar de la escritora en los márgenes y los centros de las culturas múltiples que sus textos evocan. Caren Kaplan ha señalado acertadamente que la poética feminista, a la que sin duda se adscribe Futoransky, es un espacio de la imaginación en que las desterritorializaciones son múltiples: movimientos que van desde el adentro al afuera y al espacio liminal que evocan las sucesivas experiencias de desplazamiento que tiene la mujer (1996: 367-8). En esto la escritura de autoras como Futoransky nos reenvían a una larga tradición de autoras que producen sus textos en los intersticios de la cultura masculina, moviéndose entre usos hegemónicos del lenguaje y diferentes versiones específicas de marginalidad. Una marginalidad cultural, una "consciencia oposicional” que Chela Sandoval describe como cinética, móvil, transmutando diferentes posicionalidades en un determinado lenguaje y una tradición de conocimiento (2000: 143). El collage se carga así de connotaciones políticas en Futoransky, en el sentido más fundamental de la política a partir de una descentralización o "subalternización” del lenguaje narrativo y poético, "un pensamiento de fronteras" diríamos siguiendo a Walter Mignolo en Local Histories/Global Designs.

Es en este contexto que poemarios como Babel, Babel, Partir, Digo y Prender de gajo provocan la reflexión sobre las posibilidades de una estética subalterna en los imaginarios globales. Escrita "en bajel”, en el espacio intermedio del viaje entre territorios y lenguas, esta poesía encarna experiencias de migración desde lo que Jill Kuhnheim denomina la "memoria genérica" en la poesía hispanoamericana, una memoria que recicla representaciones del género social y poético para trazar historias de movilidad y residencia de la mujer en las metrópolis globales. Estos textos se escriben desde una perspectiva subjetiva nómade que cuestiona la memoria como un mecanismo totalizador y establece espacios de fuga, de desterritorialización. Lo femenino es entonces en Futoransky no necesariamente lo femenino genérico, sino un femenino que nos abre las puertas a distintas formas de marginalización, un femenino que como bien nos han enseñado los estudios poscoloniales, nos describe una escena de distintas subordinaciones, de distintas subalternidades.

Prender de gajo trabaja sobre la idea del collage y la memoria como poderosos mecanismos de producción estética. Esta colección puede leerse como un manifiesto poético a favor de una nueva geopolítica en los tiempos de una globalización en que Futoransky busca inscribir una experiencia genérica del espacio. Todas las características estéticas que he descrito anteriormente convergen en Prender de gajo: la disolución del sujeto en un texto desterritorializado; el uso del collage y las metáforas de viaje y desplazamiento espacial construidas sobre un uso posmoderno de la cita; la búsqueda de un nomadismo fuera de las limitaciones de género y ubicación social; la estética postmoderna desfamiliarizadora y el uso del humor y del artificio; y por último, las limitaciones de la 
memoria en la "cultura contemporánea de la amnesia" que describe bien Andreas Huyssen en Twilight Memories.

El lenguaje poético de Futoransky hace evidente la circulación de enunciados y sujetos propia de la economía del pastiche característica de la economía cultural global. Sin embargo, estas experiencias de circulación están marcadas por el límite y la subalternización. En "La coleccionista", el sujeto poético habla de "atesorar ciudades" y de coleccionar "souvenires espaciales" debido a su incapacidad de abrazar de cuajo la experiencia de los lugares que visita. El sujeto femenino percibe la movilidad y la "posesión del espacio" que el turismo y la movilidad global prometen, como ilusiones creadas por un mercado que, siguiendo las ideas de Futoransky en "Elogio del olvido", busca hacer de la memoria otro "souvenir" en una actitud que encubre la sintomática amnesia histórica colectiva que aqueja a las sociedades contemporáneas. Un buen ejemplo de esto es la plaza en el poema "Cartulina de Ljubljana”. En el mercado que se improvisa allí, en la capital de Eslovenia, migrantes bolivianos y mujeres convergen en una globalidad que les otorga el valor de mercado: "Chaparritos, los bolivianos en las ciudades del norte tocan el cuatro, el charango, la quena. De preferencia los fines de semana y cerca de los grandes almacenes. ¿Cómo llegaron con sus cuecas, sus agudeces, la quemazón de sus caras de otros vientos y sus ponchos al centro de Ljubljana?” (2006: 38). El título del poema, "Cartulina de Ljubljana" hace referencia a la construcción artificial del espacio como un paisaje, un bricolage o ensamblaje que caracteriza la estética de Futoransky y que, junto al título del poemario, Prender de gajo, refiere al sujeto desterritorializado que es "trasplantado", que existe en las brechas de encuentros espaciales, culturales y lingüísticos artificialmente creados por la economía global. El mercado es un sitio de encuentro de experiencias comunes de opresión, violencia o discriminación donde lo global y lo local se intersecan, temas que trabajan otros poemas de la colección como "Por mano propia", "Por mano ajena" o "El colega dentista".

Sin embargo, Prender de gajo es, más allá de una reflexión sobre las condiciones globales y la imposibilidad de recrear una experiencia cultural auténtica en este contexto, una búsqueda de la memoria personal y la reconstrucción de una genealogía. Como en sus textos narrativos, Futoransky acude al lenguaje coloquial para nombrar una nostalgia que, paradójicamente, se sitúa en el contexto de una reflexión sobre experiencias extremas de movilidad y desarraigo, como sucede en los poemas “Corte y confección” o "El patio y los abuelos". A la par de esta búsqueda que caracteriza como un "pescar" en la memoria lingüística universal, hay una exploración del espacio poético como un territorio o un mapa para llegar al "corazón de los lugares": "Hacer las cosas bien / determinar el punto de fuga/por el que el ojo elige/todo lo que no elige/llegar a buen puerto/al corazón de los lugares" (2006: 23).

Como en su texto previo, El corazón de los lugares, Prender de gajo es una exploración de cómo los lugares son sitios para la memoria lingüística y el poema se describe como un territorio o un mapa donde el sujeto poético busca reconstruir una conexión perdida con una experiencia "original": "escribo poemas, atlas / algunas glorietas / aquella filigrana del desasosiego" (2006: 23). En "Consignas al navegante", Futoransky extiende una invitación a tal exploración poética y espera que 
el lector pueda llegar a "puerto seguro": "Hacer las cosas bien,/ determinar el punto de fuga/por el que el ojo elige/todo lo que no elige/llegar a buen puerto/al corazón de los lugares” (2006: 23). En "París, desvelos y quebrantos", un título que refiere también al intento fallido de reconstruir una memoria territorial, el sujeto poético busca, una vez más, una conexión espacial como la que los exploradores europeos describen en sus relatos "Déjame déjeme entrar / ¿querés, quiere? / Soy Colón, Vespucci, una grieta / en la pared” (2006: 66). Sin embargo, el sujeto poético se halla confrontado con su propia imposibilidad ya que es, como el personaje de Raymond Isidore o "Picassiette" que Futoransky trabaja en el poema con el mismo título, una coleccionista de fragmentos de una oralidad evocada por la memoria de una lengua desterritorializada y nómade. En este poema, "Picassiette", la casa del sepulturero permite la evocación de la casa de la infancia en Santos Lugares, aunque ambos son espacios fantasmagóricos en donde resuenan los ecos de un lenguaje infantil y de una memoria imposible de reconstruir. Como en "Poética jueza de la mi sombra", el poema "Picassiette" revela la existencia de un sujeto "tácito", imposibilitado de su propio lenguaje: "Pero, a pesar mío/en esa oración/ ¿quién es el sujeto?/El tácito burro,/ ¿adelante,/para que aún se espante" (2006: 19).

La estética posmoderna del artificio y la nostálgica búsqueda de un lenguaje "original” representan formas en que la poesía de Futoransky encarna las tensiones entre "movilidad" y “ubicación” en el contexto de un mundo globalizado. Esta memoria que señala lo artificial, el recuerdo como un bricolage, un souvenir hecho de fragmentos del pasado, vincula lo propio y lo ajeno, lo presente y lo evocado. Este proceso de construir un collage sienta las bases de una nueva experiencia espacial que socava las conexiones ficticias entre residencia, territorio y lengua. Se trata entonces de un "estar en el mundo", un "ubicarse” en espacios móviles y discontinuos. Los contextos situacionales de la poesía de Futoransky remiten entonces a las "geografías posmodernas" que describe Caren Kaplan como constituidas en forma múltiple y atravesadas por experiencias sociales heterogéneas (1996: 182). Futoransky reorganiza así los espacios poéticos como mapas múltiples donde las experiencias de París, China, o Eslovenia se conectan con aquellas traídas por la memoria de los "pagos de la infancia”. Más aún, esta "economía poética” está pautada por la materialidad de los cuerpos y sus paradójicas situaciones de deseo y represión, su contextualización en geografías comunes que como vasos comunicantes nos reenvían a aquellos espacios de opresión que subsisten en el subsuelo del imaginario global. Anclada en la paradoja fluctuante entre la movilidad global y la aguda conciencia de los contextos, la estética políglota y repetitiva del collage cuestiona la ilusoria estabilidad de las identidades fijas.

La estética posmoderna del artificio y la búsqueda nostálgica de un lenguaje “original” son formas en que la poesía de Futoransky recrea las tensiones entre ubicación y movilidad. En esta nueva "economía poética”, y para usar el término de Kunheim que se refiere a la reorganización del espacio poético y que señala nuevas formas de espacialidad social, Futoransky inscribe las tensiones locales y globales en el espacio poético en donde se ubica el sujeto poético. La idea de "ubicación”-o en inglés "location"-es percibida como discontinua y móvil y en palabras de Kaplan, "discontinuous, multiply constituted, and traversed by diverse social formations" (1996: 182). El espacio poético 
fragmentario reorganiza la página como un nuevo mapa donde múltiples citas de un uso individual y colectivo del lenguaje convergen. Un buen ejemplo es el poema "Tiananmen, 4 de junio, 1989", donde la frase "la luna perdió siglos en Pekín esta mañana" se fragmenta y se reorganiza espacialmente en la página, entre movimientos de detención poética y progresión narrativa. Cada sección de la frase evoca fogonazos de la violencia y la represión que tuvo lugar en la plaza Tiananmen. El poema se transforma así en un memorial:

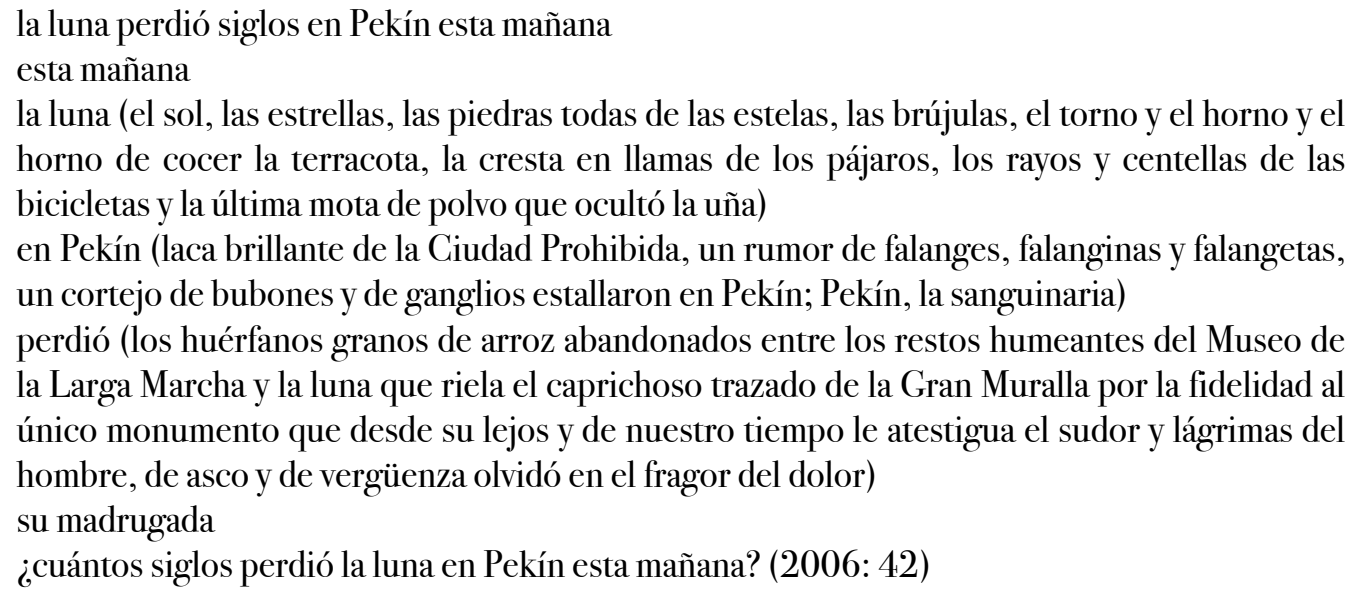

En "Elogio del olvido" Futoransky examina el intento inútil de inscribir la memoria en un lugar en particular, algo característico de la obsesión contemporánea por memoriales y monumentos. Al contrario, la memoria es dialógica, un mecanismo selectivo, una amalgama de enunciaciones múltiples, un collage histórico que incluye también una cuota saludable de olvido.

Los textos poéticos de Futoransky arman así un complejo entramado de dinámicas de memoria y olvido. Pero más aún, su estética responde a la función política de la memoria nomádica que bien describe Rosi Braidotti, una memoria que cumple el rol fundamental de cuestionar los relatos totalizadores. El nomadismo emerge en estos textos como una práctica crítica, una posibilidad de conocimiento radical, la rebelión de los conocimientos subyugados en los imaginarios globales (1994: 22). Una memoria "desterritorializadora" diríamos haciendo eco de la lúcida lectura de Ana María Forcinito sobre memoria y posfeminismo en América Latina, una memoria que establece representaciones subalternas que desestabilizan las territorialidades masculinas y sus vínculos con una política la memoria que es patriarcal, unilateral y excluyente (2004: 20).

La memoria activa en muchos de estos textos el archivo de los relatos de viaje. Futoransky lo reescribe desde la perspectiva que señala Mary Louise Pratt, como una contradicción de la ilusión de movilidad del imaginario global establecida por las narrativas metropolitanas favorables a la globalización: "El 'flujo' ejemplifica el lenguaje oficial, legitimador, de la globalización. No es un término neutro, sino un término con valor positivo que se usa desconectado de cualquier dimensión ética. Un lenguaje sin cima ni fondo, que permite la duplicación de las horas de trabajo, la explotación de los niños, la disminución de la ingestión de alimentos, el infanticidio...” (2003: 39-40). Estos poemarios pueden leerse así a la luz de los relatos que analiza Pratt, relatos de las víctimas de tragedias 
contemporáneas de dilemas de exclusión y marginalización. Prender de gajo conecta a sujetos, espacios y enunciados en una secuencia poética que señala la historia común de opresión y una búsqueda de una memoria común de subalternidad en las metrópolis globales. La "poética nómade” de Futoransky es, para usar las palabras de Francine Masiello, una expresión móvil y plurilingüe que vincula narrativas de migración y las distintas formas de opresión social y genérica que implican (2001: 42). La "economía poética" de Futoransky reescribe un mapa territorial donde los cuerpos son espacios en que se inscriben historias comunes de deseo y represión. Aunque sus poemas no se refieren directamente a la experiencia de autoritarismo militar en Argentina, su poesía cuestiona la noción de territorio y sus connotaciones genéricas. Futoransky construye así un cuerpo colectivo que inscribe experiencias de deseo femenino así como también formas de opresión social y genérica en narrativas previas de migración y residencia sobre el “oriente”, París y Argentina. Sus textos poéticos ilustran la aparente contradicción entre la movilidad y el nomadismo y la dolorosa conciencia de la posicionalidad.

Francine Masiello caracteriza las dislocaciones lingüísticas y las referencias constantes a la traducción que se hallan en los textos de Futoransky cuando señala que los sujetos de sus textos se hallan "traducidos" permanentemente por los discursos oficiales (2001: 48). La traducción y el poliglotismo se cargan de contenido político en la poesía de Futoransky. La metáfora quizás más acabada de este proceso es el barco, un tropo fundamental en el poemario Babel, Babel. Pero a diferencia de aquellos viajeros intelectuales que fundaron la tradición literaria latinoamericana desde finales del siglo XIX y que Beatriz Colombi ha estudiado en extenso, el barco refiere aquí a una subjetividad nómade que cruza las tormentosas aguas de los mares globales y nunca arriba a "puerto seguro". En este poemario recurre la imagen del barco en disolución, constantemente atacado por agentes externos. La subjetividad poética se disuelve en Futoransky y en muchos casos se transforma en una función de los grandes sistemas, de las estructuras lingüísticas y culturales a los que se halla expuesta.

Podríamos pensar que en gran medida la disolución del sujeto que se percibe en muchos de los textos de Futoransky tiene que ver con su predilección por la estética vanguardista. En cierto modo, sus textos subvierten las convenciones de lo que Peter Bürger denominó, refiriéndose a los movimientos de vanguardia, como la “institución del arte” y la figura del autor. En su ensayo clásico sobre la vanguardia, Bürger compara el arte vanguardista y el clásico señalando que para el primero, el arte no representa una totalidad, un todo orgánico, sino un montaje de fragmentos: "para el vanguardista... el material sólo es material; su actividad no consiste principalmente en otra cosa más que acabar con la 'vida' de los materiales, arrancándolos del contexto donde realizan su función y reciben su significado" (1987: 133). Tanto la producción como la recepción en la vanguardia manifiestan así una "impersonalidad", como lo señala Mignolo en un ensayo temprano, ya que el autor es sólo la evocación de “una voz” (1982: 134).

Pero leída desde un marco feminista y poscolonial la estética de Futoransky adquiere otras connotaciones. Esta aparente supresión del sujeto tiene que ver con una perspectiva poética que fluctúa entre distintas localidades y subjetividades y fundamentalmente con un sujeto que, como 
señala Masiello, se halla constantemente traducido, interpelado, atravesado por los discursos oficiales. Esta despersonalización adquiere nuevas connotaciones en poemas como "Racconto personalísimo desde un zoo perturbador" donde quien habla es una boa constrictora que, desde su jaula, observa como un turista chino le saca fotos junto a una mujer parada junto a ella. El poema concluye con una confesión desesperada de la serpiente: "el sol se derramaba en mi cabeza donde no había sitio para otra cosa que el griterío de los animales y los pájaros más extravagantes, temibles y escandalosos, desplegaban sus artimañas para que me quedara allí, con un cartel, mi nombre en latín y un mapa para que los cazadores supieran dónde podrían hallar otros de mi especie" (s/p). Este poema enuncia desde un lugar de vulnerabilidad que es común en muchos de los textos de Futoransky. Aunque la disolución de la subjetividad apunta, sin lugar a dudas, a la operación de volver "menor" a su proyecto poético, de hacer tributo a lo mínimo como una estética de revelación de aquello que, de otro modo permanece invisible en el canon, hay en Futoransky el consciente deseo de revertir la perspectiva, de mostrar lo que ven otros ojos, los de aquellos cuyas miradas permanecen en los márgenes del orden global.

Junto con la subjetividad occidental, sus textos deconstruyen ciertas cartografías estéticas y arman otras. En una escritura que emplea símbolos de la experiencia transatlántica, Futoransky aborda legados del colonialismo europeo y los filtra desde una mirada latinoamericana que distorsiona y reescribe ciertas narrativas nacionales sobre el tema. Su obra se mueve entre los recovecos de las geografías globales y una intensa necesidad de posicionarse en una localidad que se presenta cada vez más como efímera y elusiva. El poemario Partir, digo es sintomático al respecto. El título es ya un compromiso a una enunciación desde el momento de un abandono: de la tierra natal, del lugar de residencia, del lenguaje originario. Unos "Vitraux del exilio" diría Futoransky, en los que el nombrar es ineficaz y en los que el mapa es, en el mejor sentido Borgeano, un mapa en ruinas: "Toda la eficacia de los nombres / que trabajosamente la imaginería construyó para fascinarte / se derrumban silenciosos:/un rico cementerio de cenizas/eso es hoy, tu geografía” (1982: 13). Es además un mapa cuyos límites son transicionales, un mapa líquido, ubicado en una geografía de mares que conectan Buenos Aires, Europa, Japón, China. Pero es también un mapa que revela la situacionalidad del sujeto poético, la paradójica conciencia de los límites aún en el profundo desarraigo, manifestada de manera magistral en la imagen de la inmovilidad de la página en blanco con la que concluye uno de sus poemas: "mis universos son mucho más reducidos entrarían en una / pequeña hoja de block cuadriculado de una sola línea” (1982: 52).

Pero se trata-también de nuevos mapas lingüísticos, de mapas que se escriben en las "bisagras de la lengua", en las brechas entre lenguaje poético y lenguaje cotidiano. Futoransky vuelve aquí a las reliquias de un lenguaje infantil conservadas en la memoria, un lenguaje trasplantado a las ciudades globales. Lo coloquial, lo "menor", invadiendo y "ninguneando" el lenguaje de lo poético. En Futoransky se percibe una contradicción latente entre dos actitudes frente al lenguaje. Por un lado, su deseo de reconectarse con un lenguaje que evoque una experiencia hecha de sensaciones visuales, táctiles, olfativas. Pero al mismo tiempo, muchos de sus poemas revelan mapas complejos, mapas de dominación y de desarraigo, y como elabora su último poemario Seqüana Barrosa, mapas que son, 
como el cauce del río Sena, laberintos barrosos de múltiples encuentros y desencuentros lingüísticos y culturales. Son finalmente, los mapas paradójicos del sujeto poscolonial, un sujeto ubicado tanto en el adentro como en el afuera de las relaciones de dominación que describen sus poemarios, las nuevas situaciones de colonialismo que traza la esfera global. Son mapas que refutan la aparente visibilidad de lo global, mapas que vuelven opacas las geografías de los encuentros culturales de nuestra compleja realidad contemporánea.

Pensando en las paradojas en las que se encuentra la mujer de color en la sociedad norteamericana, la geógrafa Gillian Rose ha planteado la existencia de “mapas paradójicos” en el feminismo. Para Rose el espacio de resistencia del feminismo sólo puede pensarse como un espacio multidimensional, contingente y cambiante, un espacio paradójico que contrariamente a lo que sucede en el mapa bidimensional, acepta la coexistencia en un mismo lugar del centro y el margen, el adentro y el afuera. El porqué de la propuesta de Rose puede explicarse a partir de su cuestionamiento del modo en que ciertas disciplinas, en particular la geografía, construyen lo femenino como lo Otro. Lo femenino y lo masculino son posiciones discursivas, señala Rose, determinadas por la mirada de lo que Donna Haraway denomina como el "sujeto maestro" (identificado como blanco, burgués, heterosexual y masculino) (1993: 6). Un feminismo crítico sólo será posible, dice Rose, si se construyen cartografías de la "plurilocalidad” que vayan más allá de las ubicaciones trazadas por los binarismos de género y la lógica territorial del sujeto maestro (1993: 151).

La poética del espacio que entraman los textos de Futoransky en mucho semejan la propuesta de Gillian Rose. En sus textos se potencia lo que Nelly Richard denomina como la "lectura destotalizadora" que potencia "lo femenino como interrogante" (1994: 31-32) y donde la "escritura minorizada" cuestiona espacios de pertenencia a la ordenanza de los géneros (Olea 1997: 101). Desde las bisagras de la lengua, Futoransky examina el "lenguaje como un lugar de lucha" (Hooks 1990: 145), un espacio que traza puentes y encuentra puntos en contacto entre distintos mapas de dominación y lucha en los imaginarios globales. Y podríamos pensar en la imagen de la diosa Seqüana, río abajo por el Sena en su embarcación con forma de pato. Dificultado por el lodo del río, su viaje es lento, a veces infructuoso. El proyecto poético de Futoransky nos ofrece un panorama de estos itinerarios insólitos por recovecos impensables de los imaginarios globales. Desde el adentro, desde el afuera, desde el centro, desde el margen, los textos de Futoransky nos invitan a un viaje por cartografías poéticas del desarraigo y la memoria rebelde, un viaje reparador, necesario, pero también fundamentalmente dificultoso. 
Marta Sierra. Prender de gajo: sujetos transplantados...

\section{BIBLIOGRAFÍA}

BraidotTI, Rosi (1994). “Introduction: By Way of Nomadism”. Nomadic Subjects. Embodiment and Sexual Difference in Contemporary Feminist Theory. New York: Columbia University Press: $1-39$

BürGER, Peter (1987). Teorías de la vanguardia. Barcelona: Ediciones península.

Colombi, Beatriz (2004). Viaje intelectual. Migraciones y desplazamientos en América Latina (1880-1915). Rosario: Beatriz Viterbo.

Deleuze, Giles y GuatTaRI, Félix (1986). "What is a Minor Literature?." Kafka. Toward a Minor Literature. Minneapolis, Minnesota: University of Minnesota Press: 16-27

Deleuze, Giles y GuatTari, Félix (1998). A Thousand Plateaus. Capitalism and Schizophrenia. Minneapolis, London: University of Minnesota Press.

ForCinito, Ana (2004). Memorias y nomadías: géneros y cuerpos en los márgenes del posfeminismo. Chile: Editorial Cuarto Propio.

Futoransky, Luisa (1968). Babel, Babel. Buenos Aires: Ediciones La Loca Poesía.

FutOransky, Luisa (1982). Partir, digo. Valencia: Editorial Prometeo.

Futoransky, Luisa (1986). De Pe a Pa o de Pekín a París. Barcelona: Editorial Anagrama.

FUTORANSKY, Luisa (1990). “Deterritorializations”. The Nature and Context of Minority Discourse. (Abdul R. JanMohamed y David Lloyd, eds.) New York, Oxford: Oxford University Press: $357-368$

FUTORANSKY, Luisa (1991). Son cuentos chinos. Buenos Aries: Planeta.

FUTORANSKY, Luisa (2000). "On Gnosis and the Imaginary of the Modern/Colonial World System" y "Border Thinking and the Colonial Difference." Local Histories/Global Designs. Coloniality, Subaltern Knowledges, and Border Thinking. Princeton, New Jersey: Princeton University Press.

FUTORANSKY, Luisa (2005). “In Search of the Nomad's Shadow.” Luisa Futoransky y su palabra itinerante. (Esther Gimbernat González, comp.) Uruguay: Ediciones de Hermes Criollo: 41-55.

Futoransky, Luisa. Prender de gajo. Madrid: Calambur, 2006.

FutOransky, Luisa (2007). “Elogio del olvido.” Presentación en Kenyon College.

FuTORANSKY, Luisa. “Entrevista personal” Noviembre 2007.

FUTORANSKY, Luisa (2007) . Seqüana barrosa. Jerez, España: EH Editores.

GreWAL, Inderpal y Caren KAPLAN (1994). Scattered Hegemonies. Postmodernity and Transnational Feminist Practices. Minneapolis: Minnesota University Press.

HooKs, Bell (1990)."Choosing the margin as a space of radical openness.” Yearning: Race, Gender and Cultural Politics. Boston: South End: 145-53

KaPLAN, Caren (1996). Questions of Travel. Postmodern Discourses of Displacement. Durham and London: Duke University Press. 
Kunnheim, Jill (2004). Textual Disruptions. Spanish American Poetry at the End of the Twentieth Century. Austin, Texas: University of Texas Press.

Masiello, Francine (2001). The Art of Transition. Latin American Culture and Neoliberal Cities. Durham and London: Duke University Press.

MignOLO, Walter. "El poeta en la lírica de vanguardia”. Revista Iberoamericana 118-119 (1982): 131-148.

OlEA, Raquel. "La mujer ha salido al escenario. Es suya la palabra. Poesía chilena de los ochenta." Hispamérica 26 (76-77): 1997. 101-112

PerlofF, Marjorie (1983). “The Invention of Collage.” Collage. (Jeannine Parisier Plottel). New York: New York Literary Forum: 5-47.

PRATT, Mary Louise (2003). “¿Por qué la virgen de Zaporan fue a Los Ángeles? Reflexiones sobre la movilidad y la globalidad”. Sujetos en tránsito: (in)migración, exilio y diáspora en la cultura latinoamericana. (A. Fernández Bravo, F. Garramuño y S. Sosnowski) Madrid, Buenos Aires: Alianza Editorial: 29-57

RICHARD, Nelly (1994). "De la literatura de mujeres a la textualidad femenina". Escribir en los bordes. Congreso Internacional de literatura femenina latinoamericana. (Carmen Berenger et al, comp.) Chile: Editorial Cuarto Propio: 25-32

Rose, Gillian (1993). Feminism and Geography. The Limits of Geographical Knowledge. Minneapolis: Minnesota University Press.

Sandoval, Chela (2000). "U.S. Third World Feminism: Differential Social Movement" Methodology of the Oppressed. Minneapolis: Minnesota University Press: 40-63.

SCHWARTZ, Marcy (1999). "Paris under Her Skin.” Writing Paris. Urban Topographies of Desire in Contemporary Latin American Fiction. Albany, New York: State University of New York Press: 115-143. 


\title{
TANGO Y LUNFARDO:
}

\section{UN ESTUDiO TRANSATLÁNTICO SOBRE LA IDENTIDAD ARGENTINA}

Tango and Lunfardo: a Transtlantic study about Argentinian Identity

\author{
MARÍA CLAUdia ANDRÉ \\ Hope COLLEGE, ESTADOS UNIDOS andre@hope.edu
}

Profesora de estudios latinoamericanos en Hope College, Michigan. Ha publicado reseñas, entrevistas y artículos en revistas académicas nacionales e internacionales. Recientemente ha publicado Dramaturgas argentinas de los años 20 (Editorial Nueva Generación, 2010) y co-editado: The Woman in Latin American and Spanish Literature: Essays on Iconic Characters (McFarland, 2012) y Escrituras extremas: Feminismos libertarios en América Latina (Biblos, 2016).

RESUMEN: Nacido en el arrabal bonaerense, producto de múltiples influencias socio-culturales, el tango argentino indudablemente se encuentra entre los estilos de música que mejor logran transmitir el pensamiento y el sentir de un pueblo. Este ensayo examina la función y el efecto de la experiencia transatlántica de la inmigración europea como una fuerza que moldeó y transformó la cultura fundacional argentina, redefiniendo no sólo su perfil racial, sino también gran parte de su panorama intelectual, social y cultural. Empleando como lente crítico los estudios poscoloniales y transatlánticos, el presente ensayo analiza la evolución de la música y del baile del tango con el fin de definir la compleja red de referentes que conforman la identidad del país.

PALABRAS ClaVE: tango, identidad, transatlántico, poscolonial, inmigración, subalterno, lunfardo.
ABSTRACT: Born in the slums of Buenos Aires, a product of multiple socio-cultural influences, the Argentine tango is undoubtedly among the music styles that best conveys the thought and the feeling of the people. This essay examines the role and effect of the transatlantic experience of European immigration as a force that shaped and transformed Argentina's foundational culture, redefining not only its racial profile, but also much of its spiritual, social, and intellectual landscape. Through the critical lens of postcolonial and transatlantic studies, the current essay analyzes the evolution of tango music and dance aiming to determine the complex network of referents that conform the country's identity.

KEYWORDs: tango, identity, transatlantic, postcolonial, immigration, subaltern, lunfardo. 
No tengo el berretín de ser un bardo

Chamuyador letrao ni de spamento; Yo escribo humildemente lo que siento Y pa' escribir mejor lo hago en lunfardo.

CELEDONIO ERNESTO FLORES

Se dice que un argentino es un español que habla castellano con acento italiano, se viste como un inglés y se considera francés. Un dicho semejante señala que, mientras que los mexicanos descienden de los aztecas y los peruanos de los incas, los argentinos descienden de los barcos. La definición de José María Cantilo -Ministro de Relaciones Exteriores en 1914- sobre la identidad del argentino quizás sea la más apropiada:

De España recibimos nuestra sangre y nuestra religión. De Francia y de Gran Bretaña y de los Estados Unidos recibimos la dirección doctrinal de nuestras instituciones democráticas. A nuestra Madre Patria le debemos la base de nuestra literatura; la cultura francesa ha contribuido enormemente a la formación de nuestra vida intelectual, mientras que Italia y Alemania han contribuido importantes aspectos de nuestra evolución (James1953: 14).

Empleando como marco crítico los estudios poscoloniales y transatlánticos, el presente ensayo intenta dilucidar el papel y el efecto de la inmigración europea como una fuerza que moldeó y transformó la cultura fundacional argentina, redefiniendo no sólo su política y economía, sino también gran parte de su formación intelectual, social y cultural. Por otra parte, me interesa examinar, mediante el análisis de la música y el baile del tango, y el lunfardo -jerga del ciudadano porteño-, los procesos de representación y formación cultural experimentados tanto por los inmigrantes como por toda la sociedad argentina. Con ello, no intento hacer un detallado estudio del tango o del lunfardo, sino de poner en relieve -mediante el estudio de la producción cultural de la música y lenguaje porteños- la compleja red de referentes y discursos que conforman la identidad de una región, de un país o una nación. Una cartografía del tango desde sus orígenes -como un medio de expresión popular- a su configuración actual - como una commodity cultural- nos servirá para ilustrar la injerencia del discurso poscolonial y la construcción de Otredad en cuanto a la articulación y la definición de la identidad argentina.

\section{GOBERNAR ES POBLAR}

Hacia 1880, intelectuales y estadistas, inspirados por la ideología del positivismo y bajo lema de "orden y progreso," promueven en el Río de la Plata los postulados centrales del liberalismo económico en aras del desarrollo del comercio internacional. Recordemos que las élites, equiparaban el progreso económico y social no sólo al ingreso de capitales extranjeros, sino también "a los modelos europeos que representaban la civilización en contraposición a los símbolos nacionales o populares percibidos como retrógrados y amenazantes” (King, 1984: 8). 
Los presidentes Juan Bautista Alberdi (1810-1884) y Domingo Faustino Sarmiento (1811-1888), ${ }^{1}$ inspirados por el desarrollo y efectos económicos de la corriente inmigratoria de Europa a los Estados Unidos, consideraban que la Argentina podría competir en los mercados internacionales y transformarse en un país próspero con la ayuda de inmigrantes europeos, cuyos valores, tradiciones y buenos hábitos laborales se hallaban bien establecidos. El sueño de Alberdi era "europeizar América", o sea, transformar el perfil de la sociedad argentina a través de una inmigración masiva acompañada de una política de urbanización mediante las cuales se reviviría el espíritu de la civilización europea. “¿Queremos plantar y alimentar las nociones de libertad de los ingleses, la apreciación del arte y de la cultura de los franceses y la laboriosidad de de los hombres de Europa y de los Estados Unidos? Entonces traigamos ejemplares vivos de esos atributos a nuestras costas y dejemos que esas cualidades echen sus raíces aquí" (2002: 95). ${ }^{2}$

Abrazados por el afán de hacer l'America, entre 1860 y 1920, más de 6 millones de europes con aptitudes y profesiones diferentes se establecieron en la Argentina (75\% hombres y $12 \%$ mujeres), la mayoría de Italia (42\%) y España (33\%), y en menor cantidad de Francia, Inglaterra, Europa Central y del Este y del Medio Oriente (Montaldo y Nouzeilles, 2002: 158). El doctor José Ramos Mejía ${ }^{3}$ evalúa el impacto de la inmigración en la ciudad de Buenos Aires en los siguientes términos: "Los inmigrantes inundan todo: Los teatros de segunda y tercera clase, las plazas y paseos, las iglesias (porque son italianos son gente devota y pacífica). Llenan las calles, las plazas, los asilos, los hospitales, los circos y las tiendas. Trabajan en todo tipo de trabajos y profesiones, aunque su conducta es un poco extraña y elemental” (2002: 84).

La grandiosa ambición de Alberdi y Sarmiento de europeizar a la población a través de la inmigración masiva, no obstante, fue un fracaso como proyecto transnacional puesto que la mayoría de los europeos que migraban a la Argentina carecían la disciplina y los atributos anticipados por ambos políticos, o eran campesinos analfabetos con pobre educación. Por su parte, los europeos que intentaron radicarse en el interior del país se encontraron con leyes proteccionistas que preservaban el dominio de las mejores y más fértiles tierras bajo el control de los terratenientes. Al darse cuenta que el suelo productivo permanecería a manos de los estancieros ofreciendo sólo unas escasas oportunidades de trabajo, ya sea como inquilinos o campesinos, miles de inmigrantes italianos y españoles retornaron a la ciudad de Buenos Aires para unirse a la clase trabajadora, mientras que unos 170.000 aproximadamente se volvieron a Europa (Castro, 1991: 29).

\footnotetext{
1 "Gobernar es poblar", la famosísima frase de Juan Bautista Alberdi está contenida en sus "Bases y puntos de partida para la organización nacional”, obra que, en gran medida, marcó la orientación del texto constitucional argentino de 1853. Ver también Civilizacion y barbarie - texto también conocido como Facundo- donde Sarmiento se refiere a la vida de Juan Facundo Quiroga (1788-1835), un líder de la provincia de La Rioja. Sarmiento emplea la figura de Quiroga para representar la barbarie de los gauchos, los indígenas y del régimen despótico de Juan Manuel de Rosas (1793-1877), quien fuera gobernador de Buenos Aires de 1829 a 1835.

${ }^{2}$ Roberto Fernández Retamar hace un excelente estudio sobre las distintas percepciones sobre la construcción de la identidad latinoamericana entre Sarmiento y José Martí en "Caliban: Notes Towards a Discussion of Culture in Our America" en Theoretical Debates in Spanish American Literature, editado por William D. Foster y Daniel Altamiranda (Nueva York: Garland Publishing, 1997).

3 José Ramos Mejía (1849-1914) fue un médico, escritor y diputado nacional argentino.
} 
En 1871, de los abarrotados e insalubres conventillos surgió una nueva clase social conformada por inmigrantes europeos, campesinos y porteños provenientes de la clase trabajadora, y con ellos se gestaron diversos códigos socio-culturales entre los cuales se destacan hoy en día el baile y la música del tango, y el lunfardo como jerga característica de la región rioplatense ${ }^{4}$.

\section{ORÍGENES Y DESARROLLO DEL TANGO}

El tango nació en los Altos de San Pedro, un barrio habitado por estibadores y otro personal portuario proveniente de distintos países de Europa y del interior del país. Entre 1865 y 1895, la fusión de varios ritmos musicales "eventualmente formaron lo que sería luego identificado como tango" (Collier, 2002: 196). Los orígenes y la etimología de la palabra tango y su relación con el lunfardo son aun controversiales; no obstante, a simple vista, su entorno multicultural es un perfecto ejemplo de la interacción de las comunidades y de las culturas que se desarrollaron en la Argentina a principios del siglo diecinueve. La mayoría de los críticos concuerda que tanto el tango, al igual que el lunfardo, nacieron en los conventillos y caseríos de los barrios bajos del Río de la Plata entre Argentina y Uruguay ${ }^{5}$.

Para algunos tangólogos, la palabra tango es de origen africano y significa "baile africano"; otros señalan que la palabra tango se refería originalmente a los tambores y a los bailes de los negros montevideanos $^{6}$. Varios autores consideran que los esclavos africanos, en lugar de pronunciar la palabra tambor, decían "tango"7. Etimologistas sugieren que el término fue usado en España y luego, con el intercambio transatlántico entre Europa y América Latina, fue a su vez empleado en varios

\footnotetext{
${ }^{4}$ Además del tango y el lunfardo, otras manifestaciones culturales de la relación transatlántica entre Argentina y Europa se destaca la influencia de la zarzuela, la opereta y la ópera bufa en el llamado "grotesco criollo", derivado del sainete criollo y del grotesco italiano por el dramaturgo Armando Discépolo (1887-1971) a principios de siglo. El pensamiento filosófico y la literatura española de la Generación del 27 (Antonio Machado, Pío Baroja, Ramón del Valle Inclán, y Azorín) así como la de la Generación del 14 (José Ortega y Gasset, Gregorio Marañon y Juan Ramón Jiménez) ejercieron una gran influencia en los grandes autores argentinos como Leopoldo Lugones, Roberto Payró, Jorge Luis Borges y Macedonio Fernández entre otros. Cabe señalar que una de las colaboraciones transatlánticas de mayor envergadura e influencia en el mundo intelectual y literario fue la de la argentina Victoria Ocampo (1890-1979) con la creación de SUR. En 1932 con la ayuda de Waldo Frank y Ramón Ortega y Gasset (entonces director de Revista de Occidente en España), Ocampo fundó Sur, revista cultural que circuló por más de 40 años y que publicó obras de Gabriela Mistral, Virginia Woolf, María Rosa Oliver, Alfonso Reyes de México, Driew de la Rochelle, Roger Callois (traductor quien dirigió la rama de Sur en francés Lettres Francaises) y Jorge Luis Borges entre otros.

${ }^{5}$ Consultar El tango: historia de medio siglo 1880-1930 de Francisco García Jiménez (Buenos Aires: EUDEBA, 1964); 60 años de tangos de Juan Carlos Marambio (Buenos Aires: Editorial Freeland, 1973); El libro mayor del tango de Jorge Sareli (Mexico: Editorial Diana, 1974) y Bajo el signo del tango, de Enrique Cadícamo Buenos Aires: Corregidor, 1983).

${ }^{6}$ George Reid Andrews The Afro-Argentines of Buenos Aires (Madison: 1980).

${ }^{7}$ De acuerdo con Simon Collier, el término es ciertamente africano, "puede encontrarse como el nombre de un lugar en Angola y Mali". Otra teoría es que "la palabra fue asimilada por los esclavos africanos de los traficantes portugueses. En ambos, casos cruzó el Atlántico con el tráfico de esclavos (1992: 95-96). Robert Farris Thomson en Tango: The Art History of Love (New York: Vintage Books, 2006) concuerda que las influencias más significativas fueron las de los grupos africanos provenientes del Congo y de Angola y que fueron estos grupos de provinieron otras palabras como y que fueron estos grupos de provinieron otras palabras como malambo (baile masculino que incluye zapateado, acompañado de guitarra y bombo), milonga, canyenque (movimiento cadencioso o puede significar arrabal o barrio porteño) y tango (63).
} 
países latinoamericanos a fin de siglo para designar varios tipos de bailes, canciones y fiestas comunales, y que la palabra deriva del antiguo español castellano, específicamente de la palabra "tañer" o "tangir", el verbo tocar un instrumento. Tangir deriva del verbo latino tango, tetigi, tactum, o tangere (Farber, 2001: 2). A pesar de sus múltiples significados y de su incierta etimología, la palabra tango se encuentra asociada principalmente con el baile urbano argentino.

Otro tema de controversia entre estudiosos del tango es su desarrollo histórico como baile social. Algunos aseguran que los antecedentes inmediatos del tango son la milonga y el baile afro rioplatense "candombe" -o candomblé- un ritual y un tipo de música que acompaña una ceremonia religiosa. ${ }^{8}$ David. W. Foster señala que los compadritos y los rufianes italianos inmigrantes pobres quienes vivían en los puertos fueron los primeros en empezar a bailar el baile que los africanos llamaban "tango" y que, tratando de burlar sus movimientos, lo incorporaron a la milonga, un tipo de baile criollo de pareja que tiene sus orígenes en la habanera o habañera (ritmo cubano) (Forster, Loclkhart y Lockhart, 1998: 122). Aparte de su similitud con la habanera, el tango comparte el cruce de piernas con la milonga, el vértigo de los fandangos (de origen moro-hispano) y la influencia rítmica del candombe (baile afro-argentino) $)^{9}$.

Los primeros grupos instrumentales en tocar el tango eran los tercetos (bandas de tres piezas) con violín, guitarra y flauta; no obstante, hacia el 1900, con la llamada italianización del tango, los músicos italianos incluyeron piano y bandoneón ${ }^{10}$. La coreografía del tango es muy simbólica de la cultura de arrabal en el sentido de que el baile, la figura, las posturas y los gestos reflejan algunos de los manierismos y la conducta del compadrito porteño ${ }^{11}$. El tema principal del tango, como un baile de parejas, es el dominio del hombre sobre la mujer a través del contacto físico muy sugestivo del acto sexual, donde la mujer tiene el rol pasivo y el hombre el activo. El baile en sí es una declaración de machismo, confianza y aserción sexual ${ }^{12}$. Originalmente, el tango, era bailado entre hombres; pero, a

\footnotetext{
${ }^{8}$ Camdomblé es una religión Africana practicada en Brasil, específicamente en Salvador, Bahía. Se practica también en Uruguay, Argentina, Venezuela, Colombia, Panamá; en Alemania, Italia y España.

${ }^{9}$ Con ello, notamos que la identidad nacional de la Argentina de hoy comienza a forjarse desde abajo en la relación y el transatlantismo a que da lugar la necesidad económica y la convivencia en la pobreza. Para mayor información sobre la construcción de identidad nacional y otredad consultar de Ramón Grosfoguel en este mismo volumen "Las migraciones coloniales del Caribe a Estados Unidos y Europa Occidental: colonialidades diferenciadas en cuatro centros del sistemamundo."

${ }^{10}$ Existen varios tipos de tangos, aunque las tres distinciones más comunes son: tango milonga (básicamente instrumental con un ritmo muy marcado), tango canción (siempre vocal con acompañamiento musical) y el tango romanza (ya sea instrumental o vocal con un texto romántico y melódico). Los instrumentos de cuerda (violín y guitarra) y de aire, como la flauta, datan de la antigüedad (1000 AC) y son provenientes de Asia. Se estima que estos instrumentos fueron llevados de Asia a Europa donde, a través de los siglos, fueron refinados al gusto europeo.

11 Como examina Foster, "la palabra compadrito es uno diminutivo de compadre, un término que refleja la homosexualidad en la sociedad de estos hombres, considerando que las esferas de control social desde los niveles más altos del gobierno hasta las instituciones barriales, estaban basadas en la relación de amistades y interdependencia entre los hombres" (187). Ver de Foster, "Nation as Idea: Tango, Buenos Aires, Borges," en Imagination Beyond Nation: Latin American Popular Culture, editado por Eva P. Bueno y Terry Caesar (Pittsburg: University of Pittsburg Press, 1998): 169-192.

12 Para un estudio del tango y la sexualidad ver de David W. Foster “Tango and Urban Sexual Regulation” en Buenos Aires: Perspectives on the City and Cultural Production. (Florida: University Press of Florida, 1998): 52-82.
} 
medida en que éstos comenzaron a bailar con prostitutas y bailarinas pagas, la coreografía se hizo más sensual y físicamente explicita, inclusive algunas de las letras eran obscenas.

El gran escritor argentino, Jorge Luis Borges, fue uno de los primeros escritores en realizar un serio estudio del fenómeno del tango bailado entre hombres “ ...lo que observé de niño en Palermo, y años después, en la chacarita y en Boedo, es que en las esquinas de las calles, los hombres bailaban entre sí porque las mujeres del pueblo no querían participar en tal obscenidad” (395). ${ }^{13} \mathrm{La}$ escandalosa reputación del tango se produjo por su asociación con los burdeles. "Allí los hombres y las prostitutas cruzaban las barreras maritales y raciales al ritmo del tango" (Tobin 196). ${ }^{14}$ Hacia 1911, los marineros y los hombres de la clase alta quienes - generalmente visitaban los burdeles y otros lugares donde se tocaba y bailaba tango- lo llevaron Francia vía el puerto de Marsella. ${ }^{15}$ Bal Bullier de Montparnasse y Moulin de la Galette fueron los primeros dance halls donde el tango fue tocado y bailado en pareja. A pesar de que la élite argentina condenaba la música y el baile, los europeos, al no entender el significado de las letras de tango, se sintieron atraídos por la sensualidad el baile. Junto con el can-can, el tango fue popular en los cafés y los cabarets de Montmartre -el barrio popular para los artistas, prostitutas, bohemios y desempleados- y de la ciudad luz, el tango se extendió al resto de Europa, y luego, hacia Nueva York.

Las interpretaciones del tango argentino tanto en Europa como en los Estados Unidos, según Marta Savigliano eran exageradas y mal interpretadas resultando, a veces, en una combinación grotesca de elementos ${ }^{16}$. Por ejemplo, como la Argentina era famosa por el gaucho -trabajador ruraly el tango, muchas de las actuaciones combinaban el baile y la cultura exhibiendo a los bailarines vestidos con indumentaria gauchesca. Resulta significativo que, una vez legitimado en Europa, el tango obtuvo el reconocimiento de la clase alta porteña. Tras su éxito internacional, el tango fue inmediatamente adoptado por los argentinos como un baile chic importado de Francia. En 1920, de hecho, el tango se había transformado en la expresión máxima de la expresión de la cultura popular y en un símbolo de la cultura ciudadana porteña. Aparte de los salones de baile, las estaciones radio, las publicaciones musicales y los gramófonos, el tango se extendió desde los barrios pobres hasta las áreas mas acaudaladas de la cuidad a través del organillo o organito, un instrumento de mano tocado en su mayoría por inmigrantes o discapacitados que deambulaban por la cuidad en compañía de niños

\footnotetext{
${ }^{13}$ Posiblemente, un motivo por el cual el tango era en sus inicios bailado entre hombres, fuese que hacia 19815, en la ciudad de Buenos Aires, los hombres superaban a las mujeres por mas de 100,000 (Collier 1992: 95).

${ }^{14}$ Ver además Daniel Vidart, Teoría del tango (Montevideo: Ediciones de la Banda Oriental, 1964). Como indica Collier, al igual que el jazz en Nueva Orleans, existe una conexión entre los burdeles y el tango, como el espacio donde las clases altas y bajas se reunían para apreciar la música. "Para la clase alta, era una medio de escapar la restricciones sociales. Pero para los menos afortunados, las letras del tango expresaban la alienación de la vida urbana a la vez que los pasos del tango proveían una forma de relajación" (1964: 196).

15 Como examina Marta Savigliano "La urbanización y industrialización tenían una fachada, la de los hombres ricos mirando a los mujeres pobres. Estos hombres pagaban para abrazar a las mujeres pobres dado que no les era posible abrazar a las mujeres de su propia clase social sin compromiso" (1995: 31).

${ }^{16}$ Ver de Marta E. Savigliano, Tango and the Political Economy of Passion. Boulder: Westview Press: 1995.
} 
o de un animal recolectando dinero por su música ${ }^{17}$. A pesar de su gran popularidad, muchos encontraron el tango inmoral. El Papa Pío X se encontraba entre sus principales detractores y llegó a prohibir el baile del tango por relajar la moral de la sociedad católica. El Kaiser de Alemania también prohibió a sus oficiales bailar el tango en público. Por otra parte, entre sus muchos admiradores estaban el rey Alfonso XIII de España, quien junto con el duque de Windsor, tomó clases de tango ${ }^{18}$.

Jezy Placzkiewicz escribe que el tango fue un gran éxito en Polonia, donde llegó antes de la primera guerra mundial a través de los discos, los periódicos y la radio provenientes de los grupos de tango radicados en España, Francia y Berlín. Muchas grabaciones siguieron a su performance inicial como en "El último tango", una opereta de Jacoby de 1913 con música de E. Deloire, 1919, interpretada por Karlol Hanusz y Tango du reve de Edouard Malderen (1922), interpretada por Stanislaw Ratold. Después de 1925, el tango obtuvo un mayor reconocimiento cuando Zygmunt Wiehler compuso Nie dzis to jutro (Si no es hoy será mañana) para Hanka Ordonowna un popular cantante del momento (Placzkiewicz) ${ }^{19}$. Hacia 1929, el tango hace furor cuando Jerzy Petersburski compone “Oh, Donna Clara”, un tango-milonga, con letra en alemán y en inglés. La canción fue cantada por varios artistas de renombre internacional del momento como Al Jolson, Henry Varny y Edith Piaf. La mayoría de los compositores y letristas polacos eran, en realidad eran de origen judío y, según Placzkiewicz, "llevaban la carga de muchos años de la ocupación y la influencia rusa. Estas circunstancias pueden tener peso, en alguna medida, en sus elecciones artísticas y en su predilección por las tonalidades nostálgicas de la música" 20 .

En los años 40, el tango continuó su viaje hacia el este desde París hasta el Japón donde fue llevado por el Baron Tsunayoshi “Tsunami” Megata en 1946. Megata había aprendido a bailar el tango en el cabaret "El Garrón”, durante su estadía de la capital francesa. De vuelta en Japón, abrió una escuela de baile, donde no sólo enseño a bailar el tango a la clase alta japonesa, sino que también publicó "Un método para bailar el tango argentino". Carlos Manus indica que, como Megata trajo los tangos grabados por Manuel Pizzaro -como por ejemplo, “Le Veritable Orchestre Argentin” - entre otras orquestras francesas, los japoneses pensaron que el baile era de origen francés. Fue Noriko Awaya quien para entonces promovió el tango del estilo japonés, y sólo una década más tarde había más de cincuenta orquestras japonesas de tango en este país. Además de Megata, los europeos y los

\footnotetext{
${ }^{17}$ Según Héctor Luci, entre 1903 y 1910, solamente la gente rica tenía acceso a los gramófonos importados de Alemania, y se producían más o menos un promedio de 350 discos cada año, 100 de esos discos eran tangos. Ver de Luci (Alemania, la Guerra, el disco...el Tango” en “Todo tango: Crónicas <www. Todotango.com/spanish/biblioteca/crónicas/ Alemania.html>

${ }^{18}$ Coincidentemente, tanto el Duque de Windsor de Inglaterra como el rey Alfonso XIII de España fueron hombres progresistas quienes renunciaron su poder real. El Duque de Windsor abdicó el 11 de diciembre de 1936 para poder casarse con la norteamericana divorciada Wallis Simpson, mientras que Alfonso XIII tras el fracaso político de su monarquía liberal, abandonó España voluntariamente y se refugió en Italia hasta su muerte.

${ }^{19}$ Wanda (1927), un tango popular, cuenta la historia de una chica polaca vendida a un piringundín (club de baile de barrio) en Argentina, donde conoce a un guitarrista quien le promete un futuro mejor si se marcha con él (Placzkiewicz).

${ }^{20}$ En http://www.todotango.com/spanish/biblioteca/cronicas/tango_en_polonia.asp. El tango de Peterburski To Ostatnia Niedziela (The Last Sunday) (1933) con letra de Zenon Friedwald hizo furor en la Unión Soviética, al punto que era considerado una canción originalmente rusa.
} 
norteamericanos intervinieron como "activos traductores y mediadores en las circulación y la ascensión del tango alrededor del mundo" (Savigliano, 1995: 173). Durante la segunda guerra mundial, el tango reemplazó el jazz cuando fue prohibido por el gobierno japonés.

Hacia 1914, el tango había triunfado como un fenómeno mundial. Había fiestas de tango, vestidos color tango, tango salón, etc. ${ }^{21}$ En Nueva York, la renombrada pareja de Mr. y Mrs. Vernon Castle promovían el baile recomendándole a los interesados: "Tome sus clases, si es posible, de alguien que haya bailado profesionalmente en París, porque hay allí tantos buenos bailarines que cualquiera que haya bailado (y le hayan pagado) en París debe ser un buen bailarín"22. Según Jeffrey Tobin, la producción del Los cuatro j̈̈netes del apocalipsis (1900-1921) inició la fiebre en Hollywood. En la película, "Rodolfo Valentino representa a un argentino de la clase alta quien aprende a bailar el tango en los barrios bajos de la Boca, y luego se gana dinero como gigoló en París bailando el tango con las esposas de hombres ricos" (1998: 97).

Sin embargo, no fue el glamour hollywoodense ni la fama de Valentino lo que promovió el tango alrededor del mundo, sino la agraciada figura y melodiosa voz del compositor y cantante Carlos o Carlitos Gardel. Carlos Romualdo Gardés (1890-1935) es considerado el creador de la interpretación vocal del tango y su nombre, generación tras generación, se ha mantenido como referente y un símbolo de la cultura tanguera argentina. Nacido en Toulouse, Francia, Gardel es un europeo que llega al país como inmigrante a edad muy temprana con su madre, María Marta Gardés, quien lo entrega en adopción a cuatro años de edad. Gardel, también apodado "el morocho", inició su carrera como cantante folklórico deambulando por los barrios del sur de la cuidad de Buenos Aires. Fue aquí donde adquirió fama junto con varios payadores ${ }^{23}$ del momento. Gardel fue ganando reconocimiento al formar un dueto con José Razzano. Ambos cantantes hicieron del tango un éxito popular grabando más de cien discos para RCA Victor. La fama de Gardel se internacionalizó en sus viajes a Europa y los Estados Unidos donde además de cantar, actuó en varias películas producidas por los estudios Paramount. Cuatro fueron producidas en Francia y cinco en Nueva York. "Todas, excepto una, fueron hechas en castellano con excepción de Big Broadcast de 1935, producida por Adolf Zukor, con la actuación principal de Bing Crosby y George Burns" (Castro 1991:142)24. Gardel murió en un accidente aéreo en Medellín, Colombia, con ello quedando inmortalizado como figura icónica del cantante de tango argentino.

\footnotetext{
21 J. Alberto Marinas, "El tango, apunte histórico". El tango, Aug 2001. Web. <http//:esto es/tango/Historia/ historia.htm>.

22 Consultar "La enseñanza del tango en Nueva York en 1914," por Mr y Mrs.Vernon Castle en Todo tango: Las Historias, el baile publicado en "Club de tango, 48 (Mayo-Junio 2001). ‘www.todotango.com/spanish/biblioteca/ cronicas/ny 1914.asp > (2)

${ }^{23} \mathrm{El}$ payador es un cantante popular que improvisa un recitado en rima, cantado y acompañado de una guitarra. El contrapunto es una payada a dúo y es un tipo de duelo o reto cantado, en el cual los payadores deben contestarse mutuamente y payando las preguntas de su opositor.

${ }^{24}$ La radio Broadcasting Company llevó a Gardel a Nueva York, donde hizo historia al grabar un programa por teléfono con Buenos Aires. Una de sus primeras películas, Luces de Buenos Aires (1931), fue filmada en París. Luego, Paramount Pictures realizó otras películas para el mercado hispanohablante.
} 
Un factor considerable a la popularidad y reconocimiento de Gardel fue su inducción como un símbolo representativo del peronismo. En la década los 40, el gobierno populista de Juan Domingo Perón legitimó el estatus social y participación política de las clases bajas y de los nuevos inmigrantes italianos, franceses y polacos. Gardel era un símbolo del la masculinidad argentina del mismo modo que la esposa de Perón, Evita (1919-1952), ${ }^{25}$ representaba un símbolo de feminidad. De hecho, existen varias semejanzas entre estos personajes: ambos eran hijos ilegítimos de familias provenientes de la clase baja quienes a temprana edad se mudaron a Buenos Aires en busca de fama. Ambos ganaron reconocimiento y éxito como figuras radiales y estrellas de cine, y al igual que los personajes melodramáticos que representaban con frecuencia, los dos murieron en forma prematura, permaneciendo eternamente jóvenes en los registros de la cultura popular argentina (Castro 234). Donald S. Castro indica que "Carlos Gardel fue la epítome del porteño y probablemente será el símbolo de Buenos Aires en forma humana” (239).

En 1950, el compositor argentino pianista y bandoneonista Astor Pantaleón Piazzolla (1921-1992) revivió el furor del tango en los Estados Unidos y en Europa. Al contrario de Gardel, Piazzolla nació en Mar de Plata, Argentina, y de niño se mudó con padres a Nueva Jersey. En 1938, volvió a Buenos Aires donde comenzó su carrera como artista y compositor de tango. Frustrado de la falta de oportunidades, en 1954, se radicó a Francia becado por el conservatorio de música de París para estudiar con Nadia Boulanger, una de las más afamadas maestras de música del momento. En 1958, en Nueva York, comienza a desarrollar nuevas técnicas innovadoras, entre ellas, la fusión del tango y jazz. ${ }^{26}$ El estilo libre de Piazzolla habría ganarle las críticas de los amantes del tango más conservadores y la admiración de las nuevas generaciones de tangueros. Como indica Foster, Piazzolla "Introdujo la disonancia, armonía acromática, y un amplio espectro de ritmos al tango, creando un sonido que era difícil para de aceptar, para la mayoría de los puristas, y de tocar, para muchos músicos" (Forster, Lockhart y Lockhart, 1998: 126-127)27. La visión única de Piazzolla ha influenciado e inspirado mucho de la música contemporánea, ganándole junto con Gardel el estatus de icono cultural.

El tango ha vuelto a Hollywood en años recientes con varias películas taquilleras como: Scent of a Woman con Al Pacino como personaje principal (Perfume de mujer, 1992); True Lies con Arnold

\footnotetext{
${ }^{25}$ María Eva Duarte de Perón (1919 -1952), popularmente conocida como Evita, era hija ilegítima de Juan Duarte y María Juana Ibarguren, ambos de ascendencia vasca.

${ }^{26} \mathrm{El}$ tango y el jazz se asemejan en muchos aspectos. Ambos nacen a principios de siglo en los bajo fondos de la ciudad (Buenos Aires y Nueva Orleans respectivamente) y son producto del sincretismo cultural y musical entre Europa y las Américas. Los orígenes del jazz y la etimología de la palabra jazz, al igual que el tango, es incierta; no obstante, en su estudio El Jazz: De Nueva Orleans al Jazz Rock, Joachim-Ernst Berendt lo define como: "una forma de arte musical que se originó en los Estados Unidos mediante la confrontación de los negros con la música europea. La instrumentación, melodía y armonía del jazz se derivan principalmente de la tradición musical de Occidente. El ritmo, el fraseo y la producción de sonido, y los elementos de armonía de blues se derivan de la música africana y del concepto musical de los afroamericanos." (695). En El Jazz. De Nueva Orleans al Jazz Rock (México DF: Fondo de Cultura Económica, 1994).

${ }^{27}$ En Foster, Fitch y Lockhart, Performing Arts: Culture and Customs of Argentina, 126-127. Carlos Gardel y Astor Piazzola se conocieron en 1934 en los estudios Paramount durante la filmación de El día que me quieras. Piazzolla no solo actúo como extra en la película de Gardel, sino que en varias oportunidades hizo intérprete en su visita a los Estados Unidos.
} 
Schwarzenegger (1992); Evita con Madona en el rol de Eva Peron (1995) y Moulin Rouge (2001) y también en Tangos, l'exil de Gardel (producción franco-argentina, 1985), The Tango Lesson (producción británica-francesa-argentina-japonesa y alemana, 1997), y Tango (musical francoespañol, 2000). La experiencia transatlántica/transultural del tango es hoy en día exportada alrededor del mundo y mediatizada a través del Internet, las redes sociales, Hollywood, y las industrias multinacionales de cine y de música, las cuales se encargan de perpetuar la pasión por la música y el baile como un producto de consumo internacional, aceptado y consumido ampliamente afuera de las fronteras de Argentina.

\section{LUNFARDO: COMO SOCIOLECTO DEL SUBALTERNO}

El estudio de los sociolectos subalternos y su relación con el desarrollo de la identidad nacional de argentina es relevante dado que nos ayuda a entender el rol de decisivo de la inmigración europea y del intercambio intercultural en la formación de la argentinidad (Castro, 1991: 16). Percibido como símbolo social de la clase baja; el lunfado (lenguaje de las lunfas, lunfardos o ladrones), es una jerga híbrida; un léxico de los rufianes y matones urbanos que se transformó en el "estandarte ligústico de los marginados y de los porteños que vivían en los conventillos de Buenos Aires” (Washbaugh, 1998: $18)^{28}$. A pesar de sus orígenes, el tango y el lunfardo no se encuentran relacionados puesto que el tango, en la opinión de José Gobello, tiene sangre africana y el lunfardo sangre italiana. Gobello, sin embargo, concuerda con la opinión de Foster en que posiblemente las raíces italianas del cocoliche (como una interlingua, mezcla del español y el italiano) pueden preceder al lunfardo, notando que el compadrito comenzó a italianizar a español al mezclar el genovés y el napolitano con otros lenguajes europeos y otros términos coloquiales y regionales. Foster define el cocoliche como un tercer lenguaje entre el español y el italiano "dado que estos dos lenguajes se encuentran históricamente relacionados y son usualmente inteligibles, los inmigrantes podían hacerse entender rápidamente, y por ello perdieron la iniciativa de aprender el castellano" (1998: 38).

Mientras que algunos lingüistas creen que el léxico se relaciona con actividades delincuentes de los barrios conurbanos, otros consideran que el cocoliche y el lunfardo son sociolectos resultantes de varios términos introducidos por los inmigrantes al principio del siglo. Palabras como punga (robo), bufoso (revolver), candinflero, cafisho y cofiolo (proxeneta) o gayola (cárcel), son términos ampliamente usados en la jerga del porteño; sin embargo, no todo el vocabulario del lunfardo -de aproximadamente seis mil palabras- tiene con este tipo de connotación o relación ${ }^{29}$. José E. Clemente, en su excelente estudio "Estilística del lunfardo" (1968), examina que varios términos de

\footnotetext{
${ }^{28}$ Para un estudio científico de lunfardo como jerga criminal ver de Enrique R. del Valle, Lunfardología (Buenos Aires: Editorial Freeland, 1966).

${ }^{29}$ De acuerdo con la definición de Gobello, Lunfardo es un ladrón. El término deriva del lombardo natural de la región de Lombardía al norte de Italia. Además, del Romanesco, Lombardo, un ladrón y del Siciliano o lummardu. Consultar el Nuevo diccionario lunfardo (Buenos Aires: Corregidor, 1999), p. 160. También consultar de Gobello, El lenguaje de mi pueblo (Buenos Aires: A. Peña Lillo, 1974).
} 
vocabulario de lunfardo derivan del lenguajes europeos, como por ejemplo de francés: boulin (en lunfardo bulin por habitación); canne, (cana, policía); refriodi (enfriar, asesinar); del italiano: vigiar (vichar, espiar); jettatura (yeta, mala suerte); tamanco ( tamango, zapato) o del inglés: off side (orsi, fuera del lugar); sándwich (sanguche, emparedado); o inclusive de lenguajes indígenas, como del Quichua: puchu (pucho, cigarrillo); naupaco (naupas, antiguamente) ${ }^{30}$. Las primeras descripciones escritas del lunfardo datan de 1879 y se hallan relacionadas con la vida criminal porteña; no obstante, en años posteriores, con la aculturación de los inmigrantes europeos, el lunfardo se transformó gradualmente en un lenguaje poético y fue infiltrándose en la jerga popular (Castro, 1991: 17).

Aparte de su uso regional, el cocoliche trascendió por medio del sainete, una obra de un acto satírica, derivada de la opereta española del siglo diecinueve: la zarzuela. El sainete se transformó en un vehículo melodramático para representar la vida porteña, especialmente la experiencia de los inmigrantes de la clase baja.

El sainete explotaba los estereotipos locales del inmigrante europeo y el espacio del conventillo a través de la sátira y del humor; con ello, los criollos eran los compadritos; los gallegos (la gente de Galicia), eran los almaceneros avaros y las mucamas; los italianos eran los vendedores de fruta o los dueños de los conventillos; los vascos eran los lecheros; y los judíos eran los criminales. (Castro 2002: 46). Los sainetes más populares hasta hoy son Tu cuna fue un conventillo (1920) y El conventillo de la Paloma (1929), ambos de Vacarezza. Don Chicho (1933) de Alberto Novión (1881-1937), provee un perfecto ejemplo del cocoliche: "CHICHO: E te parece lindo esto? Uno aquí, viviendo contando lo chentavo, e vo atirando la plata a patada, a la calle como se nosotros foeramo hijo de Anchorena-Onzoete! Lo que yo debería hacere e agarrare no palo e arrompértelo al lomo, e tambiene a eso perro rasposo que me atrajiste" $(2002: 206)^{31}$.

Aparte del cocoliche y del lunfardo, el francés y el italiano ejercieron una gran influencia en las letras del tango. Algunos títulos representativos son: San Souci, Belgique, y Tres Symphatique (Enrique Delfino), Madame Yvonne (Enrique Cadícamo), Domani (Carlos Vivián), y Yira-Yira (Enrique Santos Discépolo). Canzoneta de Erma Suárez y Enrique Lary es uno de los tantos tangos que refleja este bilingualismo:

Cuando escucho "Oh sole mío"

"Senza Mamma e senza amore",

Siento un frío acá en el cuore.,

Que me llena de ansiedad...

Será el alma de mi mama,

Que dejé cuando era niño.

Llora, llora, Oh sole mío;

\footnotetext{
${ }^{30}$ Jose E. Clemente, "Estilística del lunfardo,” en El lenguaje de Buenos Aires (Buenos Aires: Emecé Editores, 1968): 62.

31 [CHICHO: parece lindo esto? Uno aquí viviendo contando los centavos y vos tirando la plata a patadas, a la calle si nosotros fuéramos hijos de Anchorena-Unzué! Lo que yo debería hacer es agarrar este palo y rompértelo en el lomo y también a ese perro rasposo que trajiste.]
} 
Yo también quiero llorar!

En la idealización de Buenos Aires como cuidad utópica en el imaginario del inmigrante es también una constante en la lírica del tango. Tal vez, como ha notado Foster, esto se debe a que "La cuidad no existe independientemente de sus habitantes ni su habitantes existen independientemente de la cuidad" (1998: 15). Originalmente, los espacios públicos a los cuales hacía referencia el tango eran aquellos sitios frecuentados por gentes de mal vivir o por los inmigrantes, como por ejemplo, los salones de baile, burdeles, cabarets, bares, hospitales y asilos, conventillos, estaciones de policía y centros de detención. Por otra parte, muchos tangos hacen referencia a distritos, calles, y barrios de Buenos Aires, al punto que es posible hacer un inventario de la cuidad basándonos en las letras de el tango (Foster 1998 :60). Mi Buenos Aires Querido de Alfredo Lepera y Carlos Gardel, Puente Alsina de Benjamin Tagle Lara, Esquinas porteñas de Sebastián Piana y Homero Manzi son algunos de los tangos que cantan a esta cuidad. En "Barrio de tango" de Manzi y Aníbal Troilo, se ilustra la zona sur de la cuidad, Nueva Pompeya en la intersección de las calles San Juan y Boedo:

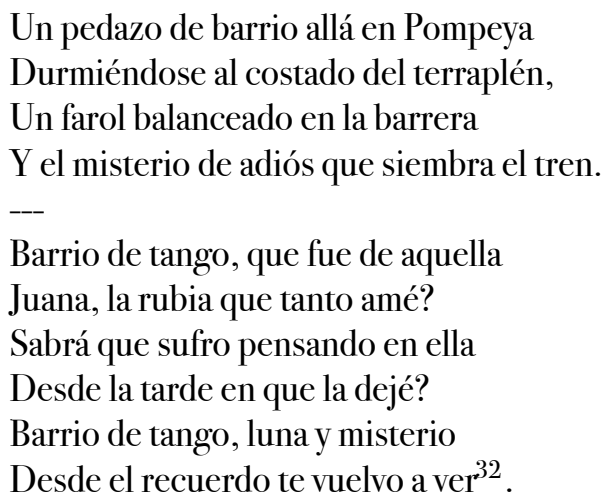

\section{CONCLUSIONES}

Como se examina en esta breve cartografía, el tango y el lunfardo además de reflejar la identidad del porteño bonaerense y, hasta cierto punto, parte de la idiosincrasia del argentino, son un claro ejemplo de las influencias y de los procesos de (trans)formación cultural generada, a principios del siglo veinte por medio del intercambio transatlántico entre América Latina, Europa, Estados Unidos y Asia.

El intercambio transatlántico entre Argentina y Europa desde principios hasta mediados del siglo veinte, reformuló no sólo el paisaje demográfico del país, sino también su identidad nacional a través de un proceso de asimilación cultural diferente al esperado por las élites hegemónicas. De hecho, la fiebre del tango sirvió como estrategia política para dar visibilidad a la cultura argentina en el exterior -favoreciendo a la élite argentina a ganar prestigio en los círculos de alta sociedad europeos-, pero por otra parte, el tango le dio voz y un espacio socio-cultural a los sectores marginados. Del mismo modo, el lunfardo se acrecentó, en particular, en el habla de los porteños, y

\footnotetext{
${ }^{32}$ Citado en Foster, "Nation as Idea," 173
} 
es aún hoy en día una jerga que identifica y caracteriza a los argentinos regionalmente y en el exterior. ${ }^{33}$

A más de un siglo en circulación, el tango -en sus diferentes expresiones y manifestacionesconstituye una cultura en sí misma; una cultura que "representa un sector de argentinos dentro del país, pero que adquiere representación nacional en el extranjero" (Savigliano, 1995:4). La pasión y sensualidad del tango aún continúan alimentando el fervor de nuevas generaciones de argentinos; por cuanto, la música y el baile son un componente esencial y un símbolo de la idiosincrasia de una sociedad representada por medio del lenguaje, del ritmo y de la canción popular.

\footnotetext{
${ }^{33}$ Cabe acotar que, en la actualidad, el lunfardo -e inclusive el inglés británico que otrora era considerado como el inglés correcto y el cual se enseñaba en las escuelas- está siendo desplazado por el inglés norteamericano dada la influencia de los mercados de consumo y los medios de comunicación.
} 
BIBLIOGRAFÍA

ALBERDI, Juan Bautista (2002). "Immigration as means of Progress". The Argentina Reader: History, Culture, and Society. (Graciela Montaldo and Gabriela Nouzeilles, eds.) Durham: Duke University Press: 95-105.

BHABA, Homi (1990). Nation and Culture. New York and London: Routledge.

BorGES, Jorge L. (1999) “A History of the Tango.” Selected nonfictions/Jorge Luis Borges. (Eliot Weinberger, ed.) New York: Penguin Putman.

CaSTRO, Donald S. (1991) The Argentine Tango as Social History 1880-1955: The Soul of the People. Lewiston: The Edwin Mellen Press.

Clemente, José E. (1968). "Estilística del lunfardo.” El lenguaje de Buenos Aires. Buenos Aires: Emecé Editores.

COLLIER, Simon (2002). “The Birth of Tango.” The Argentina Reader: History, Culture, and Society. (Montaldo y Nouzeilles, eds.): 196-202.

FARBER, Mario E. "Historia: etimología de la voz Tango". Gotán: Tango pasión argentina $(27 / 08 / 2001)$.

Foster, David. W. (1998). Buenos Aires: Perspectives on the City and Cultural Production. Gainsville, FL: University Press of Florida.

Foster, David. W, Darrell y Melissa LOCKHART (1998). Performing Arts: Culture and Customs of Argentina. Conn: Greenwood: 126-127.

García Canclini, Néstor (2001). Consumers and Citizens: Globalization and Multicultural Conflicts. Minneapolis: University of Minnesota Press.

JAMES, Bruce (1953). Those Perplexing Argentines. Nueva York y Londres: Longmans, Green and Co. Inc.

KING, John. "Victoria Ocampo, Sur, y el peronismo, 1946-1955”. Revista de Occidente 37 (1984): $31-44$.

Manus, Carlos. "Tsunami Megata and the rise of tango in Japan". Todo Tango: The Academy Chronicles.

MARINAS, J. Alberto. “El tango, apunte histórico.” El tango 9/08/2012.

Masiello, Francine (1992). Between Civilization and Barbarism: Women, Nation \& Literary Culture in Modern Argentina. Lincoln \& London: University of Nebraska Press.

Montaldo Graciela and Gabriela NouzeiLles, (eds.) (2002). The Argentina Reader: History, Culture, and Society. Durham : Duke University Press. 
Novión, Alberto (2002). La transición al grotesco criollo. Osvaldo Pellettieri, ed. Buenos Aires: Eudeba.

PlaczKieWicz, Jezy (2012)."Tango in Poland, 1913-1939”. Todo Tango: The Academy Chronicles. 9/08/2012.

SARUP, Madan (1993). An Introductory Guide to Post-Structuralism and Postmodernism. Athens: The University of Georgia Press.

Savigliano, Marta E. (1995). Tango and the Political Economy of Passion. Boulder: Westview Press.

Tobin, Jeffrey (1998). "Tango and the Scandal of Homosocial Desire". The Passion of Music and Dance Body, Gender and Sexuality, William Washbaugh (ed.). New York: Berg Publishing.

Washbaugh, William (1998). "Introduction: Music, Dance, and the Politics of Passion”. The Passion of Music and Dance Body, Gender and Sexuality. New York: Berg. 


\section{GAITAS, PANDEROS Y TAMBORES. LA NUEVA MÚSICA GALLEGA Y UNA IDENTIDAD GLOCALIZADA}

Bagpipes, tambourines and drums. New Galician Music and a Glocalized Identity

\section{EUGENIA R. ROMERO}

OHIO StaTe UNIVERSITY, EsTADOS UnIDOS romero.25@osu.edu

Profesora asociada de Estudios Ibéricos en la Ohio State University en E.E.U.U. Por más de diez años ha sido una figura destacada en el ámbito de los Estudios Gallegos. Ha escrito varios artículos sobre Galicia que abordan temas desde parques de atracciones y cementerios, hasta la música popular y la emigración. Su primer libro, Contemporary Galician Culture in a Global Context: Movable Identities (Lexington, 2011) es uno de los primeros libros publicados exclusivamente sobre Estudios Gallegos contemporáneos. Se centra en él en la representación binaria de la identidad gallega a través de tropos como emigración/inmigración, urbano/rural, tradicional/ contemporánea, gallego y español y otros paradigmas con los que cuenta la producción literaria y cultural contemporánea de Galicia.

RECIBIDO: 16 DE ENERO DE 2017

RESUMEN: La música gallega ha jugado un papel importante en la interpretación de la identidad gallega. En las últimas décadas, los nuevos movimientos musicales y algunas propuestas de relectura del floklore gallego en relación con otras tradiciones musicales ha abierto las puertas a una redifinición de la 'galleguidad' desde una perspectiva glocalizada, que incorpora tanto elementos tradicionalmente asociados a lo gallego como dispositivos y estilos propios de otras tradiciones.

Palabras Clave: Identidad, Galicia, Música, Glocalización.
ACEPTADO: 14 DE MAYO DE 2017

ABSTRACT: Galician music has played an important role in the interpretation of Galician identity. In the last decades, the new musical movements and some proposals of rereading of the Galician floklore in relation to other musical traditions have opened the doors to a redefinition of the 'Galleguidad' from a glocalizated perspective, that incorporates both elements traditionally associated to the Galician indentity and some other cultural styles and traditions.

KEY WORDS: Identity, Galicia, Music, Clocalization. 
En el Atlántico encuentro un horizonte que me habla, para yo poder expresarme más alto y más claro.

Ese mar que nos une transvasa músicas de ida y vuelta en un eterno navegar de sentimientos.

UXíA. "Eterno navegar".

Son galego de Arxentina, galego de Alemaña

galego de Cuba, de Suiza, de Holanda, de Canadá

Galego na galiza imaxinaria.

Son galego de Caracas, galego de Santiago, galego de Roma, de Lima, do Cairo, de Bogotá.

Galego na galiza imaxinaria.

NARF. "Galician Lullaby".

La música está ligada a nuestra percepción del espacio y no se puede negar que tiene una estrecha conexión con los movimientos de personas, productos y culturas que traspasa límites geográficos. Es en este sentido que la música sirve como herramienta de construcción de identidades nacionales fuera del espacio nacional ya que ofrece un vehículo de conexión entre personas que no necesariamente comparten una misma nacionalidad.

Si bien en el caso de Galicia la música ha tenido un papel transcendental a través de los siglos, faltan estudios de fondo de esta representación cultural, que tal vez más que otras expresiones de cultura, está íntimamente ligada al espacio geográfico. Mientras la representativa muñeira es uno de los ritmos más conocidos que incorpora melodías populares y danzas de corte campesino o marinero, las gaitas y las pandereitas han influenciado otra vertiente de la música popular en Galicia. A partir de los años 70 el resurgimiento de la música gallega le dio un papel preponderante a la gaita que, como Xelis de Toro ha sugerido, la colocó en posición dominante en la música gallega y la convirtió en el símbolo de galleguidad al borrar las fronteras entre el espacio rural y los mercados de masas. De hecho, el simbolismo de la gaita, como instrumento musical "nacional," ha llegado hasta Sudamérica gracias a la emigración de gallegos en el Cono Sur. En un principio, los representantes del folklore gallego estaban contenidos en los grupos de descendientes que interpretaban música gallega tradicional; con el tiempo, las propuestas de estos grupos han derivado en una síntesis de influencias gallegas y latinoamericanas.

No obstante, hoy en día gracias al acceso inmediato a los medios de comunicación (internet, móviles, etc.) más la facilidad de transportarse de un lugar a otro, las influencias musicales de otras partes del mundo han llegado también a Galicia. En este trabajo pretendo analizar la forma en que nuevos grupos musicales y compositores gallegos están incorporando estilos, ritmos e instrumentos que no son propiamente gallegos en sus producciones. Como ejemplos, me centraré en el grupo coruñés Faltriqueira y en el cantautor Xoán Curiel, entre otros. Mediante una exposición de algunas de sus composiciones exploraré la manera en que esta nueva música gallega contribuye a la creación de una identidad nacional globalizada que estos mismos artistas promueven y que encuentra ecos en 
diversas partes del mundo.

La idea de que una nación o un pueblo tenga que estar físicamente conectado a un espacio geográfico concreto ha sido una de las constantes preocupaciones de las teorías sobre nacionalismos desde la perspectiva de Benedict Anderson (1991), Eric Hobsbawm (1990) y Ulf Hedetoft (1998), entre otros. De hecho, estos teóricos han sugerido que un territorio común (físico y real) es lo que crea y mantiene una identidad nacional concreta y diferenciada. Hedetoft, ha dicho incluso que el territorio funciona "as locus and raison d'etre for national 'homogeneity' [como lugar y razón de ser para la 'homogeneidad' nacional]" (Hedetoft 1998:173). ${ }^{1}$ Por consiguiente, esta apreciación de la nación está intrínsecamente ligada al binomio nación-estado, pues como dice T.M. Scruggs “[t]o function most effectively, a nation-state requires a national consciousness-an awareness of supposedly common bonds that purportedly bind the population together" [para funcionar de manera efectiva, una nación-estado requiere de una consciencia nacional-un reconocimiento de vínculos aparentemente comunes que supuestamente atan a la población] (1999: 297). De esta manera, un territorio delimitado y soberano facilita la construcción de esta conciencia nacional, por lo que la existencia de un espacio geográfico específico es inherente a la idea de la nación misma (convirtiendo el problema de lo nacional en un tema geopolítico). Sin embargo, como los estudios sobre globalización y/o migración han demostrado, esta reducción de lo nacional a la simple conexión entre espacio e identidad no es representativa de la realidad sociológica, económica, política y cultural que se vive hoy día en una sociedad que se mueve cada vez más a nivel global pues, por un lado existen naciones sin estado (como es el caso de Galicia y las otras regiones periféricas españolas) y, por otro, hay que tomar en cuenta las formas de movilidad contemporáneas que borran fronteras entre naciones, estados, personas, etc. ${ }^{2}$

En los últimos años los estudios transnacionales se han centrado en el análisis de lo que significa "to live in an interconnected, topologically complex world" [vivir en un mundo interconectado, complejo topológicamente] (Conradson y Latham 2005: 227). Así, el uso del término transnacional normalmente se refiere a los cruces internacionales que "sustained ties of persons, networks and organizations across the borders [and] across multiple nationstates," [mantienen lazos entre personas, cadenas y organizaciones a través de fronteras [y] a través de múltiples nación-estados] (Faist 2000: 189). Al considerar estos cruces es necesario tomar en cuenta también que los movimientos migratorios problematizan la posibilidad de identificar una identidad nacional específica y 'pura' -en un espacio concreto-que no haya entrado en contacto con otras identidades. Tal es el caso de Galicia, cuya historia nacional está íntimamente ligada a las constantes y

\footnotetext{
1 Todas las traducciones del inglés y del gallego al español son mías.

${ }^{2}$ La constitución española de 1978 otorgó carácter de ‘comunidades históricas nacionales’ a Cataluña, Euskadi, Galicia y Andalucía. En 1981 se acordó el primer Pacto Autonómico que 'preveía’ un mapa de España con las 17 autonomías, pero no es hasta 1992 que se reconocen 17 regiones autónomas: Castilla y León, Andalucía, Castilla-La Mancha, Aragón, Extremadura, Cataluña, Galicia, Valencia, Murcia, Asturias, Navarra, Comunidad de Madrid, Islas Canarias, Islas Baleares, País Vasco, Cantabria y La Rioja.
} 
continuas migraciones tanto a América como a Europa. ${ }^{3}$ Como consecuencia de esta larga historia migratoria es fácil coincidir con el novelista, poeta y ensayista gallego Manuel Rivas cuando dice que “Galicia está y no está en Galicia. Es un lugar y un deslugar” (2001: 38). Esta aseveración obliga, ciertamente, a reconsiderar los elementos que conforman la identidad gallega, e inclusive a preguntar si se puede hablar de 'una' galeguidade o galleguidad, o de diversas formas de entender e interpretar lo que significa ser gallego.

José Colmeiro considera, ante todo, que es necesario acercarse a los estudios gallegos desde una perspectiva cultural transatlántica que esté "more in sync with the hybrid complexities of contemporary cultural production" [más sincronizada con las complejidades híbridas de las producciones culturales contemporáneas] (2009: 214). Así, Colmeiro sugiere, siguiendo la línea de Néstor García Canclini, que es importante considerar "the multiple interactions between the local and the global, and the creation of 'glocal' realities in complex relations of interdependence and interpenetration" [las múltiples interacciones entre lo local y lo global, y la creación de realidades 'glocales' en complejas relaciones de interdependencia e interpenetración] para entender a Galicia (2009: 214). Colmeiro incluso plantea que una identidad gallega que se mueve, como su historia demuestra, con facilidad en el mundo global se entiende precisamente a partir de su doble condición periférica, pues por un lado se encuentra a los márgenes de la nación-estado española, y por otro, gracias a su condición migratoria, se mantiene "more open to movement and engagement with the outside world in Europe and the Americas" [más abierta al movimiento y a la participación con el mundo exterior en Europa y en las Américas] (2009: 220). Lo que Colmeiro propone es una invitación y un reto a considerar otros aspectos o manifestaciones culturales que, en su hibridación como expresiones 'glocales,' ofrezcan una nueva y más abierta aproximación a la interpretación de una galleguidad que, en esencia, siempre ha traspasado las fronteras de espacio. ${ }^{4}$ Así, el papel de la música es trascendental para entender la situación gallega en el presente desde los parámetros de una identidad 'glocalizada.' En este ensayo me propongo demostrar, aceptando la invitación de Colmeiro, cómo la música gallega contemporánea ofrece un acercamiento a la galeguidade que enfatiza por un lado, una posición que va más allá de lo global y lo local (convirtiéndose en glocal) y, por otro, una

\footnotetext{
${ }^{3}$ Cerca del 70\% de emigrantes que salieron de Galicia durante la segunda mitad del siglo XIX (la primera fase de la emigración gallega) nunca regresaron a su tierra. Este grupo, en su gran mayoría hombres solos, tradicionalmente emigró hacia las Américas, asentándose principalmente en países como Cuba y Puerto Rico. La segunda fase de la emigración gallega ocurrió principalmente después de la Guerra Civil española (1936-39) y en esta ocasión, el número de mujeres, al igual que de familias enteras aumentó considerablemente. Durante estos años fueron varios los países americanos como México, Argentina, Uruguay y Brasil que recibieron a estos emigrantes y exiliados. Las fases posteriores (en los años 50s, 60 s y 70s) mantuvieron más o menos el mismo flujo de emigrantes (hombres solos, mujeres jóvenes y familias) pero los países de destino eran los Estados Unidos y Canadá, así como el resto de Europa, en especial Alemania, Suiza y Bélgica (entre otros), y las otras regiones de España. Para mayor información sobre el tema de la emigración gallega y sus fases, el lector puede consultar los textos de Rodríguez-Galdo (1993), Villares Paz y Fernández Santiago (1996), Cagiao Vila y García Domínguez (1997) y Núñez Seixas (2002) por mencionar sólo algunos.

${ }^{4}$ El concepto de "cultura híbrida" utilizado por García Canclini sugiere que todas las manifestaciones culturales son 'fronterizas' e híbridas en el sentido de que se desarrollan en relación con otras por lo que pierden "the exclusive relation with their territory, but they gain in communication and knowledge" [la relación exclusiva con su territorio, pero ganan en comunicación y conocimiento] (1995: 261).
} 
transmigración cultural y musical que a su vez produce un hibridismo de sonidos, estilos y ritmos creando una música (y una identidad) más a tono con el tiempo presente.

Ahora bien, hay que considerar que se está hablando de la imposibilidad de fijar la identidad nacional y de localizarla en un espacio concreto gracias a las transmigraciones que se definen como un proceso mediante el cual las vidas de los inmigrantes "depend on multiple and constant interconnections across international borders and whose public identities are configured in relationship to more than one nation-state" [dependen de múltiples y constantes interconexiones a través de fronteras internacionales y cuyas identidades públicas son configuradas en relación con más de una nación-estado] (Glick Schiller, et al 1995: 48). De este modo, es de suponer que los inmigrantes forjan y mantienen relaciones simultáneas entre, por lo menos, dos sociedades y culturas (la de origen y la de asentamiento) creando una transmigración que a su vez implica el movimiento continuo y el cruce entre fronteras (reales e imaginarias). Arjun Appadurai (1996) explica que en el mundo contemporáneo es casi imposible que las personas tengan a alguien cercano (pariente, amigo, vecino, etc.) "who is not on the road to somewhere else or already coming back home" [que no esté en camino a algún lugar o ya de vuelta a casa,] por lo tanto la idea del movimiento constante es una característica esencial de la contemporaneidad (1996: 4). No obstante, la música como expresión cultural, es espacial. Es decir, está íntimamente ligada a cuestiones de espacio. Más específicamente, la música nos conecta de manera directa con espacios geográficos concretos. De hecho, los mitos de lugar muchas veces se refuerzan precisamente mediante la música dependiendo de quién toca o canta una pieza o canción en particular. Así, la canción "México lindo y querido" interpretada por el charro Jorge Negrete ha sido, y continúa siendo popular entre los inmigrantes mexicanos que sueñan con regresar a su país, aunque sea después de muertos. O bien, "New York, New York" en versión de Frank Sinatra, se asocia al triunfo y éxito de aquel que estando en esta gran urbe norteamericana se siente "rey de la montaña." En el caso gallego podemos hablar de famosos temas como "Para Vigo me voy" o de "A Rianxeira" que aunque compuesta en la Argentina por inmigrantes gallegos se ha convertido en el segundo himno de Galicia y que en su versión original dice: "Moito me gustas rianxeira/que estás eiquí na Arxentina /verche cantar e bailar-e/como alá na terra miña” [mucho me gustas rianxeira/que estás aquí en la Argentina/verte cantar e bailar/ como allá en mi tierra]. Lo cierto es que no se puede negar, como John Connell y Chris Gibson sugieren, que la música está intrínsecamente "linked to particular geographical sites" [ligada a sitios geográficos particulares] y que a su vez traspasa espacios y tiempos convirtiéndose en la manifestación cultural más transmigratoria de todas (2003: 1).

Ya en su cuento "O saxo na néboa," de la colección ¿Que me queres amor? [¿QQué me quieres amor?] (1995), Manuel Rivas establece un contacto directo entre la música y la localidad, y más entre las músicas del mundo americano y Galicia. En este cuento, Rivas ilustra la situación de las orquestas gallegas al final de los años cuarenta que utilizaban nombres de lugares americanos como "a orquestra

\footnotetext{
${ }^{5}$ La versión en inglés dice: “I wanna wake up in a city that doesn't sleep / And find I'm king of the hill” [quiero despertar en una ciudad que no duerme/ quiero descubrir que soy el rey de la montaña] (Ebb y Kander 1990).
} 
Acapulco, que era da parte da montaña” [la orquesta Acapulco, que era de la parte de la montaña] (1995: 40) y que se presentaba cantando la famosa rumba cubana "El manisero" y diciendo: "Nos dirigimos a nuestro distinguido público en castellano ya que el gallego lo hemos olvidado después de nuestra última gira por Hispanoamérica" (1995: 41). ${ }^{6}$ A través del papel de la música, Rivas enfatiza la conexión entre América, como espacio de abundancia y gloria, y Galicia como espacio de "arrecendo desalgado, de caldo de morriña, de pan negro" [olor a carne de puerco salada, de caldo, de morriña, de pan negro] (1995: 40). De igual manera, el texto apunta a la borradura de límites geográficos cuando el narrador cuenta que algunas orquestas "levaban o traxe de mariachi [porque] a cosa mexicana sempre gustou moito en Galicia. [Pues] [e]n todas as cancións había un cabalo, un revólver e unha muller con nome de flor. ¿Que mais necesita un home para ser o rey?" [llevaban el traje de mariachi [porque] la cosa mexicana siempre gusto mucho en Galicia. [Pues] [e]n todas las canciones había un caballo, un revólver y una mujer con nombre de flor. ¿Qué más necesita un hombre para ser el rey?] (1995: 41). De este cuento lo que más se destaca es precisamente el papel que la música tiene, no sólo en lo que ocurre en la trama, sino también en el imaginario popular gallego. A la gente le gustaba escuchar el variado repertorio de estas orquestas que incluía boleros, pasos dobles, cumbias, cuplés, polcas, corridos, valses, jotas, etc. (1995:41). Es obvio pues, según se puede ver en este cuento, que la música tiene la capacidad de conectar lugares y personas traspasando tiempos y fronteras y que, en el caso de Galicia, la música funciona como vaso conector entre la emigración y Galicia misma y que por lo tanto siempre ha sido una expresión híbrida.

Hoy día existe una gran variedad de estudios que se centran en la manera en que entendemos lugares y espacios mediatizados por diversas formas de expresión cultural como la televisión, los medios impresos, el cine y muy recientemente, la música. Es precisamente el interés por esta última manifestación cultural el que inspira este trabajo ya que los estudios culturales gallegos sobre el papel de la música como herramienta de construcción de identidad (individual o nacional) ha sido poco estudiado. ${ }^{7}$ De igual manera, algunos musicólogos y etnomusicólogos han intentado elucidar el papel de la música como producción cultural con un alto peso discursivo en diversos contextos socioculturales. Connell y Gibson enfatizan que "[m] usic also implies much more than just texts (whether lyrics or musical scores). Musical practices include whole constalletions of social uses and meanings, with complex rituals and rules, hierarchies and systems of credibility that can be interpreted at many levels" [la música también implica mucho más que sólo textos (ya sean letras o partituras musicales). Las prácticas musicales incluyen constelaciones enteras de usos y significados sociales, con rituales y reglas complejos, jerarquías y sistemas de credibilidad que pueden ser interpretados a varios niveles] (2003: 3). Ahora bien, el papel de la música conlleva un nivel de participación en el oyente que puede ir, desde un consumo pasivo (en ascensores, centros comerciales, etc.) a un consumo activo (como en la ducha, o en el karaoke), de la misma manera que puede ser una experiencia individual (los iPods,

\footnotetext{
${ }^{6}$ De hecho, este pasaje literario tuvo su propia transmigración al cine en la película La lengua de las mariposas (1999) de José Luis Cuerda y basada en el cuento homónimo de Rivas. El énfasis es del texto original en gallego para contrastar con el uso del español.

${ }^{7}$ Existen algunos artículos que se han enfocado en este tema. Para mayor información el lector puede consultar los artículos de De Toro (2002), Romero (2006) y Colmeiro (2009).
} 
mp3s, Internet) o pública (conciertos, festivales, o música en la calle). Esta condición 'transmigratoria' de la música - pues cruza espacios y fronteras dentro de la vida social, al igual que el propio transmigrante cruza límites y fronteras nacionales/internacionales- hace, paradójicamente, de la música la expresión cultural más difícil de localizar, pero no por eso deja de 'crear' espacios que se definen en sí mismos. A este respecto Andrew Leyshon, David Matless y George Revill han argüido que:

Space and place are here presented not simply as sites where or about which music happens to be made, or over which music has diffused, but rather different spatialites are suggested as being formative of the sounding and resouding of music. Such a richer sense of geography highlights the spatiality of music and the mutually generative relations of music and place. Space produces as space is produced. To consider the place of music is not to reduce music to its location, to ground it down into some geographical baseline, but to allow a purchase on the rich aesthethic, cultural, economic and political geographies of musical language.

[El espacio y el lugar están presentes aquí no simplemente como sitios donde o sobre los cuales se hace música, o a través de los cuales la música se difunde, sino que sugieren que diversas espacialidades dan forma al sonido y a la resonancia de la música. Este extenso sentido de geografía señala la especialidad de la música y las relaciones mutuamente generativas entre música y lugar. El espacio produce en cuanto el espacio se produce. Considerar el papel de la música no es reducirla a una locación, o asentarla en una base geográfica, sino permitir la adquisición de las grandes geografías estéticas, culturales, económicas y políticas del lenguaje musical.] (1995: 424-425)

Es en este sentido, que la música sirve como herramienta de construcción de identidades nacionales (incluso fuera del espacio nacional) ya que ofrece un vehículo de conexión entre personas que no necesariamente comparten una misma nacionalidad. Así, aunque la música parece estar conectada a elementos de identidad cultural, étnica y/o geográfica, siempre ha estado ligada a la movilidad y al intercambio entre géneros, instrumentos y músicos. Además, hoy día esta conexión parece más inmediata y rápida gracias a los avances tecnológicos, a los mercados de consumo y a los intercambios culturales ofrecidos por los medios de comunicación virtual. La música es así una manifestación en la que el mercado global está íntimamente comunicado con el espacio local convirtiéndola en una experiencia 'glocal.' En efecto, Martin Stokes enfatiza que, en primer lugar, la música "often seems to do little more than fill a silence left by something else...Music is clearly very much a part of modern life and our understanding of it, articulating our knowledge of other peoples, times and things, and ourselves in relation to them" [frecuentemente parece hacer más que simplemente llenar el silencio impuesto por algo más ... La música es claramente una gran parte de la vida moderna y nuestro entendimiento de ella, articulando nuestro conocimiento de otras personas, tiempos y cosas, e incluso nosotros mismos en relación a ellos] (1994: 3). Por lo tanto, el movimiento de personas y productos (de manera virtual o física) es responsable de la transformación de la música misma, así como de espacios y tiempos.

Aunque en el caso de Galicia la música ha tenido un papel transcendental a través de los siglos, faltan estudios de fondo de esta representación cultural en la Galicia contemporánea. Lo cierto es que 
la importancia de la música gallega radica no sólo en el intento de recuperación de la música popular o folklórica de grupos como Milladoiro, Luar na lubre, Berrogüetto, Faltriqueira, y hasta Os heredeiros da crus, y solistas como Carlos Núñez, Xosé Manuel Budiño, Susana Seivane, Xoán Curiel, Uxía y Cristina Pato, por mencionar sólo algunos, sino a la apropiación tanto de ritmos e instrumentos gallegos tradicionales como de nuevos sonidos, acompañamientos, armonías, etc. para componer y crear música original que se separa de la tradicional. Lo que es cierto es, como bien apunta Xelís de Toro en su artículo "Bagpipes and Digital Music: The Remixing of Galician Identity," que el uso de la gaita recibió no sólo el favor de músicos y artistas sino el reconocimiento oficial de la Xunta de Galicia (el gobierno autonómico) como símbolo de identidad gallega desde los primeros años de la transición democrática (a mediados de los años setenta) hasta el presente (2002: 237). Así, en estos años la gaita adquirió una gran popularidad y "a position of dominance in Galician music, becoming a battle ground for competing definitions of tradition and identity," [una posición de dominio en la música gallega, convirtiéndose en el campo de batalla para las diversas y competitivas definiciones de tradición e identidad] como comenta de Toro (2002: 238). De esta manera, la gaita se convirtió en un símbolo de galeguidade gracias a que su uso borró las fronteras entre la Galicia rural y el mercado de masas, convirtiéndola en el instrumento musical gallego contemporáneo por excelencia. ${ }^{8}$ Así, a partir de la segunda mitad de los años setenta, el uso de la gaita se compaginó con el desarrollo de una nueva práctica musical que consistía en incluir música folk celta. Milladoiro es el mejor ejemplo de este tipo de música y el festival internacional Celta de Ortigueira, creado en 1978, continua siendo el foro donde convergen importantes músicos celtas como Alan Stivell y The Chieftains. En el 2009, por ejemplo, el festival contó con la participación de Xosé Manuel Budiño, Susana Seivane, los canadienses de La Bottine Souriante y la banda escocesa Wolfstone entre otros. ${ }^{9}$ Además, desde el año 2007 el festival organiza el "Proxecto Runas" en el que nuevos grupos de música tradicional folk concursan para presentarse en los 3 días que dura el festival. El concurso tiene 2 fases, una que se realiza online o mediante el voto electrónico de aquellos interesados en la música celta y que escogen a su grupo favorito; y otra en la que un jurado presente en el festival elige a uno de los grupos para que actúe en el festival del año siguiente. Esta doble confluencia entre una 'comunidad' global (y virtual) dentro y fuera de Galicia y un jurado presente en el momento de las actuaciones enfatiza lo que Appadurai (1996) considera como esencial en la producción de localidades contemporáneas: que las comunicaciones virtuales juegan un papel central para mantener el contacto entre lugares y personas de diversos 'mundos.' En este caso, la comunidad 'celta' no es exclusiva de Galicia por lo que la localidad creada (el Festival de Ortigueira) se convierte en un espacio 'glocal' e híbrido en un lugar específico.

No cabe duda de que el Festival de Ortigueira es una muestra clara del papel de la música

\footnotetext{
${ }^{8}$ Colmeiro diría que la gaita, utilizada en este contexto sería un claro ejemplo de lo que le ha llamado 'rurban,' que es un cruce entre lo rural y lo urbano, similar al cruce entre lo global y lo local (2009:n/a).

${ }^{9}$ Para mayor información sobre los participantes en el Festival de Ortigueira 2009, el lector puede consultar la página web http://www.festivaldeortigueira.com/. Así mismo, el lector puede leer la historia del festival desde su creación hasta hoy día. Toda la información está disponible en gallego, español e inglés.
} 
gallega que tiene un origen local pero que ha abierto sus fronteras para incluir a músicos e intérpretes de la llamada 'música de raíz' de todas partes del mundo. Con una asistencia altísima, que ha sido cifrada en casi 90000 asistentes y una miríada de artistas, el Festival ha adquirido nivel de Interés Turístico Internacional y hoy día es el espacio “de encontro de culturas a través da música," [de encuentro de culturas a través de la música] como dice el sitio Web del Festival .

Con relación al Festival de Ortigueira y al papel de la gaita tiene en el imaginario gallego Ramón Villares, presidente del Consello da Cultura Galega [Consejo de la cultura gallega] ha escrito que "unha das explicacións do éxito deste festival, que ten un alto poder de convocatoria, mesmo alén das nosas fronteiras culturais e lingüísticas" [una de las explicaciones del éxito de este festival, que tiene tanto poder de convocatoria, inclusive más allá de nuestras fronteras culturales y lingüísticas,] es que tal parece que el celtismo (que no deja de ser un tema controversial en relación a la identidad gallega) que se relaciona con el uso de la gaita "converteuse nun signo de identidaded do país, despois de querer ter sido un sinal de identidade nacional" [se convirtió en un signo de identidad del país, después de que se quería que fuera una señal de identidad nacional] (Web del Festival). Villares incluso dice que es en el sentimiento, en la emotividad que existe "[n]a irmandade dos pobos atlánticos anoados polo Fisterra, un certo panteísmo, a forza evocadora da poesía e, naturalmente, pola música. A gaita como tótem” [en la hermandad de los pueblos atlánticos unidos por el Finisterre, un cierto panteísmo, la fuerza evocadora de la poesía y, naturalmente, por la música. La gaita como tótem] donde se encuentra la raíz cultural (celta) que mantiene y promueve el Festival (Web del Festiva). La idea de que la cultura gallega esté en conexión íntima con otros pueblos del atlántico enfatiza la posibilidad de hablar del Galician Atlantic o del 'Atlántico gallego' como lo ha llamado Colmeiro, pues en su opinión la posición periférica de Galicia le otorga una visión más amplia y por lo tanto "more open to what is beyond the limiting confines of the centre" [más abierta a lo que está más allá de los confines limitantes del centro] que la posiciona en un espacio global "as we witness the establishment of a potential new paradigm that is both postnational and post-peripheral" [mientras somos testigos del establecimiento de un potencial [y] nuevo paradigma que es a la vez postnacional y post-periférico] (2009: 217). Este acercamiento o mirada hacia la Galicia Atlántica se hace presente también en las producciones musicales de algunos cantautores Gallegos como se verá más adelante, en especial en alguno de los discos de Uxía.

Como es de suponer, la música gallega ha tenido diversas vertientes, y en los ochenta el movimiento punk-rock protagonizado por grupos como Os Resentidos, Radio Océano, Siniestro Total, entre otros, ofreció una nueva alternativa musical que se valía de hacer covers de canciones con gran fama en otras partes del mundo cambiando las letras a un lenguaje, en mucho casos combativo y político, en el que también combinaban varias lenguas, español, inglés y gallego. Las influencias musicales de estos grupos abarcaban desde el rock sinfónico (como el de Pink Floyd o Genesis) valiéndose de la sonoridad de las sinfonías clásicas mediante el uso de orquestas, secciones de cuerda o sintetizadores, y el punk que inicialmente era una música aparentemente muy simple y de un estilo descuidado (como el de The Sex Pistols y The Ramones), hasta el power-pop con sus melodías 
pegadizas al estilo del pop de los sesenta, el country con sus instrumentos de cuerda y de vez en cuando el acordeón, el $R \& B$ con sus influencias de jazz y blues, y el heavy metal con sus baterías de doble pedal y guitarras distorsionadas. En muchos casos, la apropiación de temas musicales mediante el cover (cambiando o adaptando las letras), era una estrategia no sólo musical sino también discursiva. El punk-rock es tradicionalmente considerado el movimiento musical anti-establishment por antonomasia, por lo que era normal que muchas de sus canciones se convirtieran en instrumentos para la ironía y comentario social. Teniendo esto en cuenta, es posible decir que la canción "Miña terra galega" (1984) de Siniestro Total es el epítome de la crítica musical 'post-colonial' de esta época a la institucionalización de la galeguidade promovida por la Xunta de Galicia. El tema hace una burla irónica de lo gallego mediante referencias explícitas a todos los tópicos de galeguidade: "A una isla del Caribe / he tenido que emigrar / y trabajar de camarero / lejos de mi hogar. / Me invade la morriña / el dolor de Breogán; / cuando suena la muñeira / el llanto empieza a brotar. /Miña terra galega / donde el cielo es siempre gris / Miña terra galega /es duro estar lejos de ti” (Siniestro Total, 1984). Si bien el lenguaje directo de esta canción sugiere la posibilidad de hablar claramente sobre la galleguidad, el hecho de que la canción juegue con todos estos clichés también, como bien dice de Toro, "unsettles the Galician listener" [inquieta al oyente gallego] (2002: 249). Después de todo, los gallegos "do not know how to relate to it: whether [they] are supposed to feel sentimental, patriotic, or proud, or just amused at the pastiche" [no saben como identificarse con ella: si se supone que deben sentirse sentimentales, patrióticos, o orgullosos, o simplemente maravillados con el pastiche] (2002: 249). Con todo, resulta interesante que la gaita no sea el instrumento principal en esta canción, aunque su presencia es indiscutible (por asociación) en la mención a la muñeira (la danza tradicional gallega). El hecho de que la letra de la canción sea en castellano (aunque el título sea en gallego) representa también una posible reacción de anti-galleguidad institucional pues, en lugar de participar en el movimiento que reivindicaba el uso del gallego, Siniestro Total se posiciona fuera del discurso nacionalista oficial, llevando a cabo un gesto post-nacional. De lo que no queda duda es de que "Miña terra galega," además, al ser un cover de la canción "Sweet Home Alabama” de Lynyrd Skynyrd, evoca un sentimiento de nostalgia que se enfatiza mediante la mitificación de los elementos propios de galeguidade. Las incongruencias que se ven en "Miña terra galega" manifiestan la tensión que existe en la definición de una identidad nacional gallega y, al mismo tiempo, exponen el hecho de que ésta (la galeguidade) es una construcción y por lo tanto un producto socio-político que, en este caso, ha transmigrado a través de la música. 
En lo concerniente a las producciones musicales de los noventa, la música gallega se destacó, principalmente, por la persistente presencia de lo celta. ${ }^{10}$ Sin embargo, la proliferación de grupos y solistas como Carlos Núñez o Luar na lubre, que se mueven entre el uso de los instrumentos tradicionales (gaita y pandereita) e instrumentos digitales (teclados y guitarras eléctricas) ofrecieron un nuevo respiro para la música gallega tradicional y su posicionamiento en las listas de popularidad de la música Folk en el mundo. Además, las letras de algunas de las composiciones musicales de estos artistas se mueven entre el uso del gallego, el castellano, el portugués y el inglés sugiriendo, ya desde entonces, una polifonía lingüística al igual que musical que a su vez enfatiza la 'glocalización' de estos grupos. Esta práctica sugiere también no sólo la concepción de una galleguidad plurilingüe sino de una identidad móvil que oscila entre varios vectores y que se conforma en el movimiento mismo y que tiene su manifestación social más clara en la emigración. De ahí que la música sea el mejor ejemplo de la transmigración gallega pues los diversos ritmos, cadencias, géneros, etc. ilustran este cruce de fronteras que a su vez se conectan mediante nuevas formas de expresión musical.

Es importante resaltar que en un principio la transmigración musical era más fácilmente detectada y aceptada en los grupos de emigrantes gallegos en el exterior. Si bien el simbolismo de la gaita, como instrumento musical 'nacional,' gallego llegó hasta Sudamérica gracias a la emigración de gallegos en el Cono Sur, con el tiempo los grupos de descendientes que interpretaban música gallega tradicional comenzaron a incluir ritmos latinos creando un tipo de música gallega diferente. Por ejemplo, el grupo Os Furafoles (argentinos descendientes de gallegos y fundado en el año 2000) incluye, junto con la pandereita y la gaita, otros instrumentos acústicos como el bongó, el derbaque y el djembé. Carina Fragoso (líder de Os Furafoles), comenta que la fusión de la música tradicional gallega con otro tipo de ritmos e instrumentos ofrece no sólo una variación para la música gallega sino la oportunidad de conectarse con otros mundos (tal vez los de la emigración misma). Con respecto a esta fusión, Fragoso comenta que el uso de instrumentos no tradicionales facilita la incursión de ritmos que "que viñeron de outras terras, por exemplo as rumbas de Cuba e que constituen un aporte moi importante na producción musical” [que vinieron de otras tierras, por ejemplo las rumbas de Cuba y que constituyen un aporte muy importante en la producción musical] de Galicia. (Señoráns 2003: 1). Resulta interesante, por otro lado, que la mayoría de estos grupos de emigrados rechazan la música celta como propiamente gallega. Sin embargo, sus miembros opinan que lo celta permite la apertura de Galicia hacia el mundo (no sólo separándola de España) sino como pueblo integrante de un movimiento musical transnacional que incorpora un discurso identitario que borra fronteras

\footnotetext{
${ }^{10}$ En esta misma década el fenómeno del llamado rock bravú tuvo también un gran auge. Este movimiento es, según Colmeiro, la convergencia entre la popular movida gallega de principios de los ochenta y el fuerte resurgimiento de la música tradicional gallega de los ochenta y noventa. De hecho, Colmeiro describe el fenómeno de la siguiente manera: ' 'It would be expected that some form of merge would occur out of these two very popular musical movements, one with urban origins, the other with roots in the village, but with ample cross-crossing of audiences. [...] Thus a new generation of bands was born that incorporated traditional Galician folk roots with rock... " [Es de esperarse que ocurriera un tipo de unión entre estos dos grandes movimientos populares, uno con orígenes urbanos, el otro con raíces en la aldea, pero con una amplia audiencia que escuchaba ambos. [...] Así nació una nueva generación de bandas que incorporaron las raíces tradicionales del folk gallego con el rock...] (2009b). Para mayor información sobre este fenómeno, el lector puede consultar el artículo de Colmeiro.
} 
geográficas y las unifica mediante melodías e instrumentos musicales, como ya se ha visto en el Festival de Ortigueira. ${ }^{11}$

Otro grupo de 'hijas de la emigración’ que ha tenido éxito tanto en Galicia como en su país de origen es Ialma. Este grupo de cinco chicas de Bruselas interpreta música tradicional gallega desde el 2003 después de que Verónica Codesal, integrante del grupo y voz principal, representara a Bélgica en el festival de Eurovisión. Estas chicas se han dedicado a recopilar piezas tradicionales gallegas ya desde tiempo antes y su primer disco "Palabras darei" contiene piezas cantadas principalmente $a$ capella. Sin embargo, el grupo fue mejor recibido en Bélgica que en Galicia, según Codesal porque "había moitísimas pandereteiras [e] discos como aquel xa había moitos" [había muchísimas pandereteiras [y] discos como aquel ya había muchos] en Galicia (Rivero 2006: 57). Este comentario sugiere, por un lado que el grupo al seguir una línea 'tradicional' no aportaba nada original a la música gallega y, por otro, que era necesario buscar nuevas formas de expresión musical para que el grupo recibiera el reconocimiento del público gallego pues: "Nós tiñamos claro que se non se recoñecía a nosa música en Galicia era como si non houbera recoñecemento verdadeiro" [teníamos claro que si no se reconocía nuestra música en Galicia era como si no hubiera reconocimiento verdadero] como expresa Codesal (Rivero 2006: 57). Su segundo disco, "Marmuladas," es el espacio "where Galician melodies blend with arrangements of Belgian musicians [and] Ialma carries on with passing on its songs in a style of its own, varying from authentic to modern styles which create some seductive and festive modern music" [donde las melodías gallegas se mezclan con arreglos de músicos belgas [e] Ialma continua transmitiendo en sus canciones un estilo propio, que varía de un estilo auténtico a uno moderno que a su vez crean una música moderna, seductiva y festiva] como dicen en su página en MySpace. Siguiendo por esta línea, en el 2006, Ialma presentó su tercer disco "Era nova" en el que ofrecen una mezcla de ritmos y sonidos multiculturales que representan la experiencia transmigratoria de estas chicas que viven en una ciudad multicultural en Bélgica, pero que mantienen conexión directa con el país de origen de sus padres mediante la lengua, la cultura y la música. Incluso, el grupo ofrece una versión cover del tema clásico de los Red Hot Chili Peppers "Under the bridge”, con arreglos de acordeón, violín y gaita junto con percusiones africanas y la participación de las antiguas cantareiras de Laxoso. ${ }^{12}$ Esta combinación de elementos hace, según Codesal, esta canción tanto de Ialma como gallega, ofreciendo un tema rítmico con el que la gente se identifica pero sin conectarla directamente con la versión de los Red Hot Chili Peppers (Rivero 2006: 57). Esta idea sugiere así, que lo gallego encuentra también su expresión en las músicas de otros países y culturas y

\footnotetext{
${ }^{11}$ Para más información sobre el tema de la música gallega en la Argentina, el lector puede consultar mi artículo “Amusement Parks, Bagpipes, and Cemeteries: Fantastic Spaces of Galician Identity through Migration” (2006).

${ }^{12}$ Cantareiras es el nombre que se da a grupos de mujeres que cantan música tradicional gallega acompañándose ellas mismas con pandereitas y otros instrumentos de percusión tradicionales. Las cantareiras de Laxoso es un grupo muy conocido en Galicia formado por 11 mujeres de edades que van entre los cincuenta hasta los ochenta años. El 28 de febrero de 2006, el programa Alalá de la Televisión de Galicia dedicó un programa especial a este grupo de cantareiras.
} 
que la 'apropiación' de otros ritmos y tradiciones no le quita el 'sabor' tradicional sino que incluso lo enriquece. ${ }^{13}$

Si bien hasta ahora se ha hablado de la música gallega en el exterior debido a la larga historia migratoria de Galicia, es necesario resaltar el hecho de que en los últimos años Galicia (igual que el resto de España) ha experimentado el fenómeno inverso y se ha convertido en el lugar de destino de emigrantes de todas partes del mundo. En primer lugar, la 'migración del retorno' ha sido fundamental en la construcción de la 'nueva' Galicia en la que tanto emigrantes, como sus hijos y nietos asentados en otras partes del mundo (las Américas principalmente) han encontrado el camino de regreso a Galicia. En segundo término, gran número de inmigrantes han llegado desde países con una conexión lingüística, cultural y laboral con Galicia. Así, inmigrantes del mundo lusófono (Portugal, Brasil, Cabo Verde, etc.), que comparten variantes lingüísticas y culturales, así como trabajos en los barcos pesqueros de Galicia, han encontrado en este espacio un lugar para asentarse. Esta nueva situación que, como Colmeiro ha dicho "reinforces the Atlantic orientation of Galicia” [refuerza la orientación atlántica de Galicia] al invertir el paradigma migratorio de Galicia ofrece nuevas oportunidades para el cruce entre culturas (2009: 220). Tal es el caso de la nueva música gallega cuyo contacto con otras culturas y músicas es evidente ahora, tal vez más que antes. Por lo que, en primer lugar la realización de covers como el de Ialma (que nos recuerda lo que hacían los grupos punk-rock de los ochenta) se ha extendido también dentro de grupos asentados en Galicia. Por ejemplo, las chicas de Faltriqueira también se han valido de esta estrategia musical y han transformado la tradicional canción country "A little rosewood casket” con una versión muy propia en "Caixa de roseira" [Caja de palo de rosa]. Al igual que Ialma, Faltriqueira se vale de instrumentos gallegos tradicionales como la gaita y pandereitas, pero principalmente del juego de voces entre ellas (al estilo de las tradicionales cantareiras) que hacen que el tema compuesto hacia finales del siglo XIX en Estados Unidos adquiera un carácter gallego, reapropiándolo para un nuevo espacio y otra cultura. Lo mismo ocurre con un tema que no aparece en ninguno de sus discos: "Un poquito de mambo... ou así" que interpretaron en el programa conmemorativo para Andrés do Barro que muestra claramente la fusión de lenguas, ritmos y culturas que el cantante de pop de la época franquista hiciera popular para ofrecer una versión propia y original. ${ }^{14}$ En su disco titulado "Efffecto Faltriqueira" [sic] (2008) el grupo incluye también una canción senegalesa "Fatuo yo" en la que los ritmos y letras africanas se mezclan con lo tradicional gallego mostrando así la confluencia e influencia de la presencia de otras culturas en Galicia. De hecho, este grupo de mujeres dice que esta canción es un "exemplo da consecuencia das viaxes, os contactos e os intercambios de material” [ejemplo de la consecuencia de los viajes, los contactos y los intercambios de material] (Faltriqueira). Lo mismo puede decirse de la única versión de la tradicional "A saia de Carolina" que sólo se puede encontrar en YouTube que

\footnotetext{
${ }^{13}$ En el 2008, Ialma cruzó otra frontera entre la música y la danza al crear el programa "100 voltas” [100 vueltas]. El programa fue presentado en el "Théâtre Molière" en Bruselas con la intención de abrirse "cara a outras culturas co obxectivo de enriquecer a propia" [hacia otras culturas con el objetivo de enriquecer la propia].

${ }^{14}$ Andrés do Barro o Andrés Lapique do Barro fue uno de los primeros cantantes en utilizar el gallego durante la dictadura franquista (1936-1975) logrando colocarse entre las listas de popularidad de la radio española con el tema "O tren," canción que habla del regreso en tren a Galicia como tierra de la felicidad.
} 
comienza con el típico juego de voces que ha hecho popular a este grupo acompañadas después por ritmos afro-caribeños que transforman esta canción en un claro híbrido musical. Así, el disco incluye también una versión muy propia de "Corpiño xeitoso," [Cuerpo estiloso] otra canción que hiciera popular Andrés do Barro, en la que las percusiones gallegas y la polifonía de Faltriqueira crean un espacio musical que claramente traspasa fronteras musicales aún en una canción con gran popularidad dentro del pop gallego.

Un elemento que es trascendental para la nueva música gallega es el papel que Internet tiene en su posicionamiento como 'música del mundo' y el acceso que se tiene hoy día a la música de estos grupos y músicos. El acceso a vídeos o versiones mp3 de estos grupos (o la posibilidad de comprar todas las canciones por menos de 10 dólares facilita así la distribución y diseminación de estas producciones. Para Appadurai esto sería precisamente la condición más deslocalizada de la cultura, pues en un mundo "where electronic media are transforming the relationships between information and mediation" [donde los medios electrónicos están transformando las relaciones entre la información y la mediación] la música (gallega y de otras partes del mundo) se posiciona como la manifestación cultural más clara de un momento postcolonial (1996: 189). De esta manera, si se habla de límites entre países y géneros musicales el trabajo de Uxía Senlle (Uxía) es un claro ejemplo. Su producción "Eterno navegar" (2008) continúa su trayectoria musical en la que constantemente "reivindica su condición de raiana (fronteriza) atravesando, cuantas veces considera, la línea administrativa que separa Galicia de Portugal" al punto de que se le ha confundido como cantante de origen portugués. En el dossier de promoción del disco Uxía explica que esta nueva producción musical mantiene su conexión con la tradición gallega a través de su poesía (principalmente la de voces femeninas como ha hecho desde un principio de su carrera) y con la influencia de "territorios portugueses, brasileños y africanos" (2008: 4). En la rueda de prensa para la presentación del disco Uxía dice claramente que su objetivo no es cantar un fado portugués o una morna caboverdiana "en el sentido estricto," sino infundir este tipo de música con su propio "perfume" y hacer un "homenaje" a las músicas del Atlántico que "trasvasa músicas de ida y volta” [trasvasa músicas de ida y vuelta] tomando en cuenta las que los propios gallegos llevaron a otros sitios y que volvieron con "con aires renovados". Xurxo Souto ha dicho inclusive que “en 'Eterno Navegar’ a voz de Uxía percorre camiños de sonoridades atlánticas e ritmos africanos, partindo da tradición e das atmósferas da súa orixe” [en ‘Eterno Navegar' la voz de Uxía recorre caminos de sonoridades atlánticas y de ritmos africanos, partiendo de la tradición y de las atmósferas de su origen] (Uxía. Página oficial.). Esta producción de Uxía es una clara muestra de uno de los rumbos de la música gallega contemporánea: una representación de la realidad cultural de Galicia que es en sí misma una fusión de lenguas, culturas, ritmos, instrumentos, etc. ${ }^{15}$

Resulta interesante que hasta ahora, la nueva música gallega pareciera ser de propiedad femenina, aunque esto no es, claro, del todo así. Existen compositores y músicos gallegos que

\footnotetext{
${ }^{15}$ La trayectoria musical de Uxía es la más larga de todos los artistas mencionados. Su voz es particularmente conocida en el mundo lusófono y las seis producciones musicales de su carrera la han colocado en el gusto popular tanto en Galicia como en Portugal, Cabo Verde y Brasil.
} 
participan de esta nueva ola de infusiones y fusiones musicales y rítmicas. Las influencias musicales del cantautor Fran Pérez, mejor conocido en el ámbito musical como Narf (Fran escrito al revés), son una muestra clara de que esta fusión de ritmos africanos, brasileños, árabes y hasta el flamenco está también presente en la música hecha (e interpretada) por hombres. En la página Web de su compañía de discos explica que el título de su último disco “Tótem" se relaciona con la guitarra que Fran lleva al hombro mientras recorre el mundo (a diferencia de la gaita como decía Villares sobre el Festival de Ortigueira) pero que marca los lugares por los que pasa y que le sirven como piedrecitas con las cuales encontrar el camino de regreso a casa. Así la música de Narf es "[a] modern language, at once seductive, moved by his feelings. A non-tamed language, steeped in the acidity of some letters" [un lenguaje moderno, a una vez seductivo, movido por sus sentimientos. Un lenguaje sin domar, imbuido en la acidez de algunas de sus letras] endulzadas por la voz de Pérez. Su "Galician Lullaby" [Canción de cuna gallega] es tal vez la síntesis de esta identidad plural, global y local en la que dice ser gallego de todas partes, como se puede apreciar en el epígrafe de este artículo, y principalmente gallego en una Galicia imaginada que está y no está en Galicia (como diría Rivas). La música de Fran es tal vez la que en principio más se resiste a la localización, sin embargo, canciones como "Santiago" y "Nosa señora de Belén” [Nuestra señora de Belén] lo conectan en gran medida con Galicia, al igual que "Afroblues" y "Nao ten vocé" [No tiene ud.] que tienen un ritmo más afrobrasileiro lo desterritorializan de su tierra y lo ponen más en contacto con el mundo lusoportugués. Lo cierto es que la música de Fran rompe con las formas más tradicionales de la música gallega (no hay gaitas ni pandereitas), no obstante, es una clara muestra de la nueva vertiente de la música gallega que está traspasando, más claramente, todas las fronteras (musicales, geográficas, lingüísticas, culturales, etc.) para ofrecer algo más a tono con la realidad del mundo contemporáneo.

Algo similar ocurre con el trabajo y la propuesta musical de Xoán Curiel, quien con su primer disco titulado "Nai" [Madre] ofrece canciones de su autoría que giran en torno al universo femenino. En un sentido, la obra musical de Xoán Curiel es una fusión tanto de ritmos y músicas como de género sexual, circunstancia que rompe con los esquemas tradicionales de la música gallega. No obstante, esta conexión de Xoán con lo femenino nos devuelve a una característica muy propia de la galeguidade que es la conexión con la tierra (como madre) y como espacio habitado por mujeres (debido tanto a la emigración como a la industria pesquera que ha sostenido a Galicia por siglos). El propio Xoán describe este disco como un 'parto,' aunque en realidad el nunca pueda tener esa experiencia física, sin embargo este joven cantautor ve a su su primer disco como el resultado de grandes esfuerzos, sin sabores, dolores, etc. En esta producción musical colaboran artistas de países como Ukrania, Brasil y Galicia además de la participación de voces femeninas como Uxía que hacen de este disco un híbrido musical en el que se utilizan como instrumentos musicales "utensilios da vida cotiá como tixolas, auga percutida, batir de noces, coitelo no afiador, o copas de auga” [utensilios de la vida cotidiana como sartenes, agua percutida, batir de nueces, cuchillo en el afilador, o copas de agua] (www.xoancuriel.com). La canción "Bágoa de pataca” [Lágrima de patata] en la que el uso de la tabla de lavar ropa, sartenes y de agua corriendo hacen de esta canción un claro híbrido dentro de la música gallega, o inclusive la canción "Nai” [Madre] en la que adopta una voz 'femenina' permiten 
descubrir el universo gallego dentro de un espacio global más amplio. No cabe duda de que el disco es "fruto dun proceso que xurde da escoita de ritmos e sons de todo o mundo (galegos, árabes, subsaharianos, afrobrasileiros...)" [fruto de un proceso que surge de la escucha de ritmos y sones de todo el mundo (gallegos, árabes, subsaharianos, afrobrasileiros....] (www.xoancuriel.com). De la misma manera, este disco es también un producto local, pues comienza con un origen (con la canción "Orixe" [Origen]) envuelto en los elementos naturales (viento, agua, tierra y fuego) que sin duda está interconectado con la tierra gallega, y termina en Fonsagrada (con la canción "Fonte Sagrada" [Fuente Sagrada]) lugar de nacimiento de Xoán. Esta frescura convierte la producción de Xoán Curiel en la obra más polifónica y polifacética de todos los artistas mencionados que traspasa claramente todas las fronteras que pueden existir entre músicas, instrumentos, lugares, personas y culturas para ofrecer una propuesta musical que es difícil de identificar. No obstante, su trabajo apunta a una nueva vertiente de la música en Galicia que, tal vez de una forma mucho más audaz que ningún otro grupo o interprete mencionado en este trabajo, posiciona a la nueva música gallega en los márgenes de la música folk o tradicional.

Así, pues, la música gallega (como en muchas otras partes) ha jugado un papel importante en la interpretación de la identidad y la manera en que ésta se concibe. Como dicen Connell y Gibson, "[m]usic functions as a form of entertainment and aesthetic satisfaction, a sphere of communication and symbolic representation, and both a means of validating social institutions and ritual practices, and a challenge to them" [la música funciona como una forma de entretenimiento y satisfacción estética, una esfera de comunicación y representación simbólica, y tanto un medio para validar instituciones sociales y prácticas ritualísticas, como un reto para ellas] (2003: 43). Por tal motivo, es importante considerar el papel que ésta tiene y tomar en cuenta el contexto en el que se produce pues, junto con otras manifestaciones culturales (literatura, pintura, etc.), se encuentra "embedded in the creation of (and constant maintenance of) nationhood" [incrustada en la creación de (y constante mantenimiento de) la idea de nación] (Connell y Gibson 2003: 118). Todo esto implica que la nueva música gallega está comenzando a mostrar más su cualidad 'glocal' como una forma de expresión de una realidad híbrida que se mueve entre diversos puntos sin mantener un centro. Resulta interesante que en estas nuevas fusiones e infusiones musicales, el centro de la nación-estado (Madrid) parece haber desaparecido, lo cual sugiere, a su vez, que Galicia se produce y se construye gracias a los movimientos migratorios, tanto de los propios gallegos y sus descendientes en el exterior, como de los nuevos ciudadanos gallegos.

Se puede decir que dentro de este nuevo paradigma, Carlos Núñez con su álbum “Alborada do Brasil” (2009) captura mejor que nadie la nueva dirección de la música gallega. Después de todo, Manuel Rivas ya ha hablado de los ‘Afrogallegos' en un suplemento especial de El País, cuya portada es la foto de David, un gaitero de origen caboverdiano que vive en Burela (provincia de Lugo) "hijo del único matrimonio mixto” en esta ciudad (Rivas 2002: 2). Tanto más se puede decir del grupo Batuko Tabanka conformado por doce mujeres también de Cabo Verde que han conseguido un gran éxito con sus presentaciones en las que funden la música de su país con la realidad social que viven en Galicia, como se puede apreciar en su canción "Muller de marinero" [Mujer de marinero]. Estos son 
sólo algunos ejemplos del poder transmigratorio de la música, que en el caso de Galicia ha contribuido a la creación de 'una' identidad post-nacional, post-periférica, y que claramente traspasa un sinnúmero de fronteras (geográficas, musicales, de género, etc.) para ofrecer una experiencia pluricultural que va más allá de lo global y local (glocal) en un mundo que se encuentra en constante cambio y el cual hoy día es difícil de etiquetar. 


\section{BIBLIOGRAFÍA}

"About Ialma”. Grupo Ialma (1/07/2009).

“Alalá No. 3: Cantareiras de Laxoso”. CRTVG (28 / 02/ 2006).

“A rianxeira: su historia y su letra”. Galicia Espallada (29 /06/2009).

ANDERSON, Benedict R. (1991). Imagined Communities: Reflections on the Origin and Spread of Nationalism. London and New York: Verso.

APPADURAI, Arjun (1996). Modernity at Large: Cultural Dimensions of Globalization. Minneapolis,:London: University of Minnesota Press.

CagiaO Vila, Pilar, and Teresa García Domínguez (1997). Muller e emigración. Xunta de Galicia: Santiago de Compostela.

Colmeiro, José. "Peripheral Visions, Global Positions: Remapping Galician Culture". Bulletin of Hispanic Studies 86.2 (2009): 213-230.

Colmeiro, José. "Smells Like Wild Spirit: Galician Rock Bravú, Between the Rurban and the Glocal.” Journal of Spanish Cultural Studies 10/2 (2009b): 225-240.

ConRadson, David y Alan Latham. "Transnational Urbanism: Attending to Everyday Practices and Mobilities”. Journal of Ethnic and Migration Studies 31.2 (2005): 227-233.

Connelt, John y Chris, GIBSOn (2003). Sound Tracks: Popular Music, Identity and Place. London and New York: Routledge.

Correa, Anxa. “Uxía plasma en un nuevo disco su 'Eterno navegar' por el Atlántico.” El Progreso. $(12 / 03 / 2008)$.

Curiel, Xoán (2008). "Nai.” Xoán Curiel Web Oficial.

FAIST, Thomas. "Transnationalization in international migration: implications for the study of citizenship and culture". Journal of Ethnic and Racial Studies 23.2 (2000): 189-222.

GaRCÍA CANCLINI, Néstor (1995). Hybrid Cultures: Strategies for Entering and Leaving Modernity. Minneapolis: University of Minnesota Press.

GLicK SCHILlER, Nina, Linda BaSCH y Cristina SZANTON BLANC. "From Immigrant to Transmigrant: Theorizing Transnational Migration”. Anthropology Quartely 68.1 (1995): 48-63.

Hedetoft, Ulf (1998). "Constructions of Europe: Territoriality, Sovereignty, Identity: Disaggregations of Cultural and Political Space”. Territoriality in Modern Society. Stefan Immerfall, (ed.). Berlin y New York: Springer:173-204.

Hobsbawm, E. J. (1990). Nations and Nationalism since 1780: Programme, Myth, Reality. Cambridge and New York: Cambridge University Press.

"Ialma da '100 voltas'." Vieiros. (7/05/2008).

Leyshon, Andrew, David Matless y George Revill. "The Place of Music: Introduction”. Transactions of the Institute of British Geographers, New Series 20.4 (1995): 423-433.

NúÑEZ SEIXAS, Xosé-Manoel. "History and Collective Memories of Migration in a Land of Migrants: The Case of Iberian Galicia.” History \& Memory 14/1-2, (2002): 229-258. 
RIVAS, Manuel (1999). “O saxo na néboa.”¿Que me queres amor? Vigo: Editorial Galaxia: 35-52.

RIVAS, Manuel. “Galicia contada a un extraterrestre.” El País Semanal 1,307 (2001): 38-52.

RIVAS, Manuel. “Afrogallegos.” El País Semanal (2002): 1-2.

RIVERO, Marta. "Mozas da Ialma”. Visado: Faro de Vigo 220 (2006): 55-62.

RodríGUEZ-Galdo, María Xosé (1993). Galicia, país de emigración: La emigración gallega a América hasta 1930. Gijón: Colombres.

Romero, Eugenia R. “Amusement Parks, Bagpipes and Cemeteries: Fantastic Spaces of Galician Identity through Migration”. Journal of Spanish Cultural Studies 7.2 (2006): 155-169.

SCRUGGS, T. M. "Let's Enjoy as Nicaraguans": The Use of Music in the Construction of a Nicaraguan National Consciousness”. Ethnomusicology 43.2 (1999): 297-321.

SEnLle, Uxía. Uxía. Página oficial.

SEÑORÁnS, Andrés Javier. "Entrevista a 'Os Furafoles"”. A Grileira: Revista de Musicología Y Archivo Histórico de la Fundación Xeito Novo de Cultura Gallega 7 (2003): 1-5.

STOKES, Martin (1994) “Introduction: Enthnicity, Identity and Music.” Ethnicity, Identity and Music: The Musical Construction of Place. Oxford, Providence: BERG: 1-27.

Toro SANTos, Xelís de (2002). "Bagpipes and Digital Music: The Remixing of Galician Identity." Constructing Identity in Contemporary Spain: Theoretical Debates and Cultural Practice. Ed. Jo Labanyi. New York and Oxford: Oxford University Press: 237-54.

ViLlares PAZ, Ramón y Marcelino FernánDEZ-SANTIAGO (1996). Historia da Emigración galega a América. Xunta de Galicia: Santiago de Compostela.

Villares PaZ, Ramón y Marcelino Fernández-Santiago (2009). “Un festeiro intermitente." Experiencias en Ortigueira. Festival de Ortigueira. Consello de Ortigueira.

\section{DISCOGRAFÍA}

EbB, Fred \& John Kander (1990). “New York, New York”. The Reprise Collection, Disc 4: Duets. Reprise: Capitol.

NúÑEZ, Carlos (2009). Alborada do Brasil. BR.

Siniestro Total (1984). "Miña Terra Galega”. Menos mal que nos queda Portugal. DRO. 